\title{
Universiteit
}

Leiden

The Netherlands

\section{Rethinking resistance: revolt and violence in African history}

Abbink, G.J.; Bruijn, M.E. de; Walraven, K. van

\section{Citation}

Abbink, G. J., Bruijn, M. E. de, \& Walraven, K. van. (2003). Rethinking resistance: revolt and violence in African history. Leiden: Brill. Retrieved from https://hdl.handle.net/1887/12876

Version: $\quad$ Not Applicable (or Unknown)

License: $\quad$ Leiden University Non-exclusive license

Downloaded from: $\quad$ https://hdl.handle.net/1887/12876

Note: To cite this publication please use the final published version (if applicable). 
AD-2-abbink.qxd 26/11/2002 15:15 Page $i$

RETHINKING RESISTANCE 


\title{
AFRICAN DYNAMICS
}

\author{
EDITORIAL COMMITTEE \\ Piet Konings (Africa Studies Centre, Leiden) \\ Paul Mathieu (Catholic University, Leuven) \\ Adebayo Olukoshi (CODESRIA, Dakar) \\ Ruth Watson (Birkbeck College University of London)
}

Volume 2

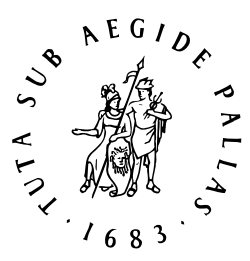




\title{
RETHINKING RESISTANCE
}

Revolt and Violence in African History

\author{
EDITED BY
}

\section{JON ABBINK, MIRJAM DE BRUIJN \\ $\&$ KLAAS VAN WALRAVEN}

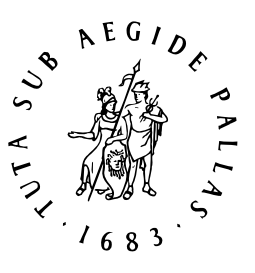

BRILL

LEIDEN $\cdot$ BOSTON

2003 
This book is printed on acid-free paper.

\section{Die Deutsche Bibliothek - GIP-Einheitsaufnahme}

Bibliographic information published by Die Deutsche Bibliothek Die Deutsche Bibliothek lists this publication in the Deutsche Nationalbibliografie ; detailed bibliographic data are available in the Internet at http://dnb.ddb.de.

\section{Library of Congress Cataloging-in-Publication Data}

Library of Congress Cataloging-in-Publication Data is also available

ISSN $1568-1777$

ISBN 9004126244

(C) Copyright 2003 by Koninklijke Brill $\mathrm{Nv}$, Leiden, The Netherlands

All rights reserved. No part of this publication may be reproduced, translated, stored in a retrieval system, or transmitted in any form or by any means, electronic, mechanical, photocopying, recording or otherwise, without prior written permission from the publisher.

Authorization to photocopy items for internal or personal use is granted by Brill provided that the appropriate fees are paid directly to The Copyright

Clearance Center, 222 Rosewood Drive, Suite 910

Danvers MA 01923, USA.

Fees are subject to change.

PRINTED IN THE NETHERLANDS 


\section{Contents}

Maps, figures, tables and photographs vii

Preface ix

1 Rethinking resistance in African history: An introduction $\quad 1$ Klaas van Walraven \& Jon Abbink

\section{PART I: HISTORICAL PERSPECTIVES}

2 Resistance to Fulbe hegemony in nineteenth-century West Africa 43 Mirjam de Bruijn \& Han van Dijk

3 Colonial conquest in central Madagascar: Who resisted what? 69 Stephen Ellis

4 Revisiting resistance in Italian-occupied Ethiopia: The Patriots'

Movement (1936-1941) and the redefinition of post-war

Ethiopia

Aregawi Berhe

PART II: SOCIAL INEQUALITIES AND COLONIAL HIERARCHIES

5 Ambiguities of resistance and collaboration on the Eastern Cape Frontier: The Kat River Settlement 1829-1856

Robert Ross

6 African mutinies in the Netherlands East Indies:

A nineteenth-century colonial paradox

Ineke van Kessel

7 Absence of evidence is no proof: Slave resistance under German colonial rule in East Africa

Jan-Georg Deutsch

\section{PART III: VIOLENCE, MEANING AND IDEOLOGY IN RESISTANCE}

8 The Kawousan War reconsidered 
9 Sawaba's rebellion in Niger (1964-1965): Narrative and meaning 218 Klaas van Walraven

10 The vagaries of violence and power in post-colonial Mozambique 253 Gerhard Seibert

\section{PART IV: RESISTANCE AS HERITAGE AND MEMORY}

11 Herero genocide in the twentieth century: Politics and memory Jan-Bart Gewald

12 'Namibia, land of the brave': Selective memories on war and violence within nation building

Henning Melber

13 Dervishes, moryaan and freedom fighters: Cycles of rebellion and the fragmentation of Somali society, 1900-2000

Jon Abbink

List of authors 


\section{Maps}

2.1 West Africa: Nineteenth-century Fulbe emirates 49

3.1 Ethnic groups of Madagascar $\quad 71$

5.1 The Kat River Settlement 119

6.1 Netherlands East Indies: Java and Sumatra 154

7.1 Slave populations resident in German East Africa, c. $1900 \quad 172$

8.1 Areas of resistance during the Kawousan War 193

9.1 Niger 235

10.1 Mozambique $\quad 262$

11.1 Namibia (formerly German South West Africa) 280

13.1 Somali clan family distribution 331

\section{Figures}

9.1 The theory of firing a gun 222

13.1 Outline of the total Somali clan genealogy 337

\section{Tables}

13.1 Approximate population distribution of the six clan families 


\section{Photographs}

The Fulbe chief of Booni 60

The menalamba leader Rabezavana $\quad 77$

Kebedech Seyoum, a female Patriot 99

Patriots at Debra Markos market 109

Andries Botha 131

Native and African troops in the Netherlands East Indies army $\quad 158$

Kawousan ag Kedda 198

Amadou Diop $\quad 242$

A Renamo unit 265

The inauguration of Heroes' Acre, Namibia 299

Heroes' Acre, Windhoek, Namibia 319

The Mullah's fortress in Taleh, Somaliland 345

Moryaan in Mogadishu 356

The African Studies Centre has tried to trace all the copyright holders for the illustrations reproduced in this volume but sometimes without success. Anyone claiming rights in this regard is kindly requested to contact the African Studies Centre, PO Box 9555, 2300 RB Leiden, The Netherlands. 


\section{Preface}

The importance of this innovative volume lies in the way it links traditional studies of resistance to the more recent literature on conflict and violence in Africa. In this way it fills an analytical void by allowing a reinterpretation of the old resistance literature and by developing a new tradition of conflict studies. In this way, Rethinking Resistance reinforces the field of conflict studies and lifts this interesting and relevant area of research to a higher analytical plane.

A further richness of this collection is its diversity. Firstly, this diversity is geographical: the articles cover areas of Sub-Saharan Africa from the Sahel to South Africa and from the Fuuta Jallon mountains in Guinea to Somalia, not forgetting of course Madagascar. Diversity in time is also to be found: various pre-colonial revolts are treated as extensively as revolts that took place around the time of colonization, as are the anti-colonial insurgencies towards the end of this period of domination and the civil wars following independence. And finally there is the diversity of subjects: most of the chapters are devoted to historical accounts of the phenomenon of resistance and their significance, although at the end of the volume there are equally discussions concerning the memory of revolt and its use towards ends which often only preserve an indirect link with historical reality.

A further interesting aspect of this book is that it focuses more, if not almost exclusively, on revolts, wars and periods of violence about which little or nothing is known than on the well-documented phenomena of resistance. This represents an important contribution to theoretical and comparative research. Let me cite two examples to illustrate this point. The first concerns the analysis of the Sawaba insurrection in Niger by Klaas van Walraven. This is the first time that such an account has been presented in the historiography of contemporary Africa, which is important as it will allow a subsequent comparison between the Sawaba revolt and that of the Frolinat in Chad. These two insurrections occurred virtually contemporaneously and in neighbouring Sahelian countries. However, the Sawaba revolt was destined to failure while the Frolinat-supported uprising evolved into a full-blown civil war that was only ended by the coming to power of a party of former guerrillas. How can two such similar events but with such different outcomes be explained? What were the factors that contributed to these contrasting results? From Van Walraven's research it might be possible to offer some first interpretations and answers to these questions. A second example is Ineke van Kessel's chapter on the Black Dutchmen in the Netherlands East Indies. As the author herself indicates, this example of a mutiny by Africans engaged in a colonial army is atypical but deserves to be compared with similar incidents that occurred in the King's African Rifles and to Senegalese infantrymen. 
Rethinking Resistance covers a wide range of issues and constitutes an important step towards a better understanding of the phenomenon of revolt and violence in Africa, as argued by the authors in the introductory chapter.

\section{Robert Buijtenhuijs}




\title{
Rethinking resistance in African history: An introduction
}

\author{
Klaas van Walraven and Jon Abbink
}

\section{Some conceptual and definitional issues}

Throughout Africa's history, distant as well as recent, Africans have resisted forces of domination. The theme of Africans rejecting or fighting the rule of others, African or non-African, and their struggle against forms of domination, injustice or exploitation has been a closely studied subject ever since the inception of modern African studies in the early 1960s. The interest in this central theme emerged in the heyday of anti-colonial struggle that was itself generally articulated through modern nationalist discourse. Spurred on by what appeared as the unstoppable tidal wave of decolonization after the Second World War, which reinforced the already widespread feeling that colonialism was a grossly unjust dispensation, many scholars felt the need to investigate whether and to what extent Africans had, all along, resisted the forces of colonial or white settler rule.

Thus, in 1958 the study by Shepperson and Price appeared, appropriately entitled Independent African, about John Chilembwe and the rebellion in Nyasaland (Malawi) during the First World War. ${ }^{1}$ This set the stage for representations of African reactions to colonialism as falling between resistance and collaboration - notions that were redolent of Europe during the Second World War. ${ }^{2}$ It also preceded the theme, pioneered by Terence Ranger, of the modern nationalist struggles of the 1950s and 1960s somehow being connected with earlier forms of violent resistance to the imposition or maintenance of colonial rule. Besides collaboration, European settlement and occupation were

\footnotetext{
${ }^{1}$ G. Shepperson \& T. Price, Independent African: John Chilembwe and the Origins, Setting and Significance of the Nyasaland Native Rising of 1915 (Edinburgh, 1958).

${ }^{2}$ S. Ellis, 'A New Look at Resistance; With Special Reference to Madagascar'; paper for the conference Revolt and Resistance in African History, African Studies Centre, Leiden, 11-12 October 2001.
} 
seen as having triggered, first, early forms of violent struggle (so-called 'primary' resistance) and, now, modern nationalist battles for independence ('secondary' resistance). ${ }^{3}$ The concept of resistance thus became the historical dimension of African nationalism. ${ }^{4}$

Inevitably, in later years, questions started to be raised about this representation of Africa's twentieth-century history. By the late 1960s historians had accepted that the construction of this history around the two antipoles 'resistance' - 'collaboration' grossly simplified its actual complexities. Resistance and collaboration were now seen as rational, alternative strategies to ${ }^{5}$ Africans trying to defend their interests in the face of the imposition of colonialism and capitalism ${ }^{6}$ - comparable in some ways, perhaps, to analyses of European reactions to Nazi occupation in terms of varying degrees of accommodation rather than through the moral prism of collaboration and resistance. More fundamentally, and much later, it was opined by Glassman that the historical resistance literature was marred by a teleology that constructed all African protest as leading inexorably to modern nationalism and decolonization. $^{7}$

Nevertheless, the early resistance literature as such could be said to have been a source of inspiration to some of the liberation struggles taking place in the 1960s or 1970s, and in that respect to have established a connection between early and later forms of resistance. This was certainly the case, at the level of elites, in the struggle for Zimbabwe, the early history of which had known a revolt against white occupation (1896-1897). ${ }^{8}$ Another example of this is provided by the work of Bley and Drechsler, ${ }^{9}$ which considerably influenced, at the level of nationalist propaganda, the struggle for independence in Namibia (see Chapter 11 in this volume).

3 T.O. Ranger, "Connexions between "Primary Resistance Movements" and Modern Mass Nationalism in East and Central Africa', Journal of African History, 9 (1968), 437-53 and 631-41.

${ }^{4}$ L. Vail \& L. White, 'Forms of Resistance: Song and Perceptions of Power in Colonial Mozambique', in D. Crummey (ed.), Banditry, Rebellion and Social Protest in Africa (London \& Portsmouth, NH, 1986), 193.

5 J. Suret-Canale, "“Résistance" et "Collaboration" en Afrique Noire Coloniale', Etudes Africaines Offertes à Henri Brunschwig (Paris, 1982), 319-31.

${ }^{6}$ See on this Vail \& White, 'Forms of Resistance', 194 and 221.

${ }^{7}$ J. Glassman, Feasts and Riot: Revelry, Rebellion, and Popular Consciousness on the Swahili Coast, 1856-1888 (Portsmouth, NH \& London, 1995), 12.

${ }^{8}$ T.O. Ranger, Revolt in Southern Rhodesia, 1896-1897 (London, 1967).

${ }^{9}$ H. Bley, South West Africa under German Rule, 1894-1914 (London, 1971) and H. Drechsler, 'Let us Die Fighting': The Struggle of the Herero and Nama against German Imperialism (1884-1915) (London, 1980). 
Yet it is doubtful whether this connection represented more than, in the words of Ranger himself, the 'continuity of resistance emotion'. ${ }^{10}$ Thus, in the midst of the 'second chimurenga' ('fighting in which everyone joins') struggle for independence, Ranger emphasized that this struggle in no sense represented a 'return to the values of the society engaged in the 1896 risings' and, more debatably, that the current struggle could not be informed by continuing Shona or Ndebele cultural forms. ${ }^{12}$ He also criticized the other key, and politically committed, figure of the early resistance literature, Allen Isaacman, for replacing his own continuist thesis with a sort of 'instant continuity' that established a direct link between, in Isaacman's case, Frelimo's struggle against the Portuguese in the 1960s and peasant militancy in Mozambique in the $1910 \mathrm{~s} .{ }^{13}$ Clearly, this sort of argument, which (implicitly) attributed proto-nationalist sentiments to early instances of resistance to colonial rule, carried the risk of anachronism. ${ }^{14}$ Ranger therefore wondered whether the debate about continuity or discontinuity of manifestations of resistance should not be transcended by a periodization of African history involving a series of qualitative transformations. ${ }^{15}$

In defence of the initial resistance literature, it should be pointed out that it was in part a response to Eurocentric studies that preceded it and characterized resistance to colonial conquest as reactionary struggles against the facts. ${ }^{16}$ The critics of these Eurocentric views saw resistance to be a forward-looking defence of African tradition against alien occupation, in the process assuming that the African societies involved were united in this common purpose. ${ }^{17}$ This assumption also underlay many analyses of Africa's later struggles for independence, which were invariably labelled nationalist and sometimes even as Marxist, transformations, thereby attributing a unity of ideas and organization to

${ }^{10}$ T.O. Ranger, 'Resistance in Africa: From Nationalist Revolt to Agrarian Protest', in G.Y. Okihiro (ed.), In Resistance: Studies in African, Caribbean, and Afro-American History (Amherst, 1986), 49; emphasis added.

${ }^{11}$ Standard Shona Dictionary, rev. ed. (Harare \& Bulawayo, 1987).

${ }^{12}$ T. Ranger, 'The People in African Resistance: A Review', Journal of Southern African Studies, 4 (1977), 1, 130.

${ }^{13}$ A.F. Isaacman, The Tradition of Resistance in Mozambique (London, 1976). See also A. Isaacman et al., "“Cotton is the Mother of Poverty": Peasant Resistance to Forced Cotton Production in Mozambique, 1938-1961', International Journal of African Historical Studies, 13 (1980), 614.

${ }^{14}$ Ellis, 'A New Look at Resistance', 3-4.

${ }^{15}$ Ranger, 'The People in African Resistance', 145-46.

${ }^{16}$ Glassman, Feasts and Riot, 9-10, on R. Robinson \& J. Gallagher, 'The Partition of Africa', in F.H. Hinsley (ed.), The New Cambridge Modern History, vol. 11 (Cambridge, 1962).

${ }^{17}$ See for a critique, Glassman, Feasts and Riot, 10. 
them that in retrospect they seldom had. According to Norma Kriger, these labels at best betrayed some of the aspirations of the leading elites involved, ${ }^{18}$ although the chapter by Klaas van Walraven in this book on Sawaba's revolt in Niger shows that the relation between revolutionary ideology and elite aspirations may have been more complex.

A fundamental point of criticism of the early resistance literature was that the focus on resistance to white people or colonialism implied concentrating more on mere reactions of Africans than their true agency in historical development. ${ }^{19}$ Moreover, historians of modern African nationalism stressed the role played by elites, just as writers on imperial history had done. ${ }^{20}$ Hence, Allen and Barbara Isaacman in 1977 critiqued resistance studies as having been 'extremely elitist, a bias contemporary African historians share[d] with their Eurocentric predecessors'. ${ }^{21}$ During the 1970s, therefore, scholars began to add a nuance to this elitist perspective by focusing increasingly on the issue of class structure, arguing that it was the specific configuration of class interests that determined whether Africans resisted or collaborated with colonial or white settler rule. ${ }^{22}$ Marxist paradigms inspired a shift away from the search for the roots of nationalism to a search for the roots of underdevelopment, especially because by then so many African countries were stricken by growing economic malaise and political instability. ${ }^{23}$ It was argued that the earlier focus on resistance and nationalism obscured the extent to which Africans had been unable to strike at what were held to be the real structures of oppression, i.e. not colonial administrations but metropolitan capital (on which more below). Studies on so-called 'modes of production' began the redefinition of protonationalist resisters in Africa's colonial history into peasants fighting international capitalism. ${ }^{24}$

One of the consequences, however, was that the concept of resistance began to widen steadily. Isaacman et al., for example, portrayed the withholding of labour for cotton production by Mozambican peasants as an act of resistance. ${ }^{25}$

\footnotetext{
${ }^{18}$ N.J. Kriger, Zimbabwe's Guerrilla War: Peasant Voices (Cambridge, 1992), 11.

${ }^{19}$ Ranger, 'Resistance in Africa', 34.

${ }^{20}$ Glassman, Feasts and Riot, 11.

${ }^{21}$ A. Isaacman \& B. Isaacman, 'Resistance and Collaboration in Southern and Central Africa, c. 1850-1920', International Journal of African Historical Studies, 10 (1977), 1, 39.

${ }^{22}$ Ibid. 41.

${ }^{23}$ Vail \& White, 'Forms of Resistance', 194.

24 Ranger, 'Resistance in Africa', 34-36 and Ranger, 'The People in African Resistance', 142.

25 Isaacman et al., "Cotton is the Mother of Poverty", passim, and Isaacman \& Isaacman, 'Resistance and Collaboration', $47 \mathrm{ff}$.
} 
Crummey argued, more generally, that resistance could also be mute, with stealth being one of its principal characteristics. ${ }^{26}$ Scott later took up the theme in a series of pioneering and highly influential sociological studies drawing attention to the social basis of 'everyday resistance' of the downtrodden and the powerless. ${ }^{27}$ In a later study Achille Mbembe showed that even the world of dreams could be interpreted as relevant to resistance - in this case against the French in Cameroon during the 1950s. ${ }^{28}$ By then others had already objected that the widening of the resistance phenomenon overextended the concept ${ }^{29}$ to the point of including 'everything from footdragging and dissimulation to social banditry, arson, poaching, theft, avoidance of conscription, desertion, migration, and riot' - in short, 'any activity that helps to frustrate the operations of capitalism'; this frankly constituted an act of violence done to language, with 'resistance' and 'collaboration' blurring analysis of, instead of enhancing insight into, human behaviour. ${ }^{30}$ While it is true that, say, tax evaders and smugglers resisted colonial governments in some sense, interpreting their activities as an attack on the underlying political order greatly expanded the notion of political action - in line with Marxist reasoning. ${ }^{31}$ Often, this kind of approach also engendered evidential problems, which were 'resolved', to some extent, by reading political intent into actual conduct (see also below).

A positive aspect of the extension of the resistance concept was precisely that it took analysis beyond the political dimensions of struggle on which relevant studies had concentrated before. Moreover, early resistance studies focused too narrowly on revolts during the colonial era, thereby overlooking acts of resistance against the rulers of pre-colonial polities and seeing revolt in the post-independence era as a mere colonial hangover. The combined effect

${ }^{26}$ D. Crummey, 'Introduction: The Great Beast', in Crummey, Banditry, Rebellion and Social Protest, 10.

${ }^{27}$ J.C. Scott, Weapons of the Weak: Everyday Forms of Peasant Resistance (New Haven \& London, 1985) and idem, Domination and the Arts of Resistance. Hidden Transcripts (New Haven \& London, 1990). The reality of silent sabotage and cheating (by peasant serfs) is delightfully presented in the great nineteenth-century novels on feudal Russia by, for example, Turgenev and Gogol. Remarkably similar in tone is the epoch-making novel on pre-revolutionary Ethiopia by Haddis Alemayehu, Love until the Grave (Addis Ababa, 1973).

${ }^{28}$ A. Mbembe, 'Domaines de la Nuit et Autorité Onirique dans les Maquis du SudCameroun (1955-1958)', Journal of African History, 31 (1991), 89-121.

${ }^{29}$ P. Geschiere, 'Le Politique "Par le Bas". : Les Vicissitudes d'une Approche', in P. Konings, W. van Binsbergen \& G. Hesseling (eds), Trajectoires de Libération en Afrique Contemporaine: Hommage à Robert Buijtenhuijs (Paris \& Leiden, 2000), 97.

${ }^{30}$ Vail \& White, 'Forms of Resistance', 195.

${ }^{31}$ Ellis, 'A New Look at Resistance', 3. 
was to exaggerate the importance of the colonial period..$^{32}$ One concept that it was hoped during the 1970s and 1980s could help in 'de-politicizing' resistance studies and focusing more on the initiatives of the dominated was that of 'social banditry' as popularized by Eric Hobsbawm in European historiography. Inspired by the legend of Robin Hood, the concept of the social bandit arises in the dialectic of social demand and interdependence, leading the bandit to protect, redistribute, avenge and sometimes even lead wholesale rebellions against the political order. ${ }^{33}$ Such revolt is mostly seen as defensive, inspired by a specific vision of the social universe as held by the lower orders of society, for example peasants, ${ }^{34}$ that attempted to protect this vision - called the 'moral economy of subsistence' - against the hegemonic ideology of the ruling classes. $^{35}$

Studies that applied the social banditry concept to African cases of resistance remained, perhaps, relatively few. Isaacman et al. presented robberies from cotton warehouses by discontented Mozambican peasants as 'a legitimate expression of peasant protest' that was 'clearly different from the predatory actions of criminals who preyed indiscriminately on all sections of society', ${ }^{36}$ in other words, fulfilling those key conditions distinguishing the social bandit from the common criminal, i.e. the desire to destroy oppressive institutions perceived to threaten the traditional order and the intention to redistribute the loot of operations to 'the people'. To Isaacman, the social bandit could help us understand early rural resistance to colonialism and capitalism, arguing that this form of banditry was an important form of resistance in early twentieth-century Africa with rural alienation and a perception of colonial governments as illegitimate interlopers and the availability of sufficient geographical space as critical factors in the growth of this social and political activity. ${ }^{37}$

Hence, studies appeared that focused on social banditry besides the resistance concept as such. An early example is the study by Edmond Keller that constructed the Mau Mau revolt in Kenya in the 1950s as a form of social banditry, ${ }^{38}$ and the volume edited by Crummey. ${ }^{39}$ This volume provided, among

\footnotetext{
${ }^{32}$ Crummey, 'Introduction'.

${ }^{33}$ Ibid.

${ }^{34}$ See E. Wolf's influential book Peasants (Englewood Cliffs, 1966), 106-9, and his Peasant Wars of the Twentieth Century (New York, 1969).

${ }^{35}$ Glassman, Feasts and Riot, 13.

${ }^{36}$ Isaacman et al., "Cotton is the Mother of Poverty", 604.

37 A. Isaacman, 'Social Banditry in Zimbabwe (Rhodesia) and Mozambique, 18941907: An Expression of Early Peasant Protest', Journal of Southern African Studies, 1 (1977), 29-30.

${ }^{38}$ E.J. Keller, 'A Twentieth Century Model: The Mau Mau Transformation from Social Banditry to Social Rebellion', Kenya Historical Review, 3 (1973), 2, 189-205.
} 
others, analyses of the shifta tradition in Ethiopia - a remarkable example of social banditry but always with a political overtone. The (Amharic) word refers to people who had a political reason to remove themselves from the authority or law of power holders and 'went into the woods' where they engaged in political resistance as well as banditry to sustain themselves. Interestingly, the chapter by Aregawi Berhe in our volume shows how the shifta tradition helped to inform and structure a more modern form of resistance to colonial rule, that of the 'Patriot' movement fighting the Fascist Italian conquest and occupation from 1935 to 1941 . However, other studies questioned the applicability of the social banditry concept to African history. Maughan Brown $^{40}$ disputed the appropriateness of the concept to Mau Mau in Kenya, as did Colin Darch for Renamo in Mozambique, ${ }^{41}$ whilst even Isaacman himself showed that the 'social' bandits he studied did prey on some of the peasants or migrants in Mozambique - in contravention of Hobsbawm's model suggesting that they refrain from predatory behaviour against the people of 'their own' territory. By arguing that these early Mozambican bandits never attacked their natal communities or rural people that explicitly supported them, Isaacman could uphold their 'social' status. Nevertheless, one could argue that the fact that these bandits lacked Hobsbawm's class consciousness and did not perceive themselves as the defender of all peasants - differentiating as they did between rural people on the grounds of social proximity and political support ${ }^{42}-$ engenders evidential difficulties and reduces the practical applicability of the social banditry concept, in this as well as most other cases.

More fundamentally, Austin observed in the volume edited by Crummey that the distinction between social bandits and common criminals requires one common political system that claims hegemony over both rich and poor. Conceptually, social banditry in Western history constituted a challenge to existing forms of control over territory and property but not of the validity of these concepts as such. This, however, is the root problem in the applicability of social banditry in African historical contexts. First, the relatively open frontiers of pre-colonial polities encouraged deviants not to challenge the common central authority but, rather, segment and constitute their own political system with their own underlying values. Second, before and since the imposition of colonial rule, the forces of the modern state and market began, to varying degrees, to pervade African societies, thus allowing for the coexistence of

\footnotetext{
${ }^{39}$ See note 4 above. Based on conference papers of earlier in the decade.

${ }^{40}$ D.A. Maughan Brown, 'Social Banditry: Hobsbawm's Model and "Mau Mau", African Studies, 39 (1980), 1, 77-97.

${ }^{41}$ C. Darch, 'Are There Warlords in Provincial Mozambique?: Questions of the Social Base of MNR Banditry', Review of African Political Economy (1989), 45/46, 34-49.

${ }^{42}$ Isaacman, 'Social Banditry', 25.
} 
competitive socio-political values. The interpenetration of two formerly distinct societies (in our case the European colonial and the African ones) therefore produced 'primary' forms of resistance with no repertoire of common values shared between the opposing sides. The Robin Hood narrative is therefore largely lacking in African mythology, with the vocabulary of deviance more often developed in the language of magic and witchcraft. ${ }^{43}$

The same fundamental objection could therefore, at least in certain cases of African resistance, be levelled against the use of the concept of protest. This notion differs from the concept of resistance in that protest entails a higher degree of vocalization. While resistance may be mute or take place through stealth, protest assumes a more explicit form of articulation of grievances, marked among others by such (modern) cultural forms as strikes, campaigns of defiance, riots and disorder. ${ }^{44}$ According to Crummey, however, as in the case of social banditry, such protest presumes some common social and political order that links the protesters to those they appeal to for redress. ${ }^{45}$

In this volume, therefore, we continue to use the concept of resistance, employing it in a broad sense to signify intentions and concrete actions taken to oppose others and refuse to accept their ideas, actions or positions for a variety of reasons, the most common being the perception of the position, claims or actions taken by others as unjust, illegitimate or intolerable attempts at domination. The concrete acts of resistance involved may or may not be acts of physical violence and extend also to other spheres of human behaviour. Resistance, however, must be defined not so much by various forms of concrete acts, as by the intent of those performing these acts, aimed usually at the defence of pre-existing and cherished socio-political arrangements, upholding other civilizational ideals, or just defending existing power structures, elite or otherwise. This also helps to distinguish (violent) resistance from the concept of violence as such, which is employed in a more instrumental or technical way here, though not without attributing meaning to it (see below). Finally, as shown in the literature, large-scale manifestations of collective resistance have been described with the aid of different notions, such as revolution, revolt, insurrection, insurgence or insurgency, and rebellion. In this volume, the concept of revolution is eschewed, ${ }^{46}$ since it usually signifies very radical,

43 R.A. Austin, 'Social Bandits and Other Heroic Criminals: Western Models of Resistance and Their Relevance for Africa', in Crummey, Banditry, Rebellion and Social Protest, 89-94.

${ }^{44}$ See, for example, R.I. Rotberg \& A.A. Mazrui (eds), Protest and Power in Black Africa (New York, 1970).

${ }^{45}$ Crummey, 'Introduction'.

${ }^{46}$ The adjective 'revolutionary' will be used, however, when referring to the rhetorical or ideological dimensions of revolutionary transformations. 
fundamental transformations of societies and political systems quite exceptional in African history. The other terms will be used more or less synonymously, although the term 'resistance' perhaps carries more of the connotation of intent referred to above.

\section{Resistance to what?}

Even if one agrees that resistance has been a marked feature of human behaviour in African history, this begs the question already alluded to in the previous section of what or whom the target of such resistance was. In trying to answer this question, one leaves the area of even minimal consensus. Did Africans resist the imposition of colonial rule or specific configurations of capitalist economic relations associated with colonialism? ${ }^{47}$ Were political forms of resistance directed at the imposition of colonial rule or, as implied in the chapter by Stephen Ellis in this volume, were they as much directed at African elites profiting from the onset of capitalist relations of production? Were manifestations of resistance during decolonization aimed at ending colonial suzerainty or also the product of intra-elite rivalry, as argued in the chapter on the Sawaba revolt (Niger) in this book?

What is clear is that communities have resisted various forms of rule or domination throughout African history - a phenomenon, as emphasized by Crummey, not just limited to colonial rule but extending far back into precolonial times and covering most of the post-colonial and contemporary period. The chapter by Mirjam de Bruijn \& Han van Dijk in this volume graphically underlines the manifestation of resistance as a near-permanent characteristic of political life in pre-colonial West Africa, or at least of certain areas or polities in that region. Closely bound up with specific political economies and fragile ecological contexts, the lack of political stability and absence of monopolies of violence represented, perhaps, the fundamental hallmarks of the history of this region, as well as of many others. Analytically, resistance would then be a derivative notion, depending (though not in any mechanistic sense) on other concepts and features such as political instability, competitive value systems, economic exploitation and social (im)mobility. This would, in effect, render the resistance concept less useful for an analysis of African historical development. Perhaps then an alternative term like 'contestation' should be used.

It could be argued that the, at times, limited value of the resistance concept could be implied from several more recent resistance studies that appeared

${ }^{47}$ Ellis, 'A New Look at Resistance', 3, and Ranger, 'The People in African Resistance'. 
during the 1990s. Two important features of these studies, some of them marked by great detail and subtle analysis, are, first, the emphasis laid on the nature and degree of internal differentiation in communities involved in rebellions and, second, the role of coercion in the mobilization of people for the rebellious cause. The combined effect of these two nuances was to show how complex and multifaceted cases of resistance could be in their structure, development and, especially, their meanings and objectives. Thus, in the introduction to his brilliant study of the 1888 rebellion on the Swahili coast, Jonathon Glassman argued that, in general, peasant consciousness and resistance during the colonial period tended to grow out of an awareness of conflicts integral to the agrarian communities in which peasants lived. 'Tradition', in this context, was the cultural language or idiom in which peasants expressed conflicting views of their world and innovated new ones. ${ }^{48}$ This also constituted an important nuance of James Scott's view of the 'moral economy of the peasant' as something universal and unchanging. ${ }^{49}$ In order to describe the awareness of his own Swahili rebels, Glassman used the term 'contradictory rebellious consciousness', to which we will return below in the section on rebellious imagination.

Norma Kriger, working on the war of independence in Zimbabwe, similarly argued that the peasant concept as such has an external bias that implicitly assumes that differences internal to the peasantry pale into insignificance when compared to members of other classes or occupation and status groups. Hence, it vitiates against examining gender, lineage, and generational and other differences that are of considerable importance in explaining the evolution of rebellion and relevant peasant responses. ${ }^{50}$

Moreover, Kriger showed that coercion played some role in the mobilization of peasants for the second chimurenga (1972-1980), thus adding a vital nuance to our view of the struggle for Zimbabwe. Her field data suggested that guerrilla coercion may have been important in winning popular compliance, a point also notable in the thirty-year Eritrean struggle for independence. If true, this could not only profoundly affect our view of historical cases of resistance and rebellion but also bring the older resistance studies more in line with analyses of more recent wars and violent conflicts, in which coercion has tended to assume an important place. Other questions, which we will consider below, are whether the ideological motivation so prevalent in, especially, anti-colonial resistance

\footnotetext{
${ }^{48}$ Glassman, Feasts and Riot.

${ }^{49}$ J. Scott, The Moral Economy of the Peasant (New Haven, 1976).

${ }^{50}$ Kriger, Zimbabwe's Guerrilla War, 240. Ranger ('Resistance in Africa', 42) had already noted that historiography ought to focus more on the different peasant experiences in resistance cases.
} 
cases should not, therefore, be interpreted in a different light and whether the ideological dimension is not an understudied aspect as far as more recent revolts and conflicts are concerned.

With regard to Zimbabwe, Kriger showed that coercion may adversely affect popular support due to the fact that cultural nationalist appeals cannot compensate for the material sacrifices of the peasantry. The lack of peasant support that Kriger noted in the districts she studied may not have been an obstacle to guerrilla success, yet peasant attitudes undoubtedly affected the outcome. Caught between the guerrillas and the Rhodesian state, peasants pursued their own agendas, seeing the guerrillas as potential allies or susceptible to manipulation for their own objectives. Peasant resentment of the white minority government did not mitigate negative views about coercion by the guerrillas. Hence, the coercive nature of mobilization also had repercussions for post-war relations between peasants and the new government party, ZANUPF. ${ }^{51}$ This was confirmed by the important study by Alexander, McGregor \& Ranger, ${ }^{52}$ who provided an important testimony on the internal divisions during the war of independence and the pain inflicted by state violence thereafter. Another volume, edited by Bhebe \& Ranger, ${ }^{53}$ nuanced in this respect the role played by spirit mediums in peasant mobilization, well known since the study by David Lan. ${ }^{54}$

Clapham ${ }^{55}$ similarly concluded that a context of insurgency may or may not be marked by a relation of common interests between insurgents and the surrounding population. His edited volume marked, perhaps, the transformation of the 'freedom fighter' into the more straightforward 'guerrilla'. Concentrating solely on cases of resistance against the governments of post-colonial states, this book could not be seen to have the political commitment to the resisters themselves, as exemplified by the Isaacmans and maybe the early Ranger. Rather, it drove home the point that resistance is a phenomenon not limited to pre-colonial and colonial Africa. If rebellions against post-colonial states used to be explained away as a hangover of colonial rule, through the heavy if vague

\footnotetext{
${ }^{51}$ Kriger, Zimbabwe's Guerrilla War, Chapter 1.

${ }^{52} \mathrm{~J}$. Alexander, J. McGregor \& T. Ranger, Violence and Memory: One Hundred Years in the 'Dark Forests' of Matabeleland (Oxford, 2000).

53 See the introduction to N. Bhebe \& T. Ranger (eds), Society in Zimbabwe's Liberation War (Oxford, 1996), 12.

${ }^{54}$ D. Lan, Guns \& Rain: Guerrillas \& Spirit Mediums in Zimbabwe (London, Berkeley \& Los Angeles, 1985).

${ }^{55}$ C. Clapham (ed.), African Guerrillas (Oxford, 1998). This volume was the result of a two-day conference on this subject at the African Studies Centre in Leiden, January 1997.
} 
ideological concept of neo-colonialism, ${ }^{56}$ now it was argued that, very generally, violent revolt derives from blocked political aspirations and in some cases 'reactive desperation'.

Hence, in his typology of guerrilla insurgencies, Clapham listed 'separatist insurgencies', 'reform insurgencies' and 'warlord insurgencies', besides the now familiar 'liberation insurgencies'. He argued that revolts against independent African states initially grew out of failures in the decolonization settlement, subjecting peoples to governing groups widely considered as alien and illegitimate. Eritrea and southern Sudan were given as examples. Alternatively, revolts were, or are, triggered by unrepresentative, autocratic regimes, a category that actually merges with cases considered as failures in decolonization. Listing Chad and the Senegalese Casamance as examples, ${ }^{58}$ we could tentatively add two cases presented in this volume, namely that of Renamo's war in Mozambique, which was in part driven by regional discontent, and that of Sawaba's revolt in Niger, where the degree of regime illegitimacy was, however, overestimated. More straightforward desperation, according to Clapham, drove rebellions in Uganda under Amin and Obote, in Somalia under Siyad Barre (discussed by Jon Abbink in this volume), in Liberia and in Sierra Leone.

Generally, these types of insurgencies were long denied any legitimacy, by the OAU and internationally, but their growing acceptance as expressions of popular alienation in the post-Cold War era with its ideals of 'good governance' and multipartyism was reflected in this new scholarly attention. (The warlord type of insurgency is discussed below). Clapham observed, in this regard, that insurgencies occur in all types of rural African settings and economies. While the structure of society does not, therefore, seem to have much bearing on the incidence of rebellion, it has nevertheless some influence on the type of insurgency, with differences between these types more due to their receptivity in society than to their own ideology or organizational models. Hence, Clapham likened the technique of guerrilla struggle to pre-colonial modes of warfare and considered it the normal way of doing battle in societies without powerful states. He observed, in this respect, that a disposition to resort to insurgency may be linked to the structures and values of a society: where state structures are weak and the use of violence in pursuit of certain objectives was a normal feature of pre-colonial society, the incidence of violent resistance merely

\footnotetext{
${ }^{56}$ Ellis, 'A New Look at Resistance', 5.

${ }^{57}$ C. Clapham, 'Introduction: Analysing African Insurgencies', in Clapham, African Guerrillas, 5.

${ }^{58}$ Ibid. 3.
} 
represents the continuation of such practice in the post-colonial era. ${ }^{59}$ This underlines what was mentioned above about political instability (in the sense of imbalance or lack of permanence of the main features of a polity and its power configurations or continued violent opposition to these structures) as the salient feature of pre-colonial life in the nineteenth-century West African Fulbe polities. These pre-colonial socio-cultural characteristics also inform much of the context of twentieth-century Somali history, as shown in the chapter by Jon Abbink in this volume, and of the Patriots' resistance to the Fascist occupation of Ethiopia analysed by Aregawi Berhe (Chapter 4).

It would, however, be going too far to conclude that resistance as a concept has lost its analytical value due to the fact that so much of the political life in Africa's past and present is characterized by instability and physical violence. As shown in recent literature, many revolts in the past decade were affected if not driven by a sociological factor that has gained increasing importance, i.e. generational tension. Hence, at least some of these insurgencies were marked by more or less explicated political or ideological intentions, thus distinguishing them as cases of resistance as defined above, from the phenomenon of violence as such. With most Sub-Saharan countries marked by high birth rates and young populations but deteriorating economies, youths have been finding it ever harder to gain access to educational facilities, employment and social advancement and political representation. Competition for jobs, schooling and privilege, especially in the urban domains, has thus begun to mark, to a greater or lesser extent, relations between different generations and has, concomitantly, become a factor in post-colonial political systems and in several violent revolts emerging as a result of blocked mobility or political communication within those systems. Interestingly, this factor appears to have been present for much of the post-colonial period, if not always with the same urgency. Thus, it played some role in Sawaba's revolt in Niger during the 1960s, as analysed by Van Walraven in this volume. Kriger, too, showed that in the war for Zimbabwe during the 1980s youths were empowered by the chimurenga and sought to challenge the authority of the elders. Moreover, aspirations to gain a modern education have, perhaps, appeared as the outstanding driving force in the political mobilization of youth. As shown in this volume's chapters on Niger and Mozambique, promises of foreign scholarships sometimes constituted an effective means of recruitment of potential rebels, as the dream of overseas studies drove or lured youngsters to participate in revolts against their governments.

An important recent study of resistance in which the anger of youth was attributed a crucial role is Paul Richards's analysis of the RUF rebellion in

\footnotetext{
${ }^{59}$ Ibid.
} 
Sierra Leone. ${ }^{60}$ Arguing that the decline in patrimonial distribution during the 1980 s tested the loyalty of the younger generation while the capacity of the state to control its formal territory diminished sharply, Richards stressed that this conflict was manifestly not an ethnic one. Rather, it was driven by a younger generation, in particular by young school drop-outs and, more generally, victims of educational collapse. Other studies have similarly underlined the importance of youths, and especially of school drop-outs, in recent resistance movements. For instance, the leader of the Lord's Resistance Army (LRA) in Uganda, Joseph Kony, was a school drop-out himself, ${ }^{61}$ while marginalized youths decided in droves, and without consulting their parents, to join the Mai-Mai militias fighting in the east of Congo-Kinshasa. ${ }^{62}$

Participants in the fierce fighting that wrecked Congo-Brazzaville in 199394 and again in 1997 were mostly young men (aged 15 to 35), in the first wave of violence from the capital itself and in the second wave from several other towns in the country, most of those involved being school drop-outs. Since educational advancement in Congo had always been affected by political considerations, the economic decline and rising graduate unemployment of the 1980s and 1990s threw idle youngsters, who had at least some experience of political mobilization, onto Congo's streets. Even if the social frustrations of these youths did not directly cause the civil war (which was very much the immediate result of rivalry between more comfortably positioned and older politicians), their thwarted expectations of social and economic advancement proved a rich recruiting ground for those wishing to create a personal army. This, of course, does not constitute the central objective to be attributed to the Congolese conflict, at least not at the level of the leaders who began the revolt against President Lissouba. Yet the social frustrations of Congolese youths deeply affected the course and nature of the insurrection. In a study of this violent period, Bazenguissa showed how the militiamen went on a looting spree to recompense themselves and their families, targeting any urban property, including that of people of their own ethnic group, as well as that of the very politicians who had hired them in the first place. With fine houses regarded as the receptacle of the power exercised by a politician, the looting became a genuine trial for a political class of elders that was collectively held responsible for the misfortune of the young. However, while the pillaging indicated some political awareness on the part of the militiamen in the sense that it symbolized

${ }^{60}$ P. Richards, Fighting for the Rain Forest: War, Youth \& Resources in Sierra Leone (Oxford \& Portsmouth, NH, 1996).

${ }^{61}$ R. Doom \& K. Vlassenroot, 'Kony's Message: A New Koinè?: The Lord's Resistance Army in Northern Uganda', African Affairs, 98 (1999), 21.

${ }^{62}$ F. van Acker \& K. Vlassenroot, 'Les "Maï-Maï" et les Fonctions de la Violence Milicienne dans l'Est du Congo', Politique Africaine, 84 (December 2001), passim. 
an emergent social distance between them and the political leaders, this ideological aspect should not be overrated as it was to some extent a mere justification to satisfy some immediate material desire. ${ }^{63}$

It is therefore hard, or has become harder when compared to past cases, to attribute more or less explicit ideological objectives to some of Africa's more recent strife. Hence, concepts like resistance and guerrillas, let alone freedom fighters have increasingly given way to notions such as 'new wars', 'warlords' and, quite simply, 'conflicts' (see also Jon Abbink's chapter in this volume). Whatever political objectives are ascribed to recent conflicts, these cannot be explained by reference to African nationalism - the ideological dimension of the original resistance studies. The armed clashes between the rival wings of Zimbabwe's guerrillas during the early 1980s had already raised uneasy questions about the nature of ethnicity and factional conflict in the nationalist movement of a country that had been at the centre of debate in the resistance literature ${ }^{64}$ Later and much more violent (or at least more atrocious) conflicts such as those in Liberia, Sierra Leone and Mozambique clearly showed that not all acts of resistance to official authority constitute forces of progress or emancipation. Consequently, as discussed further in the section below on violence, recent scholarship has produced more anthropologically oriented studies that tend to view wars as very complex social phenomena, rather than as struggles in straightforward support of modern political ideologies. ${ }^{65}$

The rise of the African warlord has had important implications for our imagination of, and the attribution of meaning to, recent violent revolt. Warlord insurgency can be described as aiming to weaken or overthrow the official state leadership, with the formal control of the state a desirable objective though not necessarily essential. Rebels such as Jonas Savimbi and Charles Taylor could simply take over substantial parts of the formal state territory and introduce quasi-governmental structures to run them without actually overthrowing the internationally recognized government. ${ }^{66}$ However, an analysis of the behaviour of warlords does not in itself constitute the meaning - in terms of objectives and

${ }^{63}$ R. Bazenguissa-Ganga, 'The Spread of Political Violence in Congo-Brazzaville', African Affairs, 98 (1999), passim.

${ }^{64}$ K.P. Yap, 'Uprooting the Weeds: Power, Ethnicity and Violence in the Matabeleland Conflict, 1980-1987', PhD thesis, University of Amsterdam (2000).

${ }^{65}$ In this field, anthropological studies on Asia and Latin America preceded those on Africa. For an excellent study on southern Sudan, see S.E. Hutchinson, Nuer Dilemmas. Coping with Money, War and the State (Berkeley, 1996). See also Ellis, 'A New Look at Resistance'.

${ }^{66}$ Clapham, 'Introduction: Analysing African Insurgencies', 7-8. The shadow state concept coined by William Reno (Corruption and State Politics in Sierra Leone, Cambridge, 1995) makes the control of formal state structures superfluous. 
intentions - of their concrete military activities, which as such represent a rebellion against the formal state authority. The study by William Reno of warlord politics and African states ${ }^{67}$ did not really define warlords and their objectives but, rather, described their actual behaviour. Against a background of collapsing state patronage politics, Reno ascribed the warlords' actions to the pursuit of power and wealth, for purely private interests completely dissociated from the state project.

Several points of interest come into play here. First, is there any similarity between this warlord action and the role of 'big men' in pre-colonial political cultures? Second, how are evidential problems resolved in reconstructing the intentions behind the actions of these modern rebels? Instead of simply reading political intent in actual conduct, one should carefully research the motives of the specific warlords in question -as far as conditions and data allow - since even in this category of political actors there are differences between individual cases. For example, recent literature suggests that there were certainly differences between the motives of the RUF leadership in Sierra Leone and, say, those driving Charles Taylor's revolt against the Liberian government of Samuel Doe. ${ }^{68}$

Furthermore, if the rebellious intention of warlords is reduced to the pursuit of wealth and power for wholly personal benefit, how close does this come to the much criticized view of Paul Collier that wars are mainly motivated by the desire for economic gain ${ }^{69}$ or even to the 'new barbarism' thesis exemplified by Robert Kaplan, ${ }^{70}$ arguing that resource competition, environmental stress and culture clashes provoke violent anarchic revolts, i.e. 'apolitical events indistinguishable from banditry and crime' ${ }^{71}$ Finally, are we not too easily overlooking the possibility of ideological motivation - even if broadly defined on the part of these modern rebels ${ }^{72}$ and could this not also be in line with the

${ }^{67}$ W. Reno, Warlord Politics and African States (Boulder, CO \& London, 1998).

${ }^{68}$ Richards, Fighting for the Rain Forest, and S. Ellis, The Mask of Anarchy: The Destruction of Liberia and the Religious Dimension of an African Civil War (New York, 1999).

${ }^{69}$ P. Collier, 'Doing Well out of War: An Economic Perspective', in M. Berdal \& M. Malone (eds), Greed and Grievance: Economic Agendas in Civil Wars (Boulder, CO, 2000) and Ellis, 'A New Look at Resistance', 7.

${ }^{70}$ As phrased by Richards, Fighting for the Rain Forest. R.D. Kaplan, 'The Coming Anarchy: How Scarcity, Crime, Overpopulation, Tribalism, and Disease Are Rapidly Destroying the Social Fabric of Our Planet', The Atlantic Monthly, February 1994.

${ }^{71}$ Richards, Fighting for the Rain Forest, xiv. Emphasis added.

72 See for this also R. Buijtenhuijs, 'The Rational Rebel: How Rational, How Rebellious? Some African Examples', Africa Focus, 12 (1996), 1-3, 3-25 and idem, 'Peasant Wars in Africa: Gone with the Wind?', in D. Bryceson, C. Kay \& J. Mooij (eds), Disappearing Peasantries?: Rural Labour in Africa, Asia and Latin America 
decline of explicit ideologies in the post-Cold War era and with, as some have argued, the 'decidedly cynical context' of current Africanist scholarship? ? $^{73}$

Here it should be noted that violence can also be constructed as a political act aimed at gaining power and ending one's social exclusion. ${ }^{74}$ Atrocities and even wholesale material destruction have, in this respect, an underlying, and what can sometimes be called political, intention. The RUF revolt in Sierra Leone is an example, as are the LRA's actions in Uganda. Thus, while Doom \& Vlassenroot ${ }^{75}$ assessed Kony's programme as 'from the start rather indistinct, a mixture of political entrepreneurship, personal frustration and warlordism' and concluded that he is no longer trying to win the conflict but is content with employing violence as a tool and end in itself, they also noted his antiestablishment message, which was to be realized through destruction and could be considered to some extent as being political in intent. This issue is pursued further in the following sections.

\section{On violence}

Even if not all of the more recent rebellions lacked political content, it is clear that they differed considerably - at least as far as style and military execution were concerned - from the project underlying, for example, Frelimo's war against the Portuguese or that of the Patriotic Front against the Rhodesian state. In particular, the nature of the violence involved has undergone changes since the onset of colonial rule, anti-colonial revolts and decolonization.

Violence can be defined as the contested use of damaging physical force against other human beings with possibly fatal consequences. ${ }^{76}$ While it should be distinguished from the concept of resistance explained above, it should be realized that violence usually involves an intention on the part of those employing it, i.e. the deliberate humiliation of other human beings, often with

(London, 2000), 112-22. Other examples of ideologically motivated insurgencies would be the SPLA struggle in southern Sudan or the resistance of the northern Somali National Movement against the Siyad Barre regime in former Somalia in the 1980s and 1990s.

${ }^{73}$ R. Jeffries, 'Ghana's PNDC Regime: A Provisional Assessment', Africa, 66, 2 (1996), 291.

${ }^{74}$ Van Acker \& Vlassenroot, 'Les "Maï-Maï", 103.

${ }^{75}$ Doom \& Vlassenroot, 'Kony’s Message', 22, 24 and 35-36.

${ }^{76}$ Cf. J. Abbink, 'Preface: Violation and Violence as Cultural Phenomena', in G. Aijmer \& J. Abbink (eds), Meanings of Violence: A Cross Cultural Perspective (Oxford \& New York, 2000), 1 and idem, 'Restoring the Balance: Violence and Culture among the Suri of Southern Ethiopia', in Aijmer \& Abbink, Meanings of Violence, 79. 
the objective of achieving or maintaining domination over them. In this analytical, and not normative, sense violence is much more meaningful than is frequently assumed, while it is also often rule-bound (though not always) and sometimes constituent of new social relations. ${ }^{77}$ Indeed, violence is a form of 'social' behaviour, ${ }^{78}$ in the sense of sociologist Marcel Mauss's 'total social fact' - set in a universe of cultural meaning and 'communication', however normatively negative that may be.

This is also true for 'terrorism', a term that may have some relevance to certain cases of resistance described in this volume. Terrorism is defined as the method, or the theory behind the method, whereby an organized group seeks to achieve its aim mainly through the systematic use of intimidating violence, ${ }^{79}$ usually against arbitrarily chosen individuals. Thus defined, it distinguishes itself from the concept of resistance through the predominance of sheer violence over any other instruments with which one could theoretically attempt to reach one's goal, such as through persuasion, propaganda, and non-coercive mobilization generally. Terrorism excludes violent clashes with the opponent, since it involves the use of violence against a target that is largely constructed as victim. According to Hardman, terrorism even excludes mere intimidation as the terrorist is defined by the actual use of violence, although this is an unhistorical definition. In contrast, Crenshaw entertained, as we do, a broader definition including also the threat of violence. ${ }^{80}$

There is a widespread view, however, that terrorism has a political purpose, which means that it must be seen as a form of rational behaviour in the instrumental sense. Terrorism represents purposive behaviour, involving a conscious strategy, to communicate a political message rather than directly defeat the terrorist's opponent. Terrorists generally seek to arouse not only the government deemed to be their enemy but also, and especially, the wider public - the message being that the government's authority does not go unchallenged. This publicity factor is a key aspect of a terrorist strategy and implies that the target of terrorist action lies in the realm of symbolism. Its users expect a reward out of proportion to the resources employed and, sometimes, the risks

\footnotetext{
${ }^{77}$ J. Abbink, 'Preface', 2 and A. Blok, 'The Enigma of Senseless Violence', in Aijmer \& Abbink, Meanings of Violence, Chapter 1.

${ }^{78} \mathrm{~J}$ Abbink, 'Restoring the Balance', 77.

${ }^{79}$ J.B.S. Hardman, 'Terrorism', in E.R.A. Seligman \& A. Johnson (eds), Encyclopaedia of the Social Sciences (New York, 1950), vol. 13, and M. Crenshaw, 'Terrorism', in N.J. Smelser \& P.B. Baltes (eds), International Encyclopaedia of the Social \& Behavioral Sciences (Amsterdam, 2001), vol. 23.

${ }^{80}$ Ibid.
} 
taken. Its use can also be seen in the context of inequality of power relations, which forces the militarily weaker party to be deceptive. ${ }^{81}$

There are several dimensions to revolts such as those staged by Renamo in Mozambique, the RUF in Sierra Leone or the LRA in Uganda that would qualify as 'terrorist' as it is defined here. Many of the more disturbing aspects of these recent forms of resistance are discussed in Gerhard Seibert's analysis of Renamo in this volume. In the early twentieth-century Somali revolt of the Sayyid Mohammed 'Abdulle Hassan (see Chapter 13), one could also speak of terrorist tactics against those Somalis opposed to him. However, before some more general remarks are made on this kind of violence, it can be noted from the above discussion that the concept of terrorism is emotionally very powerful, lending itself to subjective interpretations that are usually driven by political or moral purposes. ${ }^{82}$ It is obviously a term with strong pejorative connotations. In the hegemonic ideologies of ruling elites, the violence practised by those dubbed as 'terrorists' is denied any legitimacy - to which purpose the term 'terrorism', in its dictionary meaning, is also applied. While terrorism practised by formal governments usually appears or is presented as law enforcement, that of non-governmental, unrecognized groups is condemned as law breaking. ${ }^{83}$ Consequently, this volume avoids the term 'terrorism' and employs the notion of violence instead, although the ideas behind the terrorism concept may inform our understanding of this violence.

The horrors in Mozambique described by Seibert call for an explanation that, unfortunately, denies them unique status. Thus, an interesting comparison is provided by the war in Sierra Leone, in which atrocities were committed that Richards argued to be deliberate and intentional. First, this war had a clear political context and its belligerents had rational political aims. Rebel violence was not an instinctive response to population pressure, as suggested by Kaplan, but the result of a mobilization of youths fighting out of social frustration on behalf of a small group of angry excluded people. ${ }^{84}$ While the RUF's head, Foday Sankoh, exercised largely exhortatory leadership, the rebel war effort was, in fact, directed by a war council. Radio communication played a vital role, inspired perhaps by Sankoh's personal background as a radio signals technician and thereby striking an interesting parallel with one of his heroes fellow radio technician Pol Pot. In addition, and in marked contrast to the centrally organized structure of Renamo discussed by Seibert, the confidence

\footnotetext{
${ }^{81}$ Crenshaw, 'Terrorism'.

${ }^{82}$ Ibid.

${ }^{83}$ Hardman, 'Terrorism'.

${ }^{84}$ Richards, Fighting for the Rain Forest, 164 and 178. See also T.R. Gurr, Why Men Rebel (Princeton, 1970).
} 
reposed in RUF commanders, both boys and girls, delegated the execution of daily battle to the lower cadres, thus providing the movement with strategic flexibility. The war, therefore, was not fought by 'madmen or mindless savages', but deliberately planned and executed corresponding to a consciously elaborated strategy. ${ }^{85}$

Secondly (and in line with the concept of terrorism), Richards observed that the violence was supposed to unsettle its victims. New recruits, for example, were terrorized in the process of capture, but later treated generously, with the whole process approaching and perverting the initiation ritual of the forest cultures of Sierra Leone and Liberia. Thirdly, the perpetration of atrocities had, according to Richards, specific objectives, at least initially. Rebels began amputating the limbs of nearby villagers to thwart the harvesting of crops and thus the restoration of food production and a return of normal village life to which hungry fresh recruits could escape. Feet were cut off recruits wishing to flee, while planned elections that threatened to sidetrack the rebels were checked by severing the hands of potential voters. The increasing menace of militias hostile to the RUF was met with another spate of mutilations. In this way, acts of violence became the logical way of achieving intended strategic outcomes, even if as a last-ditch expression of sectarian rationalism. Revenge for lynchings of suspected rebels, as well as attempts to fight the magical powers attributed to hostile militias and chiefs, would have provided additional reasons for rebel atrocities. ${ }^{86}$

Doom \& Vlassenroot also pointed to the deliberate and rational use of atrocious violence or, instead, to its beneficial effects for the LRA's cause in Uganda. The violence perpetrated by the LRA strengthened the power of the field commanders far beyond their logistic and military capabilities. The unpredictability of the LRA's violence was, in this respect, a key weapon. With a minimum of weaponry and well-trained troops, it was able to traumatize the entire population of northern Uganda. The random nature of its violence reinforced the rebels' self-confidence and the experience of impunity bolstered in-group cohesion. ${ }^{87}$

There are several similarities, as well as differences, between the violence perpetrated in these revolts and in Renamo's war as described by Seibert (Chapter10, this volume). First, in most cases the recruitment of rebels was violent, with the threat of punishment by the government after escape discouraging their desertion. In the Sierra Leonean, as well as Liberian ${ }^{88}$

\footnotetext{
${ }^{85}$ Richards, Fighting for the Rain Forest, xx, xix and 179.

${ }^{86}$ Ibid., passim.

${ }^{87}$ Doom \& Vlassenroot, 'Kony's Message', passim.

${ }^{88}$ Ellis, The Mask of Anarchy.
} 
conflicts, this also involved a manipulation of initiation ritual that was not present or as explicit in Mozambique or Uganda. Yet, in general, one can observe a process of degeneration in the perpetration of violence in the context of African tradition - a process also described by Abbink for the Suri people in southern Ethiopia, although admittedly on a much smaller scale. ${ }^{89}$ Seibert also points to 'cultic' aspects of the excessive violence committed by Renamo fighters that were often of an obscure nature or directed at violating sexual taboos. Here, he cites research undertaken by Wilson, ${ }^{90}$ who argued, like Richards and Doom \& Vlassenroot, that violence perpetrated by rebel forces was purposive. Renamo's atrocities were intended to instil a paralysing fear in the wider population for purposes of control with a minimum of means, which more or less strikes a parallel with the LRA's actions in northern Uganda. The actual number of incidents in Mozambique was not very great or at least out of proportion to its impact on the population. The ritual aspects involved were deliberately made incomprehensible so as to have a maximum effect in terms of fear. By making the violence appear to lack rationality and in the process creating a vision of inhumanity that set Renamo outside the realm of social beings, the rebels instilled a belief that the violence could not be managed thereby escaping from the bounds of social control and, hence, preventing the people from resisting. ${ }^{91}$

Thus, the violence perpetrated in these revolts is, in the strategicinstrumental sense, not irrational but deliberate and reasoned if atrocious. Its random nature serves to make it unpredictable, ${ }^{92}$ which in turn makes it unmanageable and therefore increases people's fear and their propensity to submit, especially if the form of violence is incomprehensible and, hence, alienating. ${ }^{93}$ In addition to moral issues, this raises fundamental questions as to whether such violence can, therefore, be truly understood. While such questions cannot be answered here, they have not only bothered numerous scholars but also writers, poets and novelists, such as authors who focused on the consequences of the Shoah in European history. ${ }^{94}$

\footnotetext{
${ }^{89}$ Abbink, 'Restoring the Balance'.

${ }^{90}$ K.B. Wilson, 'Cults of Violence and Counter-Violence in Mozambique', Journal of Southern African Studies, 18 (1992), 3, 527-82.

${ }^{91}$ Ibid. 531-33.

${ }^{92}$ But also see Van Acker \& Vlassenroot, 'Les "Maï-Maï”, 104.

93 The question of whether such violence achieves any long-term aims is, however, doubtful because at some point its exercise becomes an end in itself, a way of life in which no one believes except those who have no choice to get out. Resistance here becomes an empty concept.

94 See D. Diner, Beyond the Conceivable: Studies on Germany, Nazism, and the Holocaust (Berkeley, Los Angeles \& London, 2000) and idem, 'Negative Symbiose:
} 
It seems, therefore, difficult to explain the sheer extent and intensity of the violence involved in these revolts. In some respects, it may have been triggered by the (initial) cause or nature of some as a kind of last-ditch and embittered attempt to save local societies from social collapse and political hegemonies deemed illegitimate (the RUF in Sierra Leone and, less convincingly, the LRA in Uganda). In other respects, however, it is the external dimensions to these conflicts that appear to have fuelled the conflicts, even if these did not determine the form of violence involved (Renamo in Mozambique, although external/regional dimensions clearly played a role in Sierra Leone and northern Uganda too).

To some extent the degree of this violence was informed by the desire to destroy rather than construct or reform. Richards related this desire to the intellectual anger of excluded educated elites whose bitterness led them to 'save' their society through a war of devastation. Whether informed by the uncompromising mentalité of university intellectualism as exemplified by Peru's Sendero Luminoso (with which Richards compared the RUF) or spurred on by the despair and embitterment of more rural leaderships and rank and files, a penchant for destruction affects most resistance movements whose (original) aim is radical transformation. Indeed, while rural movements may wish to obliterate society because they feel that they cannot defeat ruling hegemonies or fit into the political system and are encouraged in this by a self-esteem inflated by their own violent powerfulness, ${ }^{95}$ even the more sophisticated programme of Maoist thought foresees a role for chaos and ruin as the necessary precursor of revolutionary change. ${ }^{96} \mathrm{~A}$ destructive tendency is, moreover, not simply the preserve of rural rebel movements alone. In a fascinating article, Mkandawire argued that it is urban malaise that lies at the root of the activities of and antipathy exhibited by post-colonial rebel movements towards rural

Deutsche und Juden nach Auschwitz', in D. Diner (ed.), Ist der Nationalsozialismus Geschichte? Zu Historisierung und Historikerstreit (Frankfurt am Main, 1987), 186-7. Also D. Diner (ed.), Zivilisationsbruch: Denken nach Auschwitz (Frankfurt am Main, 1988); L. de Jong, 'Die Niederlande und Auschwitz', in Vierteljahrshefte für Zeitgeschichte, 1969, 16; S.R. Horowitz, Voicing the Void: Muteness and Memory in Holocaust Fiction (Albany NY, 1997); and G. Banner, Holocaust Literature: Schulz, Levi, Spiegelman and the Memory of the Offence (London, 2000).

95 Richards, Fighting for the Rain Forest, 27 and Doom \& Vlassenroot, 'Kony's Message', 26 and 35.

${ }^{96}$ F.D. Colburn, The Vogue of Revolution in Poor Countries (Princeton, 1994). See also Chapter 9 in this volume. At the other and least sophisticated end of the scale, Bazenguissa observed a propensity of Congolese militias to destroy the residences of politicians as a consequence of past politicization of domestic space, although here it fused with a desire to satisfy personal greed. Bazenguissa, 'Spread of Political Violence', 49. 
populations. ${ }^{97}$ Their extreme violence towards rural folk would stem from their fundamentally opposed aims and agendas.

On a more controversial note, Wilson argued that organized violence appeared to be seen in northern Mozambique as a normal and likely, if somewhat undesirable, tool of economic and political activity, based on cultural conceptions of spiritual and magical male power elaborated under Renamo. ${ }^{98}$ While this would to some extent put the horrors narrated by Seibert in context, it seems in contrast to, or at least to differ from, the experiences of the chimurenga in Zimbabwe and its underlying Shona and Ndebele cultural notions stipulating the need for endorsement of violence by the ancestors and the necessity of cleansing after committing the violent act. ${ }^{99}$ Perhaps the level, if not the nature, of the violence in Renamo's revolt can also be partly explained by the tendency of violence to escalate once it is employed. As Seibert shows, at least in the initial stages of the war, Renamo enjoyed some local support or sympathy before the situation got out of control, just as the movements preceding the LRA in Uganda could reckon on support from the Acholi people before this culminated in a permanent state of terror. ${ }^{100}$ In addition, the role played by external powers (on which more below) had an escalatory effect on the levels of violence involved. As mentioned earlier, Jon Abbink has analysed this process of escalation for the Suri people in southern Ethiopia, where traditional violence has had a propensity to escalate under the influence of the state modernization project, ecological pressures but also the importation of modern small arms like the AK 47. ${ }^{101}$ Such weapons allow these people a fateful quantum leap in killing techniques, thus making the use of physical force contested in a way that 'traditional' violence with spears, knives or slow threebullet rifles was not.

One of the most disturbing aspects of violence in war and resistance is the sexual dimension. Women are constructed as objects and objectives of war and violence, something clearly shown in the more shocking details of Seibert's narrative of Renamo. Wilson argued, in this respect, that the ideological superstructure reserving agency for men and constructing women as a threat to that agency was reinforced by the use of sexual violence. The violent capacities of Renamo as an institution were conceived of partly as being based on male

${ }^{97}$ T. Mkandawire, 'The Terrible Toll of Post-Colonial "Rebel Movements" in Africa: Towards an Explanation of the Violence against the Peasantry', Journal of Modern African Studies, 40 (2002), 181-215.

${ }^{98}$ Wilson, 'Cults of Violence', 535. Compare also Abbink's argument on pre-colonial Somalia in Chapter 13 of this volume.

${ }^{99}$ Lan, Guns and Rain. See also the next section.

${ }^{100}$ Doom \& Vlassenroot, 'Kony's Message', 15 and 23.

${ }^{101}$ Abbink, 'Restoring the Balance'. 
power and, consequently, intimately threatened by the existence of female sexuality. ${ }^{102}$ Alternatively, raping women was an act of asserting superiority over men, as in the case of the Rhodesian security forces and their auxiliaries who violated African women in part to humiliate the guerrillas of the Patriotic Front. ${ }^{103}$

Nevertheless, rape and the subjection of women to the status of slave wives by Renamo were not really ritualized but instead considered as a 'bonus' for men participating in the revolt. ${ }^{104}$ Again, the fighters of the chimurenga were at times also involved in exercising what they saw as their rights over women, ${ }^{105}$ just as happened later on a wider scale in Sierra Leone, Liberia and during the genocide in Rwanda. As Bhebe \& Ranger observed in the struggle for Zimbabwe, ${ }^{106}$ women had to contend with the confused sexual morality of war, even if one cannot simply reduce their role to one of objects of exploitation. This, of course, is not an African phenomenon but a universal one, as shown in the fate of thousands of Muslim women during the civil war in Bosnia and in the experiences of the countless German women overpowered by the invading Russian armies in 1944-45. ${ }^{107}$ Perhaps this aspect, more than anything else, serves as a vital correction to the heroism so often attributed to resistance, revolution and even violence as such.

One last aspect of violence in African revolts to be noted here is the role of forces external to the societies concerned - be they colonial or white settler governments, the influence of racist ideologies, the totalitarian dispositions of certain European powers or, in the post-colonial era, the involvement of regional actors. In many cases these external forces influenced the nature and form of violence or helped to drive it to much higher levels. The chapter by Robert Ross in this volume shows how the vicissitudes of war and resistance on the South African frontier were affected, among others, by racist attitudes that bolstered white self-righteousness to the point that it was regarded as legitimate not just to subject but also to exterminate the African other. These inclinations were even more prevalent in the totalitarian dispositions of German and Italian

\footnotetext{
${ }^{102}$ Wilson, 'Cults of Violence', 536-37.

${ }^{103}$ See the introduction to Bhebe \& Ranger, Society in Zimbabwe's Liberation War, 26. Also see Doom \& Vlassenroot, 'Kony's Message', 27, on the widespread and public rape of men in northern Uganda by the LRA, as acts of humiliation.

${ }^{104}$ Wilson, 'Cults of Violence', 536.

${ }^{105}$ Introduction to Bhebe \& Ranger, Society in Zimbabwe's Liberation War, 26.

${ }^{106}$ Ibid. 27.

${ }^{107}$ See, for example, for the denial and knowledge of these massive rapes at the highest level of the Soviet leadership, M. Djilas, Conversations with Stalin (London, 1962), 88 and 102 quoting Stalin himself justifying and trivializing the rape and murder of women by soldiers of the Red Army in eastern Prussia and parts of Yugoslavia.
} 
colonial rule, as shown in Gewald's chapter in this volume on the Herero genocide and its aftermath in Namibia and Berhe's analysis of the brutal Italian repression of Patriot resistance in Ethiopia. These attitudes were part of a much wider European cultural complex, in which one set of mentalities claimed, if necessary, the right to kill with regard to those considered of inferior racial or cultural status. ${ }^{108}$ Indeed, some would argue that Europe's Shoah had specific antecedents if not roots in previous colonial experiences. ${ }^{109}$

That these dispositions cannot be regarded as something of the past is, moreover, shown by Ranger in his discussion of the 'guilt-free semantics of the Rhodesian war', which shielded white Rhodesians from raising uncomfortable questions about their own humanity. ${ }^{110}$ Such guilt-free semantics are, in fact, closely bound up with the waging of war itself and can be observed in any conflict to this day. Hence, Ken Flower, the chief of Rhodesian intelligence responsible for the creation of Renamo, admitted with shocking laconism that the force he had helped to field had just developed into a monster out of control. ${ }^{111}$

While Seibert is right to stress that the war in Mozambique had specific internal roots, we should not forget, as Wilson observed, that although the nature of Renamo's violence was informed by local cultural logics, its effectiveness and intensity were to a considerable extent bound up with the intervention of regional white powers. ${ }^{112}$ The same thing could be said about some of Africa's more recent revolts. The civil war in Liberia, for example, had profound regional dimensions that served to complicate and prolong the hostilities. ${ }^{113}$ The war in neighbouring Sierra Leone experienced the considerable involvement of Charles Taylor and his NPFL rebel movement in

\footnotetext{
${ }^{108}$ This point was clearly driven home, in a literary fashion, by Joseph Conrad, Heart of Darkness (1899; Penguin Books: London, 1989). As to the veracity of the horrors perpetrated by and attitudes of European agents in the Congo and some striking parallels to their literary representation by Conrad, see A. Hochschild's widely acclaimed King Leopold's Ghost: A Story of Greed, Terror and Heroism in Colonial Africa (London, 2000). While the facts of these shocking actions and mentalities reverberated in the more enlightened circles of European society for more than a decade, the eruption of World War I had the effect of diminishing historical awareness of this racial/cultural aspect of European humanity. See also next footnote.

${ }^{109}$ H. Arendt, The Origins of Totalitarianism (New York, 1951).

110 T. Ranger, 'Afterword: War, Violence and Healing in Zimbabwe', Journal of Southern African Studies, 18 (1992), 3, 704.

111 K. Flower, Serving Secretly: An Intelligence Chief on Record. Rhodesia into Zimbabwe 1964 to 1981 (London, 1987), 262.

${ }^{112}$ Wilson, 'Cults of Violence', 581.

113 K. van Walraven, The Pretence of Peace-keeping: ECOMOG, West Africa and Liberia (1990-1998) (The Hague, 1999).
} 
Liberia as well as of Sierra Leonean exiles based there and wishing to fight their way back home. Moreover, Richards emphasized that the earliest atrocities committed during Sierra Leone's civil war, rather than being the work of Sierra Leoneans, had actually been the work of foreign mercenaries. ${ }^{114}$ Similarly, Doom \& Vlassenroot ${ }^{115}$ observed that after 1994 the LRA in Uganda began to receive 'full-scale support from Sudan'. In other words, while it cannot be completely reduced to extraneous factors it seems difficult to conceive of the horrendous violence marking many of Africa's more recent revolts as being completely isolated from external involvement.

\section{Imagining}

Resistance and, perhaps to a lesser extent, violence are conceptually dependent on more or less specified intentions. Motivation is, consequently, one of their key components. In order to understand the phenomenon of resistance and violence in African history, one must therefore focus also on what those who organized, led or participated in revolts thought they were doing or intended to achieve. While from the perspective of the older resistance literature this was considered to belong primarily to the realm of ideology, in later publications the attribution of meaning to resistance was researched from other conceptual angles as well, such as discourse, religion and predominantly cultural features (rituals, values).

The concept of ideology became somewhat disqualified, partly because of the obvious inadequacies of the explanation that resistance movements were straightforward nationalist uprisings. These inadequacies stemmed, however, to some extent from classical definitions of ideology as referring to relatively comprehensive political programmes or complex and explicated systems of thought claiming universal validity and marked to varying degrees by systematization and coherence. ${ }^{116}$ Yet, viewed more or less along the lines of the concept of discourse, ideology could be seen as encompassing any views, ideas or thoughts purporting to provide meaning to cultural reality, political systems or social existence, at whatever level of abstraction and complexity. ${ }^{117}$ Marked by descriptive and prescriptive elements, ideology, as discourse,

\footnotetext{
${ }^{114}$ Richards, Fighting for the Rain Forest, 181.

115 'Kony's Message', 25.

${ }^{116}$ E. Shills, 'The Concept and Function of Ideology', in D.L. Sills (ed.), International Encyclopaedia of the Social Sciences (no pl., 1968), vol. 7, 66.

${ }^{117}$ P.H. Partridge, 'Politics, Philosophy, Ideology', Political Studies (1961), 227 and C. Clapham, 'The Context of African Political Thought', Journal of Modern African Studies, 1970, 2-3.
} 
represents the construction of meaning as a social process through spoken and written dialogue, leading to systems of meaning through which reality is imagined. ${ }^{118}$ Such a process of imagination is a social phenomenon and as such affected by its interaction with the social context, though not determined by it in a mechanistic sense. ${ }^{119}$

An important and subtle approach to the role of ideology in African resistance, with some bearing on certain chapters in our volume, is Glassman's earlier-cited analysis of the Swahili revolt of $1888 .{ }^{120}$ As mentioned above, Glassman used the term 'contradictory rebellious consciousness' to explain the tendency of rebels to express their grievances in language marked by or reminiscent of the hegemonic ideologies of ruling groups. Inspired by Gramsci, he did not dismiss this as a form of 'false consciousness' in the Marxist sense (i.e. consciousness appropriate to the material interests of another group), but argued, first, that the perceptual languages in which class positions are articulated tend to differ since beliefs are not created by or within one specific group but are forged in the crucible of social interaction, arising from the roughand-tumble of everyday struggle. Perceptions of group interests do not precede such struggle but grow out of it.

Second, and again following Gramsci, Glassman stressed that hegemonic ideologies influence popular consciousness not through the imposition of particular ideas but by the way that these ideologies shape the questions to be asked and the issues to be debated. The language of political culture is not an instrument for the defence of underlying interests but a form of discourse within which certain issues are defined and debated. Hence, popular consciousness is not appropriate to the material interests of either subordinate or dominant groups (nor is hegemonic ideology). Affected by hegemonic ideologies, popular consciousness is rarely revolutionary in the fullest sense, yet still contains much that is expressive of perceptions of struggle against those dominating society. Such consciousness is made up of different fragments of thought originating in different times and places, including conflicting daily experiences and hegemonic ideas. The result is a bizarre combination of ideological components crafted in the course of struggle in which individuals find justification for their

${ }^{118}$ D. Macdonell, Theories of Discourse: An Introduction (Oxford \& New York, 1989); R. Boudon, The Analysis of Ideology (Cambridge \& Oxford, 1989) and D.J. Manning (ed.), The Form of Ideology: Investigations into the Sense of Ideological Reasoning With a View to Giving an Account of its Place in Political Life (London, Boston \& Sydney, 1980).

${ }^{119}$ See for example, L.G. Graham, 'Ideology and the Sociological Understanding', in Manning, The Form of Ideology, Chapter 1; Boudon, The Analysis of Ideology and M. Vovelle, Ideologies and Mentalities (Cambridge \& Oxford, 1990).

${ }^{120}$ Glassman, Feasts and Riot. 
different agendas. As an ever-changing patchwork of thought, political awareness arises, in traditional or pre-modern settings such as pre- or early colonial Africa, not only over conflicting views of the ideal society but also over definitions of custom and tradition. In this context, defence of the local community is not an objective goal of struggle but the form of discourse in which the struggle occurs. This discourse, while being shared at many levels of society, is not a uniform mode of thought but an ideological or discursive language. ${ }^{121}$

The resultant forms of contradictory rebellious consciousness can be observed during different periods of Africa's history. Robert Ross's chapter in this volume shows, for example, how Khoi and English settlers along South Africa's Kat River came into violent conflict with each other and, against the background of hardening race relations, held conflicting views on the nature of early colonial society. Measures taken by white settlers not only threatened the material aspects of Khoi life but also dashed hopes of reconstructing Khoi lives in the context of loyalty to the British crown. Hardening British ethnic and racial consciousness determined who the opponents of the British were, and Khoi settlers 'rebelled because they were declared to be rebels': 'even then many of those who were considered to be disloyal to the Cape Colony struggled as hard as they could to preserve their loyalty'. In the process, the concept of resistance blurred with that of loyalty - i.e. allegiance to an older and now contested view of society. Similarly, Ineke van Kessel (Chapter 6 this volume) concludes that the African soldiers recruited for service in the colonial army in the Netherlands East Indies were caught in a colonial paradox since they were encouraged by the Dutch to look down on the Asian indigenes and maintain a status of Europeans while at the same time they were denied the equal treatment that this status implied, due to racial bigotry and meanness. In revisiting the menalamba rising, Stephen Ellis (Chapter 3 this volume) shows that this revolt was not only a movement of resistance to colonial rule but also a campaign against an unpopular Malagasy government that had discredited itself through forced labour and enslavement practices, and association with Christianity. The resisters aimed to restore the indigenous monarchy in what they saw as its proper form, purified from alien (religious) influences and the rapacious practices of the indigenous elite.

Perhaps the best example in our volume of revolt being motivated by the desire to resist foreign intruders or usurpers is the chapter by Aregawi Berhe (Chapter 4), although even in the case of the Patriots' resistance contradictory indigenous perceptions of what local African society should look like played a role in the background and aftermath of the resistance. Thus, the shifta tradition,

${ }^{121}$ Ibid. 16-20. 
which Berhe argues inspired the Patriots to fight the Italians, involved a tradition of rebellion against indigenous authorities that were regarded as having failed to deliver justice or respect local customs. While the essence of resistance to the Italians was to safeguard Ethiopia's independence, religious values and cultural identity, it also led Ethiopians to re-examine the nature and meaning of their own state in the context of the modern world. As Berhe concludes, some of the social and other political aims of Patriot resistance, such as ideas on social justice, equality and openness of the political system, later met with repression and violence from the Ethiopian authorities.

The Patriots' revolt shows, however, that in ideological terms, not all rebellions in African history can be classified fully as contradictory rebellious discourses. The chapter by Mirjam de Bruijn \& Han van Dijk in our volume is perhaps the best example of sharp clashes between antagonistic ideologies. Upcoming Fulbe minorities sought to legitimise their political and economic ambitions against existing hegemonies by propagating a stricter, 'uncorrupted' Islam that ostensibly promoted a new egalitarianism but gave justification to the violent subjugation of other peoples (especially non-Muslim groups), the plunder of their wealth and the exploitation of their labour. In the process, the oppressed became oppressors themselves and prompted the counter-resistance of communities that adhered to other religious beliefs, objected to Islam as the dominant ideology or tried to escape from the pressure of Islamic reform and (imposed) economic marginality. Even though individual Muslims also became the victims of Fulbe expansion and the discourse involved in these revolts was, consequently, marked by contradictions and ambiguities, the ideological counter-positions were, at least seemingly, put in sharp and uncompromising relief.

This was also true, though with different ideological reference points, for the Tuareg revolt against French colonial rule in Niger (1916-1920), analysed by Kimba Idrissa (Chapter 8). Idrissa, in revisiting the famous rebellion led by Yakin Kawousan, argues that the ideology of Islam, as represented by the Sanûssiya order, functioned mainly as a mobilizing vehicle that rejected any blind fanaticism of fighters who wanted to engage in a holy war against the infidel. Rather, the alliance with the Sanûssiya was of a tactical nature. Idrissa takes issue with Fuglestad's comparison of the revolt with classical forms of Tuareg pillaging, ${ }^{122}$ arguing instead that in Kawousan's case raiding had a political purpose, namely the weakening of the colonial enemy. He explains the revolt as an anti-colonial uprising against the loss of an aristocratic Tuareg hegemony over other cultural communities. This hegemony was based on a

${ }^{122}$ F. Fuglestad, 'Les Révoltes des Touareg du Niger (1916-17)', Cahiers d'Etudes Africaines, 13 (1973), 49 and 82-120. 
political economy involving nomadism, animal husbandry, raiding and slavery and grounded in beliefs of cultural superiority and independence of mind, both of which were obliterated or jeopardized by famine and the destruction by the French of Tuareg economic power through enforced sedentarization and subjection to colonial control. Here, too, few if any intermediate ideological positions would have seemed possible between the principal adversaries involved.

Ironically, with the chapter by Idrissa the arguments of the resistance literature turn full circle as he reintroduces the explanation of rebellions as manifestations of anti-colonial, if not fully (proto-)nationalist, uprisings. The chapter by Klaas van Walraven about a much later period in Nigerien history, the Sawaba revolt during the 1960s, shows, however, that it is impossible to generalize about the role of nationalist ideology. Rather than as the exclusive result of Marxist-inspired nationalist militancy, the revolt of the Sawabists was fuelled by personal aspirations for higher education, access to jobs and social advancement coupled with some ideological conviction and pragmatic opportunism. Hence, we can concur with the argument by Alexander, McGregor \& Ranger, ${ }^{123}$ made in another historical-geographical context, that popular motivation for supporting various forms of armed insurgencies proves resistant to generalization.

Moreover, the difficulties scholars have encountered in generalizing ideological motivation have increased considerably with regard to the more recent cases of armed rebellion to which, as noted above, it is much harder to attribute explicit ideological objectives. Richards's study of the RUF revolt in Sierra Leone is exceptional here since he argued that, beyond the horrors of death and mutilation, the rebel leadership held a clear vision of a reformed and accountable state as their ideological objective. This objective was to some extent inspired or affected by the populism of Gadaffi's Green Book ideology, Pan-Africanist militancy and the writings of an American futurologist, yet could not be communicated properly due to poverty, incompetence and sectarian isolation. Internally, the rebel movement was driven, like an 'enclave' culture, by meritocratic and egalitarian ideas about social accountability, which differed strongly from the surrounding local society that it had rejected. ${ }^{124}$ Interestingly, Van Acker \& Vlassenroot also read an enclave mentality in the aspirations of the Mai-Mai militias who mobilized certain traditions and new conditions of mobility in a new interpretation of customary defence, based on the social significance of the land but with rejection of the local traditional authorities. Yet, while displacing power into the hands of these young combatants, militia

\footnotetext{
${ }^{123}$ Alexander et al., Violence and Memory, 7.

${ }^{124}$ Richards, Fighting for the Rain Forest, passim.
} 
alliances remain(ed) weak and mobilized and divided in a continual process of transformations, on ethnic as well as financial grounds, precluding a common ideological objective such as the building of a new state. ${ }^{125}$

Consequently, the usefulness of the concept of ideology for an understanding of people's imagination of revolt and resistance remains limited. Other scholars, notably anthropologists, have therefore resorted to other conceptual angles. David Lan's study of spirit mediums had already drawn a lot of attention to the role of religious practices in the mobilization of Zimbabwe's peasants for the chimurenga. ${ }^{126}$ It showed how tradition afforded the war a revolutionary element - a paradoxical situation that had important implications for the struggle and its aftermath, since 'any attempt to establish political legitimacy [would] only succeed if it obtains the endorsement of the ancestors. For the ultimate test of legitimacy of any political system is its ability to provide fertility, to ensure that the crops grow, that the people prosper and are content. ${ }^{127}$ That this is or was true not only for Zimbabwe but also other African countries is shown in the chapter on Sawaba's revolt in Niger, where the ability to muster 'luck' and provide good rains and growth represented key elements in the regime's survival. African conceptions of political legitimacy thus provide their own peculiar dimension to wars of resistance. Bhebe \& Ranger, ${ }^{128}$ for example, argued that the rain shrines of Zimbabwe provided a view of history that gave a pattern to be followed in the struggle against white rule as a whole. These religious dimensions gave Zimbabweans a specific relation to the land and held that blood could be spilled to claim it, provided that fighters and the land would be ritually cleansed afterwards. ${ }^{129}$

However, religion did or does not always play such a constructive role. While the Holy Spirit movement of Alice Lakwena represented the political manifestation of an Acholi society driven into a corner by Museveni's rise to power in Uganda, ${ }^{130}$ her succession by Joseph Kony proved much less beneficial. Kony, like a biblical prophet inspired by his own (quasi-) religious rituals and belief-system, wanted to punish the Acholi people for their 'sins' in the wake of the LRA's failing popularity. ${ }^{131}$ Similarly, Stephen Ellis's study of the civil war in Liberia drew attention to the destructive effects of manipulated

\footnotetext{
${ }^{125}$ Van Acker \& Vlassenroot, 'Les “Maï-Maï”, 109 and 115-16.

${ }^{126}$ Lan, Guns and Rain.

${ }^{127}$ Ibid. 228.

${ }^{128}$ Bhebe \& Ranger, Society in Zimbabwe's Liberation War, 8.

${ }^{129}$ Ranger, 'Afterword', 704.

${ }^{130}$ H. Behrend, Alice Lakwena and the Holy Spirits: War in Northern Uganda 1986-97 (Oxford, 1999).

${ }^{131}$ Doom \& Vlassenroot, 'Kony’s Message', 22-25.
} 
religious repertoires. ${ }^{132}$ In our volume, Seibert's study of Renamo's war in Mozambique demonstrates that ritual magic can be helpful in mustering some degree of popular support for or acquiescence in an insurgency, however bloody its execution. He shows, moreover, that one of the few effective antidotes to Renamo's expansion was the involvement of an armed peasant movement, the Naparamas, reputedly equipped with rival supernatural powers.

These various religious dimensions show that, to some extent, acts of resistance take place in the realm of the mind. The study by Mbembe, mentioned above, argued in this respect that part of the life and activities of Ruben Um Nyobè, the source of inspiration of the UPC rebellion in colonial Cameroon, revolved around dreams he experienced in the maquis. These dreams constituted the rebel's comment on and opposition to colonial violence. This, of course, also has some links to the religious dimension discussed above, since to the Beti people in Cameroon the world of the night and sleep are proximate to death and the invisible world generally. While colonialism therefore not only penetrated the physical world of Africans but also touched the very foundations of their imagination and pursued them in their sleep, the invisible world in turn allowed them to manipulate the 'economy of the day' and the strategic points controlled by the French administration. This rendered dreams relevant to anti-colonial resistance as efforts to control daily, or rather, daytime life, to direct the struggle and to heal the community. ${ }^{133}$

This naturally extends the concept of resistance considerably. One chapter in our volume which contributes to the widening of the resistance notion is the study by Jan-Georg Deutsch on the supposed absence of slave resistance under German colonial rule in East Africa. Deutsch argues convincingly that slave resistance to subjugation mainly took the form of flight. This also puts labour migration during early colonial rule in Tanganyika in a different perspective, since those who, like the Isaacmans, initially made so much of peasant resistance to capitalist encroachment appear to have overlooked the social origins of those marginal groups who, at least in East Africa, embraced colonial subordination and made early colonial capitalism work. Deutsch also criticizes the danger of romanticizing resistance by reading legitimate current concerns about the marginality of certain social strata back into African history or, alternatively, by making the existence of slave resistance dependent on the presence of a genuine Spartacus.

It is exactly this romantic dimension to resistance that is discussed, from a very different ideological angle, in the chapter about Sawaba. Inspired by

\footnotetext{
${ }^{132}$ Ellis, The Mask of Anarchy.

${ }^{133}$ Mbembe, 'Domaines de la Nuit et Autorité Onirique', 119-21.
} 
Colburn, ${ }^{134}$ Van Walraven argues that the Marxist-Leninist and Maoist dogmas that helped Sawaba's leader, Djibo Bakary, to legitimise his invasion of Niger in 1964 actually amounted to a form of romantic narrative that blurred his sense of reality. Colburn argues in this respect that Marxism represents, or represented, not so much an explicit and comprehensive ideology stipulating coherent plans for reformed government as a millenarian mentalité geared towards effecting a radical break with the past. With little precise guidance as to the concrete challenges of government, Marxism and its discursive off-shoots functioned as a dreamy mind-set inspiring its revolutionaries to behave more or less as mystics propagating the possibilities of a simple, Herculean transformation of the world they lived in. One could add to this that the associated revolutionary perceptions of the nature of chaos, anarchy and violence were necessarily rosy in character, attributing good, necessary, even constructive effects to their occurrence. Added to the alienating effects of exile that many revolutionary agitators experience(d) at some stage in their career, this could contribute towards a state of thorough misunderstanding of political reality. Van Walraven argues this to be true, as a preliminary assessment, for the leader of Sawaba, while concluding that war and revolutionary violence are not romantic at all.

Furthermore, this romantic dimension does not only create concrete effects for the nature, patterns and outcomes of rebellions (Marxist-inspired and other), but also has effects at the level of research. Thus, in discussing the concept of social banditry, Austin remarked on the romantic element of the masculine violence involved, arguing that this can only be redressed by looking at the role of women. More generally, he opined that the social bandit represents the heroic version of self-help, defying government from a geographically and socially isolated position, with his moral purity becoming reinforced by the inevitably tragic fate met out to him at the hands of the authorities. ${ }^{135}$ Not just social bandits but even the more technical concept of guerrilla in due course acquired such romantic connotations. ${ }^{136}$ Even when researchers began to detect collaborators and pragmatic opportunists making their mark on African history, the romantic narrative was upheld and, according to Ranger, ${ }^{137}$ given a new boost with the Isaacmans pleading the case of the masses and their popular struggle against colonial capitalism. Inevitably, such romanticism found its way even more easily in literary presentations of the African condition. For example, novelists living in the relative calm and security of Rhodesia's cities entertained

\footnotetext{
${ }^{134}$ Colburn, The Vogue of Revolution.

${ }^{135}$ Austin, 'Social Bandits', 91.

${ }^{136}$ Clapham, 'Introduction: Analysing African Insurgencies', 1.

${ }^{137}$ Ranger, 'The People in African Resistance', 142.
} 
a flawed notion of the chimurenga that during the 1970s began to engulf the countryside. ${ }^{138}$

While some of the authors already discussed in this chapter make passing mention of the romantic narrative, there appears to be need for more systematic scholarly attention to this aspect. The attribution of romantic dimensions to resistance, revolt, revolution, and even war and violence generally, is, in fact, an understudied theme. Lan, in discussing the more peaceful role of spirit mediums in mobilizing Zimbabwe's peasantry for the war effort, noted coolly that rural folk were 'organised, mobilised and educated sometimes by gentle means, sometimes not'. ${ }^{139}$ More generally, perhaps Western people in particular are in need of a demythologized view of the nature of war and violence. Existing attitudes to these dramatic phenomena appear to have become more and more romanticized or at least detached from their ugly realities, perhaps in part because of the effects of long-standing conditions of peace in the Western world itself, but also as a result of the alienating effect of increasingly complex weapons technology, which has a tendency to blur perceptions of the act of killing ${ }^{140}$ while not necessarily impairing the attribution of heroism to those who perform the deadly act. Media discourse on the role of high tech in the Gulf War or in the Western war against the terrorist phenomenon has in this respect been illustrative.

\section{Memory and heritage}

A final issue to be considered in the historical and social study of resistance is that of 'memory'. There is an ideological sedimentation of the impact, or the tranformative effects, of revolt and resistance, especially when they have been violent and dramatic, on the people involved. This can be recognized in the

\footnotetext{
${ }^{138}$ C. Hove, lecture, African Studies Centre, Leiden, 20 June 2002. Critical perspectives on this in the poetry of C. Hove, Up in Arms (Harare, 1982), esp. 20 and 29, and his Red Hills of Home (Gweru, 1985), inspired by the events in Matabeleland during the early 1980s, esp. 1-2, 18, 35 and 50-51. Also F. Nyamubaya, On the Road Again: Poems During and After the National Liberation of Zimbabwe (Harare, 1981), 10-11 and 13.

${ }^{139}$ Lan, Guns and Rain, 226.

140 Bertrand Russell (Power: A New Social Analysis, London, 1938, 32, 30-31) in narrating the Italian invasion of Ethiopia called this 'mechanical power', which 'tends to generate a new mentality' since 'the men in control, having been trained on mechanism, would view human material as they had learnt to view their own machines, as something unfeeling governed by laws which the manipulator can operate to his advantage'. See for a discussion S. Lindqvist, A History of Bombing (New York, 2001), 151.
} 
social, psychological and political domain. In contemporary communities and polities in Africa - even, or perhaps especially, in the non-literate ones - the stylized and selectively framed social memories of revolt and resistance continue to be felt at different levels, either as ideology or as justification for new forms of resistance. As Ranger has suggested, ${ }^{141}$ a heritage of 'excessive violence' has implications for the legitimacy of subsequent regimes that issue from it, as well as for the governability of citizens under it. Cultural factors come into play here, as practices of violence - often representing a break with the past in terms of their scope and intensity - have a qualitative effect on ideas of political order and social cohesion. For instance, the violence of the Dervish movement in Somalia in the early twentieth century, while initiating a massive rebellion against foreigners, alienated most Somalis who did not adhere to the violent and uncompromising message of the movement and created new antagonisms between clan groups that were carried well into the postindependence era (see Chapter 13 this volume). In this sense it is not surprising that the movement's leader, Mohammed 'Abdulle Hassan, who was seen by observers as the chief initiator of 'Somali nationalism', is not well remembered by Somalis today.

A critical factor determining how the memory of resistance by earlier generations against colonial rule or other oppressive dominance is institutionalized is how the proponents of resistance dealt with the people or 'the masses' on whose behalf the struggle was usually waged. Here a cultural analysis alongside a politico-historical one is necessary: movements and acts of resistance tend to have resonance when they refer or tune in to the cultural values and symbolism that animate people. As Donham suggested in a brilliant study of resistance responses of the southern Ethiopian Maale people against the violent policies of the Ethiopian revolution, people's cultural commitments are crucial. ${ }^{142}$ Here the diversity across Africa is great and challenges scholarly explanation. It is without doubt that the construction of memories of resistance is an ongoing process with political relevance in contemporary African history. As the chapters in this volume on Namibia by Melber and Gewald make abundantly clear, the ideological manipulation of history - either the German colonial mass murder of Herero or the invocation of the 'heroism' of the liberation struggle of the 1970s and 1980s - is used in the construction of legitimacy and power of new regimes in no need of a critical discourse on the past. This 'politics of memory' itself is a social fact that should receive close scrutiny from academic scholars. The different representations of the past

\footnotetext{
${ }^{141}$ Ranger, 'Afterword', 705.

142 D.L. Donham, Marxist Modern. An Ethnographic History of the Ethiopian Revolution (Berkeley, Los Angeles \& Oxford, 1999).
} 
advanced by different actors and observers are partly shaped by their contemporary concerns but this does not imply that they are all plausible. As Cole has suggested, representations of memory narratives exist within culturally defined patterns of meaning that are structured by narrative conventions as well as by the social context of their telling. ${ }^{143}$

There can also be outright disagreement on the 'facts' and often this centres on who has gained power and who lost. Some events glorified by incumbent governments as defining moments in the emergence of the (post-colonial) nation are thus rejected by others as disastrous episodes. One revealing example is the invocation by the Eritrean government at independence in 1991 of the violent bandit and raider Hamid Idris Awate as the national hero who initiated the Eritrean armed liberation struggle. Among the Kunama and some of the Nara people of western Eritrea, who were the main victims of his murderous exploits, he is seen as a notorious butcher of their people. ${ }^{144}$ In a nation emerging from a period of struggle or dominated by a certain ethnic, religious or regional group, these issues of memory of whom and for whom are crucial in shaping the internal political dynamics of a country. ${ }^{145}$

In the case of Zimbabwe, for example, the ex-ZIPRA fighters saw themselves, after the 1980 independence, as victims of a war in which tribalism at the national level had replaced nationalism and in which they perpetuated ZIPRA's struggle. ${ }^{146}$ But the scope for venting alternative views is often seriously limited. As Alexander, McGregor \& Ranger ${ }^{147}$ show, the enactment of the 'official memory' of the liberation war sought to silence alternative memories, such as the recognition of ZAPU heroes who only received scant recognition. It will be a matter of the extent to which the political system is allowed to be democratic and pluralist as to whether such memories of the liberation struggle can (continue to) be monopolized in the face of the alternative views being presented. When the state discourse on the memory of violence and struggles of the past suppresses alternative views, it not only tends to exclude certain others and falsify history but may also engender in itself new resistance to its present-day authoritarian policies in other domains. In this

\footnotetext{
${ }^{143}$ J. Cole, 'The Uses of Defeat: Memory and Political Morality in East Madagascar', in R. Werbner (ed.), Memory and the Postcolony: African Anthropology and the Critique of Power (London, 1998), 104-25.

${ }_{144}$ D. Lussier, 'Local Prohibitions, Memory, and Political Judgment among the Kunama: An Eritrean Case Study', in K. Fukui, E. Kurimoto \& M. Shigeta (eds), Ethiopia in Broader Perspective, vol. 2 (Kyoto, 1997), 444-45.

${ }^{145}$ See also the important study by M.S. Clough, Mau Mau Memoirs: History, Memory, and Politics (Boulder, 1998).

${ }^{146}$ Alexander, McGregor \& Ranger, 'Violence and Memory', 8.

${ }^{147}$ Ibid. 255-56.
} 
process, a post-colonial regime's 'amnesia' may be seen, in turn, to generate nostalgia on the part of those constituencies that feel slighted or excluded.

There is, in addition, a vast range of cultural and socio-psychological effects associated with a violent past that are encoded in the social memory. This is not limited to the colonial situation but also to preceding experiences of violence, oppression or humiliation. Some conquered peoples have episodes in their rituals whereby the conquerors - Islamic slave raiders or expanding neighbouring despots - are depicted as malevolent spirits or as dogs (as among the Malian Dogon). In many areas of East Africa, spirit medium cults multiplied after the traditional chiefs were killed or removed by the new authorities. Some examples are southern Sudan after the predatory conquest of Mohammed 'Ali, and southern Ethiopia after the conquests of Emperor Menilik II in the late nineteenth century. The vacuum left after the decline of divine kings and traditional chiefs was filled by an upsurge of crisis cults based on spirit possession, as if to reconstitute a nostalgic past.

A more active recourse to spirit mediums (and ancestors) in actual movements of resistance was seen in the well-known example of the Zimbabwe liberation war, as described, among others, by David Lan. A cultural resource in the specific setting of rural Zimbabwe became an essential asset to a political resistance movement and its success. What is interesting is the legitimacy and power it gave to the spirit mediums, perhaps ultimately even over and above the political authority of the guerrilla movement. This explains why, after independence, the new holders of power were criticized for neglecting shrines, for failing to thank the ancestors by offering an apology for the violence, and thus for not leading the way in cleansing the nation. ${ }^{148}$ President Mugabe's interventions (for example in installing certain shrine keepers) were considered wholly illegitimate. Such considerations played a role in the 2002 Zimbabwean elections when some people even talked of widespread protests as foreshadowing the third chimurenga.

Resistance studies will enter a new phase when the dominant concern with the heritage of colonial rule and the revolts this evoked recede into the past and when the already forty-year-long era of independence can be considered by itself. In some countries, this time-span has been long enough to have produced its own memories of violence and terror. The most gruelling example may well be the Sudanese civil war that has, in effect, been continuing since 1956 and seems insurmountable except by the secession of the South, which is very different both historically and culturally from the North. In some thoughtprovoking and sensitive work on the Nuer and Dinka peoples, Hutchinson and Jok Madut Jok have demonstrated the deep and often unforeseen socio-cultural

${ }^{148}$ Ibid. 265 and 267. 
impact of protracted conflict on local societies. ${ }^{149}$ The Nuer example illustrates that violence can be too massive and dramatic to allow people to 'remember the victims' in a culturally proper way. Indeed, they are, as Hutchinson suggests, consigned to a social and spiritual oblivion in order to release a more destructive use of violence against enemy government troops. ${ }^{150}$ This will reshape the social memory of resistance and probably even impair its effectiveness.

We can thus conclude, with D. Crummey, ${ }^{151}$ that for modern African history the themes of resistance, rebellion and protest are far from exhausted. Empirically, new modalities of political inequality, injustice and protest have emerged in post-colonial states, and new social dynamics of rural-urban relations ${ }^{152}$ or generational conflict are evident. Theoretically, the old notion of the 'masses vs elites' has given way to a complex of new contradictions, ${ }^{153}$ rural differentiations and old impermanent articulations. The upshot of this is that the significance of resistance as a theme is not reduced, but increased: a newer historiography combined with sociological and anthropological insights is laying the foundations for understanding resistance in post-colonial states as a wider socio-cultural, not only political, phenomenon. In addition, in reconsidering resistance in colonial times, there is the need, as argued by Stephen Ellis in this volume, to analyse issues such as African intra-elite struggles and not just those against colonialism. Those fighting colonial governments at other stages accommodated or collaborated. ${ }^{154}$ Moreover, the relation of elites vs non-elites in terms of their differential incorporation in (late) colonial states requires a new look, considering for instance that in the 1945-60 period the relations of cooperation and non-cooperation of Africans and colonial regimes became increasingly complex. ${ }^{155}$ These considerations indeed form the background to the present collection of studies.

\footnotetext{
${ }^{149}$ See: S.E. Hutchinson, 'Nuer Dilemmas'; and idem 'Death, Memory and the Politics of Legitimation: Nuer Experiences of the Continuing Second Sudanese Civil War', in Werbner, Memory and the Postcolony 58-70 and Jok Madut Jok, War and Slavery in Sudan (Philadelphia, 2001).

${ }^{150}$ Hutchinson, 'Death, Memory and the Politics of Legitimation'.

${ }^{151}$ Crummey, Banditry, Rebellion and Social Protest.

${ }^{152}$ Cf. Mkandawire, 'The Terrible Toll'.

${ }^{153}$ Cf. Ranger, 'Resistance in Africa', 49.

${ }^{154}$ Cf. Ellis, 'A New Look at Resistance', 13.

${ }^{155}$ Ibid. 10
} 


\section{The chapters}

The chapters in this volume are based on papers presented at a seminar for invited scholars held in October 2001 at the African Studies Centre, Leiden. They show a geographical and thematic diversity purposely chosen to reflect the empirical range of resistance in Africa. The book's separate sections reflect our interest in the recurring key issues in a comparative study of resistance in Africa, but in view of the extensive references to the various chapters in this introduction, it is not necessary to describe each one individually here.

In Part I the historical and in some cases pre-colonial dynamics of resistance are discussed. De Bruijn \& Van Dijk treat the contestation of Islamic Fulbe expansion in West Africa, Ellis reconsiders the complexities of conquest and resistance in Madagascar, indicating the internal divisions in Malagasy society itself vis-à-vis colonial encroachment, while Aregawi discusses the Ethiopian Patriots' resistance to the Fascist Italian conquest and occupation in the 1930s.

The chapters in the second part focus more on the internal dynamics and contradictions of moments and movements of resistance within colonial settings: the rebellion or mutiny of African soldiers in the Dutch colonial army in the Netherlands East Indies by Van Kessel, the various responses of collaboration or resistance in a settlement in South Africa's Eastern Cape by Ross, and the search for the response of slave groups in German colonial East Africa by Deutsch.

The focus of Part III is on the actual symbolism and use of violence in an ideological and practical sense: Van Walraven's study of the remarkably but largely unknown Sawaba revolt in Niger in the 1960s, Kimba Idrissa on the early twentieth-century Tuareg revolt against French colonial rule, and Seibert on the Mozambican civil war of the 1970s and 1980s. All three cases illustrate the essential role of indigenous interpretations and reverberations of power, revolt and unsettling violence.

The final section, Part IV, reconsiders some well-known resistance movements and moves back to 'memories' of resistance. Gewald and Melber discuss Namibia: the former considers the colonial period and its dreadful heritage of Herero genocide, while the latter looks at the state-cultivated memory of the country's violent liberation struggle and its highly contested representation today. And lastly, Abbink reinterprets the Somali Dervish revolt of the early twentieth century, assessing its transformative impact on Somali culture and identity and on the political dynamics of Somalia's currently stateless polity.

In some respects, these studies come full circle to the theme of our title, rethinking resistance: both for academic observers and for (the descendants of) the people involved. Here the notion of heritage or legacy is important, not only 
in shaping conceptions of colonial-era resistance movements but also for an understanding of the emerging political antagonisms of today.

We trust that this volume of selected case studies will contribute to reinvigorating the study of resistance, revolt and contestation in African history, both past and present. The subject is fascinating in its focus on the agency of African people shaping their own tormented history and also essential for an understanding of the problems and grievances of today in an unequal world of struggle and crisis. We do not necessarily want to substitute it for Marx's old idea of class struggle but, in many respects, movements of resistance are the motive force of African history.

\section{Acknowledgements}

The Editors wish to thank the African Studies Centre and especially Marieke van Winden for facilitating the organization of the seminar in October 2001 on which the chapters in this volume are based, Ruth Watson for critically reading the manuscript, Ann Reeves for correcting the English text and Mieke Zwart for her layout work. We are also grateful to Luciën van Wouw and Nel de Vink for their work on the illustrations and the maps respectively. 


\title{
Resistance to Fulbe hegemony in nineteenth- century West Africa*
}

\author{
Mirjam de Bruijn \& Han van Dijk
}

\begin{abstract}
African history of the Sahel and Sudan zone appears to have been marked by political instability. Resistance to Fulbe empires was more common than the main literature suggests. The Fulbe are pastoralists and the empires of nomadic pastoralists are inherently unstable. The Fulbe emirates are often described as having been born out of the revolts of religiously inspired nomadic pastoralists against oppressive sedentary regimes. However, the resistance movements against Fulbe hegemony itself can partly be explained as revolts of the originally nomadic population who felt their cause was not well defended by the elite of these emirates. Opposition to the ideology of Islam inspired revolts of non-Islamic groups. These resistance movements were also fed by the oppressive nature of the new emirates, whose most prominent characteristic was slavery. Resistance is expressed in contemporary ritual and oral traditions, challenging the official historiography of these emirates. Political instability was the norm illustrated by three case studies discussed in the chapter.
\end{abstract}

\section{Introduction}

Fulbe is a collective term for a number of people who are culturally, linguistically and politically related and who inhabit a vast area in West Africa

* We are grateful to Caroline Angenent for her detailed reading and extensive comments. 
and also live in Sudan and even Eritrea. They are known in the literature under a variety of names: Fulani, Peul, Haalpulaar and Fellata. In the second half of the twentieth century, they gradually migrated into the forest zones of the coastal states of West Africa such as Ghana, Benin, and Côte d'Ivoire. Their main occupation is the herding of cattle, although nowadays this is often combined with cereal cultivation. Throughout the Sahel, they are regarded as expert cattle herdsmen.

The migration of the Fulbe over West Africa probably began during the Mali Empire in the fourteenth century, when the empire's rulers promoted their dispersal to prevent them from becoming a threat to political stability. For a long time, they remained a minority in most areas. Small groups were already familiar with Islam which had entered West Africa via the trade routes across the Sahara and from 1700 onwards, they began to become politically dominant in many areas. Moreover, the political situation was highly unstable in the western Sahel because an invasion by the Moroccans had led to an anarchical situation. In addition, during the seventeenth and eighteenth centuries periods of severe drought plagued the region, negatively affecting the political situation. ${ }^{1}$

The jihads staged by the Fulbe in the eighteenth and nineteenth centuries throughout the Sahel and Sudan of West Africa can thus be interpreted as a reaction to this political instability. The Fulbe established centres of political power, some of which developed into emirates. ${ }^{2}$ The main nuclei of Fulbe power were the polities in the Senegal River Valley, the Fuuta Jallon mountains in Guinea, the Inland Delta of the Niger in Mali (Maasina), the north of Nigeria and the Adamawa Plateau in Cameroon. In between these big centres there were numerous small polities dominated by the Fulbe in the central Gourma of present-day Mali, the north and west of Burkina Faso (Jelgoji, Boboola, Dori, Liptako), northern Benin (Bornou), the Sene-Gambia, northern Senegal

\footnotetext{
${ }^{1}$ S.M. Cissoko, 'Famines et Epidémies à Tombouctou et dans la Boucle du Niger du XVI ${ }^{\mathrm{e}}$ au XVIII ${ }^{\mathrm{e}}$ Siècle', Bulletin de l'IFAN, XXX, série B (3) (1968), 806-21; M. Tymowsky, 'Famines et Epidémies à Oualata et à Tichit XIX Siècle', Africana Bulletin, 27 (1978), 35-53; B.A. Gado, Une Histoire des Famines au Sahel: Étude des Grandes Crises Alimentaire (XIX $-X X^{e}$ Siècles) (Paris, 1993).

${ }^{2}$ The terminology to indicate these political entities varies from empire to state, to political realm or Fulbe hegemony, which all demand a more precise indication of what kind of polity is meant. It is clear that the pre-colonial states described in this article are based on their superiority in the control of violence: military power and ideological weapons (Islam). These political entities are divided into core and peripheral areas where political and military control were less severe than in the centre from where rules and laws were ordered. Their basis of power was measured by the number of people they dominated by means of violence and by religious and ideological hegemony. To avoid the conception of these entities as stable, they are denoted as far as possible with their own terminology.
} 
(Bundu), ${ }^{3}$ and the southern and western parts of present-day Niger (Dallol Bosso, Birni N'konni).

Historians and social scientists have taken the organization and functioning of these political formations as their point of departure. The workings of precolonial Fulbe emirates are analysed as if they were a higher order of social organization than traditional acephalous segmentary lineage-based societies and rule of them tends to be regarded as a management problem. Others analyse this form of political and military organization as an organizational device permitting 'predatory accumulation'. ${ }^{4}$ The jihad is described as a tool for establishing power or as a means in itself for spreading Islam. ${ }^{5}$

However, by privileging the viewpoint from the political centre over that of the groups who were subjugated, and by favouring stability to political and military turmoil, these perspectives are one-sided. As is argued below, there are a number of structural features that render political entities like those created by the Fulbe in the Sahel inherently unstable. Revolt and resistance were a structural part of the histories of these emirates and politics was an arena of conflict and confrontation with people who were subjugated. Political instability was part of normal daily life and determined people's actions. '[R]esistance and the creativities that shape resistance have been in place as long as the cycles of political and military terror'. People have developed 'traditions of resistance' in situations of political oppression. ${ }^{6}$ This resistance and their expression can take various forms - from organized armed rebellion, to fleeing to remote areas, and the expression in "hidden transcripts" ${ }^{\text {" }}$ like ritual, healing practices and 'unofficial' oral traditions. ${ }^{8}$

It is difficult to appreciate the importance of revolt and resistance in the political developments of this period. There is not much information available on the plight of ordinary people and the ways in which they tried to resist political oppression, slavery and raiding by the empires. What little is known is mostly derived from sources from the political centre, such as court chronicles,

\footnotetext{
${ }^{3}$ A. Clark, 'The Fulbe of Bundu', The International Journal of African Historical Studies, 29, 1 (1996), 1-23.

${ }^{4}$ S.P. Reyna, 'Predatory Accumulation and Religious Conflict in the early $19^{\text {th }}$ Century Chad Basin', in S.P. Reyna \& R.E. Downs (eds), Studying War, Anthropological Perspectives (Langhorne PA, 1994), 127-55.

${ }^{5}$ G. Nicolas, 'Le Modèle Mobilisateur du 'Jihad' dans les Conflits du Soudan Central', Cultures et Développement, 16, 3-4 (1984), 583-610.

${ }^{6}$ C. Nordstrom, A Different Kind of War Story, (Philadelphia, 1997), 68.

7 J.C. Scott, Domination and the Art of Resistance. Hidden Transcripts (New Haven, 1990).

${ }^{8}$ J.-M. Gibbal, Genii of the River Niger (London \& Chicago, 1994), translated by B.G. Raps.
} 
correspondence between rulers, and accounts of European and Arab travellers, none of whom were in a position to reflect on the perspectives and experiences of the common people. In the case of the Fulbe, the literature is very much jihad- and Islam-oriented. ${ }^{9}$

Three examples are taken in this chapter to illustrate revolt and resistance against Fulbe hegemony: the Timbo Emirate in the Fuuta Jallon, the Diina Emirate in the Inland Delta of the Niger in Central Mali, and the Futanke Empire which followed the Diina and the Bamana Kingdoms of Kaarta and Segou in the second half of the nineteenth century. The case studies, set against the background of inherent instability in 'pastoral/nomadic' Fulbe polities, reveal experiences of rebellion and their accompanying violence. We elaborate first on this background, then explain the common features of Fulbe polities and finally examine various rebellions in these polities.

\section{The structural instability of pastoral/nomadic hegemony}

A number of structural features could have contributed to the fundamental instability of Fulbe states in the nineteenth century. Any state is, in principle, liable to collapse under the impact of revolt and resistance but those established by pastoralists are inherently more likely to disintegrate than others. ${ }^{10}$ This instability emanates from the political ecology of pastoralism that prescribes a mobile mode of exploitation of resources and a flexible political organization. According to evidence from other semi-arid regions of the world where pastoralism is the dominant mode of production, pastoral economies cannot exist in isolation because of high risks in the production environment. To gain access to cereals, pastures and water, nomadic pastoralists need to engage in relations with sedentary peoples through trade, conquest or subjugation, and especially so in periods of crisis. ${ }^{11}$

Trade relations tend to be unfavourable for pastoralists since they want to exchange animal products for basic staple food. In times of ecological crisis, frequently experienced by most nomadic pastoralists who inhabit harsh and extremely volatile ecological environments, the rate of exchange of animal products against cereals drops enormously, ${ }^{12}$ and this can lead to a rapid depletion of their assets. Under 'normal' conditions, however, the caloric terms

\footnotetext{
${ }^{9}$ G. Nicolas, 'Le Modèle', 584.

${ }^{10}$ A.M. Khazanov, Nomads and the Outside World (Cambridge, 1984).

${ }^{11}$ Ibid.

12 J. Swift, 'The Economics of Production and Exchange in West African Pastoral Societies', in M.A. Adamu \& D. Kirk-Greene (eds), Pastoralists of the West African Savanna (Manchester, 1986), 175-90.
} 
of trade (the number of calories in cereals one can get in exchange for a calorie from animal products) are quite favourable for pastoralists. ${ }^{13}$ To mitigate the high risks associated with equal exchange of animals for cereal products, one solution is to subjugate a cultivating population so as to have a source of labour for food production. An example of this is the oasis system in the Sahara worked by Tuareg slaves ${ }^{14}$ which required little political organization. However, in most cases an elaborate political and economic organization was needed to ensure hegemony.

The creation of a state-like structure by pastoralists tends to marginalize the pastoral way of life and can lead to the disengagement of the pastoral elites from the nomadic population. Historically relations between nomadic pastoralists and the state have always been difficult. A nomadic pastoral lifestyle does not fit the needs of sedentary political entities very well since they require the mobility of populations to be curtailed for political and military purposes. The levying of taxes on cattle, for example, undermines the viability of pastoralism. Pastoralists were often moved to the margins of political power even within the empires of their own creation, being encapsulated in a strict hierarchical order. In a number of cases, this inequality led to the collapse of polities under the pressure of internal rebellions of the nomadic pastoralists. ${ }^{15}$ The Fulbe, who were the major players in these jihads, were indeed mobile pastoralists and found themselves marginalized in the nineteenth century Fulbe states. $^{16}$

This structural inequality may also have served to divide risk positions. Substantial effort has to be invested to reduce the risks of the ecological environment in which nomadic pastoralists live. Trade and political hierarchies can divert risk to lower-status groups ${ }^{17}$ and this in turn increases the potential

${ }^{13}$ T. Dietz, 'The State, the Market, and the Decline of Pastoralism: Challenging some Myths, with Evidence from Western Pokot in Kenya/Uganda', in J. Markakis (ed.), Conflict and the Decline of Pastoralism in the Horn of Africa (London, 1993), 83-100; A.F.M. Zaal, Pastoralism in a Global Age: Livestock Marketing and Pastoral Commercial Activities in Kenya and Burkina Faso (Amsterdam, 1998).

${ }^{14}$ E. Bernus, 'Dates, Dromedaries, and Drought: Diversification in Tuareg Pastoral Systems', in J.G. Galaty \& D.L. Johnson (eds), The World of Pastoralism: Herding Systems in Comparative Perspective (New York, 1990), 149-76.

${ }^{15}$ Ibid.

${ }^{16}$ M. de Bruijn \& H. van Dijk, 'State Formation and the Decline of Pastoralism: Fulani Pastoralists in Central Mali', in Markakis, Conflict and Decline of Pastoralism, 122-42.

${ }^{17}$ M. de Bruijn \& H. van Dijk, 'State Formation'; M. de Bruijn \& H. van Dijk, Arid Ways, Cultural Understandings of Insecurity in Fulbe Society, Central Mali (Amsterdam, 1995); M. de Bruijn \& H. van Dijk, 'Ecology and Power in the Periphery of Maasina: The Case of the Hayre in the Nineteenth Century', Journal of African History, 42 (2001), 217-38; H. van Dijk, 'Ecological Insecurity and Fulbe Pastoral 
for revolt against the system. One would expect the oppressed and oftenenslaved groups who had the highest risk position and related lack of wealth to become part of uprisings and resistance against the dominant groups.

Pastoral/nomadic polities are often situated in harsh ecological areas, making it hard for these polities to produce enough to feed their populations and to keep the hierarchy in tact. In the past, the semi-arid climate and the soil quality did not permit a significant increase in production and the creation of a surplus to maintain the state apparatus. Trade contributed very little to the revenues of the state. ${ }^{18}$ Therefore, the revenues of the state were based on taxes and control over the labour of subjugated people. There was a permanent demand for slaves caught during raids and wars. In itself, this may have been a source of political instability and the jihad may have been an ideological masquerade for this situation of inequality and warfare, by providing a raison d'être for slavery (they were pagans) $)^{19}$ and a 'vraie morale de la guerre' (the promotion of Islam and the fight against infidels). In such circumstances, struggles between rivals can be expected. ${ }^{20}$

Thus, it may be argued that pastoral polities were inherently unstable and that revolts and rebellions were part of political life. In this chapter we further investigate whether there was indeed opposition to Fulbe hegemony in nineteenth-century West Africa, and if so, how these revolts were organized, which groups revolted and what their objectives and motivations to do so were.

\section{The Fulbe emirates in the eighteenth and nineteenth centuries}

Although each of the Fulbe emirates discussed in this chapter arose under specific conditions, they shared a common socio-economic and ideological motivation. The origin of most of these states was in fact a revolt against vested political and economic powers that opposed the economic and political

Society in the Niger Bend', in V. Azarya, A. Breedveld, M. de Bruijn \& H. van Dijk (eds), Pastoralists Under Pressure? Fulbe Societies Confronting Change in West Africa (Leiden, 1999), 237-65.

${ }^{18}$ There has been very little historical research undertaken on the economic basis of precolonial states in Africa. See M. Johnson, 'The Economic Foundations of an Islamic Theocracy - The Case of Masina', Journal of African History, XVII, 4 (1976), 481-95, for an example of research on Fulbe states.

${ }^{19}$ Whereas in reality the jihad functions as a vehicle to find slaves so that a viable political unit can be created.

${ }^{20}$ C. Rivière, 'Sociologie des Guerres au Fouta-Djalon Précolonial', Cultures et Développement, 16, 3-4 (1984), 553-81. 


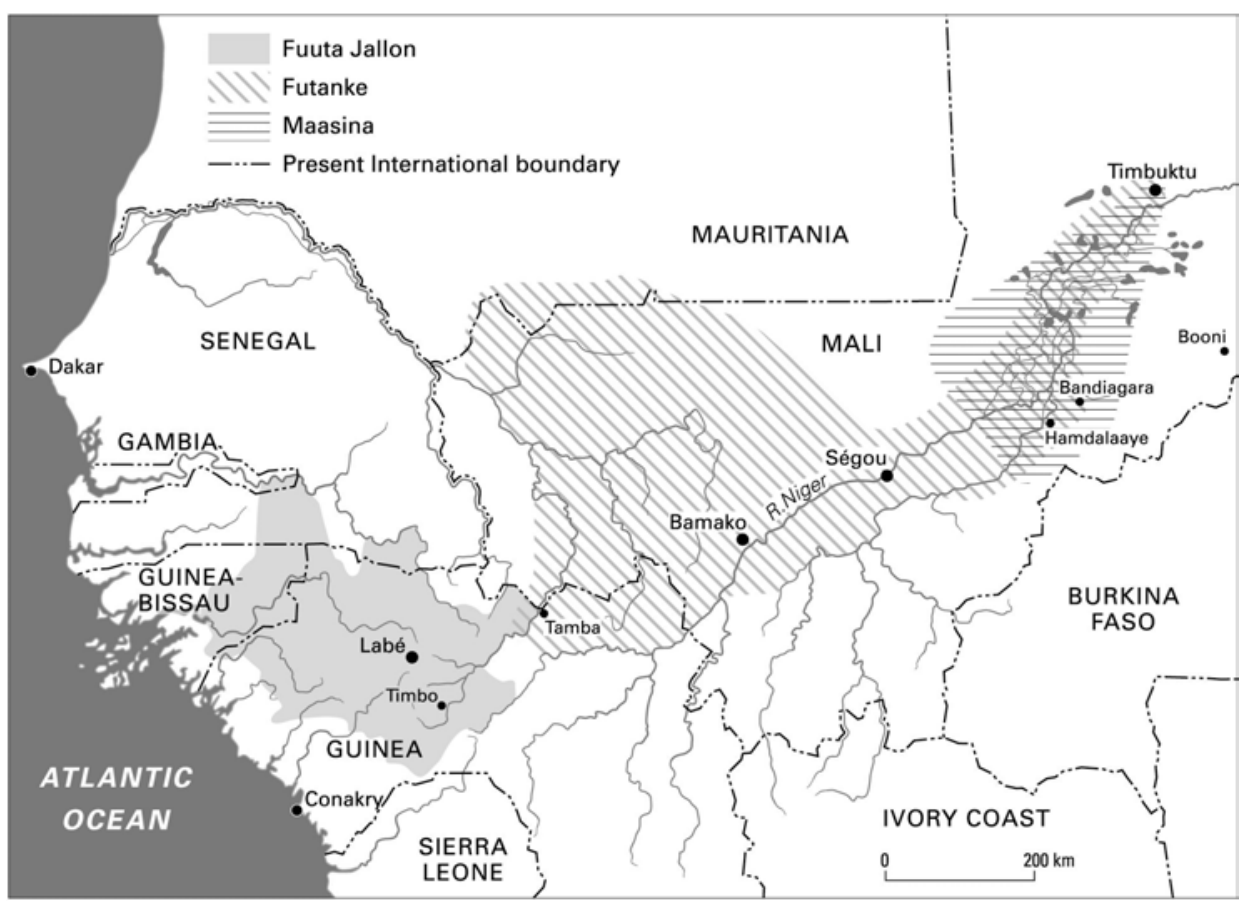

Map 2.1 West Africa: Nineteenth-century Fulbe emirates 
ambitions of an upcoming minority. For example, the Emirate of Timbo in the Fuuta Jallon developed from a revolt by Islamic Fulbe against their oppression by pagan Pulli (non-Islamic Fulbe) and Jallonke (the original inhabitants of the Fuuta Jallon). This emirate was, in fact, a federal state of nine provinces. Later, due to strife between two branches of the royal lineage, a system for the rotation of office between these branches was set up. This led to an almost permanent state of civil war since none of the parties was inclined to respect the system, which considerably weakened the power of the political centre. ${ }^{21}$

The origins of the Maasina Emirate in the Inner Delta of the Niger are also found in rebellion, this time against the Bamana Kingdom of Segon, a political power that controlled the region from outside. For some time, groups of Fulbe had been dominant in parts of the delta, hereby creating a complex hierarchy dating back through several waves of conquest. ${ }^{22}$ However, due to internal warfare they were never able to organize a countervailing force against the Bamana Kingdom. In 1818, an Islamic cleric named Aamadu Hammadi Buubu united the Fulbe under the banner of Islam and fought a victorious battle against the Bamana and their allies. He subsequently established his rule in the Inland Delta and the adjacent dry lands east and west of the delta. This state appears to have had tight control over its core area, as is testified by the fact that its political and economic organization is still visible today in the organization of agricultural production in the Inland Delta. Nevertheless, the hegemony of the emirate was constantly threatened. During the reign of Aamadu Aamadu, the grandson of Sheeku Aamadu, internal contradictions weakened the emirate to such an extent that it became easy prey for the forces of the Futanke, which subsequently overthrew the Maasina Emirate. ${ }^{23}$

The character of the Futanke Emirate was somewhat different, although its founding was related to the conquest of the Maasina Emirate and the Bamana Kingdoms of Segou and Kaarta in the aftermath of a movement for reform. Threatened by French colonial forces while at the same time being supplied with firearms by them, the Futanke staged a jihad to fight paganism and the competing Islamic brotherhood of the Tijannya. Its founder, El Hadj Umar, an

${ }^{21}$ I. Barry, Le Fuuta - Jaloo Face à la Colonization. Conquête et Mise en Place de l'Administration en Guinée (1880-1920) (Paris, 1997); Rivière, 'Sociologie des Guerres'.

${ }^{22}$ C. Fay, 'Les Derniers Seront les Premiers: Peuplements et Pouvoirs Mandingues et Peuls au Maasina (Mali)', in M. de Bruijn \& H. van Dijk (eds), Peuls et Mandingues. Dialectique des Constructions Identitaires (Paris \& Leiden, 1997), 165-92.

${ }^{23}$ A.H. Ba \& J. Daget, L'Empire Peul du Macina I 1818-1853 (Bamako, 1955); J. Gallais, Le Delta Intérieur du Niger: Etude de Géographie Régionale Mémoires de l'IFAN, 78, 2 tomes (Dakar, 1967); B. Sanankoua, Un Empire Peul au XIX Siècle: La Diina du Maasina (Paris, 1990). 
Islamic reformer originating from the Fuuta Tooro on the banks of the Senegal River, died fighting against rebels shortly after his forces defeated the Maasina Emirate. After El Hadj Umar's death, the emirate was divided in three and ruled by his sons. These three units - with Nioro, Segou and Bandiagara as their capitals - suffered political instability and were added to the French colonial empire within three decades. ${ }^{24}$

These three emirates were structured in similar ways and were based on the same religious and political ideologies. They developed political hierarchies and economic organization that may be typified as being slave-based. The strict hierarchy was based on the structural inequality of different social groups. This did not, of course, mean that there were no internal differences or that social mobility did not occur.

The most important distinction was between noblemen (free people) and the non-free. The noblemen consisted of the ruling class of political overlords and Islamic clerics. The pastoral population, who helped them come to power, formed a group of vassals to the political elite. They were considered noblemen though in reality their political influence was minimal. The conquered populations were reduced to servitude or slavery and more slaves were captured in order to provide enough labour for the functioning of the economy. In addition, there were groups of bards, courtiers and artisans who occupied an ambiguous political and social position. The political elite and Islamic clergy exploited the rest of the population. The various population groups under their command were dependent on this elite for military protection and religious services. The vassals were important for warfare, the slaves for all the work. This form of oppression and the related excessive differences in wealth may have been an important reason for resistance, although the most oppressed were the last to revolt because they simply had neither the means nor the organization to do so.

The historiography of these emirates concentrates on the political elite, the way in which they came to power, their administration and the role of religion in life and administrative affairs, and the economics of trade and taxation that formed the economic basis of these polities..$^{25}$ The basic picture emerging from

\footnotetext{
${ }^{24}$ D. Robinson, The Holy War of Umar Tal: The Western Sudan in the Mid-Nineteenth Century (Oxford, 1985).

${ }^{25}$ See for example, Ph. Burnham \& M. Last, 'From Pastoralist to Politician: The Problem of a Fulbe "Aristocracy", Cahiers d'Etudes Africaines, XXXIV (1-3), 133-35 (1994), 313-58, for an overview of the literature on northern Nigeria and Adamawa. For the Maasina Empire, see Sanankoua, Un Empire Peul; Gallais, Le Delta Intérieur; J. Gallais, Hommes du Sahel, Espaces-Temps et Pouvoir. Le Delta Intérieur du Niger 19601980 (Paris, 1984); and for the Fuuta Jallon, see T. Diallo, Les Institutions Politiques du
} 
this body of literature is that after an initial period of conquest (jihad) and skirmishes to establish control over the rebellious groups in the periphery, some kind of political unity was established. The pastoralists forming the backbone of the conquering groups produced a political elite that settled in town and governed the realm. The debate on these 'aristocracies' centres on the issue of whether the ruling groups were new formations or a return to pre-existing ruling lineages. ${ }^{26}$

For a number of reasons, this picture is not satisfactory. The whole debate on Fulbe statehood and aristocracy, while interesting in itself, does not address questions about the issue of political stability or the position of non-free people in these polities. Yet there are both empirical and theoretical arguments for broadening the debate to include these questions. In the first place, a number of Fulbe emirates were severely shaken by rebellions, and even succumbed due to a combination of outside pressures and internal weakness. The prime example of this evolution is the Maasina Emirate, which gave way to the Futanke Emirate. The collapse of the social and economic order in the periphery of the Maasina Emirate at the time its political centre disintegrated also shows its internal weakness. ${ }^{27}$

Secondly, while establishing their hegemony, the Fulbe defined a strict social hierarchy and had to impose limitations on all kinds of economic and trading activities. The freedom for pastoralists to move around was curtailed in order to ensure the smooth functioning of other production activities such as cereal cultivation and, in the case of Maasina, of fishing activities. Economic activities had to be controlled to ensure a constant flow of taxes and commodities to the state apparatus and the standing army, especially for the cavalry. ${ }^{28}$

Under Futanke rule, some of the millet harvest in Kaarta was destined for the army. In Maasina a considerable force was needed to ensure the protection of the livestock herds when they were pastured on the dry lands outside the Inland Delta of the Niger. ${ }^{29}$ These measures met with resistance from those groups in society who had to participate in new designs for their social and economic lives that were not of their own making. For example, coalitions between

Fouta Dyalon au XIXe Siècle, Série Initiations et Études Africaines no. XXVIII (Dakar, 1972); and Barry, Le Fuuta Jalloo.

${ }^{26}$ V. Azarya, Aristocrats Facing Change, The Fulbe in Guinea, Nigeria and Cameroon (Chicago, 1978); Burnham \& Last, 'From Pastoralist to Politician'.

${ }^{27}$ Van Dijk, 'Ecological Insecurity and Fulbe Pastoral Society in the Niger Bend'.

28 J.H. Hanson, 'Generational Conflict in the Umarian Movement after the Jihad: Perspectives from the Futanke Grain Trade at Medine', Journal of African History, 31 (1990), 199-215; Johnson, 'The Economic Foundations of an Islamic Theocracy'.

${ }^{29}$ Ba \& Daget, L'Empire Peul. 
pastoralists, free cultivators and slaves were formed to fight invading nomads when the central power no longer functioned. ${ }^{30}$

Thirdly, despite the fact that very little is known about the experiences of the people involved, it appears there was considerable resistance to the forced acceptance of Islam by these emirates. For example, many nomadic Fulbe, predominantly Wodaabe fled northern Nigeria when their liberty was curtailed and they were forced to convert to Islam following the jihads instigated by Usman Dan Fodio from Sokoto. ${ }^{31}$ Conversion to Islam meant not only changing one's religion but also submitting to rules dealing with all aspects of social, political and cultural life. Certainly, when the new rulers enthusiastically introduced their agenda for social and economic change in the early years of these emirates, they met with resistance and revolt. However, it is difficult to dissociate resistance against Islam from politics, since Islam was at the same time the prime ideological motivation to subjugate or enslave these pagan populations. People preferred to stick to their pagan beliefs partly because they did not want to be dominated and turned into slaves.

\section{The Emirate of Timbo in the Fuuta Jallon, Guinea}

This emirate was the first of the Fulbe emirates in West Africa, originating in a jihad fought in the first half of the eighteenth century. Malinke and Fulbe Islamic believers went to war against the animistic Fulbe (Pulli), the Jalonke and other pagan populations. After the victory of the partisans of Islam, an Islamic theocracy was imposed on the subjugated populations in the region. The first ruler took the title of Almaami ${ }^{32}$ and resided in Timbo. People who had resisted the jihad were deprived of their rights to land except for a small piece for their own subsistence, and were reduced to servitude. The nomad Pulli lost all freedom of movement and the Jalonke lost their noble status and became slaves (maccube). ${ }^{33}$

In the adjacent provinces of the Fuuta Jallon. The Malinke almaamis, not the Fulbe, were in power. These almaamis were far more tolerant than their Fulbe counterparts who dominated most of the other provinces of the empire. For the Malinke, Islam was mainly a vehicle for their commercial aspirations and the

\footnotetext{
${ }^{30}$ De Bruijn \& Van Dijk, 'Ecology and Power'.

${ }^{31}$ M. Dupire, Peuls Nomades: Etudes Descriptive des Wodaabe du Sahel Nigérien (Paris, 1962).

${ }^{32}$ Almaami is Fulfulde for Imam.

${ }^{33}$ M.S. Baldé, 'L'Esclavage et la Guerre Sainte au Fuuta-Jalon (Maccugaaku e jihaadi Fuuta-Jaloo', in C. Meillassoux (ed.), L'Esclavage en Afrique Précolonial (Paris, 1975), 183-220.
} 
repression of their opponents was not a major concern. However, the Fulbe almaamis gradually penetrated this region and submitted it to more stringent control. They followed a policy of divide and rule by carefully subdividing the various provinces under their rule and adding a hierarchy of chiefs who lived lavishly at the expense of their subjects.

In the course of the nineteenth century, discontent among the common people increased. Division of the leadership of the Fuuta Jallon between two different branches of the Fulbe royal family - each with their followers - was perpetrated at provincial and village level, increasing the pressure of the political class on their subjects. Political oppression mounted, resulting in a loss of freedom for many of the movement's followers. The almaamis became exploitative and imposed high taxes, and they lived for their own pleasure instead of living according to Islamic rules. This state of affairs led to a popular resistance movement called Hubbu ('those who refuse'). The movement developed only gradually up to the middle of the nineteenth century but it persisted for almost forty years. However, it never succeeded in reaching its objectives and ultimately, resistance turned into banditry.

The leader of the Hubbu movement, Alfa Mamadu Dyuhe, was an outsider and did not belong to the political elite of the Fuuta Jallon. He was the son of an Islamic scholar who travelled from the Seeno east of Maasina (probably with his followers and taaliibe) ${ }^{34}$ to the Fuuta Jallon and established himself in Timbo. Alfa was a pious Muslim and well respected for his intelligence. He became a fervent opponent of the almaami because of its exploitative regime, which he considered to be in conflict with Islamic ideology.

Finally, Alfa Mamadu Dyuhe had to seek refuge in the mountains of the neighbouring province dominated by Malinke and refugees of the almaami regime where he had many followers among the oppressed and marginalized. The majority of the movement were nomadic pastoralists, Pulli and Fulbe, such as slaves who had fled their masters. The movement was engaged in full-scale conflict with the almaami and even conquered the capital of the empire, Timbo, just before the death of its leader. In the end, almaami from other branches of the royal family chased them from the capital. Nevertheless, this defeat did not mean their disappearance and the movement continued to exist for forty years. Ultimately, Samoori, king of a neighbouring Bamana kingdom, stamped out the unrest because it continually made trade routes insecure. ${ }^{35}$

\footnotetext{
${ }^{34}$ Taaliibe is a word borrowed from Arabic meaning pupils.

${ }^{35}$ R. Botte, 'Révolte, Pouvoir, Religion: Les Hubbu du Futa-Jalon (Guinée)', Journal of African History, 29 (1988), 391-413; Rivière, 'Sociologie des Guerres'.
} 
A number of aspects of this rebellion deserve more detailed attention. In the first place, resistance originated from within the empire and was born out of widespread discontent with the behaviour of the Fulbe political leadership. High taxes seem to have provided the main economic motive to stage the rebellion, and this excessive taxation as well as the oppressive political structure were seen as a result of the corruption of the state.

Secondly, though composed of people who were marginalized from a social, religious and ideological point of view, the movement aimed at a more pure and uncorrupted form of Islam. Its dominant objective was not a return to paganism but instead to conquer and purify the state and promote egalitarianism (however, it seems that some were more equal than others). A reduction of the tax burden and the abolition of fines were the prime measures taken in the areas controlled by the Hubbu. Slaves were part of the movement but there was never any move to do away with slavery or to change the status hierarchy. Those who profited most from the rebellion were the bush Fulbe who were able to escape the exaction of the political elite.

Motivations for the rebellion were thus economic and ideological. A third motivation may have been frustration linked to the inferior social position of Hubbu leaders. Rivière cites Marguerite Verdat to illustrate this point by imagining the reasons of one of the leaders for continuing the Hubbu rebellion: 'il est incontestable que Tierno Aliou a souffert de la médiocrité de son origine, - matériellement... mais surtout peut-être dans son orgueil. Nul doute qu'un complexe d'infériorité n'ait pesé longtemps sur lui et ne l'ait poussé à chercher passionnément à rompre le barrage que sa naissance mettait à son ambition.... ${ }^{36}$

This rebellion was negatively regarded by neighbouring Malinke kingdoms and the British and the French on the coast. They feared the impact of this movement on trade relations in the region, as did Samoori Toure who, as we have seen, ultimately quashed it. These negative perceptions could be why so little attention has been devoted to the rebellion. It was a movement directed against the logic of oppression by a central state. Taxation formed the basis of the French colonial empire so it is logical that colonial writers and historians of the Fuuta Jallon virtually neglected the movement. ${ }^{37}$ Only in a post-colonial context under the dictatorship of Sekou Touré, who also wanted to do away

\footnotetext{
${ }^{36}$ Rivière, 'Sociologie des Guerres', 570.

${ }^{37}$ L. Tauxier, Moeurs et Histoire des Peuls, I. Origines, II. Les Peuls de l'Issa-Ber et du Macina, III. Les Peuls du Fouta-Djallon (Paris, 1937); Diallo, Les Institutions Politiques; Barry, Le Fuuta Jalloo.
} 
with the traditional leadership of the Fulbe almaamis in the Fuuta Jallon, did studies by Guinean scholars of this movement begin to appear. ${ }^{38}$

\section{Maasina or Diina, the Inner Delta of the Niger}

The Maasina Emirate, also called Diina ('religion' in Arabic), was established by the Fulbe jihad led by Sheeku Aamadu. In 1818, his forces won a decisive victory over the troops of the Bamana Kingdom of Segou. This jihad was inspired by events in northern Nigeria where an important scholar of the time, Usman Dan Fodio, established an Islamic empire with Sokoto as its capital. Sheeku Aamadu was but one of the several potential leaders in Maasina, the Inland Delta of the Niger, where the division of power was infinite and divided between several Fulbe, led by animist ardo'en $^{39}$ and Sonrai lineages. ${ }^{40}$ The different ardo'en fought continuously against the Bamana and their king, Da Monson, who ruled south of the delta in Segou. This chaotic period in which banditry, raids and violence dominated daily life produced important oral traditions and heroes ${ }^{41}$ and is today known by the Fulbe as the jahilaaku, the time before the Diina or the introduction of Islamic rule. The jihad of Sheeku Aamadu was launched at an ideal moment to resist definitively Bambara power and to implement law and order through the rule of Islam in the Inner Delta.

One of the characteristics of Sheeku Aamadu's rule was his drive to order life according to a strict regime of rules and laws organizing the structure of the rural areas. He introduced semi-sedentary pastoralism (though this may have been underway anyway) and forced the nomadic pastoral groups to settle not only in the Inland Delta of the Niger but also in the adjacent areas both east and west of the delta. A system of transhumance was put in place, and other productive economic activities such as cereal cultivation and fishing were structured in relation to each other. ${ }^{42}$ In current historiography, this scheme for

\footnotetext{
${ }^{38}$ See for example, Barry, Le Fuuta Jalloo; Diallo, Les Institutions Politiques.

${ }^{39}$ Ardo'en (sing. Ardo) means leader in Fulfulde.

40 Cf. Fay, 'Les Derniers'; C. Fay, “'Car Nous Ne Faisons Qu’Un” Identités, Equivalences, Homologies au Maasina (Mali)', Cahiers des Sciences Humaines, 31 (2) (1995), 427-56; C.C. Stewart, 'Frontier Disputes and Problems of Legitimation: SokotoMasina Relations 1817-1837', Journal of African History, XVII, 4 (1976), 497-514.

${ }^{41}$ Ch. Seydou (ed.), Silamaka \& Poullori, Récit Epique Peul Raconté par Tinguidji, Classiques Africains 13 (Paris, 1972); E. Mohamadou \& G.Vieillard (eds) Récits Peuls du Macina, du Kounari, du Djilgodji et du Torodi (Niamey, 1977).

${ }^{42}$ Y. Vincent, 'Pasteurs, Paysans et Pêcheurs du Guimballa. Partie Centrale de l'Erg du Bara', in P. Galloy, Y. Vincent \& M. Forget, Nomades et Paysans d'Afrique Noire Occidentale (Nancy, 1968), 35-156; De Bruijn \& Van Dijk, 'Power and Ecology'
} 
natural resource management has been labelled 'Diina' and has become synonymous with Fulbe hegemony in the delta and everything attached to it. The period of the Maasina Empire was in some ways a break from the past but the previous anarchistic situation was probably related to the political ecology of the region in which pastoral production played (and still plays) an important role.

It thus seems plausible that the Maasina Empire was also unstable because, especially in peripheral areas, attempts to control natural resource management and herd movements ran counter to the basic strategy of herdsmen to respond flexibly to highly variable pasture conditions. ${ }^{43}$ This analysis goes against the dominant view of the Diina as having a natural resource management system aimed at the promotion of the interests of pastoral nomads who formed the backbone of the empire. Though we have found no explicit descriptions of nomadic resistance to Maasina ${ }^{44}$ it can be argued that the Diina did not promote their interests. ${ }^{45}$ Another element of this form of state-building was the campaign begun by Sheeku Aamadu to bring Islam to all villages and cattle camps, with villagers being enslaved if they did not submit. During the

\footnotetext{
${ }^{43}$ It is therefore paradoxical that in the literature related to 'development' the structural and functional aspects of this system are central (see Vincent, 'Pasteurs, Paysans'; Gallais, Le Delta Intérieur; Gallais, Hommes du Sahel; M. Forget, 'Populations et Genres de Vie dans le Kounary (Cercle de Mopti, Soudan)', in Galloy et al. Nomades et Paysans, 159-234; R.M. Moorehead, Structural Chaos: Community and State Management of Common Property in Mali (Brighton, 1991); M.D. Turner, Life on the Margin. Fulbe Herding Practices and the Relationship Between Economy and Ecology in the Inland Niger Delta in Mali (Berkeley, 1992); T. Vedeld, Village Politics. Heterogeneity, Leadership, and Collective Action among Fulani of Mali (Ås, 1997). The Diina is now being described as a balanced indigenous pre-colonial system of natural resource management corrupted by colonialism and the modern Malian state. The inherent contradictions and weaknesses when attempting to control land use in a situation where climate variability and risks associated with agricultural production are so high are completely neglected in this description (see Van Dijk, 'Ecological Insecurity and Fulbe Pastoral Society in the Niger Bend'). Its contemporary dynamics, under the impact of political change, colonialism and the penetrating market economy, are invariably valued as negative. This is often justified because current tendencies seem to reinforce the positions of those who are already powerful and wealthy (see for example, Gallais, Hommes du Sahel). However, this may be a continuation of the situation as it was in the past.

${ }^{44}$ Writing on the Guimballa (the northern part of the Inland Delta), Vincent remarks 'Les combats des chefs Peuls contre Cheikou Ahamadou sont la source de toutes les légendes que les griots racontent encore'. Unfortunately, these oral traditions have not been published. Vincent, 'Pasteurs, Paysans', 53.

${ }^{45}$ De Bruijn \& Van Dijk, 'State Formation'; Van Dijk, 'Ecological Insecurity'.
} 
nineteenth century the number of slaves increased enormously in the Inner Delta and they formed the backbone of the empire's economy.

Such a rigid reordering of the economic and social structure of the area did not of course go without resistance. In the literature, the Maasina Emirate is presented as being successful in establishing its hegemony in the area. Nevertheless, on further inquiry it appears there was fierce resistance to the empire from the beginning to the end. For example, the 'official' history of the empire compiled by $\mathrm{Ba}$ and Daget reads as a succession of campaigns against opposing forces to the central power both from inside and outside the core of the emirate. ${ }^{46}$

The success of these opposition groups was related to the support they gained from outside forces, as a movement in the northern part of the delta shows. Around 1820, Al-Hussein Koita fiercely resisted the power of Sheeku. Brown describes him as follows:

A Pulo of the Diawando caste (who) apparently gathered... [a] following in the Fittuga... although his intentions and relationship to Shaykh Ahmad's movement are not clear. The movement, however, was clearly seen by Shaykh Ahmad as a form of threat, for he sent an expeditionary force, led by his cousin, 'the son of his paternal uncle', Al-hajj Sa'id, against Husayn whose movement was destroyed in 1822-3. ${ }^{47}$

The Koita clan in Fulbe society was responsible for trade and, as Stewart remarks, trade was hampered by the rigid political and economic order Sheeku Aamadu introduced into the area. ${ }^{48}$ This could have been the reason why the Kunta, the ruling groups of Arabs in the Azaouad (Timbuktu), supported AlHussein Koita and tried to mediate for him. Koita asked a member of the Kunta clan for advice and was told:

We are always remembering you and constantly we are asking God to give you victory and backing. We are going to write to al-Shaikh Ahmad Lebbu, recommending him to pay attention to you and to entrust you with the administration of the area (in which you reside [Fittuga]) ${ }^{49}$

The Kunta did not want Sheeku Aamadu too close to their own sphere of influence and at the same time they wanted to retain access to the Inland Delta

\footnotetext{
${ }^{46}$ Ba \& Daget, L'Empire.

${ }^{47}$ Brown cited in Stewart, 'Frontier Disputes', 505.

${ }^{48}$ Johnson, 'The Economic Foundations of an Islamic Theocracy', 490, mentions that there were virtually no exports from the Maasina Emirate and that consequently restrictions were imposed on imports and taxes were levied on transit trade.

${ }^{49}$ Stewart, 'Frontier Disputes', 505.
} 
of the Niger in order to keep their trade routes open. By supporting opponents, they tried to maintain some measure of control over the area and its economy. As Stewart explained it: '.. the object of such a policy would be to undermine Shaikh Ahmad's zealous programme of reform which seems to have offended 'Abdullahi's (Kunta) real compassion for the unlettered folk who were being persecuted and which also clearly threatened Kunta commercial interests on the Niger Bend'. ${ }^{50}$

Somewhat later, in 1825 , the Kunta supported another revolt close to the political centre Hamdallaahi. This revolt 'was led by Galajio (jalajo b. bodejo) [Guelaajo] who had joined Shaikh Ahmad's [Sheeku Aamadu] movement shortly after his jihad began, embraced Islam and joined his previously conquered Bambara lands in Kunari with those of Sheeku Aamadu. He asked his former master from Timbuktu for support against Sheeku Aamadu. They were defeated finally and fled to the east where they were received by Gwandu and settled in what became the Kunari Emirate (1840)' ${ }^{51}$ In the official historiography Guelaajo is depicted as a malcontent ruler who opposed the regulations of Sheeku Aamadu. His greatest misfortune was that his realm was halved in size.

\section{The periphery of the Diina}

One of the weak points of the organization of the Maasina Emirate was its dependence on different ecological zones that, because of their vastness, were barely controllable. The Inner Delta of the Niger could not sustain the herds during the wet season and floods made the area unsuitable for pasturing animals. These animals were then led to the dryland zones east and west of the delta, zones not automatically part of the emirate and that cannot be considered as having been incorporated in the Maasina Emirate.

Nevertheless, there is a tacit assumption in the literature that the sphere of influence of the Diina extended over these areas. For instance, the Hayre Seeno area to the east was already a Fulbe-dominated area before Sheeku Aamadu attained power. Some of these Fulbe chiefs willingly submitted to their new leader, whereas others did not. An example of the latter is Ba Bulkaasum ${ }^{52}$ who refused to accept the leadership of Sheeku Aamadu. According to the oral traditions gathered in the region, the main argument used for his refusal is that

\footnotetext{
${ }^{50}$ Ibid. 506.

${ }^{51}$ Ibid. 507-8.

${ }^{52}$ De Bruijn \& Van Dijk, 'Power and Ecology'; C. Angenent, A. Breedveld, M. de Bruijn \& H. van Dijk, Hayre, Vertelling van een Nomadisch Koninkrijk (Rijswijk, 1998).
} 


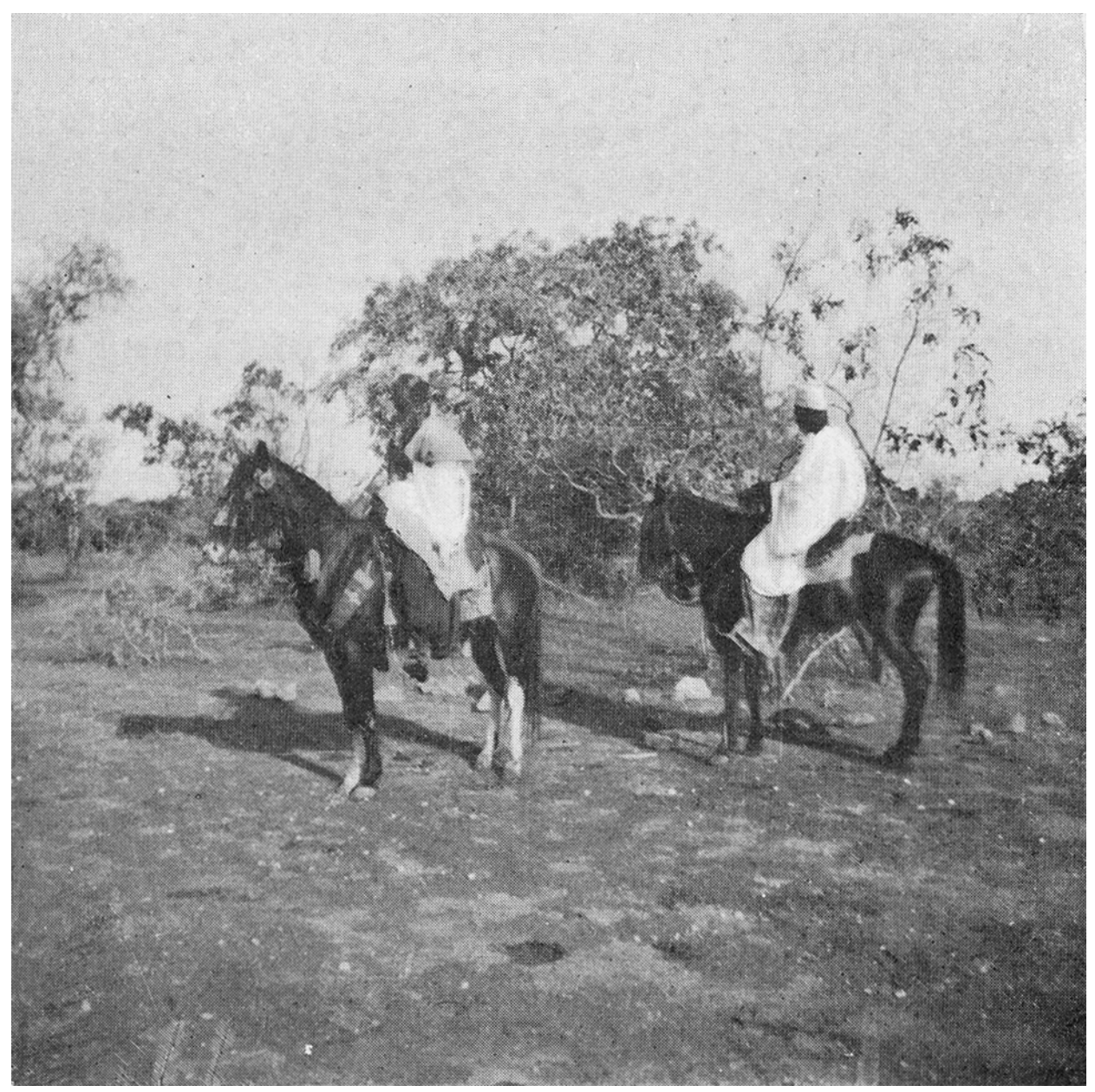

The Fulbe chief of Booni, Hamady Yero Dicko, on horseback Source: Le plateau central nigérien by Lt Louis Desplagnes (Paris, 1907) 
he did not want to submit to another Islamic leader, since he was one himself with a longer tradition. He subsequently left the area.

Towards the end of the heyday of the Diina, when the regime was becoming increasingly oppressive and exploitative, popular movements started to appear. The story about Maamudu Nduuldi, a pastoral leader in the middle of the Niger Bend in Booni, is clearly resonant of growing discontent. Maamudu Nduuldi is known as a hero with magical powers who fought and defeated the intruding Tuareg from the Niger Bend several times..$^{53}$ His movement developed in protest at the difficult economic conditions. Not only nomadic pastoralists but also runaway slaves of the Fulbe and Tuareg joined his forces, and impoverished sedentary cultivators united under his banner. According to local traditions, he brought prosperity by distributing the booty his army collected during its raids. Eventually he developed into a kind of independent warlord living on the fringes of the Diina but opposing it at the same time. He nearly went to war to fight the Hayre, the polity to which he belonged. The people here kept to magical practices and did not build a mosque or settle in camps. In short, they did not adhere to the rules imposed by the Diina.

\section{'The weapons of the weak'}

Alongside these violent and open forms of resistance to the Diina, it seems plausible that people also had other channels for opposing the state. These are not recorded in the literature but analysing contemporary rituals of the region combined with their stories about the past reveals some evidence. This is a field of study needing more in-depth analysis than is possible here. For example, there are important methodological questions attached to the problem of whether one can infer the logic and meaning of specific cultural forms in the past from their present-day existence and functioning. ${ }^{54}$ Nevertheless, one could argue that these forms are part of a cultural and historical repertoire which people draw on for specific purposes. Thus not all that one observes today has been 'invented', rather, people use memories of the past to solve current problems.

A curious example of this can be found among the Dogon of the Bandiagara Escarpment. The Dogon are a group of pagan sedentary cultivators in the drylands east of the Inland Delta. Frequently the victims of slave raids, they always opposed the Maasina Emirate and the small Fulbe chiefdoms

\footnotetext{
${ }^{53}$ Curiously, these feats have been claimed for the Maasina Emirate as well. In Ba \& Daget's book L'Empire, he is described as a warlord serving the empire. However, in Booni, the capital of the chiefdom he ultimately founded, any connection with the Diina of Seeku Aamadu is denied. Given the chronology, we are inclined to go with the Booni version of the story.

${ }^{54}$ See also De Bruijn \& Van Dijk, 'Power and Ecology'.
} 
surrounding them. Since they were not able to resist these rulers and contest their power militarily, they retreated to the inaccessible rocky areas of the Bandiagara Escarpment and Bandiagara Plateau.

The resentment this provoked among the Dogon is still recognizable in various Dogon cultural expressions. During the funerals of old men and especially the Hogon (the spiritual leader of a Dogon community), a great deal of aggression is expressed against the Fulbe. In one ritual, a dog - representing a Pullo - is killed in a particularly violent manner. Other examples of resentment are visible in the Dogon mask dances where the Fulbe, both men and women, are ridiculed: the mask representing a female Pullo only collects cow dung and has no interest in the world except for the back end of a cow; the mask representing a male Pullo expresses laziness and stupidity. ${ }^{55}$

Possession cults are found everywhere in the region, especially to the north. ${ }^{56}$ During the reign of Sheeku Aamadu, a ruthless campaign was started against pagan expressions that were unacceptable to Islam and that could not be tolerated as competing religious cults. It seems that Sheeku Aamadu accepted only certain forms of possession, for example healing rites, but no others. Today, possession cults are accepted healing practices. ${ }^{57}$ Whether the cultural expressions manifested in these possession cults were a sign of resistance, of opposition to the dominant ideology of Islam or whether they were accepted and integrated in Islam is not clear because both forms of religious expression had co-existed before the Maasina Emirate.

These cults must have been brought together in resistance to the force of an Islam that sought to take root in the smallest villages. Before this time - much before the nineteenth century - Islam had been the religion of princes and had been contained in the larger urban areas. ${ }^{58}$

A story about the confrontation of Sheeku Aamadu with one of the most important cult priests of the time suggests that the possession cults were tacitly accepted. ${ }^{59}$ However, this cannot be taken for granted: '...the Fula domination

\footnotetext{
${ }^{55}$ M. de Bruijn, W. van Beek \& H. van Dijk, 'Antagonisme et Solidarité: Les Relations entre Peuls et Dogons du Mali Central', in De Bruijn \& Van Dijk, Peuls et Mandingues, 243-66.

${ }^{56}$ Gibbal, Genii.

${ }^{57}$ Ibid. 25.

${ }^{58}$ Ibid. 27.

${ }^{59}$ Similar stories exist concerning the confrontation between Islamic scholars and the French colonial regime and between Islamic scholars and other kind of djinns (see for example, A.M. Yattara \& B. Salvaing, Almami. Une Jeunesse sur les Rives du Fleuve Niger (Brinon-sur-Sauldre, 2000).
} 
of the last century, a memory still strong in the follower's minds, had probably not been as pacific and conciliatory towards Waada Samba (the priest) and his followers as legend would lead one to believe'. ${ }^{60}$

Many of these cults' priests are riimaybe or former slaves of the Fulbe. Today the possession cults are indeed presented as a counterculture, which distinguishes riimaybe from the Fulbe nobles. This presentation of the cults also serves as a 'reinvention' of history in which the power of the Fulbe chiefs is contested and in which riimaybe heroes are presented as being neglected in mainstream history. This contestation of old power relations and the redefinition of a riimaybe identity independent of their masters is a field of study that deserves more attention.

\section{The Futanke Empire}

Many regard the Futanke or Toucouleur conquest of the western Sudan and Central Mali as a 'reform movement'. In fact, the jihad led by El Hadj Umar Tall was meant to establish the hegemony of a new Tijaniyya brotherhood over the dominant Qadiriyya (in Fuuta Jallon, Maasina, Sokoto, the Kunta, etc.). In the first instance, it can be interpreted as a resistance movement itself: '[T]o the ruling groups Umar was a dangerous revolutionary whose activities should be curtailed'. ${ }^{61}$

By the time he started his campaign, El Hadj Umar was residing in the Fuuta Jallon, which he did not subjugate. One of the reasons why this campaign developed into a real conquest was the presence of the French, who provided the Futanke with weapons through trade with the aim of using them to conquer the interior of the western Sahel. The first of El Hajj Umar's successes were in Segou, Kaarta and Maasina. However, internal rivalries between the different Futanke leaders led to a continuous struggle for control over the state apparatus and the exploitative regime built up in these areas led to further resistance against oppression. In Maasina, anti-Futanke resistance came within months of the establishment of Futanke rule. El Hajj Umar died in 1864 while fleeing to the Bandiagara Plateau (east of the Inner Delta of the Niger) following a serious rebellion staged by a coalition of forces of the Maasina Emirate and the Kunta federation from Timbuktu. ${ }^{62}$ After his death, the emirate was divided in three

\footnotetext{
${ }^{60}$ Gibbal, Genii, 34.

61 B.O. Oloruntimehin, 'Resistance Movements in the Tukulor Empire', Cahiers d'Études Africaines, 8, 29 (1968), 123-43.

${ }^{62}$ Ironically the Kunta and the Maasina Emirate were opposed during the heyday of the Maasina Emirate.
} 
parts: Segou, Kaarta and Maasina. In Segou his son, Aamadu, was the ruler, in Maasina it was Tijani. ${ }^{63}$

The coalition between the rulers of Maasina and the Kunta was finally suppressed by El Hajj Umar's successor, Tijani. In Segou the Diarra family, whose government was in exile, led the resistance while in Kaarta, the Futanke drove the opposition underground. More resistance came from the Massassi dynasty that operated from areas that were not conquered. These various resistance groups did not coordinate their actions but operated independently. This was partly due to the differences in organization of the various kingdoms that were overthrown, and their hostility towards each other, which resulted in internal fighting among the rebels. As already mentioned, the Maasina Emirate had always been an opponent of Segou's, and had been fighting against the Kunta federation. These revolts could persist and withstand the pressure of the Futanke because the French, whose interest in the interior of Africa was growing in the second half of the nineteenth century, were providing them with arms. ${ }^{64}$ The French policy was one of weakening the big empire they wanted to submit.

There are various explanations for the reasons for resistance. In the first place, it was resistance against outside conquerors but it may also have been inspired by the hostility between the various Islamic brotherhoods represented by the Futanke (Tijaniyya) and their opponents (Qadiriyya), and finally the clashes may have had their origins in ethnic opposition. Evidence of this is difficult to find since Islamic rhetoric supersedes any other possible point of friction in the available documents that were controlled by the Islamic clergy. Based on the few popular sources such as songs, poems and prose of the common people (soldiers and the like), it may be concluded that some differences did exist on the basis of ethnicity. ${ }^{65}$

Pushed ahead by the slow penetration of the French into the interior of West Africa and faced with all these pockets of resistance, the Futanke Empire remained in a constant state of war and emergency from its beginning until its gradual collapse. The string of emirates gradually gave in to French colonial forces and in 1893 after the conquest of Kaarta and Segou, the last remnants of the Futanke state, Bandiagara, were turned into a French protectorate. In local storytelling and oral traditions in Central Mali, the period from 1862 to 1893 is remembered as particularly dangerous and violent. Because of the absence of control over the peripheral areas, raiding groups of Tuareg and local rulers had a

\footnotetext{
${ }^{63}$ Robinson, The Holy War.

${ }^{64}$ Oloruntemehin, 'Resistance Movements', 133.

${ }^{65}$ J.H. Hanson, 'Islam, Ethnicity and Fulbe-Mande Relations in the Era of Umar Tal's Jihad', in De Bruijn \& Van Dijk, Peuls et Mandingues, 85-97.
} 
free hand in raiding and oppression as long as people in their own regions paid their taxes, the soldiers and slaves required by the Futanke rulers. The Futanke forged coalitions with the pagan Dogon on the Bandiagara Plateau and Fulbe from the east to withstand the pressure of the Maasina Fulbe.

The Futanke were also actively involved in raiding and plundering activities. The Inland Delta of the Niger, where the Kunta-Maasina opponents were particularly strong, was a continuous battleground and plagued by slave raids. The spatial organization elaborated under the rule of Maasina was profoundly disturbed and the establishment of the capital of the Futanke in Bandiagara on the cliffs allowed them to control areas to the east and to compete for control over the Inland Delta. ${ }^{66}$ This earned their rule qualifications like 'une guerre de pillage et massacre'. ${ }^{67}$

Internal resistance from the Futanke themselves against their own rulers also existed, though hardly any research has been done on this topic. There is, for example, a document written by a maabo, a Fulbe weaver, who fought as a soldier in the El Hadj Umar war. ${ }^{68}$ It was not published during the time of the Futanke Empire but it seems that the document was written at the court of Aamadu, but was not appreciated. It expresses grievances and critiques the war and its associated cruelties. We do not know whether this discontent was shared by a wider group of common people, and soldiers that did not want to continue the war. It is not known whether these soldiers presented serious resistance to Futanke rule or whether their opposition was only expressed in words and writing.

Internal unrest in the Futanke state of Kaarta has also been interpreted as a generational conflict. The older generation - the people who were soldiers during the conquest of Kaarta - became a wealthy landed elite who managed important trade routes and large agricultural enterprises. They opposed the war and its cruelties because it hampered their commercial ambitions. The younger generation consisted of Futanke soldiers who were newly recruited in the Fuuta Tooro and still wanted to fight to defend and expand the empire's territory and have their share in the booty before settling down as a landed elite. This generation formed a potential nucleus of resistance against the Futanke Empire from within, though for thoroughly mundane reasons. ${ }^{69}$

\footnotetext{
${ }^{66}$ Robinson, The Holy War, 312-13.

${ }^{67}$ Gallais, Le Delta Intérieur, 96.

${ }^{68}$ M. Kane, S. Fagerberg-Diallo \& D. Robinson, 'Une Vision Iconoclaste de la Guerre Sainte d'al-Hajj Umar Tall', Cahiers d'Etudes Africaines, 133-135, XXXIV-1-3 (1994), 385-419.

${ }^{69}$ Hanson, 'Generational Conflict'.
} 


\section{Discussion}

Four elements warrant further discussion. In the first place, sources on revolt and resistance from a local or a popular perspective are limited ${ }^{70}$ although numerous documents describing political unrest and leaders of revolts do appear. However, documents we collected in Central Mali only reflect the viewpoint of the political elite in power and it is therefore difficult to prove that revolts were related to the disparities created by these empires. This relationship can, nevertheless, be inferred from the fact that leaders of revolts and resistance movements were repeatedly able to mobilize a following of discontented people. This is clearly second best to eyewitness accounts. The other way to trace the existence of a counterforce is to look at the hidden transcripts in the form of ritual, storytelling and other cultural expressions. As we have indicated, there are methodological difficulties attached to this approach.

The second issue is that it is equally difficult to unravel the real sources of discontent. Often in official historiography, the propagation of Islam is the prime motivation for undertaking a jihad or to revolt against corrupt regimes. However, in other situations in West Africa, people also went to war for more mundane purposes unrelated to this ideology. In short, religion was not the only reason for revolt. Economic motives must have been equally important and the collection of booty was a widespread phenomenon in the Sahel and Sudan zone. $^{71}$ As Hanson mentions, the collection of booty was an important reason for new recruits to push for action in Futanke Kaarta. The people following Maamudu Nduuldi in the Niger Bend were impoverished and fought in his army because it brought in the livestock they lacked.

Thirdly, there is a definitional problem determining distinctions between a revolt or a rebellion and a raid or expedition to collect booty. Differences between an organized state and an emirate are also not clear-cut. All three empires discussed in this chapter originated in a revolt against established powers. Taking a long-term view of their history, political stability was the exception rather than the rule. In all three cases discussed in this chapter, the oppressed who became rebels ultimately became oppressors themselves. To remain in power they had to organize the accumulation of resources to maintain some form of administration and to feed a standing army..$^{72}$ This meant that they had to suppress their former allies and followers as the very basis of their

\footnotetext{
${ }^{70}$ The sources used by Kane et al., 'Une Vision Iconoclaste' and Hanson, 'Islam, Identity' are exceptions rather than the norm.

${ }^{71}$ Cf. Reyna, 'Predatory Accumulation'.

${ }^{72}$ For the moment, we skip the issue of ecological instability, which is an important additional factor contributing to political instability.
} 
power. As an alternative, they had to seek control over labour by raiding slaves or attempt to gain control over peripheral areas. In all cases there were costs attached to such a strategy because repercussions could always be expected. None of the empires found a lasting solution to this dilemma and political instability remained a more usual condition in the nineteenth century than political stability. This would indeed require a different approach to historical research.

Lastly, something should be said about the role of Islam. Why was Islam such a powerful vehicle behind these jihads and later revolts against the polities emanating from these jihads? As it is today, Islam provided not only an ideological framework but also a set of ideas on how to rule. This ideological component was appealing to those who were excluded from participation in the corrupt political centre. The political component of Islam provided the idea of a 'purified' state, a clear vision of the role of charismatic leadership, and rules by which life could be governed. Ironically these movements aiming at purification and emancipation often turned into their opposite. These observations from the past are relevant even today for an understanding of all kinds of events not only in Africa but also in Central and South-East Asia and recently even in Europe and North America.

From this modest investigation into resistance and rebellion in three areas of Fulbe hegemony, it is clear that the Fulbe and their associates were not able to establish stable states or empires. In the cases examined in this chapter, not only did the inherent instability of a pastoral state play a role but also the social hierarchy and its related 'class' oppositions. The relations of exploitation embedded in these hierarchies and the related feelings of inferiority seem to have been an important motive for fighting one's way up the hierarchy. Therefore, it is difficult to distinguish between a revolt against an oppressive political hierarchy and the more common wish of people in the nineteenthcentury Sahel to exploit another group. It is telling that in none of the revolts studied was the basic principle of social inequality questioned. Within the Hubbu movement slaves continued to play a subordinate role. The slaves of the Fulbe and the Tuareg who supported Maamudu Nduuldi in the Niger Bend are still of inferior status in Mali today.

Often an important drive for these revolts seems to have been an attempt to escape from the pressure of Islamic reform. However, in many cases this was the ideological justification behind more mundane motivations like the escape from economic marginality and the removal of structural limitations imposed upon one's freedom to undertake what one wanted and to raid others who were less powerful.

It is equally difficult to make a clear connection between ethnicity and revolts though this may have been important in some instances. The complexity 
of the various layers of ethnic identities, which arose over the centuries and which is largely unknown, is only beginning to unfold through new research. In a number of instances the opposition between strangers (conquerors) and the original population may have been an important dividing line. In summary, the daily reality for the ordinary people living under Fulbe rule in the eighteenth and nineteenth centuries must have been one of conflict and political instability, in which they sometimes participated actively and of which they were at other times the victims. How this influenced their daily lives will forever be hidden as there is a silence about their fate in the oral traditions and written sources of these times. 


\title{
Colonial conquest in central Madagascar: Who resisted what?
}

\author{
Stephen Ellis
}

\begin{abstract}
A rising against French colonial rule in central Madagascar (1895-1898) appeared in the 1970s as a good example of resistance to colonialism, sparked by France's occupation of Madagascar. Like many similar episodes in other parts of Africa, it was a history that appeared, in the light of later African nationalist movements, to be a precursor to the more sophisticated anti-colonial movements that eventually led to independence, in Madagascar and elsewhere. In the light of the later history of nationalism, however, it is instructive to revisit the rising of the menalamba in Madagascar and to reconsider the episode.
\end{abstract}

On 22 November 1895, less than two months after French colonial troops had taken the Merina royal capital at Antananarivo in their conquest of Madagascar, there was a violent uprising in a district immediately to the west of Madagascar's premier city. The violence was directed at local officials of the royal government and at prominent Christian converts, but what most shocked Europeans was the murder of other Europeans: the local missionary family, British Quakers who had lived in Madagascar for more than twenty years. William Johnson, his wife Lucy and their baby daughter were hacked to death by a mob of perhaps a thousand people. French troops retaliated by laying waste the area surrounding the scene of the Johnsons' murder, burning houses and killing people more or less randomly in the belief that severe punishment would prevent any repetition. ${ }^{1}$ Nevertheless, throughout the following weeks there were reports from many parts of central Madagascar of local disputes of various

${ }^{1}$ S. Ellis, The Rising of the Red Shawls: A Revolt in Madagascar, 1895-1898 (Cambridge, 1985). 
sorts getting out of control, fights breaking out at markets, unpopular village officials being attacked and church buildings being damaged. In many places there were reports of exceptionally serious raids by cattle rustlers, sometimes in bands hundreds strong, and some including Malagasy army deserters with breech-loading rifles. There were fantastic rumours of impending doom and disaster.

The French were officially committed to propping up the royal administration of Queen Ranavalona III, previously regarded by European states as the ruler of Madagascar although the state that she reigned over had never in fact controlled more than half the island. Her government was also, to a degree the French had underestimated, in an advanced state of collapse. The establishment of a protectorate was the result of lobbying by the French Foreign Ministry, which had recently achieved some success with a similar policy in Tunisia and which in principle wished to avoid any more expensive form of rule in Madagascar. This policy was contested by others in the administration in Paris, however, including some in the war ministry, members of the French expeditionary force in Madagascar and the small number of French private citizens who were already living on the island, most of them dirt-poor Creoles from the island of Réunion.

In March 1896 there was a wave of attacks on administrative posts of the Merina royal government in several parts of the central highland region. The attacks were obviously coordinated, to the point that French officials in Madagascar sensed at once that this was of a different order from ordinary cattle-stealing or even from the attack on the Johnson family four months previously. Rumours spread that the rising was secretly being organized by Queen Ranavalona, the figurehead of the protectorate government, or by some of her courtiers. There were even rumours that British missionaries were in league with the insurgents in spite of the murder of some of their own. Although these rumours were essentially false, the fact that they were so widely believed says much about the nature of the insurrection as well as about divisions among the French. This was, after all, the period of the Dreyfus affair, when French men and women were bitterly split on a great range of issues, especially those concerning the role of the army. ${ }^{2}$

The insurgents, who later became known as menalamba (red shawls), were to keep some semblance of organization until 1898 and posed a serious

\footnotetext{
${ }^{2}$ S. Ellis, 'The Political Elite of Tananarive and the Revolt of the Menalamba: The Creation of a Colonial Myth in Madagascar, 1895-1898', Journal of African History XXI, ii (1980), 219-34. Among the documents that Dreyfus was accused of having given to the German government were those relating to the French invasion of Madagascar!
} 


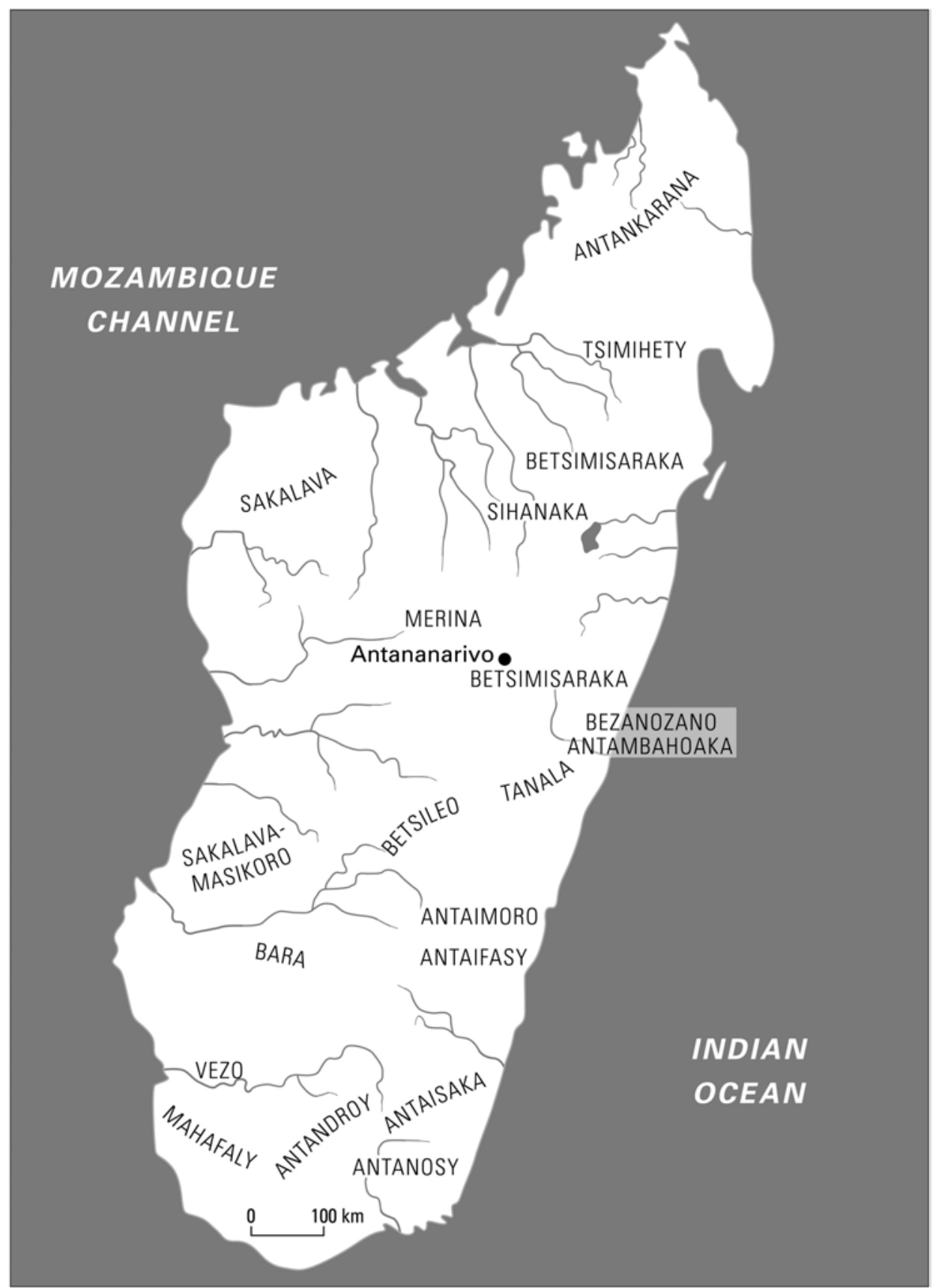

Map 3.1 Ethnic groups of Madagascar 
embarrassment to French rule. In August 1896, a senior French official on the island reckoned that 300,000 people were living in areas under menalamba control. ${ }^{3}$ In retrospect, however, it is clear that there was never the remotest chance of the menalamba forcing the French to abandon their aim of exercising formal control over Madagascar. On the contrary, the seriousness of the uprising caused the government in Paris to develop a more rigorous policy, declaring Madagascar to be a French colony and sending a military governor with wide-reaching powers, General Gallieni, to sort out the problem.

While as many as 100,000 Malagasy may have died from violence and hunger during the uprising, the number of deaths of French soldiers and civilians, more from disease than enemy action, was in the hundreds. The enormous difference in casualty figures is evidence of the superiority of French arms but perhaps also indicates something about the menalamba. It may, for example, suggest that the insurgents did not conceive of themselves as a singleminded anti-colonial resistance movement. Before exploring this idea further, however, it is useful to describe briefly the literature produced by Africanist historians on collaboration and resistance between Africans and colonial occupiers.

\section{Collaboration and resistance}

Particular historical objects or phenomena - in this case, the menalamba rising - are liable to differing interpretations as times change and new generations ask questions about the past that seem most important or interesting in the light of current circumstances. Madagascar remained a French colony from the time of the menalamba until 1960, and for 12 years afterwards its first postindependence government continued with many of the policies inherited from colonial times. For almost 80 years, there seemed little reason for anyone involved in public life to remember the menalamba other than as a reactionary opposition to colonial rule by the least educated part of the population of central Madagascar. Moreover, many Malagasy historians were Christians, who were often nostalgic about the independence of pre-colonial Madagascar but could not easily sympathize with those like the menalamba who had burned churches and killed pastors.

It was only after the uprising of 1972, when Madagascar acquired a radical nationalist and socialist government, that the memory of the menalamba was rehabilitated. The government officially commemorated the tragic anti-French insurrection of 1947, which resembled the menalamba movement in many ways,

\footnotetext{
${ }^{3}$ P. Bourde, quoted in Ellis, Rising of the Red Shawls, 97.
} 
claiming it as a precursor of its own nationalist struggle. ${ }^{4}$ The first modern book on the menalamba was published in 1976 by a Malagasy radio journalist who had devoted a series of programmes to the subject, representing the menalamba as nationalists who had fought to preserve the island from foreign rule, and including a whole series of revolts between 1895 and 1905 within this category. ${ }^{5}$ It comes as no surprise that the menalamba should have been identified as nationalists or proto-nationalists at a time when Madagascar was governed by a radical regime that based its legitimacy on its rejection of neocolonialism. In the years immediately after independence there were many African governments and their supporters that identified themselves in public with earlier anti-colonial movements. An obvious place to start looking for a radical anti-colonial pedigree was in the records of those people who had fought against European intruders in the period of conquest or of early colonial rule. This was the golden age of African nationalism: the period from 1945 until, perhaps, the independence of Zimbabwe in 1980. It was a period when it was growingly apparent to people all over the world that colonialism had become an anachronism, a politically unjust dispensation whose time had passed. Investigating the extent to which Africans had resisted colonialism was thus both interesting and politically useful.

It was in roughly these circumstances that collaboration and resistance to colonial rule were constituted as a field of formal historical inquiry by historians of Africa intent on recovering the historical records of a continent that Europeans had often dismissed as being without history. ${ }^{6}$ A pioneering work in the new history of African nationalism was Terence Ranger's book on resistance to colonial rule in Rhodesia, published in 1967 when Ranger was working at the University of Dar es Salaam's history department, a nursery of talented scholars, in a city that was one of the main diplomatic hubs of the southern African liberation struggle. ${ }^{7}$

From the beginning, one of the key themes of research on this subject was the connection between resistance to the imposition of colonial rule (dubbed 'primary resistance' by Terence Ranger) and modern nationalist movements ('secondary resistance'). ${ }^{8}$ One inclination of nationalist historians was to explore the connections between these two generations of resistance movements

${ }^{4}$ Ibid. 158-62.

${ }^{5}$ J. Rasoanasy, Menalamba sy Tanindrazana (Antananarivo, 1976).

${ }^{6}$ A notion usefully explored by E. Wolf, Europe and the People Without History (Berkeley \& London, 1982).

${ }^{7}$ T. Ranger, Revolt in Southern Rhodesia, 1896-1897 (London, 1967).

${ }^{8}$ T. Ranger, 'Connexions between "Primary Resistance Movements" and Modern Mass Nationalism in East and Central Africa', Journal of African History, 9 (1968), 437-53, $631-41$. 
with a view to determining the extent to which later nationalist movements might have been the descendants of earlier resisters, or at least with the aim of exploring the ways in which nationalists drew inspiration from earlier examples of opponents of colonial rule. Although some prominent commentators pointed out that the notions of 'collaboration' and 'resistance', redolent of Europe in the Second World War, were too stark and lacking in nuance to do justice to the complexity of most African histories, ${ }^{9}$ studies based on this approach formed a prominent school of writing in African history.

When I began in 1976 to investigate the history of the menalamba for my $\mathrm{PhD}$ thesis, it seemed obvious that the movement should in the first instance be considered as a case of resistance to colonial rule. I assumed that further and more penetrating questions would proceed from this starting-point. It was taken for granted by most Africanist historians at that time that people whose countries were being invaded by foreign troops intent on taking formal control would be naturally inclined to resist this process, so there was little point in asking why they were fighting. Ranger's work suggested that the key questions were instead related to the ways in which resisters organized themselves, whether and in what senses they could be regarded as nationalists, what the results of their struggle were, and what effects it had on later nationalist movements. I soon found, however, that the question of who precisely the menalamba were and what motivated them was of crucial importance as they seemed more intent on fighting certain other Malagasy than they did on fighting the French or Europeans more generally. Equally, there were large numbers of Malagasy who showed no interest in the menalamba, who were from the centre and centre-north of this massive island, more than two-and-a-half times the size of Britain.

I found myself being drawn not so much forward in time, as Ranger's model would imply, in order to look at the effects of the menalamba on later nationalism, but rather felt myself pulled backwards, to an examination of what sort of society the menalamba came from. The so-called Kingdom of Madagascar was something of a juridical fiction. In the eighteenth century, a powerful state had emerged in the central region known as Imerina that had subsequently expanded rapidly through military conquest. Successive rulers of Imerina after 1817 had called themselves kings and queens of Madagascar, although in fact they had never succeeded in conquering the whole island. It was apparent that the expansion of the Merina state had produced all sorts of tensions

9 For example J. Suret-Canale, "Résistance" et "Collaboration" en Afrique Noire Coloniale', in Etudes Africaines Offertes à Henri Brunschwig (Paris, 1982), 319-31. It is notable that Suret-Canale was a veteran communist who had resisted German occupation in France during the Second World War. 
and enmities tending towards social disintegration. Throughout the nineteenth century, central Madagascar had witnessed a series of movements of resistance to the royal government in Antananarivo including in the form of physical flight, occasional armed risings, and endemic banditry. The effective overthrow of this government by French forces in 1895 removed the last remaining constraints to a large-scale, violent, settling of scores.

Seen from this perspective, the menalamba movement was not only, or perhaps not even primarily, resistance to French colonization but arose from a mass of unresolved conflicts whose roots lay in the pre-colonial history of Madagascar. Another historian, Gwyn Campbell, has emphasized this aspect to the point of doubting whether the menalamba were nationalists at all, ${ }^{10}$ but this is to ignore the politics of the menalamba. There is clear evidence from their own letters that the menalamba were nationalists in the sense that many of them had a conscious notion of Madagascar as a political unity that should be governed by a single monarch, whom they often called Mpanjakan' iMadagasikara. This imagined community under one political rule qualifies as nationalism. Madagascar was rather different from many societies of mainland Africa in that the Merina Kingdom - alias the Kingdom of Madagascar acquired, before colonial times, many of the hallmarks of what contemporary Europeans regarded as a state. It had a monarch situated in a capital city who had an overwhelming armed force at his (or, after 1828, her) disposal and a high degree of control over a substantial territory, one with an industrious and generally fixed population. The second king of the ruling dynasty, Radama I (1809-28) was an autocrat who welcomed contacts with the British diplomats and missionaries who sought influence in Madagascar at the end of Britain's global war against France. King Radama had heard of Napoleon Bonaparte and developed an explicit ambition to be a conqueror like his hero, seeing the whole of Madagascar as his natural domain. He was formally recognized by Britain as the King of Madagascar in a treaty signed in 1817. Later, France, the United States and other Western countries all recognized the government in Antananarivo as the legitimate ruler of Madagascar, bringing it within the juridical field of the leading powers. Radama and his successors adopted a number of European institutions and technologies to strengthen their power, including literacy in the Latin alphabet, the institution of a state bureaucracy, and a standing army. They even made an attempt at establishing their own arms

\footnotetext{
${ }^{10}$ This is emphasized in a series of articles by G. Campbell: 'Missionaries, Fanompoana and the Menalamba Revolt in Late Nineteenth Century Madagascar', Journal of Southern African Studies, 15, 1 (1988), 54-73; 'The Menalamba Revolt and Brigandry in Imperial Madagascar, 1820-1897', International Journal of African Historical Studies, 24, 2 (1991), 259-91; 'The History of Nineteenth Century Madagascar: Le “Royaume” or “l’Empire”?', Omaly sy Anio, 33-6 (1991-2), 331-79.
} 
and munitions factories. In 1868-9 the Queen and the Prime Minister converted to Protestant Christianity and made it into the state religion, and shortly afterwards established a system of compulsory primary education.

Contemplating this chronicle 20 years ago, not only did it seem reasonable to describe the policy of successive Merina sovereigns and their leading ministers as a form of nationalism but also it was clear that elements of a nationalist ideology had taken root among at least some of their subjects. Even taking account of the decline in African nationalism as a coherent political force since the 1980s, which has suggested that its roots are perhaps more complex than once seemed to be the case, it still seems to me to be justified to describe the programme of the nineteenth-century Merina government in this way. The main objection that has been made to this is that the government in Antananarivo never succeeded in establishing control over more than two-thirds of Madagascar, and that it extended its rule by the military conquest of other parts of the island that owed allegiance to independent dynasties and other ethnic groups outside the Merina heartland. It was, it has been argued, not a national government at all, but only claimed to be such. According to this argument, the Merina state had conquered a number of independent peoples, thus being an empire rather than a national state. ${ }^{11}$ But the fact that the kingdom in Antananarivo inflicted terrible suffering in its campaign to conquer all of Madagascar, that it was never fully successful in this aim, and that the government increasingly came under the control of a clique of families from the central highlands does not detract from the identification of this government as nationalist in orientation. Part of the significance of the menalamba movement was that it demonstrated how deeply the nationalist idea had penetrated the society of the central highlands, the most densely populated area of Madagascar. It is not necessary for historians to consider nationalism as a noble or liberating force. Moreover, the various political formations throughout the island that were conquered by the Merina state did not represent ethnic groups in the sense that was to become general later, under colonial rule. The same language is spoken in the form of mutually intelligible dialects all over Madagascar, and every part of the island was influenced over the centuries by other parts of the island. The different named clusters of population at the beginning of the nineteenth century consisted of people of diverse origin who had adopted collective names in recognition of their political allegiance. ${ }^{12}$ Many of the menalamba who claimed they were fighting to restore a properly

\footnotetext{
${ }^{11}$ Campbell, 'Nineteenth Century Madagascar'.

${ }^{12}$ Cf. P. Larson, 'Desperately Seeking the Merina (Central Madagascar): Reading Ethnonyms and their Semantic Fields in African Identity Histories', Journal of Southern African Studies, 22, 4 (1996), 541-60.
} 


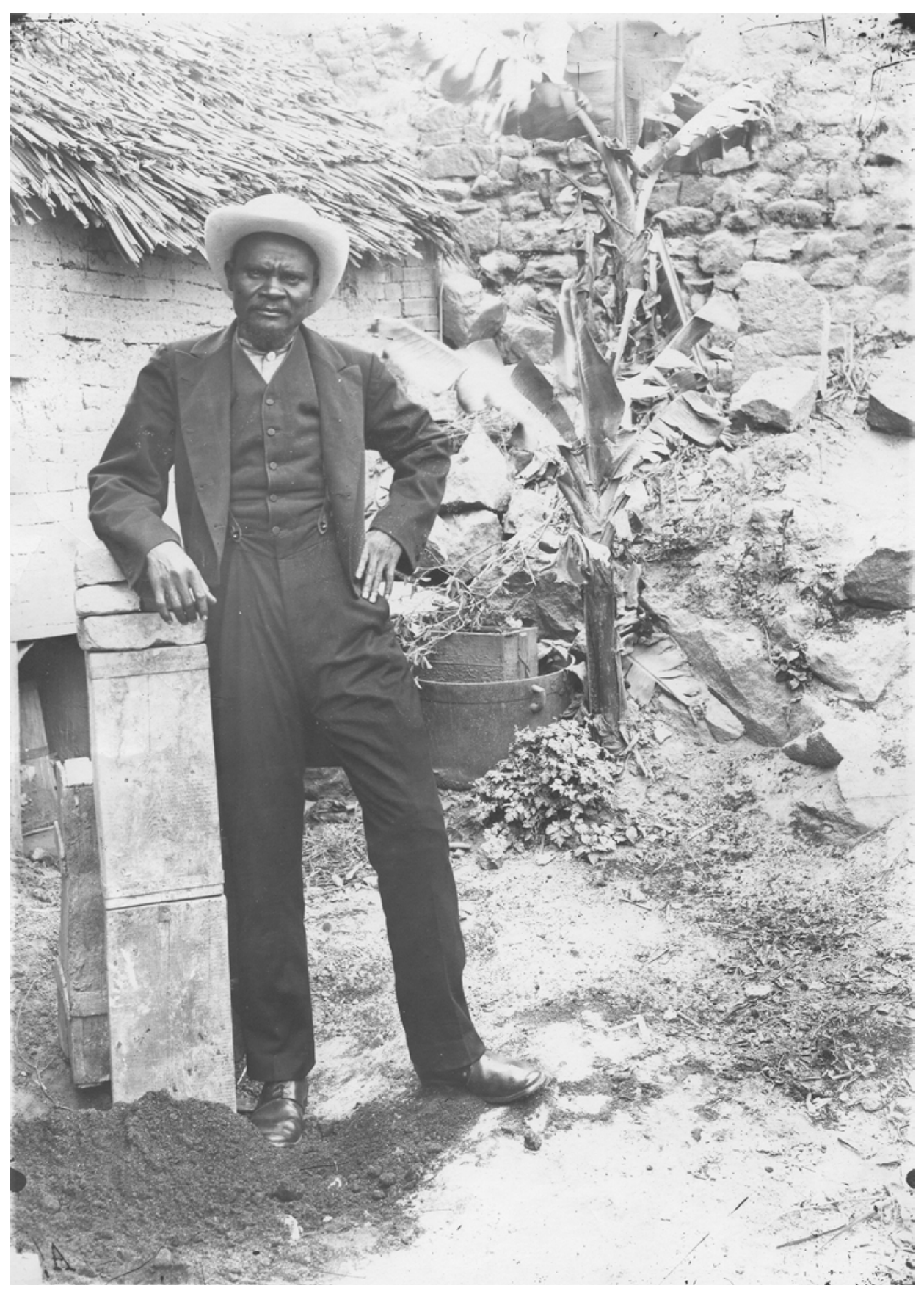

The menalamba leader Rabezavana, Madagascar, 1897 Copyright: FTM Antananarivo 
functioning sovereignty to Madagascar were not ethnic Merina in the sense of being descended from families that had lived for generations in the central highlands around Antananarivo. This is the case, for example, with one of the two most important menalamba leaders, Rabezavana.

\section{What were the menalamba resisting?}

In short, the key question that has been asked of the menalamba is what precisely they were resisting. It is clear that this was not only a movement of resistance to colonial rule. It was also a campaign against an unpopular government that had habitually used extreme brutality, particularly in the recruitment of forced labourers, and which in its earlier years had organized massive military expeditions that enslaved people on a large scale and coincidentally caused numerous deaths from disease and hunger among its own conscripts. After 1869 this same regime was associated with an official Protestant church that came to be widely resented. The abuses of this state, regarded in the emerging system of international law as independent and sovereign, provoked the anger of the menalamba, to be sure, just as they had provoked outbreaks of dissent, often in the form of flight or banditry, in earlier years. But the menalamba were more than bandits, recalcitrants or people goaded beyond endurance by material demands. They had a clear political ideology which they expounded in the messages they wrote to each other, in their public proclamations and in the actions they took. They aimed to restore the monarchy, if not in Antananarivo then in another holy place of their tradition, in what they regarded as its proper form. This was a movement of purification. The insurgents over a very large swathe of central and northern Madagascar were not resisting the principle of the Kingdom of Madagascar, as it was officially known and as the menalamba themselves sometimes called it, but the way in which it had been administered. Indeed, in September 1896 a large gathering of menalamba from different parts of central Madagascar chose one of their number to be the new king of Madagascar, to replace Queen Ranavalona whom they now regarded as illegitimate due to her relations with the French. ${ }^{13}$ This may be contrasted with anti-colonial risings in other parts of Madagascar, notably in the south and southeast in 1904-5, which had no organizational and little ideological affinity to the menalamba movement. These were risings by people who did not acknowledge the sovereignty of the kings and queens of Imerina and had no ambition to construct a single state in Madagascar. They were motivated most obviously by a refusal to submit to

\footnotetext{
${ }^{13}$ Ellis, Rising of the Red Shawls, 93.
} 
French rule and by protests against forced labour and colonial exactions and against the abolition of slavery.

\section{The penetration of capitalism}

That the self-styled Kingdom of Madagascar, ruled by Malagasy until its demise in 1895-6, was regarded by Europeans as a sovereign entity was to a considerable extent due to the growing influence of Britain in the Indian Ocean. Foreign influence in the formation of states in Madagascar was not in itself new. Successive political constructions on the island, going back many centuries, had been formed from the interaction between existing rulers and foreigners bringing in powerful political technologies, often of a ritual type. ${ }^{14}$ The European traders who frequented the coasts of Madagascar after the sixteenth century, buying slaves in exchange for guns, silver coins and manufactured goods, can be placed in a history of foreigners whose goods and skills were used as materials for political construction. However, King Radama's treaty with Britain in 1817 and the arrival of British missionaries in Antananarivo three years later was difficult. It signalled the alliance of a powerful Malagasy king who was developing an ambition to conquer the whole island with a European state (which had its own political project) able to exert unprecedented power in the western Indian Ocean. The British governor in Mauritius in 1817 had his own reasons for encouraging Radama to become king of Madagascar, to be an ally against the French and to guarantee an end to slave exports from the whole island. Unlike earlier generations of European slave-dealers and pirates, the British wanted not just to trade but also to build a new state, for which they offered technical, military and financial help.

Eighty years after the creation of an Anglo-Merina alliance, the menalamba were resisting a form of governance that, while administered by Malagasy, also represented a growing European influence. For many of the Queen of Madagascar's subjects the most obvious manifestation of this was the Christian church, considered by many to be an essentially foreign form of worship. After the $1860 \mathrm{~s}$, members of the Merina elite, for whom the church was a key structure of political administration, were increasingly likely to dress in European clothes, live in European-style houses and have a taste for imported consumer goods. The material aspects of the church, including its use for the recruitment of forced labourers and army conscripts and for raising a variety of taxes, were, before 1895, indistinguishable from its spiritual and ritual aspects.

${ }^{14}$ See, in particular, the introduction to F. Raison-Jourde, Les Souverains de Madagascar. L'Histoire Royale et ses Résurgences Contemporaines (Paris, 1983). 
The attempt to construct a Christian state of Madagascar after 1869, that was to cause such suffering before its collapse, was itself both a product and gauge of the growth of European influence that had a far-reaching effect even before the colonial period. The menalamba were fighting a Malagasy elite that they considered to have used brutal and unjust methods to enrich themselves and to have made common cause with European aggressors. Again, this is apparent in their own letters and proclamations.

If the menalamba sprang from a population that had been abused and economically exploited before the imposition of colonial rule, their greatest enemies were the members of the Christian elite who had inflicted this on them. Royal ministers and officials, encouraged by missionaries to consider European styles of consumption and living as virtuous, used their position to increase their own wealth and power. This observation could easily lead to a Marxist-tinged analysis of the pre-colonial elite of Madagascar as a comprador class, whose economic interest in collaborating with foreign capital determined their political stance. ${ }^{15}$ Such a point of view came to be quite widely applied to the analysis of resistance in Africa, raising the question of whether people who fought against colonial rule were resisting the imposition of foreign domination as such, or whether the key determinant was perhaps not in fact the incursion of capitalism. In the case of Madagascar, capitalism could be said to have had a clear effect before colonial times on the growth of markets and of a property-owning elite that traded with the West and made use of international credit. ${ }^{16}$ Studies of resistance to capitalism in this vein often took, in the hands of Marxist scholars such as Eric Hobsbawm, ${ }^{17}$ a greatly expanded notion of political action, based on the proposition that infractions of the legal or moral order are tantamount to an attack on the political order thought to underpin them. Hence, some studies of African reactions to Western encroachment took an extremely broad definition of what constituted 'resistance', sometimes considered to include not only organized military activity against colonial forces but also tax evasion, the avoidance of forced labour, flight, so-called 'social banditry' and other manifestations of a refusal to accept the official colonial order. In this way Africanists came to identify, through documents located in dusty colonial archives, a whole stream of draft and tax dodgers, vagrants and others who were now considered as potential proto-nationalists. ${ }^{18}$

\footnotetext{
${ }^{15}$ A fully-fledged Marxist analysis is P. Boiteau, Madagascar: Contribution à l'Histoire de la Nation Malgache (Paris, 1958).

${ }^{16}$ Cf. T. Ranger, 'The People in African Resistance: A Review', Journal of Southern African Studies, 4 (1977), 125-46.

${ }^{17}$ E. Hobsbawm, Bandits (Harmondsworth, 1985).

${ }^{18}$ For example A.F. Isaacman in collaboration with B. Isaacman, The Tradition of Resistance in Mozambique: Anti-colonial Activity in the Zambezi Valley, 1850-1921
} 
An analysis based rigidly on an identification of people's economic interests, however, does an injustice to historical facts, and particularly the strong political or cultural factor in people's behaviour. (Indeed, what is culture except an attribution of meaning to action?) It behoves an analyst to look at the cultural forms of behaviour, or in this instance of expressions of opposition to government. It was demonstrated on many occasions in the nineteenth century that the most effective form of opposition to the government in Antananarivo coalesced around an alternative monarch. In more distant parts of Madagascar this might be a king having an established legitimacy at least in one locality, such as the Sakalava kings on the west coast of the island, but within the area which had come under the control of the Merina kings the only politically articulate rebellions were those based on an alternative king, such as the agitation surrounding the crown prince in the late 1850 s, or the revolt in western Imerina in 1863-4 where insurgents claimed to be following a king who had miraculously resurrected or escaped assassination. ${ }^{19}$

The menalamba revolt initially convinced French colonial officials that the idea of a Malagasy nation was the construct of a Merina ethnic group (or perhaps just of its more privileged strata) that was inveterately anglophile, and that the natural allies of France were therefore to be found in other parts of the island. This led General Gallieni, the military strong man who defeated the rising and attempted to create a model colony in Madagascar, to enunciate what he called a politique des races, intended to promote the sentiment of solid ethnic allegiances to France in other parts of the island. His idea was to govern Madagascar as a series of ethnically homogeneous administrative units, all of which he hoped would be better disposed to France than the Merina were. This strategy, however, soon encountered the realization that those people deemed to be ethnic Merina were the most numerous group on the island, constituting perhaps a third of the total population. In addition, their traditions of literacy and submission to bureaucratic government and the logic of markets and cash payments made the Merina in some ways more useful colonial subjects and auxiliaries than were the inhabitants of other parts of the island. This, in time, led to the curious situation where families of the Merina bourgeoisie, who were generally well placed to derive advantage from colonization, were sending their children into the liberal professions and, later, into the upper reaches of the administration, but still retained the reputation of being fundamentally anti-

(London, 1976). This is also the approach taken in regard to Madagascar by Campbell, op. cit.

${ }^{19}$ F. Raison-Jourde, Bible et Pouvoir à Madagascar au XIXe Siècle (Paris, 1991), $197-$ 289. On the agitation around the supposed escape of Radama II, see R. Delval, Radama II, Prince de la Renaissance Malgache (Paris, 1972). 
colonial. Prominent leaders of the nationalist movement which emerged in the mid-1940s were Merina aristocrats, including even relatives of the last queen. ${ }^{20}$ The prospect of an independence that would restore to power some of the old slave-owning families of the Merina elite created a powerful counter-movement in some other parts of the island but most noticeably among the descendants of slaves in Imerina. ${ }^{21}$

Even by the 1940 s it was clear that Malagasy nationalism was complex enough to include several different strains, only some of which could be considered as belonging to the same tradition as the menalamba. At its heart was not only an aspiration to independence but also a social struggle between Malagasy. The history of the menalamba and the policies used by the colonial government to defeat the movement meant that the memory of the independent kingdom of Madagascar became an inspiration to nationalists able to point to a pre-colonial history of national government. Simultaneously however, this history was divisive, since it reminded some social groups of the exactions they had suffered under a government dominated by a ruling group of families from the central highlands. After 65 years of colonial rule, the island's populations became closer than before to ethnic groups in the modern sense, with a clear sense of regional identity and a reinvented history to fit.

\section{What is left of the resistance debate?}

I have argued elsewhere that a great deal of writing about wars in Africa from the beginning of the colonial period until the late twentieth century was influenced by the coincidence of Africa's political independence with the establishment of African history as an accepted academic sub-discipline, a process which began in Europe in the 1940s, and arguably slightly earlier in the United States by way of African-American studies. ${ }^{22}$ The literature on early resistance to colonial rule is a good illustration of how this synchronism encouraged a particular view of the past based on a sharp dichotomy between what historians have considered colonial and foreign and what they have identified as authentically African. An important aspect of historical research is

\footnotetext{
${ }^{20}$ See the biographical notes in J. Tronchon, L'Insurrection Malgache de 1947 (Paris, 1974), 207-19.

${ }^{21}$ J.-R. Randriamaro, PADESM et Luttes Politiques à Madagascar (Paris, 1997).

${ }^{22}$ S. Ellis, 'Africas Wars of Liberation: Some Historiographical Reflections', in P. Konings, W. van Binsbergen \& G. Hesseling (eds), Trajectoires de Libération en Afrique Contemporaine (Paris, 2000), 69-91. For a more extensive survey, J.C. Miller, 'History and Africa/Africa and History', American Historical Review, 104, 1 (1999), 132.
} 
to situate people as far as possible in their own time by trying in the first instance to understand what motivates them in their own terms. The danger in identifying any group of resisters of colonial rule as proto-nationalists is its inherent risk of suggesting that they were motivated by ideas that they did not in fact have. Hence, one of the main flaws in the method of identifying primary and secondary resisters of colonialism, and attempting to incorporate them into a single nationalist narrative, is the risk of anachronism which it carries.

By the same token, it is probably because of the rapidly changing fortunes of African nationalism in recent years that there have been so few studies of collaboration and resistance since the 1980s. African nationalism no longer appears to be as clearly heroic or progressive as it once did. If the debate on collaboration and resistance to colonialism ended rather abruptly, before any consensus had been reached or key questions had been really clarified, it is perhaps because of a number of contemporary developments which have served to complicate our view of the past. I would suggest that the most important of these is the onset of a new generation of wars. For example, it was in 1982 that armed clashes between rival Zimbabwean nationalist movements began in earnest, and within a short time Zimbabwean government forces were systematically killing thousands of Matabele people on suspicion of supporting the political opposition. ${ }^{23}$ Although the details of these events were not widely known at the time, it was plain that they raised a whole series of questions regarding the nature of ethnicity and factional conflict within the nationalist movements in Zimbabwe, the country which Ranger in particular had placed at the centre of debates on collaboration and resistance. This implied a need for a reformulation of discussions about which components of African societies were most opposed to colonial rule, and on what grounds, and what the consequence of their opposition was. In recent years the number of internecine conflicts in Africa has increased. War in Africa has come to seem such a disturbing phenomenon not only because of the number of victims it leaves behind, but precisely because it can no longer be so easily fitted into an explanatory framework.

The relationship to nationalism of many current wars in Africa is unclear. Armed conflicts such as those taking place in Liberia, Sierra Leone, Sudan, Congo and elsewhere today are widely perceived in the West as representing a new generation of wars thought to have been caused either by the end of the Cold War or by the impact of globalization, or a combination of the two. In an alarming number of analyses, these wars are considered a sign of reversion to an age-old barbarism said to be characteristic of Africa. This point of view is so

${ }^{23}$ K.P. Yap, 'Uprooting the Weeds: Power, Ethnicity and Violence in the Matabeleland Conflict, 1980-1987', PhD thesis, University of Amsterdam (2000). 
prejudiced as to require no further comment. ${ }^{24}$ In the most eloquent treatments, Africa's new generation of wars is bracketed together with those in the Balkans, central Asia and elsewhere as part of a wave of so-called 'new wars'. This has the considerable merit of considering Africa as an integral part of the world rather than as an enclave. ${ }^{25}$

Such an analysis supposes that a historic rupture occurred in or about the late 1980 s or early 1990s which resulted in a new wave of wars, and that these recent wars are of a radically new type. This view, though, does not really stand up to scrutiny, at least in the case of Africa. ${ }^{26}$ It is true that dictators were kept in power in Liberia and Somalia with US assistance until 1990 and 1991 respectively, and that these regimes collapsed more or less with the ending of the Cold War when the US government decided that it was no longer in its own interest to continue these relationships. In much the same way, the Mengistu regime in Ethiopia also finally collapsed in 1991 after the withdrawal of Soviet support. In all of these cases, however, military violence had already been both large-scale and systematic for years, taking the form, for example, of major conventional campaigns in Ethiopia, of substantial ethnic purges in Liberia in 1985, and of the aerial bombardment of a major Somali city, Hargeisa, in 1988. In other words, many of Africa's most serious wars actually began well before the end of the Cold War, even if these conflicts took on new forms in the 1990s.

Thus, despite arguments to the contrary, Africa's current armed conflicts go back further than the last decade and the end of the Cold War. Indeed, as shown in the introduction to this volume, wars of the current generation are often directly linked to (or they are even continuations of) struggles that occurred around the time of independence. ${ }^{27}$ This should cause us to ask some new questions about the violence which occurred during colonial times and which once seemed to be most convincingly explained as resistance to colonialism. The nature of the colonial relationship, which has been the subject of much recent research in the field of representations and identities, now appears more complex than it did three or four decades ago. The colonial bond did not consist

\footnotetext{
${ }^{24}$ See criticism of the 'New Barbarism' thesis by P. Richards, Fighting for the Rain Forest: War, Youth and Resources in Sierra Leone (Oxford \& Portsmouth NH, 1996), xiii-xxix.

${ }_{25}$ Notably M. Kaldor, New and Old Wars: Organized Violence in a Global Era (Oxford, 1999).

${ }^{26}$ The subject of an unpublished analysis by R. Marchal \& C. Messiant, 'Une Lecture Symptomale de Quelques Théorisations Récentes des Guerres Civiles', presented at a meeting in July 2001 of the Centre for Defence Studies, Kings College, London/Centre d'Etudes et de Recherches Internationales, Paris, joint study-group on African wars.

${ }^{27}$ Noted in the introduction to C. Clapham (ed.), African Guerrillas (Oxford, 1998), 118.
} 
entirely of colonial exploiters and suffering natives. Likewise, the aftermath of colonial rule in Africa was not simply a contest of continued dependency versus self-determination. There are grounds, therefore, to reconsider the whole history of violence during colonial rule and even up to very recent times within a single perspective, taking account not only of the colonial element in such conflicts but also of the social struggles within African societies.

One aspect of earlier research on collaboration and resistance which has been vindicated time after time, however, is the extent to which modern African nationalists have invoked memories of those earlier African leaders who were known to have fought against white colonizers. In Zimbabwe, as Ranger demonstrated, the same word - chimurenga - was widely used to designate both struggles. In nationalist historiography, figures such as Samory Touré in central West Africa, Rainilaiarivony in Madagascar or Sultan Rabîh in Chad have been represented as patriots or proto-nationalists whose military feats could be explained primarily by their wish to avoid being incorporated into Europeanruled states. ${ }^{28}$

These and many other historical fighters against colonialism do indeed live on in popular memory but many of them appear to have left a highly ambiguous legacy. Rainilaiarivony, the last prime minister of the pre-colonial kingdom of Madagascar, is remembered today in Madagascar but not often as a protonationalist hero. Samory Touré, to take a clearer example, was certainly regarded by French colonizers as a major opponent, and he undoubtedly built up a powerful military force which dominated areas of modern Guinea, Liberia, Sierra Leone and Côte d'Ivoire in the last two decades of the nineteenth century. French colonization of the Sahel proceeded only after his final defeat. Samory's conquests, however, were accompanied by brutal slave-raiding by his redoubtable cavalry and the forced conversion to Islam of peoples living on the historic frontier of Malinke penetration of the rain-forest. ${ }^{29}$ Ahmed Sékou Touré, the president who ruled Guinea with such ferocity from 1958 to 1984, claimed to be a direct descendant of Samory. There are probably as many West Africans today who have heard stories about Samory as a Malinke slave-raider from the north as those who know him as a fierce resister of colonialism.

At a time when politics in Côte d'Ivoire and Liberia are marked by a serious split between Malinke and others, the particular associations attached to Samory's name are of obvious relevance. Nationalists could perhaps argue that state-building, whether in Africa or elsewhere, is generally a bloody business

\footnotetext{
${ }^{28}$ See, for example, Les Africains (Paris, 1977), an eight-volume set edited by C.-A. Julien with contributions from leading historians, and published by Jeune Afrique.

${ }^{29}$ Y. Person, Samory, 3 vols (Dakar, 1968, 1975). My own observations concerning memories of Samory are based on interviews in Liberia and Côte d'Ivoire.
} 
since it proceeds via an acquisition of a monopoly of violence, and that this no more disqualifies a Samory as a nationalist hero than it disqualifies a Bonaparte or a Bismarck. This is true enough, but it is through their historic legacies that such famous nationalists are judged. The question is not how much force these people used but what their legacy is. This suggests a need to analyse the nature of memory in societies in which historical traditions are still largely orally transmitted. The findings of such an analysis would then tell us much about any particular African nationalism.

Perhaps we are better placed now than a generation ago to realize how seldom colonial rule took the form of a sudden attack by colonizers on societies previously innocent of commercial contacts with westerners. African societies had, in the past, been affected by joint interests or joint ventures in the form of the slave trade, for example. If the debate on resistance to colonial rule and its legacies is to be continued, perhaps what is most needed are new studies of various parts of Africa that dispassionately analyse what we now know of the nature of modern nationalism. 


\title{
Revisiting resistance in Italian-occupied Ethiopia: The Patriots' Movement (1936-1941) and the redefinition of post-war Ethiopia
}

\author{
Aregawi Berhe*
}

\begin{abstract}
During the Italian occupation of Ethiopia, a significant indigenous resistance movement, the Patriots Movement, emerged. The nature and impact of this resistance is reconsidered by highlighting aspects of its role in 'redefining Ethiopia', its internal policy and its position in the global community after the start of the Second World War. The resistance movement was based on the ideals of restoring national independence and preserving cultural identity. There is also discussion of the reasons for the abrupt end to the resistance - mainly due to an external intervening factor (the British army) and the defeat of Italy which prevented the challenge posed by the resistance movement and its incipient ideas of political reform being taken up seriously by the post-war imperial regime.
\end{abstract}

\section{Introduction}

In 1935, Ethiopia, until that time a traditional polity with a predominantly feudal political system, was invaded by the industrialized nation of Italy under the Fascist regime of Benito Mussolini. In defiance of the ensuing occupation, Ethiopians became involved in a multi-dimensional 'patriotic resistance' to drive the invaders out of their country, fighting against many odds, including indifference from the League of Nations and the West. It lasted for five years,

\footnotetext{
* The author wishes to express his gratitude to Professor J. Abbink for his advice and comments on this chapter.
} 
while the Ethiopian Emperor, Haile Selassie, was engaged in a largely fruitless diplomatic struggle from exile.

This chapter explains the resistance that was launched to counter the Italian occupation in Ethiopia, reconsiders the nature and impact of the resistance, and highlights aspects that 'redefined Ethiopia', its internal policy and its position in the global community following the beginning of the Second World War. The chapter has three sections. The first part is a condensed narrative of the occupation itself and the resistance it triggered. In the second part I look into the historical, religious and traditional values that drew numerous people together in resistance and discuss the actual resistance as it unfolded. Finally, I consider how the resistance came to an abrupt end because of external intervention, without which it would probably have continued for as long as the invaders could have clung on to the ancient nation. The challenge the movement posed to the post-war Ethiopian imperial state is also discussed.

\section{The Italian occupation of Ethiopia}

The Italians under Benito Mussolini were determined to have Ethiopia as their colony and make it pay for the humiliating defeat it had inflicted upon them at the Battle of Adwa in 1896, when a modern Italian army under four generals was crushed in one morning. Some years before, on 25 January 1887 at Dogali, 12 kilometres from the port of Massawa on the way to Asmara, an Ethiopian force under the command of Ras $^{1}$ Alula Ingida, the governor of the region then known as Mereb-Mellash, had destroyed another invading Italian army. As the historian Alberto Sbacchi remarked, that was 'the first major setback received by any European power at the hands of an African army'. ${ }^{2}$ The 1896 Italian defeat at Adwa, however, sent a shock wave to Rome that lingered right up until the invasion of 1935. Italy had, during this time, been contemplating a comeback to maintain its colonial interests amid competition from France and Britain in the scramble for East Africa.

'As early as 1925, Mussolini gave orders for military preparation with a view of waging war against Ethiopia, but not until 1934 did plans for the conquest of Ethiopia receive his full attention. The preparation involved huge sums of money, and quantities of trucks, tanks, artillery, airplanes, and

\footnotetext{
${ }^{1}$ Traditional Ethiopian titles denote military as well as civilian administration rankings. A ras is a chief of a region, under the emperor, and the head of a regional army.

2 A. Sbacchi, Ethiopia Under Mussolini: Fascism and the Colonial Experience (London, 1985), 4.
} 
stockpiling of poison gas, to ensure Italy's military superiority. ${ }^{3}$ In fact, 'De Bono's two visits to Eritrea in 1932 were more of military reconnaissance than a simple tour of inspection by the Minister for the Colonies'. ${ }^{4}$ The Wälwäl incident of 5 December 1934, when Italian and Ethiopian forces clashed inside Ethiopian territory over the line of the frontier was not the actual cause of the Italian invasion. Mussolini's fervour for a major onslaught on Ethiopia to build a greater empire became obvious 'when he proclaimed that he was ready to declare war on Great Britain and France rather than give up the conquest of Ethiopia'. ${ }^{5}$ Content with their victory at Adwa, the Ethiopians now had to face one of the most serious offensives in their history.

The springboard for the invasion was the land along the Red Sea coast that the Italians colonized 45 years before the 1936 invasion and which they had named Eritrea on 1 January 1890. Within two years, the final preparation for the conquest of Ethiopia was completed under the trusteeship of Marshal Emilio De Bono, the Commissioner of Colonies, who was sent to lead the invasion as Commander-in-Chief of the Northern Front, with nine divisions of 250,000 white combatants and 150,000 Africans from Libya, Italian Somaliland and Eritrea, collectively called askaris. Supported by 300 aircraft under his direct command, he had to advance from Asmara southwards into the hinterland of Ethiopia. On the southern front, one division with 100 aircraft, under Marshal Rodolfo Graziani, was deployed to head northwards. The plan was to converge on Addis Ababa, the capital city of Ethiopia, within the shortest possible time, so that pressure from the League of Nations, of which Ethiopia had been a member since 1923, for a negotiated settlement could be avoided.

The Ethiopian army, on the other hand, was estimated to have fewer than 300,000 men, mobilized by regional rases or princes whose horizontal relationship with each other was undefined and in many cases competitive, but who usually stood united when foreign enemies threatened to invade. Emperor Haile Selassie, Commander-in-Chief of the national army, experienced a lack of modern means of communication that thwarted his establishing a centralized command to coordinate the war of defence in the mountainous regions. Tactically, this was an outstanding advantage for the invaders who were to coordinate and concentrate their forces as the situation demanded. There was also the problem of armaments. 'The Ethiopian army was equipped with 200 pieces of light artillery, 1000 machine guns and rifles with 150 rounds per

\footnotetext{
${ }^{3}$ Sbacchi, Ethiopia Under Mussolini, 7-8.

${ }^{4}$ A. Mockler, Haile Selassie's War (Oxford, 1984), 41.

${ }^{5}$ R. Aron, Peace and War: A Theory of International Relations (London, 1966), 67.
} 
person. ${ }^{6}$ Logistics were self-supplied except for small ammunition and hand grenades that were provided only sporadically. With the few exceptions of those who had travelled abroad, Ethiopians had not even seen armoured vehicles, tanks or bomber aircraft before. What brought them together to confront the mighty enemy was a strong self-image of national pride and patriotism, a love of freedom vis-à-vis foreigners, and specific ideals of human dignity they had nurtured through a long history of nationhood. The determination to remain independent and defend their specific cultural and religious values was manifested in their prayers, folk music and war songs, carried through the war and the resistance that followed.

Early in October 1935 the Italians made a rapid advance towards Adwa, which was 30 kilometres from the colonial frontier that divided Eritrea and Tigray, the northern region of Ethiopia. The Ethiopian forces at Adwa were not only outnumbered but also could not withstand the long-range shelling of the howitzers, the deadly machine guns on the tanks and the bombs raining down from the air. The weapons they possessed were no match for modern Italian armaments. Before any serious engagement, they were ordered to withdraw in order to save their forces for a well-planned defensive manoeuvre deep in the country. On 6 October 1935, Adwa fell into Italian hands. Its seizure gave the invaders some psychological relief from the humiliating defeat they had suffered at Dogali and Adwa in 1887 and 1896 respectively, yet for those at the front, the war was just beginning and De Bono decided to advance with caution.

A month later, on 8 November 1935, Mekele, the capital of the province of Tigray, came under the control of the Italians. Mussolini, who was infuriated by the slow pace of the campaign, replaced De Bono with Marshal Pietro Badoglio, who was Chief of Staff of the Italian army. Following instructions from Rome, Badoglio resorted to harsh military tactics to score a quick victory, including the dropping from the air of mustard-gas bombs over Ethiopian troops and civilian areas, even though mustard gas had been banned in 1925 by the Geneva Gas Protocol, to which Ethiopia and Italy were signatories. Thousands perished.

Despite fire and air superiority and the use of mustard gas, the Ethiopian rebels and resistance fighters, who came to be known as 'Patriots' (locally known as Arbegnoch), began to regroup in their respective districts under their local leaders to confront the enemy. A series of major battles was waged over a period of three months: 15 December 1935 at Shiré and Enda-Baguna; 20-24 January 1936 at Worsege-Tembien; 27-29 February at Workamba and AbiadiTembien; 1-3 March at Selekhlekha; and in the second week of March at Emba Aradom and all the way to Alage. The battles were intense and the

\footnotetext{
${ }^{6}$ F.P. Chambers, The Age of Conflict: The Western World - 1914 to the Present (New
} York, 1962), 409. 
determination of the Ethiopians was tested against all odds. In his autobiography the Emperor later wrote: 'Although the Italians were superior to us in modern arms, our soldiers had the advantage in terms of courage. While our soldiers, who had won the battles in the Tambien and Shiré regions, were fighting with obsolete rifles like the Fusil Gras, they yet managed to capture more than 300 machine-guns and many cannons and tanks. ${ }^{7}$ (Marshal Badoglio, on the other hand, estimated the number of Italian casualties in the Shire region alone as follows: 'Our losses, including dead and wounded, were: 63 officers, 894 Italians, 12 Eritreans. The losses of the enemy as ascertained on the field were about 4,000; to these must be added those inflicted by aircraft during the pursuit, the total of which was estimated at over 3,000. ${ }^{8}$ ) This battlefront in the district of Shiré was just one of the several fronts in Tigray and was lead by Ras Imru, Governor of Gojjam Province, who later retreated to Gore in southwest Ethiopia. Virtually the whole of Tigray became a battleground for six consecutive months.

Finally, on 31 March 1936 at Maichew and Lake Ashangé, the Emperor's main force put up tenacious resistance but at the end of the day the Ethiopians were forced to retreat further south towards Dessie, the provincial capital of Wollo. Dessie fell into the hands of the Italians on 4 April 1936 after three days of long and bloody fighting. Unable to regroup and launch a counter-offensive, the Emperor and his remaining forces headed for Addis Ababa. The Battle of Maichew where the Emperor had assembled his best forces, eventually turned out to be the end of the conventional confrontation and the beginning of the Patriots' resistance movement, which in fact seemed to have already started behind enemy lines.

On the southern and southeastern fronts, however, the fighting remained intense with the forces of Ras Desta, Dejazmach ${ }^{9}$ Nesibu and Dejazmach Mekonnen, the governors of Sidamo, Harar and Illubabor regions respectively, deterring the northward movement of Marshal Graziani, who had vowed to deliver Ethiopia to Mussolini 'with the Ethiopians or without them'. ${ }^{10}$ Graziani's wild statement was a reflection of Italy's intended policy of resettling its overcrowded farmers on the fertile lands of Ethiopia. Not content with showering the Ethiopians with mustard gas, Graziani also resorted to the massacre of non-combatant villagers, for example, during battles in the Ogaden in 1936. At this time, about 900 Eritrean askaris, appalled by such Italian war

${ }^{7}$ Haile Selassie I, The Autobiography of Emperor Haile Selassie I: My Life and Ethiopia's Progress 1892-1937, translated and annotated by E. Ullendorff, (Oxford, 1976), 263.

${ }^{8}$ P. Badoglio, The War in Abyssinia (London, 1937), 119.

${ }^{9}$ A dejazmach is a duke or commander of the front.

${ }^{10}$ A. Del Boca, The Ethiopian War 1935-1941 (Chicago, 1969), 113. 
tactics, deserted to the Ethiopian side, thus testing the loyalty of the other colonial soldiers. Previously, in mid-December 1935, 400 Eritreans had already joined Ras Imru's forces on the Shiré front. ${ }^{11}$ These desertions revealed the sympathy that many Eritreans felt for the Ethiopian and anti-colonial cause.

While Graziani was contained on the southeastern front, Emperor Haile Selassie was unable to check Badoglio who was advancing from the north. The Emperor retreated from Dessie and entered Addis Ababa on the morning of 30 April 1936, only to leave again two days later on his way into exile. On 5 May 1936 Addis Ababa fell into the hands of the invaders without any resistance but amid chaos and looting triggered by the Emperor's departure.

The day the Emperor arrived in his capital, he hastily convened an assembly of his ministers and nobles. Two important agreements were immediately reached: (a) the Emperor had to go abroad to present Ethiopia's case to the League of Nations; and (b) the seat of government had to move to Gore, southwest of Addis Ababa, and Bitweded ${ }^{12}$ Wolde-Tsadik Goshu should act as regent. While the first decision called for a diplomatic and political struggle, the second in effect meant the launch of a resistance movement against the Italian conquest, and was aimed at regaining independence. Many of the younger Patriots, aware of the ensuing authority gap caused by the Emperor's absence, did not approve of his departure into exile. 'Even the young Crown Prince had been suggesting to his own followers - to Dejazmach Fikremariam and Dejazmach Gurassu - that he should abandon his father and go with them as shifta to the hills'. ${ }^{13}$ But as the decision of the Emperor could not be contested, the resistance or shiftinnet ('banditry') had to commence without him.

\section{Resistance}

\section{Historical background to Ethiopian nationhood}

Although strictly speaking beyond the scope of this chapter, a brief sketch of important moments in Ethiopia's history is provided here in order to better grasp the essence of the resistance, as it was nurtured by strong notions of nationhood and cultural identity among large sectors of the population.

The recorded history of Ethiopia as a state dates from the third century when it was known as the Kingdom of Aksum. Around 340 AD the Aksumite kings adopted Orthodox Christianity, which quickly became the religion of the

\footnotetext{
11 Nega Tegegn, Ye'Ethiopiawiyan Ye'Rejim Zemenat Tiglena Zemenawi Serawit Ameseraret 1855-1974 (Toronto, 2001), 73.

${ }^{12}$ A bitweded is a 'beloved', a trustee of the emperor.

${ }^{13}$ Mockler, Haile Selassie's War, 135.
} 
inhabitants and provided the symbolism and substance of the royal ideology. They also developed literary works, commerce through the ports of Adulis and Zeila, and the minting of coins. The empire gradually expanded over the Ethiopian highlands.

The expansion of Islam after the seventh century led to a loss of international trade routes and revenue for Aksum and a decline in its regional power. In the tenth century, a revolt by Queen Yodit of the Agew people further to the south led to the demise of the Aksum state. The kingship was reconstituted by the Christian Zagwe dynasty located in the Agew country (in the tenth to thirteenth centuries). In the thirteenth century, the Ethiopian state, now located further to the south, was revived on the basis of a restyled Aksumite royal ideology. Not long afterwards however, the expansion of Islam from the north (from the Ottoman Empire) and the assault of Imam Ahmed ibn Ibrahim al-Ghazi in 1527-1543 dealt another devastating blow to the Ethiopian Christian empire, its population, resources, religious culture and architecture. After Ahmed's defeat in 1543 it recovered only slowly. Then the Oromo migrations from the south brought another challenge by forcing a periodic shift of the political centre and a transformation of central Ethiopia's civilization. The gradual loss of dynamism of the centralized state in turn gave rise to the emergence of local kings and princes who were often entangled in violent rivalry for supremacy (1760-1855).

In 1855 the powerful Emperor Tewodros II (who reigned from 1855-1868) introduced the vision of a unified and modern Ethiopia. He managed to set up some semblance of a central state and collected royal revenues from the Amhara and Tigray regions. While challenging the encroachment of the Egyptians in the coastal area, Tewodros at the same time came into conflict with the British when he took hostage and locked up a number of European missionaries. The British sent an expeditionary force in 1868 and besieged his mountain fortress of Maqdala, where Tewodros, encircled by the British and with his offers of negotiation refused, chose to take his own life on 10 April 1868 rather than surrender to the invader. After a brief interlude he was succeeded by Emperor Yohannes (who reigned from 1872-1889) who had to fight against the Egyptians and later the Italians in the north. In the late 1880s he fought the invading Sudanese Mahdists in western Ethiopia, where he finally died at the Battle of Metemma in 1889. His successor, Emperor Menilik (who reigned from 1889-1913), was a strong, modernizing leader who defeated the Italians at Adwa in 1896. To challenge the unbridled ambition of the foreign invaders, he was fully engaged in competition with France, Italy and Great Britain to expand territorial influence in the Horn of Africa, incorporating a large number of previously autonomous regions into the empire. The last of the emperors, Haile 
Selassie (who reigned from 1930-1974) also had to fight invasion. He saw defeat (in 1936) and success (in 1941) while fighting Italian invaders.

These last four emperors maintained a similar vision of creating a unified modern Ethiopia, and attempted to impose new ideas of loyalty and national identity on a dispersed and diverse population. The effects of this long history of struggle against a series of invaders created a sense of identity and pride associated with ancient historical referents based on political glory and religion, not only among the elite but also among the common people.

\section{The resistance begins}

By the time the Italian army had Addis Ababa under its control and Mussolini had declared Ethiopia part of the Italian Empire on 9 May 1936, only a section of the northern part of the country was firmly under their control. Sbacchi ${ }^{14}$ observed that: "Five months after the defeat of Emperor Haile Selassie, Badoglio and Graziani controlled only one third of the country'. After the Battle of Maichew, resistance commenced more or less immediately. Many groups from the defeated army went into the bush and started resistance actions. Throughout the occupation period these Patriots remained active and made life difficult for the Italians, especially in rural northern, eastern and central Ethiopia. The country was thus never effectively occupied or colonized. For our purposes in this chapter it is also important to realize that during the struggle, which began as a 'defense of the motherland', new conceptions of politics and governance for Ethiopia emerged with and during the ongoing struggle.

Although Mussolini exerted repeated pressure on his marshals on the frontlines to demonstrate a swift and profound victory over Ethiopia so that his rivals (Britain and France) would recognize Italy's might, the progress made by his modern army remained slow as a result of the resistance it encountered. In the years that followed, the Italians were challenged in many a gorge, hill, mountain and village by units of Ethiopian Patriots.

For many Ethiopians, the occupation of their land and the subsequent flight of their Emperor into exile meant the loss of their dignity and identity as a nation. It also meant the threat to or destruction of their traditional values and institutions, and more importantly the disruption of their history of which they were proud. The common motto at the time became 'Tenes! atenesam woy, Hager sewrer zim telaleh woy' ('Rise up! Oh rise up, you cannot sit there when the country is invaded'). In connection with this motto, Haddis Alemayehu, in his book of personal recollections entitled Tezeta, gives a list of poems, poetic

\footnotetext{
${ }^{14}$ Sbacchi, Ethiopia Under Mussolini, 34.
} 
calls and war songs, like Bälew attilim woy! Tekur anbesa aydellehim woy (Get him, aren't you a black lion?). ${ }^{15}$

During the 1935-1936 war, behind the lines declared 'liberated' by the Italians, hundreds of Patriots emerged in their respective localities to wage a war of resistance in defiance of the occupation. While conventional battles were raging in central and southeastern Ethiopia, Tigray, the first province to be occupied in northern Ethiopia, became the first battleground for the Patriots. They operated in small groups, not far from their respective localities. Dejazmach Gebrehiwet Mesheha, Dejazmach Abbai Kahsay, Dejazmach Tesfay Medebai, Fitawrari ${ }^{16}$ Tessema Tesfay, Dejazmach Gizaw, Dejazmach Taffere, Agafari ${ }^{17}$ Birru, Kassa Sibhat, Kegnazmach ${ }^{18}$ Aberra Adale and on the women's side Woizero ${ }^{19}$ Kebedech Seyoum and Woizero Desta Gebre-Mikael were some of the prominent resistance leaders operating independently from Adwa in the north of Tigray to Maichew in the south of the province. They were engaged in activities such as the ambushing of enemy troops to acquire arms and other war materials, snowballing huge rocks off mountains and cliffs when enemy convoys passed, disrupting the enemy's communication systems by kidnapping their messengers and later cutting telephone lines, setting fire to anything under enemy control such as offices and fuel or ammunition depots by firing from long range, and harassing and killing enemy collaborators.

As the activities of the Patriots in Tigray escalated, the Italians began deploying more detachments, depleting their main force pushing southwards. The Patriots, now referred to as shifta by the Italians, were liable to be hunted down. The word shifta can be translated as 'bandit' or 'outlaw', but in the traditional Ethiopian context the concept of shifta was much broader than what the Italians wanted it to mean. To be a shifta meant to rebel against someone in authority or against an institution that had failed to render justice. To become a shifta was also generally accepted as a means of bringing grievances to the attention of the people in order to gain sympathy when higher authorities had failed to deliver justice or rights customarily due. Usually a shifta emerged from the noble classes and had some form of wider, critical vision on the social order that enabled him/her to express, in words or in action, real or perceived injustices and responses to the situation. The commitment to deliver justice that was initially denied is embedded in the concept of shifta, although a shifta may $\mathrm{him} /$ herself not necessarily be free from wrongdoing. Thus shiftinnet (being a

\footnotetext{
${ }^{15}$ Haddis Alemayehu, Tizita (Addis Ababa, 1985), $151 \& 163$.

${ }^{16}$ A fitawrari is a commander of the advance guard.

${ }^{17}$ An agafari is a master of ceremonies at the royal court.

${ }^{18}$ A kegnazmach is a commander of the right wing.

${ }^{19}$ A woizero is the title for a woman; a lady.
} 
shifta) in its diverse forms had an important social function and was one form of 'conflict resolution'. ${ }^{20}$

In Ethiopia, visionary and assertive individuals who started as shifta had risen to the level of kingship, thus legitimizing the concept of shifta itself. Two late nineteenth-century shiftas, Kassa Hailu of Gondar and Kahsai Mircha of Tigray, had passed through this political evolution to become Emperors Tewodros and Yohannes in succession. Thus 'the shiftas formed the military elite and became the core of the resistance, using their military skills against the Italians' ${ }^{21}$ A shifta, however, whose acts surpassed the socially acceptable norms would be called t'era-shifta and would be regarded as a highwayman or a malefactor and be denied the affection of the people. The Italians understandably preferred to label the Patriots t'era-shiftas of the criminal type. Nevertheless, to be described as a shifta, especially in the event of Italian occupation, was an honour for an Ethiopian and this was how resistance started and spread. A commonly sung lyrical poem in the region at that time went:

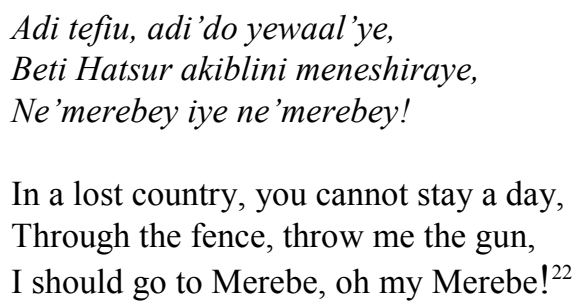

There were many such popular songs, which were in effect traditional calls for resistance before the official call came. Officially, though, on 9 December 1935, the Ethiopian Minister of War, Ras Mulugeta Yigezu, issued an order to all the chiefs of northern Ethiopia to carry on with 'patriotic resistance against the Italians for taking away the independence of Ethiopia' ${ }^{23}$

While a guerrilla war, which had basically been the tactics of the shifta, was underway in the north in 1936 where the enemy had assumed full control, conventional battles were still raging in the centre, particularly around Addis

\footnotetext{
${ }^{20}$ T. Fernyhough, 'Social Mobility and Dissident Elites in Northern Ethiopia: The Role of Banditry, 1900-1969', in 'Proceedings of the Symposium on Rebellion and Social Protest in Africa', April 22-24, African Studies Program, University of Illinois (unpublished, 1982), 1.

21 A. Sbacchi, Legacy of Bitterness: Ethiopia and Fascist Italy, 1935-1941 (Lawrenceville, N.J., 1997), 182.

${ }^{22}$ The Merebe is a long river gorge that gave shelter to shiftas and from where they could launch attacks on the enemy.

${ }^{23}$ Sbacchi, Legacy of Bitterness, 165.
} 
Ababa and to the south. After the defeat of the Emperor's troops at Maichew and the fall of Addis Ababa to the Italians on 5 May 1936, the rases, dejazmaches and all other notables withdrew to their respective areas but were within close range of Addis Ababa. They were based in familiar and strategic villages to recover from the exhaustion of eight months of war, and to reorganize their forces for the next phase of the patriotic fight. These villages were logistically well situated, in that the leaders were able to follow events in the capital that might cause them to launch attacks. Ras Abebe Aregay was in Ankober, Dejazmach Balcha Safo in Gurage land, Dejazmach Zewdu Asfaw in Mullo, Blatta ${ }^{24}$ Takele Wolde-Hawariat in Limmu, the Ras Kassa brothers (Aberra, Asfaw-Wosen and Wond-Wosen) in Selale, and Haile Mariam Mamo was engaged in hit-and-run tactics around the city. With more than 10,000 troops, Aberra, the son of Ras Kassa (who had accompanied the Emperor into exile) had been entrusted by the Emperor to coordinate the resistance in that region, which he was doing his best to accomplish. On 21 June 1936, for instance, he held a meeting of some Patriotic leaders, including the Patriarch of Wollo, Abune ${ }^{25}$ Petros, at Debre Libanos, the renowned monastery dating from 1312 and located some 70 kilometres north of Addis Ababa. They made a plan to storm enemy-occupied areas in the capital but a lack of effective means of transportation and radio communication prevented a coordinated assault from taking place. Sporadic attacks by the different groups continued, however, to dominate the battle scene around Addis Ababa.

Goré, in southeastern Ethiopia, the seat of the displaced government run by the elder regent, Bitweded Wolde-Tsadik Goshu, was far from within easy reach and never became effective in providing nationwide leadership to the resistance movement. The rases and governors had to do without the Emperor who was considered both the legitimate leader and an able commander. Indeed for many, the unexpected departure of the authoritative Emperor into exile had created a gap nobody seemed able to fill. The few rases, like Imru in Wollega and Desta in Sidamo, who had made the long retreat from the defeat in the north to the south near Goré, could neither realize effective mobility nor acquire the resources to keep their troops intact. But from a distance of hundreds of kilometres, their holding out and acts of defiance helped to inspire others to resist. Thus, they were capable of continuously 'distracting the Italians' mind and attention' ${ }^{26}$

\footnotetext{
${ }^{24} \mathrm{~A}$ blatta is the chief of staff, and an executive at the court.

${ }^{25}$ The Abun is the head of the Ethiopian Orthodox Church.

${ }^{26}$ Salome Gabre-Egziabher, 'The Ethiopian Patriots 1936-1941', Ethiopian Observer, 12, 2 (1969), 70.
} 
Early on, as information about the coordinated attack on Addis Ababa reached the Italians, they encircled the city with barbed wire and 38 cement forts. People and traffic could come into the city only through ten gates. ${ }^{27}$ This was indicative of the need for precautions against resistance activity. In general, as conventional warfare had proved ineffective in the face of the modern Italian conventional army, the need to resist the enemy in another form emerged.

\section{The spread of resistance}

The prospect of conventional war gradually faded but the spirit of resistance persisted. A different attitude of defiance and ways of attacking began to surface from many quarters. Virtually the entire membership of the Ethiopian Orthodox Church, the Ethiopian Women's Volunteer Service Association (EWVSA) and the Black Lion Organization, as well as many other small groups of individuals, appeared in the forefront of the resistance. Their activities ranged from direct assaults on top Italian leaders to providing all-round underground support to the Patriots in the villages and mountains.

The Orthodox Church, which was historically an integral part of the Ethiopian state, began to play a pivotal role in broadening the dimensions of the resistance. The Church took it as an everyday obligation, inside and outside the church, to renounce the incursion of Italian invaders in a free country with a sovereign state. Passages from the Bible were frequently cited to invoke national sentiment and loyalty. The verse 'Ethiopia shall stretch out her hands unto $\mathrm{God}^{28}$ was recited in daily prayers. It was interpreted to mean that Ethiopia deserved all the rights of a free nation as recognized by the Almighty, and the Christian world should stand by its side. Guided by such a deep-rooted belief, Abune Petros, the Bishop of Wollo, marched through the streets of Addis Ababa denouncing the Italian occupation and calling on the people to keep fighting for independence. Many people came out of their houses to support him. However he was soon apprehended and on 30 July 1936 executed by firing squad in a public square, where his statue now stands.

The killing of a bishop was unheard of in Ethiopia and shocked the nation, arousing the indignation of the people, especially the clergy. Defiance of Italian rule was mounting in different forms but such reactions did not stop the Italians who proceeded to execute monks, priests and deacons in many monasteries and churches, expecting submission. 'On 21 May 1937, General P. Maletti had executed in the monastery of Debre Libanos alone 297 monks'. ${ }^{29}$ Five days later, more priests and deacons were massacred in the nearby church of Debre

\footnotetext{
${ }^{27}$ Sbacchi, Legacy of Bitterness, 170.

${ }^{28}$ Psalms 68: 31.

${ }^{29}$ Sbacchi, Ethiopia Under Mussolini, 195.
} 


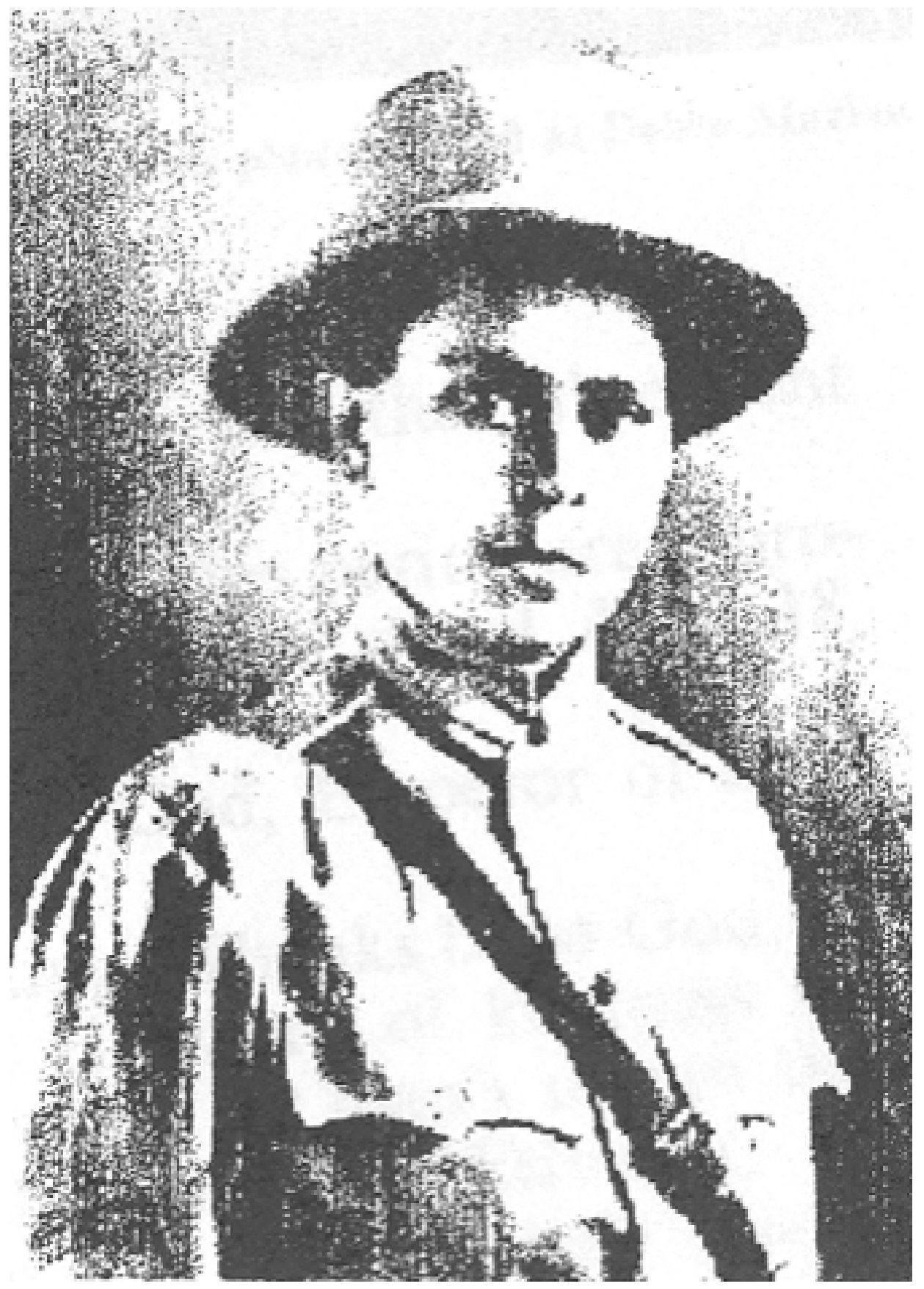

Kebedech Seyoum, a female Patriot, c. 1935

Source: Nega Tegegn, Ye'Ethiopiawiyan 
Birhan, other executions and repression followed elsewhere. Yet the numerous monasteries and churches of Ethiopia continued to be centres of resistance and propaganda and to offer sanctuary to the Patriots.

The participation of women in the resistance was crucial. It is difficult to estimate their real military contribution but their supplementary support activities, spying and sabotage actions in some instances were decisive. Historically, women had been active participants in previous wars defending the country. Not long before, Empress Taytu and her husband Emperor Menilik had marched to the battlefront in Adwa in 1896 and played an important role in bringing about the defeat of the Italians. Chris Prouty reports that Taytu had organized thousands of women, including Zewditu, her step daughter and later empress (1916-1928), and Azalech, her cousin, and strengthened the defence lines by supplying water and taking care of the wounded. ${ }^{30}$ She was also a military tactician whose participation had helped to bring about the defeat of the Italians at the Battle of Mekele a month before the Battle of Adwa. ${ }^{31}$ Ethiopian women had, thus, a reputation to uphold in defending the national cause. ${ }^{32}$

Woizero Shawaragad Gadle had turned the EWVSA, which was under the patronage of Princess Tenagne-Work, daughter of the Emperor, into a clandestine movement of resistance. The women in this association were involved in scores of activities, ranging from supplying bandages, clothes and ammunition bought or stolen from Italian troops to the Patriots in the field, to giving shelter and forging pass papers for the active Patriots to travel inside enemy-controlled territory. Some of the women gathered military intelligence and a few even planned military operations. It was Shawaragad Gadle 'who laid the groundwork for the storming of the Italian garrison at Addis Alem' ${ }^{33}$ It was during this time that the term Yewist Arbegna (clandestine Patriot) was coined.

In the countryside not only did women prepare quanta (dried meat), qollo (roasted cereals), besso (instant cereal powder) and various foodstuffs that may be compared to 'dry rations' in modern military jargon but also sharpened swords and shuttled between the zones of operation and their houses. According to G. Tafere's dramatized description, they also 'sent down from various slopes avalanches of stones, not heeding the shower of bombs that were coming down from the air, and women like Woizero Fantaye actually fought on the

${ }^{30}$ C. Prouty, Empress Taytu and Menilek II: Ethiopia 1883-1910 (Trenton, N.J., 1986), 156-57.

${ }^{31}$ Nega Tegegn, Ye'Ethiopiawiyan, 35-36.

${ }^{32}$ For a more detailed account, see Minale Adugna, Women and Warfare in Ethiopia (Addis Ababa, 2001).

${ }^{33}$ Bahru Zewde, A History of Modern Ethiopia 1855-1974 (London, 1991), 72; Sbacchi, Legacy of Bitterness, 180. 
battlefields' ${ }^{34}$ In her documentary study, Salome Gebre-Egziabher ${ }^{35}$ provides a list of 64 women patriots in the resistance movement and also gave the names of prominent Patriots from every region, including hundreds from Eritrea.

It was customary for married couples and young boys to join the resistance army and often find themselves far away from their homes for years. 'When Dejazmach Habtemariam was too sick to lead the battles in Ogaden in April 1936, his wife, equally a Patriot, took over commanding his troops' ${ }^{36}$ 'Woizero Wagaye and her husband $\mathrm{Lij}^{37}$ Bitew, the secretary of Ras Imru, have been together all the way from the northern front of Shire to the southern front in Wollega and many other married couples too were participating continuously in the patriotic resistance. ${ }^{38}$ John Spencer adds to the list of prominent women freedom fighters, 'Kebedech Seyoum, Qelemework Tilahun, Sliva Reyed Gadle, Laqetch Demissew, Qonjit Abinet, Likelesh Beyene and Abebech Cherkos ${ }^{39}$ Gessesew Ayele joined the resistance force at the age of 14 and fought on the southern front.

In Addis Ababa, a group called the Black Lion Organization was formed, composed of young intellectuals from various schools and colleges including the recently established Holetta Military College. Some of its prominent leaders included Dr Alemwork Beyene, a veterinary surgeon, Yilma Deressa, a graduate of the London School of Economics, Belay Haile-Ab and Kifle Nesibu, both Holetta graduates, and Fekade-Selassie Hiruy and the Workeneh brothers, three of them British-educated. Their aim was much broader than any other group in the resistance, their organization had a constitution and they were poised to undertake urban and rural guerrilla warfare. Their constitution reflected their political motivation and commitment, and their programme also referred to the period that would follow a successful resistance.

According to Taddasa, 'among the most striking features of the constitution [of the Black Lion Organization] were: the affirmation of the supremacy of political over military command, the provision for the human treatment of prisoners and the non-molestation of the peasantry, the prohibition of exile, and the injunction of suicide rather than capture by the enemy, ${ }^{40}$

${ }^{34}$ Tafere in Salome, 'The Ethiopian Patriots', 78.

${ }^{35}$ Salome, 'The Ethiopian Patriots', ibid.

${ }^{36}$ Mockler, Haile Selassie's War, 128.

${ }^{37} \mathrm{~A}$ lij is a young nobleman.

${ }^{38}$ Haddis Alemayehu, Tizita, 180.

39 J.H. Spencer, Ethiopia at Bay: A Personal Account of the Haile Selassie Years (Algonac, MI, 1987), 82.

${ }^{40}$ Taddasa, cited in Bahru Zewde, 'The Ethiopian Intelligentsia and the Italo-Ethiopian War, 1935-1941', The International Journal of African Historical Studies, 26, 2 (1993), 281 . The reference to the peasantry probably referred to an attitude of clemency to be 
Detachments of this group engaged the enemy in and outside the city in various forms. One of their most spectacular actions was the burning of three planes in the night of 26 June 1936 in Bonaya, Neqemte, when twelve out of the thirteen Italian officials present were also killed, including the Italian Deputy Viceroy to Ethiopia, Air Marshall Magliocco. The only survivor was Father M. Borello whose role was to guide and give a blessing to the short-lived Italian expedition in the southwest, undertaken to exploit Oromo discontent towards the Amhara-dominated Ethiopian state and pave the way for expansion through Dejazmach Habte-Mariam of Neqemte, who had shown signs of collaboration some days earlier. This indicates that by no means all Ethiopians in all regions unequivocally supported the Patriots' resistance. Many were even ignorant of such a movement in central Ethiopia. While negotiations in Neqemte were underway, "the daring assault on the Italian high ranking officials was performed by four members of the Black Lion Organisation, namely Colonel Belay Haile-Ab, Major Matias Gemeda, Captain Yosef Nesibu and Captain Benyam Nesibu, who returned safely to their unit' ${ }^{41}$ This operation infuriated Graziani and led him to order a blanket bombardment of Neqemte and its environs. History books refer to it as the Neqemte Massacre, a massacre in which hundreds of people of all ages were killed and wounded. Thus, what initially seemed to be a successful expedition for the Italians in an area thought to be sympathetic to Italian rule ended in disaster.

However, the impact of the bombardment and the negative attitude of the people in the region forced most of the Patriots to abandon the area in search of a more favourable one, while the older Patriots began retiring to remote places. Ras Desta Damtew, the son-in-law of Emperor Haile Selassie and Commander of the Southern Patriots, withdrew to Arbagoma but was encircled by three columns of Italian infantry under General Navarrini. After days of fighting, Ras Desta escaped to Eya, Butajira where he was captured and executed by firing squad shortly afterwards. The Italians estimated Ethiopian losses in these battles at 4,000 of whom 1,600 were executed by firing squad. ${ }^{42}$ The Italians thought that the defeat and later the execution of Ras Desta would kill the fervour of the resistance but this proved to be wrong, as more people were moving to support the Patriots.

observed towards peasants living in Italian-occupied territories and a different view on their position and needs from that of the imperial administration.

${ }^{41}$ Nega Tegegn, Ye'Ethiopiawiyan, 71.

${ }^{42}$ Sbacchi, Ethiopia Under Mussolini, 189. 


\section{Acts of collaboration}

The Italians found a few collaborators among the Ethiopian nobility, not so much due to mere opportunism but largely because of their ambitions and claims to power, for which the Italians might be a stepping stone. Although superior force was the ultimate means upon which the Italians relied to execute their invasion and sustain their occupation of Ethiopia, they had been looking for collaborators ever since they began preparations for the invasion of Ethiopia. Their long stay in nearby Eritrea had helped them to study, contact and recruit collaborators in Ethiopia. They had focused on three elements of contradiction that might be manipulated within Ethiopian society: rivalry among the different contending (regional) leaders; traditional Christian-Muslim tensions; and the resentment of the southern Ethiopian people towards the central government for its unfair appropriation of their lands since the late nineteenth century. Initially, these contradictions seemed to facilitate the occupation, but with the spread of the resistance and the Italians treating collaborators as unreliable servants, they did not prove sufficient.

Two well-known initial collaborators were Dejazmach Haile-Selassie Gugsa of Tigray and Ras Hailu Tekle-Haimanot of Gojjam, both rivals of Emperor Haile Selassie. Dejazmach Haile-Selassie, whose father was the grandson of Emperor Yohannes (who reigned from 1872-1889), foresaw regaining the throne of his great-grandfather with the support of the Italians. Thus he put his followers at the service of the Italians. Ras Hailu, son of Negus (King) Tekle Haimanot of Gojjam, who had been opposed to Emperor Haile Selassie's rise to power in the 1920s, had also anticipated governing Gojjam without any imperial intervention if he collaborated with the Italians. Both received arms and money from the Italians for their services but not the power and prestige they had dreamt of. Some other low-ranking nobles also collaborated with the Italians, induced by similar expectations. However, once in power, 'Mussolini ordered "No power to the rases". Italy, he said, would not rule Ethiopia on a metayer basis by sharing power with the Ethiopian nobles. ${ }^{43}$ Mussolini seemed to have rightly grasped the deeper feelings of the Ethiopian collaborators who had their own separate aspirations that would not fit in the Fascists' policy.

With the promise of reviving Muslim states like that of Harar and reinstating Oromo kingdoms like those of Abba Jifar and Abba Jobir Abdullah - kingdoms incorporated previously by Ethiopia - the Italians gained substantial collaboration from Muslims in the lowlands and Oromos in the south and eastern highlands. Abba Jobir, who was once imprisoned in Addis Ababa by the Ethiopian government for opposing the deployment of Amhara soldiers to

\footnotetext{
${ }^{43}$ Sbacchi, Ethiopia Under Mussolini, 134.
} 
collect taxes in his region, formed an army of Oromo Muslims and joined the Italians to fight the Patriots. Later when he found out that the Italians would not let him acquire the autonomous power he aspired to, he began conniving with the British councillor who had an office in Gore.

In all these major cases of collaboration, there was a feeling of victimization by the Emperor's drive to centralize authority and reign over regional power holders that also claimed authority. However, although these acts of collaboration facilitated the objectives of the invaders to a limited extent, they were essentially acts through which the collaborators hoped to secure what they had lost under the reign of the Emperor. 'Certainly they acted to protect their own interests, but these actions were not necessarily opportunistic. Instead, they reflected a long tradition of rivalry and tension between centre and periphery, particularly at times when the centre was perceived as weak or vulnerable. ${ }^{44}$

Intensified resistance and an attempt on Graziani's life

On 19 February 1937, Marshal Rodolfo Graziani together with his dignitaries and guests of honour were celebrating the birth of the Prince of Naples, in front of the Viceroy's palace in Addis Ababa. Two young Ethiopians from Eritrea, Abraham Deboch, who worked for the Italian Political Office in Addis Ababa, and Moges Asgedom, a clerk in the municipal office, approached the podium and threw seven hand grenades, killing three Italian officers and wounding 52 others. General Liotta, Commander of the Italian Air Force, lost his right eye and leg while Graziani, the main target of the attack, was wounded by some 300 splinters.

Moges and Abraham escaped to join the Patriots in Wolkait, while Tadelech Estifanos, Abraham's wife, left a day earlier for the monastery of Debre Libanos. Meanwhile the city of Addis Ababa turned into an orgy of terror. Graziani ordered random retaliatory measures be carried out and Italian soldiers went out killing virtually anyone in sight, burning houses and churches, like St. George's, and clubbing children to death. Not even the sick lying in hospital were spared. The terrible scenes prompted Mussolini into action, as he 'forbade these draconian measures for fear of negative world public opinion'. ${ }^{45}$ The attack launched by Moges and Abraham 'at the heart of the invaders' gave the Patriots' morale a boost and retaliatory measures taken by the invaders only further widened the existing gap between the Ethiopian people and the Italian occupiers.

\footnotetext{
${ }^{44}$ Taylor cited in C. McClellan, 'Observations on the Ethiopian Nation, Its Nationalism and the Italo-Ethiopian War', Northeast African Studies, 3, 1 (1996), N.S. 63.

${ }^{45}$ Sbacchi, Ethiopia Under Mussolini, 190.
} 
Revisiting resistance in Italian-occupied Ethiopia 105

After February 1937, a new mode of Patriot resistance started to grow in scope and popularity throughout the country. Yohannes Saomerjibashian, a young Ethiopian of Armenian descent, started an underground paper known as the Pillar of Ethiopian Light. Blatta Kidane-Mariam formed a clandestine movement of Ethiopian youth and worked closely with the women's organization in resistance activities. Printed by Yohannes and distributed systematically by youth organized by Kidane-Mariam, leaflets calling for an uprising against the Fascists started appearing in the city's public squares. The railway line linking Addis Ababa to the port of Djibouti was frequently attacked. By October 1936, the Patriots had already ambushed an armoured train, escorted by a squadron of warplanes, that was secretly carrying A. Lessona, the Italian Minister of Colonies and C. Gigli, the Minister of Public Works. Such train ambushes now increased in frequency. The British author Evelyn Waugh, who also travelled from Djibouti to Addis Ababa via Harar by train during that year and managed to interview Graziani, later observed that 'there was a machine-gun section posted at the front of the train; another at the rear. From Awash to Addis the line was heavily guarded. ${ }^{, 46}$ The resistance in central Ethiopia thus became widespread in numerous forms and proved tenacious. Patriot Haile-Mariam Mamo was well known for his hit-and-run tactics around Addis Ababa. In Gojjam, the professed shifta Belay Zelleke and his rival Hailu Belaw, although at times also raiding each other's territory, inflicted heavy damage on stationary and mobile Italian troops. In Begemder, Yohannes Iyasu and Asfaw Bogale were fighting the well-equipped enemy on many fronts. A successful attack in Bellesa forced Governor O. Mezzetti to retreat to Gondar, the capital of the Begemder region, where he found further unrest.

While resistance proliferated nationwide, the different groups of Patriots were, however, operating on their own, some in traditional ways (raiding, hitand-run attacks) and others employing modern tactics. There was no unified, central command structure. In most provinces, including Tigray, Gondar, Gojjam, Showa, Wollo, Arusi and Wollega, similar acts of resistance could be observed. Eritreans too were joining the resistance in large numbers. As early as January 1936, about 400 Eritreans abandoned the invaders on the Shire front alone, where the Italians had the upper hand, and joined the retreating Ras Imru. Some 600 Eritreans came to join Ras Desta at Adola on 20 February 1936 (Seifu Abawaolla, cited in Salome). ${ }^{47}$ Patriots from Eritrea like Kegnazmach Andom Tesfatsion, Kegnazmach Assefa Bahitu, Kegnazmach Seleba WoldeSelassie and many others (see the list in Salome) joined the resistance

\footnotetext{
${ }^{46}$ E. Waugh, Waugh in Abyssinia (London, 1984), 226.
}

${ }^{47}$ Salome, 'The Ethiopian Patriots', 79. 
movement on all the major fronts and hundreds were killed fighting the Italians. ${ }^{48}$ This historical fact also refutes the idea entertained by some Eritrean writers that Eritreans were not involved in the Ethiopian resistance movement.

On the economic front many Ethiopians seemed to boycott the Italian lire as currency. Especially in the countryside, people continued to use Maria Theresa thalers, the original Austrian silver dollar, for transactions although the Italians had declared the lire to be the unit of currency upon their arrival. However, the Italians had to pay Ethiopian labourers at the platinum mines at Yubdo in thalers because they would not accept lire. Furthermore, when the authorities forced the labourers to accept paper money (the lire), there was mass desertion. Several local markets almost ceased to exist as commerce went elsewhere. ${ }^{49}$ Such crippling resistance inflated the already rising costs of Italian occupation and severely devalued the lire. A Maria Theresa thaler could be obtained from the Royal Mint in London for 6.50 lire in 1937 and sold for 13.50 lire in Ethiopia. $^{50}$

The spirit of the resistance echoed through some cities in Italy as well. ${ }^{51}$ Ethiopians who were taken there either as prisoners or interpreters were expected to be moulded in Italian ideology and ways of thinking. Among the 400 notables and their families who were deported to Italy through Massawa in the summer of 1937 was the young Zerai Derres, working as an aid. 'Zerai Derres, an Eritrean interpreter of the exiled Rases, on 13 June 1938, in front of the monument of the fallen heroes of Dogali in Rome, pronounced words in favor of Haile Selassie. In an attempt to stop him, several persons were wounded. ${ }^{, 52}$ Abdisa Agga (later a colonel), a suspected accomplice of Abraham Deboch and Moges Asgedom in their attempt to kill Graziani, was taken to Libya as a prisoner. When the German army was defeated in Libya, Abdisa Agga, together with other British, Greek, Yugoslav and Albanian prisoners, was transferred to a prison in Italy from which he later managed to escape. He then engaged in guerrilla activities in the northern mountains of Italy where he met Marshal Tito, the Yugoslav resistance leader. As Nega remarked, 'Abdisa

\footnotetext{
${ }^{48}$ Nega Tegegn, Ye'Ethiopiawiyan, 73; Salome, 'The Ethiopian Patriots', 82-85.

${ }^{49}$ Rava, cited in C. Schaefer, 'Serendipitous Resistance in Fascist-Occupied Ethiopia, 1936-1941', Northeast African Studies, 3, 1 (1996), 99.

${ }^{50}$ Pankhurst, in ibid. 102.

${ }^{51}$ See for wider international reactions from Africans and Afro-Americans to the war in Ethiopia, S.K.B. Asante, Pan-African Protest: West Africa and the Italo-Ethiopian Crisis, 1934-1941 (London, 1977) and J.E. Harris, African-American Reactions to War in Ethiopia 1936-1941 (Baton Rouge \& London, 1994).

${ }^{52}$ Sbacchi, Ethiopia Under Mussolini, 138.
} 
fought the Fascists in their own land until he returned to Ethiopia after the liberation'. ${ }^{33}$

In late 1937 Mussolini realized that resistance was increasing in Ethiopia despite Graziani's appalling repression. He replaced Graziani at the end of 1937 with Viceroy U. Amadeo, the Duke of Aosta, who he thought would take a more 'pacifying approach' as governor and would contain the fermenting Ethiopian rebellion. In an effort to try a different tactic, the new viceroy began to engage in dialogue with the rases and other rebel leaders, hoping to negotiate their surrender. He offered money, titles and posts in his administration and also employed the tactic of divide-and-rule among the independently acting rases and a few other leaders. In fact, some leaders like Dejazmach Gebrehiwet Michael, Dejazmach Amde Ali, Dejazmach Ayalew Birru, Dejazmach Habtemichael, the author Afework Gebreyesus, Mengesha Wube, and some low-ranking chiefs responded positively, which again shows that the Ethiopians' response to Italian occupation and the opportunities of the new situation was neither uniform nor universal. But a majority remained defiant. This held for the Patriots, the Church, women's organizations, most intellectuals and the youth, many of whom subsequently joined the resistance movement. Some of the Patriots made use of the negotiation scheme, appearing to collaborate with the occupiers but only to buy time until a more favourable moment to strike back. For instance, the famous Patriot Abebe Aregay negotiated his possible surrender with the Italians but historians generally interpret this episode as a mere diversion to obtain breathing space for his exhausted troops. ${ }^{54}$ Guerrilla bands, led by renowned fighters like Zewde Asfaw, Abebe Aregay and Mesfin Seleshi, continued to make the wellentrenched Italians in Addis Ababa feel permanently uneasy. In addition, the provinces remained insecure for the invaders. Patriots Gerasu Duki on the Jimma road, Fitawrari Taffera on the Neqemte road, Gebre-Hiwet Meshesha in the Lemelimo Gorge, Tesfay Medebai in the Merebe Gorge and Belay Zelleke in the Nile Gorge, commanding from 500 to 3,000 armed Patriots, made rural Ethiopia continuingly hazardous for Italian movement. Only in the south and southwest was the situation more or less stable, and road-building programmes and administrative services could be set up.

As the granting of titles, bribes and negotiations failed to bring the resistance under control, the commander-in-chief of the Italian forces at the time, General Ugo Cavallero convinced the Duke of Aosta "that the "Graziani method" would bring the desired result ${ }^{55}$ This meant a full-scale military campaign and

\footnotetext{
${ }^{53}$ Nega Tegegn Ye'Ethiopiawiyan, 96-97.

${ }^{54}$ Konjit Abinet in McClellan, 'Observations on the Ethiopian Nation', 62.

${ }^{55}$ Sbacchi, Legacy of Bitterness, 190.
} 
exercise of sheer terror, as well as better defence works. Cavallero built road connections between strategic spots linked with chains of forts - still a visible Italian legacy in Ethiopia today. From 1938 to mid-1939 Cavallero's army was engaged in executing the 'Graziani method' in what seemed to be an endless war of terror and attrition.

\section{The end of resistance and post-war Ethiopia}

In 1940 Mussolini embarked on what was later to prove the most disastrous venture of his career. He signed a pact with Nazi Germany and entered the European War on 10 June. Britain and France, both accustomed to diplomatic rivalry with Italy in the colonial partition of East Africa, were now set to become the arch-enemies of Italy, as they were of her Axis partner Germany. This new alliance of world forces came as a salutary gift for Ethiopia. Emperor Haile Selassie, whose repeated cry for help in the five preceding years had been disregarded by the world powers and by the League of Nations, found support from this twist of events. Many types of assistance to the Ethiopian cause and to the Patriots began to flow in, not only from England where the Emperor was living in exile but also from the other Allied powers. Haile Selassie's return to Ethiopia was synchronized with the British offensive ${ }^{56}$ that was planned to drive the Italians out of the region.

The British organized the Emperor's journey via Khartoum, Sudan, from where he would start mobilizing Patriots in exile and at the border, and advance into Ethiopia. When he arrived in Khartoum on 3 July 1940, he received messages of support from the prominent Patriot leaders in the field. Yet, he was not sure how the people he left with the Fascist Italians back in 1936 would receive him. Possible rebellions in Gojjam, the Ogaden and Eritrea and more seriously, the republican ideals of Takele Wolde-Hawariat and the dynamic intellectuals in the resistance were some of the threats that the Emperor needed to address. The Patriots' resistance had created its own political momentum, with claims and implications for the post-war period in Ethiopia, with or without the Emperor. The role of the resistance in posing this kind of political challenge to a liberated Ethiopia is perhaps worthy of a separate study but it can be said that the ideals of just rebellion, social justice and people's rights that

${ }^{56}$ The British troops in fact were largely made up of African troops (including Sudanese, South African and other contingents). Cf. T.H. Parsons, The African Rank and File: Social Implications of Colonial Military Service in the King's African Rifles, 1902-1964 (Portsmouth NH, 1999). 


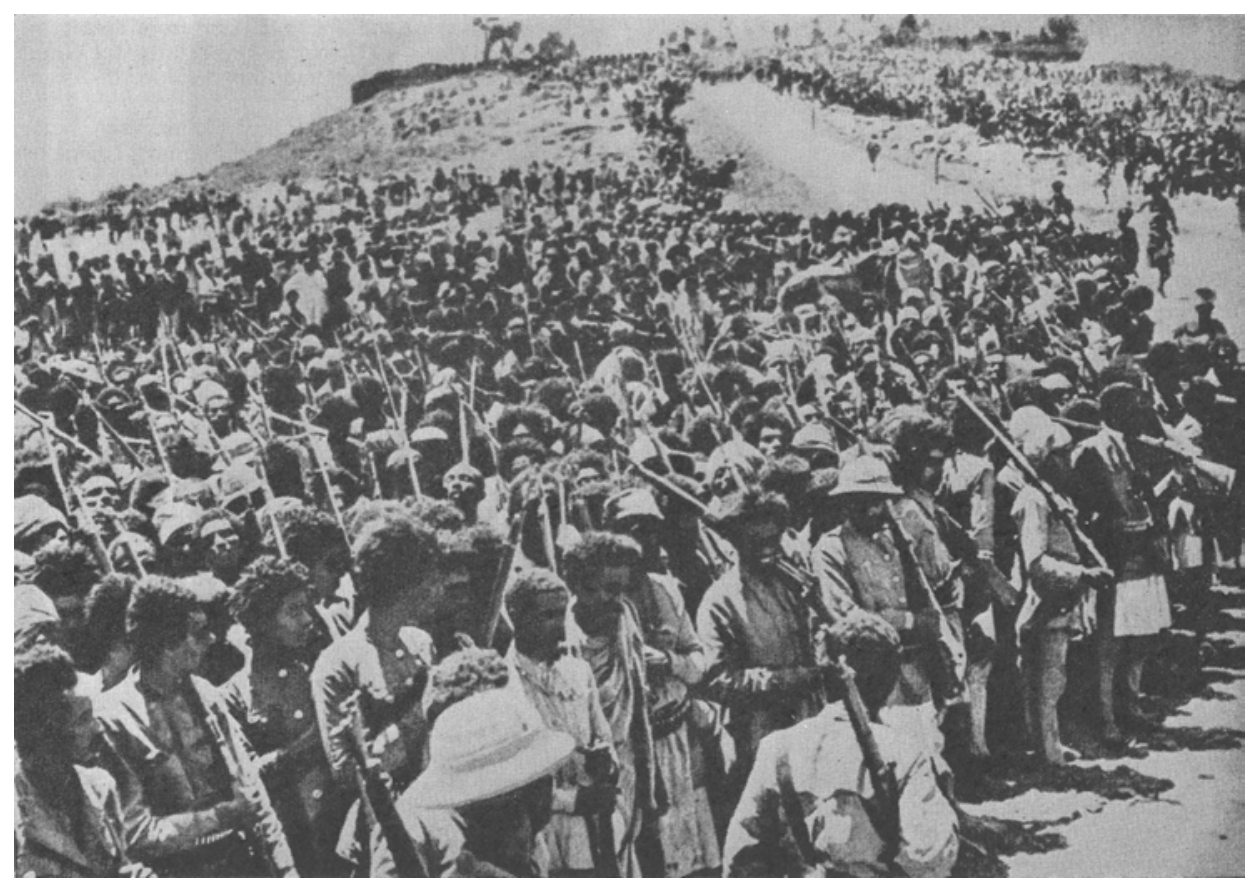

Patriots at Debra Markos market after the Italian surrender Source: R. Pankhurst, 'The Ethiopian Patriots and the Collapse of Italian Rule in East Africa, 1940-41', Ethiopia Observer, 12, 2 (1969), 114 
emerged from the resistance were a development which Ethiopia, and specifically the new government, had to deal with.

From June 1940, an intensive propaganda campaign on behalf of the Emperor attempted to improve the conditions for his return (led by the British journalist George Steer). On 30 January 1941, the day Haile Selassie crossed the border from Sudan on his way to Ethiopia accompanied by General Orde Wingate and several Patriots, he declared that there would be no retaliation against the Italians. This declaration was considered the official cessation of the resistance, although nobody was sure how the Italians were going to respond. Soon the Duke of Aosta and his army retired to the strategic pass of Amba Alagie in Tigray, leaving Addis Ababa to the Patriots, who were in the nearby mountains and inside the city, and to the British general, Alan Cunningham, who was pushing his way up from Kenya north to Addis Ababa. On 6 April 1941, Addis Ababa was liberated and a month later, on 5 May 1941, Emperor Haile Selassie entered the city. His rule was restored and he remained on the throne for the next 33 years.

Although detachments of the British army, combined with the forces of the Patriots, ended the Italian occupation of Ethiopia, this period left an impressive memory of indigenous Ethiopian resistance. At the time, it was realized how much the occupation had shaken traditional institutions and the myth of the divine Emperor (as was still written in the 1930 Ethiopian Constitution). Many also related their patriotic struggle to the war in Europe where the common enemies of the Axis had to be rooted out. What people vividly remember to this day is the horrific behaviour of the invaders on the one hand and the endurance and heroic struggle of the Patriots on the other.

In the wake of their defeat and withdrawal from Ethiopia, the Italians were expecting the Ethiopians, who had suffered brutal oppression at their hands for five consecutive years, to take revenge. Resistance, after all, is a reaction to and a product of real or perceived injustice, and the Italian injustices and exercise of violence were seen as beyond acceptable limits. Such actions had no precedent in Ethiopia: the mustard-gas bombings, the mass executions, the arbitrary massacre of civilians, the wiping out of an educated class. Yet, with the Emperor's declaration not to hurt or inflict damage on the Italians in retreat, for which he later received a letter of gratitude from President Franklin D. Roosevelt of the United States, the Ethiopians did not resort to the violent style of vengeance they had witnessed by the Italians since October 1935 (the Adua Syndrome). In these five years of occupation, the Ethiopians resisted aggression, injustice and violation of their rights as a sovereign nation. Once it was over, two factors mitigated their response and their anger to avenge. Firstly there was their traditional prudence based on a religious culture of tolerance and dignity, and in this respect there ís a difference in religious culture between 
Ethiopians and Europeans. And secondly, the international political situation (i.e. pressure from the British and Americans) and the dependence of Ethiopia on foreign diplomatic and material assistance may have played a role in softening the Ethiopian response at a higher level.

\section{Concluding remarks}

The Italian invasion (1935) and occupation (1936-1941) of Ethiopia were conducted by a modern and strong European army that could not be matched by Ethiopia at the time. Conventional military theories and diplomatic manoeuvres were employed in extreme forms against an Ethiopian army that did not have even a working central command structure, let alone modern weaponry systems or diplomatic backing. The Italian invaders unleashed an unprecedented campaign of violent submission both from the ground as well as from the air, to which the Ethiopians had no defences and which caused huge loss of life. At the beginning of the occupation, the collapse of the Ethiopian army before Mussolini's war machine followed by the flight of the Emperor into exile led many to believe that the fate of a long-independent nation was doomed. Any possible emergence of patriotic resistance also looked far-fetched. 'Mussolini's dream, one shared by the Italian people and constantly reiterated in the press, that millions of Italians would be able to find land and work in Ethiopia ${ }^{57}$ then seemed to gain ground.

But the Ethiopians were poised to fight back. The Italians controlled the major towns, yet they could in no way gain control over the vast Ethiopian countryside where resistance was gathering momentum. Despite Italian violence intended to force them into submission, the majority of Ethiopians drew upon their sense of freedom and pride, and were mentally prepared to resist the vastly superior forces that threatened their sovereign rights as an independent nation, and their historical identity, religion and culture.

Ethiopians decided to resist even without the Emperor, who some said should have been there as a symbol of unity. Thus the formal Italian war of occupation was confronted with an informal, open-ended and community-based resistance. The traditional form of resistance, shiftinnet, had found a new terrain to spread to and a new enemy to counter, this time enjoying a much broader popular support. Unlike the old shiftinnet inspired by a rebellious noble or a few politically ambitious individuals, anti-Italian resistance drew upon all sectors of Ethiopian society: the peasantry, the nobility, the clergy, intellectuals, women and the youth alike. 'From this point resistance was no longer an aristocratic

\footnotetext{
${ }^{57}$ Schaefer, 'Serendipitous Resistance', 103.
} 
affair' but in fact 'serendipitous', as Schaefer ${ }^{58}$ rightly observed - gifted with the ability to find novel ways of revolt and action. For the Italians, however, resistance was an act of violence by irrational outlaws or t'era-shiftas who deserved to be hunted down, flogged, publicly hanged or executed by firing squad in order to create a state of fear and submission. Despite the repression and atrocities against the resistance fighters, the Italians never achieved the desired result.

While the resistance expanded in scope and tenacity, the Italian human and material costs were growing, and driving the Italians to a state of increased fury. Not only was the whole objective of their occupation thwarted but also 'never in their quinquennium of rule did the fascists feel secure in Ethiopia, and their anxiety came to border on neurosis' ${ }^{59}$ To the relief of Ethiopians, Italy entered the Second World War on the side of Germany, and the Allied forces began to pour in support to bolster the resistance movement in Ethiopia. After the Italians were defeated, resistance, which had become nationwide, came to an abrupt end.

The five years of Italian occupation shook feudalist Ethiopia and the impact the occupation created in traditional Ethiopia was significant. As McClellan put it: 'It was an event that swept away old myths and created opportunity for Ethiopians to re-examine the nature and meaning of their state. For Ethiopia, the war highlighted a need to move fully into the modern world ${ }^{60}$ The fact that Ethiopia had failed to repulse the predatory Italian invasion in itself proved to many that the country had a long way to go, among other things, in building a modern system of self-defence. But, given the whole purpose of the invasion and occupation, there was another aspect to what the 'modern world' constituted in the context of the Ethiopian conception as a free and sovereign nation that had to face unprovoked aggression. While the need to move into the modern world was deemed essential, there also emerged a rethinking of why and how the occupation was conducted and how resistance had been organized. In the first place, there was no doubt that it was basically Italy's authoritarian, nationalistic and greedy colonial ambition that led to the invasion and occupation of Ethiopia. For most Ethiopians, the invasion and occupation were executed in the most barbaric and violent manner. The perception was that if this was the guise of the 'modern world', few Ethiopians would be attracted by it. Second, the essence of the resistance was to safeguard the independence, religious values and cultural identity of Ethiopia, all taking inspiration from the

\footnotetext{
${ }^{58}$ Schaefer, 'Serendipitous Resistance', 89.

${ }^{59}$ H.G. Marcus, A History of Ethiopia (Berkeley, 1994), 148.

${ }^{60}$ McClellan, 'Observations on the Ethiopian Nation', 57.
} 
domain of the past as heritage. In view of the violent 'present' defined by the Italians, the Ethiopians naturally oriented themselves to the past, i.e. all that defined their historical and cultural identity. In both cases, the raison d'être of the motivation for change was negative. Italy's modernity can hardly be seen to have positively transformed Ethiopia's traditional society. The only thing remaining and still referred to by Ethiopians is the 'heritage' of Italian roadbuilding.

After 1941 Ethiopia moved towards modernity at its own pace within the contours of the old imperial order. The Patriots' contribution to the freedom and independence of the country was highly valued, and many of their leaders were rewarded with public positions. However, the social and political aims of the resistance - ideals relating to social justice, equality and more openness in the political system - were not really followed up. Patriot leaders were also expected to be loyal to the Emperor again, and those who dissented or actively conspired against him were removed, and in some cases (like Belay Zelleke) executed. While the Emperor promulgated a new revised constitution in 1955, installed a parliament, allowed limited non-party elections, embarked on farreaching judicial reforms and developed the education system, the old property relations and the lack of democratic rights, such as a free press, free elections and political parties, remained unaddressed. In this respect, the Patriots' programme was not realized. 


\title{
Ambiguities of resistance and collaboration on the Eastern Cape Frontier: The Kat River Settlement 1829-1856
}

\author{
Robert Ross
}

\begin{abstract}
This chapter attempts to unravel the complexities of resistance to, and collaboration with, the British colonizers of the Eastern Cape, South Africa, by the inhabitants of the Upper Kat River Valley. Since the Khoikhoi landholders of the valley had received their land as a result of British action against the Xhosa, and had generally accepted the precepts of mission Christianity, it could on the one hand be expected that they would fight on the side of the British against the Xhosa. On the other hand, they were subjected to racist attacks by the British settlers whose farms they defended, and by British officials. In addition, the ethnic distinction, on which the British acted, between Xhosa and Khoikhoi was more tenuous than they generally assumed. As a result, in the successive wars on the Eastern Frontier, the stance taken by the Khoikhoi was often uncertain, and finally led to a minority joining the Xhosa, and thus going into rebellion against the British.
\end{abstract}

\section{Introduction}

The conflict between the Xhosa and the Cape Colony, along what is conventionally described as the Eastern Frontier of the Cape but which could equally be seen as the Western Frontier of Xhosaland, involved the longest series of wars in the history of Africa's colonial conquest. For almost a century, from 1779 to 1880 , the region was wracked by successive outbursts of violence 
in what has been called Africa's 'Hundred Years' War'. ${ }^{1}$ The violence varied in intensity and there were long periods of relative, even absolute, peace between those times conventionally considered to be war. Nevertheless, the threat of war, the experience of war and the recovery from war dominated the minds and lives of most of the frontier's inhabitants throughout the era, and certainly until after the end of Mlanjeni's War in 1853. This conflict clearly demonstrated that when the British Empire was forced to apply its full military might, it could not be contested by Africans. The conquest decisively led to the Cattle Killing Movement of 1857, the major breaking of Xhosa power. ${ }^{2}$

In the course of this contest, loyalties were never clear. It was never the case that there was an indubitable association between social position - ethnic or otherwise - and the political stance taken. Perhaps the only exceptions were some of the British who, imbued with a racial consciousness foreign (in the literal sense) to the shifting alliances of the Frontier, ${ }^{3}$ complicated matters for themselves and even more so for the rest of the Frontier's inhabitants by attributing ideas and loyalties to others that they did not possess. For the rest, all those involved shifted their stance from time to time as the exigencies of personal advantage developed. In this chapter I discuss one specific case, that of the Kat River Settlement where, if the oxymoron is allowed, the murk and the confusion were even clearer than elsewhere. I give a preliminary account of the dilemmas faced by its inhabitants during three major wars which, in the first quarter of a century of the Settlement's history, affected the lives of the approximately 5,000 people living in the 800 square kilometres of the Upper Kat River Valley, and in effect doomed the experiment of the Settlement to failure. ${ }^{4}$ In order to do so, it is necessary to give a short description of how the Settlement came into existence, and what its place on the Frontier was considered to be.

\footnotetext{
${ }^{1}$ C.C. Saunders, 'The Hundred Years' War: Some Reflections on African Resistance on the Cape-Xhosa Frontier', in D. Chanaiwa, Profiles of Self-Determination (Northridge CA, 1976).

${ }^{2}$ J.B. Peires, The Dead Will Arise: Nongqawuse and the Great Xhosa Cattle-Killing Movement of 1856-7 (Johannesburg, 1989).

${ }^{3}$ On the frontier in general, see the classic article by M. Legassick, 'The Frontier Tradition in South African Historiography', in S. Marks \& A. Atmore (eds), Economy and Society in Pre-Industrial South Africa (London, 1980); on the British, R. Ross, Status and Respectability in the Cape Colony, 1750-1870: A Tragedy of Manners (Cambridge, 1999), esp. chapter III.

${ }^{4}$ This chapter is as yet a preliminary discussion because not all the archival materials in the Cape Archives and in the Public Record Office in London have been fully investigated.
} 


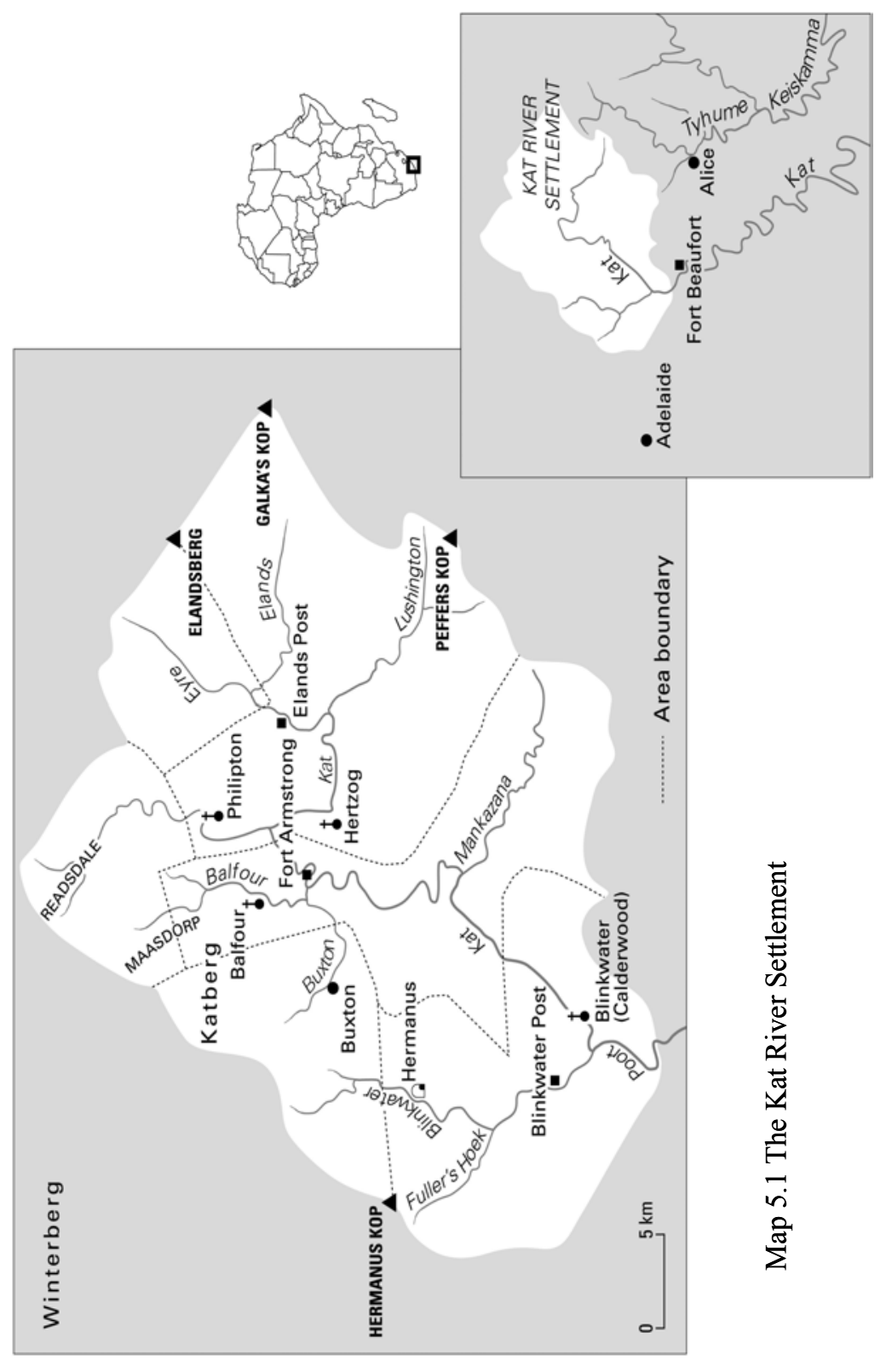




\section{The Settlement}

The upper reaches of the Kat River Valley receive rain with too little regularity to allow agriculture without irrigation, and thus lie just to the west of the ecological border of Xhosaland proper. Nevertheless, they were long part of the regular pastures used by the western Xhosa on a transhumant basis, and from about 1800 onwards began to be settled more permanently by the followers of Ngqika, the head of the Rharhabe. Ngqika himself had his 'Great Place' in the Kat River Valley, and Maqoma, his most prominent son and the most impressive Xhosa of his generation, came to live there. After the war of 1819, the area was part of the region declared neutral territory and effectively extorted (if somewhat willingly) from Ngqika as the price of colonial support in his struggle for supremacy over the Western Xhosa, and particularly his uncle Ndlambe.

Of course there was little chance that any form of neutrality would prevail as both the Cape Colony and the Xhosa attempted to claim the region. It was, in fact, marked for settlement by Scots highlanders but this measure was rescinded, as much because of personal feuds within the Cape government as for any reason of policy. Thereafter, in 1822, Maqoma came to settle in the valley, initially with the tacit support of the Cape government. There were, however, others in the government who could not countenance a Xhosa presence in the valley, notably Andries Stockenström (who owned a large farm just to the east of the Kat River), at the time Commissioner-General of the Eastern Districts, and a man whose official career at the Cape would be long and fiery. Stockenström proceeded to pick a quarrel with Maqoma, which was not difficult in the unsettled state of the frontier. In 1829, Maqoma was expelled from the valley, ostensibly for conducting a war-cum-cattle raid against some of the Thembu to the north. ${ }^{5}$

This expulsion was opportune and allowed the lands to be given to Khoikhoi in the immediate aftermath of Ordinance 50 of 1828 , which had abolished all legal discrimination in the Colony suffered by free people of colour. Within four years, 2,000 people of Khoi descent had moved into the valley, and over the next decades this number would grow rapidly. They came from a variety of places. Many had been to some extent under the influence of the London Missionary Society (LMS), and many of these, though not all, had been resident

${ }^{5}$ J.B. Peires, 'The British and the Cape. 1814-1834', in R. Elphick \& H. Giliomee (eds), The Shaping of South African Society, 1652-1840, 2nd edition (Cape Town, 1989), 484; A. Stockenström, The Autobiography of Sir Andries Stockenström Bart, C.W. Hutton (ed.), 2 vols (Cape Town, 1887), I, 300-324; J.C. Visagie, 'Die Katriviernedersetting, 1829-1839', PhD thesis, UNISA (1978), 34-36. 
at missionary stations in the Eastern Cape, notably Bethelsdorp and Theopolis. Others came from the farms of the Eastern Cape, where they had either been effectively bonded labourers, or had a more independent status and more wealth, particularly if they were in some way linked to the farm owners by ties of kinship. Others again were living in Xhosaland but as they could claim to be Gona they were admitted to the Settlement. ${ }^{6}$ Many spoke isiXhosa as well as Khoi - a dying language by this time but still occasionally used in the settlement - and Dutch, and had often lived among the Xhosa at some period in their lives. This was not surprising, since whether a man or woman was Xhosa or Khoi was frequently as much a matter of personal political choice and of the accidents of individual biography as it was determined by descent.

The Kat River Settlement was thus born out of the conflict between the Cape Colony and the Xhosa. It was also seen by those who founded it as part of the bulwark by which the Colony could be protected from the inroads of the Xhosa in subsequent wars. Its inhabitants were effectively granted their lands under military tenure, that is to say the able-bodied men were required to serve in the British forces as a militia in the event, all too frequent as it turned out, of renewed clashes between the Colony and the Xhosa.

In retrospect, Stockenström was ambivalent about the value of what he had done for the settlers in the valley. On the one hand, he quoted a governor's comments to him: 'Well, Captain Stockenström [sic], if I were the creator of this settlement, I should fancy that I had done enough for one man's life'. ${ }^{7}$ On the other, in the aftermath of the rebellion of 1851-3, he told the Cape Parliament:

To benefit the forlorn remnants of the former possessors of South Africa, upon the basis of the 50th Ordinance, was undoubtedly one of my objects, but a secondary one. It was for the selfish purpose of turning the better and more efficient part of the [Khoikhoi] into a breastwork against an exasperated powerful enemy in the most vulnerable and dangerous part of the frontier that I decoyed them from those retreats where many of them were certainly not very comfortable, but where they were, at least, safe, and legally their own masters. By the bait of a speck of land in the vast territories of their fathers, I drew them into the slavery of constant watching, patrolling, half-starving upon 'veld kost', and the chance of any day getting their throats cut. $^{8}$

\footnotetext{
${ }^{6}$ Botha to Governor Sir Harry Smith, 23 June 1850, printed in J.J. Freeman, A Tour in South Africa (London, 1851), 183.

${ }^{7}$ A. Stockenström, Light and Shade as Shown in the Character of the Hottentots of the Kat River Settlement and in the Conduct of the Colonial Government towards Them (Cape Town, 1854), 14.

${ }^{8}$ Stockenström, Light and Shade, 5.
} 
Within this context, questions of loyalty became of paramount importance. At least in the beginning the lines were clear. Those who lived in the settlement had accepted their land and their chance of a respectable life by virtue of the colonial expulsion of the Xhosa. Many had acquired their land as a reward for service in the colonial army. Others had been recommended by the missionaries and may thus be assumed to have chosen a way of life coincident with loyalty to the British. But such simplicities never last. Eventually a minority of the Khoi inhabitants of the valley joined the Xhosa in their fight against the British and proved to be among the most determined and successful of the resisters. The explanation for this volte-face, which the British themselves could not comprehend, ${ }^{9}$ lay in the combination of the impossibility of drawing a fixed line between the Xhosa and Khoi, the partial economic failure of the settlement partly as a result of its repeated destruction, and the assumption by many white colonists that the Kat River colonists were indeed disloyal or that they did not need to be treated with any consideration. Each of these processes became particularly apparent during the various wars of the settlement's tortuous military history.

The wars between the Colony and the Xhosa were ultimately about land though also to some extent about labour. ${ }^{10}$ Both Dutch and, particularly, British colonialists were greedy for pastureland, and profligate with what they had, so always needed more. The Drang nach Osten was continual and the repeated assaults on the Xhosa were the results, in the last instance, of this pressure. However, the conflicts with the Xhosa and certainly the pressure on the Kat River Settlement derived as much from the animosity between black and white as from a crude desire for land. The deeper causes of that animosity may have lain in land hunger. Nevertheless, the viciousness of British settler hatred of the Kat River people was driven by the threat they formed to British perceptions of how the world should be, not by the hope of taking over what was admittedly a fertile piece of territory but which would have accommodated at most 25 standard-sized settler farms and that was even more vulnerable than most of the Eastern Cape to Xhosa attacks.

The Settlement was involved in three major wars between the Colony and the Xhosa, beginning in the austral summer of 1834-5 (Hintsa's War), in March 1846 (the War of the Axe) and in the summer of 1850-1 (Mlanjeni's War). In all of these battles, the Settlement was laid waste, most of its houses burnt to the ground and many of its agricultural improvements destroyed, at least temporarily. The majority of the settlers were required to abandon their

\footnotetext{
${ }^{9}$ See for example, Sir Harry Smith to Earl Grey, 12 June 1851, British Parliamentary Paper (hereafter BPP) 1428 of 1852.

${ }^{10}$ In the case of the Kat River, labour played a minimal role.
} 
dwellings and congregate in what can only be described as South Africa's (and the world's) first concentration camps, in conditions of great and frequently fatal hardship. They were set up by the British during the first two wars around Fort Armstrong, a position of natural strength in the centre of the settlement, and later at Eland's Post, the modern town of Seymour. At the same time, most of the adult male population were enlisted into the British forces. Ninety per cent of the Kat River men fought in the War of the Axe, as opposed to 3 per cent of the white men in any of the country's districts. ${ }^{11}$ They fought well and their arrival was primarily responsible for preventing the British army's defeat at Burn's Hill, when it had lost all its baggage. More generally, they, together with their regular fellows in the Cape Mounted Rifles, possessed the skills of irregular light infantrymen and cavalrymen which were needed in the bush warfare of the Eastern Cape, ${ }^{12}$ and which the heavily laden, red-coated British regiments singularly lacked.

\section{Hintsa's War}

Despite the above-mentioned actions, the loyalty to the colony of at least some of the Kat River settlers was called into question, first during Hintsa's War when they were falsely believed to be resisting the British forces. There were two reasons for this, neither of which were the responsibility of the Khoi. First, once the Xhosa had decided to launch an attack on the Colony, which only occurred in the weeks immediately preceding the invasion, ${ }^{13}$ their leaders, notably Maqoma, began spreading information that the Khoi had agreed to join them. ${ }^{14}$ While this was primarily designed to strengthen the resolve of their own

\footnotetext{
${ }^{11}$ Berkeley to Pottinger, 23 March 1847 in B. Le Cordeur \& C. Saunders, The War of the Axe, 1847: Correspondence between the Governor of the Cape Colony, Sir Henry Pottinger, and the Commander of the British Forces at the Cape, Sir George Berkeley, and Others (Johannesburg, 1981), 89.

${ }^{12}$ C.L. Stretch, The Journal of Charles Lennox Stretch, edited by B. Le Cordeur (Cape Town, 1988), 55; Read to Kitchingman, 9 May 1847, in B. Le Cordeur \& C. Saunders (eds), The Kitchingman Papers (Johannesburg, 1976), 8.

${ }^{13}$ Statement by the Rev. John Ross of the Glasgow Missionary Society cited in N. Mostert, Frontiers: The Epic of South Africa's Creation and the Tragedy of the Xhosa People (London, 1992), 653; depositions by the Glasgow missionaries James Weir, John Bennie and William Chalmers, by the Xhosa chiefs Tyhali and Bhotomane, and the Khoi Klaas Plaatje and Louis Arnoldus, in BPP 503 of 1837, 76-77, 80-83, 237-38.

14 R. Godlonton, A Narrative of the Irruption of the Kafir Hordes into the Eastern Province of the Cape of Good Hope, 1834-1835 (Grahamstown, 1836), 14-15. Here, Godlonton discounted the rumours as Xhosa propaganda; thirty pages later, 46-47, he claimed that 'the fears [of Khoi disaffection] entertained at the time were perfectly well
} 
followers, the chiefs knew that the rumours would soon reach the Colony and spread dissension among their opponents. This duly happened.

Second, these rumours were taken up on the colonial side by Captain Armstrong, commandant of the fort that bore his name. While he initially dismissed the idea, ${ }^{15}$ on 17 January 1835 he wrote to the commandant of the Frontier, Lieutenant-Colonel Harry Smith (later governor) of 'an intrigue which is suspected to have been carried out with extreme subtlety between some of the people of the Kat River Settlement' and the Xhosa. His argument, as he himself admitted, was based on a number of surmises and not on any observable occurrences during the first weeks of the war. The suggestions of Xhosa forbearance towards the Khoi were contradicted by the fact, as Armstrong admitted, that his prime suspects had lost property and had shot at least one raiding Xhosa. ${ }^{16}$ Rather the surmises are extrapolations from a number of facts in the past, as construed within Armstrong's imagination. These were, first, that there had been considerable conflict within the Settlement in the previous year, in particular in regard of the government's proposal to introduce a Vagrancy Ordinance; secondly, that the division between the supporters and the opponents of the Vagrancy Ordinance was conceived along racial lines, between the 'Bastards' and the Khoikhoi in the Settlement; ${ }^{17}$ thirdly, that many of those in the Settlement were people of Gona extraction; fourthly, that the LMS missionary James Read, with his son (of the same name), had been active in the protests against the Vagrancy Ordinance; and fifthly that some of the Gona and James Read had both had regular contact with Maqoma in the past. ${ }^{18}$

The extrapolations which Armstrong made from these facts were threefold, and all very problematic. The first was that the genuine fear that many in the Kat River felt at the introduction of a Vagrancy Ordinance would manifest itself in rebellion against the British and allegiance with the Xhosa. Armstrong's view

founded'; deposition by April, a 'Bechuana', 9 February 1835, Cape Archives (hereafter CA), LG 9.

${ }^{15}$ Read Jr to Kitchingman, 31 December 1834, in Le Cordeur \& Saunders, Kitchingman Papers, 148.

${ }^{16}$ Armstrong to Smith, 9 January 1835, BPP 503 of $1837,89$.

17 See S. Trapido, 'The Emergence of Liberalism and the Making of "Hottentot Nationalism" 1815-1834', in Collected Seminar Papers of the Institute of Commonwealth Studies, London: The Societies of Southern Africa in the Nineteenth and Twentieth Centuries, 17 (1992); R. Ross, 'The Kat River Rebellion and Khoikhoi Nationalism: The Fate of an Ethnic Identification', Kronos: Journal of Cape History, 24 (1997); E. Elbourne, 'Freedom at Issue: Vagrancy Legislation and the Meaning of Freedom in Britain and the Cape Colony, 1799 to 1842', Slavery and Abolition, 15 (1994), 133-45.

${ }^{18}$ See two letters from Armstrong to Smith, 12 January and 14 January 1835, both printed in BPP 503 of 1837, 84-86. 
on the matter was moreover jaundiced by the fact that he had put pressure on the Kat River settlers to sign the memorial in favour of the Ordinance. ${ }^{19}$ The second derived from his failure to understand the complicated politics of identity and language common on the Eastern Frontier, and indeed throughout Southern Africa. For Armstrong, as for most Britons at the time, one was either Xhosa or Khoi - the possibility of having dual nationality did not occur to them. The Gona therefore presented a problematic taxonomic anomaly. As Armstrong described it:

The Gonahs are a race between a [Xhosa] and a [Khoi]. At one time the [Xhosa] took a number of [Khoi] into their service; they compelled the [Khoi] women to live with them. The children are Gonahs, entertaining partly a [Xhosa] and partly a [Khoi] feeling. ${ }^{20}$

They were however 'aliens' who were illegally in the settlement as a result of Read's intrigues.

There were many people in the Kat River whose personal biographies crossed the vague but hardening boundaries of the Eastern Cape and many were bilingual in Xhosa and Khoi. By the mid-1830s, if not much earlier, they would have added Dutch to their linguistic repertoire and were probably beginning to lose their Khoi. Andries Stoffels, for instance, the most famous of the LMS's converts, first came into contact with the missions when he arrived at Bethelsdorp in the company of a number of Xhosa chiefs for whom he was to act as interpreter. ${ }^{21}$ Many of the Kat River Khoi had kin among the Xhosa, just as there were many with kin among the boers. The two groups were not mutually exclusive. In the racist ${ }^{22}$ vision of men like Armstrong, this made the former group suspect. It could, however, be argued that by leaving, or not going to live in Xhosaland and taking up residence in the Kat River, these people had made a conscious political choice as a result of which their loyalty to the Colony would be firmer, not weaker.

The third problem with Armstrong's analysis was the assumption that the contacts which Read and Stoffels, among others, had with Maqoma had to be in some way connected with plans against the Colony. In the first place, contacts need not necessarily have entailed conspiracy or incitement. In the second, the likelihood is that Maqoma's decision to launch the attacks were only taken in

\footnotetext{
${ }^{19}$ Stretch, Journal, 88.

${ }^{20}$ Footnote in Armstrong to Smith, 14 January 1835, BPP 503 of 1837, 85.

${ }^{21}$ E. Elbourne, 'Early Khoisan Uses of Mission Christianity', in H. Bredekamp \& R. Ross (eds), Missions and Christianity in South African History (Johannesburg, 1995), 88.

${ }^{22}$ In the broadest sense.
} 
December 1834, and there is no evidence that anyone from the Kat River visited during this crucial period.

The whole episode derived from panic on the part of Captain Armstrong, whom Read described as 'the most timid man ever seen', and who in the days around Christmas 1834 had to be restrained by the Kat River settlers from abandoning the Settlement entirely and withdrawing to the comparative safety of Fort Beaufort. ${ }^{23} \mathrm{He}$ would not have been the only British soldier in the nineteenth century to take the credit where none was due, in this case for snuffing out potential rebellion by resolute action.

There was also considerable animus against James Read in colonial circles. His consistent non-racialism, both in theory and even more discomfortingly in practice, was always a potential challenge. It gave him contacts and friendships outside colonial circles that were at once an affront and a threat to both his fellow clergymen and to the white society in general. As a result, he was continually suspected of involvement in all sorts of nefarious practices, and on 20 January 1835, together with the rest of his family, he was ordered out of the Kat River Settlement. ${ }^{24} \mathrm{He}$ would not return for three years, although his absence was extended by a visit to Great Britain.

As Le Cordeur and Saunders pointed out some years ago, ${ }^{25}$ it should have been obvious that it was not in the interests of the Kat River settlers to join the Xhosa. They would have been aware that the main demands of the Xhosa included the restitution of territory, most notably the valley in which they were now settled, and which they were transforming into agricultural land by arduously digging irrigation furrows. ${ }^{26}$

\section{The War of the Axe and ethnic cleansing}

In the War of the Axe, no such implication of treachery in matters military was made and although the Kat River men were considered first-class soldiers, they were not treated as such. The distinction between themselves and the whites alongside whom they fought, was all too clear. They were not paid - though this was largely at their own volition so as to give them more command over their

${ }^{23}$ Read to Philip, 3 January 1835, cited in J.G. Pretorius, 'The British Humanitarians and the Cape Eastern Frontier, 1834-1836', Archives Year Book for South African History, (hereafter AYB), 51, I (1988), 49.

${ }^{24}$ Smith to Armstrong, 20 January 1835, in G.McC. Theal (ed.), Documents Relating to the Kaffir War of 1835 (London, 1912), 27.

${ }^{25}$ Le Cordeur \& Saunders, Kitchingman Papers, 149.

${ }^{26}$ D. Campbell, 'Detailed Report on the Progress and Present State of the Settlement at the Head of the Kat River, District of Albany', 7 June 1833, CA CO 2742. 
own services. ${ }^{27}$ They did not receive clothing, soap or coffee; ${ }^{28}$ and their dependants' claim to rations was countermanded by the governor, Sir Henry Pottinger. ${ }^{29}$ They did not receive their full share of the booty; ${ }^{30}$ and the governor tried to impose even stricter conscription on the Khoi at a time when there were in fact no men capable of service who were not already under arms. ${ }^{31}$ By voicing their displeasure at the treatment they received, they were accused of being in a state 'bordering on rebellion', and were only kept quiet by the issuing of rations they needed to stay alive. ${ }^{32}$ The racist assumptions of colonial society, perhaps fuelled by the Khoi success in the war, were being imposed ever more stringently on the Khoi.

In the years after the War of the Axe, the British administration of the Settlement became more intrusive and oppressive. For the first time, a magistrate was appointed to oversee the district, a position awarded to a confirmed enemy of the Kat River settlers, T.J. Biddulph. After protests about his actions, he was transferred elsewhere but his position was taken over by T.H. Bowker, a man of much the same ilk. Between them, they did much to alienate the Kat River settlers from the colonial government.

Paradoxically, they did so by measures that at first sight might have been seen to favour the Khoi. In the years following its foundation, considerable numbers of Xhosa and Mfengu ${ }^{33}$ had come into the valley. The most notable of these was Hermanus Matroos, alias Ngxukumeshe, the son of an escaped slave and a Xhosa woman, who had worked on a white farm in his youth and as an interpreter for the British since at least 1819. He fell foul of the Xhosa chiefs at the time of Maqoma's expulsion from the Kat River Valley, and later was

${ }^{27}$ Read to Directors, LMS, 23 March 1847, Archives of the Congregational Council for World Mission (LMS), School of Oriental and African Studies, London, Incoming Letters South Africa (hereafter LMS-SA) 23/1/C. They could also not be certain that they would actually receive their pay. In 1851, the men of the mission station at Bethelsdorp did not respond to the call of the civil commissioner that they again enlist because 'they had been defrauded of their very pay by two of their Captains' during their service in the War of the Axe. Port Elisabeth Telegraph, 23 January 1851.

${ }^{28}$ Remonstrance of the Council of Loyal Burghers, Philipton, 20 February 1851, in LMS-SA 26/4/A.

${ }^{29}$ Le Cordeur \& Saunders, War of the Axe, 82-83.

${ }^{30}$ J. Read, The Kat River Settlement in 1851 (Cape Town, 1982), xiv.

${ }^{31}$ Le Cordeur \& Saunders, War of the Axe, 77-92.

${ }^{32}$ Memorandum by Sir Henry Pottinger, Accompaniment $G$ to Despatch 154, Sir Henry Pottinger to Earl Grey, 20 October 1847 (Grahamstown, 1847), 24-25.

${ }^{33}$ The Mfengu were Xhosa speakers, many of whom were originally from Natal, who had in effect chosen the side of the British in the long conflict on the Eastern frontier. 
dismissed by the British, who suspected him of being untrustworthy. ${ }^{34}$ After some time wandering in the Eastern Cape, he received permission to settle on the Blinkwater River in the Settlement, even though he clearly did not belong to any of the categories for whom the land was reserved. It seems to have been largely his service on the colonial side during Hintza's War that led to this permission being granted. ${ }^{35}$ At any rate, by the late 1840 s he was well established in the Middle Blinkwater as a Xhosa headman with four wives, one of whom had been a dependent of Maqoma's, ${ }^{36}$ and with considerably more followers than the sixteen who had originally accompanied him. In the War of the Axe, he fought on the colonial side against the Xhosa, although his initial application to join had been refused by Sir Andries Stockenström who did not want him fighting against his own countrymen, and who had a long-standing distrust of the man who had managed to worm his way into the settlement. This decision was later overturned, but not to the extent that Hermanus was paid the money the Colony owed him for his services, as had been promised. ${ }^{37}$

The other Xhosa and Mfengu who came into the valley were less prominent and less independent but their relationship with the settlers was by no means uniform. Where the relationship between the settlers and the incomers was tenuous or competitive, the settlers attempted to have the newcomers expelled. There were petitions for the removal of illegal squatters in Fuller's Hoek in the mountains of the south-west of the valley, ${ }^{38}$ and protests against the government allowing Mfengu to pasture their cattle in the Mancazana Valley. On the other hand there were many Mfengu who lived as clients of the settlers, herding stock and growing sorghum and maize on the commonage. The vagueness of the distinction between Xhosa and Khoi survived, as there were many Gona living around Buxton in particular, who seemed to have maintained a material culture which was largely Xhosa, but who were nevertheless clients, and often kin, of the settlers.

The advice which the governor received from one of its officials, Charles Brownlee, was to send out of the settlement all [Xhosa] who had come into the settlement after the war [of the Axe] and who were suspected of having fought against the colony, whilst the Gonas and [Xhosa] who had resided in the Settlement before the war and

34 Bell to Somerset, 3 April 1829, CA CO 5111, cited in J.C. Visagie, 'Die Kat Riviernedersetting, 1829-1839', PhD thesis, UNISA (1978), 63.

${ }^{35} \mathrm{R}$. Godlonton \& E. Irving, A Narrative of the Kaffir War, 1850-1851, facsimile reprint (Cape Town, 1962), 144.

${ }^{36}$ Armstrong to Hudson, 15 August 1837, CA 1/FBF 6/1/1/1.

${ }^{37}$ Stockenström, Light and Shade, 17.

${ }^{38}$ Read to Freeman, 31 January 1850, LMS-SA25/2/B. 
had assisted in repelling and conquering the enemy should be promised farms either at Kat River or elsewhere. ${ }^{39}$

In practice those who suffered were the clients of the leading settlers and the missionaries, the first being a number of Mfengu who were acting as cattle herders for James Read Jr and the Rev. Arie van Rooyen, a man of Khoi descent and originally from Theopolis, who had been ordained as minister for Tidmanton in the Lower Blinkwater a few months earlier. In September 1849, the civil commissioner of Fort Beaufort, N.J. Borcherds, who was shortly afterwards to commit suicide as a near-bankrupt, ${ }^{40}$ led a party of police to burn a number of Mfengu huts around Tidmanton, even though the huts were there legally and there had never been any complaint against these families from settlers living in the neighbourhood. ${ }^{41}$

This, though, was only the beginning. Through the first half of 1850, the campaign by the local officials of the colonial state against the residents of the Blinkwater Valley and later in the adjacent area of the Upper Buxton River became steadily heavier. They had, in their own eyes, reason for their actions. There were certainly considerable numbers of Xhosa who had come into the area since the War of the Axe and were squatting in Fuller's Hoek and the Koems Valley to its north who were a threat to the cattle of the farmers in the Koonap Valley across the mountains. Nevertheless, the relationship between the officials and the Koonap farmers was too close for propriety. As James Read $\mathrm{Sr}$ wrote: 'An Albany farmer will not do for magistrates for the [Khoikhoi], they are full of prejudice and will not rest until this is an English settlement. ${ }^{42}$ Certainly, Bowker had been levying fines upon the Gonas under Andries Botha (on whom more below) for what he claimed were stock offences, but had done so illegally. As a result, he earned a reprimand from the governor and was ordered to repay the fines, although he tried to put off doing so for as long as possible. ${ }^{43}$ At the same time there is clear evidence of corruption, of the use of office for personal pecuniary gain, on the part of one of Bowker's subordinates at least, which further raised the level of tension. ${ }^{44}$

\footnotetext{
${ }^{39}$ Read Jr to Freeman, 20 June 1850, LMS-SA 25/4/B; a copy of Charles Brownlee's report, dated 5 May 1850, is enclosed in Brownlee to Read, 22 June 1850, LMS-SA $25 / 4 / B$.

${ }^{40}$ Read to Freeman, 29 January 1850, LMS-SA 25/2/A.

${ }^{41}$ Read to Freeman, 6 March 1850, LMS-SA25/2/B.

${ }^{42}$ Read to Freeman, 20 June 1850, LMS-SA 25/4/B.

${ }^{43}$ Freeman, Tour in South Africa, 190.

${ }^{44}$ A man called Cobb, who had been appointed in somewhat dubious circumstances as superintendent over the Mfengu of the Blinkwater, claimed land in the middle of the Tidmanton commonage as his own, and then began impounding cattle which strayed
} 
Whatever the motives, in the winter of 1850 in a week of rain, wind and even snow, a party of Xhosa police in colonial service, led by a British officer, proceeded through the western part of the Settlement eliminating the homesteads of those they described as Xhosa 'squatters'. Their first targets were the Xhosa in Fuller's Hoek and the other kloofs on the western boundary of the Kat River Settlement. Some were relatively independent or at least the subjects of Xhosa chiefs, including Bhotomane. One of the leaders, a certain Mali, was known to have fought against the colony during the War of the Axe. Others claimed to be followers of Hermanus but were living outside the restricted area he had been allocated. The party then moved on to Buxton where they found more squatters than in any other place among the followers of Field Cornet Andries Botha. The men, women and children were then shepherded off to Fort Hare, together with their goats and cattle. In total, more than 300 huts were burned, and 145 men, 350 women and an unknown number of children were driven off the land, together with nearly 2,500 head of cattle and 1,400 goats. ${ }^{45}$

There were many offensive aspects to this campaign. The missionaries, and probably many of the settlers in the Kat River, disapproved of the police continuing their work of destruction on a Sunday. The expulsion of men, women and children in the dead of a Cape winter without warning and without any real provision for their future residence was widely seen as brutal, harsh treatment, although it might be argued that, unlike Maqoma and his followers 21 years earlier, this meant that they did not have crops standing in the fields waiting to be harvested. But, as he complained of the matter to his old commander, Sir Andries Stockenström, Andries Botha took exception above all to two matters: those who destroyed the houses, and those whose houses were destroyed.

The Xhosa police force had been formed in the aftermath of Hintsa's War and its numbers had been more than doubled during and after the War of the Axe. In wartime, the police had had a dubious reputation as spies and scouts, while in peacetime they were primarily engaged in the fruitless task of preventing cattle thefts and smuggling. Not surprisingly, both colonists and the other Xhosa distrusted them. At the outbreak of Mlangeni's War though, the majority took up arms with their fellow Xhosa, taking with them several

across the unfenced boundary and charging substantial fees to have them released. See for example, Stockenström to Montagu, 11 July 1850, printed in The Trial of Andries Botha (Cape Town, 1852), (reprinted Pretoria, State Library, 1969), 237-39. In this letter, Sir Andries was recording the complaints made to him by Andries Botha. Also, Stockenström in Light and Shade, 22.

${ }^{45}$ Davies to Mackinnon, 20 June 1850, printed in Freeman, Tour in South Africa, 17679. 


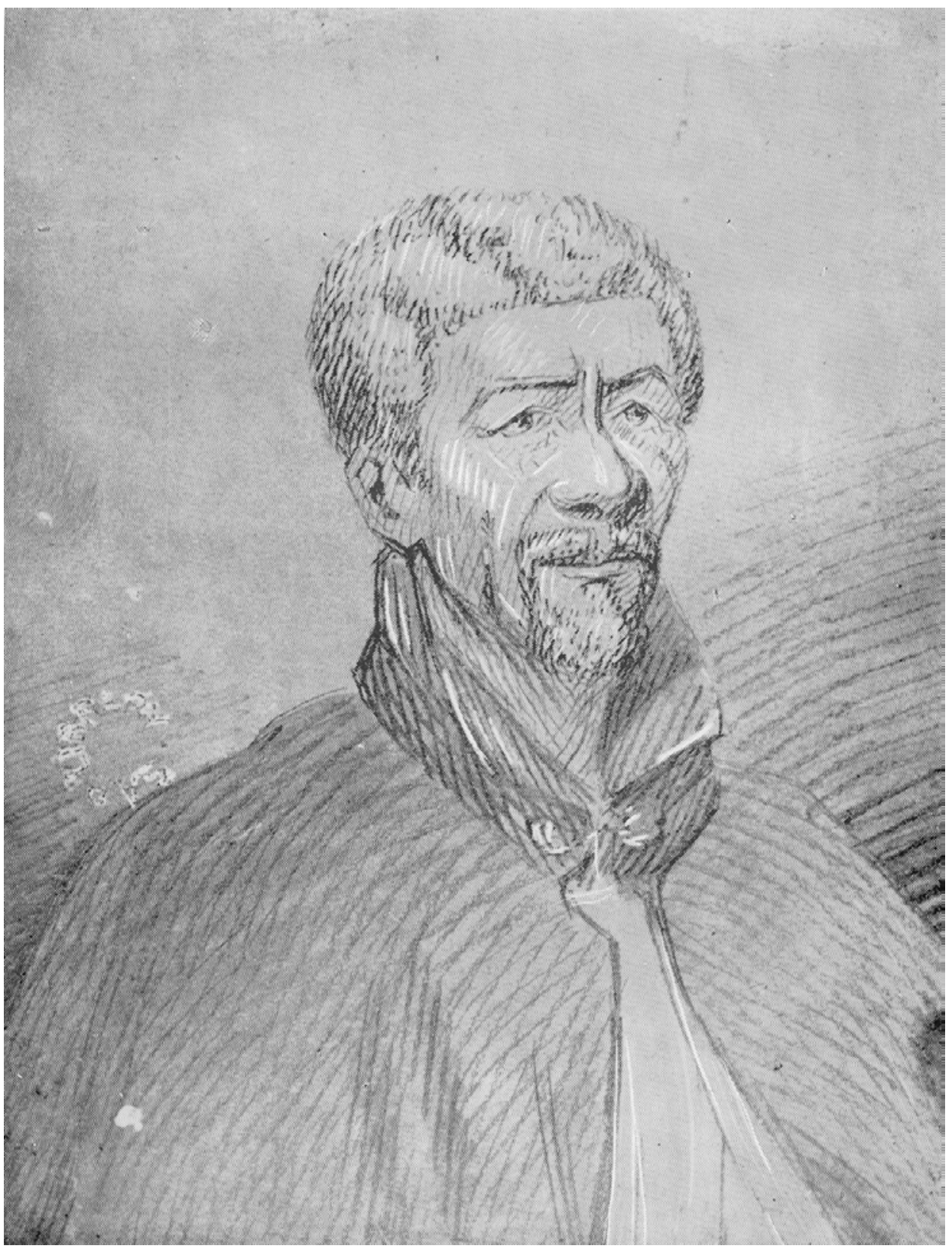

Andries Botha

Photo courtesy of the Cape Town Archives Repository, reference number M1056 
thousand rounds of ammunition. ${ }^{46}$ Most recruits after 1847 were probably men impoverished during the war. Certainly, relatively few had fought with the British then, unlike Botha, of whom Stockenström wrote: 'Her Majesty has not in her dominions a more loyal subject, nor braver soldier'. The police relished the reversal of roles, shouting 'exultingly' - but probably in isiXhosa so that their officers, unlike Botha, could not understand when they said, 'To-day we burn Botha out of the Blinkwater as he burnt us out of the Amatola last war'. ${ }^{47}$

Nowhere is it made clear how the police force decided who were squatters and who should be expelled. The boundary between Xhosa and Khoi was always vague, especially when Gona were involved. Botha himself was identified by the Xhosa police as 'a Ghona Kaffir', ${ }^{48}$ but a man with the office of field cornet, a regularly granted erf and a rectangular wattle-and-daub house could not be considered a squatter. ${ }^{49}$ It might have been that those whose homes were destroyed had made the mistake of maintaining a round, beehive-style isiXhosa hut. According to Botha, many were among his friends and perhaps his kin who had come to the settlement from Xhosaland in 1829. Those who had settled in Balfour had received erfs immediately, and some of those who went to Philipton later got land, largely in the Lower Blinkwater. However, very few of those who had gone to Buxton or to the neighbouring settlement of Wilberforce in the Upper Blinkwater Valley, a more pastoral region where irrigated agriculture had failed, had been granted title to land, and many had since become adults. As was commented at the time:

They have always been expecting to get erfs, according to promise, but it was not done, and as they were among the friends, and no complaints, we did not urge their leaving; thus they have remained among their friends until now. They were ready for any duty, paid regularly the taxes as long as we paid, went on patrols against the [Xhosa], and fought two wars. ${ }^{50}$

Indeed, according to a list drawn up by the Reads, of 36 Gona 'burnt out' at Wilberforce and Buxton, 29 had been in the settlement for twenty years, i.e. since its foundation, five since the 1835 war, one (whose name would suggest that he had relatives among the others) for three years and for one no period of time was given. There were also ten Mfengu families who had come to the settlement in the wake of Hintsa's War and six who had been policemen and

\footnotetext{
${ }^{46}$ K.I. Watson, 'African Sepoys? The Black Police on the Eastern Cape Frontier: 18361850', Kleio, 28 (1996), 62-78.

${ }^{47}$ Stockenström to Montagu, 11 July 1850, in Trial of Andries Botha, 237.

${ }^{48}$ Freeman, Tour in South Africa, 178.

${ }^{49}$ On the shape and material of Botha's house see CA 1/UIT 14/37, case 1.

${ }^{50}$ Botha to Smith, 23 June 1850, printed in Freeman, Tour in South Africa, 183.
} 
were afraid to reside among the other Xhosa who had entered the Colony in 1842, in part because they had fought with the Colony in the War of the Axe. ${ }^{51}$ There were also those who worked as servants for the Kat River Settlers, including at least one case where the labour contract, for a year, had been registered by Bowker only four months before the labourer in question had his hut burnt. ${ }^{52}$ The repulsion which Botha, as the leader of the Buxton and Wilberforce community, felt at what had happened is understandable and, though it is not expressed in the historical record, that of the younger inhabitants of the area was as great, if not greater. The fact that the inquiry into this affair brought Bowker a reprimand and led to his being replaced as magistrate of the settlement did little to mollify them. ${ }^{53}$

The pressure on the inhabitants of the Blinkwater did not end with the burnings and the dismissal of Bowker. A stream of complaints of cattle and sheep thefts from the farmers of the Koonap against the followers continued unabated. As a result, the government appointed a commission to investigate the matter. It was scarcely impartial. One of its four members was Robert Godlonton, the editor of the Graham's Town Journal and an inveterate enemy of the Kat River settlers. Another was Major J. Blakeway, whose family had made the most vocal complaints against Hermanus and the Fuller's Hoek squatters and who was believed to be attempting to buy part of the Fuller's Hoek commonage. Nevertheless, at Godlonton's request, the commission was accompanied by James Read Jr and the Rev. Arie van Rooyen. ${ }^{54}$ For six days in November 1850, they poked around the huts and houses of the Blinkwater, trying to find evidence of stolen cattle. One was even reported to have put his hand inside cooking pots to discover whether they were still greasy. One of the places which they investigated was a cattle post belonging to Oerson Magerman, a Kat River settler James Read described as 'one of the most respectable men of the Blinkwater', who, together with Andries Botha's son, had commanded one of the Kat River parties invading Xhosaland during the War of the Axe. Magerman arrived while they were doing so and complained that his servants were being interrogated while "he was master of the place and would answer everything that might be asked of him'. This led to a

\footnotetext{
${ }^{51}$ This list is to be found in LMS-SA 25/4/B.

${ }^{52}$ Contract between Louis Hendrik and Mahe, before Bowker, Resident Magistrate of Stockenstrom, 8 February 1850 , in LMS-SA 26/4/C.

${ }^{53}$ A.E. du Toit, 'The Cape Frontier: A Study of Native Policy with Special Reference to the Years 1847-1866', AYB, 17 (1954), 50.

${ }^{54}$ Significantly, the commission referred to the latter as 'the Missionary, $\mathrm{Mr}$ van Rooyen', as if it was unable to give him the title of 'Reverend'.
} 
confrontation in which blows, or at least shoves, were exchanged. ${ }^{55}$ The incident can only further have soured the fragile relations between the settlers and the government.

\section{Mlanjeni's War and the Rebellion}

At the end of December 1850 after a period of mounting tension, war once again broke out between the Xhosa and the Colony. It was to be the longest and bloodiest war fought in South Africa in the nineteenth century. To the Xhosa, it is known as Mlanjeni's War, after the prophet whose doctoring was believed, erroneously, to give them protection against British bullets. This time, in contrast to the previous wars, a number of the Khoikhoi from the Kat River Settlement joined the rebellion against the British and fought alongside the Xhosa.

The trigger for the involvement of Kat River men on the Xhosa side was the defection of Hermanus Matroos. At some stage, probably after the assaults on the Blinkwater Xhosa in the winter of 1850 , he had made his peace with the Xhosa chiefs and was privy to their plans to attack the Colony. He too began slaughtering his dun-coloured cattle, as Mlanjeni had ordered, sending their hides to the merchants at Fort Beaufort and to the shop in Tidmanton. His followers also did not cultivate that year, missing the opportunity to profit from the good rains. ${ }^{56}$ Certainly, he was aware of Xhosa plans to attack the Colony, which they did on Christmas Day 1850 after what they saw as an unsuccessful attempt to arrest the Ngqika chief Sandile. Thereafter Hermanus Matroos revolted too, although not until after he had been issued with guns and ammunition from the British armoury in Fort Beaufort. ${ }^{57} \mathrm{He}$ collected all the men he could around him and forced the Khoi in the neighbourhood to join him. Deprived of their arms and with only 90 Khoi surrounded by 900 Xhosa, there was little they could do to oppose him. The Rev. Arie van Rooyen, the LMS minister at the Blinkwater, tried to persuade Hermanus not to impress the men

\footnotetext{
${ }^{55}$ Godlonton et al. to Montagu, 28 November 1850, in Proceedings of and Evidence Given before the Committee of the Legislative Council Respecting the Ordinance to Prevent the Practice of Settling or Squatting on Government Lands (Cape Town, 1852); J. Read Jr to Thompson, 28 November 1850, LMS-SA 26/4/C; Read, Kat River Settlement in 1851, xiv, xvii-xix.

${ }^{56}$ Read, Kat River Settlement in 1851, 18-19; Read Sr to Freeman, 13 April 1851, LMSSA 26/1/C; on the harvest, Read to Tidman, 12 July 1851, LMS-SA 26/2/B.

${ }^{57}$ Evidence of the Rev. H. Renton, BPP 635 of 1851, 419. The British commanders had been warned of Hermanus's obedience to Mlanjeni's commands before they handed out the arms.
} 
Ambiguities of resistance and collaboration on the Eastern Cape Frontier 135

and sent messages requesting assistance to both the magistrate of the Settlement, J.H.B. Weinand, and Commandant Groepe in Fort Armstrong. Neither could spare forces to relieve or give assistance to the Blinkwater Khoi, a fact that was to exacerbate the spread of the rebellion. This message was carried by Oerson Magerman, the man who had been gravely insulted by the Blinkwater commission a couple of months earlier and who would later join the rebellion - although as yet I do not know under what circumstances. ${ }^{58}$

Hermanus began by capturing the fortified farmhouse belonging to $\mathrm{W}$. Gilbert, who had been one of the Blinkwater commissioners, near Fuller's Hoek. Then after a few days, he launched an attack on the British forces in Fort Armstrong. The British, however, were forewarned, largely because James Read had sent a message to the army that rumours of such an attack were circulating in the valley. Hermanus was killed in the streets of the town and the attack beaten off. Nevertheless, a number of those who had been pressed into accompanying him continued the rebellion, even when they had the opportunity to escape to the missionaries (and thus the British) in the coming weeks.

The rebellion began to attract adherents from outside the Kat River Settlement. Within the first week, considerable numbers of farm labourers and tenants from the Winterberg and the Koonap to the west of the Kat River Valley began to take advantage of their employers' isolation and to react to the aggression which the farmers were showing towards them. There had been attempts before the rebellion begun to persuade the farm labourers in the area to join the rebellion. ${ }^{59}$ Indeed when the Winterberg farmers went into laager, their Khoi servants accompanied them but then went over to the rebels taking with them the guns they had received for the defence of the camp. ${ }^{60}$ By 2 January, they had come to the rebel camp in the Blinkwater, with some of the spoils of their actions. James Read Jr went out with one of his deacons to meet them there in an attempt to persuade them to leave the rebellion. He found that the camp was in a carnival mood.

Now we saw the fatherlander sheep browsing - one slaughtered (sometimes two) in each house, pots boiling, meat roasting, and bread, cakes, and pancakes baking in abundance, while the whole scene seemed frantic with mirth and good cheer; and yet

\footnotetext{
${ }^{58}$ Read, Kat River Settlement in 1851, 8, 82; BPP 635 of 1851, 474; Cape Parliamentary Paper G18 59, 40; Oerson Magerman was in Philipton on 25 February when General Somerset marched into the place (see below) prima facie suggesting that he was at that time loyal.

${ }^{59}$ Elbourne, 'Race, Warfare and Religion in Mid-Nineteenth Century Southern Africa: The Khoikhoi Rebellion against the Cape Colony and its Uses, 1850-1858', Journal of African Cultural Studies, 13 (2000), 21.

${ }^{60}$ I. Staples, A Narrative of the Eighth Frontier War of 1851-1853 (Pretoria, 1974), 13.
} 
there was a pensive but wrought-up solemnity - so characteristic of the [Khoi] - but which occasionally broke loose in unbounded laughter. ${ }^{61}$

Nevertheless, there were a number of Khoi from within the settlement who joined in the rebellion, either immediately or later. The Reads, who saw the rebellion, correctly, as ruining their lives' work, tended to portray the participants as giddy young men - not surprisingly as the young are always likely to be the most radical - while the loyalists were the established, respectable farmers. ${ }^{62}$ Statistically there is considerable support for this. On the basis of the Reads' figures, it can be calculated that 22 per cent of those in possession of an erf joined the rebellion, as opposed to 45 per cent of the Khoi inhabitants of the valley who did not own an erf. ${ }^{63}$ The rebel erfholders, most common in the west of the valley where they had been pressed by Hermanus, had suffered most from government actions in 1850 and in general, they had been less likely to recover from the depredations of the War of the Axe. There were also many rebels among the people in those parts of the north of the valley that were laid waste by the British army and the white settler militias in February $1851 .^{64}$

Such sociological comments cannot disguise the fact that among the rebels a substantial number of the established figures of the Settlement had joined the rebellion, and that others, including the two most prominent military figures, Field Commandant Christian Groepe and Field Cornet Andres Botha, were suspected of, at the very least, not being totally committed to its suppression. ${ }^{65}$ There were a number of reasons for this. Certainly both Botha and Groepe were held back by the presence of one or more of their sons among the rebels, ${ }^{66}$ and the shearing loyalties of civil war in a close, small community must have been difficult for many on both sides. ${ }^{67}$ More generally, British settlers in the militia

${ }^{61}$ Read, Kat River Settlement in 1851, 23.

${ }^{62}$ Andries Botha commented that 'All is up; my sons and all the young people have left me, and I, my wife and the old people are all that are left'. See Read, Kat River Settlement in 1851, 22.

${ }^{63}$ Calculated on the basis of Read, Kat River Settlement in 1851, Appendix, 3.

${ }^{64}$ See below.

${ }^{65}$ Botha was tried and convicted of high treason as a result of his actions, not a verdict I would endorse, on the basis of the evidence led in his trial, Trial of Andries Botha (Cape Town, 1852); for Groepe, see 'Answer to an Address of the House of Assembly to the Lieut. Governor', dated 20 July 1854, for the Reports of the Commissioners Appointed for Investigating into the Causes of the Kat River Rebellion', Cape Parliamentary Paper (1854), 2.

${ }^{66}$ D. Williams, When Races Meet: The Life and Times of William Ritchie Thomson (Johannesburg, 1967), 148-49, and above note 60.

${ }^{67}$ Read, Kat River Settlement in 1851, 59. 
and the British army were driven by the widely articulated belief that Mlanjeni's War was a struggle between black and white, with no room for the greys (or browns) of the Kat River, ${ }^{68}$ and were unable, or more probably unwilling, to distinguish friend from foe. There were certainly loyalists who were killed by British forces in the belief that they must have been rebels. ${ }^{69}$ A party of loyalists from the Kat River was fired upon by the inhabitants of the town while escorting the magistrate into Fort Beaufort, exacerbating the anti-colonial feelings of those involved. These included Andries Botha, who exclaimed later that 'he would join the rebels...take Fort Beaufort and convince the inhabitants that they had a different man than Hermanus to deal with' ${ }^{70}$ Later, as General Somerset together with units of the army and the white militia swung through the Settlement, their forces took the opportunity to impose themselves on the Khoikhoi and the missionaries who had threatened their vision of the true order of the world. Some of the 'Gentlemen Settlers', as James Read Sr ironically called them, had marched up the valley flying a red flag with the word 'extermination' affixed to it. The burgher militia burnt the houses and crops of the loyalists in Readsdale, Bruceton, Wilsonton and among the Groepes, for instance, as readily as they destroyed those of the rebels. The schoolhouses of the LMS seem to have been marked out for specific treatment in this regard, both out of prejudice against the mission and no doubt in protest against their potential role in removing the Khoi from dependence on the whites. ${ }^{71}$ Andries Botha, afraid of being lynched, spent several nights in the bush before giving himself up to army commanders, an action that was to lead to his being condemned to death for high treason. ${ }^{72} \mathrm{He}$ was certainly not the only one of the

\footnotetext{
${ }^{68}$ Elbourne, 'Khoikhoi Rebellion', 26-27.

${ }^{69}$ Read, Kat River Settlement in 1851, 48.

${ }^{70}$ Read, Kat River Settlement in 1851, 61-62. The quotation comes from the evidence of John Green, a hostile witness, in Trial of Andries Botha, 65; if it was not a fabrication of Green's imagination (which I do not believe, though I have no evidence either way), it was merely the explosion of momentary anger. See also Trial, 72-73, 233.

${ }^{71}$ Read to Freeman, 13 April 1851, LMS-SA 26/1/C; Read, Kat River Settlement in 1851, 79-80, 97; Evidence of the Rev. H. Renton, BPP 635 of 1851, 427.

72 The court that condemned Botha in what was perhaps South Africa's first political trial saw matters differently, believing that he had connived with the rebels during the days in which his movements were unaccounted for. On reading the evidence, I am more persuaded by the arguments of the defence, which I am here recounting, than by those of the prosecution. See Trial of Andries Botha, passim. Botha's sentence was commuted and he was released after a short stay in gaol. This might seem to suggest that the prosecuting counsel, William Porter, had convinced himself somewhat less fully than he had convinced the jury that Botha was guilty. As Attorney-General, he would have had some say in Botha's release.
} 
Khoi to take such an action. ${ }^{73}$ Though he did not condone all the actions of the men under his command, Somerset took no measures to restrain them. Certainly he accepted their ideas as to the responsibility for the uprising, writing in an official despatch that Philipton, the residence of the Reads and the main mission settlement,

...so proverbially stated to be loyal, had in fact been the focus of almost all the disaffected in the settlement. ...I found, upon undoubted evidence, that from this body of people detachments had been furnished to support the rebels in their desultory attacks on the farms in the colony; in fact that the most disgraceful deception had been carried on to an incredible extent. ${ }^{74}$

This sort of taxonomic lumping did much to drive doubters into the rebel camp.

All the same, the rebellion was driven on, in part at least, by a Khoikhoi ethnic consciousness that was certainly not called into existence by the actions and categorizations of the Europeans. As has been shown elsewhere, ${ }^{75}$ it had a history in the Kat River Valley that went back at least to the 1830s, and it was used to mobilize and justify the actions of the rebels. The Xhosa certainly played on it in an attempt to persuade the Khoi to join them. At one meeting, held at Sandile's 'Great Place', the Ngqika chief proclaimed:

I shall re-establish the Kingdom of Chama [one of the old Khoi chiefs, James Read noted]. Do you know of any of the heirs of the old [Khoi] dynasty? If so, I shall give my sanction to their again assuming the rank of their fathers. I see that notwithstanding all the assistance you have given the Government to fight against us in every war, and all your toil for the white man, you are still very poor... If you will join me, ....you may trust my word, that you shall be completed with cattle and all that a man should have; and farther, the first cattle that shall be taken will be distributed to the children of Chama. ${ }^{76}$

The Khoi themselves articulated such ideas, for instance in two of the letters written by rebel leaders to urge others to join their cause. In the first, Speelman Kieviet wrote in the first days of the rebellion:

\footnotetext{
${ }^{73}$ Read, Kat River Settlement in 1851,80 . This, it should be pointed out, was written before Botha was arrested and charged.

${ }^{74}$ Somerset to Smith, 28 February 1851, BPP 1352 of 1851, 13.

${ }^{75}$ Trapido, The Emergence of Liberalism; Ross, 'The Kat River Rebellion and Khoikhoi Nationalism'; Elbourne, 'Race, Warfare and Religion'.

${ }^{76}$ J. Read Sr to Freeman, 13 April 1851, LMS-SA 26/1/C; Read, Kat River Settlement in 1851,41
} 
Our circumstances as the Hottentot nation...are now become very melancholy and on this account we have put our hands to a work from which we have no wish to retreat. We have done this without acquainting all of you who belong to our nation, and in this we have acted very improperly...but with this we take the liberty to acquaint you, as our nation, that we have commenced war with the settlers (meaning the English), and to call upon you as our nation to assist us. Break the bands of indecision or [sic] come at once with all speed to assist us in this great and important matter. Time is important. It is a national cause and can you as a nation remain inactive? Arise courageously and work for your motherland and freedom. ...The world is against us and who will be for us. ${ }^{77}$

Five months later, Willem Uithaalder, commander of the rebel forces in the Amatola Mountains, had a letter written to Adam Kok III, Captain of the Philippolis Griquas, in which he called upon Kok to:

Rise manfully and unanimously as a nation and children of one house to engage yourselves in this important work, a work which concerns your mother country, for not a single person of colour, wherever he may be, will escape this law. Trust, therefore, in the Lord (whose character is known to be unfriendly to injustice), and undertake your work, and he will give us prosperity - a work for your motherland and freedom, for it is now the time, yea, the appointed time, and no other. ${ }^{78}$

For both Kieviet and Uithaalder, and for most of their followers, the nationalism they propagated was a very Christian nationalism, building on a long tradition of socially engaged mission Protestantism, which went back to the establishment of the LMS mission in the Eastern Cape. At the same time it was highly ethnic. Ethnicity, as ever, was a way to think about matters beyond the existential which it propounds on the surface, thus not just 'Who am I?' but also 'Why is this happening to me?' The rebellion was explicitly not just an assertion of Khoi ethnicity: it was a protest against the threats of settler rule, which the Khoi saw, not unjustly, in the proposed establishment of the Cape Parliament. At one extreme there were those who hoped for the establishment of a Khoi state - a monarchy or republic - in the Eastern Cape. ${ }^{79}$ Those who were somewhat more realistic saw their protests primarily aimed at the European settlers in the Colony, and particularly at the possibility, which had been mooted by various of the farmers, of the reintroduction of measures that it was believed would reduce the Khoi once again to bondage, notably a Vagrancy

\footnotetext{
${ }^{77}$ BPP 1635 of 1853, 171, Speelman Kieviet to [Peffer], 10 January 1851.

${ }^{78}$ BPP 1635 of 1853 , Willem Uithaalder to Adam Kok. 11 June 1851. (The original is in the Free State Archives, HC 1/1/3.)

${ }^{79}$ Cited in Godlonton \& Irving, 'Narrative', 176, from The South African Commercial Advertiser (they do not give the date).
} 
Act. ${ }^{80}$ The hopes and fears were enough to make them risk what they had built up in the hope, forlorn as it turned out, that they would be able to reconstruct their lives.

\section{Conclusion}

By the end of the nineteenth century, the whole of what was to become South Africa was under colonial rule. A couple of years later it was all under British rule. This is not surprising. British power was vastly superior to that of all other South African groups and when it was called upon it could, eventually, steamroller them. Moreover, the British, or at least some of them, had an almost teleological sense that they would master the sub-continent. It was a decision based on ideas of racial supremacy and racial difference, or at the very least on an ethnic consciousness which the British assumed for themselves and which they imputed to all the others with whom they came into contact. In the course of this process of ethnic labelling, they decided, effectively, who were to be their opponents. ${ }^{81}$

Matters seem very different and certainly more complicated when the point of view shifts to that of the non-British. As the history of the Kat River Settlement shows, the British perspective was usually based on an accurate assessment of the true motives and intentions of people to whom the British attributed hostility. Ethnicity, in particular, was not necessarily as evident a motive as the British assumed. It was not unusual for those who had thrown in their lot with the British to be rejected by them because of their association, in the eyes of the British though not in their own, with people who, at that moment, the British assumed to be their enemies. Many Kat River settlers rebelled because they were declared to be rebels, and even then many of those who were considered to be disloyal to the Cape Colony struggled as hard as they could to preserve their loyalty and to hold to the course they had chosen. What was called 'loyalty' was, in its way, just as much 'resistance' as was taking up arms. Loyalty was resistance to the increasingly racialized bifurcation of colonial South African society, while fighting, paradoxically, was an affirmation of that division.

\footnotetext{
${ }^{80}$ Elbourne, 'Fit for Freedom'; Memorandum by John Montagu, Colonial Secretary, 2 February 1852, BPP 1636 of 1852-3, 109.

${ }^{81}$ For an analogous case, see S. Marks, Reluctant Rebellion: The 1906-8 Disturbances in Natal (Oxford, 1970).
} 


\title{
African mutinies in the Netherlands East Indies: A nineteenth-century colonial paradox
}

\author{
Ineke van Kessel
}

Between 1831 and 1872, the Dutch government recruited 3,000 Africans from the Gold Coast and Ashanti for service in the colonial army in the Netherlands East Indies. The majority of them were ex-slaves but were promised that their conditions of service would be the same as those of Europeans. With the 'equal treatment' clause, the Dutch government defended itself against British accusations that the recruitment operation amounted to a covert form of slave trading. While this policy made sense in the context of the pre-colonial relations prevailing in the Gold Coast, its merits were less obvious in the East Indies. The colonial army here was the instrument of empire building but mutinies among African troops stationed on Java and Sumatra caused it to rethink its policy concerning African soldiers. This chapter explores the background to these rebellions.

'Wherever the Negro soldiers served together in a company, they have banded together in mutiny, under the pretext that infringements had been made on the promise of equal treatment with the European soldier.' ${ }^{\text {(Major-General }}$ Cochius to the Department of Colonies in The Hague, 8 August 1840)

\footnotetext{
${ }^{1}$ Algemeen Rijksarchief (ARA), Ministerie van Koloniën na 1850 (hereafter Kol.), Generaal Overzigt van hetgeen betrekking heeft tot de werving van Afrikanen en van de verkregen resultaten, $\mathrm{nr}$ 49, exh. 4-11-1850, Missive van den kommandant van het leger, dd 8 augustus 1840 , geheim.
} 


\section{Introduction}

Revolts and resistance by Africans occurred not only on the African continent but also among Africans in the diaspora. The best-known examples are the slave rebellions in the western hemisphere, where historians have also explored and described patterns of accommodation and acquiescence among slave populations. However, very little is known about instances of resistance and patterns of accommodation among other groups of Africans in the diaspora. This chapter deals with a series of mutinies by West Africans recruited in the nineteenth century as soldiers in the Dutch colonial army in the Netherlands East Indies, present-day Indonesia.

The vast majority of the 3,000 Africans who were shipped to Java between 1831 and 1872 had previously been of slave status. Their freedom had been purchased with an advance on their army pay. Although they entered army service as free men, there is reason to doubt the voluntary nature of their enlistment. But the Africans in the East Indies did not rise in protest against their conscription into the Dutch army. On the contrary, they fully identified with their prescribed role. They had been recruited with the promise of equal treatment with the European soldiers, and they insisted that the promise be kept in every detail. The series of mutinies erupted in protest against repeated infringements on their status as European soldiers. With their newly acquired corporate identity as 'African soldiers' or 'Negro soldiers', these men of disparate ethnic origins and largely of slave descent banded together in solidarity to demand that their European status be respected to the letter.

Enlisting Africans in colonial armies was of course common practice during the nineteenth and twentieth centuries. Like the Africans in the Dutch East Indies army, the famous Tirailleurs Sénégalais, established in 1857, were also largely of servile descent. As Myron Echenberg pointed out, the roots of the African Tirailleurs are much older and can be traced back to the era of company rule in Senegambia in the seventeenth century. ${ }^{2}$ African soldiers were not only instrumental in wars of conquest and in the consolidation of empire in Africa but were also used for military expeditions overseas. In 1827, the French sent 200 Wolof soldiers to Madagascar, followed in 1831 by the despatching of 220 troops to Guyana. In Sierra Leone, the British recruited among freed slaves to swell the ranks of the British West Indies regiments. In the twentieth century, the King's African Rifles played a vital role in the consolidation of British rule

\footnotetext{
${ }^{2}$ M. Echenberg, 'Slaves into Soldiers: Social Origins of the Tirailleurs Sénégalais', in P. Lovejoy (ed.), Africans in Bondage: Studies in Slavery and the Slave Trade (Madison, 1986); M. Echenberg, Colonial Conscripts: The Tirailleurs Sénégalais in French West Africa, 1857-1960 (Portsmouth NH, 1991).
} 
in East Africa. ${ }^{3}$ The rationale for African recruitment was remarkably similar in all cases: a shortage of European recruits and high mortality rates among European soldiers who, voluntarily or involuntarily, were despatched to the tropics. The lower cost of local personnel could also have been a compelling argument, although there were obvious limitations to cost cutting. The loyalty of African troops was generally ensured by granting them special benefits and privileges. Thus, even when they were of servile origins, African soldiers used their newly acquired corporate identity as military men to enhance their status $v i s$-à-vis civilian society. It fitted the purposes of colonial rulers to instil their African soldiers with a sense of superiority over their civilian colonial subjects. In his history of the King's African Rifles, Timothy Parsons pointed out that African servicemen both consciously and unconsciously exploited the contradictions of the colonial state to seek greater rights and status. He aptly quotes Ann Laura Stoler and Frederick Cooper who remind us that: 'One of the most basic forms of colonial control (...) depended on soldiers who were simultaneously coerced and coercing, who enforced the will of the elite yet made demands themselves'.

Certainly in the phase of conquest and early consolidation, imperial rulers generally deemed it advisable to use foreign-born Africans rather than locals. But even foreign-born African soldiers were not always reliable tools of imperial expansion. It is noteworthy that, in the phase of conquest, the British preferred to strengthen their colonial forces in East Africa with Indian troops. As the Inspector-General of the King's African Rifles put it bluntly in 1912: 'The Indian contingents were introduced in order than we might have a body of troops with no religious or local sympathies, and therefore no incentive for throwing in their lot with the native inhabitants'. The same rationale underpinned the Dutch decision to recruit African soldiers for the East Indies rather than expand local recruitment in the Indies.

Yet, the story of African recruitment for the Dutch East Indies is somewhat different from the British and the French experiences. Unlike the British and the French, the Dutch exercised no territorial control on the Gold Coast and fostered no colonial ambitions in West Africa. The African soldiers for the East Indies army were not despatched as an expeditionary force to be repatriated after the campaign was over. If the experience with African recruits proved satisfactory, the African presence was envisaged as a permanent feature of the East Indies army. After the expiry of their long-term contracts (on average 12 to

\footnotetext{
${ }^{3}$ T.H. Parsons, The African Rank and File: Social Implications of Colonial Military Service in the King's African Rifles, 1902-1964 (Portsmouth NH, 1999).

${ }^{4}$ Ibid. 6.
} 
15 years), they could opt for re-enlistment, repatriation to the Gold Coast, or permanent residence on Java.

While the Netherlands had no colonial ambitions in West Africa, the East Indies was the mainstay of its overseas empire. By 1830, the Dutch had reestablished colonial control over Java. During the Napoleonic wars the island had been under British rule. Subsequently Dutch rule was undermined by a major uprising, known as the Java War or the Diponegoro War, after its princely instigator. As many rebels found a refuge on the southern and western parts of Sumatra, this became the scene of future military campaigns. In the 1820 s, three Islamic leaders from these parts of Sumatra went on a pilgrimage to Mecca, from where they returned full of zeal to launch an orthodox reform movement in their home areas. The hadjis engaged the infidel Dutch intruders in a series of armed conflicts, known as the Padri Wars, which, with some interruptions, would last for about 20 years. The mutinies to be explored in this chapter took place both on Sumatra and on Java.

But before turning to the 1840-1841 mutinies, I will first make some remarks on the information sources and the historical context. Since the African recruitment was launched as an experiment, the colonial army documented in considerable detail both the positive and the negative experiences they encountered with the Africans as soldiers. The abundance of army records allows us today to describe the rebellions in some detail. What were the grievances of the Africans? How did the Africans view their predicament? What was the response of their commanding officers? Apart from its inherent interest, the story of the mutinies provides an intriguing insight into colonial ambiguities with regard to race and social status. The military archives offer a mine of information on the army careers of the African soldiers: it is unusual to have such a wealth of information on individuals of low social status in a nineteenthcentury colonial setting. By their very nature, army sources have their obvious limitations since the army was interested in the Africans as soldiers and paid little attention to other dimensions of their experience. As for the Africans' own interpretations of their predicament, we have unfortunately no direct sources. The vast majority were illiterate. A handful of soldiers of mixed Dutch-African parentage, recruited in the experimental phase in the early 1830 s, were literate in Dutch but unfortunately their writings have not survived, to my knowledge. An additional source of information is to be found in the memoirs published by Dutch army officers who served in the East Indies. Some were prolific writers who recorded military campaigns and daily life in great detail. African soldiers indeed figure in some of these accounts but usually only on the margins: officers tend to elaborate on their own feats and those of fellow officers, not on the exploits of soldiers and NCOs. In these memoirs, we again see the Africans through the eyes of Dutch officers. From some of these accounts, it clearly 
transpires that at least some of the Dutch officers did not accept the rigid racial stratification of the colonial army as a natural order with a self-evident logic. ${ }^{5}$ The professional publications by and for the military are a third important source of information but they only came into existence in the last quarter of the nineteenth century. ${ }^{6}$ A final word of caution: the present chapter very much represents 'work in progress' as I am still delving my way through vast amounts of archival records. In order to capture the atmosphere of the time and the place, I have used extensive quotations from these nineteenth-century sources, although some of the racial qualifications are out of tune with present codes of correctness.

The military records allow a fairly detailed reconstruction of the story of the 1840-1841 mutinies on Java and Sumatra within the colonial setting of the midnineteenth century, a period of rapid Dutch expansion in the vast Indonesian archipelago. The consolidation of Dutch rule also meant that the Dutch East Indies were shaped as a colonial society with a rigid social and racial stratification, with the inherent racial stereotypes underpinning white domination. By contrast, the Gold Coast presented a radically different picture in the mid-nineteenth century. In the pre-colonial balance of power, the Europeans on the Gold Coast were heavily dependent on the cooperation of local rulers and middlemen. In spite of the grand name of the 'Dutch possessions on the Guinea Coast', the Dutch 'possessed' only a tenuous foothold in a few coastal settlements, symbolized by a string of derelict and partly deserted forts, remnants of the days of the now-defunct Dutch West India Company. Trade had almost come to a standstill and attempts to revitalize these 'possessions' by the introduction of plantations and the exploitation of goldmines - mining had always been fully controlled by local rulers - failed miserably. For any endeavour, including the recruitment of soldiers, the Dutch were heavily dependent on the cooperation of local rulers. Under these conditions, it makes sense that race relations on the Gold Coast were still far more fluid than in the East Indies. In Dutch-African relations, social status was a more important category than pigmentation. In the Netherlands itself, soldiers were a social category held in very low esteem, and this was even more true for the soldiers who entered colonial service. The colonial recruiting depot in Harderwijk, the assembly point for 'volunteers' from many European nations, was known as 'the sinkhole of Europe'.

Colonial domination could only be maintained with the cooperation and collaboration of the subject population. Throughout most of the nineteenth

\footnotetext{
${ }^{5}$ See for example the prolific writings of W.A. van Rees.

${ }^{6}$ The Indisch Militair Tijdschrift, the main professional periodical of the East Indies Army, began publication in 1870 .
} 
century, half of the Dutch colonial army in the East Indies consisted of native soldiers. It was considered too risky to increase the native component beyond this $50 \%$ mark because the native soldiers might be tempted to use their weapons and their training against their colonial masters, as some of them did in the Java War (1825-1830). Therefore, the other half needed to be European soldiers, who were unlikely to make common cause with the natives. As an instrument of colonial domination, the army itself was organized on racial and ethnic principles: Europeans were at the top of this racial hierarchy and the natives at the bottom, with an intermediate category of Amboinese, soldiers of privileged status from the Moluccan islands. As Christians, the Amboinese were unlikely to fraternize with the largely Moslem Javanese and Sumatrans. By allocating European status to the Africans, the colonial power minimized any danger of the Africans being tempted to fraternize with the native population. But when the Africans took their European status seriously, they undermined the colonial logic, which held that people of colour ought to fear and respect the superiority of the white man.

In this respect, there are certain parallels between the African mutinies in the East Indies and African protest movements in colonial Africa. In many instances of so-called anti-colonial protest, Africans did not challenge colonial rule as such but demanded their rightful place in the colonial order. The demand for equality, for equal rights and privileges as enjoyed by the Europeans, was often a more pervasive theme than the desire to undo the process of colonization. Nevertheless, acceding to these demands undermined the logic of the colonial state and inevitably led to the demise of the colonial order. The African soldiers in the East Indies did not challenge colonial rule or the racial hierarchy of a colonial state. They insisted on their rightful place in this racial hierarchy: as African soldiers they were entitled to 'European status'. Before turning to the mutinies, we need to explore the preceding decade, which marked the beginning of the experiment with African recruitment.

\section{African recruitment: An experiment}

The idea of recruiting Africans to compensate for the lack of European army volunteers came from Dutch army officers who had served in Surinam and the Dutch West Indies. They had been impressed with the performance of the blacks in the British West Indies regiments and suggested to the government in The Hague that the Dutch footholds on the Guinea coast be used to recruit blacks for the East Indies army. After several years of discussion about the manpower problem in the East Indies army, the Department of Colonies decided to experiment with a detachment of 150 volunteers from the Guinea 
Coast. If all went well, recruitment would be stepped up to achieve a target number of 1,800 Africans. In 1831 and 1832, three ships were contracted to collect the volunteers in Elmina, the headquarters of the Dutch on the Guinea Coast, and take them to Java. However, as Governor Last in Elmina had already warned, young African men were less than enthusiastic about a military career in a foreign army in unknown lands. His instructions specified that recruitment be limited to free men, without the use of force or coercion. The three ships collected no more than 44 volunteers. The low numbers resulted in astronomical costs. Governor-General Van den Bosch in the East Indies calculated that the 44 African volunteers had cost the enormous amount of Dfl 1,232 per head, while European soldiers were shipped to Batavia for Dfl 120 per head. Initial reports on the military qualities of the recruits were highly favourable but the governor suggested stopping the experiment because of the excessive costs.

Recruitment at the Guinea Coast proceeded nevertheless but with meagre results. At the request of the Dutch governor in Elmina, the king of Ashanti promised to send some slaves as 'army volunteers' but these recruits never materialized. To comply with his instructions from The Hague, the new governor, Lans, therefore decided to purchase some slaves himself, who were then shipped off to Batavia as 'army volunteers'. In 1836, the Dutch government decided to send a high-level mission, headed by Major-General Jan Verveer, to the Ashanti king in Kumasi to obtain 2,000 recruits in exchange for 6,000 to 8,000 guns and 2,000 tons of gunpowder.

As a first step, Verveer opened a recruiting station in Elmina but subsequently had to report that coastal Negroes would not volunteer for army service and that therefore the only option was the recruitment of slaves. ${ }^{8}$ His mission to Kumasi seemed successful: the Asantehene Kwaku Dua did indeed sign a treaty promising to deliver 1,000 recruits within a year and permitting the Dutch to open a recruitment station in the Ashanti capital. As proof of good faith between the contracting partners, the Asantehene trusted his son and nephew into the care of Verveer, with the request that they be given a European education. The story of Kwame Poku and Kwasi Boakye has acquired deserved fame with the publication of Arthur Japin's historical novel on the life of these two Ashanti princes. ${ }^{9}$

Verveer's initial hope of recruiting Ashanti men, reputed for their warrior qualities, proved unrealistic. Ashanti warriors were not available as mercenary forces for foreign armies. The recruiting process was, therefore, limited to

\footnotetext{
${ }^{7}$ Kol., Generaal Overzigt, KB 11 mei 1836, no. 91.

${ }^{8}$ Kol. na 1850, nr 5820, Nota betrekkelijk de negerwerving, exh. 16 april 1839, no. 20.

${ }^{9}$ A. Japin, De Zwarte met het Witte Hart (Amsterdam, 1997); English translation: A. Japin, The Two Hearts of Kwasi Boach (London, 2001).
} 
slaves, known as Donkos. The king delivered a number of Donkos, while individual Ashanti could also bring their slaves to the Dutch recruiting station. Their freedom was purchased with an advance on their army pay. With a document of manumission, they went to the Indies as free men, although it is not clear to what extent their army career was a voluntary choice. ${ }^{10}$ The promised large numbers of slaves did not materialize, possibly because the amount of money offered by the Dutch - about 100 Dutch Guilders (Dfl) a head - was less than could be obtained for healthy young males in the illegal slave trade. Another possibility is that the supply of marketable slaves in Kumasi was less bountiful than the Dutch had imagined, or that the Northern trade had overtaken the coastal trade in importance.

Nevertheless, between 1837 and 1841, over 2,000 African recruits were shipped from Elmina to Batavia. This was not only a quantitative but also a qualitative shift in the African recruitment operation. Initially, the army in the Indies absorbed dozens of African recruits without many problems. As these men were recruited on the coast, they were familiar with Europeans. Some spoke Dutch - more or less fluently - and could be used as interpreters and mediators in cases of misunderstanding. A few had had previous military experience serving in the Elmina garrison. All of them probably understood Fante and/or Twi and a few of the coastal mulattos were even literate in Dutch.

The massive numbers enlisted from the interior were not familiar with ships, the world of Europeans or European concepts of armies and soldiers. Many of them, originating from north of the Akan-speaking region, probably did not understand Fante or Twi. None could serve as interpreter or mediator and communication problems caused numerous misunderstandings as the lingua franca in the East Indies army was Dutch or Malay. Moreover, the Africans were counted as part of the European component of the army. The annual troop supplements shipped from the Netherlands were now to a large extent replaced by Africans. Training the African troops took up more time and involved more communication problems than with European or native troops. The massive replacement of the regular troop supplements from Europe by Africans must have overwhelmed the European officers in the Indies, who were totally unprepared for this new development. From the perspective of Dutch army

\footnotetext{
${ }^{10}$ Larry Yarak argues that slaves on the Gold Coast could in fact make their own choices, at least to a certain extent. He therefore concludes that the Dutch recruitment operation should not be seen as a revival of the slave trade but rather as a form of nineteenth-century indentured labour recruitment. See L.W. Yarak, 'New Sources for the Study of Akan Slavery and Slave Trade: Dutch Military Recruitment in the Gold Coast and Asante, 1831-1872', in R. Law (ed.), Source Material for Studying the Slave Trade and the African Diaspora Papers from a Conference of the Centre for Commonwealth Studies (Stirling, 1996), 35-60.
} 
officers, it made little sense that these untested newcomers were entitled to better pay and better treatment than the loyal Amboinese who were reputed to make good soldiers and NCOs.

The instructions flowing from Verveer's treaty with the Ashanti king were quite clear: the African soldiers were to be treated as Europeans with regard to pay, promotion, clothing, food and in all other respects. This policy made sense in the conditions of the Gold Coast and Europe, where the Dutch were very concerned to counter British allegations that the recruitment operation amounted to a covert form of slave trading. The situation in the East Indies was more ambivalent. On the one hand, it made sense to treat the Africans as Europeans because as Europeans they were unlikely to fraternize with the natives. On the other hand, treating people of colour as equals undermined the logic of the colonial state.

In later years, the Ashanti prince Kwasi Boakye fell victim to the same colonial contradiction. While pursuing a classical education in the Netherlands, Boakye and his cousin may have aroused curiosity because of their unusual appearance but their status was first and foremost determined by their royal lineage. They were welcome visitors at the Dutch royal court. After graduating in Delft as a mining engineer, Boakye opted for a career in the Netherlands East Indies. The Governor-General in Batavia objected. In a letter to the Minister of Colonies, he argued that: 'The principle of la noblesse de peau and of the moral and intellectual superiority of the white race above the brown, upon which our domination in the Indies rests, would receive a severe blow by this [appointment]'. His objections were overruled and Boakye was given his appointment but with the title of 'extraordinary engineer'. Secret instructions from the Minister of Colonies ensured that Boakye was never promoted to a position in which he would exercise authority over Dutch officials. ${ }^{11}$

\section{Mud and mattresses}

A series of incidents that culminated in the armed mutinies had in fact begun with some economizing measures that initially affected the Amboinese but were later extended to the Africans. From 1835, the Amboinese were no longer issued with straw mattresses (bultzakken) as the Europeans were, but with native sleeping mats and leather pillows. The measure was of course advertised

\footnotetext{
${ }^{11}$ L.W. Yarak, 'Kwasi Boakye and Kwame Poku: Dutch-Educated Asante "Princes"”, in E. Schildkrout (ed.), The Golden Stool: Studies of the Ashante Center and Periphery Anthropological Papers of the American Museum of Natural History, vol. 65, part I, (New York, 1987), 140.
} 
as being in the best interests of the health of the Amboinese. The argument was that the Amboinese, not being used to straw mattresses anyway, did not know how to keep their sleeping quarters clean. Unlike the native soldiers, the Amboinese were entitled to wear shoes. As this privilege was equated with European status, the Amboinese would never leave their barracks without this important attribute. While shoes were an important status attribute, they were not necessarily comfortable. Inside military quarters, the Amboinese thus often walked barefoot, muddying their mattresses. When the army decided that they had to change their mattresses for sleeping mats, the Amboinese accepted this ruling without protest.

In 1838 this measure was extended to the African soldiers. ${ }^{12}$ Like the Amboinese, the Africans took off their shoes inside their army quarters and, according to documents from army headquarters in Batavia, "were known to be of an uncleanly nature, to have a greasy skin, greasy hair and a peculiarly strong and unpleasant smell'. ${ }^{13}$ Thus, the army reasoned that native sleeping mats would make more suitable bedding for the Africans too.

The Sumatra revolt was sparked off by the replacement of mattresses with native mats, while the issue of bedding is also mentioned among the grievances of the mutineers in Kedong Kebo, in central Java. Discontent had, however, apparently been brewing for some years. On 16 March 1838, the commander of the $1^{\text {st }}$ battalion had already reported a 'spirit of discontent'. He advised against having more than one company of Africans per battalion, as the Africans were 'choleric, quick-tempered and extremely insolent' and could easily band together to cause mischief. ${ }^{14}$ Army organization prescribed that ten battalions would each have one African company, with the other companies consisting of natives, Europeans and perhaps Amboinese. Two battalions would each have three African companies, while the other half of these battalions would then consist of three companies with only Europeans.

\section{Courageous but ill-disciplined}

In 1838, seven years after the start of African recruitment, the commander of the colonial army started to receive regular reports of disturbances in the African companies and several cases of desertion and protest. Army headquarters reported to the colonial government the difficulties they had when

12 Kol. na 1850, Generaal Overzigt, Missive van den kommandant van het observatiekorps dd 6 februarij 1838, no. 186.

${ }^{13}$ Kol., Generaal Overzigt, bijlage La G, Aantekeningen op nevenstaande memorie.

${ }^{14}$ Ibid. 
dealing with the Africans and warned that it would require much patience and caution to obtain the desired results. But in spite of the manifold difficulties, the overall opinion of the Africans as soldiers was still largely positive, as is evident from reports sent in 1838 by battalion commanders with Africans under their command. ${ }^{15}$ As this is a combined report covering various regions and battalions, it is worth summarizing extensively. According to their commanders:

The Africans had adjusted well to the military way of life, but they had little notion of subordination and showed little respect for non-commissioned officers and corporals. Yet they were rarely punished, as the army command had given instructions for lenient treatment. Much patience was required to make capable and orderly soldiers out of the African recruits, with communication problems being the main obstacle. The Africans spoke and understood neither Dutch nor Malay, the languages of instruction in the army. They spoke a variety of African languages, so that even among themselves communication problems persisted. As a consequence of the communication problem, it was not yet possible to submit the Africans fully to the rules of army discipline.

Their cleanliness left much to be desired, they did not know very well how to handle their clothes, but demonstrated more interest in cleaning and maintaining their weapons. Initially diseases were widespread, notably stomach problems, skin infections (due to laziness resulting in uncleanliness), syphilis, and worms in their legs. But most of these problems had been overcome.

The Africans kept their distance from both Europeans and natives. They were very distrustful and always worried that they were being cheated (with good reason, as will be shown later). Some spoke a bit of broken Dutch and a little Malay, just enough for shopping in the bazaar. The Donkos from the interior were less intelligent than coastal Negroes. In the third battalion, Lieutenant De Villepois had organized a daily language class with the Eurafrican Corporal Ruhle, while the 4th battalion had admitted eight of the most ambitious Africans to the garrison school. Arms instruction took a lot of time, due to language problems.

According to their commanding officers, the nature of these Africans was hottempered, irascible and often very insolent. Used to having one master only, they could not understand that so many were giving them orders. They were of a rough nature, jealous, distrustful and greedy. On the other hand, they were honest men; no traces of thievery had been reported. They were mostly strong, muscled, indefatigable and very adapted to the tropical climate. During military expeditions they demonstrated bravery and fearlessness, even more so than the Europeans. In combat their ardour needed to be tempered, otherwise they ignored the orders of their officers. Some reports mention a substantial use of alcohol, but less so than with the European soldiers. Much friction was reported between the various tribes, notably between coastal Africans and those recruited from the interior, known as Donkos. It was repeatedly emphasized that the Africans looked down on the native population.

\footnotetext{
${ }^{15}$ Kol., Generaal Overzigt, Verslag over bij het leger dienende Afrikanen, attached to
} Missive van het militair departement dd 3 september 1838, no. 3 geheim. 
Their main vice was laziness. Their greatest pleasure was doing nothing, or lying down to smoke tobacco. Therefore it required constant attention to make them attend to cleanliness, but otherwise their conduct was deemed satisfactory. The reports advised strongly against plans for the formation of a separate African corps in the East Indies Army. This proposal was put forward by the Department of Colonies in The Hague, but in the Indies it was feared that then the Africans would develop a too dominant esprit de corps, which would go against military subordination. With too many Negroes in one corps, they might become ungovernable and as they were already inclined to mutinies, they would then cause great mischief. Summing up, the conclusion of the battalion commanders was overwhelmingly positive: the Africans were to be preferred even above Europeans, and it was therefore deemed desirable that African recruitment be maintained.

Yet, only three years later, African recruitment was reduced to 200 new recruits annually, and shortly afterwards, in December 1841, recruitment in West Africa was stopped altogether. ${ }^{16}$ Then the Minister of Colonies in The Hague even proposed schemes to rid the army of the Africans as far as possible and as soon as possible, by assigning them coolie duties or employing them as rowers and crew on navy or transport ships in the Indies. These proposals were never implemented but are indicative of the drastic change in perception in official Dutch minds. What had happened to cause this startling reversal of judgment?

\section{A series of mutinies $1838-1841$}

In June 1841,37 fully armed African soldiers of the $10^{\text {th }}$ infantry battalion walked out of the Dutch fortress of Van der Capellen on the west coast of Sumatra after repeated refusals to obey orders. A detachment of soldiers was sent in pursuit and met the deserters near Fort Kayoetanam on the way to Padang. Attempts to persuade the Africans to return to their duties were futile. They were obviously prepared to resist attempts to escort them back. When the pursuing party attempted to take them by force, a fight ensued, leaving two Africans dead and four badly wounded. The remainder were taken prisoner. ${ }^{17}$

A year before, in April 1840, African soldiers of the $4^{\text {th }}$ infantry battalion in the garrison town of Kedong Kebo (Purworejo) in central Java had staged an

\footnotetext{
${ }^{16}$ By Royal Decree of 17 December 1841, African recruitment at the Guinea Coast was abandoned altogether. The decree specifically cited the African mutiny of 1841 in the $10^{\text {th }}$ infantry battalion on the west coast of Sumatra as the reason for stopping African recruitment.

${ }^{17}$ Kol., Generaal Overzigt, Missive van den militairen kommandant ter Sumatra's Westkust dd 9 julij 1841, no. 1143/84.
} 
armed revolt after a row regarding their pay. This $4^{\text {th }}$ battalion was unusual in that it had three African companies, numbers 3, 4 and 5. Discontent had been brewing among them because of infringements on promises made to them in Elmina of equal treatment with Europeans. With regard to pay, clothing (underpants) and bedding, these promises had not been kept. With the formation of a third African company, the Africans apparently gained confidence and began to protest openly. It had been reported to the commander of this battalion that the Africans had gathered in the moonlight and had sworn an oath that on 16 April they would insist on receiving equal pay with the Europeans or otherwise would go on strike. On this day, the Africans of the $3^{\text {rd }}$ and $5^{\text {th }}$ companies disobeyed their officers, stormed into the kitchen and returned armed with wooden sticks. Shouting rebellious slogans, they returned to the barracks to get hold of guns. Meanwhile, the $4^{\text {th }}$ company had already armed itself. As the commander had had prior warning, the European troops had already occupied the barracks to prevent the Africans from taking the guns. The mutineers were dispersed and armed patrols were sent out in pursuit. They succeeded in apprehending 85 Africans, while three men managed to escape. The African NCOs and corporals did not take part in the rebellion but it was assumed that they were not totally innocent of this conspiracy. ${ }^{18}$

The commander of the $2^{\text {nd }}$ military department on Java, Colonel Le Bron de Vexala, had now had enough. He sent the battalion commander's report to army headquarters and recommended imposing an exemplary punishment as the only way to clip the mutinous instincts of the Africans. He asked government permission to shoot the instigators of the mutiny. If the instigators could not be identified, a certain number of the Africans who had participated in the uprising would be shot as an example to the others. Thus far, insubordination had been punished by disciplinary measures (i.e. caning), but Colonel Le Bron de Vexala believed that this had led the Africans to the wrong conclusion. They no longer behaved with the usual respect towards their officers and were getting out of control. $^{19}$

\footnotetext{
${ }^{18}$ Kol., Generaal Overzigt, Missive van den militairen kommandant te Kedong Kebo, 17 april 1840, (no number).

${ }^{19}$ Kol., Generaal Overzigt, Missive van den kommandant der 2e militaire afdeeling dd 18 april $1840, \mathrm{~L}$ D.
} 


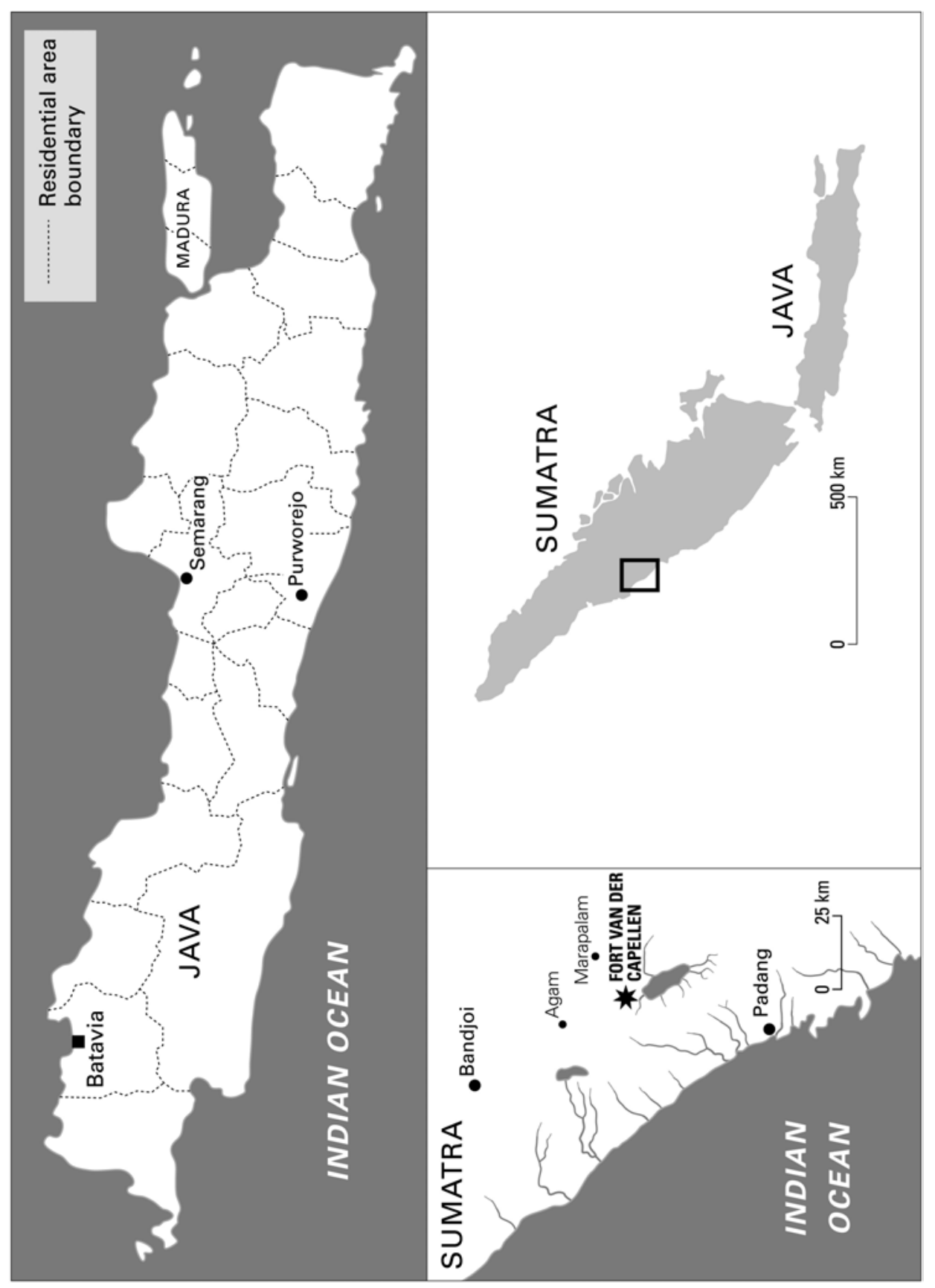

Map 6.1 Netherlands East Indies: Java and Sumatra 


\section{Court martial}

The commander-in-chief chose to ignore this hotheaded recommendation and asked the military prosecutor to start an investigation. ${ }^{20}$ The prosecutor agreed that vigorous action was necessary but pointed out that if the accused Africans were not familiar with the army's disciplinary code, the judge might decide that the Africans could not be held responsible. ${ }^{21}$ An investigation by army headquarters brought to light the fact that there was no uniform procedure to make Africans familiar with the disciplinary code that dealt with offences such as desertion, treason, insubordination and theft. In the $4^{\text {th }}$ battalion, the scene of the Kedong Kebo Mutiny, the articles of the code were read monthly in the Malay language, as the Africans were more familiar with Malay than with Dutch, as a result of their contacts with native women. Elsewhere, a translation of the disciplinary code in the Ashanti language was read to the troops every month, while the $1^{\text {st }}$ battalion on Sumatra's west coast used a translation 'in the African language'. No procedure existed to acquaint the Africans who had been assigned to artillery and cavalry battalions with the rules. The various translations were now circulated through the different battalions to find out whether the Africans understood the contents.

For the first time, insubordination by Africans was now referred to the military courts. The Supreme Military Tribunal in Semarang passed sentence in the Kedong Kebo case on 18 December 1840. The sentences read as follows: the five ringleaders were sentenced to 25 lashes (klingslagen) and two years in prison; six were sentenced to 25 strokes and one year in prison; four to 25 lashes and 6 months in prison; 18 mutineers received a sentence of one month in prison; 50 Africans were sentenced to 14 days in prison and one African was acquitted. $^{22}$

On 29 November 1841, the ringleaders of the 1841 mutiny on Sumatra were tried by the military court in Padang. The Supreme Military Court confirmed the sentences on 8 April 1842. Two suspects, Coffie Prins and Kudjo Serroe, were identified as the instigators and leaders of the mutiny. They were sentenced to death but the Governor-General exercised his prerogative to change the verdict to ten years in prison. After serving their prison sentences, Coffie Prins and Kudjo Serroe were discharged from the army and shipped back

${ }^{20}$ Kol., Generaal Overzigt, Missive van den kommandant van het leger dd 21 april 1840 , no. 12 spoed.

21 Kol., Generaal Overzigt, Missive van den Advocaat Fiscaal voor de Land- en Zeemagt dd 22 april 1840, no. 171 spoed.

${ }^{22}$ ARA, Stamboeken onderofficieren en minderen van het Nederlandsch Oostindisch Leger. Some of the military personnel registers for this period are missing. This list of verdicts, therefore, may not represent the complete picture. 
to Elmina. Three ringleaders were sentenced to 6 months detention and 25 strokes each, while six convicted mutineers got off only with 25 lashes. ${ }^{23}$ In army terms, these were remarkably lenient sentences.

Who were the mutineers? Coffie Prins, Kudjo Serroe and their associates were former slaves but they had been recruited in coastal settlements such as Elmina and Accra and were therefore probably quite accustomed to the world of Europeans and unlikely to have been overawed by their white commanders. If the ringleaders were indeed correctly identified, we can discern much the same pattern in the sentences passed both in the Sumatra case and the Kedong Kebo case. The ringleaders - those who were sentenced to prison sentences of six months or more - were all slaves from coastal towns. Their followers - those who got off with 25 strokes and perhaps a few weeks in prison - were a mixed bunch of former slaves from the coast and from the interior, including Ashanti. Only one of the mutineers was of free descent: Kobbena Esson from Elmina enlisted as a free man who needed the advance on his army pay to pay off his debts. With a sentence of two years and 25 lashes for his part in the Kedong Kebo Mutiny, he was obviously among the perceived ringleaders.

The mutiny in Kedong Kebo was the final straw for the commander-in-chief of the East Indies Army, General Cochius. He concluded that the experiment had failed. Experience had shown that the 'Negro race' was not as suitable for the army as had initially been thought. Moreover, he believed that the promise of equal treatment had been a serious psychological error and that the immediate and total emancipation of former slaves inevitably caused problems, even with those who had previously been exposed to the civilizing influences of European masters. Even more so would this apply to slaves who had recently been liberated from the most abject state of slavery where they had been treated as cattle waiting to be slaughtered at the whims of their Ashanti masters. This psychological misjudgement, he believed, was the cause of all the uprisings and mutinies. In any case, Cochius deemed equal treatment nearly impossible because of the 'uncleanliness and the peculiar stinking exhalations' of the Negro race, which made them most unfit to use the European type of bedding. In his opinion, the Africans had no need of mattresses in view of their previous life style. The army had not dared to take their shoes from them even though their performance as soldiers was hampered by this novelty to which they were not accustomed. The commander stated that their 'childish conceit' and 'stupid pride' should not be encouraged but suppressed.

Cochius concluded that experience had shown that the Negro soldiers would never be a substitute for Europeans in the army: 'Wherever the Negro soldiers served together in a company, they have banded together in mutiny, under the

${ }^{23}$ Ibid. 
pretext that infringements had been made on the promise of equal treatment with the European soldier.' In support of this conclusion, he cited Colonel Michiels, who had commanded the expeditionary force on Sumatra: 'They should not send us any more Negroes, as they are only fit to be used as beasts of burden, ruled by the whip. Even in combat they are not useful: they shout more than they have courage, are dirty and will never act in a disciplined manner.' Cochius proposed halting the recruitment of Africans, or at the very least reducing their numbers and sending out more Europeans. ${ }^{24}$

For army officers in the East Indies, it was difficult to understand why the Africans ought to be treated better than the tried and tested Amboinese soldiers. The privileged position of the Africans must have been puzzling to many Dutch, Amboinese and native soldiers alike. From the point of view of the Africans, the distinction between Amboinese and natives most likely made no sense. They had been promised equal treatment with the Europeans and vociferously objected to being treated as 'natives'. They were probably unimpressed when their commanders retorted that they were not being treated like natives at all but as Amboinese, and therefore as Christians.

From the memoirs and sketches by W.A. van Rees, a retired army captain who later became a prolific writer, it is obvious that even contemporaries did not universally endorse the racial hierarchy of the army as the natural order of things. In one of his volumes, he presented a sketch of the tragic dilemma of native Lieutenant Saridin, a fictitious character who figures in the non-fictitious story of the African mutiny in Kedong Kebo. ${ }^{25}$ As a reward for his bravery and model behaviour, Saridin had made it to the rank of sergeant. Yet, as he now had 'set foot on the road of civilization', he became disgruntled with the discriminatory treatment of the Javanese in the army. 'Javanese were undeniably stupid people, compared to Europeans, but they did not remain stupid. Old soldiers often performed better than quite a few Europeans.' Yet they received lower pay and lesser quality food. They could not even hope to reach the status of the Amboinese. Enter the African soldiers, whose company was lodged next to Saridin's Javanese company. What had caused these 'loud and throaty speaking people' to be categorized above the Javanese? They were after all at least ten times, even twenty times, darker in complexion than the Javanese! As a native sergeant, Saridin, who was always impeccably dressed, was ordered to take off his shoes. Standing on guard duty with the African

\footnotetext{
${ }^{24}$ Kol., Generaal Overzigt, Missive van de kommandant van het leger dd 8 augustus 1840, no. 1, geheim.

25 'Een Inlandsch Luitenant', in W.A. van Rees, Historisch-Indische Schetsen: Leesboek voor den Militair (Arnhem, 1873), 238-58.
} 


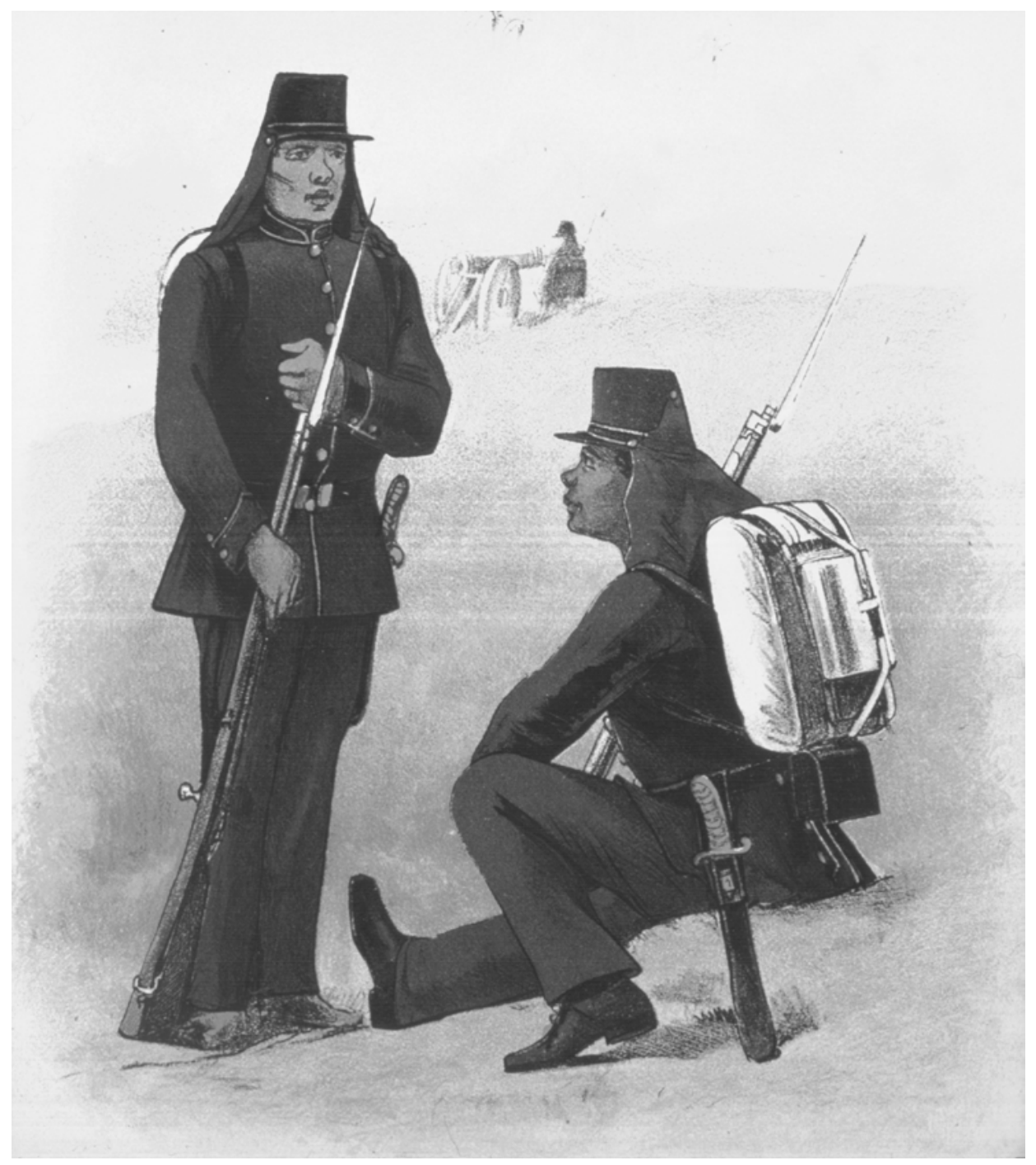

Native and African troops in the Netherlands East Indies army. The African soldier is wearing shoes, while the native is barefoot.

Source: P.F. Brunings, Onze Krijgsmacht. 's Gravenhage: Charles Ewing, n.d. Collection: Legermuseum, Delft 
Corporal Kidjekroe, Saridin noticed that he himself was standing barefoot while the African was wearing shoes on his big ungainly feet. Kidjekroe told his Javanese companion how, in Africa, he had been captured and carried off as a slave to be sold to the Dutch. Kidjekroe is pictured as the apex of barbarity. 'With eyes flashing with lust', he related to Saridin, how in his native land, they used to slaughter their enemies and drink their blood. Now why did this African rank higher in status than the Javanese? Only because the Africans were not born on Java? Unlike the Amboinese, the Africans were not even Christians at the time of their recruitment. The African had been a slave in his native land, used to walk about naked, had no notion of morality and was much darker than the Javanese. Yet the Dutch had placed him above the Javanese! Incomprehensible! The brave and loyal Sergeant Saridin then is instrumental in quelling the African mutiny in Kedong Kebo, for which feat he is rewarded with promotion to the rank of second lieutenant - with the right to wear shoes. However, as an officer he is even more acutely aware of his inferior status, which means that he receives only half the pay of a European lieutenant while he has similar expenses. Saridin's musings reflect, of course, Van Rees's own doubts about the fairness and logic of this racial and ethnic hierarchy. Many contemporary European officers probably shared these sentiments. Moreover, it is quite conceivable that similar grumblings were to be heard in the Javanese and Amboinese barracks too.

\section{Causes of the mutinies: Two views}

The causes of the African mutinies are discussed at some length in a later memorandum and counter-memorandum, written respectively by J. de Bruijn who had accompanied Verveer on his mission to Kumasi, and by an anonymous author on behalf of the East Indies army, probably Cochius. ${ }^{26}$ De Bruijn was subsequently put in charge of matters relating to the African recruitment operation at the Department of Colonies in The Hague.

De Bruijn identified one serious error as the cause of African discontent: the Africans had been treated as natives or Amboinese, not as Europeans. De Bruijn argued that in African religion (which he labels 'fetish superstition'), God created only two kinds of men: whites and blacks. God gave brains to the white

${ }^{26}$ Kol., Generaal Overzigt, bijlage La G, Pro memorie aan den heer secretaris generaal bij het ministerie van koloniën op den brief van den Gouverneur Generaal van Nederlandsch Indië dd 18 november 1838, 558/19, het berigt inhoudende van eene plaats gehad hebbende muiterij bij de Afrikaansche Kompagnie van het $1^{\mathrm{e}}$ Bataljon Infanterie ter Westkust van Sumatra. 
man and gold to the black man, thus creating a balance between them. All people who are of mixed race thus deserved to be held in deep contempt by both whites and blacks. Naturally therefore, the Africans looked down on the Asians, who were neither white nor black. Africans had no reason to differentiate between Amboinese and other natives. According to De Bruijn, they looked down in contempt on all the peoples in the Indies and therefore found it unbearable to be treated like natives. Sleeping mats might have been suitable for the natives but the very fact that the Europeans had a different kind of bedding was sufficient reason for the Africans to reject the mats with indignation.

Verveer equally believed that Africans detested anybody who is not Negroblack or European-white. ${ }^{27}$ De Bruijn recalled that the issue of equal treatment was central to the African recruitment exercise. He had repeatedly witnessed how Verveer had assured hesitant recruits that they would be treated as "white soldiers', acting in strict compliance with his instructions. Verveer also dwelled on the significance of religion. Africans from the Ashanti region presumably held a 'fetish' religion, which Verveer considered a point in their favour. If the African soldiers had been Moslems, they would possibly have been tempted to fraternize with the Javanese and Sumatran Moslems. But if their religion was 'fetish', they could easily be persuaded to adopt 'the external appearances' of the Christian religion that would ensure they kept their distance from the Javanese and 'other Eastern tribes'. ${ }^{28}$ The Roman Catholic faith was deemed the most appropriate for this purpose.

De Bruijn believed that Africans had a natural sense of justice. The African was inclined to respect whites as long as they did not offend his sense of justice. The issue was not, according to De Bruijn, whether native sleeping mats were adequate for the Africans. The issue was that infringements on the promise of equal treatment were felt as deeply humiliating. 'Men who have so many talents to be proud, mighty and courageous soldiers risk becoming troublesome mutineers, not to be reined in by even the most severe application of military law, if the initial promises are not loyally implemented.' Employment of African troops would only be profitable, stated De Bruijn, when they were treated as Europeans in every respect. Would it not be a wise policy to organize the Africans in a separate African corps, to protect them from the harmful influences of European soldiers, many of whom had been assigned to the East Indies by way of punishment for their misconduct in the Dutch army in the Netherlands?

\footnotetext{
${ }^{27}$ Kol., Generaal Overzigt, Gouvernements renvooi dd 3 julij 1837, no. 1 kabinet.

${ }^{28}$ Kol., Generaal Overzigt, bijlage La G. Verveer's message dd 11 November 1836 no. 1 to the Governor General of the Netherlands East Indies is quoted in this Memorandum.
} 
According to the anonymous author (maybe Cochius) of the countermemorandum, the mutinous behaviour of the African company had nothing to do with the Africans' sense of justice but with their presumptuous conduct now that they found themselves liberated from slavery and arbitrary masters. Coming from a position of extreme hardship where slaves were living in constant fear of becoming victims of a gruesome sacrificial death, the Africans in the Indies now found themselves in positions of relative wealth, thus becoming 'intoxicated and presumptuous'. The anonymous author believed that De Bruijn's explanation of the causes of the rebellions was mistaken: the Africans were not being treated as natives but as Amboinese. And the Africans had no reason at all to look down with contempt on the Amboinese, who had so often demonstrated that they made good and loyal soldiers. On the contrary, it would be most unfair to allow better treatment for Africans than for the Amboinese.

The author of this counter-memorandum conceded that benign treatment of the Africans in the army was necessary, but with sufficient firmness. Immediate punishment had to be applied after misdemeanours until their rough characters became more civilized. He concluded that Africans could only be submitted to the European procedures of the army's disciplinary code once it has become possible to appeal to reason. With the massive influx of African recruits from 1837 onwards, the government decided to suspend the application of military law for Africans in the army. Offenders were to be punished by disciplinary methods (usually by the withholding of pay or by caning) and the corps commanders were expected to send a detailed report of any incident to army headquarters in Batavia. Only very serious cases, involving murder or injuries, would be referred to the military court and then only after authorization by the military prosecutor. ${ }^{29}$

The reason for the mutinies seems clear: the Africans protested against infringements on the promise of equal treatment with Europeans. The Africans said as much and the European officers apparently understood these grievances perfectly. Time and again, this explanation was given in the army records dealing with this and other African mutinies. Nevertheless, a dense fog of mystification developed with regard to their motives. Why was the issue of equal treatment of such paramount importance to the Africans? And why was this so difficult to understand for the Europeans?

In the reasoning of Dutch army officers, most recruits were of Donko origin and therefore used to a life of hard labour and arbitrary masters. They were men who, according to Verveer's reports, walked for a whole day with a heavy load

${ }^{29}$ Kol., Generaal Overzigt, Kabinetsmissive van den Gouverneur-Generaal dd 18 april 1838, no. 55 . 
and, sustained only by a few bananas and a handful of maize, slept nearly naked on the soil before continuing on their way at sunrise the next morning with their head-loads. They were not used to eating meat and had never tasted a drop of alcohol. Moreover, at any time they could be selected as sacrifices to accompany their deceased masters to the other world. Living in these conditions, entering Dutch military service must have been seen as the greatest luck that could befall them. ${ }^{30}$ Why would they now make such a fuss about the issue of equal treatment?

The key to unravelling the psychological mindset of Africans and Europeans might be found in the privileged position of the Amboinese soldiers. To a European officer in the East Indies army, 'being treated as Amboinese' indicated a privileged status, usually enjoyed by Christians only. The Africans should have been grateful that they enjoyed equal status with the Amboinese. To the African soldiers, the Amboinese most likely were just another kind of native. And they were most determined not to be treated as natives. Had the Europeans slept on sleeping mats, they would undoubtedly not have objected to this bedding arrangement. But with their newly acquired corporate identity as 'African soldiers with European status', they resented being put on the same footing as 'natives'.

\section{Gradual erosion of status}

The Africans had good reason to jealously watch their status. While the promise of equal treatment was observed with the first detachment of 44 soldiers, later, when the operation assumed a larger scale, numerous infringements occurred. This began on board the troop ships. Unlike Europeans, African recruits were not paid for the duration of the voyage with the rationale being that this was in their best interests. Otherwise they would squander their three months' salary accumulated during the trip soon after arrival, in the gambling houses of unscrupulous Chinese, and on drink and women. In other words, they would behave exactly like European soldiers disembarking in Batavia. On the ships they might not have noticed being disadvantaged but when their European comrades went off partying after disembarking, they surely must have sensed that something was not in order.

During the voyage they were issued with their military outfits, minus a few items that were part of the standard European outfit such as sewing equipment, brushes, a knapsack and water bottles. On board, their daily ration of jenever (Dutch gin) was half that received by the Europeans but this measure might

\footnotetext{
${ }^{30}$ Kol., gouvernementsrenvooi, dd 3 julij 1837, no. 1 kabinet.
} 
indeed have been inspired by health concerns as some of the Africans, notably those from the interior who had never tasted alcohol before, reacted badly to this regular Dutch army 'medicine'. In July 1838, the military department ordered that socks and underpants no longer be issued to African soldiers because, after all, Amboinese were not entitled to these articles either.

Much thought and paper was devoted to the issue of delegatien (delegated payments). At the time of recruitment, most, but not all, Africans had made arrangements that a part of their army pay would be transferred to relatives or in most cases to creditors. In the early stage of recruitment, most recruits were debtors or pawns. Army service was a way to pay off these debts. In view of the slow communication lines between the Indies, the Netherlands and the Guinea Coast, this was an administrative nightmare. Payments on the Gold Coast could continue for a year after the death of a soldier because it could easily take a year before the death notice reached Elmina. Soldiers in hospital did not receive any pay but nevertheless payments to relatives or creditors in Africa continued, usually at a rate of Dfl 2.50 a month. State treasury loss was the subject of much correspondence. In 1837, it was decided that 8.5 cents per day would be subtracted from the pay of every African in the army: they would thus earn Dfl 2.55 a month less than Europeans. This way the government tried to limit the damage it sustained through the system of delegations although an exception was made for those 10 Africans already in the Indies and who had not delegated any money to family or creditors in Africa. ${ }^{31}$

This meant that henceforth Africans were paid less than Europeans, not just on the basis of delegated payments to relatives or debtors, but by virtue of being African. This discriminatory measure was introduced to ease the bureaucratic nightmare of dealing with individual arrangements. It also meant that the 8.5 cents were subtracted every day throughout the soldiers' army careers, even when their debts in Africa had long been paid off. With the mission of MajorGeneral Verveer to Kumasi, the system of delegated payments was abandoned as it was too open to abuse. Governor Lans had himself pocketed the delegatiën from the slaves whom he had sent out as army volunteers. However, a new system was introduced whereby the recruit had to repay the money paid for his manumission. It became a bureaucratic headache for the East Indies army and a new cause of dissatisfaction on the part of the Africans. The chief of staff in the East Indies suggested simply continuing to deduct 8.5 cents a day but now for the purpose of repaying the money paid for manumission. But he realized that this system was unfair to those Africans who had enlisted as free men and who

${ }^{31}$ Kol., Generaal Overzigt, Missive van den kommandant der troepen dd 28 october 1836, no. 6 aan de Gouverneur Generaal; Besluit van de GG dd 19 november 1836, no. 8. 
were therefore entitled to a full European salary. The chief of staff suggested that the most honourable solution would be if the Dutch state paid for manumission, leaving the Africans fully entitled to their European salaries.

Part of the cost could then be reclaimed by not paying salaries for the duration of the three-month sea voyage. In this way, the confusion surrounding money transfers would be avoided. The Governor-General decided that indeed no pay would be given for the duration of the voyage, while the issue of full pay or reduced pay was left to the government in the Netherlands. ${ }^{32}$ The final outcome of this drawn-out procedure was that 8.5 cents per day would be deducted throughout an African's military career, even though the amount due to cover the costs of manumission (about Dfl 100) would have been paid off in about three years. The new rationale for the deductions was simply that the army's budget could not sustain equal pay for Africans, and that recruitment in Africa had caused much unexpected expense anyway. Equal pay would have meant extra costs of about Dfl 41,685 annually, based on the 1,500 Africans still in active service in 1842 .

As a consequence of the deduction of 8.5 cents per day, a new ruling had to be issued with regard to the premium to be paid for every deserter brought back to the army. The captors of a European deserter would receive an amount of Dfl 12, while the bounty for an Amboinese amounted to only Dfl 6. The rule was that this bounty money would be withheld from the deserter's salary over the following three months. It was therefore decided to put the African deserter on an equal footing with the Amboinese, as his pay would not sustain a restitution of Dfl $12 .^{33}$

An important difference between Africans and Europeans in the army was the duration of their term of service. The first batch of Africans signed contracts for six years, just like the Europeans. But the Africans recruited under the terms of Verveer's treaty were enlisted for an unspecified period of time. In 1844, after the mutinies, their terms of service were reduced to 15 years. When Africans signed up for another term of service after the expiry of their initial contract, their re-enlistment premium was lower than that of Europeans. And then, while grievances were already accumulating, the Africans were told that they were no longer entitled to their 'European' straw mattresses. This was obviously interpreted as another step in the gradual erosion of their status as European soldiers.

\footnotetext{
${ }^{32}$ Kol., Generaal Overzigt, Besluit van den Gouverneur Generaal 8 augustus 1837, no. 18 .

${ }^{33}$ Kol., Generaal Overzigt, Missive van den kommandant van het leger dd 26 september 1839 , no. 4.
} 
Another bone of contention was the career of Pieter Hermans, the only African who rose to the rank of officer in the course of the nineteenth century. His unusual career did not fit the colonial pattern and, therefore, became a source of conflict and considerable correspondence. The African sergeant had been appointed second lieutenant with the $1^{\text {st }}$ infantry battalion, and received half the amount of pay to which a European second infantry lieutenant was entitled. $^{34}$ That meant that he was treated as an Amboinese lieutenant. Not surprisingly, he complained. As a sergeant, he had received a regular European salary. Pieter Hermans, born in Axim in 1812, was literate and put his complaints in writing. ${ }^{35} \mathrm{He}$ was probably of mixed Afro-European descent because his father's name was given as Jan Hermans while his mother is mentioned only as Johanna. He belonged to the very first detachment of recruits that had arrived on the ship Rotterdams Welvaren in Batavia on 15 March 1832. His career was quite successful. By April 1834 he had been promoted to sergeant, followed by this promotion to second lieutenant in 1837. Yet all was not well. Hermans complained about being paid as a 'native lieutenant' and he also added a number of grievances voiced by his mates who had travelled with him in 1832. The Africans complained about ill treatment and a lack of proper bedding and said that they received neither rice nor meat. The issue of maltreatment was investigated and was found to be 'highly exaggerated', while redress was given for unspecified 'real grievances'. ${ }^{36}$

Colonel Michiels, commander on the west coast of Sumatra, explained to Hermans that he was not being treated as a native but as an Amboinese, and therefore as a Christian. Hermans, baptized in 1835, remained deaf to this argument and insisted that the colonel put his grievances to the commander-inchief of the army in the Indies. ${ }^{37}$ His superiors warned the African lieutenant that his behaviour would block opportunities for advancement for his fellow Africans. Hermans's military career came to an end due to his insistent demands for equal treatment. In 1842, the commander-in-chief proposed dismissing him since his 'misconduct and lack of zeal' was deemed harmful to the army. He was to be sent back to Africa via the Netherlands with an annual pension of Dfl 184.

\footnotetext{
${ }^{34}$ Kol., Generaal Overzigt, Besluit van den Gouverneur Generaal dd 1 december 1837, no. 7.

${ }^{35}$ Unfortunately his writings have not been preserved in the Dutch archives.

${ }^{36}$ Kol., Generaal Overzigt, Missive van het Militair Department dd 9 junij 1838, no. 7.

${ }^{37}$ Kol., Generaal Overzigt, Missive van het Militair Departement dd 10 october 1838, no. 1.
} 


\section{Accommodation and identification}

After the Sumatra mutiny, the situation calmed down. Throughout the 1840 s, a few reports trickled in about new disturbances and fighting but army correspondence no longer reflected a sense of urgency. Obviously the army and the Africans had settled into a routine that both sides could live with. The disturbances apparently did not exceed normal patterns, and once or twice the commander-in-chief even concluded that the Africans had understandable grievances that needed redress. Some were indeed duly addressed but the position of the African soldiers remained ambiguous. They counted as part of the European formations and were treated as Europeans in many, but not all, respects. Sometimes they equalled Europeans, sometimes they were treated like the Amboinese, and in some respects - re-enlistment premiums and pensions in particular - specific regulations were introduced for Africans as a separate category. ${ }^{38}$ The deduction of 8.5 cents for the 'restitution of the advance payment for manumission' continued and was initially even extended to the second generation of Indo-African soldiers, men who were born free in the East Indies! In 1891(!), the Indisch Militair Tijdschrift carried an anonymous plea for the abolition of this unfair deduction. ${ }^{39}$

The story of the Africans in the East Indies received a new and unexpected turn with the Third Expedition to Bali in 1849, a successful expedition following two previous failures, which was celebrated with much pomp and circumstance in the main square in Batavia. The untiring efforts of the Africans, their courage, loyalty, state of health, strength and endurance had greatly impressed the newly arrived commander-in-chief, Duke Bernhard van SaxenWeimar Eisenach. In his view, this experience proved that Africans were very suitable as troops. The Africans compared favourably with the European part of the army below the rank of officer, which mostly consisted of 'soldiers with a criminal record, deserters from the Dutch national army, drunkards, deserters from the Belgian and French armies and Germans, most of whom are rascals and tramps, and for whom the service in this colony is a last refuge'. According to the new commander, the Africans could hardly be blamed for all the

\footnotetext{
${ }^{38}$ Verzameling der Algemeene Orders en van Eenige der Meest Belangrijke Besluiten en Instructiën Uitgevaardigd aan de Koninklijke Nederlandsche Landmagt Dienstdiende in Oost-Indië. Derde Deel, bevattende de jaren 1850 tot en met 1855 (Breda, Broese, 1858); D.R.F. van Haeften, Pligten en Regten van den Indischen Militair in het bijzonder van den Infanterist. Handleiding voor den Soldaat, tot de Kennis zijner Dienstpligten. Gids voor Officieren en Onderofficieren, bij het Houden van Theoriën (Batavia, 1882).

39 'Een voorstel in het belang der Indo-Afrikanen', Indisch Militair Tijdschrift II, (1891) 481-83.
} 
problems that had been detailed in earlier military correspondence. They simply had been unable to understand that promises of equal treatment, which had been made in the name of the King, were not kept. And since they had been unable to express their grievances in Dutch or Malay, discontent had escalated to violent protest. For their part, the African soldiers readily conformed to their role as loyal European troops. At the parade in Batavia after the 1849 victorious campaign on Bali, one of the African sergeants proposed a toast:

$\begin{array}{ll}\text { Gezigt Zwart } & \text { Face Black } \\ \text { Hart Wit } & \text { Heart White } \\ \text { Leve de Koning } & \text { Long Live the King }\end{array}$

This anecdotal evidence is cited in several publications as proof that the Africans identified with their prescribed role. ${ }^{40}$ More convincingly perhaps, the local population did indeed perceive the African soldiers as Europeans: in Malay they were known as Belanda Hitam (Black Dutchmen) and in Javanese as Londo Ireng (Black White Men).

The new commander-in-chief, supported by the new governor in Batavia, urged a resumption of African recruitment. ${ }^{41}$ The enthusiasm of the Duke is perhaps not so surprising. Twenty years earlier, he had been one of the main advocates of the recruitment of Negroes (either from America or from Africa) to solve the manpower problem of the army in the East Indies. The government in The Hague initially decided against a reopening of African recruitment but a decade later, in 1860, recruitment in Elmina was resumed albeit on a much smaller scale than in the $1830 \mathrm{~s}$. Measures were introduced to ensure that all recruits enlisted voluntarily, even if their pay and enlistment premiums were still used to pay off debts or to buy manumission from slavery. Between 1860 and 1872, some 800 African recruits sailed from Elmina to the East Indies, where most of them served in the Atjeh (Aceh) war. The epic of African recruitment for the Netherlands East Indies army came to an end with the transfer of the Dutch Possessions on the Guinea Coast to Great Britain in 1872.

\section{A colonial paradox}

The Dutch position on the issue of equal treatment was ambivalent. On the one hand, emulating European standards was deemed necessary to heighten the sense of self-esteem on the part of the African soldiers. Therefore, the wearing

\footnotetext{
${ }^{40}$.See for example, Tijdschrift voor Nederlands Indië, 16, I (1854), 367-78.

${ }^{41}$ Kol., Generaal Overzigt, Missive van Zijne Hoogheid den kommandant van het leger dd 21 augustus 1849, no. 4, zeer geheim.
} 
of shoes, for example, was indispensable. Army policy aimed at maintaining a social distance between the Africans and the indigenous population, notably the Javanese.

Thus, Dutch army officers deemed it opportune to inculcate in the Africans a sense of superiority vis-à-vis the indigenous population of the East Indies. It was probably assumed that the Africans would look down on the Asians anyway, and this fitted the purpose of preventing too much fraternizing between the colonial army and the local population. From army records, it would seem that the Africans willingly adopted their prescribed role as 'European soldiers'. But when they displayed a behaviour befitting this role - looking down on the natives for example - they were at the same time out of tune with prevailing notions about the proper racial hierarchy in the East Indies. In the view of some of their commanding officers, the Africans behaved unbearably arrogantly and were thought conceited and insolent. They expected the Africans to be grateful for their upliftment from an abject state of slavery to an almost-European status as soldier. Looking down on the natives was apparently only acceptable if the Africans would look up to the Europeans. But that did not make sense as the Africans had been told that they were indeed to be regarded as Europeans in the army's racial hierarchy.

The African soldiers in the East Indies were caught in a colonial paradox. As soldiers in a colonial army, they were encouraged to look down on the natives, to foster a corporate identity as soldiers who were above the colonized civilian population, and to maintain a status of Europeans. From the point of view of the army command, their loyalty would be ensured by their privileged position vis$\grave{a}$-vis the natives. For this purpose, it was acceptable that the Africans be given European status. But the same army command found it difficult to cope with Africans who took their European status at face value and insisted that their treatment be accorded in every detail with that of Europeans. The African soldiers fully identified with their role as European soldiers. Their story is largely one of adaptation, accommodation and even identification with the Dutch colonial administration. The mutinies mentioned in this chapter were caused by encroachments on their status as Europeans. Once they felt that their rightful place in colonial society was being respected, they established a reputation of bravery and loyalty. In the course of the nineteenth century the African soldiers played their part in the process of Dutch colonial expansion in the Indonesian archipelago, notably in the decades-long Atjeh (Aceh) war. Their Indo-African grandsons and great-grandsons fought against Japan in the Second World War, suffered in prisoner-of-war camps and ultimately fought the Indonesian nationalists until the final transfer of sovereignty in 1949. For the majority of these Indo-African descendants, Sukarno was not the hero of the liberation struggle but the evil genius who was going to evict them from 
paradise. After Indonesian independence, most Indo-Africans opted for repatriation to the Netherlands.

Later judgments on the performance of the Africans in the East Indies Army were largely positive. As summed up in the Encyclopaedia of the Netherlands East Indies (1917): 'These Africans were a highly valued element in the army: although their training was difficult and they were intemperate and ill disciplined in combat, they were also strong and courageous'. The mutinies around 1840 were now explained by 'injudicious acts' on the part of the army commanders. ${ }^{42}$

${ }^{42}$ Encyclopeadie van Nederlandsch Oost Indië I, ('s Gravenhage, 1917), 13-14. 


\title{
7
}

\section{Absence of evidence is no proof: Slave resistance under German colonial rule in East Africa}

\author{
Jan-Georg Deutsch
}

The chapter examines the lack of evidence regarding slave resistance in German East Africa and the related question of whether the colonial stereotype of the 'docile slave' is true. It starts with a brief surmise of the history of slavery and an analysis of slave actions in the period concerned (1890-1914). The labour history of population movements in Unyamwezi in central Tanzania is taken as a case study. The chapter concludes that the colonial stereotype of the submissive slave is highly misleading. The social heterogeneity of servility prevented slaves from taking concerted militant action. However, it should be acknowledged that this diversity was the result of protracted everyday struggles by individual slaves for a better life in their places of residence.

\section{Introduction}

This chapter examines the issue of slave resistance in East Africa in the early colonial period. There is tentative evidence of concerted slave action in precolonial times ${ }^{1}$ but so far historians of the early colonial period have not come up with any archival documentation concerning slave militancy, let alone fullscale slave revolt. Oral historical sources seem to be absent on this topic as

\footnotetext{
${ }^{1}$ J. Glassman, Feasts and Riot. Revelry, Rebellion, and Popular Consciousness on the Swahili Coast, 1856-1888 (London, 1995), 109, 111-13.
} 
Absence of evidence is no proof 171

well. ${ }^{2}$ There may have been 'Feasts and Riots' in early colonial East Africa ${ }^{3}$ but these were neither exclusively nor predominantly slave riots, although slaves very likely took part in them. Could it be that the colonial stereotype of the 'docile slave' was fairly accurate? This is the central question addressed in this chapter.

The chapter is divided into four sections: the first briefly recounts the history of slavery in German East Africa, the second part examines the evidence regarding slave militancy and the colonial impact, the third section discusses the role of slave resistance in the development of the colonial economy by taking Unyamwezi as a case study and the chapter ends with a brief conclusion.

\section{Slavery under German colonial rule}

Slavery in the region was legally abolished in Tanganyika by the British in 1922. Until then slaves could be freely bought and sold, inherited, taken as concubines or put up as sureties for credit. In contrast to the policy pursued by other colonial powers in Africa, the German colonial authorities officially recognized the legal status of slaves. ${ }^{4}$

Slavery was not, however, a colonial or a German invention. In the late nineteenth century, slavery was the most widespread form of labour recruitment, generating the surplus on which many pre-colonial empires and their rulers and traders thrived, albeit at terrible cost to human life. ${ }^{5}$ This was the outcome of a development which had started much earlier in the century when, owing to the expansion of commerce and agricultural production, local slave populations began to increase rapidly. In Unyamwezi, this process was related to a growth in the caravan trade that provided the wealth to import large numbers of slaves into the area, as well as the need to do so. The coast

2 Cf. for example, M. Wright, Strategies of Slaves \& Women. Life-Stories from East/Central Africa (London \& New York, 1993).

${ }^{3}$ Glassman, Feasts and Riots, 146-74.

${ }^{4}$ See J.G. Deutsch, 'Slavery under German Colonial Rule in East Africa, c. 1860-1914', Habilitationsschrift, Humboldt University (Berlin 2001), 110-84. Also S. Miers \& M.A. Klein, 'Introduction', in S. Miers \& M.A. Klein (eds), Slavery and Colonial Rule in Africa (London, 1999), 1-15.

${ }^{5}$ For more details on the nineteenth-century slave trade, see E.A. Alpers, The East African Slave Trade (Nairobi, 1967) and A.H.M. Sheriff, Slaves, Spices \& Ivory in Zanzibar. Integration of an East African Commercial Empire into the World Economy, 1770-1873 (London, 1987). For an overview, see A. Wirz, Sklaverei und Kapitalistisches Weltsystem (Frankfurt am Main, 1984). 


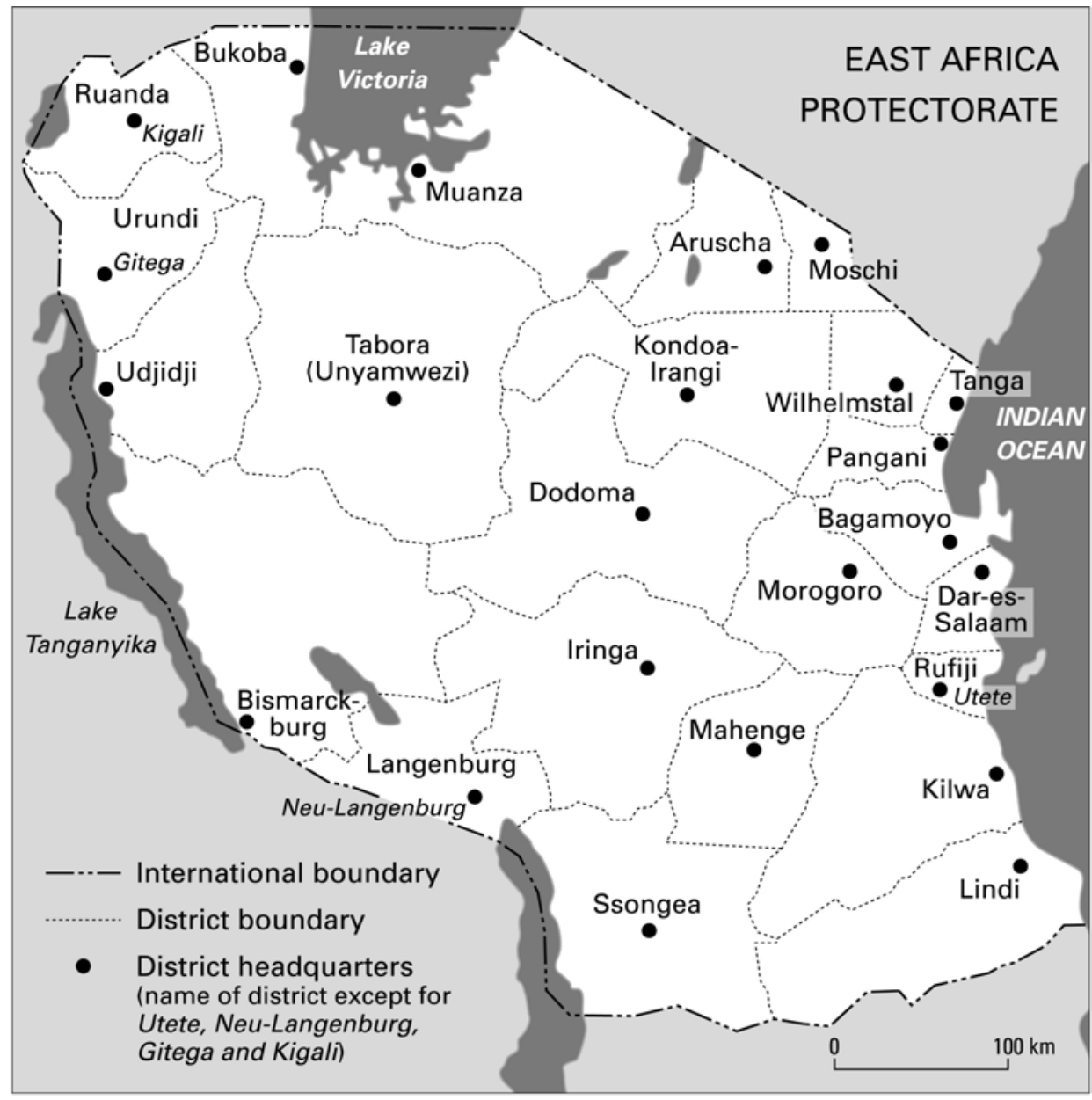

Map 7.1 Slave populations resident in German East Africa, c. 1900 
experienced a similar increase in local slave populations, mainly due to the development of clove plantations on the islands of Zanzibar and Pemba, which necessitated the import of foodstuffs from the mainland that were produced by small-scale farmers and a growing number of plantation slaves, particularly in areas located along northern parts of the coast.

At the turn of the century, the colonial authorities believed that the number of slaves resident in Tanganyika exceeded 400,000 or roughly 10 to 15 per cent of the entire population. ${ }^{6}$ In some areas, such as in coastal towns, they constituted up to 70 per cent of the urban population. ${ }^{7}$ Slaves could be found almost everywhere in Tanganyika but the majority lived in Unyamwezi in central Tanganyika (over 200,000) and in areas adjacent to the coast in eastern Tanzania (over 100,000). The geographical extent of these regions was imprecise at the time but there can be little doubt that slavery permeated all aspects of the societies resident there.

These figures have their own problems. Apart from practical statistical considerations, their reliability hinges on the definition of what the colonial administration actually meant by the term 'slave'. The German colonial authorities employed a judicial classificatory system. According to the relevant decrees, a slave was a person owned by another person. This definition formed the basis for all sorts of colonial regulations, for example compensation payments, or the 'freeing' of slaves by official certification and the enforcement of involuntary labour contracts.

Several studies have shown that - as far as East Africa was concerned ownership represented only one aspect of the relationship between slaves and their owners. ${ }^{8}$ Colonial classificatory systems are particularly unsatisfactory when it comes to understanding African social realities in the early colonial period. This has some bearing on the question of whether there was concerted slave action at that time. It could be argued that the general paucity of detailed historical data for this period coupled with a heavily skewed colonial classificatory system explains why there is no evidence of slave militancy in the colonial archives. There was determined slave action but it was not recognized as such by the colonial administration and nothing is known about it. Absence of evidence, as the argument goes, is no proof.

\footnotetext{
${ }^{6}$ Bundesarchiv, Abteilungen Berlin, Reichskolonialamt (BAB RKolA) 7382/27: 42-93, 'Berichte der einzelnen Verwaltungsstellen in Deutsch-Ostafrika über die Sklaverei', n.d. (c. 1900).

7 A. Leue, 'Bagamoyo', Beiträge zur Kolonialpolitik und Kolonialwirtschaft, 1900/1901, 11-31.

${ }^{8}$ See F.L. Cooper, 'The Problem of Slavery in African Studies', Journal of African History, 20, 1 (1979) 103-25.
} 


\section{Struggles without a class}

There is more to this peculiar absence of evidence. As already indicated, the colonial definition of a slave is reductionist in the extreme. Slaves were peasants, sharecroppers, pawns, squatters, traders, artisans, day labourers, caravan porters, trusted advisers, religious leaders and destitute beggars. In fact, in late nineteenth-century East Africa, slaves could be found in almost any profession, strata or social position. ${ }^{9}$

Some slaves on the coast called themselves Waungwana (free born) to obscure their humble origins, others called themselves Waswahili in order to underline their aspirations of participating in coastal society on an equal footing. Slaves were mothers and fathers who succeeded in marrying off their children, thereby gaining access to intricate networks of kinship relationships by which they were socially defined - families whose freeborn members had little reason to advertise the lowly status of their new in-laws. It was not uncommon for female slaves to become wives of freeborn husbands and their children were regarded as free, i.e. as having the same rights and obligations as other children in the household. Some male slaves became the husbands of freeborn women, often widows whose first husbands had died, or divorcees who had been abandoned by their previous husband's family.

On the coast, slaves were owned by the rich but also by the poor, the pious and the bigots, and sometimes even by other slaves. Most lived in the countryside but the largest numbers of slaves relative to the freeborn population were found in the coastal towns and chiefly residences in the interior. Slaves took part in various aspects of social life, gaining entry for instance to religious groups, frequently Muslim brotherhoods, whose leaders preached the equality of all believers before God.

The social position of slaves differed as much between societies as they varied within them. Beyond their precarious marginal social position, female and male slaves residing in Unyamwezi in central Tanzania, for example, and those living on the coast had little in common. They were divided by religion, kinship ideas, language and culture, work and pastimes. Professional life, family relationships and religious affiliations were contested social terrains honour as much as personal autonomy had to be earned and was not infrequently denied - but the defining feature of slavery in East Africa was the heterogeneity of the slaves' social, political and economic position.

\footnotetext{
${ }^{9}$ This and the following paragraphs are based on Deutsch, 'Slavery', 15-56; Glassman, Feasts and Riots, 79-111 and F.L. Cooper, Plantation Slavery on the East Coast of Africa (New Haven, 1977), 23-149.
} 
In short, while slaves were persons owned by other persons, they were not just that. Except perhaps for a few small areas dominated by commercial plantation agriculture, slaves (as well as their owners) did not constitute a class in any meaningful historical sense because they had so little in common which is - after all - the basis for concerted social or political action. Slaves, like those who believed themselves to be free, had multiple social identities and their slave status was not the dominant feature of everyday interaction. Rather than constituting a class, slaves perceived themselves as semi-autonomous clients, wives, tenants or distant kin - social positions that they anxiously sought to defend. ${ }^{10}$ Thus the absence of evidence regarding slave revolts or slave resistance in colonial archives arguably reflects the social heterogeneity of servility in East Africa. If slave resistance was a class struggle, then it was one without a class.

\section{Slave resistance}

The social heterogeneity that defined slavery in East Africa was not a given historical phenomenon. It evolved from the long struggle by slaves to better their lives in the societies into which they had been born or brought. From the moment of purchase or capture, slaves strove constantly to improve their social and living conditions and to reduce their marginal position in society. ${ }^{11}$ They tried as far as possible to evade the demands of their owners for their time, efforts and reverence. The most famous example of slave militancy in the nineteenth century comes from a coastal village called Makorora near the town of Pangani. ${ }^{12}$ Owing to the harsh treatment they had received from their owners, a group of plantation slaves - men, women, and children - fled the sugar estates in the Pangani Valley in 1873 and established a watoro (runaway) community. According to oral history sources, their owners made several attempts to recapture the slaves but their forces, numbering several thousand mercenaries, were unable to overcome the heavy fortifications of Makorora, which was stalwartly defended by its slave inhabitants. In the end, the slave owners were forced to give up their plans and Makorora was left alone. However, such

\footnotetext{
${ }^{10}$ See Glassman, Feasts and Riots, 106-14 and also his earlier article 'The Bondsman's New Clothes. The Contradictory Consciousness of Slave Resistance on the Swahili Coast', Journal of African History, 32, 2 (1991) 277-312.

${ }^{11}$ See I. Kopytoff \& S. Miers, "Introduction. African "Slavery" as an Institution of Marginality', in S. Miers \& I. Kopytoff (eds), Slavery in Africa. Historical and Anthropological Perspectives (Madison, 1977), 3-81.

${ }^{12}$ Glassman, Feasts and Riots, $109 \mathrm{f}$.
} 
examples are rare. Far more often, slaves endeavoured to improve their lowly position within the confines of their social situation. The historian Marcia Wright collected several female slave biographies that underline precisely this point. ${ }^{13}$ The life stories of Narvimba, Msatulwa Mwachitete and ChisiNdjurisiye-Sichyajunga showed how slave women employed several strategies to improve their lot: by attaching themselves to powerful patrons, by finding suitable new 'husbands' or by repeated flight. ${ }^{14}$ Even if they could not leave, they tried to withhold as much of their labour and honour as possible from their owners. The 'insolent, lazy slave' about whom African slave owners later so frequently complained to the German colonial administration was thus not merely a figment of the imagination ${ }^{15}$ but more often than not an accurate, if somewhat biased, description of a social practice with a long history. ${ }^{16}$

The struggle between owners and slaves was highly uneven and there were in fact many struggles within the bigger struggle. First of all, not all slaves took an active part in it. There were slaves who for whatever reason - such as loyalty to their owners - did not want to change their lives or lowly social position. Slavery in East Africa was characterized, as elsewhere, not only by resistance and contestation but also by accommodation and acquiescence. Secondly, and more fundamentally, slave owners and slaves competed for wealth, honour and power in the historical setting of a particular locality. The outcome of these conflicts depended on the material and ideological resources available to the individual or collective contestants at a given moment in time in that particular locality and these, as argued above, varied greatly between and within societies according to the age, gender and descent of the slave, his or her skills and upbringing, the profession of the owner, and the local political set-up. Thus, while slaves struggled in a piecemeal fashion for a better life, their individual successes and the ensuing heterogenization of slavery precluded concerted militant action against slave owners.

As has been observed in many African societies, slaves and especially those brought to their owner's localities by force to occupy the very margins of society forged social ties over time and acquired protective rights of various

\footnotetext{
${ }^{13}$ Wright, Strategies, 21-121.

${ }^{14}$ Ibid. 163-65. See also E.A. Alpers, 'The Story of Swema. Female Vulnerability in Nineteenth Century East Africa', in C.C. Robertson and M.A. Klein (eds), Women and Slavery in Africa (Madison, 1983), 185-219.

${ }^{15}$ For a description of slave beatings by district officials, see BAB RKolA 1004/97: 8, 'Bericht des Bezirksamts Bagamoyo', 14 September 1897.

${ }^{16}$ For a much more sophisticated elaboration of this argument, see J.C. Scott, Domination and the Arts of Resistance: Hidden Transcripts (New Haven \& London, 1990).
} 
descriptions, sometimes even a measure of honour. By gradually becoming 'insiders', their social marginality was slowly reduced. ${ }^{17}$

Demarginalization was arguably a precondition for the permanent subordination of slaves. The host societies had not (yet) developed a state apparatus capable of controlling the movement of people, and the only way to keep slaves in their place was to offer them an existence that seemed more promising than the alternative, namely, flight. In the second half of the nineteenth century, runaway slaves formed communities on the fringes of the societies from which they had escaped, far enough away not to be militarily defeated but near enough to participate in markets that satisfied certain needs, particularly arms and ammunition, and often in exchange for slaves. ${ }^{18}$ Desertion was an ever-present option for slaves especially for those, in particular young men, who had not yet formed a firm attachment to their places of residence.

Flight was a risky undertaking in nineteenth-century East Africa. Fugitive slaves were often re-enslaved so that their oppression continued. As one acute observer noted, slaves would usually run away 'only... when the slave knows of some place to which he can go with reasonable chance of escaping recapture'. ${ }^{19}$ There was no guarantee of personal safety in the hinterland, ${ }^{20}$ especially in the nineteenth century, as, for instance, a group of children found out to their peril when they were caught by slave traders and kidnappers and sold abroad. ${ }^{21}$ Consequently, comparatively few slaves dared to run away.

\section{The colonial impact}

Conquest and the establishment of colonial rule had little immediate impact on the character of slavery in East Africa. Despite the anti-slavery rhetoric at home, neither the colonial administration nor the missionary societies in Tanganyika were prepared to undertake measures which would effectively weaken or even eradicate slavery because it was perceived to be one of the

\footnotetext{
${ }^{17}$ For this argument, see Kopytoff \& Miers, 'Introduction', 3-81.

${ }^{18}$ Glassman, Feasts and Riots, 111-13.

19 S.T. Pruen, The Arab and the African. Experiences in Eastern Equatorial Africa during a Residence of Three Years (London, 1891), 236.

${ }^{20} \mathrm{~S}$. Feierman, 'A Century of Ironies in East Africa (c. 1780-1890)', in P. Curtin, S. Feierman, S. Thompson \& J. Vansina (eds), African History. From Earliest Times to Independence (London, 1995), 352-76.

21 C. Velten, 'Sitten und Gebräche der Suaheli', Mittheilungen des Seminars für orientalische Sprachen. Afrikanische Studien I (Berlin, 1898), 76.
} 
main pillars of colonial rule. ${ }^{22}$ This policy was justified on the grounds that, on the whole, owners were supposedly treating their slaves extremely well. Consequently, the colonial authorities described the attitude of slaves as 'docile', almost like animals that, when properly fed and fairly treated, are by and large satisfied with their condition. ${ }^{23}$ This obviously served the interests of colonial propaganda and reflected the preference of both slave owners and the administration to maintain the status quo.

In any case, since all Africans were seen as colonial subjects with strictly limited rights, it did not matter to the administration whether those who were called upon to provide free labour for the building and maintenance of roads, agricultural projects, plantations or the district offices were of servile or freeborn origin or status. As far as local society was concerned, slavery mattered a great deal but in their external interaction with the colonial administration, slaves and their owners were treated more or less as equals, that is, as colonial subjects. It is reasonable to assume that slaves took part in anticolonial resistance movements, notably the Maji Maji Uprising of 1905-7 but they probably did so as millenarian believers and not as slaves. So far, no missionary or administrative evidence has come to light that specifically refers to slaves taking part in the war. Rather, the colonial government put the blame on slave owners who were accused of having joined the Maji Maji movement for fear the government would eventually get rid of the 'evil institution' and forcefully liberate slaves. ${ }^{24}$

Instead of outlawing slavery, the colonial authorities embarked on a policy of obfuscation that left core issues deliberately unclear, such as whether district officers were officially required to return fugitive slaves to their rightful owners. The consequence was, as it was put at the time, that 'nobody knew what the score [was] ${ }^{25}$ because administrative practices varied greatly between the districts and over time. The colonial government gradually suppressed wholesale slave raiding and commercial slave trading in the areas under its

\footnotetext{
${ }^{22}$ Deutsch, 'Slavery', 110-83.

${ }^{23}$ See for instance, F. Weidner, Die Haussklaverei in Ostafrika (Jena, 1915).

${ }^{24}$ See for instance, Reichstag Anlagen, 11. Legislaturperiode, 2. Session, 1905/1906, Nr. 194, G. A. von Götzen: Denkschrift über die Ursachen des Aufstandes in Ostafrika, 1905. This was most likely a deliberate strategy to deflect criticism from the government. Internal government reports explicitly stated that there was no proof of either slave or owner participation. See BAB RKolA 726:91, G. von Winterfeld, 'Bericht der zur Erforschung der Ursachen des Aufstandes eingesetzten Kommission', 4. December 1905.

25 See A. Leue 'Die Sklaverei in Ostafrika', Beiträge zur Kolonialpolitik und Kolonialwirtschaft, 1900/1901, 608 [translation by the author]. For a similar view, see BAB RKolA 1004/97: 8, 'Bericht des Bezirksamts Bagamoyo', 14 September 1897.
} 
control, particularly the kind of warlordism that had previously guaranteed owners a steady supply of cheap captives. It thus became increasingly difficult for owners to replace any slaves lost through flight or natural death. However, direct government intervention was limited in effect and, as far as the relationship between slaves and their owners was concerned, of secondary importance only.

The development of the colonial economy in German East Africa was of far greater consequence in this respect because it strengthened the bargaining position of slaves vis-à-vis their owners. ${ }^{26}$ By forcing open roads and markets, the colonial administration inadvertently removed major obstacles which had previously kept slaves in their place. Flight became a viable alternative to merely seeking a better life in the slave-holding society. Huge numbers of slaves took up paid work with European employers without their owners' consent, particularly after the turn of the century when wage employment rapidly increased. Unyamwezi in particular experienced a tremendous population loss as tens of thousands of people, including slaves, left for the coastal plantations.

During the 1890s and again after 1904, German plantations experienced severe shortages of labour, a pattern which did not change until the outbreak of the First World War. ${ }^{27}$ The shortages resulted from the rapid growth of the industry itself, especially of the sisal plantations in Tanga District in the late 1900 s and early 1910s. The number of people employed on European plantations in German East Africa between 1900 and 1914 is an indication of this expansion. In 1902, German plantation companies employed about 5,000 people $^{28}$ and just eleven years later, in 1913, they employed over 92,000 people. The railway companies, particularly those involved in the construction of the central line to Lake Tanganyika, also employed large number of workers, with an increase in numbers from 6,000 in 1906 to a peak of about 25,000 in $1910 / 11 .^{29}$ All in all, some 172,000 people or roughly 20 per cent of the total African labour force were believed to be in paid employment in 1913, about 140,000 of whom worked for German or other European employers, mainly in

\footnotetext{
${ }^{26}$ Deutsch, 'Slavery', 232-54.

${ }^{27}$ C. Pfrank, Die Landarbeiterfrage in Deutsch-Ostafrika (Berlin, 1919), 25.

${ }^{28}$ BAB RKolA 6475/13: 62-5, 'Denkschrift über die Entwicklung der deutschen Schutzgebiete in Afrika und der Südsee 1901/1902. Anlage VII. Nachweis über die in Deutsch-Ostafrika vorhandenen Plantagen und deren Stand am 1. Januar 1902', n.d. [1902].

29 J. Koponen, Development for Exploitation. German Colonial Policies in Mainland Tanzania, 1884-1914 (Helsinki \& Hamburg, 1995), 609.
} 
private companies, the government, the railways and the missions. ${ }^{30}$ In comparison, the number of people employed by Africans in the caravan trade in 1913 was estimated to have been about $15,000 .^{31}$

\section{Unyamwezi: A case study}

In the early 1890 s, the plantation companies had already tried to persuade Wanyamwezi caravan porters to work on the plantations. Around this time they were still coming in their tens of thousands to the northern coast and particularly to Bagamoyo, which was then the centre of both the colonial administration and European commerce. ${ }^{32}$ However, the independent 'workers of African trade' were not keen on becoming dependent wage labourers on the plantations, at least not at this early stage. ${ }^{33}$ Consequently, in the mid-1890s the plantation companies sent labour recruiters into the interior, especially to Unyamwezi in central Tanganyika, to the southern coast, and even to northern Mozambique. ${ }^{34}$ These early attempts at private labour recruitment did not enjoy great success. ${ }^{35}$ A series of scandals occurred involving false declarations of advances, headhunting by recruiters, the deception of labourers, and fraud. ${ }^{36}$

Despite these inauspicious beginnings, more and more labourers came to the coast from Unyamwezi around the turn of the century, and some stayed there permanently. ${ }^{37}$ They maintained contact with their areas of origin and persuaded others - neighbours, friends and others - to migrate to the coast. This is why some plantations employed large numbers of workers from the same areas in Unyamwezi. ${ }^{38}$ In the 1900s, migrants from Unyamwezi

\footnotetext{
${ }^{30}$ J. Iliffe, A Modern History of Tanganyika (Cambridge, 1979), 157.

${ }^{31}$ Pfrank, Landarbeiterfrage, 31.

${ }^{32}$ For the development of the caravan trade in the German period, see Iliffe, Modern History, 129.

${ }^{33}$ Pfrank, Landarbeiterfrage, 25-27. The phrase 'workers of African trade' refers to the title of the ground-breaking volume on porterage in West Africa by C. CoqueryVidrovitch \& P. Lovejoy (eds), The Workers of African Trade (Beverly Hills, 1985).

${ }^{34}$ Iliffe, Modern History, 160. See also Pfrank, Landarbeiterfrage, 11.

${ }^{35}$ Pfrank, Landarbeiterfrage, 112.

${ }^{36}$ Pfrank, Landarbeiterfrage, 25-27. See also F.P. Nolan, 'Christianity in Unyamwezi, 1878-1928', PhD thesis, University of Cambridge (1977), 217.

37 The following paragraphs are largely based on Pfrank, Landarbeiterfrage, 113- 15, Iliffe, Modern History, 151-63 and Koponen, Development, 348-53.

${ }^{38}$ Hpt. Charisius, 'Aus dem Bezirk Tabora', Deutsches Kolonialblatt, 18 (1907), 461.
} 
dominated the coastal labour market. According to Iliffe, more than a quarter of Dar es Salaam's 23,000 inhabitants in 1905 were believed to be Wanyamwezi. ${ }^{39}$

In the early 1900 s labour recruitment became more formalized. ${ }^{40}$ It involved the signing of two contracts, one between the labour recruiters and the companies concerning the supply of labour, and one between the companies and the workers in question. The latter was the all-important labour contract, specifying wages, the length of contract and the type of work labourers were expected to do. The contract between recruiters and companies usually contained the number of labourers the recruiter was to bring to the plantation, the kind of work contract labourers were to sign, the advance payment recruiters were to receive for their services and the fee to be paid to the recruiter by the companies for each labourer delivered. According to one source, these fees could be up to 60 rupees for each labourer delivered to the company although 20 rupees per labourer was the more common sum. ${ }^{41}$ Because there were so many recruiters - in 1913 over a thousand in Tabora District alone ${ }^{42}$ - competition was fierce. ${ }^{43}$

Later migration patterns from Unyamwezi changed. From about 1907 onwards, fewer and fewer migrant labourers left Unyamwezi to work on the coast. ${ }^{44}$ Instead they went to work for construction companies that were building the central railway line between Lake Tanganyika and the coast. Construction began in 1905 and in the first two years, the companies involved employed mainly migrant labourers but also tax defaulters and war captives $(1,500)$ from the Maji Maji Uprising. ${ }^{45}$ The Dar es Salaam to Morogoro section of the line was completed in 1907 and then it took five years for the line to be extended to Tabora (1912) and another two years to reach Kigoma on Lake Tanganyika. ${ }^{46}$ From about 1908 on, growing numbers of Wanyamwezi labourers began to work on the railway line. In 1913, the construction companies

\footnotetext{
${ }^{39}$ Iliffe, Modern History, 161.

40 T. Sunseri, 'Dispersing the Fields. Railway Labour and Rural Change in Early Colonial Tanzania', Canadian Journal of African Studies, 32, 3 (1998) 564. See also by the same author, Vilimani. Labor Migration and Rural Change in Early Colonial Tanzania (Portsmouth, 2002), 165-92.

41 R. Tetzlaff, Koloniale Entwicklung und Ausbeutung. Wirtschafts- und Sozialgeschichte Deutsch-Ostafrikas 1885-1914 (Berlin, 1970), 244.

${ }^{42}$ Iliffe, Modern History, 160.

${ }^{43}$ For more details on recruitment practices, see Sunseri, 'Dispersing', 564.

${ }^{44}$ Iliffe, Modern History, 159.

${ }^{45}$ Tetzlaff, Koloniale Entwicklung, 88.

${ }^{46}$ For more detailed information on the construction of the central railway, see Tetzlaff, Koloniale Entwicklung, 81-100, Iliffe, Modern History, 135-8 and Koponen, Development, 297-314.
} 
employed over 16,000 people, the majority of whom were believed to have come from Tabora District. The building of the railway line caused a dramatic decline in the caravan trade between Tabora and the coast. By 1912, less than a hundred porters had arrived in Bagamoyo from the interior, whereas only ten years earlier tens of thousands had done so each year. ${ }^{47}$

The move of Unyamwezi migrant labourers into paid employment was accompanied by a massive decline in the resident population of some parts of Tabora District. ${ }^{48}$ In the 1900 s, labourers, especially men, were often absent for years. Villages that had teemed with people in the 1890s were almost deserted as only the aged, and women and children remained. ${ }^{49}$ According to the missionary Van der Burgt who had been working in Unyamwezi since 1892, the population declined by over 50 per cent in some places between 1890 and $1912 .^{50}$ An official report from Tabora claimed that in 1912/13 only ten out of every hundred taxpayers in the district were able-bodied men. ${ }^{51}$ The issue raised enormous political interest and criticism, even in the Reichstag. ${ }^{52}$

The involvement of Wanyamwezi labourers in the plantation economy of the northern coastal districts and subsequently in the construction of the central railway line cannot solely be explained by the trickery of labour recruiters, the application of forced labour policies or taxation. Although force was not totally absent, on the whole the colonial administration did not use coercive means taxation or the labour card system - to induce Wanyamwezi labourers to take jobs on the plantations or the railways. ${ }^{53}$ Moreover, although labour recruiters often tried to lure people into wage labour employment with all kinds of false promises and material inducements, the actual work contract still had to be signed by the labourers themselves, and in the case of railway employees in the presence of district officials. All the available evidence suggests that this was

\footnotetext{
${ }^{47}$ Iliffe, Modern History, 137.

${ }^{48}$ A. Seibt, 'Fragebogen-Beantwortung für ganz Unyamwezi durch Missionar A. Seibt, in Urambo stationiert [Januar 1910]', in A. Gottberg, Unyamwesi. Quellensammlung und Geschichte (Berlin, 1971), 176.

49 Ibid.

50 J.M.M. van der Burgt, 'Zur Entvölkerungsfrage Unjamwesis und Usumbwas', Koloniale Rundschau (1913), 706.

${ }^{51}$ This report was cited by Gustav Noske, a member of the Social Democratic Party, in a Reichstag debate in 1913. See Stenographische Berichte über die Verhandlungen des Reichtages [abbreviated as RT] 1912/14, 7 March 1913: 4349.

${ }^{52}$ RT 1912/14, 7 March 1913: 4344-50.

${ }^{53}$ Koponen, Development, 352.
} 
done voluntarily in the great majority of cases. ${ }^{54}$ It raises the question of what motivated people to seek wage labour employment in such large numbers. ${ }^{55}$

Any analysis which exclusively focuses on external factors to explain the large-scale migration of Unyamwezi labourers to the coast and to the railway construction sites fails to take into account the agency of those who were most directly concerned with this process, the labourers themselves. ${ }^{56}$ Admittedly, evidence on this issue is exceedingly scarce but it appears that in the early 1890s some chiefs sold their subjects to labour recruiters and travelling traders for a small fee, probably to recoup the losses sustained during the rinderpest epidemic of $1891 .^{57}$ Many labourers never came back to their previous places of residence, preferring instead to remain on the coast or move to Tabora Town where better income opportunities were available. ${ }^{58}$ Fearing the permanent loss of their subjects, which was after all the basis of their power and prestige, some chiefs introduced a new custom. ${ }^{59}$ According to the most detailed contemporary document on this issue, these chiefs decreed that their serfs (Hörige) were not allowed to leave the villages and hamlets without the explicit permission of their chief. This permission could be acquired by the payment of a lump sum a ransom - whereby the prospective migrant was relieved forever of his or her supposed duty to pay tribute to the chief. ${ }^{60}$

It appears that in the late 1890s and early 1900s some Unyamwezi chiefs permitted their subjects to travel to the coast, presumably after receiving a small monetary inducement from labour recruiters. ${ }^{61}$ However, realizing that the migrants were not going to return, the fee was subsequently raised by the chiefs to approximate their putative future tribute payments or labour service, i.e. his or her commercial value. Thus, on the point of departure to the coast, some supposedly free chiefly subjects (serfs) seem to have become commercial slaves. Archival evidence points to widespread buying and selling of persons in Unyamwezi, regardless of whether they were supposed to be free or commercial slaves. In 1900, the Tabora district officer informed the colonial

\footnotetext{
${ }^{54}$ Sunseri, 'Dispersing', 563.

${ }^{55}$ Ibid, 565.

${ }^{56}$ Ibid. 574.

${ }^{57}$ Nolan, 'Christianity', 148, 170. For more details on Nyamwezi chiefship, see W. Blohm, Die Nyamwezi, 2 vols (Hamburg, 1931-1933) and F. Bösch, Les Banyamwezi. Peuple de l'Afrique Orientale (Münster, 1930). For the history of the area in general, see A.D. Roberts, 'The Nyamwezi', in A.D. Roberts (ed.), Tanzania before 1900 (Nairobi, 1968), 117-50.

${ }^{58}$ Charisius, 'Tabora', 459.

${ }^{59}$ RKolA 1007: 65, 'Aufzeichnung des Bezirksamtmann Löhr', 31 May 1916.

${ }^{60}$ Ibid. For a similar description, see Nolan, 'Christianity', 148.

${ }^{61}$ Sunseri, 'Dispersing', 563.
} 
government in Dar es Salaam that 'only well-to-do owners sold their slaves, as the poorer ones were afraid of losing their only labourers' ${ }^{62}$ Ten years later, the widely respected district judge, Karstedt, observed that hundreds of people were being sold in Tabora District each year. ${ }^{63}$

The power of the chiefs to sell slaves was limited. The Tabora district officer, Puder, reported in 1898 that 'owners treat their slaves well, for fear they might run away'. ${ }^{64}$ The reason for this development was that labour recruiters paid advances to anyone who wished to work on the coast, irrespective of the status of the person involved. ${ }^{65}$ By the turn of the century, flight had become a matter of choice and the authority of slave owners and chiefs consequently declined. ${ }^{66}$ According to Koponen, this development occurred in the first half of the $1900 \mathrm{~s}$. He relates that when the former district officer of Tanga, Meyer, visited Unyamwezi in 1906, he found that 'some 90 percent of those who had gone to European farms had done so without the order of their chiefs and not seldom against it. The people sent by the chiefs were their slaves in most cases. ${ }^{, 67}$ Meyer also stated that Nyamwezi workers on the coast generally belonged to the lower classes. ${ }^{68}$ Thus, it appears that labour recruitment gave slaves an opportunity to leave their owners. It also enabled the subjects of the chiefs to escape from their rapacious rulers. ${ }^{69}$

When the railway companies arrived in the area in 1907, the process was already well advanced. According to one observer, by that time the chiefs and slave owners were no longer able to extract labour or tribute from their slaves and/or subjects. ${ }^{70}$ The latter were free to move and this arguably explains why they were able to set off in such large numbers to the construction sites or leave the villages for smaller, more autonomous settlements of family units. It also explains why slave ransoming prices in Unyamwezi rose in the late colonial

${ }^{62}$ BAB RKolA 7382/27: 89, 'Berichte der einzelnen Verwaltungsstellen in DeutschOstafrika über die Sklaverei', Station Tabora, Berichterstatter: Hauptmann Puder, n.d. [1900]. [translation by the author]

${ }^{63}$ F.O. Karstedt, 'Zur Sklavenfrage in Deutsch-Ostafrika', Koloniale Rundschau (1913), $619 f$.

${ }^{64}$ BAB RKolA 7382/27: 89, 'Berichte der einzelnen Verwaltungsstellen in DeutschOstafrika über die Sklaverei', Station Tabora, Berichterstatter: Hauptmann Puder, n.d. [1900] (translation by the author).

${ }^{65}$ Charisius, 'Tabora', 459.

${ }^{66}$ RKolA 1007: 65, 'Aufzeichnung des Bezirksamtmann Löhr', 31 May 1916.

${ }^{67}$ Meyer, quoted in Koponen, Development, 352.

${ }^{68}$ Ibid.

${ }^{69}$ For a similar view, see Nolan, 'Christianity', 154.

${ }^{70}$ Seibt, 'Fragebogen-Beantwortung', 206 
period: there were fewer slaves to be ransomed. ${ }^{71}$ This argument is supported by circumstantial evidence. Seibt, a missionary who worked in Unyamwezi, reported in 1910 that slaves who had once been forced to live in the same village as their owner could now freely choose their place of residence. ${ }^{72}$ Löbner, another missionary, observed that by 1910 a significant sector of the slave population had been absorbed into the general population. ${ }^{73}$

The available evidence does not allow a distinction between the actions of those who were regarded as slaves and those who were assumed to be free but were subject to the whims of Unyamwezi chiefs. Sources are also silent about who was actually regarded as a chief. Were they 'sultans' appointed by the government as administrative agents and tax collectors, village heads who ruled over only a limited number of people or merely commercial slave owners who had acquired slaves in the 1880s to relieve labour shortages in their extended households? ${ }^{74}$

It is reasonable to assume that a significant number of the estimated 100,000 to 200,000 Wanyamwezi who left their villages to work in the wage labour economy between 1900 and 1914 were slaves who were trying to improve their lives through migration. ${ }^{75}$ Clearly, new kinds of employment opportunities opened up for both the free and the slaves. However, as constraints on them diminished, the 'unfree' probably responded more quickly to these opportunities than the free, since on the whole they had less to lose. ${ }^{76}$

The account above suggests that in the early colonial period the slaves and the free in Unyamwezi began to merge imperceptibly, as both groups applied the same strategies to make use of the wider opportunities available through the imposition of colonial rule and the development of the colonial economy. It became increasingly impossible for many observers - both local and foreign to tell the two groups apart. ${ }^{77}$

It thus appears that while German colonial rule provided the means to destroy the power of the slave owner in Unyamwezi, namely wage labour employment and a minimum degree of personal security, it was left to the

\footnotetext{
${ }^{71}$ Nolan, 'Christianity', 267.

${ }^{72}$ Seibt, 'Fragebogen-Beantwortung', 187.

${ }^{73}$ M.H. Löbner, 'Fragebogen-Beantwortung für ganz Wanyamwezi durch Missionar M. H. Löbner, stationiert bei Tabora [Usoke, March 1910]', in A. Gottberg, Unyamwesi. Quellensammlung und Geschichte (Berlin, 1971), 129. See also by the same author 'Zur Entvölkerungsfrage Unyamwezis', Koloniale Rundschau, 1914, 267-70.

${ }^{74}$ R.G. Abrahams, The Peoples of Greater Unyamwezi, Tanzania. Nyamwezi, Sukuma, Sumbwa, Kimbu, Konongo (London, 1967), 45f.

${ }^{75}$ For these estimates, see Tetzlaff, Koloniale Entwicklung, 252, 287.

${ }^{76}$ See Wright, Strategies, 42.

${ }^{77}$ Nolan, 'Christianity', 154.
} 
slaves to commit the deed themselves. In other words, the runaway slaves of the late nineteenth century became the labour migrants of the early twentieth century. Labour migration helped to bring slavery in Unyamwezi to an end.

\section{Conclusion}

In this chapter it was argued that the social heterogeneity of servility in East Africa prevented slaves from taking concerted militant action. At the same time this very diversity was the result of protracted individual everyday struggles by slaves for a better life, be it to ensure physical survival or to obtain a measure of honour and autonomy or partial independence in their different places of residence. The colonial stereotype of the 'docile slave' is thus highly misleading.

Moreover, slave resistance can be said to have brought slavery in East Africa to an end. Yet, slaves did not militantly challenge or seek to reform slavery through concerted action but when they had the opportunity, they completely rejected their personal subjugation. In the pre-colonial nineteenth century, this rejection generally took the form of flight. By the early colonial period flight was no longer required since migration would fulfil a similar purpose. But, because of the number of people involved, these seemingly isolated and personal strategies of advancement had a major social and political impact on the societies concerned as well as on the region as whole. Without the need for a formal organization or concerted action, by leaving their places of residence in large numbers slaves ultimately undermined the evil institution. Slavery in East Africa persisted throughout the German colonial period but the number of slaves who were prepared to accept their marginal social position, their dependence and exploitation declined dramatically.

The migrant slaves became (temporary) wage earners on European-owned plantations and urban informal-sector workers, hoping to and often succeeding in ultimately joining the ranks of the free independent peasantry. It is strange that those who have written so much about 'resistance to capitalist encroachment' by the peasantry and about the 'development of exploitation' in East Africa seem to have overlooked the social origins of those who made early colonial capitalism work.

The history of the end of slavery has wider implications for the study of resistance in Africa and elsewhere. There is a danger of romanticizing resistance, of reading legitimate current concerns about the marginal social position of various social, political and ethnic groups and their apparent lack of political leadership, ideology and militancy backwards into (African) history. The fact that there was no Spartacus leading the servile masses of East Africa 
into freedom does not mean that slaves did not struggle for a better life. It is all too easy to overlook the fact that marginalized people are able to confront effectively social, political and economic hegemony and that they can do so in their everyday lives without being represented by a formal organization, taking part in concerted militant actions or subscribing to an overarching political ideology. Although the colonial subordination of a large part of the world brought untold misery and suffering to most of its inhabitants, this should not prevent historians from critically appreciating the motives of those marginal groups who apparently wholeheartedly embraced it. 


\title{
8
}

\section{The Kawousan War reconsidered}

\author{
Kimba Idrissa
}

The Kawousan War was one of the longest periods of resistance known in Niger and through it the local peopleTuareg, Hausa and others - fought to free their society from French colonial domination. Unlike other interpretations, this chapter looks at the structural causes of the war related to the ecology and economy of the area, the influence of French colonial politics on the nomadic lifestyle, and Islam. It also considers the decisive role of the individual leaders, the breakdown of Tuareg confederations and the creation of new political unities, and the reduction in the powers of the regional chiefs. The effect the Kawousan War had on regions outside the immediate vicinity of the fighting is also investigated. The causes of the war were multi-faceted and made it more than purely a religiously inspired revolt.

\section{Introduction}

The most important anti-colonial period of resistance in Niger in popular memory is the Yakin Kawousan or the Kawousan War, which may well have been the longest, the best organized and equipped of all previous anti-colonial wars of resistance. The military post at Agadez was under siege for about 80 days from 13 December 1916 to 3 March 1917 and the war then continued in the mountainous Ayir region, ending only with the deaths of the main leaders: Kawousan on 5 January 1919 and Tagama during the night of 29-30 April 1920. The fierce fighting and opposition to the colonial system lasted for some 40 months. 
The Kawousan War was the subject of numerous reports at the time. ${ }^{1}$ Many historians and anthropologists have taken an interest in the events that raised so much controversy. ${ }^{2}$ The various interpretations have their weaknesses as they have tended to focus on a description of events, especially on political and military issues. The revolt has also been likened to a simple act of looting or pillage, or at the most to a Sanûssi-influenced ${ }^{3}$ anti-French religious movement organized by Italy and Germany against France. These judgements hide the complexity of an event whose deeper roots resurfaced at the start of colonial occupation. In this chapter I critically analyse various types of material: oral historical sources from a visit to Agadez during July and August 1985, $\mathrm{AOF}^{4}$ archival material in Dakar, information gleaned from the archives of the former Cercles of Zinder, Agadez and Niamey, documents written at the time, and other related works on the subject.

To be interpreted correctly, the Kawousan War has to be placed in the region's socio-political and economic context of the time since the actual causes of the revolt were essentially socio-political and economic and such explanations often have deep structural causes. Here I propose to show the impact of colonial domination on socio-economic life, to discuss the true role of the chiefs and local noblemen, and to describe the repercussions of the revolt in other regions. This information is used to analyse the different interpretations for the reasons behind this revolt and to propose an alternative view.

\footnotetext{
${ }^{1} \mathrm{M}$. Allane, Relations de Voyage de Mohamed Allane à Djanet et à Ghât, recueillie M. Abridat, officier interprète de reserve (undated); H. Boubou, 'Documents Nigériens, tome I, l'Aïr'; R. Gaffiot, L'Ä̈r en Feu, ronéo (undated); P. Mangeot, 'Le Siège d'Agadez Raconté par un Prisonnier de Kaosen', Renseignements Coloniaux et Documents, 8 (1930), 479-82; Colonel Abadie, Afrique Centrale: La Colonie du Niger (Paris, 1927).

${ }^{2}$ A. Bourgeot, 'Les Echanges Transsahariens, la Senousiya et les Révoltes Twareg de l'Aïr de 1916-1917', Cahiers d'Etudes Africaines, 69-70, XVIII, 1-2 (1978), 159-85; F. Fuglestad, 'Les Révoltes des Tuareg du Niger (1916-1917)', Cahiers d'Etudes Africaines, 13 (1973), 49; K. Muhammad Zubairu, 'The Kaoussen Rebellion of 19161918 with Particular Reference to its Impact on Northern Nigeria', PhD thesis, Ahmadu Bello University (Zaria, 1973); H.T. Norris, The Tuareg: Their Islamic Legacy and its Diffusion in the Sahel (Warminster, 1975); Y. Riou, La Révolte de Kaocen et le Siège d'Agadez, 1916-1917, ronéo (1968); J.L. Triaud, 'Un Episode Oubliée de la Guerre de Kaossen: La Lettre des Marabouts d'Agadez au Colonel Mourin (4 mars 1917)', Annales de l'Université de Niamey, no. 2 (1978), 263-71; A. Salifou, Kawousan ou la Révolte Sénoussiste, Etudes Nigériennes no. 33 (Niamey, 1973).

${ }^{3}$ The Sanûssi is an Islamic brotherhood that organized resistance to the French.

${ }^{4}$ Afrique Occidentale Française.
} 


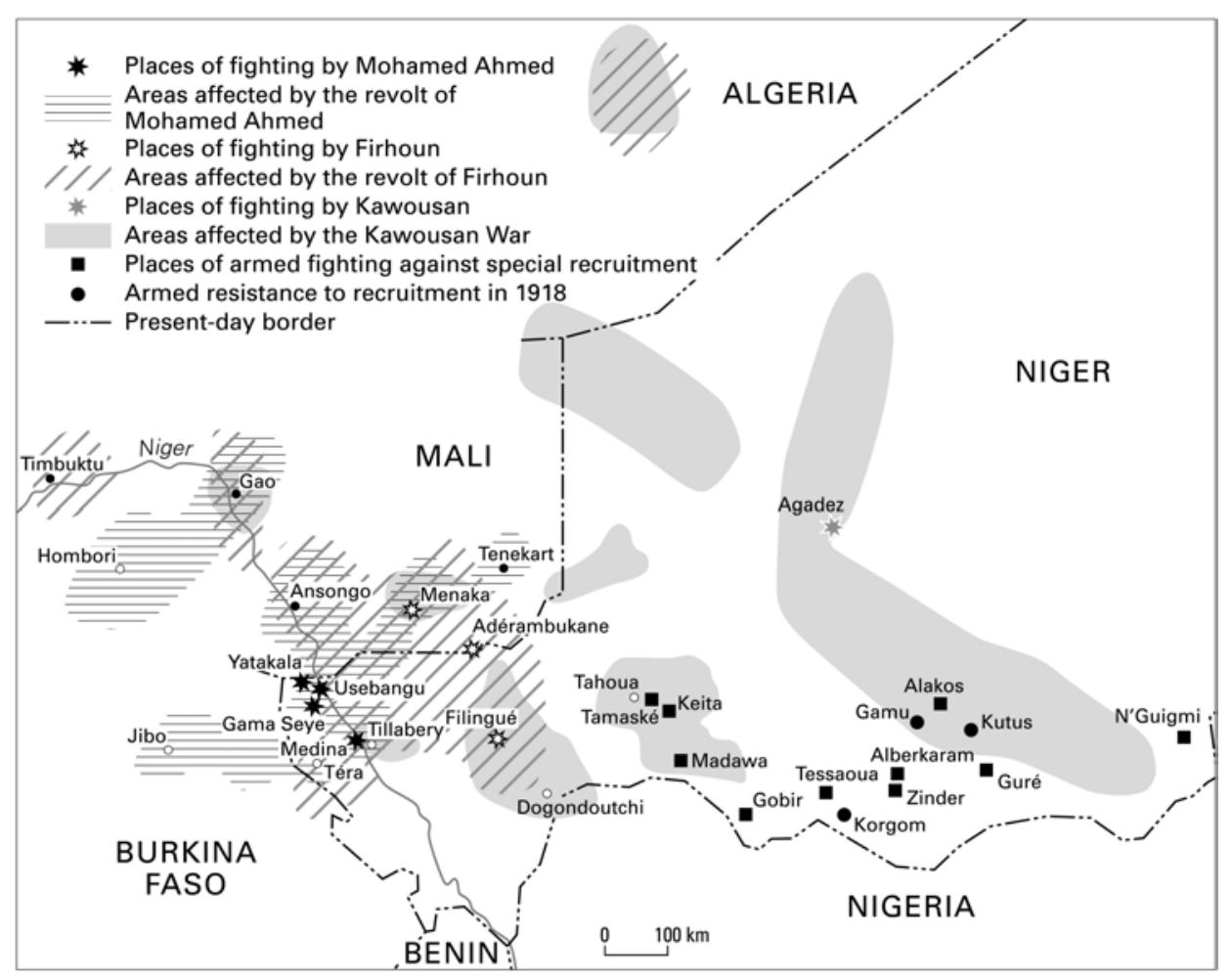

Map 8.1 Areas of resistance during the Kawousan War 


\section{The roots of the revolt}

\section{The occupation and administration of the Ayir, Kawar and Djado}

To connect its possessions in North Africa with the Atlantic Coast and to build a French-African bloc, France had first to conquer the Sahara and central and western Sudan. The Sahara served not only as military and political cover vis-àvis Nigeria and as a protective barrier for the Algerian hinterland but also provided a transit route and link for trade between the Mediterranean and Sudan.

The first official French military mission to the Niger Sahara is known as the Foureau-Lamy Mission and is recognized as the first act of French colonization in the Ayir region. This mission's aim was to join the Sahara with the French Sudan, ${ }^{5}$ and to mark the French presence in the region, thus preventing the ambitions of the Ottoman Empire in Kawar. The treaties signed between August and November 1899 with the Sultans of Agadez, Tessaoua and Zinder and the delegates of the Sultan of Bilma helped to consolidate the French position in the region. The conquest and subsequent occupation of the Nigerian Sahara had five objectives: to stop the progressive expansion of the Turks; to prevent any German ambitions in the area; to access Niger from Algeria and to find the best way to supply Niger militarily from there; to ensure the safety of caravan routes between Damergou and Damagaram and those coming from Tripoli; ${ }^{6}$ and to prepare for the conquest of Tibesti.

According to the political and administrative plans in these regions, French colonization aimed to reduce the authority of the regional chiefs and to consciously maintain a degree of tension between the nomadic and sedentary populations, and between the warring and religious nobles. For example, the colonial administration put pressure on the Tuareg imajaren (warrior) clan until the start of the Kawousan War. After the repression came a period of 'political maraboutism' with the election of the marabouts' chiefs (ineslimen). The French occupiers could not tolerate the lifestyle of these desert populations, particularly that of the nomadic Tuareg who carried out raids, were involved in itinerant animal husbandry and observed a strong social hierarchy. This way of life was not compatible with a modern state system with the values of equality for all, and where the control of people and resources was pivotal to all political

\footnotetext{
${ }^{5}$ It had to join Lake Chad with the Voulet-Chanoine mission in Central Africa and the Congo-Chad mission led by Gentil.

${ }^{6}$ A.N.F. Paris, Vincennes, S.H.A., Niger 3, dossier III, Sous/dossier a, pièce 2, Souslieutenant Jean, commandant la colonne du Damergou: Rapport sur la Question de l'Azbin, Djajidouna, 18 mars 1904. A.N.N., Niamey, Instructions du Résident à Zinder, Peroz, au commandant du poste de Guidjigaoua, RASH Y (1972), 60.
} 
activities. The aristocratic Tuareg, therefore, had to be disbanded. This dislocation passed for the suppression of slavery under the form of collective dependency in breaking the ties of bondage and in encouraging the autonomy of servile tribes and their dependants. In return, reports of social domestic servitude were ignored and the aristocratic Tuareg were allowed to keep their domestic slaves.

The break-up of the aristocratic Tuareg followed the abandonment of confederations and the establishment, in their place, of a policy of enforced sedentarization. In the Tuareg nomadic zones, artificial political groups were created with their own autonomy ${ }^{8}$ and formerly independent tribes were placed under the authority of the Sultan of Agadez. In the Kawar, in spite of its low population density and an acephalous political system, previously stateless communities were regrouped into three cantons called 'sultanates'.

\section{Socio-economic causes}

\section{The decline in caravan traffic}

The logic of French policy declared that the submission of the aristocratic Tuareg groups could be realized by depriving them of their military and economic power - the Trans-Saharan caravan traffic. ${ }^{10}$

Military operations were the most important factor in the decline of the interregional caravan traffic. Operations of conquest and pacification deprived the local people of the capital that was the main focus of long-distance exchanges, namely camels. Massive reductions in the number of camels resulted in a loss of livelihood for an important group of Tuareg who lived off this commercial trade, as well as for all the other people involved such as guides and escorts.

\footnotetext{
7 This emancipation of dependants remained formal. Slavery in itself rarely led to uncertainty and the trade in slaves was pursued in this region to such an extent that trans-Saharan trade kept its dynamism.

${ }^{8}$ See P. Bonte, 'Esclavage et Relation de Dépendance chez les Tuareg Kel Gress', in C. Meillassoux (ed.), L'Esclavage en Afrique Précoloniale (Maspéro, 1975), 49-76; E. \& S. Bernus, 'L'Evolution de la Condition Servile chez les Tuaregs Sahéliens', in C. Meillassoux (ed.), L'Esclavage en Afrique Précoloniale (Maspéro, 1975), 27-48.

${ }^{9}$ Capitaine Hautefeuille, 'Les Origines de l'Islam au Kawar', Documents du Centre des Hautes Etudes sur l'Afrique Noire, 1654 (1950), 7; J. Chapelle, Nomades Noirs du Sahara (Paris, 1957).

${ }^{10}$ Bourgeot, 'Les Echanges Transsahariens', 162-65.
} 
Losses increased to around $40 \%$ in the Cercle of Zinder, 30\% in the Cercle of Madaoua and $60 \%$ in the Cercle of Agadez, according to official reports. ${ }^{11}$

The 1912-1915 famine

While trade was declining in the north, Niger as a whole was experiencing an exceptionally bad famine that lasted from 1912 to 1915. Fiscal pressures, problems in the caravan trade as well as levies on foodstuffs and livestock all contributed to the effects of the famine in the Ayir in 1913:

Il sévit actuellement dans tout le cercle d'Agadez une disette qui fait de nombreuses victimes. Les habitants sont partis en masse vers le sud et il ne reste plus personne au nord d'Agadez. Ceux qui y sont encore mangent les quelques graines et fruits comestibles des arbres de la zone désertique mais cette nourriture peu substantielle ne les soutient guère et ils meurent de faim en grand nombre... ${ }^{12}$

\section{Economic consequences of the conquest of Tibesti}

The conquest of Tibesti started in September 1913 and lasted until July 1916 when it was finally evacuated and then abandoned, with the requisitioning of men, food products and camels from neighbouring areas, first Agadez and later N'guigmi, Zinder and Madaoua.

Une grande partie des animaux de l'azalai fut réquisitionnée à Bilma pour la colonne du Tibesti et bien peu revinrent: les propriétaires ne furent pas dédommagés de leurs pertes; le mécontentement qui en résulta ne compta-t-il pas pour beaucoup dans les raisons qui menèrent à la révolte? On peut le supposer...Cette question est importante et est le gros sujet de mécontentement des tribus nomades dont la principale, presque l'unique ressource est le chameau... ${ }^{13}$

In 1915 the people in Ayir provided about 850 camels for the Tibesti caravans in response to 1,100 requests for animals. ${ }^{14}$ The drought and a lack of pasture exacerbated losses and resulted in a decline in the north-south caravan trade with the number of caravans being cut to half their original number between

${ }^{11}$ Archives Nationales du Sénégal, Dakar, 2 G 14-4, NIGER à AOF, Rapport Agricole, $4^{\text {ème }}$ trimestre $1914,7$.

12 Archives Nationales du Niger, Rapport Politique du Cercle d'Agadez, $2^{\text {ème }}$ trimestre 1914, Agadez le 30 juin 1914.

13 Capitaine Fonferrier, 'Etudes Historiques sur le Mouvement Caravanier dans le Cercle d'Agadez', Bulletin du Comité d'Etudes Historiques et Scientifiques de l'A.O.F. (1932), 305.

14 Archives Nationales du Niger, Agadez, Commandant du Cercle d'Agadez au Lieutenant-Colonel Commissaire du Gouvernement Général au Territoire Militaire du Niger, Agadez le 9 juin 1916. 
1912 and 1914. At the time of the 1912 annual caravan, 16,821 camels were recorded in Bilma and 6,721 in Fachi as compared to 8,220 and 2,410 respectively in $1914 .{ }^{15}$

\section{The political and military situation before the revolt}

On 27 July 1916, Sub-lieutenant Lenoir, commander of the forces at Tibesti, decided to evacuate the posts at Bardaye and Zouar and to abandon Tibesti. The official reason given was the problem in defending the post in the face of an imminent Sanûssi attack. ${ }^{16}$ Lenoir had undoubtedly seen that the political situation was giving cause for concern. Unrest was spreading in the north and the northeast and especially in the Ayir region. Echoes of the fighting by the Sanûssi in the north, the revolt by the Tuareg in the west, ${ }^{17}$ and finally the hurried departure of the French troops from Tibesti all contributed to the radicalization of local anti-colonial resistance. Regular raids started to spread from Ayir to Damergou, Ader and Tarka. ${ }^{18}$ Such acts, however, remained unpunished, testifying once again to a reduction in the power and influence of the colonizers.

The French administration was being threatened from all sides and was incapable of containing demonstrations against its presence, in part because of the influence of the First World War raging in Europe. Captain Sabatié, Captain Bosch's successor as head of the Cercle of Agadez as of 1 December 1916, inherited a precarious situation because the second company of the $3^{\text {rd }}$ Senegalese rifle battalion based at Agadez was weak and widely dispersed. Captain Sabatié tried to reinforce the defence of the post of Agadez and demanded reinforcements from Zinder. By deciding to take a different approach from that suggested by his predecessor, Captain Sabatié displayed a certain amount of flair just a few days before the attack. Who were the leaders of this famous revolt? How was it planned and who was involved?

\footnotetext{
15 Archives Nationales du Niger, Niamey, Cercle d'Agadez, Rapport Politique, $4^{\text {ème }}$ trimestre 1912 et 1914.

${ }^{16}$ Archives Nationales du Niger, Niamey, 21-0-29, 'Rapport du Sous-Lieutenant Lenoir commandant le confrérieur du Tibesti et le poste de Bardaye sur les circonstances qui ont amené cet officier à abandonner les postes de Bardaye et de Zouar, et à évacuer le Tibesti', Faya le 25 août 1916, 23 pages manuscrites.

${ }^{17}$ It concerns primarily the revolt of Firhoun.

${ }_{18}$ Archives Nationales du Sénégal, Dakar, 2 G 16-13, Niger à AOF, Rapport Politique, $3^{\text {ème }}$ trimestre 1916, Zinder le 28 octobre 1916.
} 


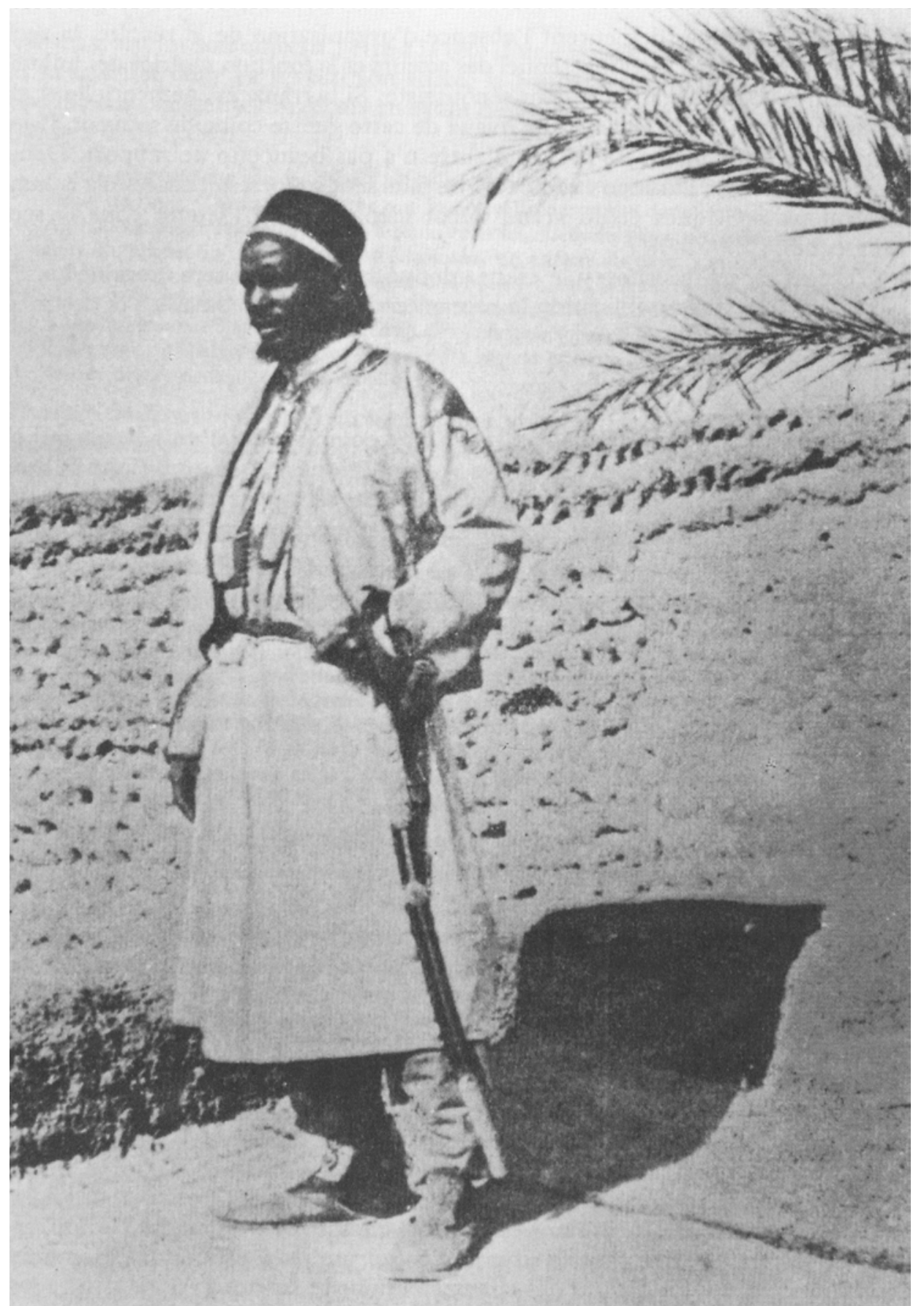

Kawousan ag Kedda

Copyright: 'Touaregs exil et résistance', Revue du Monde Musulman et de la Méditerranée, 57 (Paris, 1990) 


\section{The leaders and their doctrine}

\section{Mouhamad Kawousan ag Gedda}

Mouhamad Kawousan ag Gedda was an Ikaskazen Igerzawen born in the Ayir towards the end of the nineteenth century. ${ }^{19} \mathrm{He}$ did not inherit a title from his father nor was he born into a chiefdom endowed with incarnate politico-military power. His tribe was not descended from a political power. He was affiliated to a junior line that hierarchically occupied a subordinate position and could not accede to a title of aghola or tribal chief..$^{20}$ By way of compensation, his mother was a noble in the Igerzawen chieftaincy. ${ }^{21}$

As a young man, Kawousan had taken part in the exodus of certain Tuareg groups that wanted to withdraw from French domination and he stayed in Kanem where he participated in the anti-colonial struggle against the French. He was in Gouro when he got in contact with - or attached himself to, according to some - the anti-European El Hirwan (The Brothers) movement connected to the Sanûssi. ${ }^{22}$ This would have been in August 1909. In November of the same year, he participated on the side of Abdallah Tower, chief of the Sanûssi Zawiya of Aïn Galaka, in the attack on the French camp of Washenkale commanded by Lieutenant Moutot. ${ }^{23}$ Progressively, and thanks to his courage and intelligence, Kawousan acquired the esteem of the powerful brotherhood's leader. He developed a strong friendship with Sidi Ahmed Sherif, the head of the Sanûssiya, who appointed him Governor of Ennedi. He was involved in the war for a while with the Italians and later was harassed by the French troops of Commmander Hilaire and forced to take refuge in Darfour for nine months from August 1910 to May 1911. He left Darfour in August 1912 at the end of the conflict with the powerful sultan, Ali Dinar. Threatened on all fronts, he gave himself up to the French who put camels at his disposal allowing him to proceed towards Ounyanga Kebir in the Ennedi region. The Turks had just installed themselves in Borkou, and Kawousan offered his services to their

\footnotetext{
${ }^{19}$ All the authors then adopted, according to colonial archives, the name Wan Teggida which was unknown to the population. According to the same authors, Kawousan would have been born in Damergou around 1880. H. Claudot-Hawad, 'Exil et Résistance ou la Continuité Touarègue', Revue du Monde Musulman et de Méditerranée, 57 (1990), 29.

${ }^{20}$ A. Bourgeot, 'Révoltes et Rébellions en Pays Tuareg', Afrique Contemporaine, 170 (1994), 8.

${ }^{21}$ Claudot-Hawad, 'Exil et Résistance', 30.

${ }^{22}$ Information Rhoubeidi, Agadez, August 1985.

${ }^{23}$ Archives Nationales du Niger, AGADEZ, Territoire Tchad au Territoire Niger, 30 janvier 1917.
} 
leader, Kaïmakan d'Aïn Galaka, and followed him to Ennedi. In May 1913 they found themselves involved in the Battle of Oum-Et-Adam on the side of the Sanûssi overthrown by French troops. Kawousan regrouped, left Borkou and withdrew to the oasis at Timmerin. There is no information about his activities there until April 1915 when he helped his friend Sidi Mahdi Souni, the son of Mohammed Souni, against the Italians. In February 1916, he was seen in the Tripolitanian Djebel. He returned to Ghât in August after the Italians had occupied Janet with an army estimated to be made up of 200 regular soldiers and six canons. Four months later, Kawousan besieged the French post at Agadez with the help of Sultan Tagama.

\section{Abderahamane Tagama Ag Bagari}

Abderahamane Tagama Ag Bagari was roughly 40 years of age in December 1916, about the same age as Kawousan. From a young age he had studied the Koran in Agadez and had then become involved in petty trade, following the caravans south to the markets along the Kano-Katsina-Sokoto road. He lived in Bornou and then in Kano where he resumed his studies but at a higher level. He was still in Kano when he was asked to take up the head of the sultanate. He ascended the throne in 1908 as successor to Ibrahim Ed-Dasouqi who was judged 'feeble and incapable' by the French. ${ }^{24}$ Although put in place by colonization, Tagama, like his father Sultan Mohammed Al Baqary dit Bâ Sôfô, ${ }^{25}$ lived modestly and was generous towards his people, especially during the 1912-1915 famine. ${ }^{26}$

In addition to these two leaders, two other people who played a decisive role in this event should be mentioned. As chiefs of war, political leaders and members of the aristocracy, the participation of Fona and El Moctar Kodogo Ben Mohamed brought about a loyalty between the elements of the warring group in the Kawousan War. Fona was an agholla (chief) of Kel Tafidet who participated in all the major battles against the French before 1916 in the Ayir, Damergou, Agram and Tibesti. After becoming Kawousan's lieutenant, he led the resistance in Tibesti and Kawar where he participated in the sacking of

\footnotetext{
${ }^{24}$ Information Malam Yaro, Agadez, August 1985.

25 'Al Baqary est considéré comme un roi philosophe, (Waliyi-n-sarki) qui refuse de puiser sa nourriture dans les finances de la ville et qui vit très modestement. Il est l'un des rares sultans à être enterré dans le cimetière du palais.' A. Adamou, Agadez et sa Région, Thèse de $3^{\text {ème }}$ cycle en géographie (1976), 81.

${ }^{26}$ The famine was first called Yunwa Tagama (the 'Famine of Tagama') due to the important quantities of food the Sultan procured from his own personal resources to distribute to the people.
} 
Fachi in 1918. Kodogo was the son of an old Ikaskazen chief. He left in dissidence, as did Kawousan.

\section{The siege of the French post at Agadez}

The revolt extended beyond the borders of the Ayir region. Virtually all the groups in the Ayir were involved in the action in one way or another and to varying degrees over time. Groups of people alone or under the leadership of their chiefs joined the resistance fighters. The Kel Ajjer made up Kawousan's original force before his arrival in the Ayir; Moussa ag Amastane was in charge of the Kel Ahaggar; Mohammed Ibrahim - the chief of the Almouskare - led the Arabs from Tahoua, and the Amenokal Al Khorar led the Kel Dinnik. The Kel Nan of Azawak, Taitoq of In Gall, Ifadayen, Toubou of Kawar and Tibesti, all people of the Damergou and certain villages in the sedentary cantons close to the desert regions of Manga and Damagaram also took part in the uprising.

How can such enthusiasm be explained? It came without doubt initially as a result of people's declining living conditions, and historical ties through religious and tribal solidarity also united these people. The role of the leaders should not, however, be underestimated. Without pretending to put the results of history down only to the role of great men, it is enough to stress the real impact politicians can have on their people and in the process of revolt. As far as Abderahamane Tagama was concerned, his role was decisive and central although this does not emerge from written documents. He was at the heart of this resistance movement because he knew how to channel the diverse dissatisfactions and to assemble around him the necessary forces required for the fight, not in order to realize his own personal ambitions but to respond to collective aspirations.

Kawousan et Tagama ont conjugé leurs efforts. La révolte aurait pu être déclenchée sans Kawousan s'il y avait des armes, Kawousan a apporté les armes. Mais c'est un inconnu. Rien n'aurait pu être entrepris sans Tagama à qui appartient le pays et qui jouissait de l'estime des populations. ${ }^{27}$

Bourgeot supports this point of view: 'Tegama demeure un allié irréprochable sans lequel Kaosen et ses partisans n'auraient été que des bandes de pillard' ${ }^{28}$

More so than Kawousan, Tagama was the spiritual leader and the ideological force behind the resistance, and was the most politically minded of the people

\footnotetext{
${ }^{27}$ Information Rhoubeidi.

${ }^{28}$ Bourgeot, 'Les Echanges Transsahariens', 171, note 24.
} 
involved in the movement. He was not a professional military man but more an ideologist and an active propagandist who knew how to undertake patiently, discretely and methodically the job of mobilizing and sensitizing the local people, whose interests and positions were not always convergent. The Ayir, in spite of its relative ethnic homogeneity, did not constitute a unified political whole: three zones of political influence split the region. The eastern and mountainous areas were under the political and military control of the Kel Ewey, legally the dependants of the Anastafidet. They were constantly fighting the Tuareg of Damergou who regularly pilfered their caravans. The In Gall region was under the influence of the Kel Fadey while the Kel Ferwam was the predominant group in Agadez and in the western highlands, regions where theoretically the Sultan's power was limited. In addition, there was the original sedentary population of Songhay origin who were Hausa speaking and accounted for a large part of the population of Agadez. The town and the surrounding regions had 2,490 and 25,872 inhabitants respectively in $1916 .{ }^{29}$

Tagama's chief merit was to have been able, through dialogue, to realize a large regrouping of volunteers and to organize and unite them as a group against the common enemy, in spite of the cleavages created by wars in the nineteenth century, and the policy of division and terror pursued by the French colonial administration. It is equally to the credit of these populations that they were able to reach a degree of consciousness and establish a sense of internal cohesion. It is now possible, thanks to the written evidence of witnesses received by the colonial authorities after the revolt, to assess the central role Tagama played in the events. ${ }^{30}$

Tégama était le seul maître: tout le monde lui obéissait ${ }^{31}$

Tégama commandait à tous ${ }^{32}$

Tagama was the movement's principal leader who, both ideologically and politically, was able to inspire people and develop strategies. He discretely made preparations before Kawousan's arrival.

\footnotetext{
${ }^{29}$ Archives Nationales du Sénégal, Dakar, 22 G 33: Niger. Statistiques Générales 1916. Annuaire de l'A.O.F. 1916.

${ }^{30}$ Archives Nationales du Niger, Niamey, 'Affaire Tegama', Cercle d'Agadez, 2-7-2.

${ }^{31}$ Archives Nationales du Niger, Cercle d'Agadez, 2-7-2, no. 2, dépositions du témoin Massadou.

${ }^{32}$ Archives Nationales du Niger, Cercle d'Agadez, 2-7-2, no. 3, dépositions du témoin Mamadou.
} 
Seul Tagama savait quand Kawousan arriverait. Personne n'était dans le secret. $C$ 'est un homme extrêmement discret et rusé. ${ }^{33}$

Available data do not allow an accurate description of preparations or of the first contacts between Kawousan and Tagama, although a letter from Sidi Mohammed El Labid to the Sultan is dated 1913 or 1914. By the beginning of 1916, Tagama was diverting the attention of Captain Bosch from the troubles that were unfolding in Ayir. From April 1916, the commander of the cercle issued orders demanding that the post be defended. ${ }^{34}$

Tagama continued his diversionary actions until Captain Sabatié took up his position and recognized the extraordinary effort that Tagama had made to curb the colonial administration's power in Agadez without arising any suspicions and to ease the infiltration of the Sanûssi. ${ }^{35}$ It was during the first part of 1916 that Tagama could skilfully have had assassinated one of his closest collaborators, Elhadj Tourawa Melle, who was on very good terms with the French. ${ }^{36}$ Then Tagama undertook the construction of housing for Kawousan and his men, explaining that the building was destined to 'héberger des hôtes illustres, de grands marabouts'.

Kawousan's army, which had to reach Agadez via Djado and Iférouwane, was made up of mainly Chaamba Arabs originally from southern Algeria, of Toubou and of Tuareg Kel Ajjer, Kel Ewey, Kel Fadey and Ikaskazen. With modern equipment (rapid-fire guns, machine guns and canons), the army was in a strong position to be able to recruit a large proportion of professional soldiers, notably deserters from the Italian army (askaris) and from French Saharan camelry units that had already gained some experience with modern warfare.

The first part of the column making up the advanced guard was led by the chief of a group of Tuareg Ikaskazen, Agali Touboushkouwan. They arrived in Agadez during the night of 12-13 December 1916. According to Tairou, the

\footnotetext{
${ }^{33}$ Elhadj Aman Bougounou, Agadez, August 1985.

${ }^{34}$ Archives du Cercle d'Agadez, Commandant du Territoire au Commandant du Cercle d'Agadez: Note confidentielle no. $99 \mathrm{C}$ du 14 avril 1916. On this point it seems dangerous to say that 'le capitaine Bosch était sans doute de connivence avec le sultan Tagama', Salifou, Kawousan, 62, note 83. There is no proof of this.

${ }^{35}$ Archives Nationales de France, Vincennes, Fonds A.O.F. Section Niger, V: Rapport du Capitaine Sabatié, commandant le poste d'Agadez sur le siège du poste, 13 décembre 1916 au 3 mars 1917 inclus. p. 1-2.

${ }^{36}$ Elhadj Tourawa Mellé was Sarkin Tourawa (leader of the Arabs) and with this title was second in command under the Sultan. He was both Chief of War and Chief of Caravans of Bilma.

${ }^{37}$ Malam Yaro, Agadez, August 1985.
} 
group of about 200 riflemen, who were received and put up by Tagama, ${ }^{38}$ was made up of Ikaskazan, Kel Fadeye, Kel Tedele, Ifadeyan and Kel Ferwane. It was the following day that Tagama sent several missions to various tribal chiefs in order to win back Agadez. The Ikaskazan, Ifadayen, Kel Gharous, Kel Ferwane, Almousakarès and Kel Dinnik responded first and went to set up camp just outside the town. The same requests were sent to chiefs Moussa Ag Amastane of the Kel Ahaggar, Attati of the Esharifane, Kel Ewey and Kel Gres. ${ }^{39}$ Tagama then gave the order to stop all people who had contacts with the French: boys, cooks, interpreters, riflemen's wives, and certain traders including the Tunisian negotiator Mohammed Allane. Most were held in prison, although a few, such as Samba the interpreter at the French post, were executed. ${ }^{40}$

Aghali's army began to attack the post early in the morning of 13 December 1916. Captain Sabatié, alerted by Samba's widow, just had enough time to move arms, ammunition and money that had been left outside the keep. They organized the defence of the post with the equipment they had at their disposal. $^{41}$

Kawousan reached Agadez with the main part of the column, the canon and the machine guns on 17 December:

Le lendemain, grande palabre. Tégama préside, Agali et Kaossen y prennent part. Kaossen déclare être venu sur l'invitation de Tégama pour chasser les Français. Des messages écrits sont envoyés à toutes les tribus de l'Ä̈r, par les hommes de Tégama. Il y était dit que les Français allaient être détruits et chassés par la force; que ceux qui ne se déclareraient pas pour Tégama seraient considérés comme ennemis, attaqués et punis après la prise du poste d'Agadez. Au bout de quinze jours, le résultat était acquis : toutes les tribus s'étaient rendues à Agadez, plus ou moins volontairement. Les plus récalcitrantes (tels que les Kel Ewey) avaient été visitées par l'anastafidet Ekade et Kaossen lui-même. Un message avait été envoyé au Sultan de Kano pour le prévenir des événements qui allaient se passer. ${ }^{42}$

\footnotetext{
${ }^{38}$ Archives Nationales du Niger, Niamey, 2-7-2. Déposition du Témoin Tairou, p. 1.

${ }^{39}$ Salifou, Kaoussan, 61. From a document by Malam Bohary Tanode d'Agadez à Boubou Hama; see Boubou, 'Documents Nigériens', 172.

${ }^{40}$ Allane, Relations de Voyage, 6-9. Archives Nationales du Niger, 2-7-2, dépositions des témoins Mamadou et Massadou. They talk 'd'un sujet anglais de couleur le nommé Marc Farlane, agent de la London Kano Company Limited' who would have been assassinated by Tagama's men. Archives du Cercle de Zinder: Le Capitaine commandant le cercle de Zinder au Commissaire du Gouvernement Général au Territoire Militaire du Niger, Zinder, le 9 janvier 1917.

${ }^{41}$ Archives Nationales de France, Vincennes, A.O.F., Niger, V: Rapport du Capitaine Sabatié sur le siège d'Agadez, p. 6.

${ }^{42}$ Archives Nationales du Niger, Niamey, 2-7-2: Affaire Tégama, déposition du témoin Tairou, p. 2.
} 
Tagama again seems to have played a pivotal role during the siege in a military, ideological and political sense. It was he who assembled the arms and ammunition, assumed the coordination of the operation and organized the fighting against the French troops sent to assist their soldiers. ${ }^{43}$

Agadez was under siege, a state that would last for 80 days and even then the war would not be finished and would last for long months in the mountains, in Kawar and in Fezzan. This military episode is well known ${ }^{44}$ so our attention now turns to the direct and indirect repercussions of the attack of Agadez on other regions.

\section{Repercussions of the attack on Agadez on other regions}

The long Kawousan War provoked violent and open actions throughout the rest of the region. In the Azawak, Tamesna and Ahaggar, numerous groups of fighters soon joined Kawousan's troops ${ }^{45}$ Further to the south, participation by Damagaram, Damergou and Manga was invaluable, even decisive, in certain places. Control over this area, traditionally seen as the grain reserve of the northern region, was more than once at stake during the struggle, with both sides wanting to command access to it. The resistance forces were able to infiltrate the area and receive protection and assistance from the people near Gouré, Zinder and Madaoua. ${ }^{46}$

In the west of Niger and mainly in the subdivision of Filingué, the sedentary bella people in the cantons of Imanan and Tegraza were cautious following the

${ }^{43}$ Archives Nationales du Niger, Niamey, 2-7-2: Affaire Tégama, p. 1-4.

${ }^{44}$ Riou, La Révolte de Kaocen, 19-25; Fuglestad, 'Les Revoltes des Tuareg', 96-116; Salifou, Kawousan, 66-157; F. Fuglestad, A History of Niger, 1850-1960 (Cambridge, 1983), 95-100; J.L. Dufour, 'Les Confins Sahariens du Territoire Militaire du Niger pendant la Grande Guerre. Aîr, Tibesti, Kaouar, Mémoire de Maîtrise d'Histoire' (Paris, 1974); J.L. Dufour, 'La Révolte Tuareg et le Siège d'Agadez (13 Décembre 1916 - 3 March 1917)', Relations Internationales, 3 (1975), 57-77.

${ }^{45}$ F. Nicolas, Tamesna: Les Loullemenden de l'Est ou Tuareg Kel Dinnik (Paris, 1950), 89-104; E. Séré de Rivières, Histoire du Niger (Paris, 1965), 225-28. On the attitude of the leaders of the Kel Ahagar Moussa ag Amastane during the revolt, see Archives Nationales de France, Vincennes, A.O.F., Niger, V. Rapport du Capitaine Depommier, commandant le groupe mobile du Hoggar sur la conduite de Moussa ag Amastane pendant la période de décembre 1916 à août 1917; Norris, The Tuareg, 168-71; H. Lhote, Les Tuareg du Hoggar (Paris, 1955), 345-77.

${ }^{46}$ Archives Nationales du Sénégal, 2G17-12. Rapport Politique, $2^{\text {ème }}$ trimestre 1917; Archives Nationales du Niger, Cercle de Zinder. Rapport Politique du Cercle de Zinder, $4^{\text {ème }}$ trimestre 1917; Archives Nationales du Niger, cercle de Gouré, $4^{\text {ème }}$ trimestre 1917. 
failure and repression of the revolt of Firhoun. They therefore had some reservations after the announcement of the siege of Agadez. The military precautions taken (and enforced by the French administration in Niamey), which included the disarming of the population and the sending of a reconnaissance patrol, hardly favoured a manifestation of open revolt. ${ }^{47}$

In neighbouring Nigeria, Governor Lugard received a telegram on 23 December from Dakar informing him of the invasion of the French Sahara by the Sanûssi. A day later, news of the siege of Agadez arrived as well as a request from the Secretary-General of the AOF, Fournier, who demanded safe passage between Kano and Zinder for troops sent from Dakar. At the same time, Fournier informed Lugard of the instructions issued by the head of the military forces in Zinder to call on the nearby British garrison in case of emergency. Lugard, deeply concerned by the developing situation in Niger, declared a state of emergency on 3 January 1917.

Captain Faulque de Jonquières demanded reinforcements from Lugard in the middle of January 1917 and British colonial soldiers were given the role of protecting the sedentary zones of Tahoua, Maradi and Madaoua and of quashing any sign of incursion by resistance fighters in the south. Two British columns were sent to the military area in Niger. One, led by Colonel Coles, left Katsina with two mounted companies, one canon and two machine guns. The contingent arrived in Maradi on 13 January and received orders to meet at Tessaoua on 19 January. ${ }^{48}$ The second column, coming from Sokoto, was commanded by Captain Randall and was made up of 65 riflemen on foot, a mounted company of 85 men and two machine guns. It was sent to Tahoua where it arrived on 20 January. Lugard did not want his men to intervene in the fighting around Ayir and their role was principally to offer help in patrolling and in setting up several mobile posts. After staying about four months in the military zone in Niger (from mid-January to mid-May 1917), the two British columns returned to their respective bases in Nigeria.

As a result of this cooperation with the British administration in Nigeria, the French had at their disposal some 2,000 extra riflemen, 8 machine guns, 6

\footnotetext{
${ }^{47}$ Archives Nationales du Sénégal, 2G17-12. Rapport Politique, $2^{\text {ème }}$ trimestre 1917; Archives Nationales du Niger, Cercle de Zinder. Rapport Politique du Cercle de Zinder, $4^{\text {ème }}$ trimestre 1917; Archives Nationales du Niger, Cercle de Gouré, $4^{\text {ème }}$ trimestre 1917.

${ }^{48}$ Archives Nationales du Niger, Niamey; Lieutenant-Colonel Coles commandant la colonne du Katsina au Lieutenant-Colonel Mourin commandant la colonne de l'Aîr et Commissaire du Gouvernement Général au Territoire Militaire du Niger. Kaduna le I juin 1917. The remainder of the column (100 sharp shooters) remained in Katsina ready to go to Niger.
} 
canons, 394 camels, 109 mounted soldiers and 17 tonnes of equipment. This equipment would allow the French army to consolidate its positions in Niamey, Bilma, N'Guigmi, Filingué and Tahoua and to deploy more forces in the centre of the area of resistance ${ }^{49}$ with the men who were already in Ayir to liberate Agadez.

Alongside this military assistance, the British authorities adopted a number of political and administrative measures in areas adjacent to the military zones likely to assist the French: a reintegration of immigrant populations into the area, the policing of nomadic groups that were allied to the resistance movement, the requisitioning of camels, horses and porters for provisioning, a constant exchange of political information of the highest importance etc. ${ }^{50}$

What evidence is there of allegations about relations between the resistance leaders and Nigeria? The French authorities' reports are based on correspondence found after the liberation of Agadez or from their intelligence agents.

The first item in the dossier would be Kawousan's letter of October 1916 to his uncles El Hajj Mousa and Adambar in which he stated that the Germans and the Turks had to join forces at Kano with the columns coming down from Tripolitania. $^{51}$ In May 1917, the chief of battalion, Laforge, asked the Ayir commander to order an inquiry 'pour savoir si Kaossen au cours du siège d'Agadez a adressé des lettres ou envoyé des émissaires à des sultans de la Nigéria et plus particulièrement à celui de Kano, ${ }^{52}$

Accusations were laid first against the Emir of Kano and then the Sultan of Sokoto. The chief colonial officer of Niger passed his information on to Lugard and Sarkin Musulmin of Sokoto would be constantly in touch with Kawousan to whom he had promised his help if the Sanûssi managed to enter the town. ${ }^{53}$ Lugard wanted to verify all the details so set off on a journey to the north of

\footnotetext{
${ }^{49}$ Colonial Office Records: 583/58/43044. Lieutenant-Colonel Jenkins, 'Report on the Situation on the Northern Frontier', 25 juillet 1917.

${ }^{50}$ Archives Nationales du Sénégal, Dakar, 2G17-12, Niger à A.O.F. Rapport Politique, $1^{\mathrm{er}}$ trimestre 1917, p. 14.

${ }^{51}$ Archives Nationales du Niger, Niamey, 2.7.2; Mangeot, 'Le Siège d'Agadez', 47982.

52 Archives Nationales du Niger, Agadez. Note confidentielle, Chef de bataillon Laforgue chargé de l'expédition des affaires au Territoire militaire du Niger au commandant de la colonne de l'Aîr, Zinder le 10 mai 1917; M. Zbairu Kolo, 'The Kawousan Rebellion of 1916-1918 with Particular Reference to its Impact on Northern Nigeria', PhD thesis, Ahmadu Bello University (Zaria, 1973).

${ }^{53}$ J. Osuntokun, 'The Response of the British Colonial Government in Nigeria to the Islamic Insurgency in the French Sudan and the Sahara during the First World War', Bulletin de l'I.F.A.N, XXXVI, B, 1 (1974), 23.
} 
Nigeria to check on the loyalty of the emirs vis-à-vis the British administration. No evidence of their relations with Kawousan or Tagama could be detected.

Alongside these rumours and police indications, the affirmation by Séré de Rivières and by Fuglestad should be mentioned, according to whom, before the end of the siege of Agadez, 'des éléments sanûssi installés au Nigéria septentrional avaient organisé un convoi de ravitaillement destiné à Kaocen et ses hommes. Mais le convoi fut intercepté et capturé par un détachement français, assisté des Kanouri de Goudoumaria,. ${ }^{54}$ As far as oral tradition is concerned, the information is contradictory. While Elhadj Aman Bougounou remained quiet, ${ }^{55}$ the others were more outspoken:

Tagama était en relation avec Sarkin Katsina qui confectionnait les gris-gris et les envoyaient à Agadez par des émissaires. Tagama a informé Sarkin Katsina du plan. ${ }^{56}$

Finally, were relations between Kawousan, Tagama and the traditional authorities of northern Nigeria myth or reality? Undoubtedly the colonial authorities gave the question some thought. Whatever credit is placed on these sources, it is likely that the emirs of northern Nigeria would have been informed of the situation in Agadez. However, they reacted according to their own interests and to the situation in their own territories: with discretion and flexibility in Borno, Kano and Sokoto where Tagama had numerous contacts, but also with manifest opposition in Kabi which was clearly on the side of the colonial authorities. The situation was delicate for the emirs who had fresh and recent memories of the deportation to Ilorin of defeated colleagues who had collaborated in the revolts of 1915-1916. They had to proceed with caution and tact as 'one never knows what will happen'. Their loyalties were divided between Islamic loyalty for their Muslim brothers and their loyalty vis-à-vis the administration. It was the latter which ultimately carried more weight.

\section{Interpretation}

The Kawousan War extended beyond traditional political players, witnessed the use of modern armaments and received support from external sources. The involvement of the many colonial powers of the time - France, Italy, Great Britain, Germany and Turkey - and the alliance with the Sanûssiya gave it an

\footnotetext{
${ }^{54}$ Fuglestad, 'Les Révoltes des Touraeg', 107; Séré de Rivières, Histoire du Niger, 226.

${ }^{55}$ Information Elhadj Aman Bougounou, Agadez.

${ }^{56}$ Information Malam Yaro, Agadez.
} 
international dimension, which is probably why it attracted so much attention and was so widely debated by writers at the time. Four principle theses constitute the fundamental axes of the different approaches: (i) the bandits pillards (plundering bandits) theory; (ii) the révolte sénoussiste (Sénoussiste revolt) theory which emphasized the religious factors and attributed the Sanûssiya with a decisive role in the conflict; (iii) the war-against-the-French theory; and (iv) the modernist theory put forward by the leaders of political parties fighting for independence as well as the recent Tuareg rebellion in Niger.

\section{The 'bandits pillards' theory}

This interpretation does not consider the Kawousan War as a revolt but more as a raid, an opportunity to plunder and loot. Fuglestad, who supports this theory, wrote that the Kawousan War 'ajouta seulement une bande supplémentaire à toutes les bandes qui parcouraient le pays ${ }^{57} \mathrm{He}$ ignores the political dimension of the movement dismissing it as a simple pillaging operation that was essentially materialistic in origin. In this way he puts all Tuareg raiding actions down to reaction against colonial domination. At the same time it implies an ineptitude on the part of the Tuareg to rise above their internal rivalries to unite against a common enemy. This all translates into a profound misunderstanding of the double defence strategies adopted by the Tuareg from the outset of colonial penetration. This consisted in part of establishing internal and external alliances with a view to reinforcing their defences and also of organizing the raids against the enemy to weaken and defeat its army. ${ }^{58}$ Actions varied from escape and evasion (avoiding the enemy and playing for time) to armed resistance, but also the use of submission, diplomacy, underground tactics and exile.

\section{A Sénoussiste revolt? A Muslim plot?}

Islam, and the Sanûssiya in particular, have been considered by various writers as the driving force behind the Kawousan War. This interpretation came largely from colonial sources and was subsequently reproduced in numerous publications. Abadie spoke of the Mouvement Sénoussiste ${ }^{59}$ and for Séré de Rivières it was all about un complexe de guerre sainte (a complex religious war). ${ }^{60}$ André Salifou's book was entitled Kaoussan ou la Révolte Sénoussiste, and one of the chapters in Norris's book was 'The Twareg Jihâd against the

\footnotetext{
${ }^{57}$ Fuglestad, 'Les Révoltes des Touraeg', 115.

${ }^{58}$ Claudot-Hawad, 'Exil et Résistance', 23-26.

${ }^{59}$ Abadie, Afrique Centrale, 327.

${ }^{60}$ Séré de Rivières, Histoire du Niger, 225.
} 
French' ${ }^{61}$ Finally Casajus describes the role of the religious engagement in the resistance. ${ }^{62}$ Clarification of the role of the Sanûssiya in this revolt involves returning to the political and ideological roots of the revolt and determining the nature of the alliance between the resistance and the Sanûssiya.

The Sanûssiya and their brothers - a group of individuals joined by the same doctrine and the same religious philosophy - were established in 1837 by Mohamed Ben Ali es Sanûssi el Hassani el Idrisi who was born in 1792 in Torch in Oranie. ${ }^{63}$ The Sanûssiya enjoyed considerable success and its leaders had complete authority throughout Libya and northern Chad. They had numerous disciples in Algeria, Morocco, Tunisia, Saudi Arabia, Egypt, eastern Sudan and Somalia and its influence spread through Mesopotamia as far as Indonesia. In Nigeria, the Kawar, the Ayir, the Damagaram and the Damergou were the main areas of Sanûssiya influence between 1860 and 1899. Many Zawiya including schools and mosques were founded in Bilma and Zinder and in the Ader and Ayir.

The Sanûssiya are orthodox and similar to the Wahhâbist order set up in Saudi Arabia at the beginning of the nineteenth century by Mohammed ibn Abd-al-Wahhab. ${ }^{64}$ The Sanûssiya and the Wahhâbites represented 'les tendances conservatrices des mouvements islamiques prémodernistes de réforme ${ }^{65}$ Like the Wahhâbites, the Sanûssi can be identified by a rigorous adherence to a pure and primitive Islam, rejecting all that was introduced later including the cult of saints, tombs, relics etc. that are considered to negatively influence the true belief. ${ }^{66}$ The Sanûssiya totally reject the doctrine of union with God conceived by Sufism and substitute a mystical union with the spirit of the prophet Mohammed. This is the origin of the name Mohammediya tariqa sometimes given to the movement. It equally rejects Islamic intellectual tendencies and preaches a direct interpretation of its origins without erudition.

\footnotetext{
${ }^{61}$ Norris, The Tuareg, 162-73.

${ }^{62}$ D. Casajus, 'Islam et Noblesse chez les Tuareg', L'Homme, XXX, 3 (1990), 7-30.

${ }^{63}$ O. Meynier, 'La Guerre Sainte des Senousya dans l'Afrique Française (1915-1918)', Revue Africaine, LXXXIII, 2 (1939), 227-75. His date of birth is different in other sources: 1787 in J.S. Trimingham, A History of Islam in West Africa (Oxford, 1974), 159, and 1781 in A. Gouilly, L'Islam dans l'A.O.F. (Paris, 1952), 165.

${ }^{64}$ The leadership of the movement reverted to Mohammed ibn Saoud, the founder of the royal dynasty of Saudi Arabia.

${ }^{65}$ R. Fazlur, 'Revival and Reform in Islam', in The Cambridge History of Islam, volume 2 (Cambridge, 1977), 637.

${ }^{66}$ It could even be said that the Sanûssi were the puritans of Western Islam as the Wahhabites are the puritans of the East. W.E. Muhlamann, 'Mouvements Islamiques et Hindous', in W.E. Muhlamann (ed.), Messianismes Révolutionnaires du Tiers-Monde (Paris, 1968), 158-59.
} 
In addition, the Sanûssiya opt for the promotion of a moral and Islamic solidarity based on honesty, egalitarianism, Islamic cooperation and economic justice. ${ }^{67}$ They thus set up cooperative farms and undertook commercial activities. The Sanûssiya relied on the Zawiya, a monastic group with places where educational retreats could be held of a religious and cultural nature. ${ }^{68}$ Except for these distinctive traits, the aims of Sanûssiya dogma were generally the same as other brotherhoods, especially regarding the step-by-step reunification of African Muslims and the creation of a Muslim empire that would be united, pure and respectful of the authentic teachings of the prophet.

It was with all these considerations in mind that the colonial authorities at the time called the brotherhood movement 'xénophobe, militant, agressif et fanatique' and 'anti-européen'. ${ }^{69}$ In reality, the newly founded brotherhood wanted to affirm its orthodoxy in relation to existing practices that it considered tainted by pernicious influences. It wanted to withdraw from these and promote emigration or jihad (holy war) and to retreat into the austerity of the Sahel to preserve the purity of an original Islam. Subsequently its anti-colonial activities were more or less force of circumstance.

It was in the name of all these principles that the Sanûssiya established contact with the leaders of the Ayir. The strength of relations before the siege of Agadez between Tagama, Kawousan and Sanûssiya chiefs is acknowledged by oral tradition and colonial archive material. Sidi Mohammed El Labid, the representative of the Sanûssiya in Fezzan, wrote a letter dated 1914 to Tagama. ${ }^{70}$ The two had never met but their correspondence suggests a secret project dating from around this time. Let us now consider the position of the main leaders and the population vis-à-vis the Sanûssiya.

To fully appreciate Kawousan's relations with the Sanûssiya, it is necessary to look at his time in exile and analyse the nature of the alliances he had with the different camps. What is most remarkable is the diversity of the alliances and the different volte-face. Kawousan always seems to have been guided by the need to set up and maintain a strong and modern army. This was the main motivation behind all his actions. He received arms from the Sanûssi who he helped fight against the French between 1909 and 1912, then from the French

\footnotetext{
${ }^{67}$ Fazlur, 'Revival and Reform', 638-39.

${ }^{68}$ Following a policy of systematic Islamization, the Sanûssi gradually opened schools everywhere and bought young slaves in Chad who they taught before sending them back to their own country to spread the word of the Koran.

${ }^{69}$ Gouilly, L'Islam dans l'A.O.F., 166.

${ }^{70}$ Archives Nationales du Niger, Cercle d'Agadez: Lettre de Sidi Mohamed el Labid au Sultan d'Agadez, écrite à la fin de kaada 1332 (1914). Traduction de l'officier interprète de deuxième classe, Gisselbrecht, Agadez le 10 mars 1917.
} 
with whom he fought from 1912 to 1915, then the Turks and finally again the Sanûssi during his stay in Tripolitania in 1916 before going to the Ayir region. Even after the retreat of resistance fighters outside Agadez (13 July 1917) and then from the Ayir (25 March 1918), he adopted the same attitude. Initially allied to the Turks in Fezzan, he then formed an alliance with the Sanûssi who provided him with significant quantities of arms and ammunition. Kawousan played this game of double alliances until the end and eventually it was the cause of his own death. Having received vital armaments from the Sanûssi, he wanted to conclude an alliance with the Turks in Tibesti. They, however, were aware of his tactics, and attacked, captured and hung him.

In this game of reverse alliances, there is no place for ideology and Kawousan did not concern himself with such trivialities. He was pragmatic, manipulating with a rare persuasive power the Sanûssi, the Turks, the French and the Italians depending on the circumstances. He no doubt fully understood the context of the colonial complexities in which each of the camps had its own colonial agenda. His references to Islam and to the holy war in his correspondence with Tagama and other Tuareg leaders is based on political propaganda. Kawousan knew that Islam alone could convince the population to accept resistance and enrol their children in his army. In the political context of the time, only Islam could play a unifying role because it could overcome internal political opposition within Tuareg groups. In this respect, Islam - and the Sanûssi - could only have had an instrumental function and did not assume any ideological role. Elsewhere, Kawousan always rose up against the blind fanaticism of fighters who wanted to engage in a holy war and pronounced religious incantations and honour against the bullets of adversaries. He wanted a well-structured and disciplined army with soldiers knowledgeable about the tactics of modern warfare, like those led by his European enemies. ${ }^{71}$

Regarding the position of Tagama, Bourgeot may have been right when he affirmed that 'Tegama était probablement le plus senoussiste des dissidents - ce qui est inhérent à la fonction de sultan, qui doit assurer un rôle religieux? ${ }^{, 72}$ In Agadez, only one informant could confirm Tagama's affiliation with the Sanûssi with any certainty:

Tagama a étudié au Borno et à Kano. Il était à Kano lorsqu'on fit appel à lui pour diriger le sultanat. C'est un grand musulman et un grand marabout. C'est une fois devenu sultan qu'il a été converti à la Sanûssiya par Sidikou, un marabout arabe de Ghât installé à Agadez. ${ }^{73}$

\footnotetext{
${ }^{71}$ Claudot-Hawad, 'Exil et Résistance', 36.

${ }^{72}$ Bourgeot, 'Les Echanges Transsahariens', 171.

${ }^{73}$ Oral information Aman Dan Mallam, Agadez, July 1985.
} 
Elhadj Bougounou was more nuanced:

Tagama sénoussiste? Non ... C'est difficile de dire à quelle confrérie il appartenait. Il est musulman. C'est tout. C'était là la base de ses relations avec Kawousan. La raison du ralliement de Tagama à la révolte, c'est l'islam. Il ne pouvait accepter d'être un subordonné des Français, des Kafrs... C'est une guerre contre les Français qui voulaient imposer leur coutume et altérer l'islam. Au moment de tirer, les résistants s'écriaient: 'La illaha illala, jihadi fi sabih allah'. C'était une jihad, pas pour le pillage ou le butin mais pour défendre l'islam. Les combattants ont fait la guerre aux Français mais pas aux musulmans. ${ }^{74}$

This is a similar point of view to Malam Alfaki Almoustapha's, according to whom Kawousan would have obtained Tagama's agreement by stressing the following theme:

Mou kori kafiray, mou samou kassan mou.

Guerre aux kafrs, libérons notre pays. ${ }^{75}$

This slogan agreed with the interests of the resistance fighters and Tagama. The rallying of Tagama to the resistance was in accordance with his political and religious beliefs. Were external threats not the main cause of the creation of the Sultanate? Ayir traditions bestowed the official title of Imam Amir-al-Mouminin (Commander of the Believers) on the Sultan. His legitimacy in the eyes of his people was related to his devotion to Islam. The fight also offered him the chance to increase his political power - limited until now - and to impose an authority weakened by political rivalries dividing the Kel Ayir. Alliances with Kawousan and above all with the Sanûssi allowed him to bask in his prestige. In this Muslim country, the words 'Guerre aux Kafrs, libérons notre pays' were mobilizing. It was a political programme that conformed to the immediate interests of the population. It was the religious and political duty of the Sultan to whom he had pledged to fight this war with the infidels and to liberate his country from French domination. This all conforms to the Islamic vision that divided the world into two domains: dar al islam (the land of Islam) and dar ek $k u f r$ (the land of the infidels). Islam demands that men live according to Muslim authorities. The power of the unfaithful over Muslims represents a situation of scandal in their faith. Islam preaches either jihad (holy war) or hijra (emigration) for believers in order to cleanse themselves of the power of the

\footnotetext{
${ }^{74}$ Oral information Elhadj Bougounou, Agadez, July 1985.

${ }^{75}$ Oral information Malam Alfaki Moustapha, Agadez, July 1985.
} 
infidel. Kawousan and Tagama opted for a holy war because it better fulfilled their purposes. Islam or Sanûssiya served to overcome political opposition, to assemble and mobilize the people, and to recruit fighters.

How did the people interpret this resistance? Firstly, popular history remembers this period by the name of Yakin Kawousan. This highlights the importance accorded to Kawousan, who is considered the one who won the war at Agadez and was seen as the main military leader. Secondly, when analysing the same oral sources, it becomes apparent that Tagama was showered in eulogies for the period prior to the resistance but judgements were severe and criticism harsh when one considers the revolt. The Sultan would have brought bad luck to Agadez by allying with Kawousan and by wanting to fight the French who were judged as being too powerful. Informants described the opinion of the people of Agadez at that time as follows: 'Tagama ya cu ce mu' meaning 'Tagama has hurt us'. ${ }^{76}$ Oral tradition retains the negative character of the war to highlight the harsh repression that was endured by Agadez and the whole of the Ayir. Responsibility for this is laid squarely on the shoulders of Tagama who wanted to fight the French who were clearly too strong for him. The Ayir was ruined and the region lost half its population. However in no way was the resistance seen as a religious war supported by the Sanûssiya.

Between Tagama, Kawousan and the Sanûssiya there was a tactical alliance, a convergence of military, political, religious and economic interests. The Sanûssiya certainly supplied Kawousan's army. However all the objective conditions of a revolt were laid down well before Kawousan and his men's arrival in the Ayir. Identifying the resistance as a Sanûssiya movement appears to be too hasty a conclusion to draw and diminishes the complexity of the revolt at the same time as simplifying its meaning and its extent. To consider the Kawousan War as a Sénoussiste revolt tends to corroborate the thesis of a war led from outside by the Sanûssi supported by Turkish-German agents of which Kawousan was a part. Adherence to the Sanûssiya and adhesion to the resistance movement do not cover the same reality. This false interpretation of the revolt led the French troops to indiscriminately exterminate all Muslim groups in Agadez. More than 100 Muslim scholars assembled in a mosque were massacred in March 1917 even though they had told Colonel Mourin in a letter that they denied all responsibility for what had happened. ${ }^{77}$

\footnotetext{
${ }^{76}$ Information Elhadj Aman Bougounou, Agadez, August 1985.

${ }^{77}$ Triaud, 'Un Episode Oubliée', 263-71.
} 
An anti-French war?

This theory sees the revolt as a simple prolongation of the First World War, a movement armed and financed by the Germans. For the French, the causes of the war were external. In their opinion, it was a vast Muslim plot supported ideologically by the Sanûssiya, and materially by Turkey and Germany. ${ }^{78}$ It is only colonial mythology that involves people like Dr Frobenius with the revolt and magnifies facts to make it appear as if the revolt was due to the power of the Sanûssiya or was an alleged holy war backed by a German-Turkish alliance to attack French bases in Africa. ${ }^{79}$

The authorities in Niger do not agree with this interpretation:

.... On ne peut guère admettre que ce soit là le vrai mobile qui ait poussé les insurgés. Il est vraisemblable et même probable que ces mouvements ont été encouragés par les nationaux allemands et turcs de la Tripolitaine, mais ces encouragements sont restés jusqu'ici purement platoniques ou tout au moins de bien faible importance. Il n'y a pas de lien entre la guerre européenne et les événements de l'Aïr. Les causes sont purement locales. ${ }^{80}$

Two further reasons allow the European war and the Kawousan War to be separated. The Sanûssiya, as already mentioned, were militarily weak and politically in crisis. Additionally, any Sanûssiya alliance with a particular European country should not be overestimated. Sanûssiya alliances during the war experienced various fluctuations: they fought against the English in Egypt and in Sudan, then against the Italians in Libya until 1928. In 1943 they collaborated with the English and the French against the Italians in Libya.

\section{The War of Kawousan and contemporary nationalist movements}

For the leaders of the political parties who fought for independence and for the leaders of the recent Tuareg rebellion in Niger, there was more continuity between the different periods of resistance. They all identified with the Kawousan War. The Sawaba party led by Djibo Bakary declared in one of its publications:

C'est de ce passé glorieux [les résistances anticoloniales], parfois douloureux et dramatique, que nous pouvons puiser à la fois des leçons de courage et de patriotisme et des éléments nécessaires pour réhabiliter notre culture et notre Histoire....N'étaient-ce pas les valeureux guerriers de l'Aîr, conduits par Kaoussen

\footnotetext{
${ }^{78}$ Abadie, Afrique Centrale, 327-28.

${ }^{79}$ Séré de Rivières, Histoire du Niger, 224-25.

80 Archives Nationales du Sénégal, Dakar, 2G16-12. Niger à A.O.F. Rapport d'ensemble annuel, 44.
} 
et Tegama, qui, en 1916 infligèrent aux troupes françaises de dures défaites et vinrent mettre le siège devant Agadez où les Français durent s'enfermer dans un fort ${ }^{81}$

The leaders of the Tuareg rebellion in Niger established a link between the anticolonial revolts and recent rebellions. They have made a personalized history of Tuareg society based on the Kawousan War and still see this event as a step in the long process of a search for a certain modernity at the heart of Tuareg society in which the rebellion was inscribed and which continues to this day. Kawousan is considered as having brought an egalitarian society and democratic opposition to the conservatism represented by the aristocracy who wanted to maintain a social hierarchy directed by the old code of honour. Kawousan has been given the role of liberator, the federator seen as the unifier of the Tuareg world. ${ }^{82}$

\section{Conclusion}

The Kawousan War was undoubtedly the longest period of resistance ever known in Niger's previous military history, extending beyond colonial frontiers and even traditional politics. However, its root causes were purely internal, linked to colonial domination and to local economic and political factors. Economically, the Ayir region had faced a long period of decline in the living conditions of the local pastoralists and agro-pastoralists whose wealth was principally based on the trans-Saharan caravan trade that was declining significantly due to military operations in the area. French colonization had upset the way of life of these populations by the introduction of a policy of divide and rule, the breakdown of Tuareg confederations, the imposition of a policy of sedentarization, the creation of artificial political unities, the suppression of lines of bondage and the trafficking in slaves, the introduction of a double tax (a poll tax and a tax on cattle) and the huge requisitioning of men and livestock. In the eyes of the locals, these changes symbolized the establishment of dependent relationships and by extension, a policy of dependency and of servitude.

Neither a raid conducted by bandits pillards nor a Sénoussiste revolt, the Kawousan War was more than a simple Tuareg revolt. It was an anti-colonial

\footnotetext{
${ }^{81}$ Sawaba Parti Politique, 'Pour l'Indépendance Effective du Niger: Les Raisons de Notre Lutte' (Bamako, 1961), 14.

${ }^{82}$ Claudot-Hawad, 'Exil et Résistance', 32-33.
} 
The Kawousan War reconsidered 217

war through which the local populations attempted to free themselves from the yoke of colonialism and in particular French domination that had resulted in the loss of their main source of wealth - control of (trans) Saharan resources and trade - as well as their political independence. 


\title{
9
}

\section{Sawaba's rebellion in Niger (1964-1965): Narrative and meaning}

\author{
Klaas van Walraven
}

One of the least-studied revolts in post-colonial Africa, the invasion of Niger in 1964 by guerrillas of the outlawed Sawaba party was a dismal failure and culminated in a failed attempt on the life of President Diori in the spring of 1965. Personal aspirations for higher education, access to jobs and social advancement, probably constituted the driving force of Sawaba's rank and file. Lured by the party leader, Djibo Bakary, with promises of scholarships abroad, they went to the far corners of the world, for what turned out to be guerrilla training. The leadership's motivations were grounded in a personal desire for political power, justified by a cocktail of militant nationalism, Marxism-Leninism and Maoist beliefs. Sawaba, however, failed to grasp the weakness of its domestic support base. The mystifying dimensions of revolutionary ideologies may have encouraged Djibo to ignore the facts on the ground and order his foot soldiers to march to their deaths.

This chapter attempts to reconstruct a neglected episode in the post-colonial history of Niger. It focuses on an abortive invasion of this West African country in the autumn of 1964 by members of a clandestine political party, Sawaba. On the orders of their leader-in-exile, Djibo Bakary, armed commandos infiltrated Niger and tried to instigate a popular insurrection against the regime of President Hamani Diori and his ruling Parti Progressiste Nigérienne (PPN). Despite elaborate preparations, the commandos were caught completely off guard by the hostile reception they received from the peasant population and the government had little trouble in rounding them up with the assistance of the peasantry. By the end of November 1964, barely two months after the invasion, the Sawaba commandos had been routed. A dozen men had been killed, several were wounded and more than a hundred taken prisoner, while the rest had fled 
across the border. Several activists faced the death penalty or long terms of imprisonment. In April 1965, a last attempt was made to oust Niger's government, when a young Sawabist tried to assassinate the president. The attempt failed as dismally as the autumn revolt the year before and marked Sawaba's definitive exile into the political wilderness.

The main interest of this episode, on which no scholarly research has ever been undertaken, derives from the insight it provides into a bitter power struggle between two rival political forces. The underlying cause was, at least ostensibly, the search for an ideological foundation and definition of the legitimacy of the new, post-colonial polity. The revolt ${ }^{1}$ and its failure also involved certain other dimensions that make it of more than a passing interest to observers of Africa's past and contemporary politics.

This chapter argues that, despite the existence of regional, if not ethnic, cleavages and rivalries, the insurrection was caused by various factors, and regional tensions were probably only contextual. Since Niger's independence, its politics have to some extent been affected by regional fault lines that have set different regions and communities against each other. The principal fault line is the competition between the eastern parts of Niger, inhabited by Hausa-speaking communities, and the western regions of the country that are dominated by Zerma- and Songhai-speaking groups. While the groundnut-producing areas of the east constituted the main source of the country's national income at independence, it was the western Zerma and Songhai groups that took control of Niger's political system.

Nevertheless, social-generational competition may have been a more important aspect in the revolt, as this set younger people - Hausa as well as nonHausa - apart from an older generation of Nigeriens who either belonged to Hausaland's chiefly class or had monopolized the country's public life and assumed control of the limited numbers of jobs and benefits. Part of Sawaba's support base in the late 1950s was thus made up of relatively young men, some of Hausa origin and in particular, recent immigrants to Niger's emergent urban areas. Many were traders, transporters or members of Muslim brotherhoods such as the Tijaniyya - and retained links with their home region. As the most mobile and economically active members of their community, they resented the domination of Hausa society by the (neo)traditional canton chiefs or Sarkis conservative elements whose interests did not necessarily coincide with those of the younger generation. Many youngsters, Hausas and non-Hausas alike, wanted access to modern education or aspired to wealth and new positions in society,

\footnotetext{
${ }^{1}$ The terms 'revolt', 'rebellion' and 'insurrection' are used interchangeably here. The concept of 'invasion' points to the mode of, and the external-spatial dimension to, the rebellion.
} 
which neither the Hausa chiefly class nor Niger's state elite would provide. Sawaba's appeal, in this context, stemmed not only from the more militant strain of African nationalism that it professed, but probably also from its ability to offer these young men the possibility to go abroad to see new countries and learn new trades - an offer that the more ambitious and adventurous among them found difficult to resist. The party's ability to provide such attractive benefits depended on its charismatic leader, Djibo Bakary, who had longestablished contacts with the French communist party and had managed to build up a network of contacts in the Eastern bloc.

His reliance on Eastern-bloc aid brought Sawaba's violent bid for power squarely within a Cold-War ambit. As discussed below, Eastern European countries, the Soviet Union and especially communist China provided the party with political and military support. In fact, for the People's Republic of China, assisting Sawaba's revolt represented its first violent attempt to gain a foothold in West Africa. This in itself was not unique, since the Eastern bloc was, at the time, aiding nationalist parties and liberation movements in various Sub-Saharan countries, especially those still under colonial or settler suzerainty. However, for the communist bloc, Niger represented an attractive prize. While economically weak, the country was suspected, by the early 1960s, of having important deposits of uranium, one of the most strategic mineral resources of the Cold War. Secondly, the country was strategically located in West Africa between the region's would-be superpower - Nigeria - and Algeria, France's former mainstay that had also been its first nuclear testing ground. Thirdly, since Niger's political leadership was closely allied to President Houphouët-Boigny of Ivory Coast - France's staunchest and most anti-communist ally - a successful Sawaba takeover in Niger would have dealt a severe blow to the interests of France, the Western world and its African allies. Conversely, part of Sawaba's failure to topple Niger's government also stemmed from this Cold War context, as it led the French to defend their interests in Niger by trying to thwart Sawaba's invasion plans.

The Cold War context of Sawaba's insurrection also accounted for another astonishing - aspect of this story, namely the unfounded optimism with which the party's leadership went about its business. As argued in the last section of this chapter, this may have been tied to an understudied dimension of Marxistinspired liberation ideologies, which involve a degree of romanticism about revolutionary struggle that can easily blur one's view of reality.

The principal cause for failure stemmed from Sawaba's lack of domestic support. As will be shown, the party did not really have the backing of the Hausa peasantry, something which substantially weakened its internal support base that could, in practice, only sustain a ramshackle coalition of diverse interests between its leadership and the rank and file. That Sawaba drew at least some of 
its backing from Hausa and non-Hausa youths could not compensate for the lack of support of the Hausa populace and may well have dissipated its strength in a political system that was partly affected by regional fault lines. This weakness may have been reinforced by the fact that the party's rank and file was probably driven more by a mixture of personal aspirations and pragmatic opportunism than ethnic jealousies or revolutionary zeal per se. This assortment of motivations linked up with what was probably the main driving force behind Djibo Bakary's decision to instigate an insurrection - a long-standing personal feud with, and the desire to capture power from, his main political adversary. However, this assessment can only be tentative since data on the motivations of the individual actors are still sketchy, particularly those of Sawaba's rank and file. Further research is needed to gain a deeper understanding of what drove these men to their deaths or imprisonment.

Lastly, in trying to reconstruct the exact trajectories that the Sawabists followed before they met their fate, this chapter touches on two other external dimensions - one which today would probably be portrayed as a typical example of globalization, and the other involving a striking resemblance to the subversive political networks marking the regional context of some of West Africa's contemporary conflicts. Thus, the prelude of the rebellion took Sawaba activists to the far corners of the world, visiting, studying and training in Eastern Europe, the Soviet Union, North Vietnam, Chinese cities like Peking and Nanking, Cuba and, possibly, North Korea. Moreover, in the run-up to the insurrection, Sawaba activists spread throughout North and West Africa, keeping in touch with each other, building subversive contacts and acquiring support from different African governments.

\section{A note on sources}

Before tracing the revolt's background, planning, execution and aftermath, and providing a tentative interpretation of its internal and external features, a few words are needed on the sources on which this reconstruction is based. The reconstruction of Sawaba's insurrection is hindered by a dearth of sources, especially primary source material. The sources at hand consist mainly of secondary documents such as newspaper reports and journalistic articles, which do not cite sources and are partly based on interviews by Western journalists with Sawabists caught after the revolt. 


\section{Théoric de tir.}

1.) Ie processas ble tir él's le recuel de l'assuc

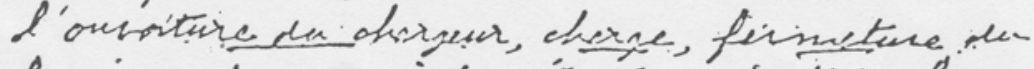

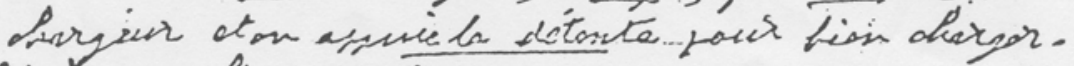
s.) De reul de t'rsme

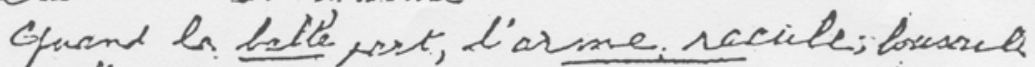

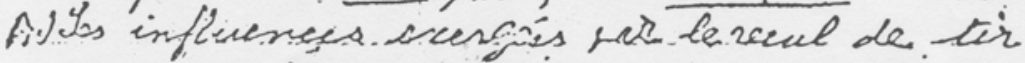
guend in tire de fivoil recule et sa teverone que ha ballo estójín pertie.

La reule inflivence la balle quxid wae fris tirs', sans swise be memey directions bo balles ext

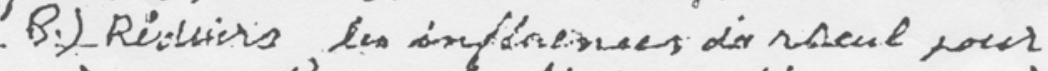

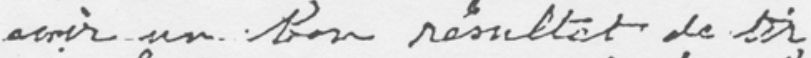

$$
\text { Entre he brens ot le fusit il deity }
$$

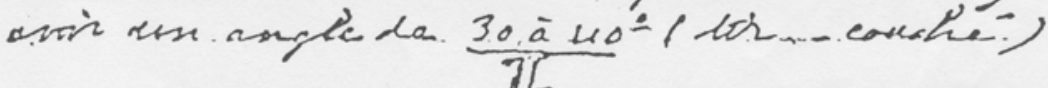

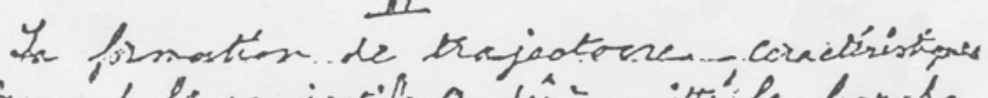
1). Guand le projectipls a deja' quitte' he brache - fere de savion it fair une hene crarbe

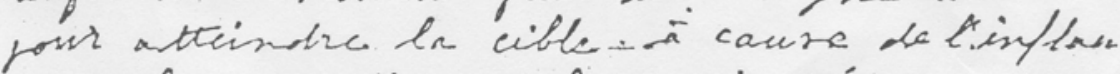
ee de la pacsanteur ot la pression presiatancel de $l$ 'air.

$$
\text { fliche, ha bollew de print be }
$$

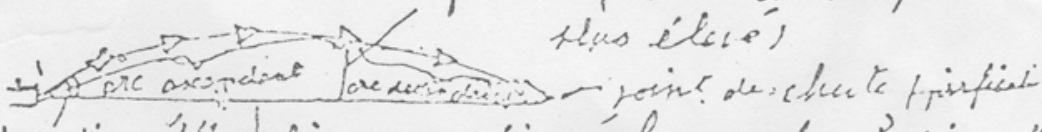

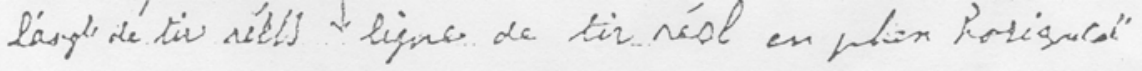

Figure 9.1 'The theory of firing a gun'. A page from the exercise book allegedly found on écolier terroriste Hassane Djibo who was taught in French by North Vietnamese instructors in Nanking.

Source: Fraternité Hebdo, 14 May 1965 
One should be careful in interpreting such evidence, as it was usually obtained in the presence of government officials. ${ }^{2}$ These interviews, nevertheless, contain a wealth of information about the planning and execution of the invasion. The same is true for a speech given by Camille Aliali, Niger's Foreign Minister, at the extraordinary session of the OAU Council of Ministers in Lagos in June 1965, where the complicity of other West African countries in the insurrection was discussed. All these sources contain illustrative material such as photocopies of maps with the invasion plans and notes written in the personal notebooks of Sawaba guerrillas, which Niger's government claimed were found on activists when they were arrested (Figure 9.1). In addition to notebooks, maps and invasion plans, they also included ideological tracts of a Marxist-Maoist nature and texts of oaths that activists swore to the Sawaba cause. $^{3}$

\footnotetext{
2 The interview conducted by Wolfgang Bretholz (National Zeitung, Bern) with incarcerated Sawabists was reprinted in Fraternité Hebdo of 14 May 1965, the organ of the ruling party in Ivory Coast, an ally of Niger's government. Entitled 'Les Camps de Sofia, Nankin et Accra en Ont Fait un Tueur', it was conducted in the presence of the Assistant Director of Niger's Sûreté. Handcuffs were taken off during the interview. While treatment of the Sawabists was harsh, Bretholz's interviewees said they were not maltreated but that they had been sentenced to death or might face the death penalty and that they did not know whether they would be pardoned. In the second part of the interview (reprinted in Fraternité Hebdo, 21 May 1965, as 'Comment N'Krumah et Ses Amis Communistes Transforment de Jeunes Africains en Tueurs') other Sawabists denounced Djibo Bakary's 'criminal policy'. Another journalist, J.P. Ruttiman, mentioned complaints over insufficient or poor food. He also noted that, at one moment in his interview, the Director of the Bureau of Coordination in the President's Office, former French colonial governor Colombani, walked out and that the prisoners did not retract any statements. However, this interview took place in 1967 when the atmosphere in Niger had become more relaxed. Yet, this is an interesting source as it contains a description of a discussion between leadership and rank and file and their disagreements. Ruttiman also mentions that Ousmane Dan Galadima, the Sawabist who supervised the invasion in 1964, refused to sign the protocols of his interrogation, accusing government officials of twisting his words: J.P. Ruttiman, 'Le Président Hamani Diori Nous Déclare: "Djibo Bakary ne Constitue pas Actuellement un Danger pour Nous, Mais...", Afrique Nouvelle, 1035 (8-13 June 1967).

${ }^{3}$ See Bretholz, 'Les Camps de Sofia, Nankin et Accra' and 'Comment N'Krumah et Ses Amis Communistes', and an interview by Randolph Braumann, 'So Bildet China Mörder aus', Rheinischer Merkur, 18 (30 April 1965), 14. This was reprinted in French in Fraternité Hebdo of 28 May, 4 June and 11 June 1965 as 'Avec les Tueurs de la SAWABA'. Journalists were astonished that the Sawabists were caught with this material. Aliali's OAU speech was reprinted in Fraternité Hebdo of 2, 9 and 16 July 1965 as 'Le Contentieux Nigéro-Ghanéen'.
} 
While this material should not be interpreted at face value, ${ }^{4}$ it seems unlikely, in view of the amount and wealth of detail, that it was all fabricated by Sawaba's enemies. Much of it fits into a pattern of what is known about militant nationalism and movements of kindred organizations in other African states. Hence, it enables us to establish a picture of the patterns and meaning of the revolt when compared to other material, such as documentary sources retrieved from the National Archives of Ghana, ${ }^{5}$ whose government supported the invasion. Admittedly, the picture remains incomplete, notably with regard to the motivations of Sawaba's foot soldiers. Djibo Bakary himself never publicly came back to the issue ${ }^{6}$ nor, it seems, did other high-ranking Sawaba functionaries.

\section{'Thorez' - The prehistory to exile}

In the 1950s, Djibo Bakary was a rising star in public life in Niger. The son of a Zerma chief from the west of the country, and of low birth, Djibo was brought up in the central town of Tahoua where he learned Hausa. He was a cousin of Hamani Diori, and for some time also his friend, until the two fell out. Nicknamed 'Thorez', Djibo became a charismatic nationalist, who would soon

\footnotetext{
${ }^{4}$ Thus Bretholz's interviews were clearly arranged by the governments of Ivory Coast and Niger. See 'Les Camps de Sofia, Nankin et Accra'. Other journalists, like JeanPierre Morillon and Gilbert Comte, were openly anti-communist and sympathetic towards Niger's government, dubbing the Sawabists as terrorists. Georges Chaffard wrote a chapter containing the most detailed account of the insurrection in Les Carnets Secrets de la Décolonisation, vol. 2, (Paris, 1965), 269-332. While being less partisan and clearly having had access to some of the material mentioned above, Chaffard did not cite his sources. According to Finn Fuglestad, Chaffard was 'brilliant but not always accurate'. F. Fuglestad, 'Djibo Bakary, The French, and the Referendum of 1958 in Niger', Journal of African History, 14, 2 (1973), 313 n. 1. Also his A History of Niger 1850-1960 (Cambridge, 1983).

${ }^{5}$ Cited as 'GNA'. An early secondary source that sheds light on this dimension is W.S. Thompson, Ghana's Foreign Policy, 1957-1966: Diplomacy, Ideology, and the New State (Princeton, 1969).

${ }^{6}$ His autobiography ends in 1960 and in an interview at the end of the book, he evaded the issue. D. Bakary, Silence! On Décolonise ... Itinéraire Politique et Syndical d'un Militant Africain (Paris, 1992), 291. In an interview with J.R. de Benoist, he also stopped short of discussing political developments after 1960. 'Djibo Bakary Parle', Politique Africaine, 38 (June 1990), 98-110.

${ }^{7}$ After Maurice Thorez, leader of the French communist party, PCF.
} 
Sawaba's rebellion in Niger 225

antagonize the colonial administration with his militant rhetoric. ${ }^{8} \mathrm{He}$ was an active trade unionist in emerging urban areas, organizing strikes that resulted in substantial salary increases for urban wage earners. Backed by his close alliance with the French communist party and trade-union federation, Djibo was independent of the colonial administration and soon considered a major troublemaker. He tried, with some success, to penetrate traditional youth movements, women's organizations and crafts guilds, and built up some support among groundnut farmers in the west of the country.

Until the mid 1950s, however, Djibo's power base did not add up to an electoral majority. By 1956 this was in sight when his party, the Union Démocratique Nigérienne, merged with another political group that enjoyed backing in Hausaland, including that of many Sarkis or canton chiefs. Moreover, the ambitious Djibo decided to break with the communists, as association with a communist party was an electoral liability not only because of the hostility of the colonial administration but also in the face of attempts to gain a foothold in the more traditionally oriented Hausa areas.

The Hausas generally resented the domination of the Zerma and Songhai in Diori's PPN and the country's civil service, especially as Hausa groundnut production contributed the largest share to the national income. While half of Djibo's most prominent lieutenants came from other West African countries, his party was mainly staffed with Hausas, notably young, urban trade unionists who had, by the early 1960 s, left the countryside and could help to spread the party message. Nevertheless, his followers now made for strange bedfellows. Besides the trade unionists, Djibo's most faithful allies were local traders and followers of the Tijaniyya brotherhood, economically active people who opposed the traditional order represented by the party's other allies, the Sarkis, against whom Djibo had been agitating at an earlier stage in his career. Moreover, the extent of his influence among the Hausa peasantry remained limited.

Notwithstanding this shaky alliance, the new party managed to win the legislative elections of 1957, after which Djibo was appointed government leader acting under the supervision of the French colonial governor. The victorious party changed its name to Sawaba, a Hausa word variously translated as 'freedom', 'independence', or 'tranquillity'. Tranquil was it not to be, however, since the French pushed through constitutional reforms allowing them to retain considerable influence over their African territories, even after their eventual independence. Djibo found it hard to accept this constitutional scenario, perhaps in part because of Sawaba's ideological tenets - which involved

\footnotetext{
${ }^{8}$ This section is based on Fuglestad, History of Niger, and 'Djibo Bakary, The French, and the Referendum of 1958 in Niger'; Chaffard, Les Carnets Secrets; and S. Decalo, Historical Dictionary of Niger (Lanham, MD \& London, 1997).
} 
relatively militant nationalist rhetoric and Pan-Africanist sentiments - and because he may have wanted the full command of state machinery to consolidate his fragile power base. While this made him oppose the plans, the French exerted heavy pressure on the population, including the chiefly class in Hausaland, to approve their reforms in a referendum. Consequently, an overwhelming majority of the electorate voted in favour of the reforms, even in the capital Niamey and the Hausa east. Djibo had to resign as government leader. When the PPN gained a majority in subsequent legislative elections, Hamani Diori succeeded Djibo in office.

Thus, Sawaba was abandoned by most of Hausaland's chiefs and peasants. In addition, it was now confronted by a hostile government intent on eliminating the party as an effective opposition force. In February 1959 Djibo left the country for Dakar, Senegal. Six months later, Diori's government banned Sawaba, accusing it of colluding with foreign forces and planning subversion. In June 1960, eighteen Sawabists, including Abdoulaye Mamani, Adamou Sekou and Issaka Koke, were arrested on conspiracy charges. In September, barely a month after Niger had acceded to independence, sentence was passed, with Mamani facing the heaviest penalty - two years' imprisonment - and Djibo Bakary and Ousmane Dan Galadima, Sawaba's Assistant Secretary-General, being sentenced in absentia. Although Mamani and other detainees were subsequently pardoned and reintegrated in the administration, Sawaba had been dealt a painful blow.

The political significance of this was more than mere electoral defeat. In Niger's traditional political cultures, including that of Hausaland, the position of the chiefly leader depended on his ability to muster 'force' or command 'luck' (Hausa: nasara k'arfi or arzika), which in turn depended on his relationship with the invisible world of deities that formed the ultimate sanctification of political rule. Evidence of the ruler's favour with the divine beings could be his success in battle, good rains and harvests or, more generally, a flourishing political career. ${ }^{9}$ This political world-view provided Nigerien politics with a hard edge that rewards success and, if need be, ruthlessness but penalizes weakness and the decline of political fortune. The banning of Sawaba, therefore, showed to Niger's electorate that its 'luck' was up and that it did not deserve further support.

In contrast, Diori's party managed to capture the highest office in the land, lead the country to independence and maintain vital relations with the French. In order to confront potential challenges, the country was governed by a triumvirate, made up of President Diori, Boubou Hama, the Chairman of the National Assembly, and Diamballa Yansambou Maïga, the Minister of the

\footnotetext{
${ }^{9}$ This interpretation is based on Fuglestad, History of Niger, passim.
} 
Interior. Maïga was its most powerful member and also represented the leadership's ruthless core. Together with the uncompromising Hama, who was detested by segments of Niamey's population, this enabled Diori to present the regime's more benign and forgiving image. ${ }^{10}$ Yet Sawaba still enjoyed some support among the younger generation, the economically active, those aspiring to higher social status, and residents in the urban environment of Niamey.

\section{External and internal preparations}

In September 1959, Djibo relocated to Bamako in Mali where the atmosphere was more in tune with Sawaba's militant posturing than that in Dakar. The headquarters of Mali's ruling party in the eastern city of Gao served as a mailbox for Djibo and Sawaba's underground leadership in Niger. Djibo was allowed to broadcast once a week on Radio Bamako and, in possession of a Malian passport, travelled to the Ghanaian capital Accra where he established a section of Sawaba among the local community of Nigeriens. Many were regional traders or people who had fallen out with Diori's government. Djibo asked John Tettegah, leader of the Ghana-financed All-African Trade Union Federation for financial support, while trade unionists in Nigeria were asked to facilitate contacts with the Hausa communities living along the border with Niger. $^{11}$

Ghana, however, proved to be Djibo's best regional source of support. Its president and fervent Pan-Africanist, Kwame Nkrumah, tried to spread his ideological tenets throughout Africa. The Nkrumah government invited liberation movements from countries still under white domination to establish groups in Ghana, but extended this hospitality also to nationals from independent African states whose regimes did not share Nkrumah's political convictions. $^{12}$ To assist its political allies, the Ghanaian government had established a Bureau of African Affairs (BAA), which developed into a semiautonomous nerve-centre for clandestine operations in other African states. ${ }^{13}$ Consequently, Djibo got in touch with Nkrumah and asked for training facilities

\footnotetext{
${ }^{10}$ G. Comte, 'Les Principaux Dirigeants Nigériens: Un Triumvirat Surprenant', EuropeFrance-Outremer, 430 (November 1965), 16-20, and Decalo, Historical Dictionary of Niger, $157 \& 201$.

${ }^{11}$ Chaffard, Les Carnets Secrets, 307.

${ }^{12}$ Details in Thompson, Ghana's Foreign Policy; I.W. Zartman, International Relations in the New Africa (Englewood Cliffs, 1966); and K. van Walraven, Dreams of Power: The Role of the Organization of African Unity in the Politics of Africa 1963-1993 (Aldershot, 1999), Chapters 3-4.

${ }^{13}$ Thompson, Ghana's Foreign Policy, 107 \& 222-26.
} 
for guerrillas who he hoped to send to Niger at some time in the future. At least in ideological respects, the two men had roughly similar, or potentially compatible, interests. The close friendship of the Diori government with President Houphouët-Boigny of Ivory Coast, Nkrumah's principal rival, facilitated the establishment of political relations with the Sawaba leader. ${ }^{14}$ Thus, Djibo opened a bank account in Accra, fed by local Nigerien traders and the BAA. ${ }^{15}$

Djibo also established contact with the Algerian government, Morocco, the People's Republic of China and North Vietnam. There are not many details available about how Djibo achieved this, although Sawaba later established military training camps in several of these countries. Djibo may have met with Ben Bella in Oujda in Algeria in 1962, ${ }^{16}$ while in January of that year he had a meeting with the chairman of the East German Afro-Asian Solidarity Committee, Eggebrecht, in East Berlin. The Sawaba leader was promised arms in return for future repayment and preferential prospecting of Niger's sub-soil resources, once Djibo came to power. ${ }^{17}$ The year before, Salle Dan Koulou, a member of Sawaba's political bureau, was sent with a delegation to a Marxistinspired youth festival in Helsinki where he got in touch with eight Nigeriens from the Soviet Union. They impressed him with stories about insurgency training in the Eastern bloc, which Dan Koulou reported to Djibo. ${ }^{18}$

By 1962, Sawaba's section in Ghana had built up some influence with the government. ${ }^{19}$ The party had to maintain a lower profile in Mali, as the government there was prepared to turn a blind eye to Sawaba's presence but still wanted to improve its own ties with France. Moreover, Ardaly Daouda, a Sawabist responsible for youth matters, was assassinated in Bamako in May

\footnotetext{
${ }^{14}$ Chaffard, Les Carnets Secrets, 307, who wrote that Nkrumah was one of Djibo's friends. Thompson (Ghana's Foreign Policy, 245-46) denies this, however. It appears that they met each other in April 1964 to discuss events in Niger. See Nkrumah's Subversion in Africa: Documentary Evidence of Nkrumah's Interference in the Affairs of Other African States (Ministry of Information: Accra, n.d.), 39. R.A. Higgot ('Colonial Origins and Environmental Influences on the Foreign Relations of a West African Land-Locked State: The Case of Niger', PhD thesis, University of Birmingham (1979), 306, n. 93) speaks of a personal allowance for Djibo by the BAA of $£ 1,500$ a year as of 1962 .

${ }^{15}$ Chaffard, Les Carnets Secrets, 309.

${ }^{16}$ J.P. Morillon, 'La Tentative Insurrectionelle du SAWABA', Est et Ouest, 342 (16-31 May 1965), 22.

${ }^{17}$ Chaffard, Les Carnets Secrets, 307-8. An obvious reference to uranium, the presence of which was already suspected.

${ }^{18}$ Le Monde, 4 February 1965, and G. Comte, 'An Assassination that Failed', National Review: A Journal of Fact and Opinion, 7 (New York, 15 June 1965), 509-10.

${ }^{19}$ An example is given by Thompson, Ghana's Foreign Policy, 366.
} 
1962, possibly as a result of an argument with Djibo over money and women, after which Sawaba's leader relocated to Accra. ${ }^{20}$

The cadres necessary for an onslaught on the Diori regime were recruited as early as $1961 .{ }^{21}$ Sawaba emissaries, disguised as itinerant marabouts or traders, travelled through Niger and contacted youngsters who, as Chaffard described, were promised scholarships and the chance to study abroad. Possibly some three hundred men were persuaded to leave for Bamako, which served as the point of rendez-vous before they travelled on to their educational destinations. These destinations consisted, however, of a network of camps spread across West and North Africa and beyond, whose principal goal was military training and political indoctrination. The Bamako office was manned by Salou Damana, who had had trade-union education and military training in Guinea-Conakry and Morocco. He was charged with welcoming recruits and maintaining relations with foreign embassies. He was assisted by Issaka Koke, who had fled Niger after his pardon and worked as an employee of a French technical assistance scheme in the Malian capital. ${ }^{22}$

After Bamako, some activists were sent to North Africa where Sawaba was allowed to use a camp belonging to the Algerian FLN (Front de Libération Nationale) in Kibdani in the north-east of Morocco, and later a camp in Marnia in the Oran region of Algeria itself. Sawaba's Assistant Secretary-General, Dan Galadima, had already been based in the Moroccan capital Rabat for some time. When Algeria became independent, he left for Accra, the Kibdani camp was closed, and Sawaba opened an office in Algiers. This was headed by Abdoulaye Mamani, who had again fallen out with Diori and fled to Bamako to escape rearrest. Besides maintaining control over the recruits in Marnia, Tiaret and at a school in Algiers, Mamani had the task of purchasing arms and dispatching them to Ghana. ${ }^{23}$ One Louis Bourges, described as a métis and transporter based in the Saharan town of Tamanrasset, was charged with the relevant liaison duties. ${ }^{24}$ According to Aboubakar Oumarou, ${ }^{25}$ the Algerian camps were meant for

\footnotetext{
${ }^{20}$ For the few details available, see Chaffard, Les Carnets Secrets, 308-9.

${ }^{21}$ Comte, 'An Assassination that Failed', 510.

${ }^{22}$ Chaffard, Les Carnets Secrets, 310.

${ }^{23}$ The school was the Ecole des Transmissions d'Alger. Chaffard, Les Carnets Secrets, 309. Chaffard gives May 1961 as the date for Mamani's escape. For details, see the necrology in West Africa, 28 June-4 July 1993, which claims 1962 was the year of his flight to Bamako.

${ }^{24}$ Morillon, 'La Tentative Insurrectionelle du SAWABA'.

${ }^{25}$ A chauffeur for the municipality of Niamey when Djibo Bakary was in power. Later he gave evidence on the Sawaba rebellion. Morillon, 'La Tentative Insurrectionelle du SAWABA'.
} 
political-military training of the middle cadres. In December 1962, 52 Nigeriens travelled there and were integrated in the Algerian armed forces. ${ }^{26}$

Sawaba's prospective force commanders first made an astonishing itinerary throughout the Eastern bloc. Some, like Hassane Djibo, ${ }^{27}$ waited for seven months in Accra before travelling on by plane, via Dakar and Prague, to the Bulgarian capital Sofia. At a trade-union school there, he was taught about Marxism-Leninism, the workers' movement, trade unionism and industrialization, before heading back - via the Black Sea resort of Varna - to Accra. Others, like Boubakar Djingaré, travelled from Bamako to Accra and then on to Moscow. Here he and ten other Nigeriens followed an eight-month training course at a trade-union institution before returning to Ghana. ${ }^{28}$ Then they flew to the People's Republic of China or North Vietnam. For example, Hassane Djibo and another companion were taken by a Sawaba official, Issoufou Gado, to Cairo and then flew on to Karachi, Rangoon and Peking. There, they took a train to Nanking. ${ }^{29}$ Another Sawabist, Djibo Seyni, ${ }^{30}$ took a more difficult route. In the autumn of 1962 he and another compatriot flew from Accra to Prague, where they stayed for two days before taking the train to Moscow. There they were met by an official from the North Vietnamese embassy. Three days later, they took the trans-Siberia railway to Peking and then, again by train, went on to Hanoi, where they were received by three other Nigeriens who had flown to Vietnam the week before. The five of them then went on to the Ecole Nationale Militaire at Son Tay, located on the Red River, $36 \mathrm{~km}$ northwest of Hanoi. ${ }^{31}$

In China, trainers and translators helped to teach the Nigeriens, in addition to the tenets of Marxism-Leninism and Maoism, a variety of military skills, such as how to handle a rifle (Figure 9.1), make bombs, commit acts of sabotage, ambush troops and organize coups d'état. ${ }^{32}$ Some of the training took place in

\footnotetext{
${ }^{26}$ One other Sawabist who travelled to Marnia was Yacouba Dari, a companion of Aboubakar Oumarou, who was based there until September 1963. ibid. and Comte, 'An Assassination that Failed', 510.

${ }^{27}$ An agricultural teacher. Bretholz, 'Les Camps de Sofia, Nankin et Accra'.

${ }^{28}$ Djingaré was a 26-year-old mason from Niamey. Braumann, 'Avec les Tueurs de la SAWABA'.

${ }^{29}$ Bretholz, 'Les Camps de Sofia, Nankin et Accra'.

${ }^{30}$ A nurse by profession. Bretholz, 'Comment N'Krumah et Ses Amis Communistes'.

${ }^{31}$ Ibid. and Chaffard, Les Carnets Secrets, 311.

${ }^{32}$ Hassane Djibo claimed that military training was only theoretical and that his instructors did not allow them to carry arms. However, he had been condemned to death and may have had an interest in playing down his training. Bretholz, 'Les Camps de Sofia, Nankin et Accra'. Chaffard, Les Carnets Secrets, 311, claimed Sawabists were trained at an exercise ground fifteen $\mathrm{km}$ outside Nanking.
} 
the so-called School of the Chinese Revolution. ${ }^{33}$ All in all, the training lasted three months. ${ }^{34}$ While in Nanking the Nigeriens were only in the company of compatriots or other Africans, but in North Vietnam they met thousands of other trainees, mostly Vietnamese, but also other foreigners. ${ }^{35}$ Training there consisted of indoctrination and guerrilla warfare and took eight to nine months. ${ }^{36}$ In total, some thirty Nigeriens received such training, either in Nanking or Son Tay. ${ }^{37}$ Then came the return journey to West Africa, usually along the same route that had taken them to the Far East. Djibo Seyni, for example, arrived back in Accra in May 1963 and, according to him, was personally welcomed by Bakary. Seyni and his men were then taken to Mampong, north of Kumasi. ${ }^{38}$

While the Nanking contingent represented Sawaba's force commanders, ${ }^{39}$ Mampong and other Ghanaian camps trained the party's foot soldiers. The other camps where Sawabists would have received training were at Half-Assini, Axim and Konongo-Odumassi near Syniani. ${ }^{40}$ If it is true that Sawaba's total force amounted to some 300 men, of which roughly one third ${ }^{41}$ were middle and higher cadres receiving training in Algeria and the Eastern bloc, then the Ghanaian camps could have instructed some 200 Sawabists. Their training involved military skills, details of which were published later by the government that toppled Nkrumah's regime. Some of the instructors may have been Russian,

\footnotetext{
${ }^{33}$ Bretholz, 'Les Camps de Sofia, Nankin et Accra'. Boubakar Djingaré spoke of a big school on the outskirts of the city. Braumann, 'Avec les Tueurs de la SAWABA'.

${ }^{34}$ Braumann, 'Avec les Tueurs de la SAWABA' and Chaffard, Les Carnets Secrets, 311. Comte, 'An Assassination that Failed', 509, suggests ten months on the basis of the trainees' personal notebooks.

35 Son Tay was a major North Vietnamese training site, later to be attacked by US Special Operations Forces in an effort to free POWs (1970). See the website www.sontayraider.com

${ }^{36}$ Bretholz, 'Les Camps de Sofia, Nankin et Accra' and 'Comment N'Krumah et Ses Amis communistes' and Braumann, 'Avec les Tueurs de la SAWABA'.

${ }^{37}$ Later, some people received training in Cuba. See Fraternité Hebdo, 9 July 1965.

${ }^{38}$ Bretholz, 'Comment N'Krumah et Ses Amis Communistes'.

39 Morillon gives the following names: Dodo Hamballi, Baro Alfari, Dandouna Aboubakar, Sékou Béri, Harouna Bonkourou, Issoufou Bambaro, Souley Gori, Tini (or Tine) Malélé, Joseph Akouët and Issoufou Gaho (Gado?), former announcer on Radio Moscow's Hausa service. Morillon, 'La Tentative Insurrectionelle du SAWABA'. To this list should be added Salle Dan Koulou, who flew to Peking with eight or ten activists. Le Monde, 4 February 1965 and Comte, 'An Assassination that Failed', 510.

${ }^{40}$ Aliali, 'Le Contentieux Nigéro-Ghanéen'. Obenemasi should also be included in this list, where, for example, 50 Nigeriens were enrolled in May 1965. See Nkrumah's Subversion in Africa, 20.

${ }^{41}$ Morillon, 'La Tentative Insurrectionelle du SAWABA'.
} 
as Chinese trainers arrived only in October 1964 - the very month of the invasion of Niger. ${ }^{42}$

In Niger itself, meanwhile, political tensions were rising. In November 1963 the Diori government became embroiled in a row with neighbouring Dahomey over the sacking of Dahomeans from Niger's public services and a related frontier dispute. Domestic opposition came from trade unionists whose organization had been banned; students who accused the educated elite of having monopolized power; and Touareg resenting Zerma-Songhai domination of the country's political system. Moreover, in the eyes of the government not all sections of the army could be relied upon. Two top functionaries, both of them Peul, were considered suspect: Zodi Ikiah, the Minister of Defence, and Captain Hassan Diallo, an officer in charge of a heavy weapons unit who staged a failed mutiny to get redress for various grievances. Both men, who were interned in December 1963, were approached by Sawaba in a bid to secure their support against the Diori regime. ${ }^{43}$ About that time, the first clandestine operation was undertaken inside Niger, either to assist in a military mutiny or to contact different opposition figures. The infiltrator, possibly the Son Tay trainee Djibo Seyni, then returned to Accra and is said to have reported negatively on the country's revolutionary potential. ${ }^{44}$

Efforts to reconcile Niger's government with its arch enemy came to nothing, at least in part because of Djibo's own intransigence. Things turned uglier with Sawaba sympathizers being beaten up in Zinder and Tahoua and a terrible incident near the town of Maradi, which was in the heart of Hausaland and seen as Djibo's fief: ${ }^{45}$ in May 1964 Sawaba sympathizers attacked Boubou Hama and Maïga, the two government hardliners, in the course of a local meeting, after which police moved in and some forty people, the majority of whom were not Sawabists, were thrown in prison. In the overcrowded conditions, 21 of them, many youngsters, died of asphyxiation. The incident scared people in the Hausa east and it was reported that several took refuge in Nigeria. ${ }^{46}$ Gendarmes also killed Alzouma Koussanga, a vet and one of Sawaba's most respected internal leaders. He was arrested in Maradi on 2 September, as were other people, and

\footnotetext{
${ }^{42}$ Nkrumah's Subversion in Africa, 6-7.

${ }^{43}$ Details in Chaffard, Les Carnets Secrets, 313-16; Fuglestad, History of Niger, 160; Decalo, Historical Dictionary of Niger, 118 \& 332; and Afrique Nouvelle, 898 (23-29 October 1964).

${ }^{44}$ Bretholz, 'Comment N'Krumah et Ses Amis Communistes'.

${ }^{45}$ See Afrique Nouvelle, 898 (23-29 October 1964).

${ }^{46}$ It was said that Sawaba recruited among these people. Afrique Nouvelle, 898 (23-29 October 1964).
} 
died in detention shortly afterwards. ${ }^{47}$ Another leading Sawabist, Adamou Sekou, was again taken into custody and incarcerated in a camp in the Sahara. Boubacar Ali Diallo, a cabinet minister and former Sawaba militant, was dismissed on suspicion of complicity in the mutiny of the previous year. ${ }^{48}$

These events may have convinced Djibo that discontent was widespread, while most reports of clandestine Sawabists suggested that the party's guerrillas would be received with open arms. Yet, while the toughening of the government did much to escalate the conflict, Djibo had possibly all along entertained the option of violent action. At roughly the time that the Maradi detainees died, Djibo, Abdoulaye Mamani and Ousmane Dan Galadima met in Porto Novo in Dahomey to review operational planning. ${ }^{49}$ Moreover, by the summer of 1964 military training had been under way for well over two years.

The cadres assembled in Accra. In September, Sawaba's main forces were dispatched in small groups to Porto Novo, which could be used as a forward base as the Dahomean authorities, embroiled in their own dispute with Diori, were prepared to turn a blind eye and facilitate operations. Sawaba issued several communiqués and declarations, broadcast throughout West Africa, in which it announced that it would liberate Niger from the Diori regime, which was deemed 'anti-national' and neo-colonialist, imposed as it had been by 'foreign' (French) forces that together with Diori had 'illegally usurped' power in the years before. $^{50}$

\section{Invasion}

Some guerrillas would infiltrate via Dahomey, some through Upper Volta and others through Nigeria, assisted by activists of the Nigerian Labour Party. Operations were directed by Dan Galadima, Sawaba's Chief of Staff, in Porto Novo, where weapons would be distributed. Units would first attack Niger's border posts and then try to occupy the urban and rural centres with the help, it was imagined, of the local population. At a given signal, the internal Sawaba party would rise in support of the guerrillas. ${ }^{51}$ Djibo had ordered Salle Dan Koulou, Nanking trainee and member of Sawaba's political bureau, to dispatch

\footnotetext{
${ }^{47}$ Koussanga had been director of political affairs in Djibo's government. The most detailed description of this sad tale is in Afrique Nouvelle, 895 (2-8 October 1964).

${ }^{48}$ West Africa, 17 October 1964.

${ }^{49}$ Chaffard, Les Carnets Secrets, 321.

50 Thompson, Ghana's Foreign Policy, 366; Marchés Tropicaux, 7 November 1964; Afrique Nouvelle, 898 (23-29 October 1964); Fraternité Hebdo, 9 July 1965; Chaffard, Les Carnets Secrets, 321-24.

${ }^{51}$ Comte, 'An Assassination that Failed', 510.
} 
the guerrillas in small groups, spread along the entire length of the frontier with Upper Volta, Dahomey and Nigeria. The units would consist of ten to fifteen men each. Those in the western sector (Téra to Doutchi) were to attack the towns of Téra, Gotheye, Say and Gaya, those in the central sector Birni N'Konni, Tahoua and Madarounfa, and the eastern commandos would take on Matameye, Bosso and N'guigmi (see Map). ${ }^{52}$

Those in the western sectors were to attack first. ${ }^{53}$ One unit would establish contact in the Téra region with a group from Upper Volta, led by Nanking trainee Tini Malélé, and incite the local Peul and bellas (people of slave origin) to revolt. According to documents found later on this group, it had to isolate Téra by cutting communications, attack the administrative post of Bankilaré, capture all arms, and together with the Upper Volta group charge on Kokoro, take Téra and march on to Dargol. If it were not possible to occupy Téra, the guerrillas would try and capture its armaments, create confusion and start harassing 'the whole of the Songhai region'. Both the population of the Téra canton and the people of Diagourou would be incited to rebel. ${ }^{54}$

During the final stages of the operation, commandos would try and capture the capital. They would have to destroy its water supply, cut electricity and telephone lines, silence Radio Niger and destroy the Shell and Mobil Oil depots. Other commandos would occupy the airport, ammunition depots and the police headquarters. Across the country, market towns had a special importance, as they represented sources of people, ideas and money. ${ }^{55}$ Money taken from border and administrative posts would be used for the cause and detainees freed from prison recruited for the struggle. ${ }^{56}$ Once the various sectors had been occupied, Dan Koulou had to impose the villayas system - the autonomous military regions that had been used by the FLN in Algeria in its struggle against the French. ${ }^{57}$ Some commandos were given orders to take certain people hostage or liquidate members of the government, such as the hated Minister of the

\footnotetext{
${ }^{52}$ Chaffard, Les Carnets Secrets, 321-24. At the OAU, Niger's foreign minister referred to a western sector, a southern one (Birni N'Konni to N'Guigmi) and a northern sector (Filingué-Tahoua to Agadez), led by Abdoulaye Mamani and Issoufou Dambaro. Text in Fraternité Hebdo, 9 July 1965.

${ }^{53}$ See undated letter of Djibo Bakary to Salle Dan Koulou, printed in Fraternité Hebdo, 9 July 1965.

${ }^{54}$ Morillon, 'La Tentative Insurrectionelle du SAWABA' and Le Monde, 4 February 1965.

${ }^{55}$ G. Comte, 'Les Carnets de Nankin', Est et Ouest, 357 (16-28 February 1966).

${ }^{56}$ Morillon, 'La Tentative Insurrectionelle du SAWABA' and Le Monde, 4 February 1965.

${ }^{57}$ Djibo Bakary to Salle Dan Koulou, undated. Malélé's instructions, of Chinese origin, also spoke of creating 'free zones'. Comte, 'An Assassination that Failed', 510.
} 


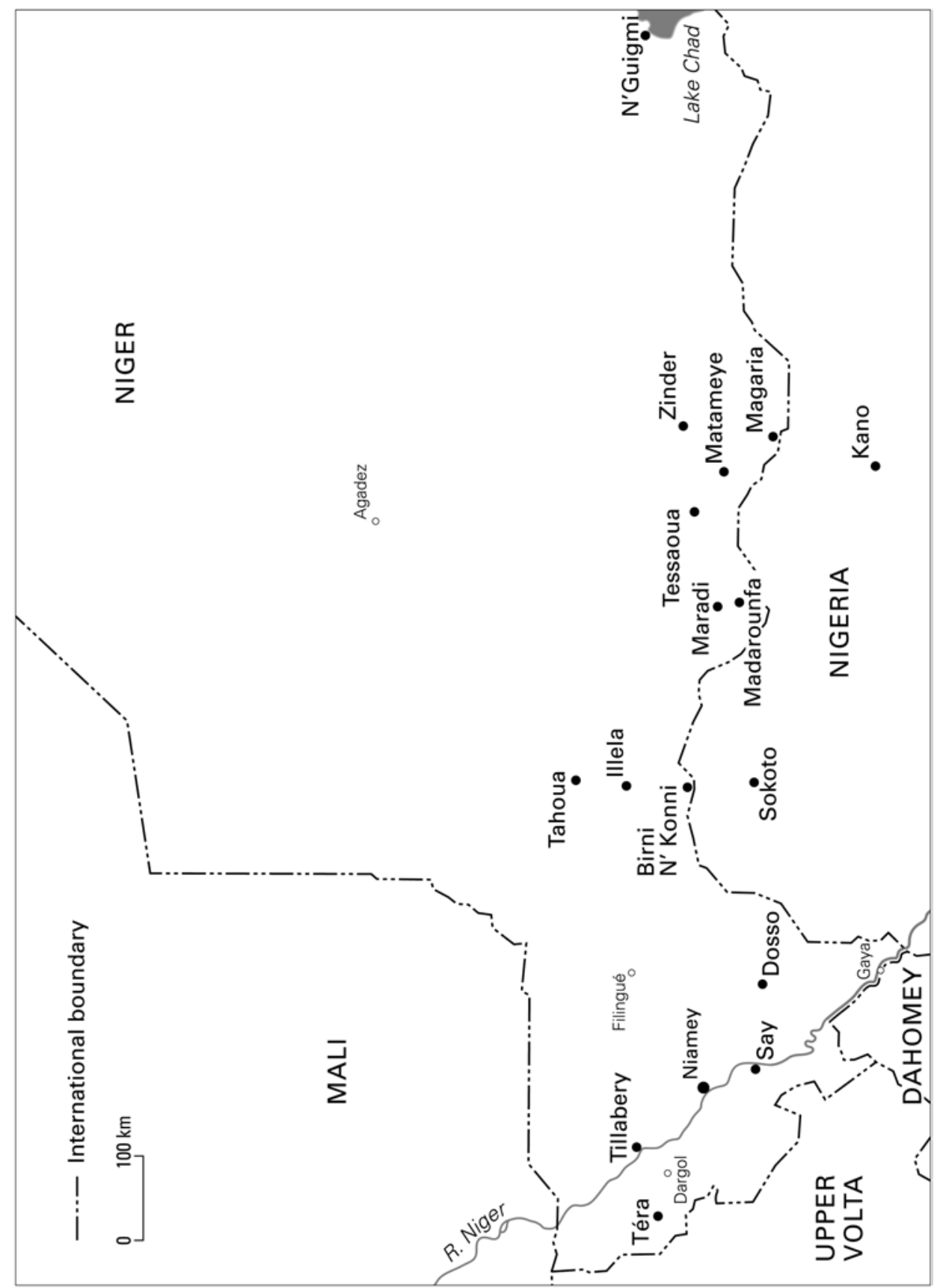

Map 9.1 Niger 
Interior Maïga, on whose comings and goings domestic activists had collected valuable information. ${ }^{58}$ All commandos were ordered to hide their documents before crossing into Niger. Djibo himself was to monitor infiltrations from Porto Novo. ${ }^{59}$

The central units were to be led by men from Sawaba's highest political hierarchy, as this region had provided considerable electoral support in the past. Hence, Dandouna Aboubakar, a former trade unionist and Nanking trainee, would attack Birni N'Konni, Salle Dan Koulou would take on Madarounfa and, if all went well, Maradi; and, further to the north, Abdou Iddi, a Son Tay trainee and political commissar attached to the guerrilla force, ${ }^{60}$ would infiltrate Djibo's political stronghold at Tahoua. ${ }^{61}$

Thus, eight commando units went on the attack between late September and mid-October. ${ }^{62}$ On 27 and 28 September attacks took place in the west of Niger. ${ }^{63}$ Between Say and the border with Upper Volta, one guerrilla unit was intercepted, five commandos were caught and their leader, Hassane Moussa, was killed. According to documents found on Moussa, the unit had planned to attack Say and incite a rebellion. It had infiltrated as two groups, one from Malanville in Dahomey and the other from Upper Volta ${ }^{64}$ Further west, a group of fourteen men, who had to establish contact with Tini Malélé's unit from Upper Volta, penetrated the Téra region. ${ }^{65}$ On 2 October 1964, seven commandos, who had infiltrated from Upper Volta, attacked Gotheye in the west, 70 kilometres northeast of Niamey. They shot several PPN cadres and were heading for Téra when they were nearly all captured by armed villagers. ${ }^{66}$ On 4 October, Salle

\footnotetext{
${ }^{58}$ Chaffard, Les Carnets Secrets, 324.

${ }^{59}$ Djibo Bakary to Salle Dan Koulou, undated.

${ }^{60}$ According to Morillon, 'La Tentative Insurrectionelle du SAWABA', Iddi had been trained in Nanking from 22 November 1962 to 4 May 1963, together with Yacouba Issa, Amadou Boube, Souley Chaibou and Amadou Chaibou.

${ }^{61}$ Chaffard, Les Carnets Secrets, 321-25. One of these central units also included Dodo Hamballi, a Sawaba delegate from Zinder-Magaria. Aliali, 'Le Contentieux NigéroGhanéen'.

${ }^{62}$ Chafard, Les Carnets Secrets, 325. Morillon, 'La Tentative Insurrectionelle du SAWABA', speaks of nine. A few more could be counted, depending on what constituted a commando unit.

${ }^{63}$ Marchés Tropicaux, 7 November 1964.

${ }^{64}$ Aliali, 'Le Contentieux Nigéro-Ghanéen'.

${ }^{65}$ Le Monde, 4 February 1965. The fourteen could have been the total of both groups or Malélé's group alone, as Comte ('An Assassination that Failed', 510) speaks of Malélé's ‘fourteen armed partisans'.

${ }^{66}$ Chaffard, Les Carnets Secrets, 324. According to Niger's foreign minister (note 61), at least four groups penetrated from Upper Volta, and at least three from the town of Sokofé.
} 
Dan Koulou's unit struck the post of Madarounfa in the central sector. It consisted of twelve men assembled in Kano, Nigeria, at the end of September and was armed with grenades and machine guns. ${ }^{67}$ In the eastern sector, Sawaba commandos overran the customs post of Bosso near N'Guigmi around 8 October, ${ }^{68}$ wounding several people, killing two officials, and capturing ten old rifles. They were led by a former chief, Katchella Abba Kaya, and assisted by smugglers active along the border with Chad and Nigeria. This unit had originally assembled in Kano, left the city on 14 September and regrouped at the Komadougou River before the attack. ${ }^{69}$ Matameye, in the Hausa heartland, was attacked on 12 October by guerrillas armed with grenades and automatic rifles who had also left Kano, two days earlier. ${ }^{70}$ Other guerrillas charged on Magaria $^{71}$ and Ayorou, having crossed the border from Watagouna in Mali. ${ }^{72}$

On 11 or 13 October, Dandouna Aboubakar and ten guerrillas, who had entered Niger from the Nigerian city of Sokoto, attacked Dosso in the Birni N'Konni region and shot the schoolmaster of Dibissou, who was considered to be pro-government. On this party more information is known thanks to an interview by a Western journalist with one of its captured members, Boubakar Djingaré, and the speech by Niger's foreign minister at the OAU. Djingaré's group left Sokoto on 14 September, travelling to the towns of Amaroua and Gamdawa, before it crossed into Niger and headed for the town of Illela. The commandos hid in the fields for several days, avoiding all contact with villages, while their commander and political commissar went off during the evening. Then the unit attacked a land rover and drove through the night to a homestead where a peasant had prepared a hideout. ${ }^{73}$

The Bosso operation mentioned above could be interpreted as the high-water mark of Sawaba's invasion, as all other attacks backfired, were prevented or could not be followed up with forward action. Thus, one group was discovered by peasants only three days after having entered the western sector from Malanville. While eleven managed to escape, three were caught, among them

\footnotetext{
${ }^{67}$ Le Monde, 4 February 1965; Morillon, 'La Tentative Insurrectionelle du SAWABA'; and Aliali, 'Le Contentieux Nigéro-Ghanéen'.

${ }^{68}$ The dates vary from 7 to 10 October. Marchés Tropicaux (7 November 1964) gives the night of 8 to 9 October. Le Monde (4 February 1965) mentions 8 October.

${ }^{69}$ Chaffard, Les Carnets Secrets, 325; Le Monde, 4 February 1965; Afrique Nouvelle, 898 (23-29 October 1964); and Aliali ('Le Contentieux Nigéro-Ghanéen') who said the two victims in Bosso were a nurse, shot in his dispensary, and a defenceless peasant.

${ }^{70}$ Le Monde, 4 February 1965, and Aliali, 'Le Contentieux Nigéro-Ghanéen'.

${ }^{71}$ Morillon, 'La Tentative Insurrectionelle du SAWABA'.

${ }^{72}$ Aliali, 'Le Contentieux Nigéro-Ghanéen'.

${ }^{73}$ Braumann, 'Avec les Tueurs de la SAWABA'; Le Monde, 4 February 1965; Marchés

Tropicaux, 7 November 1964; and Aliali, 'Le Contentieux Nigéro-Ghanéen'.
} 
Djibo Seyni. ${ }^{74}$ From Madarounfa, Salle Dan Koulou was supposed to press on to Maradi. On 6 October, however, the Nanking trainee brought about his capture by accidentally firing his gun, killing one of his men and in the process betraying the unit's presence. ${ }^{75} \mathrm{He}$ was shot - possibly by a woman ${ }^{76}$ - wounded and arrested with at least three other guerrillas. ${ }^{77}$ Four of his comrades were killed. Djingaré's unit could not use the hideout prepared by their peasant friend, who feared that villagers would find out since the guerrillas had arrived during daylight. They were forced to take cover in the bush and after a few days left in the direction from which they had originally stolen the land rover. This time the men attacked a farmstead but peasants caught up with them. ${ }^{78}$ They were all arrested, including Djingaré, a certain 'Momon" 79 and one Amadou Diop. The unit's leader, Dandouna Aboubakar, was interrogated and beaten to death with sticks. $^{80}$

Several others hid in the countryside, demoralized by the hostile reception they had received and at a loss as to what to do. ${ }^{81}$ On 6 November at Gaya on the Dahomean border, one guerrilla was attacked by dogs and caught by peasants. ${ }^{82}$ Another was killed near Tahoua on 28 November. ${ }^{83}$ His commander, Abdou Iddi, had shot himself in the mouth but was captured alive. ${ }^{84}$ Possibly around mid-October, security officers arrested Dodo Hamballi, Nanking Sawabist from Zinder-Magaria, while he was trying to smuggle weapons into the country. ${ }^{85}$ On 24 October, the group of fourteen men in the Téra region,

\footnotetext{
${ }^{74}$ Bretholz, 'Comment N'Krumah et Ses Amis Communistes'.

${ }^{75}$ Morillon, 'La Tentative Insurrectionelle du SAWABA'.

${ }^{76}$ According to Chaffard, Les Carnets Secrets, 325. No other information is known on this.

${ }^{77}$ West Africa, 31 October 1964, and Marchés Tropicaux, 7 November 1964.

${ }^{78}$ Braumann, 'Avec les Tueurs de la SAWABA'.

${ }^{79}$ Possibly trained in Algeria. The people from this group, who according to Djingaré constituted seven in total, not ten, would also have included Balkara (or Boukara) Abdou, a Nanking trainee, and one Djibo Hassan (not to be confused with Hassane Djibo, who was in a unit that went from Malanville to Botou in Upper Volta and from there into Niger [Bretholz, 'Les Camps de Sofia, Nankin et Accra']). These events were reconstructed from Braumann, 'Avec les Tueurs de la Sawaba' and the original article in the Rheinischer Merkur, 'So Bildet China Mörder Aus'.

${ }^{80}$ According to Chaffard, Les Carnets Secrets, this took place on 9 October, which does not tally with other sources that give 11 or 13 October as the date of his attack.

${ }^{81}$ See, for example, Bretholz, 'Les Camps de Sofia, Nankin et Accra'.

${ }^{82}$ Possibly he was part of the unit that penetrated from Malanville on 6 November. Aliali, 'Le Contentieux Nigéro-Ghanéen'.

${ }^{83}$ Perhaps from the unit that crossed the frontier with Mali at Ménéka. Ibid.

${ }^{84}$ Chaffard, Les Carnets Secrets, 325.

${ }^{85}$ Comte, 'Les Carnets de Nankin'.
} 
possibly led by Tini Malélé, was intercepted by PPN youth cadres. ${ }^{86}$ Six days later, another group of five, who were armed with Russian machine guns and had been ordered to take the administrative post of Say, was captured, among them Hassane Djibo, the trainee from Nanking and Sofia. ${ }^{87}$ Commandos who attacked Bosso were caught some three weeks later. Numerous others hid in the countryside for weeks, chased and starved, before being taken prisoner. Of some 240 guerrillas, 136 were captured and a dozen or so killed, while the others fled back across the border. A wide assortment of weapons was confiscated. ${ }^{88}$

\section{Interlude}

The response of Niger's authorities was swift and harsh. They benefited from the fact that they knew well in advance that the guerrillas were coming. Despite its elaborate planning, Sawaba had trumpeted its attack with communiqués broadcast throughout the region. French intelligence had also kept a close watch on Sawaba activities and French officers still occupied various positions in Niger's security structures. Colombani, the former colonial governor, held a high-level position as Director of the Bureau of the Presidency, being responsible for state security. ${ }^{89}$ In other West African countries, too, French officers continued to man high-security posts, maintaining a network of political and military informers. French troops were stationed in Dahomey and in several cities in Niger right up until the autumn of $1964 .{ }^{90}$

West African governments were equally aware of the guerrilla training courses taking place in Ghanaian camps and even had their own spies there. West African diplomats posted in Accra were, according to a scholar who interviewed them in the mid-1960s, well informed about what was going on. ${ }^{91}$ The governments organized in the so-called Entente, at least those of Niger, Ivory Coast and Upper Volta, also kept in close touch with each other. Moreover, Nkrumah's government constituted a ramshackle administration with

\footnotetext{
${ }^{86}$ Morillon, 'La Tentative Insurrectionelle du SAWABA'; Le Monde, 4 February 1965; and Comte, 'An Assassination that Failed', 510.

${ }^{87}$ Comte, 'Les Carnets de Nankin'.

88 Chaffard, Les Carnets Secrets, 325 and G. Comte, 'Treize Années d'Histoire Nigérienne', Revue Française d'Etudes Politiques Africaines, 72 (1971) 35. Le Monde (4 February 1965) speaks of 150 men who travelled from Ghana to Niger. For a list of weapons, see Aliali, 'Le Contentieux Nigéro-Ghanéen'.

${ }^{89}$ Ruttiman, 'Le Président Hamani Diori Nous Déclare'.

${ }^{90}$ Afrique Nouvelle, 895 (2-8 October 1964).

${ }^{91}$ Thompson, Ghana's Foreign Policy, 375-76.
} 
various interests and self-serving institutions led by loose-tongued militants - a situation not conducive to discretion.

Thus warned, Niger's police, military and PPN cadres could mobilize the population, a fact that explains the hostile reception the guerrillas received from the peasantry. Those guerrillas that survived the encounters were quickly rounded up and incarcerated while awaiting trial. On the night of Monday 12 October, the State Security Court sentenced to death the four Sawabists who had been caught the week before at Madarounfa, including the wounded Salle Dan Koulou. The following evening they were shot, watched by a crowd of 10,000 people who had been incited to assemble by a police loudspeaker touring the capital. The body of Dandouna Aboubakar, who had been lynched by peasants in Birni N'Konni, was exhibited in front of the new police headquarters and lay there for three days. ${ }^{92}$ This move was clearly meant to intimidate the government's enemies and anyone sympathizing with the Sawaba cause. ${ }^{93}$ After this, a special court was constituted to try the remaining guerrillas. Although they would be allowed defence counsel, there would be no right of appeal, not even in the event of the death penalty being handed down. ${ }^{94}$ In total, eleven Sawabists were sentenced to death but only ten were executed as the eleventh was lucky enough to be forgotten about and left in his cell. He was subsequently pardoned. ${ }^{95}$

The political consequences of Sawaba's autumn attack reverberated across the region as Diori's government waged a diplomatic offensive to improve its strategic position. Undaunted, Djibo issued a hollow statement in Accra announcing that his men had inflicted 'severe losses' on Niger's government and appealing to the population to take up arms. ${ }^{96}$ The party's leadership had, in fact, envisaged a second invasion for June or July 1965, which would apparently be supervised by the Ghanaians and members of the Nigerian Labour Party. ${ }^{97}$ In a

${ }^{92}$ Ghana's ambassador to Niamey wrote that Aboubakar's body lay in front of Niger's parliament. GNA: N/POL 65, Ambassador B.L. Placca to H.E. M.F. Dei-Anang, African Affairs Secretariat, 14 April 1965.

${ }^{93}$ Afrique Nouvelle, 898 (23-29 October 1964); Africa Research Bulletin, (1964), 166 \& 171 (here only of Political Series); Marchés Tropicaux, 7 November 1964; and Le Monde, 15 \& 16 October 1964.

${ }^{94}$ However, those sentenced to death would not be executed before the government had decided on a possible commutation of the sentence. West Africa, 7 November 1964.

${ }^{95}$ Chaffard, Les Carnets Secrets, 326. I do not know the names of those executed, apart from Salle Dan Koulou. One activist condemned to death was Hassane Djibo, who was still alive in 1965 and was interviewed by Bretholz. Boubacar Ali Diallo, the recently dismissed cabinet minister, was arrested. Africa Research Bulletin, (1964), 171. He died of a fever in prison on 11 May 1965. Decalo, Historical Dictionary of Niger, 117.

${ }^{96}$ Afrique Nouvelle, 898 (23-29 October 1964).

${ }^{97}$ Chaffard, Les Carnets Secrets, 326. 
letter from Sawaba's leadership to the BAA, it was observed that the party would gain political power through 'the revolution', which would lead to a social and economic transformation that would give it 'complete revolutionary victory'. In order to achieve this, however, the leadership intended to change strategy ${ }^{98}$ With still some 250 to 300 Sawabists in Ghanaian training camps, ${ }^{99}$ the training of recruits continued, now with the help of Chinese instructors. Ghana Airways was requested to transport men and armaments to Cotonou, Dahomey, and the BAA was asked to follow up on its recent gift of $£ 25,000$ and resolve the party's financial difficulties. ${ }^{100}$

Things did not run smoothly, however, as the catastrophe of the autumn had led to tension inside Sawaba's leadership. In February 1965, Dan Galadima and Abdoulaye Mamani ${ }^{101}$ met with Djibo in Accra and criticized him for overestimating Sawaba's popularity and underestimating the strength of Diori's regime. According to them, he had also purchased arms of poor quality, declined to make full use of training possibilities and failed to boost the guerrillas' morale. In addition, they accused him of spending too much time and money on women. ${ }^{102}$ The upshot of these exchanges was that Issaka Koke, the Sawabist based in Bamako, would take control of party funds. ${ }^{103}$

\section{Climax}

The second invasion never took place as it was superseded by a dramatic turn of events. At 9 a.m. on Tuesday 13 April 1965, during celebrations to mark the Muslim Tabaski festival, a Sawabist threw a grenade at President Diori who was present at a gathering of more than 20,000 people in the Grand Mosque in Niamey, on the very spot of the 1964 executions. As the American grenade fell

\footnotetext{
${ }^{98}$ Some activists dispatched to China and Cuba for instruction had returned to Accra under the guidance of one Salifou Abubakar. Excerpts of a letter dated 31 October 1964, in Fraternité Hebdo, 9 July 1965.

${ }^{99}$ Chaffard, Les Carnets Secrets, 326.

${ }^{100}$ Excerpts of the same letter (note 98) in Fraternité Hebdo, 9 July 1965.

${ }^{101}$ Apparently, the latter had not been in Niger during the autumn infiltration, as Niger's foreign minister had claimed, or he had escaped.

${ }^{102}$ It was rumoured that he sent a monthly cheque of 50,000 FCFA to a woman in Ouagadougou and purchased cars for two female friends. Chaffard, Les Carnets Secrets, 326. Ruttiman, 'Le Président Hamani Diori Nous Déclare', speaks of a 'beautiful red sports car'. The personal use of funds was also echoed in a letter of the Ghanaian ambassador in Niger to his government in Accra. GNA: N/POL/66, Ambassador B.L. Placca to H.E. M.F. Dei-Anang, African Affairs Secretariat, 16 April 1965.

${ }^{103}$ Chaffard, Les Carnets Secrets, 326 and G. Chaffard, 'La Subversion au Niger en 1965', France-Eurafrique, 190 (December 1967), 36.
} 


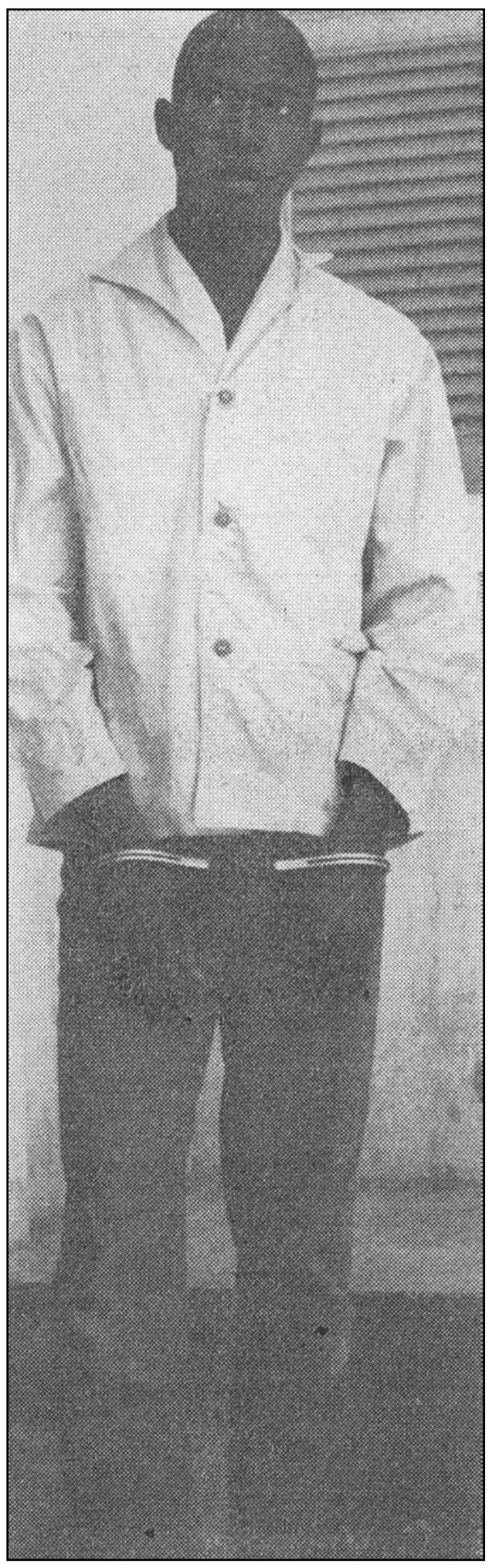

Amadou Diop, who tried to assassinate President Diori Copyright: Rheinischer Merkur, 18 (30 April 1965), 14 
three rows behind him, Diori - who was in the middle of praying - escaped injury. The projectile exploded and killed a four-year-old boy. Three Nigeriens were wounded, including a member of parliament, as well as three members of a Malian basketball team on tour in Niger. Having missed Diori, the Sawabist threw a second grenade but it failed to explode. ${ }^{104}$

According to the Ghanaian ambassador to Niamey, the perpetrator, who went by the name of Amadou Diop, had missed his target as he "was probably both nervous and incapable of stretching his arms fully'. ${ }^{105}$ The ambassador cabled to his superiors in Accra:

From all accounts, Amadou Diop is the suicide type and was fully aware and prepared for the consequences of throwing the bomb at President Diori at such an open space and from among such a crowd as at the prayer congregation. He bit his finger hard in expression of disappointment at not getting his target and that sums him up. ${ }^{106}$

The assassin was immediately arrested and stripped naked. A pistol was found on him. The crowds were asked through a microphone to remain calm and the area was quickly cordoned off. With the exception of the president and the chief Imam, everyone, including cabinet ministers, was searched before being allowed to leave the grounds. Three more people were found carrying grenades and pistols. ${ }^{107}$ Interrogation of the assassin yielded several details about his background and planning: Diop was from the Zinder region, his mother was Nigerien and his father Senegalese. In the early 1960s he had left Niger to

${ }^{104}$ GNA: NC/47, From Ghana Embassy Niamey to Ministry of Foreign Affairs, Accra (for Dei-Anang from Placca), 14 April 1965; GNA: N/POL 65, Ambassador B.L. Placca to H.E. M.F. Dei-Anang, African Affairs Secretariat, 14 April 1965; Fraternité Hebdo, 9 July 1965; Comte, 'An Assassination that Failed', 509; and 'L'Attentat Manqué contre M. Hamani Diori est Vivement Ressenti en Afrique', Afrique Nouvelle, 924 (22-28 April 1965). Chaffard, Les Carnets Secrets, 327, speaks of five wounded. GNA: NC/47, From Ghanaian Embassy Niamey to Ministry of Foreign Affairs, Accra (for Dei-Anang from Placca), 14 April 1965 speaks of 7 wounded. A Malian, Mohamedine Sylla, was slightly wounded in the face. The Malian arbiter, Alioune Diouf, sustained a serious injury to his liver. 'L'Attentat Manqué contre M. Hamani Diori'.

${ }^{105}$ GNA: N/POL 65, Ambassador B.L. Placca to H.E. M.F. Dei-Anang, African Affairs Secretariat, 14 April 1965.

${ }^{106}$ GNA: N/POL/66, Ambassador B.L. Placca to H.E. M.F. Dei-Anang, African Affairs Secretariat, 16 April 1965.

${ }^{107}$ GNA: NC/47, From Ghana Embassy Niamey to Ministry of Foreign Affairs, Accra (for Dei-Anang from Placca), 14 April 1965 and N/POL 65, Ambassador B.L. Placca to H.E. M.F. Dei-Anang, African Affairs Secretariat, 14 April 1965. Le Monde, 16 April 1965, spoke of one other accomplice being arrested. 
receive training abroad. The places and countries mentioned included Marnia, Nanking, Son Tay and North Korea. ${ }^{108}$ In China, he had served as an announcer for Radio Peking's Hausa service. From China, he had returned to Ghana and received training in Mampong. ${ }^{109}$

As mentioned above, he was arrested in October 1964 when peasants caught up with his unit and beat to death its leader, Dandouna Aboubakar, whose body was exhibited to the public. Diop, who was described as Dandouna's assistant, ${ }^{110}$ had been imprisoned but escaped. He had fled to Nigeria ${ }^{111}$ and returned to Accra and was said to have sworn to avenge his comrades and their families who, Sawaba's leaders would have told him, had all been shot. ${ }^{112}$ Diop left Accra again either on 19 March or some date in February, travelled to Kano and entered Niger at the beginning of April $1965 .{ }^{113} \mathrm{He}$ arrived in Niamey with a party of eight men, who were carrying twelve grenades each. He would have admitted that he got the grenades from an undisclosed source in Nigeria and that he had originally planned to kill the president at the airport upon his return from a visit to Abidjan. ${ }^{114}$ Since Diop originated from the Zinder area, few people in the capital knew him, which could explain why he had been able to come so close to the president. ${ }^{115}$ Ghana's ambassador wrote that activists had planned to throw grenades simultaneously in all the district capitals during Tabaski prayer meetings. Underground activists would have openly warned the government that 'their number was great' and that these actions would continue. ${ }^{116}$

${ }^{108}$ Africa Research Bulletin, (1965), 279. The only reference, so far, to Sawaba training in North Korea.

${ }^{109}$ GNA: N/POL 65, Ambassador B.L. Placca to H.E. M.F. Dei-Anang, African Affairs Secretariat, 14 April 1965. Also Chaffard, Les Carnets Secrets, 327.

${ }^{110}$ Africa Research Bulletin, (1965), 279.

111 GNA: NC/47, From Ghanaian Embassy Niamey to Ministry of Foreign Affairs, Accra (for Dei-Anang from Placca), 14 April 1965.

${ }^{112}$ Chaffard, Les Carnets Secrets, 327.

${ }^{113}$ Fraternité Hebdo (9 July 1965), citing Niger's foreign minister's speech (Aliali, 'Le Contentieux Nigéro-Ghanéen'), gives 19 March as the date of Diop's departure from Accra and 10 April as the date of his arrival in Niger. GNA: NC/48, For Dei-Anang from Placca, 15 April 1965, gives February as the time of departure for Nigeria and says that Diop's party arrived in Niamey 'since' 5 April. Kano is mentioned as a forward base in Africa Research Bulletin, (1965), 273.

${ }^{114}$ However, when he was spotted at the airport, he disappeared quickly from the scene. GNA: NC/48, For Dei-Anang from Placca, 15 April 1965 and N/POL 65, Ambassador B.L. Placca to H.E. M.F. Dei-Anang, African Affairs Secretariat, 14 April 1965.

115 'L'Attentat Manqué contre M. Hamani Diori'.

${ }^{116}$ GNA: NC/47, From Ghana Embassy Niamey to Ministry of Foreign Affairs, Accra (for Dei-Anang from Placca), 14 April 1965 and N/POL 65, Ambassador B.L. Placca to H.E. M.F. Dei-Anang, African Affairs Secretariat, 14 April 1965. A source of the 


\section{Aftermath}

By now the high point in Sawaba's war had come and gone and Niger's government lashed out at its enemies. Disagreements in the country's triumvirate healed overnight, with Maïga and Boubou Hama uniting behind the president. On 25 May, the State Security Court sentenced five people to death, including Zodi Ikiah, the former Minister of Defence, and Captain Hassan Diallo, who had both been interned for the 1963 mutiny. Fourteen people were sentenced to life imprisonment, 28 received sentences ranging from four to fifteen years, while eighteen others were acquitted. ${ }^{117}$

While the government was busy rounding up activists, it also turned its attention to foreign quarters. It consulted Western governments, mended relations with Mali and Dahomey and improved diplomatic ties with Nigeria, where Sawabists were arrested after a shooting incident in Kano. ${ }^{118}$ Ghana was isolated through action in the OAU. When Ben Bella was toppled in a coup d'état in Algeria in June 1965, Sawabists there were ordered to desist from political activity in return for their right of abode. ${ }^{119}$

More dramatic were the consequences of Nkrumah's fall from power the year after. With Nkrumah toppled, Sawaba's men were effectively trapped inside Ghana, and only a few leading figures and assistants managed to escape to the country's Eastern-bloc embassies. ${ }^{120}$ In April 1966 some sixty ${ }^{121}$ handcuffed Sawabists were deported to Niamey. ${ }^{122}$ Dan Galadima, Sawaba's Chief of Staff, was arrested in January 1967. ${ }^{123}$ Djibo had found temporary solace in Accra's Bulgarian mission. Later, he managed to leave Ghana. At the end of 1966, he

Ministry of the Interior said that 'similar terrorist activities' had taken place in many parts of Niger on the day of the attempt on Diori's life. Africa Research Bulletin, (1965), 279. I am not aware of any evidence of this.

${ }^{117}$ Presumably all Sawabists or Sawaba sympathizers. Africa Research Bulletin, (1965), 298.

${ }^{118}$ Ibid., 335.

${ }^{119}$ Chaffard, Les Carnets Secrets, 329-30.

120 Comte, 'Treize Années d'Histoire Nigérienne', 36-37 and idem., 'Ou en Est le Niger?', France-Eurafrique, 175 (July 1966), 11, which mentions the Cuban and Albanian embassies.

${ }^{121}$ A. Faujas ('La Politique Etrangère du Niger', Revue d'Etudes Politiques Africaines, 72 (1971), 46) speaks of 34 Sawabists being deported as of March. These would have included eight commandos who had participated in the 1964 invasions. Africa Research Bulletin, (1966), 485.

${ }^{122}$ Comte, 'Ou en Est le Niger?', 11.

${ }^{123}$ It is unclear in which country. West Africa, 22 July 1967. In that same year he was in prison in Niger, to which he was presumably deported. Ruttiman, 'Le Président Hamani Diori Nous Déclare.' 
was spotted in Algiers, where Abdoulaye Mamani was still based, and early in 1967 he left for Dar es Salaam. ${ }^{124}$

The party's staff base had shrunk from some 300-400 people to possibly twenty or thirty diehards. ${ }^{125}$ As of 1966, the government began to pardon individual activists, while others were thrown in prison. ${ }^{126}$ The partial clampdown continued until the end of the decade. In 1969 the authorities organized trials in Tahoua and Agadez, following which 134 people were sent to prison for several years. Two years later, 53 of these were pardoned, Amadou Diop's death penalty was commuted to life imprisonment and 81 life sentences were reduced to twenty years' imprisonment. ${ }^{127}$

\section{'In search of estuaries': Interpretation and conclusion}

At the time of the invasion, outside observers saw Sawaba's actions as evidence of a regional-ethnic conflict, placing east against west and the northern Touareg against the south, with the Zerma majority in government accused of favouring the ethnic communities in the west. ${ }^{128}$ The government's inner circle was staffed mainly by Zermas and Songhais, while Sawaba specifically aimed to incite members of minority ethnic groups (Peul) or people of inferior social status (bellas). Moreover, there were tensions in the Hausa east in the run-up to the invasion. There were, however, also other cleavages that cross-cut with these ethnic-regional divisions and, hence, reduced their salience. The government had also adopted a profoundly conciliatory attitude towards Hausaland's chiefly

\footnotetext{
${ }^{124}$ Chaffard, Les Carnets Secrets, 331 and idem., 'La Subversion au Niger en 1965', 37. Both men returned to Niger in 1974 when Diori's regime was toppled, but a little later were incarcerated and spent several years in prison before being released. Mamani died in 1993 and Djibo in 1998.

${ }^{125}$ Comte, 'Ou en Est le Niger?', 11. However, in the Ruttiman interview Diori estimated Djibo's followers to be between fifty and seventy. Ruttiman, 'Le Président Hamani Diori Nous Déclare'.

${ }^{126}$ Comte, 'Ou en Est le Niger?', 12, and 'Treize Années d'Histoire Nigérienne', 3. On 10 August 1967 Hassan Diallo had his death sentence commuted to life imprisonment. The same happened to Zodi Ikiah. Both were released in February 1971. Boubacar Ali Diallo, former Sawabist and cabinet minister arrested after the 1964 invasions, had died of a fever in prison on 11 May 1965. Adamou Sekou, incarcerated in the Sahara, was released and reintegrated into the administration. Le Monde, 21-22 February 1971; Decalo, Historical Dictionary of Niger, 117-18 \& 332-33; Chaffard, Les Carnets Secrets, $328 \& 331$

${ }^{127}$ Le Monde, 21-22 February 1971. Also C. Raynaut, 'Trente Ans d'Indépendance: Repères et Tendances', Politique Africaine, 38 (June 1990), 9.

${ }^{128}$ See the editorial in Le Monde, 16 October 1964.
} 
class, ${ }^{129}$ something that weakened Sawaba's power base in an area where its support among the peasantry had never been strong.

In this context, Sawaba agitation was less the expression of regional-ethnic deprivation than a revolt against the social-generational dimensions of the status quo in Hausaland itself, a dimension that was also much broader than the cultural confines of Hausaland. It should be noted, for example, that while many activists appear to have been Hausa, several others were not. Some even originated from other countries. That generational tensions ${ }^{130}$ were present in Nigerien politics in the 1960 s had already been noted by contemporary observers, who referred specifically to people in their twenties and thirties, with relatively high levels of education and good incomes. ${ }^{131}$ Looking at Sawaba, one may conclude that this conflict was much wider and involved youths of lower status. While the available evidence is sketchy, one is struck by the relatively humble backgrounds of the guerrillas. They had had vocational training and included masons, nurses, gardeners and agricultural instructors with an aspiration for higher education. Most claimed they were lured with promises of schooling abroad, an assertion not so extraordinary in view of Djibo's international linkages. In their confessions, the arrested guerrillas presented themselves as eager, gullible youngsters who were intent on going abroad and enrolling in foreign institutions, but were kept dangling until they found themselves in Eastern bloc schools studying, not their desired courses in agriculture or architecture, but Marxism-Leninism and agit-prop. Once they discovered the true reasons behind their travels, they could not opt out and return home since they were financially dependent on their benefactors. Hence, they decided to make the best of it. ${ }^{132}$

This should not be dismissed outright as disingenuous. In Niger and West Africa generally, then as now, one could not lightly dismiss an offer of a free

\footnotetext{
${ }^{129}$ S. Abba, 'La Chefferie Traditionnelle en Question', Politique Africaine, 38 (1990) 56.

${ }^{130}$ These were specifically noted by Le Monde (16 October 1964) in relation to the insurrection.

131 V.T. Le Vine, Political Leadership in Africa: Post-Independence Generational Conflict in Upper Volta, Senegal, Niger, Dahomey, and the Central African Republic (Stanford, 1967), 31-32 \& 84-85.

${ }^{132}$ See the interviews conducted by Bretholz and Braumann. A tendency to make the best of it could also be observed in other contexts and periods. See for example, C. Dunton, 'Black Africans in Libya and Libyan Images of Black Africa', in R. Lemarchand (ed.), The Green and the Black: Qadhafi's Policies in Africa (Bloomington \& Indianapolis, 1988), 150-66, especially 159.
} 
education or foreign travel. ${ }^{133}$ Moreover, a contemporary eyewitness who went to study medicine in the People's Republic of China reveals the misunderstanding over the true purpose of these journeys to Eastern bloc countries. Many had expected they would be taught a profession but to their surprise faced sub-standard courses and political indoctrination. ${ }^{134}$ This part of the testimony may, therefore, well have been genuine.

Whether this was also true for the journeys to the Far East, which were follow-up visits for the higher cadre, is open to question. The testimonies consistently pleaded ignorance about military training as the objective of the long road to China, although they are not unambiguous. ${ }^{135}$ Perhaps the guerrillas were just blessed with a mixture of personal aspirations, ideological conviction and pragmatic opportunism. In addition, Sawaba's recruits were subjected to what appeared to be stiff discipline. The Instructions et Directives aux Missions found on arrested commandos included what Gilbert Comte quoted as 'Le Serment du Combattant Nigérien', which provided en detail the text and procedure of the oath of allegiance that the party's soldiers had to swear before Sawaba's flag. It came down to an unconditional subjection to the party's leadership, on pain of unspecified sanction - more or less along the lines of the dogma of democratic centralism as practised in communist parties. ${ }^{136}$ Several of the arrested guerrillas complained about the discipline they had been subjected to. ${ }^{137}$ One Sawabist, who had provided his leaders with intelligence running counter to party analysis, was treated as a 'counter-revolutionary' and 'defeatist'. He was reminded of his oath and the money spent on his education. ${ }^{138}$

Nevertheless, their oath of allegiance and military preparations made it clear that the Sawabists had come to kill if necessary. Hope of attaining good domestic positions as veterans of a victorious army and a certain eagerness to

\footnotetext{
${ }^{133}$ See, in other contexts/periods for example, Dunton, 'Black Africans in Libya' and K. Peters \& R. Richards, "'Why We Fight”: Voices of Youth Combatants in Sierra Leone', Africa, 68, 2 (1998), 183-210.

${ }^{134}$ E.J. Hevi, An African Student in China (London \& Dunmow, 1963), 119-43. Translated excerpts of this book were published in extenso in Fraternité Hebdo in the spring and summer of 1965.

135 'C'est vrai ... les dirigeants nous ont envoyés en Asie sans préciser le caractère de notre formation. En apprenant là-bas qu'il s'agissait d'entraînement militaire, nous ne pouvions pas prétrendre avoir été induits en erreur.' Ruttiman, 'Le Président Hamani Diori Nous Déclare.'

${ }^{136}$ G. Comte, 'Un Plan de Destruction du Niger', France-Eurafrique, 161 (April 1965), 9-10.

${ }^{137}$ Ruttiman, 'Le Président Hamani Diori Nous Déclare'.

${ }^{138}$ Djibo Seyni to Bretholz ('Comment N'Krumah et Ses Amis Communistes').
} 
return home after several years in exile may have given them the final push. In addition, some activists, like Amadou Diop, may have been motivated by revenge for what the authorities did to fellow activists. However, as Diop had come straight from Accra and arrived in Niamey with several other men, the attempt on Diori may have been approved at the highest level of the party. ${ }^{139}$ That the act was carried out during a Muslim prayer meeting - a fact met with contempt among Nigeriens, including Sawaba sympathizers ${ }^{140}$ - shows the degree of hostility between Sawaba and Niger's political leadership.

Ideological justification for this violence was provided by a cocktail of militant African nationalism, Marxism-Leninism and Maoist beliefs. Many of the party's arguments centred on the degree of foreign (French) influence in Niger, which had 'imposed' a 'neo-colonial' regime on its people. In addition, Maoist and Marxist-Leninist doctrines suggested an analysis of Niger's political situation involving a systematic justification for Sawaba's war as historically correct. That these ideological perspectives were unsuited to the circumstances pertaining in Niger is beside the point, as the evidence suggests that the Chinese and, perhaps, Sawaba's officers, thought they were appropriate. When Niger's authorities arrested the party's commandos, they found various documents and personal notebooks faithfully reproducing Maoist and Marxist beliefs. The notebooks, embellished with dragons and pagodas, contained heavy ideological prose copying Chinese views on such outlandish issues as Peking's quarrels with the Soviet Union and Soviet-Yugoslav 'revisionism'. Alternatively, the handwritten notes reproduced more stereotypical and unsuitable tenets as the vanguard role of the proletariat and the identification of imperialism, feudalism and the 'comprador bourgeoisie' as the targets of Sawaba's revolutionaries. The fact that these notes were found alongside gris-gris (personal fetishes meant for protection against evil) shows that if these Marxist beliefs had been internalized by the party's fighters, they were at least part of a blend of discursive imaginations of reality. ${ }^{141}$

In the past, doubts have been expressed about the sincerity of Djibo Bakary's own ideological convictions. ${ }^{142}$ They involved a militant-nationalist interpretation of Niger's situation, the portrayal of Diori's presidency as a neocolonial usurpation of power and occasional references to Pan-Africanist tenets. Djibo's militancy may also have been fed by the experience of exile. The sketchy evidence on his behaviour during this period paints a picture of an

\footnotetext{
${ }^{139}$ See Ruttiman's interview with Diop ('Le Président Hamani Diori Nous Déclare').

${ }^{140}$ GNA: N/POL/66, Ambassador B.L. Placca to H.E. M.F. Dei-Anang, African Affairs Secretariat, 16 April 1965. See also Comte, 'An Assassination that Failed', 509.

${ }^{141}$ Comte, 'Les Carnets de Nankin'.

${ }^{142}$ Fuglestad, History of Niger, and 'Djibo Bakary, The French, and the Referendum of 1958 in Niger'.
} 
uncompromising personality, driven perhaps by revenge, and intent on capturing power from a rival politician by capitalizing on resentment among certain sections of Niger's population. Even after the disastrous autumn invasions, Djibo did not show any signs of soul-searching or regret about the fate of his foot soldiers.

Sawaba's analysis failed to grasp the weakness of its support base, which was flawed as a result of its inability to penetrate the Hausa peasantry, hold the backing of the Sarkis and gain a significant foothold in the west of the country. The rising tensions in Hausaland in 1963-1964 did not, therefore, provide enough ground for a successful revolt. Exile may have militated against realistic appraisal. While the party possessed a network of internal spies, its command structures precluded careful processing of information. In many cases, informers tried to please the leadership by feeding it data confirming its analysis, ${ }^{143}$ while contrary intelligence was ignored. ${ }^{144}$

Despite meticulous planning the execution of the invasion was marred by mistakes and inattention to detail. Many of the rank and file had not been paid for some time and before reaching the targeted entry points in Niger had to fend for themselves. ${ }^{145}$ Weaponry was insufficient ${ }^{146}$ and a possibly fatal error in strategy was the decision to attack along the entire length of the southern and western frontiers. While this required considerable capacity for planning and coordination, it also diminished the strike power of Sawaba's forces. The decision to attack the western sector first, possibly induced by a desire to reach the capital as quickly as possible, diminished any chance of success even further, as it was here that the party enjoyed least support.

Nevertheless, guerrillas and leadership appeared to display shocking confidence in the run-up to the invasion. The guerrillas had expected to be received with open arms as they would have been told by the party leadership that they could expect a triumphant welcome. ${ }^{147}$ This anticipation may have been part of the reason why Sawaba thought that it could gain control of a country the size of Niger with only 240 men at its disposal. It could also explain why guerrillas claimed that they had been fooled by their leaders. The rank and file were possibly convinced that things were about to change. Hence, they were eager to leave their Ghanaian base camps. ${ }^{148}$ This psychology of coming home, which nobody who has experienced years of exile can fail to ignore, may have

\footnotetext{
${ }^{143}$ Ruttiman, 'Le Président Hamani Diori Nous Déclare.'

${ }^{144}$ Djibo Seyni to Bretholz ('Comment N'Krumah et Ses Amis Communistes').

145 For complaints about this by arrested commandos, see Ruttiman, 'Le Président Hamani Diori Nous Déclare'.

${ }^{146}$ Ibid.

${ }^{147}$ Ibid. and Morillon, 'La Tentative Insurrectionelle du SAWABA'.

${ }^{148}$ Chaffard, Les Carnets Secrets, 322.
} 
driven them to their death. ${ }^{149}$ This could additionally explain why many of the leaders headed the units that infiltrated the country and why no one bothered to destroy their papers as they had been instructed to. ${ }^{150}$

The actions of Djibo himself appeared influenced by naive - even romantic - conceptions about the nature of revolutionary struggle. While he was instructing Salle Dan Koulou to introduce the villayas system of autonomous military regions, Sawaba's commandos would not have had the possibility of applying a system that drew its inspiration from a very different war of liberation. Coupled to his years in exile, this romantic touch led to what Ghana's ambassador in Niamey deemed Djibo's dependence on miracles rather than political organization. ${ }^{151}$ Yet a belief in miracles may have been a crucial part of Sawaba's inspiration. In fact, it had that romantic dimension in common with most Marxist-inspired ideologies of revolutionary liberation, which were fashionable at the time and stipulated the need for a radical break with the past, but with little precise guidance. Colburn notes, in this respect, that MarxismLeninism amounts, or amounted, more to a mentalite than a coherent plan of government, which explains the millenarian ideas of revolutionary elites and their ignorance of how to realize society's Herculean transformation. ${ }^{152}$ Imbued by such conceptions, revolutionaries could be seen as the mystics of the twentieth century. ${ }^{153}$ Consequently, as the nationalist agitator trained in the best French communist tradition, Djibo could be considered representative of or at least affected by a dreamy framework that urged him to walk inexorably towards the attainment of his burning desire - the capturing of political power. ${ }^{154}$

\footnotetext{
${ }^{149}$ Thus in 1962, a homesick party activist gave himself up to Niger's authorities. Ibid., 308.

${ }^{150}$ Alternatively, retention of their writings may have been an act of self-assertion, as induced the behaviour, for example, of Alice Lakwena's followers. H. Behrend, Alice Lakwena \& the Holy Spirits: War in Northern Uganda 1986-1997 (Oxford, 1999), 4.

${ }^{151}$ GNA: N/POL/66, Ambassador B.L. Placca to H.E. M.F. Dei-Anang, African Affairs Secretariat, 16 April 1965.

${ }^{152}$ F.D. Colburn, The Vogue of Revolution in Poor Countries (Princeton, 1994).

${ }^{153}$ As phrased by Edmundo Desnoes.

${ }^{154}$ As Sawaba had contacts with Castro's Cuba, Che Guevara's popularity at the time may also have added to this romantic streak. It is not inconceivable that Djibo and Che met, as Che visited Ghana and Dahomey, among others, while on an African tour between December 1964 and March 1965 - according to a US State Department memorandum of 19 April 1965 (copy in W. Gálvez, Che in Africa: Che Guevara's Congo Diary (Melbourne \& New York, 1999), 136-37.
} 
The same buoyancy characterized the Chinese, whose leader Mao Tse Tung enjoyed exceptional prestige among Third World revolutionaries. ${ }^{155}$ In the same decade as the Cultural Revolution, the creation of chaos would have fitted into Chinese ideas of revolutionary advancement through conflict and destruction. ${ }^{156}$ If Sawaba's commanders presented, at best, a rather mediocre picture of the party's intellectual forces, this was certainly matched by what appeared to be a complete misunderstanding by the Chinese of African conditions - something that can partly explain their spectacular failure. ${ }^{157}$ Thus, instructions found on Sawabists assured the latter that the revolutionary potential of the rural areas was 'inexhaustible', as the peasant masses were eager to shake off the forces of imperialist domination. Inspired by their own history, China's instructors advised Sawaba's men to conquer the countryside and then encircle the cities; and just in case the situation should turn against them, they were advised to establish support bases in mountainous regions or areas with "networks of rivers, lakes and estuaries'. ${ }^{158}$

Predictably, once on the ground, the Sawabists appeared to be at a complete $\operatorname{loss}^{159}$ and were destroyed as much by their own ineptitude as by the government's forces. Shooting each other by accident and stumbling on hostile peasants, they were beaten to death in a lynching party or captured alive, stripped naked in public and shot by firing squads and their bodies laid to rot in desecration. They met total humiliation, demonstrating for all to see that Sawaba's luck had run out. If contemporary observers found the idea of desperate guerrillas seeking refuge in Niger's imaginary estuaries amusing, ${ }^{160}$ later authors were perhaps closer to the truth when judging it pitiful. ${ }^{161}$ This, of course, does not transform Sawaba's men into moral champions. They were, after all, carrying arms, shot their enemies and wounded others. While this is not the place to engage in conjecture, one wonders what would have happened if the invasion had turned into a rout of the PPN. War is ignorant of romance.

\footnotetext{
${ }^{155}$ C. Clapham, 'Introduction: Analysing African Insurgencies', in C. Clapham (ed.), African Guerrillas (Oxford, 1998), 8.

${ }^{156}$ Colburn, The Vogue of Revolution in Poor Countries, 10-11.

${ }^{157}$ That such a misunderstanding was mutual was shown by Hevi, An African Student in China.

${ }^{158}$ Text in Comte, 'Les Carnets de Nankin', 29.

${ }^{159}$ Le Monde, 4 February 1965.

${ }^{160}$ Comte, 'Les Carnets de Nankin', 29

${ }^{161}$ R. Colin, 'Dynamiques Populistes et Cristallisations Institutionnelles (1960-1990)', Politique Africaine, 38 (1990), 31.
} 


\title{
The vagaries of violence and power in post- colonial Mozambique
}

\author{
Gerhard Seibert
}

Renamo fought a bloody war from 1976 to 1992 against the socialist Frelimo government that devastated the country, but since Renamo had been created by Rhodesia and subsequently supported by South Africa, the internal dimensions of the conflict were played down. However, the resistance of large sections of Mozambican society against the authoritarian politics of the Frelimo regime explains why Renamo did not remain a small guerrilla force but finally controlled entire regions of the country. The excessive violence against civilians by Renamo obscured the fact that in certain regions the movement enjoyed popular support. The conflict in Mozambique was both a modern war with sophisticated weapons and an armed conflict where ritual powers played a role. After the war, collective and individual rituals contributed to the reconciliation of the warring parties and the reintegration of individuals into their local communities.

\section{Introduction}

Just one year after independence and the end of the struggle by the Liberation Front of Mozambique (Frelimo) against the Portuguese colonial army, Mozambique once again became a theatre of war when the Mozambican National Resistance (Renamo) began its campaign against the socialist Frelimo government. The war lasted twelve years and was one of the most violent and destructive periods in post-colonial African history. The conflict was not only a 
modern war with sophisticated weapons and the interference of foreign powers but was also an armed conflict in which traditional methods of warfare and ritual powers were influential. Renamo used terror and excessive violence often of a ritualized form in areas controlled by the government and in zones where initial popular support for Renamo had vanished due to the forced recruitment of youngsters and the coercive methods the rebels employed to compel people to hand over food. This chapter considers the violence not as the individual acts of sadistic commanders or the consequence of poor military discipline but as Renamo's way of deliberately terrorizing the local population. However violence and terror tactics were not the prerogative of the Renamo forces and were employed equally by government forces.

About one million people lost their lives during the conflict, an estimated 200,000 children were orphaned and another 250,000 separated from their families. ${ }^{1}$ Some 1.7 million people, more than 10 per cent of the total population, fled to neighbouring countries and another 4.3 million people became so-called deslocados (displaced persons) and sought refuge in the cities and other government-controlled areas $^{2}$ while the rebels systematically destroyed their schools, hospitals and government buildings. The excessive violence against civilians frequently tended to obscure the fact that there were considerable regional differences on both sides as far as the relationship between soldiers and the local population was concerned.

Popular resistance by large sectors of Mozambican society to the modernization projects of the socialist Frelimo regime, as well as the regional contradictions stemming from the (pre-)colonial era and the widespread use of violence can all help to explain how Renamo was able develop from a small, externally created rebel group into a large guerrilla army that finally controlled entire regions of the country.

\section{The origins of Renamo}

Renamo was set up in 1976 by the Rhodesian secret service, the Central Intelligence Organisation (CIO), to attack Zimbabwe African National Liberation Army (ZANLA) bases across the border in Mozambique and destabilize the Frelimo regime because of the support it offered the

\footnotetext{
${ }^{1}$ A.A. de Abreu, 'Mozambican Women Experiencing Violence', in M. Turshen \& C. Taagiramariya (eds), What Women Do in Wartime: Gender and Conflict in Africa (London \& New York, 1998), 74.

2 S. Maslen, ILO Action Programme on Skills and Entrepreneurship. Training for Countries Emerging from Armed Conflict. The Reintegration of War-Affected Youth: The Experience of Mozambique (1997), 1.
} 
Zimbabwean African National Union (ZANU). ${ }^{3}$ However the Rhodesian army itself also attacked ZANLA bases, refugee camps and infrastructure in central Mozambique. For example, during a raid on a refugee camp in Nyazonia (Manica Province) in 1976 the Rhodesians killed some 600 people. ${ }^{4}$

The first members of Renamo recruited by the Rhodesians were demobilized Mozambican soldiers of the Portuguese colonial army and former Frelimo guerrillas who had fallen into disgrace at home. The rebel group was not given any political programme during its three-month military training in Odzi, Rhodesia but recruits were submitted to anti-communist and anti-Frelimo propaganda. The Rhodesians used to pay the rebels a regular monthly salary and an additional bonus for every successful operation they undertook, ${ }^{5}$ money that was an important motivational factor that encouraged young men, and their families in central Mozambique, to participate in the war. ${ }^{6}$

\section{Violent recruitment methods}

Many of the Renamo fighters were young men and children kidnapped during attacks on their villages. ${ }^{7}$ In many cases Renamo forced children to kill one of their parents or a relative to break their links with the community and bind them to the movement through shame and guilt. Child soldiers were reportedly forced to smoke a mixture of soruma (marijuana) and gunpowder to increase their courage and physical strength. ${ }^{8}$ Child units were primarily employed in attacks on civilians and in looting raids on local communities to provide bases with supplies. They were rarely involved in direct confrontations with government troops. ${ }^{9}$ Most children were abducted in the south where Renamo was less wellestablished among the local population. Escape was risky since Renamo would retaliate with immediate execution and abducted men and children were usually taken to distant training camps to prevent escape. In addition, the threat of being

\footnotetext{
${ }^{3}$ At the time the official designation was Mozambican National Resistance (MNR).

${ }^{4} \mathrm{~W}$. Finnegan, A Complicated War: The Harrowing of Mozambique (Berkeley, Los Angeles \& London, 1992), 31.

${ }^{5}$ G. Tajú, 'Renamo: Os factos que conhecemos', Cadernos de História. Boletim do Departamento de História da Universidade Eduardo Mondlane, 7 (1988), 16.

${ }^{6} \mathrm{~J}$. Schafer, 'Guerrillas and Violence in the War in Mozambique: De-socialization or Re-socialization?', African Affairs, 100 (2001), 224.

${ }^{7}$ Female soldiers fought on both sides during the conflict but their numbers were insignificant. Only 1,380 women were demobilized (about 1.5 per cent of the total of 92,881). J. Schafer, 'A Baby Who Does Not Cry Will Not Be Suckled. AMODEG and the Reintegration of Demobilized Soldiers', Journal of Southern African Studies, 24, 1 (1998), 16.

${ }^{8}$ Ibid. 16 \& 21.

${ }^{9}$ O. Roesch, 'Renamo and the Peasantry in Southern Mozambique: A View from Gaza Province', Canadian Journal of African Studies, 26 (3), 472.
} 
punished by the government after their return discouraged the captives from abandoning Renamo. Anyone who escaped the clutches of Renamo was likely to find himself in a no-win situation as government forces frequently accused escaped captives of having failed to fight Renamo forces or of being Renamo collaborators, in which case they were severely punished.

Promotion within Renamo military ranks was not dependent on how a person had been recruited and some of those abducted during Renamo raids even made it to the rank of general. One, for example, had been travelling in a bus full of young men who had been forcefully recruited by the government when Renamo attacked the vehicle and took all the men to their own training camp.

Frelimo used to act similarly and did not only regularly organize raids to kidnap young men for military service, but also recruited children by force, albeit to a lesser extent than Renamo. At the time of their recruitment, 16,553 government soldiers (23.3 per cent of the total Frelimo soldiers later demobilized) and 8,945 Renamo guerrillas (40.7 per cent) had been under 18 years of age. Another 4,334 Renamo soldiers (19.7 per cent of total ex-Renamo fighters) and 3,073 government soldiers were aged between 10 and 14 at the time of their abduction and can be considered child soldiers. ${ }^{10}$ According to a survey conducted during the demobilization process, 82 per cent of Frelimo soldiers and 87 per cent of Renamo guerrillas were recruited by force. ${ }^{11}$

To increase the educational level of its cadres, Renamo lured some 200 secondary school students into its ranks by promising scholarships to study abroad. However, the opportunities never materialized and many of the students died in the rebel camps of disease and hardship. ${ }^{12}$ While coercion was dominant in recruitment, voluntary participation in the war was due to a lack of alternative opportunities. Basic survival and the chance of gaining access to goods and food, and sometimes a vague notion of political conviction against Frelimo's socialist projects played a role in the recruitment process. ${ }^{13}$ Even in the south of the country where Renamo did not enjoy much popular support and despite the dangers of war and the Renamo's notoriously strict discipline, young men were attracted by the excitement of guerrilla life, adventure, the availability

10 S. Barnes, The Socio-Economic Reintegration of Demobilised Soldiers in Mozambique. The Soldiers' View (Maputo, 1997), 17. Children under 15 years of age at the end of the war were excluded from the official demobilization process.

${ }^{11}$ Schafer, 'A Baby', 217.

${ }^{12}$ J.C.G. Pereira, 'The Politics of Survival: Peasants, Chiefs and Renamo in Meringue District, Mozambique, 1982-1992', Unpublished MA thesis, University of the Witwatersrand (Johannesburg, 1999), 43.

${ }^{13}$ Schafer, 'Guerrillas', 236. 
of women, and easy access to looted goods. ${ }^{14}$ Occasionally during Renamo attacks on local communities, young boys even joined the rebels in looting their neighbours' houses and then left with the attackers. Everywhere in the impoverished country large sectors of the population found themselves without schooling, skills or employment. The rampant economic crisis and the devastating war had increased the numbers of those marginalized, creating a fertile ground for further Renamo recruitment. Derluguian suggests that people who find themselves constantly in a situation of disintegrating social relations and generalized instability caused by crisis and war lose any immunity to violence and easily become both its object and subject. ${ }^{15}$

\section{Renamo's military organization}

Renamo was never composed of loosely operating small units but was a centrally organized and hierarchical military organization. Under the supervision of Afonso Dhlakama who became Renamo's president and commander-in-chief in 1980, there was a 15-member military council composed of the three principal commanders of the north, centre and south zones and ten provincial commanders. The basic operational unit was a company of some 100 to 150 men, generally stationed at a central main base with smaller attached bases responsible for special tasks such as security and patrols. A company was divided into platoons, while two or three companies formed a battalion. Usually two or more battalions were based near the provincial headquarters but spread over several bases. Each company had modern radio transmission facilities operated by a communications officer who was in regular contact with the provincial base and indirectly with the headquarters in Gorongosa. The general staff was equipped with a system capable of frequency hopping that impeded detection by government forces.

While the middle and lower-level cadres were multi-ethnic, ${ }^{16}$ the military leadership was dominated by Ndau speakers from central Mozambique, a subgroup of the Shona to which Dhlakama also belongs. They were the first to have been recruited by the Rhodesians and over time had assumed senior

\footnotetext{
${ }^{14}$ A. Harneit-Sievers, 'Sozialgeschichte des Bürgerkrieges in Mosambik. Ein Workshop in Maputo', Afrika Spectrum 30, 1 (1995), 88; Roesch, 'Renamo and the Peasantry', 476.

${ }^{15}$ G. Derluguian, 'Social Decomposition and Armed Violence in Postcolonial Mozambique', Review XIII, 4 (1990), 439-62.

${ }^{16}$ M. Cahen, 'Nationalism and Ethnicities: Lessons from Mozambique', in E. Braathen, M. Bøås \& G. Sæther, Ethnicity Kills? The Politics of War, Peace and Ethnicity in SubSaharan Africa (New York \& Houndmills, 2000), 172.
} 
positions within Renamo's military hierarchy. Consequently, Ndau was the official language in Gorongosa and at many bases, but the lingua franca used in a particular unit depended on the ratio of different ethnic groups represented in its ranks. ${ }^{17}$ When Renamo arrived in a new area the majority of the rebels were Ndau speakers. However, over time they became the commanders, while the majority of the ordinary guerrillas were local people. Also the madjuba (sing. $n d j u b a),{ }^{18}$ the local Renamo representatives and spies, used to come from the native population. Many had been colonial tax collectors or junior officials dismissed by Frelimo after independence. The madjuba maintained links between the Renamo base and the local population and were in charge of the labour recruitment of carriers and others. They did not usually live on the base, but nearby. They were not issued with firearms but used knives, machetes or other similar weapons. It was the madjuba who were said to have committed many of the worst atrocities during the war and regularly mutilated their victims by cutting off their ears, noses, and hands.

\section{Renamo bases}

The principal bases were established in sparsely populated regions but at a distance of less than about $50 \mathrm{~km}$ from more densely populated areas and main roads since the rebels needed access to these areas for supplies. ${ }^{19}$ The excellent radio communication of Renamo troops enabled dispersed units to assemble quickly to mount large-scale attacks and then disperse again.

Although Renamo's communication system was superior to the Frelimo's, the rebels had almost no heavy artillery or mechanized transport ${ }^{20}$ so its troops had to cover large distances on foot, sometimes walking more than $500 \mathrm{~km}$. They relied on the plundering of local food stocks and the abduction of local people to supply their labour requirements. During looting and pillaging raids, everything that could be transported was taken away: cattle, pigs, poultry, foodstuffs, clothes, radios, china and household items. To supply the food needs of the base, Renamo soldiers exchanged looted goods with the local population for foodstuffs and some of the captured goods were even sold in neighbouring countries. During their attacks, Renamo forced local inhabitants to carry the booty back to the military base and as they were often taken by surprise during night-time raids they had to walk barefoot and in their underwear. In a few cases the captives even had to walk distances of more than $250 \mathrm{~km}$ to the

\footnotetext{
${ }^{17}$ M. Hall, 'The Mozambican National Resistance Movement (Renamo): A Study in the Destruction of an African Country', Africa, 60, 1 (1990), 46.

${ }^{18}$ ZANU used the same designation for supporters within the local population.

19 G. Liesegang, 'Der Bürgerkrieg in Mosambik ca. 1980-1992. Abläufe und struktureller Wandel des Landes', Unpublished manuscript (Maputo, 1995), 14.

${ }^{20}$ Finnegan, A Complicated War, 58.
} 
bases. ${ }^{21}$ Usually the whole group walked in Indian file, with the rebels at either end and in the middle to prevent the abducted inhabitants escaping. During the march to the base only the guerrillas were allowed to eat. Exhausted load carriers who were unable to walk further would be killed in front of the others and babies were murdered immediately as the rebels feared that their crying would alert government forces to their presence. Renamo soldiers frequently raped the mainly female carriers during the retreat in front of the other captives.

Most men and some of the women were released after the guerrillas reached their bases. Civilians who were forced to stay with the rebels on the base found themselves in what was cynically called liberdade (freedom) ${ }^{22}$ If a Renamo spy at the base was recognized by one of the newly arrived captives, he usually ordered the immediate execution of the kidnapped, since he feared being denounced if the person managed to escape. ${ }^{23}$ The abducted women and girls were forced to join the officers' and soldiers' households, either as wives or in the case of young girls as servants. Some commanders reportedly had more than five women. ${ }^{24}$ In the early 1980s when the main base was in Garágua (Manica), Dhlakama himself was said to have eight wives, who were officially his bodyguards. ${ }^{25}$ As the wife of a military man, a captive woman enjoyed some protection and was not expected to render sexual services to other men. However, the women of soldiers whose units were transferred remained at the base and received new partners. ${ }^{26}$ Young women in the camps who did not become pregnant risked being killed by their partners. ${ }^{27}$ Newly arrived women frequently became the source of disputes between the guerrillas so to avoid conflict, the problem was solved by killing the woman. ${ }^{28}$ The rebels considered rape and the use of slave wives as their right of access to women and important war booty. ${ }^{29}$

\footnotetext{
${ }^{21}$ Liesegang,'Der Bürgerkrieg', 9.

${ }^{22}$ F. Pequenino, 'Estudo de Caso: Localidade Administrativa de Mugeba (Zambezia), 1982 a 1992', Unpublished paper, Universidade Eduardo Mondlane (Maputo, 1994), 21. ${ }^{23}$ P. de Jesus, 'Alguns Aspectos do Impacto da Guerra em Certas Zonas de Inharrime e Zavala', Unpublished paper, Universidade Eduardo Mondlane (Maputo, 1994), 17.

${ }^{24}$ N. Castanheira, Ex-criança Soldado: 'Não Queremos Voltar para o Inferno' (Maputo, 1999), 11.

${ }^{25}$ Tajú, 'Os factos', 21.

${ }^{26}$ Liesegang, 'Der Bürgerkrieg', 32.

${ }^{27}$ Ibid. 24.

${ }^{28}$ H.C. Mucusete, 'Um Estudo de Caso: O Distrito de Angoche', Unpublished paper. Universidade Eduardo Mondlane (Maputo, 1994), 39.

${ }^{29}$ K.B. Wilson, 'Cults of Violence and Counter Violence in Mozambique', Journal of Southern African Studies, 18, 3 (1992), 536.
} 
The women living on the bases carried goods between bases, looted villages and in the case of permanent bases cultivated plots to produce food. Despite the threat of immediate execution, married women in particular often tried to escape as soon as they had more freedom of movement, while younger single women tended to make the best of their situation and only returned home after the war, often with children. Some continued their relationships with the fighters but most women returned home and were accepted back by their former husbands. Families submitted these women and returning child soldiers to purification rituals performed by traditional healers or pastors of Zionist churches. ${ }^{30}$ Schafer maintains that during the war both government soldiers and Renamo guerrillas considered women in enemy-controlled areas as fair prey for capture and sexual abuse, whereas women in their own areas were generally treated according to local social norms. ${ }^{31}$

A base such as that in Chigowa, Tete Province, was representative of other permanent Renamo bases located in the centre and north of the country. ${ }^{32}$ The military command was situated at the centre of the base, surrounded by the compounds of guerrillas with more than two or three wives, depending on the number of women taken captive. Further out beyond these residences were the huts of the single women who had to render sexual services to off-duty soldiers. Then came the old people and the children's houses and the corrals where the commanders' stolen cattle were kept. The base was surrounded by three circular protection rings. The machambas, the fields for cultivation, were located between the first and second rings. Renamo bases in the south were by contrast only small, often mobile, bases that did not usually have fields or permanent huts but only provisional tents made of plastic sheets or cotton. In the case of a government attack they could easily be moved. The bases relied entirely on plunder and looting for their everyday supplies.

Both soldiers and captives were severely punished for disobedience and the bases often had prisons. Child soldiers were not excluded from punishments that ranged from corporal punishment, the withholding of food, the amputation of fingers, noses and ears, and executions carried out by one or more of the other children. ${ }^{33}$ Captives who could not endure the military training were also killed. ${ }^{34}$ The people on the Renamo bases were also affected by disease and periods of famine when attacks and plundering failed to provide sufficient food.

30 E. Muianga, 'Mulher e a Guerra', Unpublished paper, Universidade Eduardo Mondlane (Maputo, 1994); Castanheira, Ex-criança Soldado, 12.

${ }^{31}$ Schafer, 'Guerrillas', 233.

${ }^{32}$ R.M. Kuyeri, 'História Social da Guerra em Tete', Unpublished paper, Universidade Eduardo Mondlane (Maputo, 1994).

${ }^{33}$ Maslen, ILO Action Programme, 15.

${ }^{34}$ Castanheira, Ex-criança Soldado, 26. 
If food supplies were limited, the guerrillas received what was available and the civilians were simply left to their own devices. ${ }^{35}$ Some of the permanent bases had a military hospital and occasionally Renamo kidnapped curandeiros (healers) and pastors of Zionist churches and took them to the bases where they were obliged to tend the sick and wounded. ${ }^{36}$

\section{The unfolding of the conflict and external support}

The first Renamo attack occurred on 3 February 1977, on the anniversary of the death of Frelimo's first president, Eduardo Mondlane. ${ }^{37}$ On that day two men attacked a school bus on the road between Chimoio and Manica town, just across the border, to kidnap students for military training in Rhodesia. ${ }^{38}$ One of the two attackers was the legendary André Matsangaíssa, a Manyika shoemaker and former Frelimo guerrilla who had fled to Rhodesia from the re-education camp in Sacuza (Gorongoso District, Sofala Province), where he had been imprisoned for embezzling funds after independence. Later in 1977, Matsangaíssa, who in the meantime had become Renamo's leader, commanded a group that attacked the prison camp in Sacuza and succeeded in freeing 75 detainees who were all taken to Rhodesia and incorporated into the emerging Renamo. ${ }^{39}$ As a result of Matsangaíssa's fame Renamo guerrillas became popularly known as matsangas, whereas the official propaganda labelled them as bandidos armadas (armed bandits). Matsangaíssa was killed during a battle with Frelimo in Gorongosa on 17 October 1979 and his succession was fiercely disputed. Finally Afonso Dhlakama, the son of a local chief in Sofala Province, got his way and became the new Renamo leader. He had reportedly given orders to execute his rival Lucas Muchanga, Renamo's second-in-command at the time. ${ }^{40}$

During the years of Rhodesian patronage Renamo's operations were largely restricted to the central provinces of Manica and Sofala. Projects associated with Frelimo such as so-called lojas do povo (people's shops), aldeias comunais

\footnotetext{
${ }^{35}$ Pereira, 'The Politics of Survival', 48.

${ }^{36}$ Castanheira, Ex-criança soldado, 25.

${ }^{37} \mathrm{He}$ was killed by a parcel bomb in Dar es Salaam in 1969.

${ }^{38}$ Personal account of Sebastião Chapepa alias Janota Luís, one of the participants, Chimoio, December 1999.

${ }^{39}$ Tempo, 26 January 1997.

${ }^{40}$ In 1983 and 1988 respectively, other internal conflicts resulted in the murders of Renamo's two first secretary-generals: Orlando Christina, a white Portuguese, in South Africa, and Evo Fernandes, a Mozambican of Goan descent, near Lisbon, Portugal.
} 


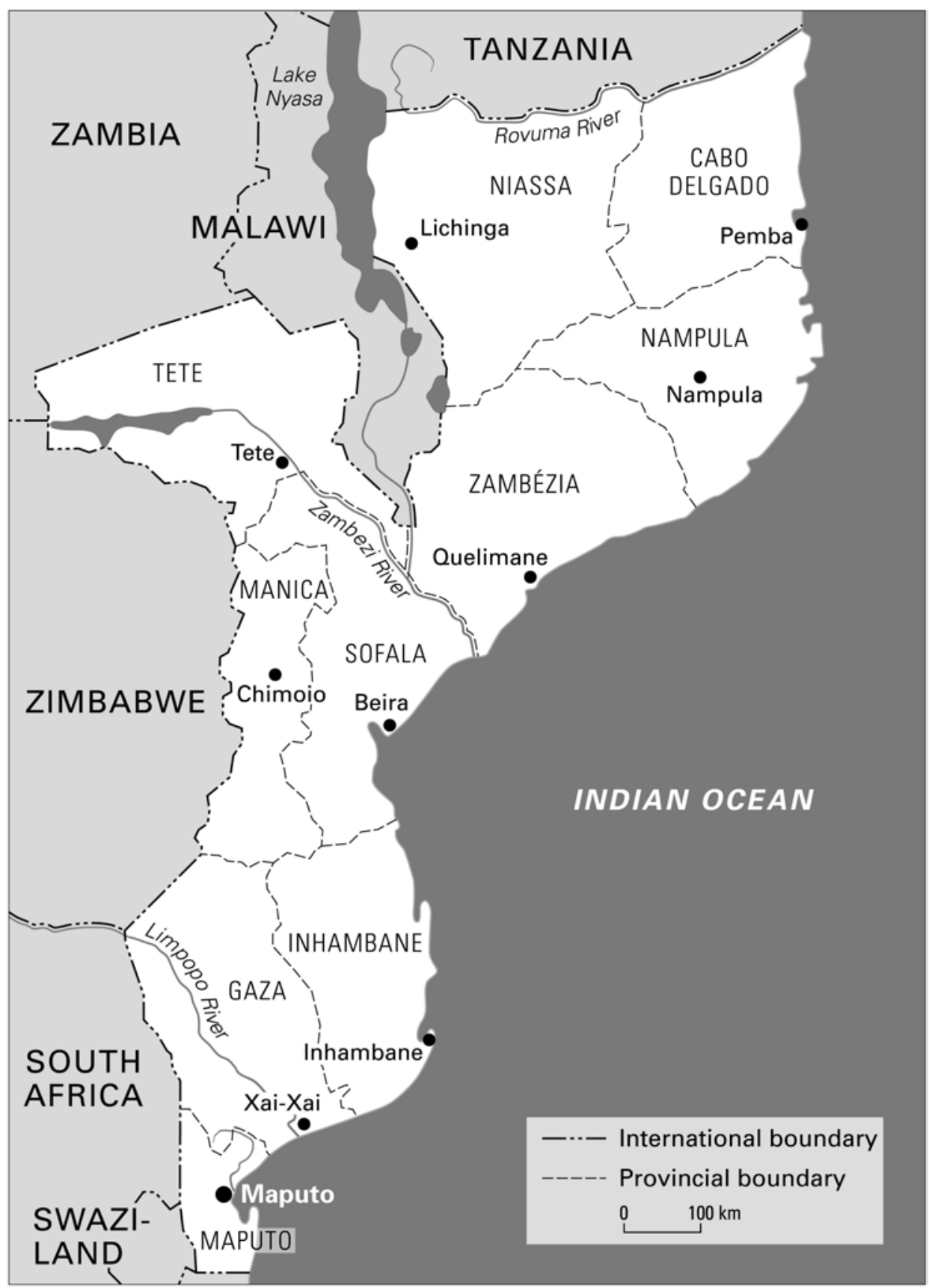

Map 10.1 Mozambique 
(communal villages) and agricultural cooperatives, as well as lorries, buses and trains were the principal targets for attack. At that time, Africa Livre, another small rebel movement based in Malawi, frequently infiltrated and attacked border areas in Zambezia and southern Niassa.

Following Zimbabwe's independence in 1980, Renamo was taken over by South Africa that was keen to support and equip the movement in an attempt to destabilize the Frelimo government. The South Africans were easily able to supply Renamo by air or by sea, since Mozambican government forces were unable to defend the country's large air space and its 2,000 km long coastline. Pretoria's political objective was to force Frelimo to abandon its socialist policy, pursue a more friendly attitude towards South Africa and deny the ANC a safe haven. South Africa was not, however, motivated by a desire to see a Renamo government in power in Mozambique.

Encouraged by its new patrons to promote its international credibility, Renamo for the first time opened representations abroad and in 1981 approved a political programme calling for a government of national unity, democratic elections and a mixed economy. The following year, the movement published a list of members of the National Council. However, the political structures remained minimal and Renamo was always predominantly a military organization.

With South Africa's support, the movement began a successful military expansion into the country's remaining provinces. Within two years its strength had increased from 500 to 8,000 guerrillas ${ }^{41}$ and following the opening of a northern front with Malawi as a staging ground in 1981, the splinter group Africa Livre merged with Renamo. In late 1983 Renamo transferred its headquarters from Phalaborwa (Northern Transvaal) to Gorongosa in Mozambique. The 35,000 government troops were unable to stop Renamo since they were not prepared for anti-guerrilla warfare. Instead, Frelimo forces had been trained in conventional army operations, fearing a possible invasion by the white Rhodesian and South African minority regimes after independence. Government forces were additionally constrained by a lack of education and low morale. ${ }^{42}$

Faced with the advancing rebels, a non-existent infrastructure and a collapsing economy, the Mozambican government sought a peace settlement with South Africa and in March 1984 the Nkomati Accord was signed by the

${ }^{41}$ C. Alden, 'Political Violence in Mozambique: Past, Present and Future', in W. Gutteridge \& J.E. Spence (eds), Violence in Southern Africa (London \& Portland, Or, 1997), 43.

${ }^{42}$ S.L. Weigert, Traditional Religion and Guerrilla Warfare in Modern Africa (New York \& Houndmills, 1995), 83. 
two countries. According to this agreement South Africa would end its support of Renamo, while Mozambique would expel the ANC. In September 1985 Mozambican government troops overran the Gorongosa headquarters, but Renamo soon recaptured it. Documents found in Gorongosa proved that, despite the non-aggression pact, some sectors of the South African regime still continued to support Renamo. Military support for Frelimo, provided by Tanzanian troops in Quelimane in 1987 and Zimbabwean forces in central Mozambique from 1982 onwards, could only temporarily help the government troops to recapture some of the lost ground, but was not able to halt the rebels' expansion. Besides, the Zimbabwean contingent's mission was primarily restricted to protecting the Beira-Mutare corridor that provided trade access for most of Zimbabwe's imports. When Renamo had to leave its bases in Malawi in late 1986 several thousand expelled fighters invaded Zambezia Province in a wave of violence. Subsequently the fighting intensified in the northern provinces of Niassa, Nampula and Cabo Delgado.

While Renamo controlled large parts of the rural areas, the government always maintained control of the cities and most district capitals. Consequently, and contrary to what happened in Angola, Mozambique's larger cities were not affected by fighting and shelling at all. The areas permanently defended and protected by the government covered little more than 10 per cent of the country. ${ }^{43}$ In areas in central and northern Mozambique that remained permanently under its control for many years, Renamo ran schools and a health service and reinstalled deposed local chiefs who assumed some juridical and administrative functions. The origin of the soldiers reflected the government's control of the urban centres: Frelimo recruited most of its soldiers in the cities, while the majority of Renamo troops came from the countryside.

\section{Peace}

As at the beginning of the conflict, the international and regional political constellations were instrumental in the cessation of the bloody war in Mozambique. Government troops received weapons, transport, fuel and the bulk of its food supplies from abroad ${ }^{44}$ and Renamo relied on external sources

43 G. Liesegang, 'Der Bürgerkrieg in Mosambik ca. 1980-1992. Abläufe und struktureller Wandel des Landes', unpublished manuscript (Maputo, 1995), 28.

${ }^{44}$ Liesegang, 'Der Bürgerkrieg', 41. 


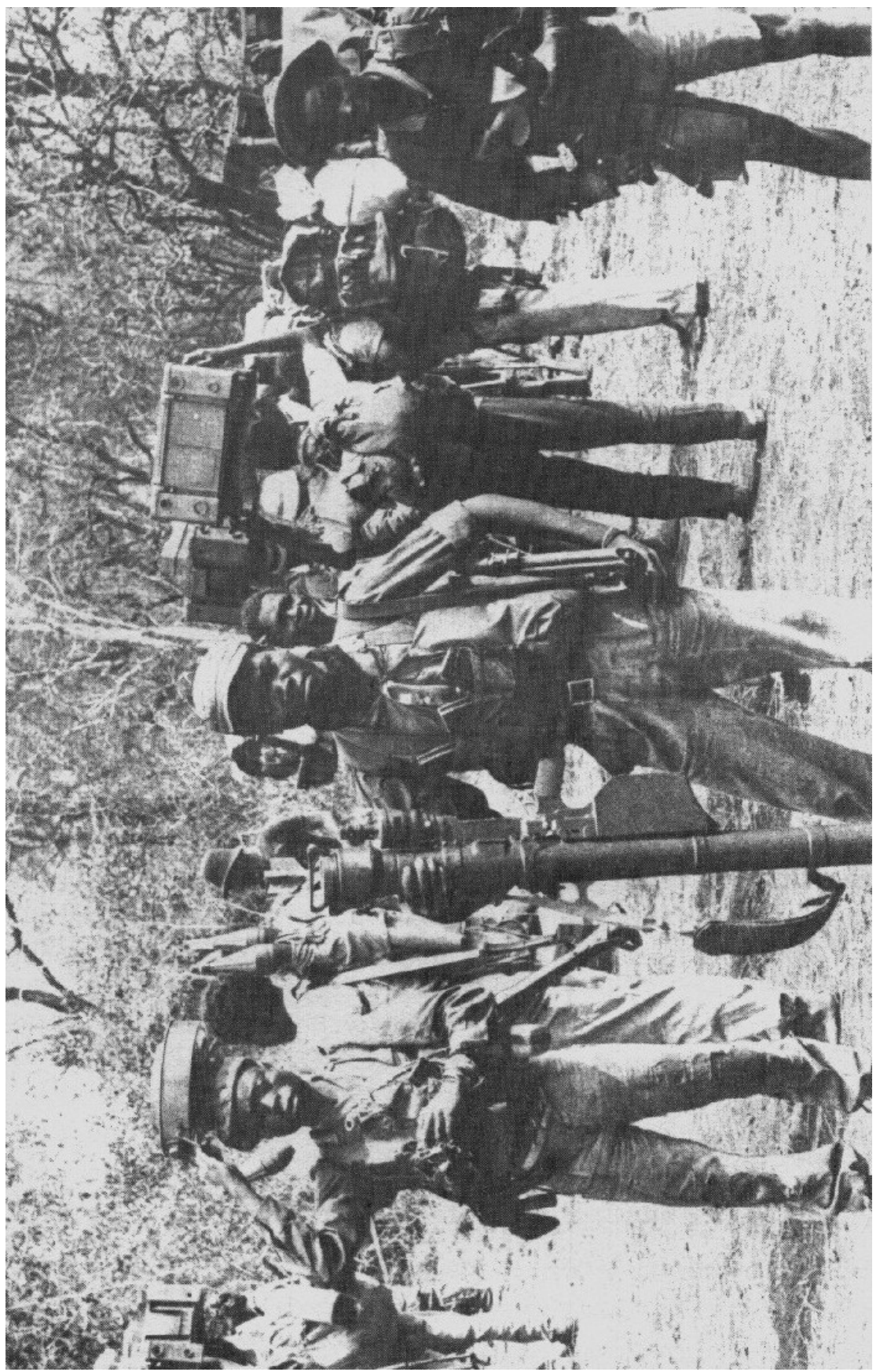

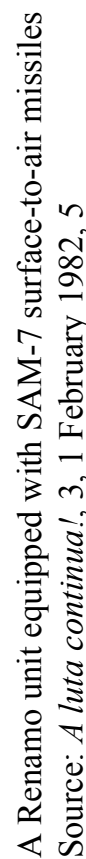


for its supply of arms, sea and air transport, and modern communications equipment. With the end of apartheid and the Cold War, the warring parties in Mozambique lost this necessary external support and were ready to negotiate a peace settlement.

The success of the amnesty offered from early 1988 to Renamo fighters who turned themselves over to the authorities was limited. During the two years of this programme, Renamo recruited more men than the approximately 4,000 who officially surrendered to the government. ${ }^{45}$ Despite offers of clemency, more Frelimo soldiers deserted than did Renamo rebels. ${ }^{46}$ At the end of the 1980 s the failure of the socialist development project had forced Frelimo to introduce political and economic reforms that largely met both the demands of Renamo and the interests of its foreign sponsors. At its $5^{\text {th }}$ party congress, held in mid1989, Frelimo dropped all Marxist-Leninist dogma from its programme and a new democratic constitution was approved in November the following year.

Negotiations in the late 1980s brought Renamo the political recognition it demanded from Frelimo. After several rounds of negotiations in Rome, with the Santo Egídio community serving as mediators, a general peace accord was signed in October 1992. Following the end of hostilities 64,130 government troops and 22,637 Renamo guerrillas were demobilized under the supervision of a special UN mission (UNUMOZ). The number of Renamo soldiers considerably surpassed that of the 8,000 Frelimo guerrillas who had fought against the Portuguese colonial army during the 1964-1974 liberation struggle that had only affected five provinces. ${ }^{47}$ In the course of this conflict the strength of the Portuguese colonial army had increased from 30,000 men to $75,000 .{ }^{48}$ By the end of the colonial war about 60 per cent of the Portuguese army in Mozambique were local African troops. ${ }^{49}$

\section{Internal dimensions}

As Renamo had been created and supported by the white minority regimes in Rhodesia and South Africa, for many years the internal dimensions of the conflict were largely played down or completely denied. ${ }^{50}$ Initially external factors dominated the scholarly debate on the war in Mozambique and it was preliminarily understood to have taken place as a result of Rhodesian and

${ }^{45}$ Ibid. 21.

${ }^{46}$ Weigert, Traditional Religion, 85.

${ }^{47}$ Ibid. 23.

${ }^{48}$ Finnegan, A Complicated War, 111

${ }^{49}$ Weigert, Traditional Religion, 127.

${ }^{50}$ See Cahen, 'Nationalism', 164. 
subsequently South African destabilization that was supported by neo-colonial and reactionary groups in Portugal and the United States. This view was largely in accordance with that of the Frelimo government that insisted that the conflict was a case of external aggression, with Renamo being used as a proxy force.

Only in the late 1980s following the publication of the pioneering work of the late French anthropologist Christian Geffray, who had done research on the causes of the conflict in the northern province of Nampula, did the local dynamics of the conflict receive more attention and the discussion become more open. Geffray demonstrated that conflicts and social changes within the peasantry that emerged due to the government's forced resettlement of many people as part of the communal village programme had created a favourable environment for Renamo. ${ }^{51}$ Meanwhile it has become almost uncontested that it was popular resistance against Frelimo policies that formed fertile ground for the emergence of Renamo. Large sectors of the population resisted government policies because they felt marginalized, discriminated against and oppressed.

\section{Resentment of villagization}

Prominent among the groups that resented Frelimo's policies were the peasants and former local chiefs who provided most of Renamo's support since they were most directly affected by the regime's socialist modernization project. ${ }^{52}$ The central government's ambitious programme of compulsory villagization of the countryside, the establishment of the aldeias comunais that forced thousands of peasant families to leave their ancestral rural homesteads and move to other areas provoked anger and bitterness directed towards Frelimo, particularly when the people began to realize that the promised improvements in their living and working conditions were not materializing. ${ }^{53}$ Renamo's military expansion increased the speed of villagization efforts, since Frelimo tried to keep the

${ }^{51}$ C. Geffray \& M. Pederson, 'Sobre a guerra na província de Nampula. Elementos de análise e hipóteses sobre as determinações e consequências sócio-económicas locais', Revista Internacional de Estudos Africanos, 4-5 (1986), 303-18 and C. Geffray, La Cause des Armes au Mozambique. Anthroplogie d'une Guerre Civile (Paris, 1990), published in Portuguese as A Causa das Armas. Antropologia da Guerra Contemporânea em Moçambique (Porto, 1991).

${ }^{52}$ Ibid. 5.

${ }^{53}$ The villagization programme, a cornerstone of the rural collectivization policy, had been approved at Frelimo's third party congress in 1977. By the early 1980s, 1,350 communal villages had been established, accommodating 18 per cent of the rural population, more than 1.8 million people. A. Dinerman, 'In Search of Mozambique: The Imaginings of Christian Geffray in La Cause des Armes au Mozambique. Anthropologie d'une Guerre Civile', Journal of Southern African Studies, 20, 4 (1994), 571. 
peasants away from the rebels. Pereira suggests that the regime's major concern with regard to villagization was the concentration of the rural people to exert political control, rather than to improve agricultural output by collective production. ${ }^{54}$ Increasingly peasants perceived villagization as a government attempt to facilitate tax collection, apply public corporal punishment and oblige people to participate in so-called voluntary labour. Frequently, discontented residents of communal villages who wanted to return to their former homesteads helped Renamo to destroy the newly formed settlements.

The central government had substituted the local chiefs with administrators and party secretaries who often came from other regions, did not speak the local language and were not familiar with the local culture. The substitution with outside administrators of the régulos who derived their legitimacy and authority through the political and religious functions they exercised in their communities created considerable discontent in many rural areas. This dissatisfaction increased when the regime's promises of an improved standard of living did not come about and the people were confronted with the hardships of the economic crisis and the regime's coercive measures. In general, the new people in charge within the public administration and the economy throughout the country were southerners. This southern dominance, which was veiled by Frelimo's antitribal discourse of national unity, nurtured existing regional tensions that stemmed from the colonial period..$^{55}$

The disproportionately high number of senior positions occupied by people from the south has frequently been denounced by non-southerners as domination by a second Gaza Empire, a reference to the Gaza kingdom of the Nguni in the nineteenth century that controlled large parts of central Mozambique. The régulos, the former chiefs, were prohibited from exercising their political functions as early as 26 June 1975 since, according to the Frelimo, they had been part of the colonial system. Therefore many régulos were willing to support Renamo when the rebels appeared. In turn, Renamo accepted local traditions and religion, reinstated the former régulos and entrusted them with the public administration of the controlled area. Renamo restored customs such as polygamy and lobolo (bride price) that Frelimo had banned as feudal and reactionary practices.

As a result of southern dominance after independence, the local elites in the centre and the north felt marginalized by Frelimo. There were certain ethnic groups (Ndaus, Sena, Macua) who were represented neither in the party nor in the state that also resented Frelimo. Not surprisingly, the interruption of traffic between Rhodesia and the seaport of Beira, as a consequence of the sanctions

${ }^{54}$ Pereira, 'The Politics of Survival', 30.

${ }^{55}$ Cahen, 'Nationalism', 169-71. 
introduced in 1976 against the Smith regime and the resulting economic decline of this city, were perceived by many local inhabitants as a deliberate measure imposed by the central government in Maputo. The results of the elections in October 1994 and December 1999 when Renamo gained a majority of the votes in the central and northern provinces, while Frelimo completely dominated the southern provinces and the capital city, emphasized the crucial role played by regional factors in Mozambican politics.

In addition, Frelimo's Marxist-inspired revolutionary campaign against all religions including ancestor worship as obscurantism and the harassment of churches and traditional healers in the first years after independence alienated large sectors of the rural population. Other groups that were opposed to Frelimo were the former prisoners of the re-education camps established right after independence, including former colonial officials and Frelimo opponents, and some 50,000 urban migrants who were considered unproductive and arbitrarily deported from the cities in the south to the rural areas in the north, particularly to Nampula and Niassa, as part of the Operação Produção (Operation Production) in 1983. Many of these men voluntarily joined Renamo since they were eager to take revenge on the government. For many who had initially been in favour of Frelimo, the rapid economic decline after independence, the resulting scarcity of consumer goods, poor marketing of agricultural products, and queues in the shops discredited the government's programme of national reconstruction and constituted another factor in favour of Renamo.

Naturally there was not always a direct correlation between discontent with Frelimo and acceptance or support of Renamo. However, it is unlikely that without the cooperation of the local population Renamo would have been able to expand to such an extent that it was able to mobilize support throughout the whole country. Renamo was more successful in capitalizing on popular disenchantment with Frelimo in central and northern Mozambique where specific social and cultural conditions prevailed that were unfavourable for Frelimo. ${ }^{56}$ The initial support for Renamo decreased over time due to the forced recruitment of youngsters and the permanent coercion of the rural population to supply food. Consequently many peasants fled from Renamo-controlled areas and those who remained tried to hide their possessions and produce in the bush. In response, Renamo increasingly resorted to terror and violence to force the local population's submission in occupied areas. ${ }^{57}$

\footnotetext{
${ }^{56}$ Roesch, 'Renamo and the Peasantry', 463.

${ }^{57}$ Pereira, 'The Politics of Survival', 49.
} 


\section{Violence and terror}

Renamo rarely challenged government forces directly but preferred to attack civilians in rural areas. In war in non-industrialized societies, plundering and pillaging for food and other supplies and the abduction of women for sexual services have always instilled greater fear in the local population than the violence of a true battlefield. ${ }^{58}$ Similar tactics were employed by Renamo in Mozambique where the preferred targets in the south and centre of the country included the majonijoni (the migrants who worked in the South African mines) whose houses were systematically looted due to their relative wealth. ${ }^{59}$ Many migrant workers lost everything they had accumulated.

There appears to have been considerable regional variation in Renamo's military tactics and strategies, recruitment methods and violence against civilians. In his report on Mozambican refugees, Gersony identified three areas under Renamo's control according to the violence used against the population in each. The people living in tax areas that were located between the zones permanently controlled by Renamo and by the government were obliged to supply food to the guerrillas. The inhabitants of a control zone near a Renamo base had to provide forced labour including the transport of goods and booty to and between bases. They also had to provide food, and participate in patrolling and looting. ${ }^{60}$ The population within a control zone was composed of local inhabitants, government dissidents and people abducted from other areas. The social relations between guerrillas and civilians were based on a system of organized violence where any disobedience or resistance was severely punished. However, there are also reports of cordial relations between peasants and Renamo soldiers, who, for example, asked the villagers for goats and chickens and promised to replace them as soon as they could loot zones beyond their permanent control. ${ }^{61}$ Destruction zones were areas where Renamo had not established a permanent presence and in these zones the rebels frequently attacked and looted rural settlements and communal villages.

\section{Renamo violence against civilians}

As long as it enjoyed the support of local communities, Renamo was less cruel and violent in the centre and the north of the country than in the south where Frelimo had a strong base and from where most of its leaders originated. Some people living in areas occupied by Renamo even claimed never to have

\footnotetext{
${ }^{58}$ Harneit-Sievers, 'Sozialgeschichte', 87.

${ }^{59}$ Liesegang, 'Der Bürgerkrieg', 15; Roesch, 'Renamo and the Peasantry', 478.

${ }^{60}$ Jesus, 'Alguns Aspectos', 14.

${ }^{61}$ Ibid. 15.
} 
witnessed any atrocities against civilians. ${ }^{62}$ However, the worst Renamoorganized violence and atrocities against civilians occurred in the south and in government-controlled regions elsewhere in the country. Renamo's violence against the rural population was instrumental in the sense that it undermined its legitimacy by demonstrating the inability of the Frelimo government to defend its population. Even spectacular mass killings like the July 1987 massacre of 424 civilians in Homoine (Inhambane) were apparently not spontaneous actions of local commanders but were deliberately committed with the agreement of the Renamo leadership to force the government to surrender. The major massacres occurred around 1987 in the south of Mozambique after the new government under Joaquim Chissano had rejected negotiations and tried to win the war. ${ }^{63}$ Yet, the rebel movement has never assumed responsibility for the massacres, which were counterproductive regarding its international reputation and in the end prevented Renamo from receiving official American-government support.

During Renamo attacks, the principal targets were Frelimo party and state officials who were usually killed in front of the local population. Occasionally, local villagers had betrayed the officials to the arriving rebels ${ }^{64}$ and exemplary violence including public mutilations and executions served to intimidate the general population, maintain control, and prevent escape from the occupied areas. Such atrocities aimed at spreading the news about Renamo violence far beyond the operational area to break any possible resistance in advance of the rebels' arrival. The rebels always allowed someone to escape to tell the terrifying story. ${ }^{65}$ Frequently, the executioners used machetes and knives instead of firearms since they would not alert government forces, saved ammunition and created a maximum of fear.

Targets of systematic destruction were infrastructure such as local offices, schools and health posts because they symbolized the hated Frelimo state and represented a few of the regime's success stories. The local church or mosque was often the only building that was not destroyed during a Renamo attack, since Renamo sought religious legitimacy inside and outside the country. ${ }^{66}$ The destruction of social infrastructure was part of a wider strategy based on the simple belief that whatever weakened Frelimo reinforced Renamo. ${ }^{67}$ However, the rebels also engaged in inconceivable acts of brutality against defenceless

\footnotetext{
${ }^{62}$ Finnegan, A Complicated War, 72.

${ }^{63}$ Liesegang, 'Der Bürgerkrieg', 21, 30.

${ }^{64}$ A. Cunhela, 'Uma análise sobre o impacto da Guerra nos aspectos sócio-económicos em Morrumbala, Zambezia, 1982-1992', Unpublished paper, Universidade Eduardo Mondlane (Maputo, 1994), 4.

${ }^{65} \mathrm{~K}$.B. Wilson, 'Cults of Violence', 527.

${ }^{66}$ Ibid. 540.

${ }^{67}$ Finnegan, A Complicated War, 77.
} 
people that defy any concept of rationality. Some of the excessive violence was directed at sexual taboos. Rebels raped women in the presence of their husbands, relatives and neighbours and in other cases, fathers were forced to rape their daughters, and brothers were coerced into have sex with their sisters. ${ }^{68}$ Obscure rites were also frequently practised by Renamo. For example, former captives reported that they had to drink water from the skulls of dead people. ${ }^{69}$ Wilson stresses that ritualized violence often has to be incomprehensible in order to have the desired effect. ${ }^{70}$

\section{Government atrocities}

The rural population also suffered from atrocities committed by government forces. People living in Renamo-controlled areas accused government soldiers of committing most of the violence directed at the local population. ${ }^{71}$ Occasionally, people living in areas visited by Renamo guerrillas were accused by the local authorities of having permitted Renamo forces to pass through their area, before being executed. Peasants living in areas in central Mozambique, which had been recaptured by Frelimo, fled into the bush or to Malawi since they feared that government troops would kill them in retaliation for their supposed support of Renamo. ${ }^{72}$ Government soldiers who accompanied convoys of citizens to protect them from Renamo assaults simulated ambushes to rob the people of their property. To avoid the loss of goods during such a journey and to ensure a safe arrival at their destination people went to the barracks prior to departure to bribe the commander of the convoy. ${ }^{73}$

When government troops surprised Renamo guerrillas they often did not return stolen goods to their owners but took possession of them themselves. Mucusete reports from Angoche (Nampula) that when the local population tried to flee during a Renamo attack in the forest they found the paths blocked by police and government soldiers who beat them up and forced them to return to their homes saying 'Do you want to see us die alone?'. ${ }^{74}$ While fleeing to their hiding-places during Renamo attacks, the military often took the goods that the peasants tried to rescue. Most of the government's popular militias were inferior to Renamo in terms of military training and equipment and were unable to

\footnotetext{
${ }^{68}$ In local culture these cases are reminiscent of ritual violations when a curandeiro asks his client to have sex with his mother or daughter to empower certain magic powers. Magic implying the use of human organs is also common in this context.

${ }^{69}$ Castanheira, Ex-criança Soldado, 29.

${ }^{70}$ Wilson, 'Cults of Violence', 533.

${ }^{71}$ Schafer, 'Guerrillas', 219.

${ }^{72}$ Pereira, 'The Politics of Survival', 28.

${ }^{73}$ Pequenino, 'Estudo de Caso', 16.

${ }^{74}$ Pequenino, 'Estudo de Caso', 39.
} 
defend the people. Instead of defending the locals, many militia units abused their power by maltreating the population at control posts and during nightly patrols. Not receiving regular pay, the militias lived on what they confiscated from the locals or recaptured from Renamo forces. ${ }^{75}$ The situation of the regular troops was not much better. Due to insufficient supplies caused by organizational shortcomings and disrupted military logistics, particularly in remote areas, government forces suffered from a lack of food and ammunition, and their wages were paid months in arrears. Morale deteriorated and soldiers coerced the local population into providing them with women and foodstuffs, attacked houses and plundered villages. In addition they diverted food aid from government institutions and international organizations. Frelimo soldiers in the cities were much less dependent on local resources since they had access to food supplies that could be used for barter.

\section{The role of ritual power}

In its propaganda, Renamo claimed that it was fighting in an alliance with the ancestral spirits to return the country to its ancestral traditions. It accused Frelimo of showing total disrespect for local religion and culture. On the battlefield Renamo commanders did not only place their trust in their modern weapons and sophisticated radio communication, but frequently resorted to local diviners and spirit mediums to protect them in combat or to guarantee the success of an attack. By reverting to magical military powers, Renamo continued the old traditions of war medicines used during anti-colonial rebellions and pre-colonial wars. ${ }^{76}$ Matsangaíssa, who was surrounded by legends of magic powers and invulnerability, reportedly never waged an attack without first consulting his diviner. The same holds true for the majority of Renamo commanders. ${ }^{77}$ Renamo's cult of violence terrified both the population and Frelimo soldiers, and its military successes were generally attributed to its superior magical powers. ${ }^{78}$ People were convinced that the rebels, and particularly the Ndau speakers among them who are famous for their ritual powers throughout Mozambique, had powerful magic at their disposal. ${ }^{79}$ The

\footnotetext{
${ }^{75}$ Liesegang, 'Der Bürgerkrieg', 37.

${ }^{76}$ Wilson, 'Cults of Violence', 546; D.A. do Rosário, Makombe. Subsidios à Reconstituição da sua Personalidade (Maputo, 1996); E. Rodrigues, 'A Africanização da Guerra nos Rios de Sena no Século XVIII', XXIV Congresso Internacional de História Militar. Lisbon, 24-29 August 1998.

${ }^{77}$ Weigert, Traditional Religion and Guerrilla Warfare, 81.

${ }^{78}$ Wilson, 'Cults of Violence', 547.

${ }^{79}$ Finnegan, A Complicated War, 228.
} 
fame of a local curandeiro who possessed the ability to make men resistant to bullets, invisible to the enemy or transform government bullets into water served to attract new recruits. ${ }^{80}$ The frequent consultation of their traditional healers gained Renamo the respect of the local people, who believe in the existence of powerful supernatural forces. On the other hand, spirit mediums working for Renamo forced peasants to cooperate with the rebels by praising their abilities, claiming that otherwise their ancestral spirits would become angry. ${ }^{81}$

Local beliefs in spirits and magical powers have always been widespread among the entire population, including Frelimo followers. Cuahela reported from Zambezia that people believed that government troops only succeeded in killing a feared Renamo guerrilla after they had managed to tie him up and remove his magical power from his pocket, a knot of hair in which a human nail and a glass-bead were tied together. ${ }^{82}$ In the same province the population attributed the recapture of a district capital by government forces in late 1987 to the intervention of a curandeiro whose magic resulted in a complete loss of vigilance within the Renamo ranks on that day. As it was felt that successful military leaders owed their abilities to supernatural powers, particular efforts were made to defeat and kill them. After the war, former guerrillas owed their survival to the protection of their ancestral spirits and many demobilized rebels spent part of their demobilization allowance on conducting rituals to thank the spirits for their safe return. ${ }^{83}$

As a result of the inability of government forces to protect the population, an armed peasant movement known as Naparama (meaning 'irresistible force' in the Makua language) emerged in Nampula in 1988, where it successfully fought against Renamo and subsequently expanded to Zambezia. Naparamas, who were armed with traditional weapons such as assegais and machetes, were feared because of their supernatural powers that involved what Wilson calls a 'cult of counter-violence' ${ }^{84}$ Before they got their weapons, the peasant soldiers, who wore a red ribbon attached to their clothes, were initiated by being vaccinated with a medical plant that was rubbed into three cuts in their chests before they were plunged into water and had their bodies greased with oil. The commanders were initiated by the leader Manuel António, a Makua curandeiro who claimed to have died of measles only to be resurrected from the dead six days later and thought by Jesus Christ to make anti-bullet vaccines. The

${ }^{80}$ Ibid. 49.

${ }^{81}$ Pereira, 'The Politics of Survival', 67.

${ }^{82}$ A. Cunhela, 'História da Guerra na Zambézia. Um Estudo da Guerra em Namarrói, 1976-1996'. Unpublished paper, Universidade Eduardo Mondlane (Maputo, 1994), 12.

${ }^{83}$ Schafer, 'Guerrillas', 228.

${ }^{84}$ Wilson, 'Cults of Violence', 561. 
syncretic Christian elements in António's religious discourse distinguishes it from Renamo's ritual powers that were derived from ancestral religious traditions. António's fighters were forbidden to rape, argue with or steal from the local population, shake hands with married men and women, or to have sex on the day prior to a battle. As in the case of other ritually empowered people in Southern Africa, it was believed that breaking these rules would result in death during combat, since the fighter had lost his supernatural powers and was no longer resistant to bullets.

The Naparamas also forced the local population to obey certain rules. People were not allowed to wash plates and pots in the river, shake off the water from washed clothes, beat clothes heavily during washing, spread out clothes on roofs, or pound grain at the end of the day. Disobedience required the summoning of the Renamo. ${ }^{85}$ The peasant soldiers did not constitute a full-time standing army but usually stayed at home and tilled their machambas, only fighting Renamo when called upon to do so. They attacked in their hundreds, armed with spears and machetes, rattling tin cans and blowing cow horns to terrify the enemy. Thanks to the military successes of the Naparama, thousands of displaced people could return to their home areas. António claimed to have some 30,000 men at his disposal ${ }^{86}$ and thanks to their magical protection, the Naparamas were believed to be able to fight the Renamo rebels without being hit by bullets themselves. Despite their superior arms, Renamo troops were so terrified by the appearance of Naparama fighters that the latter were able to withstand rebel attacks in large parts of northern Mozambique until António's death in Macuse near Quelimane in December 1991. The Naparama were militarily successful since they came from the same cultural background as the Renamo guerrillas, which allowed their magical forces to become an effective weapon. Accordingly, Renamo only succeeded in defeating the Naparama after having regained the superiority of magical powers. ${ }^{87}$ In turn, Frelimo forces did not accuse Naparama of obscurantism but cooperated with them and supported them logistically. Frelimo soldiers are reported to have frequently asked them for their amulets to become resistant to bullets themselves. ${ }^{88}$ However, while Frelimo soldiers resorted to magic predominantly on an individual base, for both Renamo and Naparama forces, the traditional religious and ritual discourse constituted an integral part of their struggle.

\footnotetext{
${ }^{85}$ Pequenino, 'Estudo de Caso', 11.

${ }^{86}$ Finnegan, A Complicated War, 255.

${ }^{87}$ Wilson, 'Cults of Violence', 575.

${ }^{88}$ Ibid. 29.
} 


\section{Conclusion}

Renamo was set up by external forces hostile to the socialist Frelimo regime. However, the destabilization policy of the white minority regimes is insufficient explanation of the transformation of Renamo from a small rebel group into a powerful guerrilla army that controlled most of Mozambique by terrorizing the local populations. Large sections of the rural population facilitated the successful expansion of the rebel movement since they had been alienated from Frelimo by its forced collectivization of the countryside, the removal of traditional chiefs, and religious persecution. Entire regions and ethnic groups in northern and central Mozambique backed Renamo because they felt marginalized by the domination of southerners within the Frelimo regime. Regional divisions within Frelimo had emerged during the liberation struggle in the 1960s but historically their roots go back much further. Renamo's electoral successes in the 1994 and 1999 elections, when the opposition party gained a majority of votes in most central and northern provinces, have ultimately confirmed that the movement has always enjoyed considerable regional support.

Supernatural powers played an important role in this conflict. For Renamo, traditional religious discourse and resorting to magical rituals were integral parts of the war. Renamo committed the worst atrocities against civilians during the conflict in areas controlled by Frelimo and where the local population's initial support started to decrease as a result of the rebels' coercive measures. Renamo deliberately used excessive ritualized violence to instil a maximum of fear in the local population to maintain control and to guarantee supplies for their soldiers. According to this strategy, 'cult' violence had to be necessarily unpredictable, irrational and terrifying to achieve its intended goals. Renamo's lack of mechanized transport and of supplies led to the recurrence of traditional methods of transporting goods and persons. The acquisition of supplies by attack and coercion became a salient feature of the war. However, the terror and violence of Frelimo forces should not be ignored. Government troops did not accept any passive neutrality and frequently perceived the local population in areas controlled or visited by Renamo as collaborating with the rebels. Summary justice was meted out.

With both the government-controlled Frelimo forces and the Renamo rebels instilling fear in rural communities while expecting collaboration and cooperation in return, the result was a traumatized people who, regardless of which side they had initially supported, often became unsure of who was truly fighting on their behalf during this dark period in Mozambique's recent past. 


\title{
Herero genocide in the twentieth century: Politics and memory
}

\author{
Jan-Bart Gewald
}

\begin{abstract}
Between 1904 and 1908 imperial Germany pursued an active policy of genocide in German South West Africa, present-day Namibia. This chapter analyses the manner in which, during the course of the twentieth century, numerous people in varying contexts have sought to use the genocide perpetrated upon the Herero to further their own ends. It charts the manner in which an historical event has come to be deployed for varying and, at times, contradictory interests by German social democrats and English imperialists through to anti-Apartheid activists and postcolonial tribalists. It has been used to strengthen arguments that range from colonial policies through to claims that call for ethnic autonomy and compensation.
\end{abstract}

\section{Introduction}

On 11 January 1904, the Herero-German War broke out in a small dusty town in central German South West Africa (GSWA), present-day Namibia. By the time hostilities ended in 1908, genocide had been committed, the majority of the Herero people had been killed, and the survivors, mostly women and children, incarcerated in concentration camps as forced labourers. ${ }^{1}$ Throughout the twentieth century, Herero survivors and descendants used the memory of this seminal act of failed resistance to substantiate and justify further acts of resistance against the colonial and post-colonial state in Namibia.

\footnotetext{
${ }^{1}$ J.B. Gewald, 'Forced Labour in the Onjembo, the Herero German War of 1904-1908', Itinerario, XIX, 1 (1995) and J.B. Gewald, Herero Heroes: A Socio-Political History of the Herero of Namibia 1890-1923 (Oxford, 1999), 141-91.
} 


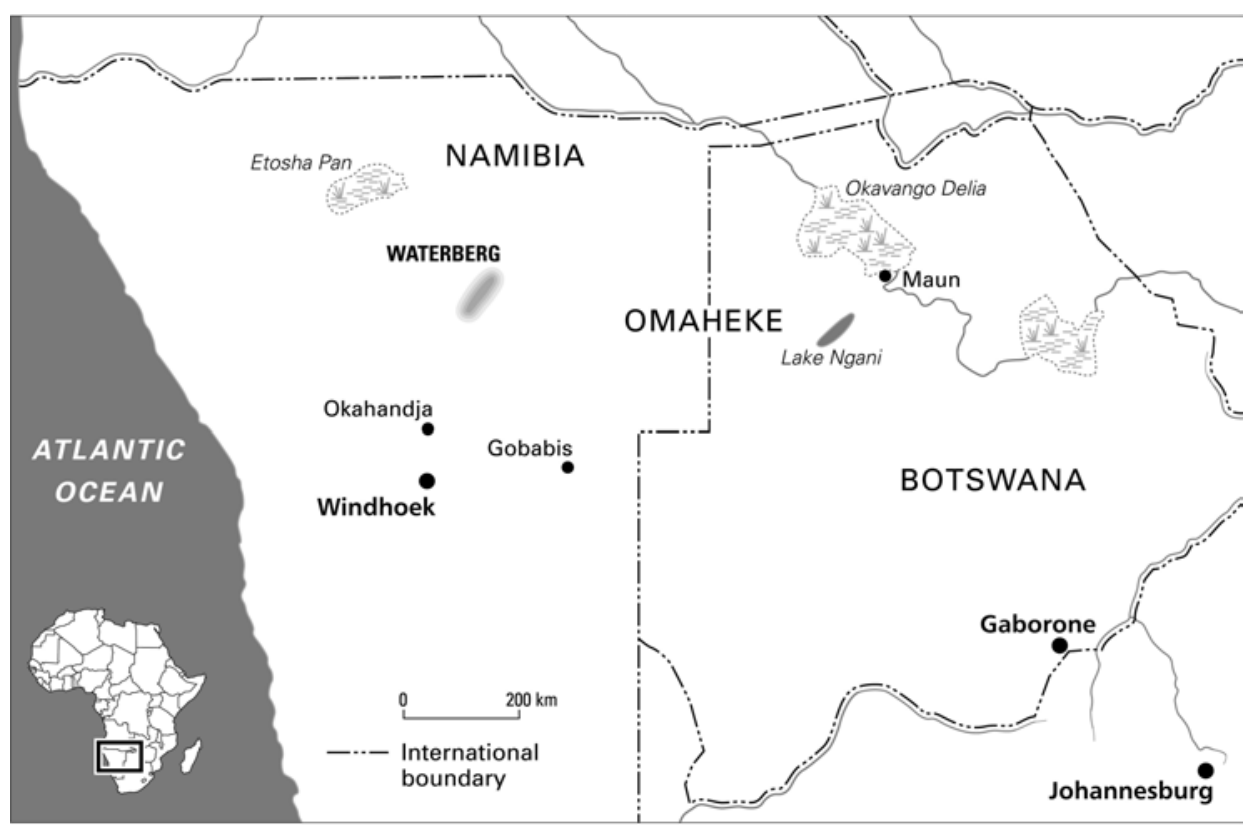

Map 11.1 Namibia (formerly German South West Africa) 
In this chapter, after a short description of the Herero genocide, a chronological overview is provided of the manner in which Herero and others have used the memories and historical recollections of the Herero-German War as a political instrument to support and further their own ends. The conscious deployment or negation of memories and references to the genocide has been used to strengthen arguments in support of a variety of issues ranging from colonial policies and claims through to ethnic autonomy and compensation. This is followed by a short discussion on the manner in which historical memories may be used to further political objectives. In conclusion it is noted that memories of resistance are powerful incentives for further resistance, and that a continued dialectical relationship between memory and resistance existed among the Herero of Namibia throughout the twentieth century. ${ }^{2}$

\section{The Herero-German War (1904-1908)}

Misunderstandings and the paranoia of self-fulfilling settler prophecies led to a war of extreme brutality and conscious genocide perpetrated by German troops against the Herero and to a lesser extent Nama peoples of colonial South West Africa. ${ }^{3}$ The increasing socio-economic pressure placed upon Herero society by the arrival of ever more German settlers demanding land and assuming racial privilege produced a tense situation. The war did not result from premeditated insurrection against German rule, rather, amid the tension that had developed over time, a single shooting incident served as a trigger. Starting in Okahandja, the war spread across central Namibia and developed in intensity and brutality as fresh contingents of German troops disembarked and attempted to impose their vision of order on the territory and its inhabitants. The Kaiser's personal choice and appointment of commanding officers in GSWA signalled the highest authorization and endorsement of what occurred in the name of imperial Germany. In a policy of genocide, German soldiers and settlers sought out, shot, beat, hung, starved and raped Herero men, women and children. By the end of

\footnotetext{
${ }^{2}$ For those interested in looking at a similar approach to history, i.e. the manner in which memories of violence influence and determine later action, see J. Alexander, J. McGregor \& T. Ranger, Violence and Memory: One Hundred Years in the 'Dark Forests' of Matabeleland (Oxford, 2000) and L.H. Malkki, Purity and Exile: Violence, Memory, and National Cosmology among Hutu Refugees in Tanzania (Chicago, 1995).

${ }^{3}$ Those seeking a detailed day-to-day introduction to the Herero-German War are referred to G. Pool, Die Herero-Opstand 1904-1907 (Cape Town, 1979). For an English introduction see J.M. Bridgman, The Revolt of the Hereros (Berkeley, 1981). Regarding the concept of self-fulfilling settler prophecies, see S. Marks, Reluctant Rebellion: The 1906-8 Disturbances in Natal (Oxford, 1970).
} 
1904 the war had spread to southern Namibia. Here it also overwhelmed the Nama inhabitants of GSWA. When it finally ended, no fewer than $80 \%$ of the Herero and at least $50 \%$ of the Nama had lost their lives. ${ }^{4}$ Most of the Herero who remained, primarily women and children, survived in concentration camps as forced labourers employed on state, military and civilian projects. ${ }^{5}$ In short, the war and its aftermath were characterized by acts of excessive violence and cruelty on the part of German soldiers and settlers.

Indiscriminate shootings, hangings and beatings were the order of the day. The diaries, letters and photographs of contemporaries are littered with references to these events. Missionary Elger, working in the settlement of Karibib along the railway line to Windhoek, reported in his diary that all he heard was 'aufräumen aufhängen niederknallen bis auf den letzten Mann, Kein Pardon' (clean-up hang-up shoot-down till the last man, no pardon). Elger also described the manner in which Herero prisoners were treated:

Things proceeded in a particularly brutal manner. Herero prisoners were terribly maltreated, whether they were guilty or not guilty. About 4 Herero were taken prisoner, because they were supposed to have killed a railway worker (Lehmann, Habis). The courtmartial ordered them to be freed and declared them to be not guilty. However one could not release them as they bore too many marks of shameful abuse [Schändlicher Mißhandlung] on their bodies. For example, people had beaten an eye out of one. After the court martial had declared them to be innocent, some of the Germans outside immediately resumed the abuse with the words, 'the court has declared you to be innocent, we however want to string you up'. ${ }^{6}$

After the initial battles, the civilian governor was relieved of his command and replaced by the Kaiser's own candidate, Lieutenant-General Lothar von Trotha. ${ }^{7}$ Under the command of Von Trotha, the German army sought to engineer a crushing defeat of the Herero in the vicinity of the Waterberg. ${ }^{8}$ In keeping with Von Moltke's principles of separate deployment and encirclement,

\footnotetext{
${ }^{4}$ The history of the Nama-German War and its ongoing aftermath as well as the impact on Nama society are not dealt with in this chapter. Interested readers are advised to read H. Drechsler, 'Let us Die Fighting': The Struggle of the Herero and Nama against German Imperialism (1884-1915) (London, 1980), first published in German (Berlin, 1966).

${ }^{5}$ Gewald, Herero Heroes, 141-230.

${ }^{6}$ Evangelical Lutheran Church in the Republic of Namibia (ELCRN), V12 Karibib, JBG's translation.

${ }^{7}$ See H. Bley, South-West Africa under German Rule 1894-1914 (London, 1971), 15863 for a discussion on the appointment of Von Trotha.

${ }^{8}$ Pool, Opstand, 210-11.
} 
Von Trotha sent out his armies to annihilate the Herero at the Waterberg. Or, as he put it in his own words:

My initial plan for the operation, which I always adhered to, was to encircle the masses of Hereros at Waterberg, and to annihilate these masses with a simultaneous blow, then to establish various stations to hunt down and disarm the splinter groups who escaped, later to lay hands on the captains by putting prize money on their heads and finally to sentence them to death. ${ }^{9}$

On 11 August the Battle of Hamakari took place at the Waterberg. The Herero were defeated and fled in a southeasterly direction into the dry desert sands of the Kalahari, known to the Herero as the Omaheke. ${ }^{10}$ Von Trotha issued orders which, by placing a cordon along the waterholes, cut off all escape routes to the west, south and northeast. This effectively forced the fleeing Herero to move ever further into the inhospitable Omaheke. ${ }^{11}$ Surrounded by the desert and German patrols, the Herero chiefs and their followers congregated along the Eiseb River.

Around 1 October 1904, General Lothar von Trotha, who was actively taking part in the pursuit, and his retinue had reached the Osombo-Windimbe waterhole. During the afternoon of the following day, Sunday 2 October 1904, after the holding of a field service, General von Trotha addressed his officers. ${ }^{12}$ In his address he declared that the war against the Herero would be continued in all earnestness and read out a proclamation, which stated amongst others that:

The Herero people must...leave the land. If the populace does not do this I will force them with the Groot Rohr [Cannon]. Within the German borders every Herero, with or without a gun, with or without cattle, will be shot. I will no longer accept women and children, I will drive them back to their people or I will let them be shot at.

These are my words to the Herero people.

The great General of the mighty German Kaiser. ${ }^{13}$

Of late a number of authors have sought to deny or at least downplay the existence and implications of Von Trotha's proclamation, which has become

\footnotetext{
${ }^{9}$ Von Trotha's diaries cited in G. Pool, Samuel Maharero (Windhoek, 1992), 251.

${ }^{10}$ Pool, Opstand, 219-40. Omaheke is the Otjiherero name for the sandveld area east of the Waterberg.

${ }^{11}$ Pool, Opstand, $245 \mathrm{ff}$.

${ }^{12}$ C. Rust, Krieg und Frieden in Hererolande: Aufzeichnungen aus dem Kriegsjahre 1904 (Berlin, 1905), 384.

${ }^{13}$ Namibian National Archives Windhoek (NNAW), ZBU D.1.a Band 3-4, leaf 165. With thanks to Mr W. Hillebrecht for finding it at such short notice. JBG's translation.
} 
known as the Vernichtungsbefehl. ${ }^{14}$ However, Von Trotha's own words, in his diary and elsewhere, indicate that he knew full well what his proclamation would entail. On the day the proclamation was issued, Von Trotha wrote in a letter:

I believe that the nation as such should be annihilated, or, if this was not possible by tactical measures, have to be expelled from the country by operative means and further detailed treatment. This will be possible if the water-holes from Grootfontein to Gobabis are occupied. The constant movement of our troops will enable us to find the small groups of the nation who have moved back westwards and destroy them gradually.

My intimate knowledge of many central African tribes (Bantu and others) has everywhere convinced me of the necessity that the Negro does not respect treaties but only brute force. ${ }^{15}$

From 1904 and through into 1905 Ludwig von Estorff, one of Von Trotha's officers, 'had the thankless task of chasing after the refugees in the Sandveld and preventing their return'. ${ }^{16}$ Estorff's own words describe clearly what he did and what his commanding officer's intentions were:

I followed their tracks and found numerous wells which presented a terrifying sight. Cattle which had died of thirst lay scattered around the wells. These cattle had reached the wells but there had not been enough time to water them. The Herero fled ahead of us into the Sandveld. Again and again this terrible scene kept repeating itself. With feverish energy the men had worked at opening up the wells, however the water became ever sparser, and wells evermore rare. They fled from one well to the next and lost virtually all their cattle and a large number of their people. The people shrunk into small groups who continually fell into our hands [unsere Gewalt kamen], some of the people escaped now and again through the Sandveld into English territory [present-day Botswana]. It was a policy which was equally gruesome as senseless, to hammer the people so much, we could have still saved many of them and their rich herds, if we had pardoned and taken them up again, they

\footnotetext{
${ }^{14}$ B. Lau, 'Uncertain Certainties: The Herero-German War of 1904', in Mibagus, 2 (April 1989) 4-8; K. Poewe, The Namibian Herero: A History of their Psychosocial Disintegration and Survival (Lewiston, 1986); G. Spraul, 'Der "Völkermord" an den Herero: Untersuchungen zu einer neuen Kontinuitätsthese' in Geschichte in Wissenschaft und Unterricht (1988/12), 713-39; and G. Sudholt, Die deutsche Eingeborenenpolitik in Südwestafrika. Von den Anfängen bis 1904 (Hildesheim, 1975).

${ }^{15}$.Pool, Samuel Maharero, 272-74.

${ }^{16}$ L. von Estorff, Wanderungen und Kämpfe in Südwestafrika, Ostafrika und Südafrika: 1894-1910, (Windhoek, 1979), 117. JBG's translation.
} 
had been punished enough. I suggested this to General von Trotha but he wanted their total extermination. ${ }^{17}$

In early 1905 the German parliament rescinded Von Trotha's extermination order following which captured Herero were placed in concentration camps (Konzentrationslager) and put to work as forced labourers. By late 1905, an estimated 8,800 Herero were confined in camps and forced to work on various military and civilian projects across GSWA. ${ }^{18}$ Missionary sources provide firsthand eyewitness accounts of conditions in the camps. In Karibib missionary Elger wrote:

And then the scattered Herero returned from the Sandfeld. Everywhere they popped up -not in their original areas-, to submit themselves as prisoners. What did the wretched people look like?! Some of them had been starved to skeletons with hollow eyes, powerless and hopeless, afflicted by serious diseases, particularly with dysentery. In the settlements they were placed in big kraals, and there they lay, without blankets and some without clothing, in the tropical rain on the marshlike ground. Here death reaped a harvest! Those who had some semblance of energy naturally had to work. (...)

It was a terrible misery with the people; they died in droves. Once 24 came together, some of them carried. In the next hour one died, in the evening the second, in the first week a total of ten - all to dysentery - the people had lost all their energy and all their will to live. (...)

Hardly cheering cases were those where people were handed in to be healed from the effects of extreme mistreatment (schwerer Misshandlungen): there were bad cases amongst these. ${ }^{19}$

The Herero camps were finally abolished in 1908, after which the Herero were confined within a tangled web of legislation that sought to control the lives, in their entirety, of all black people living in German South West Africa. Within the areas of German control, all Africans over the age of eight were

\footnotetext{
${ }^{17}$ Ibid. 116-17. JBG's translation.

18. Berichte Rheinische Missions Gesellschaft (BRMG) 1906, 10.

${ }^{19}$ ELCRN, V. 12, Missions Chronieken, Karibib 1906, written by missionary Elger. See also $B R M G$ 1906, 11-12. That this mistreatment of Herero was not merely incidental but structural is indicated by a circular letter from military headquarters in Windhoek to the German officer commanding Karibib in late 1906. The letter noted '(...) due to the mishandling of Herero prisoners, who act as carriers, it is advisable to recruit Ovambo labour as carriers'. NNAW, STR 19 1.und 4. Kompagnie Karibib, Letter Windhuk $16 / 11 / 06$.
} 
ordered to wear metal passes. They were embossed with the imperial crown, magisterial district and labour number, and were used to facilitate German control of labour. In addition, all Herero were prohibited from owning land and cattle - the two basic necessities of a society based on pastoralism.

\section{'Blue Book' (1914-1921)}

At the outbreak of the First World War, South African forces under British command invaded German South West Africa and defeated the much-vaunted German army. Between 1915 and 1921, Namibia fell under the jurisdiction of a military administration. As the war progressed, it became clear that the victorious parties had no intention of allowing Germany to retain its colonies. To this end, from at least 1915 onwards, British colonial officials were instructed to gather material which would strengthen the British Empire's claims to Germany's colonies. ${ }^{20}$ In Namibia this task was facilitated by the existence of a well-organized and detailed German government archive which the incoming military administration found waiting for it in Windhoek. In the most chilling detail, officials found in it accounts and reports on the manner in which the settlers of German South West Africa and its administration had dealt with the country's original inhabitants. Apart from files dealing with the way in which the Herero had been incarcerated in concentration camps and distributed amongst settlers and companies, the archives also contained a series of documents dealing with the excesses of settlers who had flogged Herero. Glassplate negatives detailed the torn and rotting backs of women flogged for alleged insubordination, and pages and pages of court transcripts covering the brutal lashings of labourers. ${ }^{21}$

Apart from detailed archives, the South Africans were greeted by a population more than willing to provide information about their experiences under German rule. During the course of their successful military campaign, South African forces were dependent on Herero scouts for information regarding watering points, routes and so forth. These scouts had in many cases fought against German forces between 1904 and 1908 and had vivid memories of the atrocities committed by German soldiers at that time. Often these scouts

${ }^{20}$ Public Records Office (PRO) CO 537/1-17 Telegram from Mr Long, to Australia, New Zealand and South Africa, 4 January 1918 quoted in 'Memo for War Cabinet', 15 October 1918.

${ }^{21}$ The glass-plate negatives and files, and in fact most of the original source material used to compile the Blue Book have been sought out by J. Silvester and J.B. Gewald in the National Archives of Namibia. Silvester and Gewald are currently engaged in republishing an edited and annotated edition of the Blue Book. 
were the sons of Herero chiefs who prior to and in the course of German colonialism had turned in vain to Britain for assistance. They were highly articulate men who left a deep impression on the South African officers they were assigned to. Being Herero royals, these men also had direct access to substantial numbers of people. When in 1917 the military administration formally called upon its magistrates to provide information that would substantiate the British Empire's claims to the territory, men such as magistrate O'Reilly of Omaruru could depend on the support of the Herero community. A memorandum for the war cabinet noted:

The fullest reply received has been from the Union which sent a series of statements on oath by responsible and respected leaders of the various native races of SouthWest Africa. ${ }^{22}$

The combination of testimony taken from the German archives found in Windhoek along with a series of painstakingly detailed statements taken under oath from large numbers of surviving Namibians resulted in the publication of one of the most shocking documents of colonial history. The Report on the Natives of South-West Africa and their Treatment by Germany (London 1918), generally referred to as the 'Blue Book', remains an indispensable source document on the nature of German colonial rule in Namibia. It is beyond doubt that the events and issues presented so clearly in it served to scuttle any attempts by Germany to retain control over its former colonies, and Namibia in particular. ${ }^{23}$ In the Treaty of Versailles, Germany was deemed to be unfit to govern colonies and forced to renounce 'in favour of the Principal Allied and Associated Powers, all her rights and titles over her overseas possessions' ${ }^{24}$ In addition, in terms of the Charter of the League of Nations, Namibia, which was seen to be 'inhabited by peoples not yet able to stand by themselves under the strenuous conditions of the modern world", was deemed to be a territory which could 'be best administered under the laws of the Mandatory [the Union of

\footnotetext{
${ }_{22}^{2}$ PRO CO 537/1-17 Memo for War Cabinet, 15 October 1918.

23 A.J. Mayer, Politics and Diplomacy of Peacemaking: Containment and Counterrevolution at Versailles, 1918-1919 (New York, 1967) provides a detailed and authoritative account of the Versailles Treaty negotiations. Carnegie Endowment for International Peace, The Treaties of Peace 1919-1923 (New York, 1924) contains a complete text of the 1919 treaty.

${ }^{24}$ Article 119 of the Treaty of Versailles.
} 
South Africa] as integral portions of its territory'. ${ }^{25}$ As such, Namibia was placed under the jurisdiction of South Africa. ${ }^{26}$

The Blue Book was not unique. The British also commissioned research into the Armenian genocide perpetrated in 1915 by the forces of the Ottoman Empire, Germany's First World War allies. In the aftermath of the humiliation of Versailles and in direct response to the Blue Book, the Germans published a 'White Book' on the activities of Britain in its colonies. Nevertheless, the Blue Book had fulfilled the purposes for which it had originally been compiled, and the genocide perpetrated by imperial Germany on the Herero had been successfully used for political purposes. Germany was forced to relinquish forever its colonies. ${ }^{27}$

\section{White settler unity and the Blue Book (1920-1928)}

Within settler society in Namibia under South African mandate, the existence of the Blue Book continued to bedevil settler politics. German settlers wanted to have the Blue Book banned and all copies of the publication destroyed. In 1925 the first all-white election for a legislative assembly took place. Representatives of the German settler party, the Deutsche Bund in Südwestafrika, opposed settler parties allied to the Union of South Africa. Anxious to maintain a working relationship within the legislative assembly, the administrator, A.J. Werth, acceded to German settler demands for the abolition of the Blue Book. Thus in 1926, Mr Stauch, a member of the all-white legislative assembly in Namibia, tabled a motion stating that the Blue Book:

...only has the meaning of a war-instrument and that the time has come to put this instrument out of operation and to impound and destroy all copies of this Bluebook, which may be found in the official records and in public libraries of this Territory. ${ }^{28}$

${ }^{25}$ Article 22 of the Charter of the League of Nations.

${ }^{26}$ A. du Pisani, SouthWest Africa/Namibia: The Politics of Continuity and Change (Windhoek, 1985), 76.

${ }^{27}$ This must have been galling given that there was a secret convention in 1898 which contemplated the partition between Great Britain and Germany of certain of Portugal's African colonies in the event of it not being found possible to maintain the integrity of the African possessions of Portugal. PRO CO 323/957/5 'Draft Memo: The Case for Mandate', Under-Secretary of State for the Colonial Office, 30 June 1926.

${ }^{28}$ NNAW, ADM 225, Memorandum on the Blue Book, Annex A. In addition, the administration was 'requested to make representations to the Union Government and to the British Government to have this Bluebook expunged from the official records of those Governments'. Furthermore Stauch's motion requested that the administration 'take into consideration the advisability of making representations to the Union 
The motion was passed and legislation came to into force, to be applied in all territories administered by the Union of South Africa that circumscribed the distribution of the Blue Book. Copies were no longer made available to the public, and were removed from libraries and destroyed. In the rest of the British Empire, copies of the Blue Book were moved to the Foreign Office. Even in wartime Britain as late as 1941, in response to a request from the Ministry of Information, it was noted that: 'No copy may be issued without authority of the librarian'. ${ }^{29}$

Stauch and his fellow members of the Deutsche Bund consciously denied the recorded role of German settlers and soldiers in the Herero genocide and put pressure on the South African administration to accede to their demands. As Stauch noted, the passing of the motion 'would...remove one of the most serious obstacles to mutual trust and co-operation in this country [Namibia]'. In his view, 'the honour of Germany had been attacked in the most public manner and it was right that the attack should be repudiated in an equally public fashion. (...) The defence of the honour of one's country was a solemn duty imposed upon all sons of that country.' The validity of Stauch's claims were not questioned by the assembly, even less was any Herero view of the recorded events given an airing. The subjective arguments of Stauch and his compatriots sought to obscure a historical past in the interests of their own continued privileged position as settlers. The promise of peaceful cooperation with the German settler community was uppermost in the minds and concerns of South Africa's administrators. Stauch claimed that 'the Germans were ready and anxious to co-operate in the building up of South West but they could not do so fully until the stigma imposed by the publication of the Bluebook ...had been removed from their name'. This claim was considered to be more important than historical veracity and the views of Namibia's African inhabitants. In other words, the Herero who died in the genocide were dismissed and forgotten in the interests of white settler cooperation.

\section{Michael Scott and Herero representations to the UN (1945-1952)}

To the members of the white settler community it may have looked as if their attempts to rewrite their own vision of the past had succeeded. For a number of years after 1926 nothing was heard of the Herero genocide. Within the territory,

Government and the British Government to impound and destroy all copies of the Bluebook, which may be found in the public libraries in the respective Countries and with the official booksellers mentioned on the title-sheet of the Bluebook'.

${ }^{29}$ PRO F= 371/26574 Minute, 20 June 1941. 
Herero had withdrawn to the newly established native reserves and refrained from directly articulating demands that related to the genocide. ${ }^{30}$ This is not to say that the genocide was no longer of any importance to Herero society, far from it. Instead, Herero society literally turned in upon itself and sought as much as possible to refrain from any form of interaction with the colonial state. References to the genocide perpetrated upon the Herero surfaced from time to time in unexpected places, yet it was no longer an essential part of the colonial discourse. $^{31}$

In the aftermath of the Second World War, the South African government undertook steps to incorporate Namibia as the fifth province in the Union of South Africa. To this end, in 1946, a series of staged meetings was held with the African population of the territory. As the newly formed United Nations had taken over from the League of Nations, Namibia, as a mandated territory, fell under the jurisdiction of South Africa under the auspices of the United Nations. With carefully structured meetings, it was hoped that the colonially appointed and recognized leaders of Namibia's African populations would sanction South Africa's plan to incorporate Namibia. However, this was not to be. The events of 1904-1908 once again became part and parcel of settler and administrative concerns with the arrival of Rev. Michael Scott in Windhoek in $1947 .^{32}$ In conjunction with Herero leaders, Scott used the atrocities perpetrated in the Herero genocide as a weapon at the United Nations against the incorporation of

\footnotetext{
${ }^{30}$ J.B. Gewald, 'We Thought We Would Be Free': Socio-Cultural Aspects of Herero History in Namibia 1915-1940 (Cologne, 2001).

${ }^{31}$ Thus while searching for waterholes in the newly established Herero reserves in the eastern reaches of South West Africa, British administrators stumbled across the site of the German massacre of Herero at Ombakaha. Gewald, Herero Heroes, 182.

${ }^{32}$ Scott is one of the more remarkable figures of Southern African history. Having experienced Ghandi in India, Scott became actively involved in the anti-colonial struggle, first in India and later in Southern Africa. Initially Scott campaigned amongst the Indian community in Natal, and later became active in drawing attention to and improving the shameful living conditions in Bethel, one of Johannesburg's 'native locations'. In exile he founded the Africa Bureau in London and continued campaigning for Namibia's independence, even going so far as to drop his initial non-violent approach. In 1958, whilst attending the All African People's Conference in Accra, Scott delivered a speech to the delegates on behalf of the Herero people living in Namibia who had been prevented from sending their own representatives. In his speech, Scott called for the creation of an African freedom army saying, 'Africa needs such a freedom army desperately urgently if it is to be saved from inhumanity'. Scott continues to be fondly remembered by many in Namibia. His activities brought the injustices of colonial rule in Namibia to the attention of the wider world. For an overview of this remarkable man's life see F. Troup, In Face of Fear: Michael Scott's Challenge to South Africa (London, 1950).
} 
Namibia into South Africa. In the immediate aftermath of the Holocaust, the full extent of which was still only just beginning to be understood, genocide committed by an earlier generation of Germans made powerful political ammunition.

Throughout most of 1948, Michael Scott lived in a tent along the Gammans River just beyond the Windhoek old location. Here he met and entertained township residents, many of whom had experienced the horrors of German rule at first hand. ${ }^{33}$ Scott's attention was drawn to the Herero genocide. Here, in a nutshell, Scott realized the sum of the inequities of colonial rule: a people driven off their land, slaughtered, banished to live in barren homelands, and still with no rights. An article entitled 'Michael Scott and the Hereros' published in The New Statesman and Nation in 1949 presented Scott's summary of Namibian history:

Then came the German colonists, hungry for land; and finally von Trotha, a general whom Hitler would have delighted to honour. (...) In 1904 he issued the 'Extermination Order'. All Hereros whether man, woman or child were to be killed. An orgy of looting, torture, and massacre followed. To read the records is exactly like reading the accounts of the obliteration of Poland, except that the Germans had not gas chambers then, but killed babies with their own hands, or burned sick old women in their huts. The tribe broke and fled... The majority, all but fifteen thousand out of ninety thousand, were hacked to pieces by the Germans or died of thirst. $^{34}$

The mention of Von Trotha's 'Extermination Order' clearly indicates that Scott must have gained access to a copy of the Blue Book. Scott's history also made explicit the link between the horrors perpetrated by the Nazis and the activities of the forces of Imperial Germany in Namibia, a link that continues to garner extensive academic interest. ${ }^{35}$ In addition, Scott indicated how the South Africans had betrayed the Herero:

\footnotetext{
${ }^{33}$ Troup, Face of Fear, 173-80.

${ }^{34}$ NNAW, SWAA 1981, A 427/48, Rev. M. Scott, Typed copy of article that appeared in The New Statesman and Nation, 5 March 1949.

${ }^{35}$ Hannah Arendt became the first academic to alert the world to the linkages that exist between Germany's colonial past and the later development of the national socialist state. H. Arendt, The Origins of Totalitarianism (London, 1967). The work of East and West German historians, Horst Drechsler and Helmut Bley further developed this theme, and recently a new generation of historians has once again taken it up. A selection of some of the papers presented at the annual meeting of the African Studies Association in Houston, Texas in November 2001 clearly brings this trend to the fore. J.B. Gewald, 'Anticipating the Kaiser: German Soldiers and the Herero-German War'; J. Gaydish, "Die Lösung der Eingeborenenfrage": The Role of the Swakopmund
} 
In the 1914 war, lured by British promises that native lands would be returned, the desert remnant trekked back. But in 1918 they met not the British as the Mandatory Power, but the South Africans, who never for a moment considered giving them back their tribal lands. Some pastures were left to the German settlers who remained. More went to the Afrikaner settlers, ... ${ }^{36}$

Throughout 1948 and 1949 and in the face of constant harassment, Scott sought to bring conditions as they existed in Namibia to world attention. Eventually in November 1949 the United Nations granted Scott an official hearing. In the months following this hearing, the colonial authorities in Namibia started a campaign to dismiss his statements. ${ }^{37}$ Vilified in the press, Scott continued to be supported by Herero, many of whom recalled the events of 1904-1908 to justify and support their faith in Scott. One such Herero, who signed his letter as 'A Native who had been deprived of his land from 19041950', noted:

I want to emphasise that the information given by the Rev. Michael Scott at UNO is what actually happened in S.W.A. and was obtained from the best reliable sources. ${ }^{38}$

Finally in 1950, Scott, already the victim of constant harassment, was declared a prohibited immigrant and prevented from ever returning to Namibia.

\section{The Herero genocide and nationalist struggle (1958-1990)}

In Namibia, the events of 1904-1908 informed the establishment of the South West African National Union (SWANU) and the South West African People's Organization (SWAPO). Particularly within SWANU, which came to be dominated by Herero ideologues, the loss of the land incurred in the Herero genocide proved to be a major mobilizing factor. ${ }^{39}$ Within Namibia, the political

Concentration Camp in the Development of German "Native Policy" in Southwest Africa'; C. Erischsen, 'Shark Island: Forgotten Concentration Camps and History in Colonial Namibia 1904-1908'.

${ }^{36}$ NNAW, SWAA 1981, A 427/48, Rev. M. Scott, Typed copy of article that appeared in The New Statesman and Nation, 5 March 1949.

${ }^{37}$ See for example, NNAW, SWAA 1981, A 427/48, M. Scott, Draft letters of Bowker written to the Windhoek Advertiser and published 1 March 1950.

${ }^{38}$ Windhoek Advertiser, 18 March 1950.

${ }^{39}$ Z. Ngavirue, Political Parties and Interest Groups in South West Africa (Namibia): A Study of a Plural Society (Basel, 1997), 214 ff, and T. Emmett, Popular Resistance and the Roots of Nationalism in Namibia, 1915-1966 (Basel, 1999), $283 \mathrm{ff}$. 
mobilization, which had begun in earnest in the years after the Second World War, was brutally terminated by the December shootings of 1959. These shootings, by the South African authorities, took place in response to African protests against the Apartheid Group Areas Act. ${ }^{40}$ In the aftermath of the shootings, there was a substantial South African government clamp-down on nationalist political organization in Namibia. This saw the flight into exile of many of Namibia's most highly skilled and articulate Herero. ${ }^{41}$ It was in the context of these events that some of the Herero leaders who had remained within the territory sought to play down the ideas of conflict and tension engendered through the remembrance and commemoration of the Herero genocide. Instead they sought to pursue a policy of appeasement in which they urged leaders of the German community to do the same. The conditions of heightened repression and tension that existed in Namibia at the time made some of the Herero leaders within the territory seek cooperation as opposed to opposition to the settler community. As Herero chief Hosea Kutako stated in response to German commemorations of the Battle of Hamakari:

We do not want to cling to the past or to have old war grudges. Our aim is to forget the past and to look forward rather than backward and to have good relations with all sections of the population but good relations cannot exist if some people try to remind us of the bad past. ${ }^{42}$

Younger Herero such as Clemens Kapuuo, Hosea Kutako's eventual successor, were far less conciliatory. When German settlers wanted to commemorate the Herero-German War, Kapuuo reminded them of the terror wrought in the genocide and its links to the Holocaust.

To our minds there is little difference between the extermination order of General von Trotha and the extermination of Jews by Adolf Hitler. The members of the Alte Kameraden are today a free people whereas the Hereros are not and are under a foreign Government which was elected partly by members of the Alte Kameraden. It is natural that the Hereros would be opposed to the celebration of a battle which placed them under foreign domination up to this day. ${ }^{43}$

\footnotetext{
${ }^{40}$ K. Dierks, Chronology of Namibian History: From Pre-Historical Times to Independent Namibia (Windhoek, 1999), 124.

${ }^{41}$ Amongst others, Moses Katjiongua, Mburumba Kerina, Fanuel Kozonguizi and Zedekia Ngavirue.

42 '"Forget the Past": Improve Race Relations Kapuuo Urges Kameraden', in Windhoek Advertiser, 7 August 1964.

${ }^{43}$ 'Hereros Oppose Waterberg Celebrations: Alter Kamerad Denies "Extermination"', in Windhoek Advertiser, 29 July 1964.
} 
As might well have been expected, Carl Schrader, a spokesman for the Alte Kameraden, denied that the Herero had been 'exterminated'.

In exile, the genocide perpetrated upon the Herero and the Nama came to be one of the pillars of anti-colonial propaganda used by those who wanted to rid Namibia of its South African occupiers. Initially, this propaganda was based primarily on the works of Bley and Drechsler. Given the gravity of the Herero genocide, it seems remarkable that the only published account of it in English until the 1970s was the Blue Book. The reworked academic theses of the German historians Horst Drechsler and Helmut Bley first appeared in German in 1966 and 1968 in East and West Germany respectively. Bley's work came out in English in 1971, whilst Drechsler's was only published in English in $1980{ }^{44}$ These two excellent studies were primarily concerned with a debate relating to the nature of German imperialism and the development of totalitarian societies. Both books sought and found the roots of National Socialism in Germany's colonial past in Namibia. For both historians, the genocide committed upon the inhabitants of Namibia between 1904 and 1908 foreshadowed later events in Western Europe between 1939 and 1945. As Bley noted in the conclusion to his work:

In SWA conditions crossed over into totalitarianism. This confirms, perhaps even reinforces, Hannah Arendt's contention that in African colonialism one may find the seeds of modern totalitarian rule. ${ }^{45}$

The publication of To be Born a Nation by the SWAPO publicity bureau in London owed much to these two works. ${ }^{46}$ The title referred to SWAPO's nationalist slogan 'To die a tribe, to be born a nation', which reflected the earlier words of the Nama anti-colonial warrior Hendrik Witbooi who, while fighting against the Germans, had called others to arms with the words:

Let us die fighting rather than die as a result of maltreatment, imprisonment or some other calamity. ${ }^{47}$

For the first time in a single volume, the atrocities committed by the Germans were linked directly to the atrocities being committed by South

\footnotetext{
${ }^{44}$ See notes 4 and 7 above.

${ }^{45}$ Bley, South-West Africa under German Rule, 282. Bley was referring to the work of Arendt, Totalitarianism, 185-222.

${ }^{46}$ Dept of Information and Publicity, SWAPO of Namibia, To Be Born a Nation: The Liberation Struggle for Namibia (London, 1981).

${ }^{47}$ H. Witbooi cited in P. Katjavivi, A History of Resistance in Namibia (London, 1988), 9.
} 
African security forces operating in Namibia and Angola at the time. Photographs of emaciated Herero with lashed backs were juxtaposed with images of migrant workers and affluent whites. The genocide perpetrated upon the Herero and Nama was conveniently linked to the exploitation of predominantly Ovambo migrant labourers. This oppression and exploitation were seen as two examples on a linked continuum of illegal colonial rule. ${ }^{48}$ In this manner, the Herero genocide became the shared history of oppression of all Africans living in Namibia, and not just the Herero. The beaten backs of Herero in 1908 came to be linked to the beaten and burnt faces of Koevoet prisoners in northern Namibia in the 1980 s. $^{49}$

In the early 1980s, shortly after he had completed his $\mathrm{PhD}$ in history at Oxford University, Peter Katjavivi - the current Vice-Chancellor of the University of Namibia - became the highly articulate SWAPO spokesman in London. Well-versed in the history of Namibia, Katjavivi did not hesitate to liken the attacks of South African forces to those perpetrated by Von Trotha 75 years earlier. The anti-colonial struggles of the Herero and the Nama came to be applied to all of Namibia, as if the nationalist struggle had begun with the wars undertaken by imperial Germany against the Nama and the Herero. The published version of Katjavivi's thesis A History of Resistance in Namibia clearly fell within this paradigm. It argued that Namibia's colonial governments were a single continuum where South African soldiers and police in the 1980s were continuing the work started by the German colonial Schutztruppe in the 1890 s. $^{50}$ To a lesser extent, the work of Kaire Mbuende, who like Katjavivi was a Herero historian in exile, also emphasized the perceived continuum. ${ }^{51}$

\footnotetext{
48 Thus for example, Peter Katjavivi, SWAPO's publicity officer in London, wrote: 'Although the hopes of a change with the end of German rule were soon dashed, the Namibian people were not deterred from pursuing their cause further'. P. Katjavivi, 'The Development of Anti-colonial Forces in Namibia', in Namibia 1884-1984: Readings on Namibia's History and Society (London, 1988), 561.

${ }^{49}$ Koevoet was a paramilitary anti-insurgency police unit established by the South African administration in Namibia in response to a legal loophole in UN Security Council Resolution 435 which allowed the presence of police in the envisaged changeover to Namibian independence. Guilty of outright murder, torture and extensive and consistent human rights abuses, Koevoet built up a ferocious reputation for itself in northern Namibia and southern Angola. See T. Cleaver \& M. Wallace, Namibia Women in War (London, 1990).

${ }^{50}$ P. Katjavivi, 'The Rise of Nationalism in Namibia and its International Dimensions' PhD thesis, Oxford University (1984). The thesis formed the basis for History of Resistance.

${ }^{51}$ K. Mbuende, Namibia, The Broken Shield: Anatomy of Imperialism and Revolution (Lund, 1986).
} 
South Africa and the Herero genocide (1970-1990)

Whilst SWAPO used the history of the genocide to further its nationalist struggle from exile, the South African authorities sought the collaboration of the Herero and other communities inside Namibia through a selective commemoration of historical events. As SWAPO had effectively appropriated the sole rights, as it were, to use the genocide, those Herero who cooperated with the South African government could not use it for political purposes even though they were well aware of their history. In addition, they could not afford to alienate a major influential constituency, namely that of the economically and politically powerful German-speaking settler community.

Members of the South African Defence Force (SADF) operating in Namibia must have been aware of cross-currents in the minds of people in Namibia at the time. The mass conscription of Herero into the South West African Territorial Force (SWATF), the SADF proxy force in Namibia, united German settlers and Herero in the same uniform for the first time since 1908. Indeed, the beret badge of a section of the SWATF was that of a kudu, the symbol of the Herero royal house of Tjamuaha. The SWATF officers' school was situated in Okahandja at the ancestral site of the residences of the Tjamuaha chiefs. Herero and German settler conscripts were expected to run up a hill at Osona and bring down leaves from the tree at the top of this hill. The fact that the hill was one on which Herero chief Samuel Maharero anticipated the arrival of German soldiers in 1892 , or that the tree in question was a Witgat boom that is considered by Herero to bear ritual meaning, cannot have been missed by observers. ${ }^{52}$

From 1978 onwards the massed annual commemorative marches of Herero para-militaries to the graves of Herero chiefs in Okahandja became an event that was almost totally dominated by the SADF and SWATF. The commemorations of Herero chiefs, and through them the Herero dead of the genocide, became a demonstration of South African-sponsored opposition to SWAPO. In what is one of the profound ironies of Southern African history, SWATF forces, consisting in large measure of Herero conscripts, marched in staged spectacles in support of South Africa and against the liberation of their country. Indeed, the fraternity of blood brotherhood, which had allegedly been created between Herero and German settlers in the 1904-1908 genocide, now came to be realized in the massed marches of Herero and German settler conscripts. In support of this new-found fraternity, and in conscious negation of the past, Herero symbols were used to forge an opposition to nationalist forces. It was in this period that

\footnotetext{
${ }^{52}$ In the first weeks immediately after Namibian independence the tree in question was sawn down, an act that would have been considered sacrilege on the part of any Herero.
} 
Namibian papers carried extensive coverage of Herero soldiers at the graves of German soldiers at the annual commemorations in Okahandja.

In the second half of the 1980s, there was a flurry in which officially sanctioned monuments, graveyards and game reserves were established. Under the auspices of the SADF, ethnologists were asked to find and document the graves and monuments of Namibia's African people. In so doing, ethnologists travelled throughout the territory documenting graves and, in part, history. As a result of these activities, state-funded monuments came to be erected to the memory of Herero chiefs who had cooperated with the South African colonial administration.

At the same time, the Waterberg and its immediate environs, the site of the defeat of Herero forces in 1904, was declared a game reserve. In other words, the Waterberg, the symbol and site of the Herero genocide, was consciously robbed of its potent symbolic function by relegating it to the status of a tourist resort. ${ }^{53}$ In the Namibian newspapers of the period, in particular those owned by the South African-funded Republican press, there is no mention of the genocide. In addition, the genocide is almost totally missing from historical work being conducted in Namibia at the time. The Herero oral historian Alexander Kaputu, who was employed by the South African-sponsored Namibian Broadcasting Corporation, also steered clear of the subject. Afrikaner historian Gerhardus Pool discussed the war but not the genocide, and settler historian Sudholt denied that the genocide had taken place. This was a clear case of what Anderson charmingly referred to as 'remembering to forget'. ${ }^{54}$

The successful sublimation of the Herero genocide in the interests of a unified front against the forces of nationalism drew the attention of SWAPO military planners. SWAPO propaganda continually railed against those Herero leaders who cooperated with the South Africans and referred to the history of anti-colonial resistance of Herero chiefs such as Samuel Maharero. It is possible that military operations were undertaken by SWAPO in eastern Hereroland because SWAPO planners wanted Herero to 'remember to remember'. Throughout the Bush War in Namibia, SWAPO military activities in eastern Hereroland were doomed to failure, and SWAPO planners were well aware of this. By the end of 1978, South African forces had effective and total military

\footnotetext{
${ }^{53}$ Interestingly in post-independence Namibia, the tourist nature as opposed to the commemorative function of this site continues to be emphasized. This is done primarily with the argument that 'all Namibians suffered', and that as the sites are allegedly linked solely to a single ethnicity, commemoration would support tribalism. Implicit in this position is a denial of the genocide.

${ }^{54}$ B. Anderson, Imagined Communities: Reflections on the Origin and Spread of Nationalism, revised and extended edition (London, 1991), chapter 11.
} 
control of Namibia. In the event of attempted infiltrations by SWAPO's People's Liberation Army of Namibia (PLAN), South African 'hunter-killer' units, such as Koevoet, ensured that incursions were short-lived. Although SWAPO planners knew that their forces would be defeated, captured and killed, the symbolic action of an infiltration into eastern Hereroland would not have been lost on the Herero population. The PLAN fighters who were infiltrated by SWAPO into Hereroland were a carefully selected multi-ethnic group of young Namibians, representative of the nation that was to be. Given that the military validity for their incursion was non-existent, one could argue that this group of young people was sacrificed in the hope that their actions would trigger memories of the Herero genocide, memories that would come to substantiate support for SWAPO, as opposed to collaboration with the South Africans. ${ }^{55}$

Namibian independence, Herero genocide and Herero unity (19902000)

Whereas in the years leading up to independence in 1990 the Herero genocide had been successfully appropriated by the nationalist forces allied to SWAPO, immediately after Namibian independence the Herero genocide became the preserve of Herero elites opposed to the new government. In the run-up to independence, Herero activists began seeking a formal apology from the German government for the events of 1904-1908. In the late 1980s, SWANU activists living in Germany had already approached the anti-Apartheid movement in the Netherlands for assistance in bringing a case against the West German government. ${ }^{56}$

After independence, the SWAPO government of Namibia tried to ensure that Herero claims for reparation would remain muted or couched within the demands of the nation-state which they controlled. The last time that

\footnotetext{
55 'Omaheke Region to Mark Heroes' Day', The Namibian, 25 August 1993.

${ }^{56}$ Author's personal observation regarding meetings held in Amsterdam in 1988 and 1989.
} 


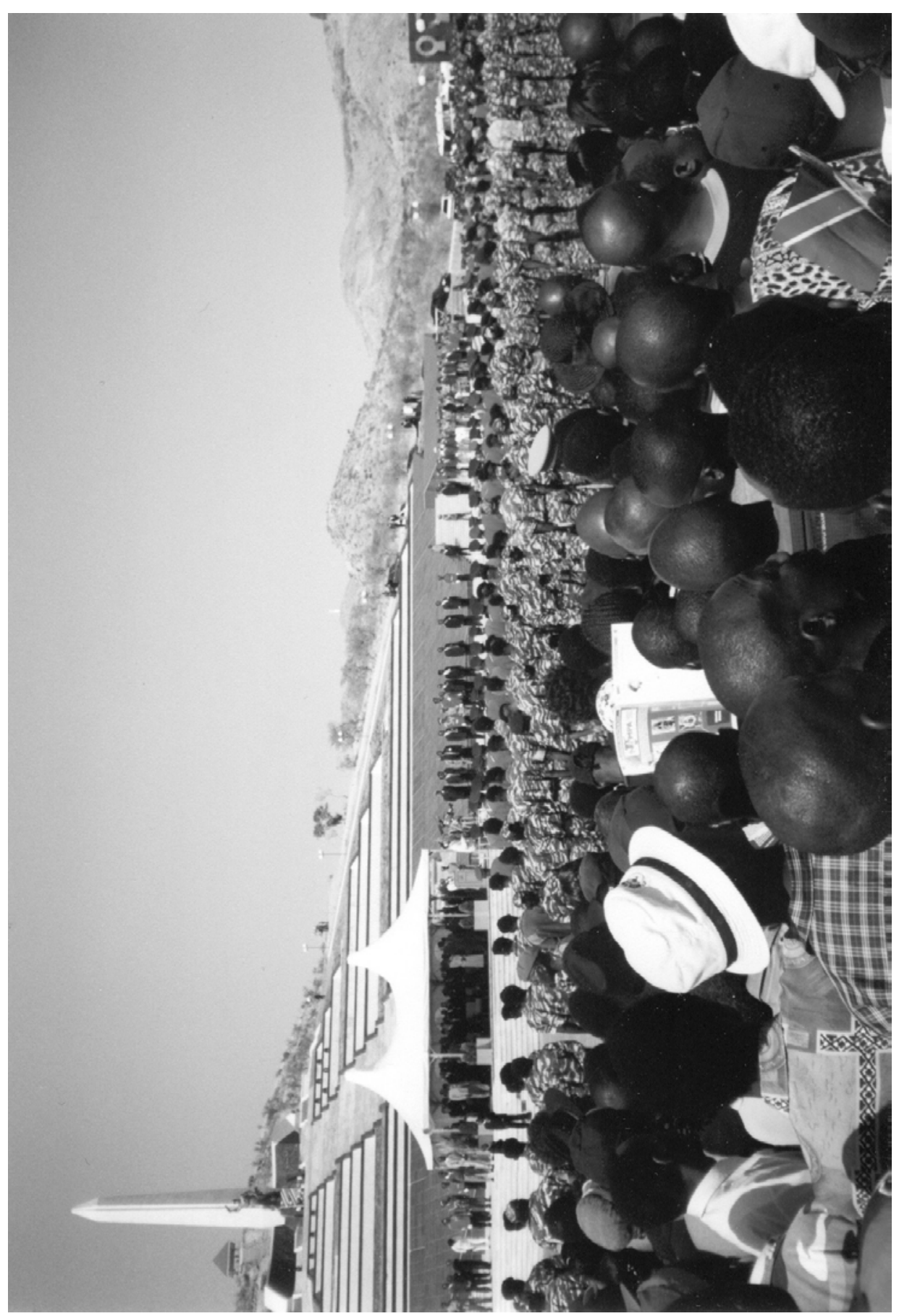

The inauguration of Heroes' Acre on Namibian Heroes' Day, 26 August 2002 Photo by Jan-Bart Gewald 
government ministers referred directly to the issue was during the visit of Chancellor Helmut Kohl and Bundes-President Herzog to Namibia in 1995. At the time, Foreign Affairs Minister Theo-Ben Gurirab noted in an interview that the injustices committed against the Namibian people by the former German colonial power would always remain a 'festering sore' and the two countries needed to discuss war reparations 'at some stage'. Yet he also said that the issue was at that time not a priority for the government, though he did add that 'we must have the courage and frankness to discuss this when the time is right.${ }^{57}$ In 2002 , the government, reaping the rewards of a booming tourist industry, was well aware of the benefits that accrue to the state on account of continued close economic and military cooperation with Germany. ${ }^{58}$

During their 1995 visit, Chancellor Kohl and President Herzog refused to meet Herero representatives and found themselves unable to offer an apology to the people of Namibia for what had happened in the past. Instead, Herzog referred to the war as 'a dark chapter in our bilateral relations' and made the extravagant claim that the massacres formed 'a burden on the conscience of every German'. ${ }^{59}$ Up to 2002, the government of Schroeder and Rau has also made no official statement with regard to Herero claims. This is in contrast to when the former governing parties were still in opposition and they agreed that what had occurred in Namibia constituted genocide. ${ }^{60}$

The current government of Namibia is dominated by people who know that their support base is largely to be found in the Ovambo north. ${ }^{61}$ This area, though deeply affected by war during the dying days of South African occupation, was left untouched by German imperialism. Although Herero and Nama lost all their lands, the inhabitants of the Ovambo kingdoms were never driven off their lands by either the German or South African colonial presence. As such, the present government does not feel itself called upon to fight for something that is not part and parcel of its shared historical experience. In addition, the government is at pains to ensure that its heroes, and not those of another sector of society, receive recognition. This was well illustrated by the spectacle of the statue of the Herero chief Hosea Kutako that was placed in front

\footnotetext{
${ }^{57}$ L. Fild, 'War Reparations on Govt Agenda' in The Namibian, 21 September 1995.

${ }^{58}$ No less than $46 \%$ of the country's development budget is paid by Germany. 'German Visit is a "Total Success"', in The Namibian, 24 June 1996. German military advisors and technicians are stationed in Namibia where they teach and assist Namibian Defence Force personnel. B. Weidlich, 'Helmut Bistri: Offizier und Gentleman', in Allgemeine Zeitung, 1 December 1995.

${ }^{59}$ D.G. McNeil Jr., 'Its Past on its Sleeve, Tribe Seeks Bonn's Apology', in New York Times, Late Edition - Final Edition, COL 01, P. 3, 31 May 1998.

60 'Major German Parties Agree on "Genocide", in The Namibian, 5 November 1990.

${ }^{61}$ On the post-colonial state, see the chapter by Henning Melber in this volume.
} 
of the Namibian parliament in early 1999 and immediately covered with black plastic sacking. Kutako, a major nationalist leader, also happened to be Herero, and though the government did not state so outright, Kutako's ethnic background ensured that his statue remained clad for no less than two years. The statue was eventually unveiled on 10 December 2001, Namibia's Human Rights Day. However, Kutako's statue was not unveiled alone. Instead it was unveiled together with two others hastily commissioned after the original statue of Hosea Kutako had been erected in early 1999. The two other statues were those of Reverend Theophelus Hamutumbangela and Captain Hendrik Samuel Witbooi, two nationalist leaders who had done much to ensure the establishment and maintenance of the ruling SWAPO party. ${ }^{62}$ The disrespect shown to Kutako, a man who came through the genocide and sought to reestablish Herero society and later fought for Namibian independence, merely serves to ensure that Herero speakers who entered post-colonial society in a thoroughly divided condition now find a shared identity in the genocide experienced by their ancestors and not by the ancestors of the current government.

It is in this context that, on 22 August 1999, Dr Kuaima Riaruako, the selfappointed paramount chief and king of all of the Herero, proclaimed that the 'Herero nation' as a whole had decided to approach the International Court of Justice in The Hague, where a charge of genocide was to be laid against the German state and war reparations would be demanded for genocide committed in Namibia against the Herero between 1904 and 1907. At the time, Riaruako's statement caused a few ruffled feathers in Namibia. German diplomats in Windhoek emailed colleagues in Bonn and Berlin to look into the issue, and then two days later a clinically worded statement by a spokesperson of the International Court in The Hague put everyone, with the exception of Riaruako, at ease.

Only states may be parties in contentious cases before the ICJ and hence submit cases to it against other States. ${ }^{63}$

However, nobody had actually approached the International Court of Justice, and clearly no case was being seriously constructed against the German government to plead for war reparations in Namibia. Why then did Riaruako go out of his way to claim that this was so? A possible explanation is that, since Herero identity increasingly appears to be determined by a shared history of genocide, Riaruako can claim to speak on behalf of his people as long as he is

${ }^{62}$ The Namibian, 11 December 2001.

${ }^{63}$ Published accounts in The Namibian, 25 August 1999 and 8 September 1999. 
able to control the calls for reparation. ${ }^{64}$ If the Namibian government fails to take the initiative and call for reparation on behalf of the Herero and Nama, Riaruako can continue to control these financial demands, secure in the knowledge that he enjoys the support of the majority of Herero speakers.

In the absence of a formal apology, the call for war reparations from Germany has become more vociferous. Government inaction and the continued extensive presence of German tourists, settlers, businesses and farms merely serve to legitimate and emphasize the demands on the part of the Herero and strengthen the bonds of a shared genocidal experience. Recently, this has been emphasized with the launch of two court cases in the District Court of Columbia in the United States. With the assistance of Afro-American organizations, the Herero People's Reparations Corporation was established, with the objective of suing three German companies, Deutsche Bank AG, Terex Corporation (Orenstein und Koppel) and Woermann Linie (Deutsch Afrika Linien), as well as the Federal Republic of Germany in the person of its foreign minister, Joschka Fischer, for reparations. The introductory paragraph of the charge reads as follows:

...the Federal Republic of Germany ('Defendant' or 'Germany'), in a brutal alliance with German multi-national corporations, relentlessly pursued the enslavement and the genocidal destruction of the Herero Tribe in Southwest Africa, now Namibia. Foreshadowing with chilling precision the irredeemable horror of the European Holocaust only decades later, the Defendant formed a German commercial enterprise which cold-bloodedly employed explicitly-sanctioned extermination, the destruction of tribal culture and social organization, concentration camps, forced labor, medical experimentation and the exploitation of women and children in order to advance their common financial interests. ${ }^{65}$

Possibly the historical linkage between the Herero genocide and the later Holocaust was emphasized because of the notable success that Holocaust claimants have had in the American courts.

\footnotetext{
${ }^{64}$ Regarding earlier work dealing with Herero identity, see in particular the work of $\mathrm{H}$. Hendrickson, 'Historical Idioms of Identity Representation among the Ovaherero in Southern Africa', unpublished PhD thesis, University of New York (1992); 'The Long Dress and the Construction of Herero Identities in Southern Africa", African Studies, 53, 2 (1994) 25-54, and Clothing and Difference. Embodied Identities in Colonial and Post-Colonial Africa (London, 1996). For an interesting discussion on the power of historical genocides in attributing identity, see R. Lemarchand, paper presented at the ASA Chicago 1998 and Malkki, Purity and Exile.

${ }^{65}$ Case papers in the possession of the author.
} 
While in the past it was the Otruppe or Truppenspieler ${ }^{66}$ that maintained Herero identity in the face of colonial repression, now it is participation in discussion about genocide that performs that role. Association with the dreadful events of 1904-1908, even if only through language or fourth-generation descendancy, allows for the participation of all in the world of war reparations. This has also come to be combined with a notion of remembering-to-forget the often enormous differences that existed and still exist between the Herero. ${ }^{67}$ Historically, Herero speakers were divided amongst themselves. Not all sections of Herero society were equally affected by the genocide, let alone in the South African Apartheid years. Yet discourse on the genocide allows people to paper over these distinctions. It is thus the first truly shared experience of all Herero speakers in the present. ${ }^{68}$

\section{Genocide, memory and resistance}

In Namibia, memories of the genocide perpetrated between 1904 and 1908 have been instrumentalized and were used to further the aims and objectives of differing socio-political actors during the course of the twentieth century. Herero have sought to use the memory of their seminal act of resistance, which was in effect a disastrous failure, to advance and substantiate further acts of resistance since 1904, and memories of the genocide have been redeployed over the years in differing circumstances and with varying goals. Yet underlying all of these deployments has been the intention of Herero political actors to further their position and resist colonial and current post-colonial domination.

The immensity of the catastrophe that befell the peoples of central Namibia between 1904 and 1908 was such that it could not, and still cannot, be banished from public memory and debate. However, in Namibia prior to the Second World War, though the enormity of the genocide was known, it was not necessarily appreciated and expressed by all. For the Herero, it was an event in history that knows no comparable precedent. Yet though both Herero survivors and German perpetrators were aware of what had happened in Namibia between

${ }^{66}$ Herero paramilitary organizations formed after 1915. See W. Werner, "'Playing Soldiers": The Truppenspieler Movement among the Herero of Namibia, 1915 to ca. 1945', Journal of Southern African Studies, 16, 3 (September 1990), 485-502.

${ }^{67}$ For an interesting discussion on the issue of remembrance, memory and forgetting, see Anderson, Imagined Communities, 187-206.

${ }^{68}$ To a large extent this was also displayed by the presence of Chief Munjuku in Okahandja in August 1999. Munjuku who had previously been closely allied with the SWAPO government has of late left the fold, and through the articulation of claims to a shared genocide has found refuge with Herero associated with Riaruako. 
1904 and 1908, German settlers were able to dismiss the Herero genocide as nothing more than a colonial war. However, the full horror of the Herero genocide became apparent to observers when, in the aftermath of the Second World War, the Nazi Holocaust became known to the wider world. The real and imagined linkages of the Herero genocide to the Nazi Holocaust could not be hidden and came to be deployed in further discussions relating to the Herero genocide. Hence, the Nazi holocaust changed forever the import and meaning of the Herero genocide.

Engaged as the Herero are at present in a legal tussle for war reparations, Herero political actors are well aware of the Nazi Holocaust and are making full use of the implications of this fact. In this manner the Herero indicate how memories, even of failed acts of past resistance, can be used as acts of resistance in the present. Though resistance to colonial rule in Namibia was by and large unarmed, it was not passive. Instead, it was a struggle for control of memory that informed and guided Herero political actors in their dealings with the colonial and post-colonial state. From 1945 onwards it came to be seen in the wider context of the Nazi Holocaust, and the issue of morality began to be emphasized. In Namibia the party that speaks on behalf of those killed in the Herero genocide can now claim the moral high-ground.

Thus, the case of the Herero genocide in Namibia emphasizes once more that though physical resistance may be of a passing nature, memories may continue to inform and justify political action long after the events that spawned them have receded into the past. 


\title{
'Namibia, land of the brave': Selective memories on war and violence within nation building*
}

\author{
Henning Melber
}

The limits to the memory of liberation are investigated with regard to the factors affecting a liberation movement in the process of achieving legitimate power in a post-colonial society. The case of Namibia is explored in the transition from anti-colonial resistance to comprehensive control, by the former liberation movement, over the state. The concepts of political rule, the state and democracy are tested against the impact of a liberation struggle in terms of the applied understanding of political dominance once access to power has been achieved. The political culture under a government with a record of liberation struggle suggests limitations to the implementation of democracy.

Namibia, land of the brave, freedom fight we have won, glory to the bravery, whose blood watered our freedom.

These are the first four lines of Namibia's national anthem. Its melody was composed and selected during a competition before independence in early 1990 and the words were added a few months later. ${ }^{1}$ The anthem is evidence of the

\footnotetext{
* I am grateful to Reinhart Koessler for his comments on the draft manuscript of this chapter.

${ }^{1}$ These introductory lines led to some raised eyebrows and concerns among members of the white minority with regard to the extent to which the declared notion of national
} 
pride of an emerging new nation placing itself on the map of sovereign states after more than a century of foreign occupation and continued resistance, including more than two decades of an armed liberation struggle. The introductory words also illustrate the legacy of this struggle for post-colonial development. Such legacies are nothing new, and far from typically African, but they also have a history on the continent. ${ }^{2}$

This chapter explores, presents and comments upon some visible features of a political culture affected by a militaristic orientation in the independent Republic of Namibia. This is not to say that Namibia is governed either by warlords or the military but the picture sketched by this overview highlights an aspect of Namibian society that, to my knowledge, has not yet been explicitly made a thematic subject, unlike in other societies in the region. ${ }^{3}$ It can be considered one of the historical, structural and psychological legacies of colonial rule, that an earlier study termed 'the violent heritage'. ${ }^{4}$

This heritage, from a dialectical point of view, shaped mentalities and ideologies not only among the colonizers but also among the colonized. There is a growing tendency to critically analyse the processes in which victims in the

reconciliation is taken so seriously by the newly elected political leadership of the country. They did not in fact contribute to eliminating their original worries in facing the fate of an endangered species, though subsequent experiences have so far not confirmed their fears. That these first lines bear striking resemblance to the concluding words in the United States national anthem, 'The Star Spangled Banner', did not occur to those confined to the Namibian perspective. But this is a healthy reminder that the subject of this chapter is clearly not typically African but is one of patriotism in nationbuilding processes all over the world.

${ }^{2}$ See, as impressive early evidence of coming to terms with such a history in the African context of decolonization, the essays on various topical subjects compiled in the volume by A.A. Mazrui, Violence and Thought (London \& Harlow, 1969).

${ }^{3}$ In particular the social history of Zimbabwe has in recent years produced a striking range of in-depth analyses dealing with the impact of the second chimurenga upon (post-)colonial identity formation and ideological discourse. See among more prominent recent examples the variety of contributions to the two volumes by $\mathrm{N}$. Bhebe \& $\mathrm{T}$. Ranger (eds), Soldiers in Zimbabwe's Liberation War (London, Portsmouth \& Harare, 1995) and Society in Zimbabwe's Liberation War (Oxford, Portsmouth \& Harare, 1996), and especially R. Werbner, 'Smoke from the Barrel of a Gun: Postwars of the Dead, Memory and Reinscription in Zimbabwe', in R. Werbner (ed.), Memory and the Postcolony. African Anthropology and the Critique of Power (London \& New York, 1998).

${ }^{4}$ D. Soggot, Namibia: The Violent Heritage (London, 1986). Soggot has been active as a South African-based lawyer for several years in Namibia defending those accused in political trials. His story reveals numerous atrocities and the kind of human rights violations notorious under Apartheid, which as a legacy to the post-colonial society shaped the mentality of both the colonizers and the colonized. 
'Namibia, land of the brave' 307

role of freedom fighters became perpetrators. Breaking such taboos is necessary in a debate that is dealing increasingly with the content of liberation and reflecting (if not questioning) the concept of solidarity of the past years and marks the end of the cultivation of 'heroic narratives'. ${ }^{5}$ Growing insight shows that armed liberation struggles were not a suitable breeding ground for the establishment of democratic systems of government after independence. The forms of resistance against repressive regimes were themselves organized along strictly hierarchical and authoritarian lines because otherwise they would have had little prospect of success. In this sense, the new societies bore the essential elements of the old system they had fought. Aspects of the colonial system reproduced themselves in the struggle for its abolition and subsequently in the concepts of governance applied in post-colonial conditions. They share the binary view of the colonial discourse of the past. ${ }^{6}$

Governments were formed by the anti-colonial liberation movements that had themselves been far from non-violent. They assumed control of the state machinery and reorganized themselves as political parties. The legitimacy to rule stemmed from their emergence from the decolonization process as democratically elected representatives of the majority of the people. Since then and with varying results (and sometimes with the use of further organized violence, as the case of Matabeleland illustrates), they have been able to strengthen their political dominance and maintain control over the state. This is true even though in Zimbabwe at present it can be seen that these governments may not last forever. ${ }^{7}$

The social transformation in these southern African societies shaped by a settler colonial brand, can at best be characterized as a transition from controlled change to changed control. The result is a new ruling political elite operating from commanding heights constructed in the particular context of the post-Apartheid societies and shaped by selective narratives and memories related to the war(s) of liberation. In this context, new traditions to establish an exclusive post-colonial legitimacy were constructed or invented under the sole authority of one particular agency of social forces. The 'mystification' of the

5 G. Harrison, 'Bringing Political Struggle Back in African Politics, Power \& Resistance', Review of African Political Economy, 89 (2001), 390. See also R. Kössler \& H. Melber, 'The West German Solidarity Movement with the Liberation Struggles in Southern Africa. A (Self-)Critical Retrospective', in U. Engel \& R. Kappel (eds), Germany's Africa Policy Revisited (Münster \& Hamburg, 2002).

${ }^{6}$ See, for example, B. Ashcroft, Post-Colonial Transformation (London \& New York, 2001), 21.

7 See for a more detailed overview, H. Melber, 'From Liberation Movements to Governments: On Political Culture in Southern Africa', African Sociological Review, 6 (2002). 
liberators plays an essential role in this process. What has been stated with regard to the ZANU-PF in Zimbabwe applies to Namibia's SWAPO too. It 'had since independence sought to ground the nation's identity as well as its own political legitimacy in the liberation war'.

The evidence presented here is an attempt to collect and assess the impact of histories of war and violence on the post-colonial mental environment of Namibia, which still shapes and affects memories and their institutionalization in symbols, rituals and daily practices related to the present political culture and hegemony. By doing so, the significance of revolt and resistance in the history of Namibia and its utilization for the legitimacy of currently dominant patterns of rule under a previous liberation movement can provisionally be explored. ${ }^{9}$ This follows the appeal by Werbner:

The critique of power in contemporary Africa calls for a theoretically informed anthropology of memory and the making of political subjectivities. The need is to rethink our understanding of the force of memory, its official and unofficial forms, its moves between the personal and the social in postcolonial transformation. ${ }^{10}$

This exploratory effort does not claim to provide any definitive answers but seeks to offer some thought-provoking input on reflections on the current sociopolitical environment after more than a decade of Namibian independence. I suggest that the post-colonial reality reflects the contradictions and challenges predicted so convincingly by Artur Carlos Maurício Pestana, a former MPLA fighter. He published, under his nom de guerre, the notes he made in 1971 during his participation in the guerrilla war in the rainforest of the Cabinda front in Angola for the MPLA. As a novel and narrative it offers a remarkable degree of sensitivity and insight into the complexity (and limits) of social transformation subsequent to a situation of armed resistance against foreign colonial rule. As the commander of the guerrilla unit ('Fearless') explains to the

\footnotetext{
${ }^{8} \mathrm{~J}$. Alexander, J. McGregor \& T. Ranger, Violence and Memory: One Hundred Years in the 'Dark Forests' of Matabeleland (Oxford, 2000), 254.

${ }^{9}$ To that extent this chapter relates directly to the one by Jan-Bart Gewald in this volume (and vice versa). For other recent efforts to find a more systematic analytical context assessing the track record of the SWAPO liberation movement as the party in political power since independence, see H. Melber, 'The Culture of Politics', in $\mathrm{H}$. Melber (ed.), Namibia - A Decade of Independence, 1990-2000 (Windhoek, 2000) and H. Melber, 'Liberation and Democracy in Southern Africa: The Case of Namibia', in H. Melber \& C. Saunders (eds), Transition in Southern Africa-Comparative Aspects. Two Lectures (Uppsala, 2001).

${ }^{10}$ R. Werbner, 'Beyond Oblivion: Confronting Memory Crisis', in Werbner, Memory and the Postcolony, 2.
} 
political commissar ('New World'), for whom he ultimately sacrifices his life in battle:

We don't share the same ideals. (...) You are the machine type, one of those who is going to set up the unique, all-powerful Party in Angola. I am the type who could never belong to the machine. (...) One day, in Angola, there will no longer be any need for rigid machines, and that is my aim. ... what I want you to understand, is that the revolution we are making is half the revolution I want. But it is the possible. I know my limits and the country's limits. My role is to contribute to this halfrevolution. (...) I am, in your terminology, adventurist. I should like the discipline of war to be established in terms of man and not the political objective. My guerrillas are not a group of men deployed to destroy the enemy, but a gathering of different, individual beings, each with his subjective reasons to struggle and who, moreover, behave as such. (...) I am happy when I see a young man decide to build himself a personality, even if politically that signifies individualism. (...) I cannot manipulate men, I respect them too much as individuals. For that reason, I cannot belong to a machine. ${ }^{11}$

This conversation is more than fiction: it sets the parameters and social constraints for a post-colonial society with a history of armed resistance against settler colonialism in southern Africa - a society like that of present-day Namibia.

\section{'Let us die fighting': Armed resistance as a historical continuity}

In 1960 the South West African People's Organization (SWAPO) was formed as a result of the organizational structures emerging during the 1950s among the contract workers from the northern part of Namibia - Ovamboland - a region named after its population. ${ }^{12}$ Until the mid-1960s SWAPO was competing with

\footnotetext{
${ }^{11}$ Pepetela, Mayombe (London, 1996), 197-98.

12 The different Ovambo communities form more than half of Namibia's population and are the backbone and power base of SWAPO. The SWAPO narrative is thus strongly guided and influenced by an Ovambo perspective. This chapter, however, does not explore the regional-ethnic aspects and components of post-colonial national ideology in Namibia in depth. For a comprehensive official historiography on the liberation struggle and SWAPO's role, see Department of Information and Publicity/SWAPO of Namibia, To Be Born A Nation. The Liberation Struggle for Namibia (London, 1981). Other semi-official historiographies include the scholarly works of two long-time SWAPO activists who graduated in exile from Oxford and Lund respectively: P. Katjavivi, A History of Resistance in Namibia (London, 1988) and K. Mbuende, Namibia, the Broken Shield: Anatomy of Imperialism and Revolution (Lund, 1986). Katjavivi has been the Vice-Chancellor of the University of Namibia since its
} 
other anti-colonial organizations for a leadership role but its decision to launch an armed struggle as the ultimate means to liberate Namibia marked a turning point and paved the way for SWAPO's international and local recognition as the most relevant organization of the Namibian people to bring about independence. The subsequent steps to hegemony within the anti-colonial resistance were constituted by the United Nations General Assembly Resolution 3111 of 12 December 1973, recognizing SWAPO as 'the authentic representative of the Namibian people' and its amendment in the United Nations General Assembly Resolution 31/146 of 20 December 1976 to be the 'sole and authentic' representative. It thereby endorsed the exclusive status and political monopoly of SWAPO in the ongoing negotiations on behalf of the Namibian people.

The armed struggle - as executed by SWAPO's military wing, the People's Liberation Army of Namibia (PLAN) - constituted a substantial if not decisive step towards legitimacy in this process. ${ }^{13}$ In principle decided upon in the early 1960s, it finally started after a ruling by the International Court of Justice in The Hague that denied the Namibian people a hearing on their right to selfdetermination on purely legal grounds. Its announcement on 18 July 1966 provoked a statement, released the same day by SWAPO's external headquarters (then in Dar es Salaam, later in Lusaka and finally in Luanda), declaring that: 'We have no alternative but to rise in arms and bring about our liberation'. ${ }^{14}$

The first military encounter between SWAPO insurgents and the South African army occurred on 26 August 1966 when the colonial forces attacked a guerrilla base at Omgulumbashe in Ovamboland (nowadays in politically correct post-colonial terminology more vaguely referred to as Northern Namibia). Subsequently, August 26 was commemorated by the United Nations as 'Namibia Day'. An editorial in the June/July 1968 issue of the SWAPO publication Namibia News illustrates the crucial element introduced with the armed liberation struggle to the historiography of SWAPO, which from now on could claim to represent the continuity of resistance by the people of Namibia against foreign occupation:

26 August is a day of commemoration for our people. One of our early uprisings against the Germans took place on this date and ever since the date has been

establishment in the early 1990s, while Mbuende was Deputy Minister of Agriculture, then SADC Executive Secretary and since 2000 a Member of Parliament.

${ }^{13}$ See T. Emmett, Popular Resistance and the Roots of Nationalism in Namibia, 19151966 (Basel, 1999), 331-34.

${ }^{14}$ Department of Information and Publicity/SWAPO of Namibia, To Be Born A Nation, 177. 
remembered. On 26 August this year it is two years since we, the people of Namibia, entered a new phase in our fight against the racist white minority by launching our armed struggle. Until then we fought by non-violent means, but this brought us nothing but increased violence and brutality from our enemy. When we saw there was no way out - the last straw was the let-down by the world community in The Hague - we took up arms.

Namibia's history contains many accounts of armed uprising against foreign invaders. For instance, from 1904 to 1907 the Germans faced continuous revolts which were led by the dynamic chiefs, Maherero and Witbooi. The Germans met the resistance with what they called 'a war of extermination', during which they ruthlessly killed any Namibian they could find, whether soldier or civilian. When the war ended, the population in parts of our country was reduced by two-thirds. In 1917 another uprising took place, this time under the leadership of King Mandume. Mandume's men fought the Boers in the South and the Portuguese in the North. Although this revolt was crushed, we did not lose our determination to free our country from white overlordship. Today we are again engaged in an armed battle against our enemy, but this time we cannot be stopped until we have liberated Namibia from the white settler regime. ${ }^{15}$

With the armed struggle, SWAPO had entered a new stage in Namibian history. Not only did this add a further dimension to the efforts to bring about independence, but it also opened the way for its consolidation as the one and only decisive organization within the anti-colonial movement. It created the idea of historical continuity since the days of the early 'primary' anti-colonial resistance beginning in the late nineteenth century. This is clearly illustrated by the quotation above which underlines the direct links to the efforts of leaders among the Nama (Witbooi), the Herero (Maherero) and the Kwanyama/ Ovambo (Mandume) under early colonial rule to resist foreign occupation by means of armed resistance too.

'Let us die fighting', a quote accredited to a letter by Herero Chief Samuel Maherero, in which he tried to convince the Nama Kaptein Hendrik Witbooi shortly before the first organized military attack on the German colonial authorities in 1904 to join the resistance, emerged during the $1980 \mathrm{~s}$ as a catchphrase to link the contemporary struggle with the early history of armed anti-colonial struggle. It became popular as a result of a qualitatively new perspective within historical analysis, with subsequent prominent and also politically relevant impact. ${ }^{16}$ Maherero's letter, actually sent to the Kaptein of

${ }^{15}$ Quoted from A. de Braganca \& I. Wallerstein (eds), The African Liberation Reader. Volume 2: The National Liberation Movements (London, 1982), 5-6.

${ }^{16} \mathrm{H}$. Drechsler, 'Let Us Die Fighting': The Struggle of the Herero and Nama against German Imperialism, 1884-1914 (London, 1980). The title of the German original (Südwestafrika unter deutscher Kolonialherrschaft), a thesis published in the GDR in 1966 (and published in a revised version in 1984) did not make use of the quote. See on 
the Rehoboth Basters and instead of being handed over to Witbooi passed on to the Germans, contained the following appeal, which allowed later analysis to suggest the emergence of a common interest and alliance during early anticolonial resistance between hitherto divided groups:

I appeal to you, my Brother, not to hold aloof from the uprising, but to make your voice heard so that all Africa may take up arms against the Germans. Let us die fighting rather than die as a result of maltreatment, imprisonment or some other calamity. ${ }^{17}$

The claim to historic continuity was one of the things illustrated by the fact that The Combatant, the monthly organ of PLAN, in a later standard front cover header combined the images of Hendrik Witbooi and Tobias Hainyeko, a PLAN commander who was killed and praised as one of the fallen heroes. ${ }^{18}$

SWAPO's military activities were never as effective and successful as efforts on the diplomatic front. This was partly the result of the relative weakness of the combat units and the unfavourable geographical and geostrategic conditions for guerrilla warfare in many parts of the country. It was at the same time at least as much Namibia's genuine status in terms of international law that resulted in special attention by the United Nations towards this 'trust betrayed'. ${ }^{19}$ It allowed for diplomatic offensives that other anti-

the relevance of Drechsler's study, also in current debate, the chapter in this volume by Jan-Bart Gewald.

${ }^{17}$ Ibid. 143. For a more recent summary of the context of 'primary' resistance in the process of colonization, see H. Melber, 'Economic and Social Formation in the Process of Colonisation: Society and State Before and During German Rule', in C. Keulder (ed.), State, Society and Democracy. A Reader in Namibian Politics (Windhoek, 2000).

${ }^{18}$ The Combatant - The Monthly Organ of the People's Liberation Army of Namibia (PLAN) was published from 1980 onwards in mimeographed and stapled A4 format but changed its layout in the mid-1980s into a more sophisticated A5 format print version. The relevance of the armed struggle is also illustrated by the fact that The Combatant was among the SWAPO publications and periodicals (such as Namibia News and Namibia Today) with the longest continuity and ceased publication only at the end of 1988 with the ceasefire agreement and subsequent implementation of United Nations Security Council Resolution 435 (1978).

${ }^{19}$ Namibia - A Trust Betrayed had in fact been the title of a United Nations publication to explain the case in terms of international law. As a result, SWAPO received not only support from the majority of member states in the United Nations General Assembly, as already mentioned by its recognition as 'sole and authentic representative', but could subsequently claim observer status to the United Nations and was supported by a United Nations Council for Namibia, as well as a later established United Nations Institute for Namibia - both agencies collaborating closely with SWAPO or in the latter case even run by a considerable number of SWAPO cadres. For a recent comprehensive summary 
'Namibia, land of the brave' 313

colonial movements rarely had at their disposal. But without the existence of the armed struggle, the diplomatic and political successes as well as the internal mobilization of Namibians could not have been achieved to such a degree.

\section{'To be born a nation': The armed struggle as a midwife}

The battlefield offered few, if any, victories over the South African forces of occupation. The war was waged mainly in the Angolan border area and on foreign soil. But however much a military victory might have boosted morale, defeats contributed to a growing identity in the struggle. Seen in this light, the 'ravages of war ${ }^{20}$ did not only have a devastating impact on the further course of the struggle for liberation but also brought together the oppressed Namibian majority. The collective trauma of the Cassinga massacre hence symbolized not defeat but a determination to resist and to make sacrifices. This refugee camp in southern Angola was bombed - as the height of cynicism and in an obvious effort to sabotage the acceptance of the decolonization plan as defined in the United Nation Security Council Resolution 435 - on 4 May 1978 (Ascension Day) by the South African army. ${ }^{21}$ The several hundred victims (mainly women and children) have remained a symbol of the Namibian struggle for independence ever since.

The idea of martyrdom created in every case of violence exercised by the occupation army and police, both in exile as well as on the home front, in police cells and in the townships, added to the consolidation of resistance under the SWAPO banner. The glorification of resistance and sacrifices on the battlefield were articulated in numerous (often crude) praise poems published in SWAPO's various publications. One, which gave the title to the only published anthology documenting the spirit of these days, ends with the following lines:

We fear not your beatings

Neither your brutal bombardments

and documentation of the role of the United Nations in the dispute, see L.C.W. Kaela, The Question of Namibia (London \& New York, 1996).

${ }^{20}$ Described in some detail in B. König, Namibia - The Ravages of War (London, 1983) and D. Herbstein \& J. Evenson, The Devils are Among Us. The War for Namibia (London, 1989).

${ }^{21}$ The best accounts are A. Heywood, The Cassinga Event (Windhoek, 1994) and M.Y. Nangolo \& T. Sellström, Kassinga. A Story Untold (Windhoek, 1995). As the titles show, Cassinga is also referred to as Kassinga. 
For you cannot smash our strength

We so united and strong

Your flesh and heart we shall bear. ${ }^{22}$

The same volume includes a poem about Cassinga, which ends with a similar appeal to the masses, reminding them of the legacy left behind by the dead and the obligation of survivors still suffering from oppression to fight for liberation:

They have died for our country,

They have died for our people.

Their blood is shed - but not in vain!

Their brightest sacrifice - won't be in vain!

The task is over to you and me,

The task is given to all of us,

We have to continue from where they ended,

Never betray their sacred blood!

Their blood is shed - but not in vain!

Their highest sacrifice - won't be in vain!

Ensure the success of the struggle!

Defend the revolution for the good of all! ${ }^{23}$

Frantz Fanon's classification of this mode of expression is a relevant characterization of the 'midwife' function the armed struggle was able to assume in the creation of a national consciousness. For him, this 'literature of combat'

${ }^{22}$ F. Tshirunga, 'It Is No More a Cry', in H. Melber (ed.), It Is No More a Cry. Namibian Poetry in Exile (Basel, 1982), 38.

${ }^{23} \mathrm{~N}$. Wakolele, 'Kassinga', in ibid. 47. In the early 1980s, the author was a student at the United Nations Institute in Lusaka. When he died in the mid-1990s, he was Permanent Secretary in the Ministry of Information of the Republic of Namibia. Other authors of the 'literature of combat' included the current Namibian ambassador to Germany, Hinyangerwa Asheeke. I hereby admit to have actively disseminated the revolutionary pathos and phraseology of two decades ago without much of a critical distance, as the introductory essay to this aforementioned volume testifies: H. Melber, 'Colonialism, Culture and Resistance: The Case of Namibia', in ibid. As a member of SWAPO since 1974 and banned from entering Namibia after 1975 until independence, I was part of the dominant anti-colonial spirit in exile, propagating the gospel of the national liberation struggle with few or no doubts concerning the absolute moral superiority of the historical mission. While I do not see a reason to regret the commitment of the time or to revoke my affiliation to SWAPO and its goals and ideals of national sovereignty, I am having second thoughts on some of the issues then unnoticed by myself from today's perspective. 
...calls on the whole people to fight for their existence as a nation. It is a literature of combat because it moulds the national consciousness, giving it form and contours and flinging open before it new and boundless horizons; it is a literature of combat because it assumes responsibility, and because it is the will to liberty expressed in terms of time and space. ${ }^{24}$

Praise poems have remained a relevant mode of expression in the context of post-colonial Namibian culture and politics, though their content has changed from revolutionary pathos to other forms of similarly robust patriotism. ${ }^{25}$ The socio-psychological impact of the armed struggle to the formation and consolidation of an emerging identity of a Namibian nation in combat for independence is an obvious message from the quoted documentary evidence and is also reflected in SWAPO's national anthem, the words of which followed the tune of 'Nkosi Sikeleli Afrika':

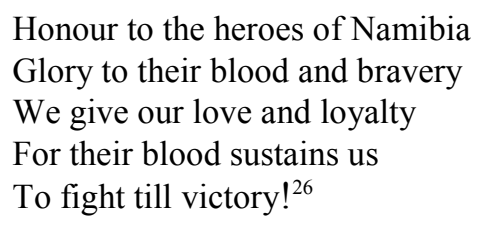

The armed struggle was conceived as an integral part of the battle for liberation among the SWAPO activists by the early 1970s and considered to be a shared responsibility. Evidence of this is in one of the recommendations tabled by a report compiled after investigations into dissent and power struggles within SWAPO in the mid-1970s. The conflicts were a result of frustrations over issues related to the armed struggle, the relationship between the political and the military as well as the treatment of combatants. ${ }^{27}$ The Commission of Inquiry emphasized:

\footnotetext{
${ }^{24}$ F. Fanon, The Wretched of the Earth (Harmondsworth, 1967), 193.

${ }^{25}$ Including a collection of praise poetry on President Sam Nujoma.

${ }^{26}$ Verse three of the national anthem, quoted from SWAPO News and Views, Special Issue, 1 (1989) 2, 52. Any resemblance to the first lines of Namibia's national anthem quoted at the beginning is of course not purely coincidental!

${ }^{27}$ The most detailed account so far on these internal tensions and conflicts are presented by C. Leys \& J.S. Saul, Namibia's Liberation Struggle. The Two-Edged Sword (London \& Athens, 1995) and L. Dobell, Swapo's Struggle for Namibia, 1960-1991: War by Other Means (Basel, 1998). Both studies offer the best explanatory and analytical framework so far for the legitimizing function of the armed struggle in SWAPO's strategy, relevant for substantial subsequent practices and their ideological justification.
} 
the framework of the principle of armed struggle as being the only viable and effective means of achieving total liberation. Within this principle all SWAPO members are soldiers. As a rule all SWAPO officials should spend at least two months a year at the front. ${ }^{28}$

Namibia's ultimate decolonization in a transitional phase with direct United Nations involvement during 1989/1990 was brought about by a combination of local, regional and global factors. The military aspect, though certainly not decisive, was one of them. SWAPO, in its efforts to underscore its claim to have been the ultimate force of liberation through the barrel of a gun, presented a different view in line with its self-image. This was expressed in what was probably the last issue of The Combatant, which for ten years published news from the battlefield on a regular basis:

...the intensification of the armed liberation struggle for the last 22 years has finally made South Africa seek a negotiated solution to Namibia's independence problem and avert a humiliating military defeat that would shatter its dreams of being the socalled regional superpower. ${ }^{29}$

In fact, an emphasis on the military dimension attached to the liberation struggle almost derailed the transition to independence. On 1 April 1989, the day of the implementation of United Nations Security Council Resolution 435 (1978), many of the several hundred SWAPO combatants gathered in Northern Namibia were massacred in cold blood by South African troops in spite of a ceasefire agreement. ${ }^{30}$ They were blamed for having invaded an area outside their originally confined (Angolan) bases in violation of the ceasefire agreement. South Africa claimed, on the basis of reconnaissance evidence, that PLAN insurgents had sneaked into Namibia to create the impression that they had been occupying bases inside the country (a fact which would have given additional support to SWAPO claims that it was playing a relevant military role by operating from Namibian territory). While SWAPO still officially denies that the PLAN fighters had been ordered only a few days earlier to move into

\footnotetext{
28 'Report of the Findings and Recommendations of the John ya Otto Commission of Inquiry into Circumstances which Led to the Revolt of SWAPO Cadres between June, 1974 and April, 1976', submitted 4 June 1976 to the SWAPO Central Committee at its meeting in Lusaka, Zambia, July 1976 (unpublished), 16. I am not aware, however, that this recommended rule was indeed applied.

${ }^{29}$ The Combatant, 10 (1988) 5, 7.

${ }^{30}$ A detailed but unashamedly biased pro-South African description of the events is offered by P. Stiff, Nine Days of War. Namibia - Before, During and After (Alberton, 1989).
} 
Namibian territory, and vigorously refutes any other interpretation, ${ }^{31}$ serious evidence points in a different direction. ${ }^{32}$ Be that as it may, the hundreds of young men caught by surprise had to pay the highest price and sacrificed their lives on a battlefield that was no longer supposed to exist. ${ }^{33}$

In the Republic of Namibia's first hours, the first (and so far only) president - who has also been SWAPO's president since its foundation - did not forget to remember the price of liberation paid by so many. He closed his inaugural speech with the following words:

Master of Ceremony, Sir, in accepting the sacred responsibility which the Namibian people have placed on me, as the first President of the Republic of Namibia, I would like to bow and pay homage to our fallen heroes and heroines, whose names Namibia's present and future generations will sing in songs of praise and whose martyrdom they will intone.

In conclusion, I move, in the name of our people, to declare that Namibia is forever free, sovereign and independent $!^{34}$

\section{'Where others wavered': Post-colonial war narratives and militarism}

It should come as no surprise that Namibia's society today still bears the scars of its violent colonial history. The official political discourse, with the national

\footnotetext{
${ }^{31}$ See, for example, the surprisingly offending remarks in President Sam Nujoma's autobiography where he accuses Martti Ahtisaari as the highest United Nations official in charge of Namibian decolonization 'to be more concerned with his career at the United Nations than with his responsibilities towards the oppressed people of Namibia'. He further maintains that 'Ahtisaari's action betrayed our cause' and that he 'plotted'. S. Nujoma, Where Others Wavered (London, 2001), 396-97.

32 See the interview with Martti Ahtisaari, previously Head of the United Nations Council for Namibia, then in charge of the United Nations Transitional Assistance Group (UNTAG), in I. Soiri \& P. Peltola, Finland and National Liberation in Southern Africa (Uppsala, 1999), 185-86.

${ }^{33}$ There are earlier sacrifices of a similar nature, though not the same dimension, on record. See the failed incursion by SWAPO combatants into Eastern Hereroland in the late 1970 s, motivated by other deliberations than any chance for a military success. JanBart Gewald's reference to this incident in his chapter in this volume indicates that the young people were sent to their death for reasons of political mobilization among the Herero.

${ }^{34}$ Quoted from the speech as reproduced in full length in Nujoma, Where Others Wavered, 447. Nujoma dedicated his autobiography 'to the gallant sons and daughters, heroes and heroines under the leadership of their vanguard SWAPO, and to those who struggled and sacrificed their precious lives for the total liberation of Namibia'.
} 
liberation movement assuming the power of definition by seizing legitimate and democratically based control over the state as the elected Namibian government since then, reflects a continued affinity towards authoritarian structures required to wage war. The dominant narrative of post-colonial Namibia is presented here by means of several examples. It has been suggested elsewhere with reference to Zimbabwe's second chimurenga that the 'variety of appropriations of violence is the dating of events' and 'the memorising of dates of wars and battles (as well as biographies of great men - and women) as markers of history, ${ }^{35}$

Namibian independence started by choosing such a day: 21 March 1990 was agreed upon as Independence Day following a SWAPO suggestion to the Constituent Assembly to honour the memory of the Sharpeville massacre in South Africa by opting for this date. Though largely unknown in the public sphere in Namibia, it reiterates the liberation movement's commitment to remember victims of struggles in times of peace. On 4 May, Kassinga Day - a public holiday - marks the biggest single massacre of refugees in exile. Heroes Day on 26 August, introduced earlier as Namibia Day by the United Nations, is also a public holiday and commemorates the beginning of the armed struggle in Omgulumbashe (where a memorial has since been erected) ${ }^{36}$ Human Rights Day on 10 December focuses, in the Namibian context, on the violent oppression in 1959 when police opened fire on those demonstrating against the planned forceful removal of black urban residents from the 'old location' in Windhoek to the new 'township' of Katutura, killing eleven people. ${ }^{37}$

These national public holidays tend to be monopolized by SWAPO as the party in control of government. Their one-sided celebrations, including the display of party emblems by the head of state during official ceremonies,

\footnotetext{
${ }^{35}$ H. Schmidt, 'Neither War Nor Peace: Making Sense of Violence', in G. Elwert, S. Feuchtwang \& D. Neubert (eds), Dynamics of Violence (Berlin, 1999), 219.

${ }^{36}$ It is also revealing that the Namibia Defence Force (NDF) runs a holding company with the registered name 'August 26'. It owns a diamond mine in the Democratic Republic of Congo, with an NDF general as the company's managing director.

${ }^{37}$ This incident marked a turning point in the history of the Namibian liberation struggle in as far as it contributed to the formation of SWAPO in early 1960 and the subsequent decision to ultimately resort to an armed struggle against colonial repression. See for documentary evidence, D. Ridgway, M. Jafta, N. Kautja, M. Oliphant \& K. Shipingana, An Investigation of the Shooting at the Old Location on 10 December 1959 (Windhoek, 1991) and an eyewitness account, J. Ya-Otto, Battlefront Namibia (London, 1982) in the chapter entitled 'The Windhoek Massacre', 34-54.
} 

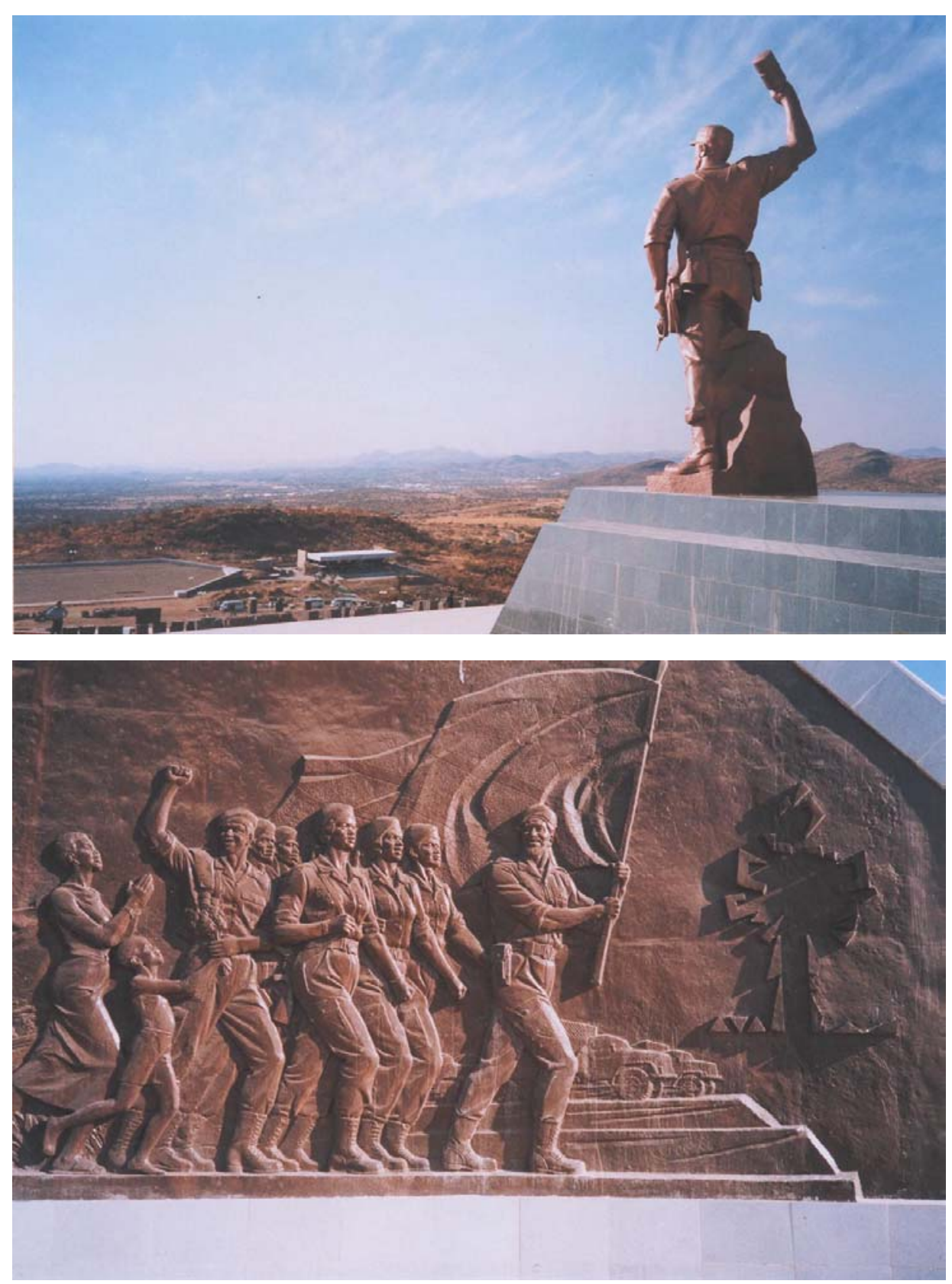

Heroes' Acre (and detail of relief) on the outskirts of Windhoek, July 2002, just prior to its official opening Photos by Henning Melber 
motivated a political opponent to articulate public criticism in parliament. ${ }^{38}$ In addition to these national public holidays, particular group memories contribute to aspects of regional-ethnic identity in a historical perspective. In Okahandja, the Herero commemorate their war against the Germans at the end of August. ${ }^{39}$ So do the Witbooi Nama in Gibeon each year in October. ${ }^{40}$ Kaptein Hendrik Witbooi, the leader they pay most prominent tribute to by re-enacting the war against the Germans, has been reproduced on the different Namibian dollar notes introduced as the country's own currency in the early 1990s. ${ }^{41}$

A monument outside the capital Windhoek complements the war memorial constructed in Omgulumbashe according to the declared aims of the political leadership in SWAPO. Plans for a Heroes' Acre have been implemented with the assistance of North Korea. ${ }^{42}$ The state's annual budget for 2001/2002 financed the construction work at a site in the direct vicinity of the military base of Luiperds Valley. Commentary in the local daily German newspaper characterized this project as a gigantic symbol of a late-nationalist triumph. ${ }^{43}$ North Korean architects are also designing an Independence Museum to be built next to the Alte Feste (the colonial fort erected by the German Schutztruppe) and in close vicinity to both the Tintenpalast (the previous administrative

\footnotetext{
${ }^{38} \mathrm{~A}$ former SWAPO activist in exile (during the first five years of independence the Permanent Secretary in the Ministry of Trade and Industry) and since 2000 an elected parliamentary representative of the opposition Congress of Democrats tabled a motion in early April 2002. He blamed SWAPO, in the light of the recent Independence Day ceremonies, for using national commemorative events and public holidays for party propaganda and thereby acting against the spirit of national reconciliation. See M. Springer, 'Feier Missbraucht', Allgemeine Zeitung (Windhoek), 9 April 2002.

${ }^{39}$ See the chapter in this volume by Jan-Bart Gewald for a comprehensive analysis of the historical events and their psychological and political implications for Namibian politics.

${ }^{40}$ See R. Kössler, 'Tradition als Politische Strategie. Vom Witbooi-Fest zum Heroes Day in Gibeon, Namibia', in A. Eckert \& J. Müller (eds), Transformationen der Europäischen Expansion vom 16. bis 20. Jahrhundert (Rehberg-Loccum, 1997), 62-74; R. Kössler, 'Rebuilding Societies from Below: Reflections on Heroes Day, Gibeon, October 1995', in R. Kössler, H. Melber \& P. Strand, Development From Below: A Namibian Case Study (Uppsala, 2002).

${ }^{41}$ The subject is further touched upon in Jan-Bart Gewald's chapter in this volume with reference to the monuments of three Namibian patriots from different regions and population groups unveiled in Windhoek in 2001, after the statue of Hosea Kutako had to remain covered under a layer of black plastic for several years.

${ }^{42}$ See on the symbolic relevance of such a memorial site under Mugabe's ZANU-PF in neighbouring Zimbabwe (also erected with North Korean involvement), N.J. Kriger, 'The Politics of Creating National Heroes: The Search for Political Legitimacy and National Identity', in Bhebe \& Ranger, Soldiers in Zimbabwe's Liberation War.

${ }^{43}$ E. Hofmann, 'Selbsterkenntnis', Allgemeine Zeitung (Windhoek), 6 February 2002.
} 
'Namibia, land of the brave' 321

offices of the German colonial authority, now the National Assembly) and the Christuskirche. The old colonial monument of the German equestrian Schutztruppenreiter, which has looked down from the hillside onto the centre of town for about 90 years, is to be moved, due to construction work, to a less prominent site a few hundred metres away. ${ }^{44}$

Sam Nujoma, as the political father figure of Namibian independence, personifies in a marked and pronounced way the cultivation of the memories of the liberation war beyond such changes in infrastructure. Testimony to this is not only to be found in his autobiography, which ends with independence and words from one of his earlier speeches during the days of the struggle:

When the history of a free and independent Namibia is written one day, SWAPO will go down as having stood firm where others have wavered: that it sacrificed for the sacred cause of liberation where others have compromised. ${ }^{45}$

The president's vivid memory of combat motivated him in May 2001 to a physical re-enactment of a war scene in front of a television camera when he was visited on his farm by a South African Broadcasting Corporation (SABC) team. The scenes, in which he throws himself to the ground and imitates shooting, are in stark contrast to the expectations of how an elder statesman ought to behave in public. To the embarrassment of State House, the pictures were included in a less than favourable profile of Namibia's head of state broadcast in neighbouring South Africa in a popular documentary series. Following official protests by the Namibian government on biased reporting, the film crew had to offer an apology.

The tendency towards glorification of the history of warfare for liberation (which by implication is for a just cause and hence tends to embrace affirmatively the dubious notion of a 'just war') is an obvious symptom in Namibian society today. It plays a relevant role in the current symbolism and rituals of the post-colonial political culture. (After all, the pictures in the controversial film documentary did indeed show the president.) It also allowed for a rather problematic treatment of the far-reaching decision to become militarily involved in ongoing conflicts beyond Namibia's borders (in the sense of showing little visible concern for the consequences). In August 1998 troops were sent to the Democratic Republic of Congo (DRC) where they came to the

\footnotetext{
${ }^{44}$ Ironically, some of the newly built manifestations of independence (including the Constitutional Court constructed in the mid-1990s close to the site of the future Independence Museum) bear some obvious resemblance to the Nazi architecture of Albert Speer.

${ }^{45}$ This quote is taken from the brochure SWAPO Information on SWAPO: An Historical Profile (Lusaka, 1978).
} 
rescue of President Kabila. Since the end of 1999, Namibia has also been directly involved in the ongoing war in neighbouring Angola, where the Namibian army has been involved in fights with UNITA guerrillas. In neither case was parliament or the cabinet consulted, and decisions were taken solely by the head of state who is also in command of the army and entitled to act in the national interest. ${ }^{46}$ In a parliamentary debate on the additional budget in November 1998, Namibia's foreign minister declared categorically that the debate over Namibia's intervention in the DRC had come to an end and labelled any further criticism as 'un-African'. The first soldiers officially returning from the Congo in June 2001 were honoured with a heroes' reception. ${ }^{47}$ In his New Year's Message for 2002, President Nujoma deemed this military involvement a remarkable event:

I can state with pride that the gallant soldiers of the Namibian Defence Force (NDF) and other SADC Allied Forces showed great courage and bravery ... Our soldiers completed this task with honour and returned home in triumph... ${ }^{48}$

\section{'One Namibia, one nation'?}

More than a decade after independence, many of the high-ranking political office bearers still have a track record as comrades dating back to SWAPO's formative years during the 1960s and 1970s. The situational application of militant rhetoric as a tool for inclusion or exclusion in terms of the post-colonial national identity is common practice. It demonstrates that the declared notions of national reconciliation and the slogan of 'unity in diversity' do not always receive the desired acknowledgement in terms of political pluralism and tolerance. Namibian identity is instead defined increasingly by those in power along narrow lines of definition and (self-)understanding. What has been suggested with reference to the understanding of post-independent power

\footnotetext{
${ }^{46}$ While he was chairing the United Nations General Assembly sessions in New York, his deputy minister, in an acting capacity, accused the print media in Namibia critical of Namibia's involvement in the Angolan conflict in January 2000 of being a 'fifth column' of UNITA and of damaging the country's reputation.

${ }^{47}$ See the eyewitness report by R. Kössler, 'Szenen einer Heimkehr. Siegesfeier auf der Independence Avenue in Windhoek', afrika süd, 4 (2001).

48 'Let's Look Back at the Great Events'. President's New Year Message, Die Republikein (Windhoek), 2 January 2002. Shortly afterwards, when a volcano erupted in the Congolese border area of Goma during late January 2002, the president publicly expressed his regrets that this human tragedy had taken place on enemy territory (implying that Namibia would not be able to offer any kind of humanitarian aid to the victims).
} 
relations in neighbouring Zimbabwe has much relevance for the Namibian case too:

...whilst power relations had changed, perceptions of power had not changed. The layers of understanding regarding power relations, framed by socialisation and memory, continued to operate. ... actors had changed, however, the way in which the new actors executed power in relation to opposition had not, as their mental framework remained in the colonial setting. Patterns from colonial rule of 'citizens' ruling the 'subjects' repeated and reproduced. ${ }^{49}$

This is reflected in a dichotomy of polarized perceptions along the 'we-they' divide. If you are not with SWAPO, you are considered to be an enemy. Given the blurred boundaries between party, government and state under a factual oneparty system (with SWAPO having an overwhelming majority of votes allowing it to rule as it pleases) and the growing equation of the party being the government and the government being the state, any opposition or dissent is considered to be hostile and the person involved is branded an enemy of the people and the national interest.

The so-called ex-detainee issue is a classic case in point. This is a group of former SWAPO members who were detained in exile following various internal disagreements that led to mass repression. From the early 1980s onward, hundreds if not thousands were kept in dungeons in southern Angolan camps where they were tortured and executed as suspected South African spies. ${ }^{50}$ Many did not survive. Most of the others were traumatized for the rest of their lives. Following their return to independent Namibia, they have not been rehabilitated, despite numerous efforts. Nor was SWAPO prepared to be held accountable on this issue of violating human rights in its own ranks during the struggle. Instead, the 'ex-detainees' continued to live under the stigma of being considered by many as traitors and collaborators with the Apartheid regime and directly or indirectly held responsible for the deaths of numerous Namibian refugees, combatants and political activists both at home and in exile. Their plight was brought to renewed public attention by the personal account of an external witness with moral credibility. ${ }^{51}$ It provoked a considerable reaction

\footnotetext{
${ }^{49}$ K.P. Yap, 'Uprooting the Weeds: Power, Ethnicity and Violence in the Matabeleland Conflict, 1980-1987', PhD thesis, University of Amsterdam (2000), 312-13 (original emphasis).

${ }^{50}$ See for a concise summary of the issue and its implications, G. Lamb, 'Putting Belligerents in Context: The Cases of Namibia and Angola', in S. Chesterman (ed.), Civilians in War (Boulder \& London, 2001). For more details, see Leys \& Saul, Namibia's Liberation Struggle.

${ }^{51}$ S. Groth, Namibia - The Wall of Silence (Wuppertal, 1995). For detailed accounts on the subsequent controversies, see L. Dobell, 'Silence in Context: Truth and/or
} 
from SWAPO. Advocates of attempts to seek reconciliation through open discussion were accused of acting against the national interest. A senior political activist and member of parliament in a public address at a rally in Northern Namibia (Ovamboland) encouraged the audience to burn the incriminating book that had raised the issue anew. The party released a public statement that it

cannot allow this country to be made ungovernable and be turned into a chaotic and lawless society by irresponsible, unpatriotic elements and foreign remainents (sic!) of fascism and apartheid. ${ }^{52}$

Such an attitude displays striking similarities to the failure in neighbouring Zimbabwe to come to terms with the atrocities committed during the mid-1980s by the special units using violence against the civilian population on behalf of the central state authority by ZANU-PF in Matabeleland:

The metaphor of 'opening old wounds' was a powerful one, invoked by former Zapu and ZANU-PF politicians as well as by ordinary citizens and human rights groups. The 'wounds' stood as markers of a history of violence, inscribed on both individuals and the body politic; 'opening' them meant public probing. Whether they had ever healed, and hence stood to be 'opened', whether 'opening' them constituted a destructive or a healing act, were subjects of contention which begged a range of questions regarding the proper commemoration of the dead and appropriate ways in which history might be invoked in the present without 'tearing the nation apart'. ${ }^{53}$

As a result of the new taboos, those reminding the new rulers of an 'unfinished business' of such a nature are the targets of personalized defamation campaigns with the aim to discredit the individuals, normally on the basis of accusations that they betrayed the struggle. One of the previous SWAPO members, who during the exile years was originally trained in the Soviet Union but then left the organization in 1980, has established a National Society for Human Rights (NSHR) in independent Namibia. It is accredited in an advisory status with the United Nations and cooperates with both Amnesty International and the United Nations High Commissioner for Refugees (UNHCR). The

Reconciliation in Namibia', Journal of Southern African Studies, 23 (1997) and C. Lombard, 'The Detainee Issue: An Unresolved Test Case for SWAPO, the Churches and Civil Society', in I. Diener \& O. Graefe (eds), Contemporary Namibia. The First Landmarks of a Post-Apartheid Society (Windhoek, 2001).

${ }^{52}$ Media Statement by SWAPO Party on the so-called Detainee Issue, 12 March 1996, 1.

${ }^{53}$ Alexander, McGregor \& Ranger, Violence and Memory, 259. 
'Namibia, land of the brave' 325

NSHR is a highly critical human rights watchdog and at times very negative (if not prejudiced) concerning government policy. It regularly raises publicly issues concerning individual cases of violence exercised by the army and police. The Namibian army's quarterly NDF Journal in its issue at the end of 2001 accused the NSHR director of having deserted the liberation struggle, disseminating lies and propaganda. ${ }^{54}$

Other political opponents of SWAPO are similarly stigmatized. A previous guerrilla fighter, who after being captured spent several years on Robben Island, became a militant trade-union leader after his release. He was then appointed deputy minister and later ambassador to the United Kingdom before he articulated open dissent with the policy of the SWAPO leadership and resigned from his prestigious diplomatic post. After his subsequent suspension from the Central Committee, of which he was a member, he left the party and founded a new political opposition party campaigning for the parliamentary and presidential elections at the end of 1999. SWAPO responded with an orchestrated smear campaign, denouncing him personally as a former South African agent who had sacrificed the lives of his comrades in arms. ${ }^{55}$ Other personalized attacks similar to the two examples just presented, aiming to discredit the individuals, disclose patterns of a war mentality that still guides opinion leaders in the former liberation movement.

While the constitutionally enshrined civic rights and political liberties that exist in Namibia are formally defined and coded essentials of a plural democracy, the dominant political culture does not support a vibrant civil society. Instead it divides the people along narrowly defined yardsticks of loyalty. A professor of public law involved in the process of drafting the Namibian constitution has hence described the hostility and intolerance displayed towards civil society actors as a worrying sign:

Lawyers assisting the inhabitants of Kaokoland in 1999 with respect to Government plans for a dam in the Kunene River (which would have flooded ancestral land) were severely criticised and their involvement equated with undermining Namibia's ideals. The same fate met academics writing critically about the elections of 1999 . Such reaction may be indicative of personal intolerance; it unfortunately also reflects negatively on the political culture and lack of tolerance in society and the State apparatus. ${ }^{56}$

\footnotetext{
${ }^{54}$ See the articles in Allgemeine Zeitung (Windhoek) of 24 and 25 January 2002.

${ }_{55}$ While SWAPO maintained that it was in possession of evidence to prove this accusation, it never explained why it had co-opted him into the upper echelons of the party and government structure after independence until his own articulation of dissent.

${ }^{56}$ G. Erasmus, 'The Constitution: Its Impact on Namibian Statehood and Politics', in Keulder, State, Society and Democracy, 99.
} 
How issues can escalate under growing intolerance towards deviations from the increasingly narrow-minded national norm became obvious in August 1999. A secessionist Caprivi Liberation Movement (CLM), aiming at autonomy from Namibia, launched an unsuccessful attack in the isolated and marginalized northeastern part of the country, the Caprivi Strip. ${ }^{57}$ This could be seen as an unrealistic response to failed integration in nation-building processes based more on the exclusion than inclusion of minorities. The desperate military attack culminated in the subsequent proclamation of a state of emergency for the first time in the history of the Republic of Namibia. The serious loss of any sense of reality on the side of the secessionists met its match in an over-reaction by the state and its security organs (the army and police) ${ }^{58} \mathrm{~A}$ background article concluded that, in retrospect, the attack in the Caprivi led to a new stage of national chauvinism, guided by the primacy of the military. ${ }^{59}$

On the basis of its quasi-monopoly of political power, SWAPO displays an exclusionist tendency, which defines nation building in terms of marginalizing 'the others' as enemies. Namibia remains - despite the liberation movement's earlier claims of fighting for 'one Namibia, one nation' to establish a postcolonial society characterized by 'unity in diversity' - a deeply divided society. Similar to what has been diagnosed with regard to neighbouring Zimbabwe, 'the postcolonial state has sponsored a whole complex of elite memorialism, ${ }^{60}$ but by doing so at the same time has buried other relevant memories:

...the state has itself become the agent of nostalgia, for the sake of nation-building; heritage is state cultural policy, often in an anti-colonial appeal inventing tradition for an authentic past; (...)

${ }^{57}$ See for background information to the event, H. Melber, 'Grenzen einer Nation: Koloniale Territorien und Staatsentwicklung - das Beispiel Namibia', in Geopolitik. Zur Ideologiekritik politischer Raumkonzepte (Wien, 2001).

${ }^{58}$ Amnesty International reacted to the physical violence exercised by the state actors against the accused secessionists and the civilian population by articulating official concern over the violation of human rights. Local NGOs such as the Legal Assistance Centre and the National Society for Human Rights expressed public criticism on several occasions about the heavy-handed treatment of both civilians and arrested suspects. At the time of writing, more than a hundred prisoners accused of high treason had already been under arrest without trial for almost two and a half years, during which time several had died.

${ }^{59}$ G. Hopwood, 'Caprivi - A Year After', The Namibian (Windhoek), 2 August 2000. See also the account published by the Human Rights Committee of South Africa, Namibia in Focus (Johannesburg, 1999), 22-28.

${ }^{60}$ Werbner, 'Beyond Oblivion', 8. 
'Namibia, land of the brave' 327

Despite the weighty monumentalism or the substantial flow of material and immaterial tribute from the redistributive state to its honoured citizens, the commemoration of the nation is remarkably fragile. (...) Tensions emerge in a variety of ways, sometimes explosively subverting the carefully scripted course of state pomp and ceremony. The state theatrics, so full of impassioned appeals to higher moral bonds in the 'undying struggle for national freedom', are risky. ...the controversies over remembered identity and postwar trauma heighten as the postcolony itself transforms from an early period of triumphalism to a current one of widespread disaffection, subverting the regime's mandate and legitimacy. ${ }^{61}$

Namibia has not yet copied the two decades of post-colonial experiences of Zimbabwe as summarized in this diagnosis, but the writing is on the wall. ${ }^{62}$

In mid-December 2001, President Sam Nujoma attended a street re-naming ceremony as the guest of honour in the coastal town of Swakopmund. This town with its particular German flavour had its main street named after Kaiser Wilhelm - an anachronism today. Some of the German-speaking business community rendered an unfortunate disservice to the meaning of reconciliation when they strongly objected to the overdue abandoning of such a colonial relict. In reaction to their protest, the president explained in his speech that the population of Namibia in an independent Namibia has to honour its currently recognized heroes - and he unveiled the new street name: Sam Nujoma Avenue.

${ }^{61}$ Ibid. $1 \& 8$.

${ }^{62}$ Evidence of this is also the embarrassing degree of uncritical solidarity with the Mugabe regime under ZANU-PF on the occasion of the presidential elections in Zimbabwe. For a summary of the SWAPO (and in fact Namibian government) position see H. Melber, 'Zimbabwe and "The Pitfalls of National Consciousness"', in H. Melber (ed.), Zimbabwe and Beyond (Uppsala, 2002). 


\title{
Dervishes, moryaan and freedom fighters: Cycles of rebellion and the fragmentation of Somali society, 1900-2000
}

\author{
Jon Abbink
}

\begin{abstract}
There has been a state of near-permanent revolt in Somali society since 1991. This chapter offers a cultural analysis of patterns of political and military activity from the precolonial era through the Italian and British colonial period, state independence (1960-1991), to the present period of statelessness. The focus is on a comparison of elements in the campaigns of revolt against the colonial states between 1900 and 1920 with those in the late Siyad Barre period (1988-1991) and the era of statelessness (1991 onwards). A transformation of ideas of revolt and violent action has occurred in which Somali notions of egalitarian social order, kinship and local leadership have taken on a different shape. This prevented the institutionalization of crosscutting alliances and the emergence of a wider political arena - except in certain regions such as Somaliland and Puntland. The cultural and social unity of Somali society has always been overestimated. Somali political culture is by nature centrifugal, preventing the institutionalization of a legitimate leadership at state level but not at a regional clan level.
\end{abstract}

\section{Introduction}

The Somali remain an enigma. Fiercely attached to their independence and rebellious towards any perceived or real outside interference in their country, their society appears deeply divided and chronically unstable, as exemplified 
by the absence of a central state since 1991. Certainly, the decentralized and centrifugal Somali political culture, marked by localized if not fragmented authority structures, is one explanation. Their culture is rooted in a strong segmentary lineage and clan organization based on a predominantly pastoral way of life and guided by a remarkable genealogical self-consciousness ${ }^{1}$ that has persisted through time. The phenomenon of group division based on instrumentalized clan identities, while not explaining everything, goes a long way in accounting for the perpetual tensions in Somali socio-political organization, as the Somali themselves are the first to admit. ${ }^{2}$

At the same time, the diversity of patterns of economic adaptation and socio-cultural difference within Somali society should not be underestimated. ${ }^{3}$ Although more than $60 \%$ of Somalis are transhumant pastoralists, there is more sedentary settlement, hierarchy and class formation in the southern part of the country, while an urban trader/hustler class is increasing in size as well. In the riverine Digil-Rahanweyn area there is also more clan flexibility in that people have changed their clan affiliation, and many newcomers or migrants have been included in the clan system. In coastal cities there is a distinct sub-culture of traders and urban people of mixed origins. In addition, there are 'despised', low-status caste groups and other small minorities who have always been on the lower rungs of the social ladder and have been disproportionately hit by successive armed conflicts. In recent years, the non-urban and non-pastoral Somali, like the sedentary agricultural Digil-Rahanweyn peoples of the area between the Juba and Shebelle (see Map), the Bantu-speaking (or Jareer) groups, ${ }^{4}$ the Wa-Gosha and the occupational caste minorities (for example,

\footnotetext{
${ }^{1}$ The great value attached to personal genealogical reckoning (abtirsiinyo) is proverbial in Somali culture. See for instance, I.M. Lewis, Blood and Bone. The Call of Kinship in Somali Society (Lawrenceville NJ, 1998), 19, 82, and I.M. Lewis, 'Doing Violence to Ethnography: A Response to Catherine Besteman's "Representing Violence and 'Othering' Somalia"', Cultural Anthropology, 13 (1998), 101. See also G. Prunier, 'Segmentarité et Violence dans l'Espace Somali, 1840-1992', Cahiers d'Etudes Africaines, 146 (1997), 381.

${ }^{2}$ Said S. Samatar, 'Somalia: The Politics of Poetry', Africa Report, 38 (1993) (Online version: www.anaserve.com/ mbali/samatars.htm); see also G. Hanley, Warriors and Strangers (London, 1971), passim.

${ }^{3}$ Cf. L.V. Cassanelli, The Shaping of Somali Society: Reconstructing the History of a Pastoral People, 1600-1900 (Philadelphia, 1982); V. Luling, 'The Other Somali Minority Groups in Traditional Somali Society', in T. Labahn (ed.), Proceedings of the Second International Congress of Somali Studies, University of Hamburg, August 1-6 1983, vol. IV (Hamburg, 1984), 39-55. For a map of the Somali clan families, see www.lib.utexas.edu/maps/africa/somalia_ethnic92.jpg.

${ }^{4}$ F. Declich, "Gendered Narratives", History and Identity: Two Centuries along the Juba River among the Zigula and Shanbara', History in Africa, 22 (1995), 93-122. See
} 
Midgan, Yibir, Tumaal), were involved in the civil war predominantly as victims and less as perpetrators. ${ }^{5}$

Civil war and disunity (1991-2001) have exacted a heavy toll among the Somali population in general. After the failed war against Ethiopia in 1977-78, ${ }^{6}$ Somalia, under an increasingly brutal dictatorship, crept towards oppressive clan-based rule, ${ }^{7}$ disunity and armed strife, with the northern regions becoming the prime victim. This led to the death of tens of thousands of people, well over half a million refugees and displaced persons, a dramatic increase in clan-based conflict, malnutrition and famine, and economic and environmental crisis. ${ }^{8}$ As a result, the political structure of a united Somalia unravelled in the 1980s during the regime of President Mohammed Siyad Barre and evaporated after the demise of his regime in January 1991. Since then, the country has remained vulnerable to famine, natural disaster and predation by warlords. Civil strife again resulted in vast numbers of human casualties. ${ }^{9}$

also M. Mohamed-Abdi, 'Les Bouleversements Induits de la Guerre Civile en Somalie: Castes Marginales et Minorités', Autrepart (Cahiers des Sciences Humaines N.S.), 15 (2000), 131-48. In the pre-colonial era, many Bantu-speaking people were brought to Somalia as slaves.

${ }^{5}$ See A. Haji Mukhtar, 'The Plight of the Agro-Pastoral Society of Somalia', Review of African Political Economy, 23 (1996), 543-53; L.V Cassanelli, 'Victims and Vulnerable Groups in Southern Somalia', Research Directorate, Immigration and Refugee Board Canada Occasional Paper (Ottawa, 1995); Mohamed-Abdi, 'Les Bouleversements', 132.

${ }^{6}$ See Gebru Tareke, 'The Ethiopia-Somalia War of 1977 Revisited', International Journal of African Historical Studies, 33 (2001), 635-67.

${ }^{7}$ By Marehan-Ogaden-Darod clan elites.

${ }^{8}$ See Hussein M. Adam, 'Somali Civil Wars', in T.M. Ali \& R.O. Matthews (eds), Civil Wars in Africa. Roots and Resolution (Montreal, 1999), 180-81; I.M. Lewis, 'UN Paperclips for Somalia', Horseed, online newspaper [www.horseed.com/jan/03/24/htm], 3; IRIN news message of 13 June 2002 on the massive destruction of remaining Somali forests for charcoal for export to Saudi Arabia and the Gulf States. See also: www.padrigu.gu.se/EDCNews/Research/SomaliaCharcoal.html

${ }^{9}$ For a good chronology of developments in Somalia over the past 41 years, see M.A. Pérouse de Montclos, Interprétations d'un Conflit: Le Cas de la Somali (Pessac, 2001), 7-18. What is remarkable in this chronology is the high incidence of violent events and episodes. For a report on the devastation before 1991, see also www.somaliawatch.org/archivefeb01/010202301.htm 


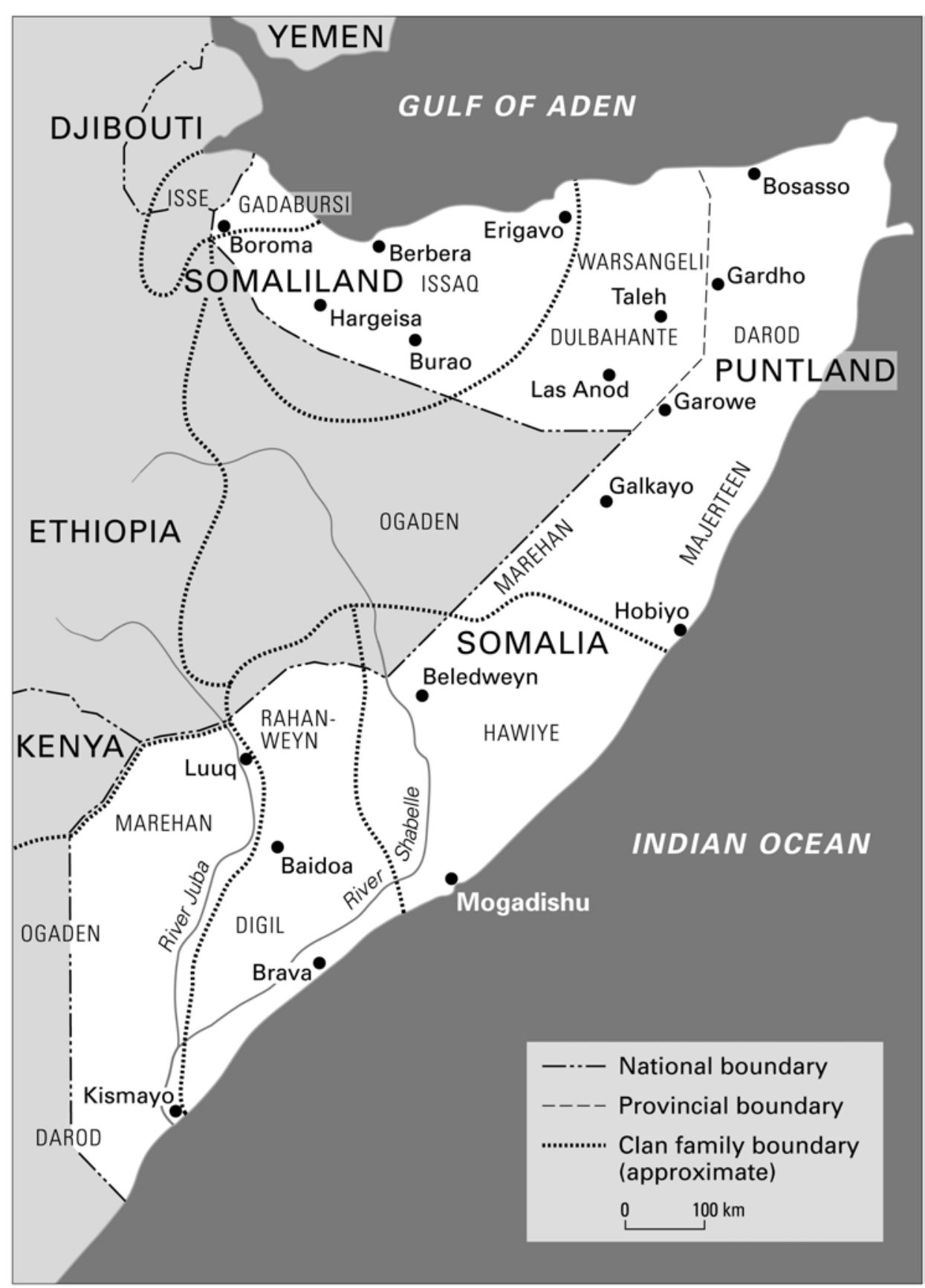

Map 13.1 Somali clan family distribution 


\section{Somali culture and politics}

There is by now a rather familiar account of the causes of the civil war and the havoc it has wreaked in post-1991 Somalia. ${ }^{10}$ Political analyses of the Somali drama tend to yield similar stories, referring to socio-political decline and internal division in the absence of a developed state tradition. Analysts only differ in the relative weight accorded either to certain political and historical factors or to the role of 'clan identities' used as a basis for political action or abused for personal or factional gain, igniting conflict. These points were reiterated, respectively, by those termed the 'traditionalist' and the 'transformationalist' scholars of Somali affairs. ${ }^{11}$ Those who aim to transcend these two polarized positions ${ }^{12}$ usually end up with a modified version of the second position, stressing elite private abuse.

In my view, the core of the enigma of Somalia's violent decline is not only explained by an appeal to greedy elite competition or class conflict at the level of state elites. This would not account for why competing factions and fighting groups have assumed such notable clan identities and also judge their opponents in the same way. In addition, the elite is divided and shows a highly shifting basis for the recruitment of supporters and private pursuits. The fact that Somali socio-political organization has lent itself to such monumental abuse and has actively worked against the emergence of any accepted central state authority or durable territorial or other alliances is telling of the peculiarities of and continuities in Somali society, and sets it apart from other societies.

\footnotetext{
${ }^{10}$ See for instance, Adam, 'Somali Civil Wars'; 'Pérouse de Montclos, Interprétations, 19; Prunier, 'Segmentarité et Violence'; M. Jama, 'Trajectoire du Pouvoir en Pays Somali', Cahiers d'Etudes Africaines 146 (1997), 403-27; Th. Vircoulon, 'La Crise Somalienne', Afrique Contemporaine, 177 (1995), 3-16.

${ }^{11}$ See Abdi I. Samatar, 'Destruction of State and Society in Somalia: Beyond the Tribal Convention', Journal of Modern African Studies, 30 (1992), 625-41. 'Traditionalists' are those seen to be putting (too much) emphasis on clan identities and lineage segmentation as the persistent (and explanatory) basis of Somali politics, while the 'transformationalists' stress social inequality, personal abuse of resources, and exploitative elite or class rule as the motor of divisive politics and conflict. The 'traditionalists' reject the epithet given to them by their opponents.

${ }^{12}$ For instance, M. Jama, 'Sur la Violence en Somali: Genèse et Dynamique des Formations Armées', Politique Africaine, 47 (1992), 147-51; C. Besteman, 'Representing Violence and "Othering" Somalia', Cultural Anthropology, 11 (1996), 120-33. See also the recent PhD thesis by A. Mohamoud, 'State Collapse and PostConflict Developments in Africa: The Case of Somalia (1960-2001)', University of Amsterdam (2002).
} 
In this chapter, I do not repeat the conventional explanations of political crisis but instead reconsider the impact of some historical and cultural factors on Somali political and military rebellion and revolt across time. The ideas and practices of (armed) rebellion seem to have dominated Somali society in the past century, and specifically in the past fifteen years, but the ultimate aims and benefits appear to have been lost along the way. In this respect, cultural premises and the manner in which they were made to interact with the political dynamics of Somalia (as determined by both internal and external factors) need renewed attention. Cultural and social structural elements are simply part of the longue durée structure of Somali history. Such a cultural analysis is, however, hampered by the comparative lack of empirical field research done in Somalia in the past decade, and this chapter can only be a modest attempt towards an understanding of the topic.

While conflicts and violence were common features of life in pre-colonial Somali society, ${ }^{13}$ the emergence of collective revolt can be located in the era of foreign colonization by the Italians and the British since the late 1890s. The response to this external domination was marked by violent ideological and armed rebellion. In the era of state independence (1960-1991) and right through the period of statelessness (1991-present) such a violent response surfaced again with renewed and much more destructive force. But it might be said that the Somalis were not only in revolt against the above-mentioned external forces but also against themselves, as is evident from persistent patterns of kin-group feuding, regional antagonism or rebellion against indigenous elite groups forming in the urban centres and through trade networks. Most dramatic perhaps were the revolts against the independent state that had become deeply suppressive and violent especially in the last decade (1980-1991) of Siyad Barre's rule.

More historically and culturally informed explanations for the centrifugal forces that have prevented the Somali nation from successfully organizing its own state structure ${ }^{14}$ remain necessary. Indeed, the Somali experience provides the most convincing argument to date that an 'ethnic group' (and one with illdefined boundaries at that) ${ }^{15}$ is not the best or even a necessary unit for the construction of a 'national state'. In particular, one could ask what the

\footnotetext{
${ }^{13}$ Cassanelli, The Shaping of Somali Society; I.M. Lewis, A Modern History of Somalia. Nation and State in the Horn of Africa (Boulder \& London, 1988); G. Prunier, 'Segmentarité et Violence'.

${ }^{14}$ Cf. D. Laitin \& Said S. Samatar, Somalia: Nation in Search of a State (Boulder Co., 1988); G. Schlee, 'Régularités dans le Chaos: Traits Récurrents dans l'Organisation Politico-Religieuse en Militaire des Somalis', L'Homme, 161 (2002), 17-50.

${ }^{15}$ Schlee, 'Régularités', 18.
} 
mitigating or reinforcing role of Somali Islam and cultural precepts related to customary law (or heer) have been in the articulation and perpetuation of conflict in Somalia. A theoretical approach to structure and agency would emphasize that cultural organizing principles do not disappear under the force of political conjunctures but are brought to play a role in the power game. ${ }^{16}$

While attention will be paid to the intervening decades, two historical episodes stand central in this chapter: the upheaval and resistance led by a notable religiously inspired leader, Mohammed 'Abdulle Hassan ${ }^{17}$ (from 1899 to 1920 , see below), and the period of 'clan-faction' violence ${ }^{18}$ between 1991 and 2001. I consider these two periods not to assert that they are similar in their way of revolt but to illustrate the continuity and change in the character of armed conflict and resistance in Somali society. In addition, I sketch the transformative impact of new forms of violent revolt on local society.

Briefly, the dominant image in the literature is that of a 'Somali identity' in the political sense. The first period was a formative, nationalist one while the second was fragmenting. One of my theses in this chapter is that the mythical image of Mohammed 'Abdulle Hassan and his Dervish movement as 'nationalist' obscures the nature of Somali political identity. Although he initially appealed to all Somalis in the name of a religious identity, to speak of his rebel movement as advancing a nationalist cause is somewhat anachronistic. The parallels between then and now are remarkable because of the effect of its violent tactics on Somali society.

Somali politics has retained an undercurrent of cyclical conflict based on certain principles of kinship, ideology and (perceived) material group interests, and in this sense one could say that politics is 'absorbed' or reproduced by Somali culture. Somali cultural values, ideas of personhood and identity, achievement and self-image have changed much less over the past century than the vagaries of political crisis and conflict would suggest. In this sense, the dramatic demise of the Somali state in 1991 was not a sudden and unexpected

\footnotetext{
${ }^{16}$ For instance, it could be said that the failure (except in its humanitarian work) of the US-led 'Operation Restore Hope' in the early 1990s was based on a well-intentioned but monumental ignorance of the cultural substratum of Somali society and politics. 'Black Hawk Down', the recent film based on the 1993 armed confrontation in Mogadishu, does not suggest that the Americans have learnt much since. See for a review, http://www.alternet.org/story.html?StoryID=12175

${ }^{17}$ Here I follow Abdi Sheik-Abdi, in his excellent book Divine Madness. Mohammed Abdulle Hassan (1856-1920) (London, 1993), 44, by rendering his name in the Somali not the Arabic spelling (which would be Muhammad ibn 'Abdullah Hassan).

${ }^{18}$ I use 'clan-faction' instead of the widely popular but somewhat misleading term 'warlord' violence.
} 
event but the result of a longer, incremental process of decline of a political structure that could never do what it was expected to do.

I do not wish to succumb to any primordialist view of the force of clanship and segmentary identities as the basis of all politics, let alone as the explanation for recurring factional fighting and social chaos: there is no direct link between the existence of clan identities and their violent and divisive instrumentalization. But certainly it is a fact that the idiom of kin- and clanship, genealogy and segmentation forms the structural basis of competition and political strife, aided by a territorial dimension of clans and clan families being concentrated in certain areas. As such, this idiom is an excellent vessel for manipulation by elite groups or classes that emerged in the colonial and postcolonial era, allowing for meaningful collectives to be formed as well as for flexible alliances. ${ }^{19}$ This is mainly because kin- and clanship and segmentation (i.e. situational positioning vis-à-vis others) provide the basic identity that people fall back upon and recognize as defining themselves. This is also true in modern conditions. No one with first-hand knowledge of Somalis and Somali society will underestimate this fact. In Hussein Adam's view, ${ }^{20}$ Somali political culture is pervaded not only by ideas of kinship and segmentation but also by an ethos of equality, pride and prestige between groups at any level of segmentation, jealously guarding public status vis-à-vis each other. The important point is that people want recognition and reciprocity, even if they are not prepared to give it to others. They also make claims to social justice. Following Hussein Adam, one could say that this characteristic attitude is politically relevant in Somali life, in that clan consciousness is mobilized in the struggle for prestige and justice.

Thus, a political-economic view must be developed in dynamic linkage with a culturalist view to explain continuities and change in patterns of group identity and political agency that have shaped rebellion in Somalia. An understanding of what motivates the Somali people in socio-cultural terms would help in devising international assistance programmes and sounder political cooperation with Somalia.

\footnotetext{
${ }^{19}$ This is because most Somali clans allow for filiation on a non-descent basis and have clientship or 'adoption' (sheegad) of people from other clans.

${ }^{20}$ Hussein M. Adam, 'Militarism and Warlordism: Rethinking the Somali Political Experience', African Studies Center, Boston University Working Paper no. 49 (Boston, 1993).
} 


\section{Pre-colonial Somalis}

Revolt and resistance seem perennial themes in Somali history and are often tied to the segmentary nature of Somali society, dominated by patrilineal kinship links (tol waa tolaane - 'agnates are connected') as well as reconstructed lineage and clan identifications ${ }^{21}$ of individuals and groups. While the system has a patrilineal bias, the uterine links in the paternal line as well as the links though the mother's clan or lineage are also of vital importance.

Somalis traditionally neither knew a state authority nor recognized the primary binding force of an external power beyond the (sub-) clan. The clan/lineage and its nominal authority structure, based on elders and certain chiefs (boqor, ugaaz, garad) ${ }^{22}$ and buttressed by religious leaders (wadaaddo, ma'allimiin) and the structure of the Sufi orders (turuuq), ${ }^{23}$ formed the bedrock of society. Due to the nature of their mobile economy and social organization, Somalis could (and still can) largely afford to ignore the claims of state or other overarching institutions. An oft-cited comment is that by the Baganda companion of a British soldier travelling for the first time in the Somali area in 1910: 'Somalis, bwana, they no good; each man his own sultan'. ${ }^{24}$ Somalis still cultivate this self-image of personal pride and independence. ${ }^{25}$

It should also be emphasized that the Somali social order, while recognizing links through females, is deeply patriarchal, with public, religious and political activity strongly dominated by men. Married women are vocal, economically active and central figures in domestic life and maintain important links with their family and clan of birth ${ }^{26}$ but husbands or male relatives should give their approval for what their womenfolk do.

${ }^{21}$ Tol means patrilineal kinship linking and is situational as to the actual links stressed. Starting at the lowest level and then going up, Somalis are members of a qoys (family), a reer, a jilib, a qolo and a qabiil (this is the most inclusive level, that of the six large clan families). Jilib and reer, and to a lesser degree qolo, can be mag (blood money)paying groups in the case of homicide.

${ }^{22}$ These had no meaningful executive power and cannot be considered on a par with the chiefs known elsewhere in Africa.

${ }^{23}$ Ahmadiyya, Qadiriyya and Salihiyya.

${ }^{24}$ Cited in Samatar, 'Somalia: The Politics of Poetry'. R.F. Burton's remarkable book First Footsteps in Africa (London, 1856) is replete with similar observations.

${ }^{25}$ Gerald Hanley's memoir Warriors and Strangers, about his time as a British officer and administrator in Somaliland after 1941, offers a penetrating and delightful picture of this.

${ }^{26}$ See Aman, with V.L. Barnes, Aman, the Story of a Somali Girl (London, 1997). 


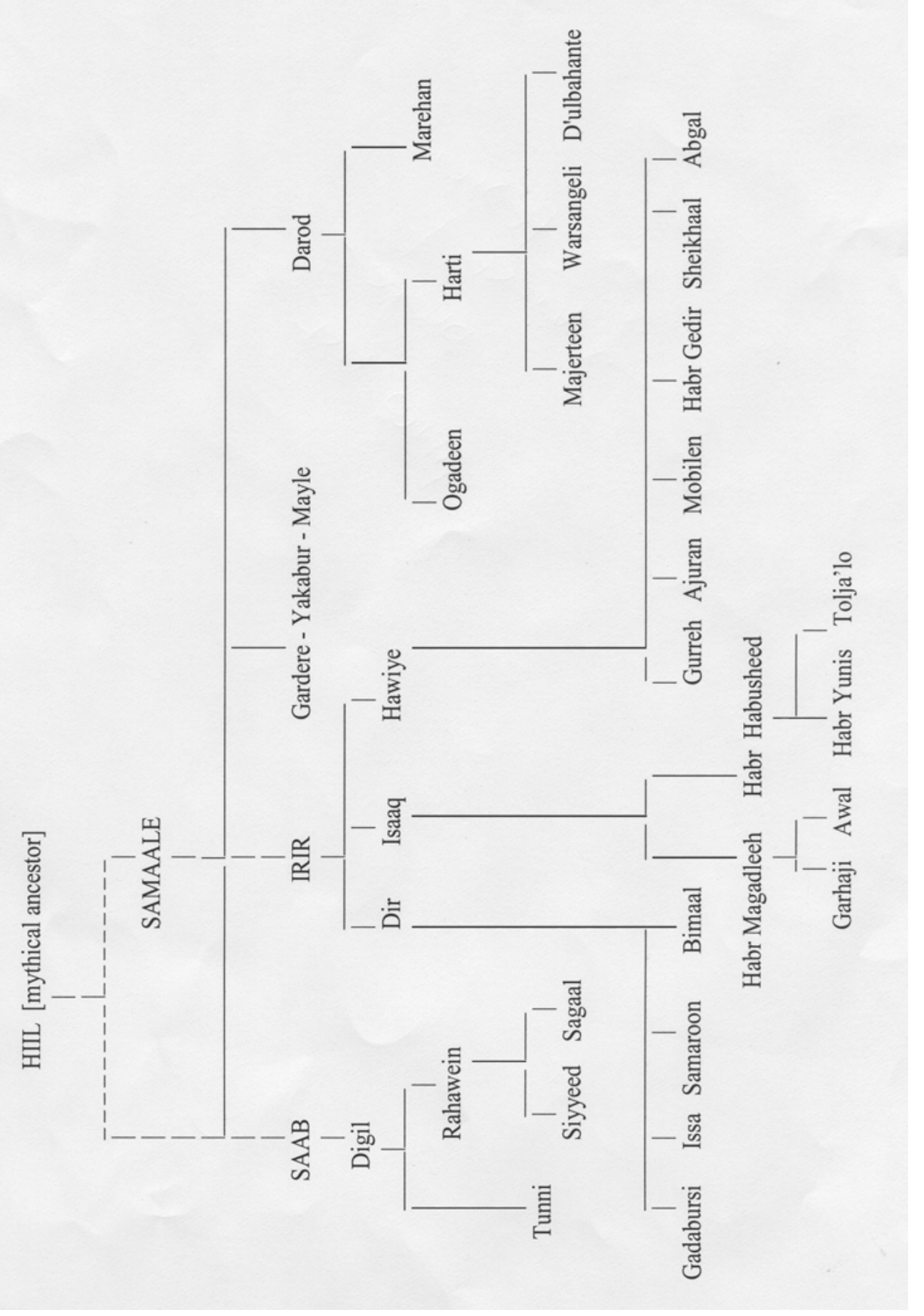

Figure 13.1 Outline of the total Somali clan genealogy Modified on the basis of the chart in T. Lyons \& A.I. Samatar, Somalia: State Collapse, Multilateral Intervention and Strategies for Political Reconstruction (Washington DC, 1996) 
Pre-colonial economic conditions in Somalia, a vast, semi-arid country with a widely dispersed population, never allowed state formation processes based on surplus extraction or power monopolization to take off because the main source of wealth was 'mobile capital' in the form of livestock and local trade, neither of which is easily controlled or taxed by central authorities (like in the kingdoms of, for instance, Buganda, Ethiopia or Congo). Also, a state in Somalia could, almost by definition, only be a territorial, clan-based structure at the expense of others, perhaps even at that of the Somali heer, the customary law based on principles of social contract. This was the case in the pre-colonial past as well as today. States formed by agreement or social contract, as in today's Somaliland under the Somali National Movement ${ }^{27}$ since 1991, remain beset by internal tension and are conditional upon careful respect for, and a balancing of, the rights and local interests of the common people, especially if they are of another, non-dominant clan (family). ${ }^{28}$

Nor was there any ideology or idea of nationalism in the pre-colonial period. There was a vague and decentred notion of cultural and religious identity of Somali-speaking groups but most of the clan and territorial units did not know each other and had little or no contact. Politics was localized and based on nested segmentation without central leaders. There was substantial diversity also in dialects, lifestyle and prestige between Somali groups, not only between the Samaale and Sab (see Figure 13.1) but also within these two great divisions and between them and the craft-worker groups and the Bantu speakers in the south. ${ }^{29}$ The only meaningful crosscutting loyalties were formed by the Sufi orders (turuuq) to which most Somalis (males and also many females) ${ }^{30}$ were affiliated, but even here the orders and their local settlements had membership of a dominant clan, and in times of conflict and feuding they did not prevent violent confrontation.

Discussing violence in Somalia, Prunier $^{31}$ has described pre-colonial Somalia as a real 'culture of violence' and cites instances to this effect. Violent strategies were part and parcel of the harsh way of life in the country, and competition was necessarily fierce. A forced reconstruction of an idyllic Somali social space where custom reigned and people settled their disputes in amicable rituals should therefore be rejected. Even the much reputed heer, or

\footnotetext{
${ }^{27}$ Dominated by the large Isaaq clan.

${ }^{28}$ For example, the 'Iisa and Gadabursi in the Awdal area and the D'ulbahante in the east are minority clans under the Isaaq.

${ }^{29}$ Not to mention the people of Hamar (Mogadishu), Baraawa, Kismaayu and other coastal towns.

${ }^{30}$ See F. Declich, 'Sufi Experience in Rural Somalia: A Focus on Women', Social Anthropology, 8 (2000), 295-318.

${ }^{31}$ Prunier, 'Segmentarité et Violence', 384.
} 
customary contract law, was only valid within the agnatic (clan) groups, not outside them, at least not if there was no prior agreement or patron-client relationship. What has to be kept in mind is that violence in Somalia - as in so many pre-colonial or pre-industrial societies - while frequent, was not seen as controversial and problematic as it is today in the global normative discourse on human rights. Violence as part of accepted relations between groups and the threat of feuding were facts of life. The early travel literature (for example, R. Burton's First Footsteps in Africa, published in 1856) regularly mentioned such feuding and massacres. Hanley also described repeated incidents of Somalis robbing, killing and preying upon each other. ${ }^{32}$ On the coasts, they had a tradition of looting shipwrecks and also of piracy. ${ }^{33}$ The Somalis thus formed a loosely connected pre-colonial realm of dispersed pastoralists, coastal towns and sultanates, related through ideas of common descent, clan fission and fusion, a violent pastoral economy, Islamic religious identification (since the thirteenth century) and regional trade links. In this realm, the European powers arriving in the $1880 \mathrm{~s}$, with their claims to take possession of coastal areas to protect sea-lanes and establish political control, were to pose a challenge.

\section{Italian and British interference: Chimeras of governance and order}

As elsewhere in Africa, Western colonial expansion in the late nineteenth century reshaped local Somali society and politics. Indeed, it led to the reactive forging of an incipient national identity, initially couched in a religious idiom. ${ }^{34}$ The British established a protectorate in 1885 in the north, the Italians their presence in 1889 in the south, and both carved out their domains of influence in subsequent years. The French, after concluding treaties with local chiefs, had, in 1884, secured what is now Djibouti as a vital port on the Red Sea route. While the British originally had no intention of occupying the hinterland beyond the coastal strip, the Italians - established in southern Somalia with its fertile inter-riverine plains - sought to control the interior and make it productive and to settle substantial numbers of Italian agrarian

\footnotetext{
${ }^{32}$ Hanley, 'Warriors and Stangers', 80, 98, 101.

${ }^{33}$ Cf. L. Kapteijns \& J. Spaulding, 'From Slaves to Coolies: Two Documents from the Nineteenth-Century Somali Coast', Sudanic Africa, 3 (1992), 2-3.

${ }^{34}$ Cf. E.R. Turton, 'Somali Resistance to Colonial Rule and the Development of Somali Political Activity in Kenya, 1893-1960', Journal of African History, 13 (1972), 119-43; Said S. Samatar, Oral Poetry and Somali Nationalism. The Case of Sayyid Mahammad 'Abdille Hasan (Cambridge, 1982).
} 
immigrants there. ${ }^{35}$ Italy's greater aim was to ultimately conquer the fertile highlands of Ethiopia. ${ }^{36}$ The purpose of the British and French was not to substantially colonize and transform indigenous society. Even more than in other African regions their attitude to the Horn was one of 'indirect rule', taking advantage of trade and maintaining public order. But even this modest form of political control proved to be a challenge on the Somali coast. From the start, the colonizers did not intend to alter the religious character of the local population: their primary motive was political and they hoped for consent from or co-optation of the local leaders. The colonizers did not pursue or even allow a missionary Christian agenda, as was asserted by Somali religious opponents. The colonial state was more of a secular administrative structure, with an often-remarkable fascination with and admiration for the Somali's pride and demeanour. ${ }^{37}$ Colonialism certainly brought new forms of power, economic control and submission in the Somali regions. These challenged the local economy of land use and pasture, as well as the decentralized political system of Somali clan groups and their kin-ordered social structures. ${ }^{38}$ Stirrings of resistance were not unusual in the early colonial period. One important anticolonial party was that of the Somali slave owners. ${ }^{39}$

The nature of the colonial enterprise in the Horn was thus mixed. France, Britain and, to a lesser extent, Italy were primarily there to compete with each other and with Ethiopia (that resented European intrusion and defeated Italy in the 1896 Battle of Adwa) for sea and trade routes. In the case of the British and the French, there was no effort to root out customary law and local leadership in Somalia. The Italians, however, came to see Somalia as a settler colony, the productive resources and political structures of which were to be utilized. Their policies (for example of creating 'state domains') were a threat to local Somali forms of collective tenure of land and pasture. ${ }^{40}$ But these policies came to

\footnotetext{
${ }^{35}$ As in Eritrea, the northern coastal part of Ethiopia, which was made a colony in 1890. Somalia was an Italian protectorate until 1905 when it was also made a colony.

${ }^{36}$ M. Guadagni, 'Colonial Origins of the Public Domain in Southern Somalia (18921912)', Journal of African Law, 22 (1978), 1.

${ }^{37}$ Cf. A. Jardine, The Mad Mullah of Somaliland (London, 1923), 34, 319; Hanley, 'Warriors and Strangers', 20, 49, 107, 124-27, 149; also I.M. Lewis, 'Unravelling a 'Flawed' History', Journal of African History, 41 (2000), 522. These social and cultural relationships of colonizer and colonized, while prominent in recent anthropological and historical debates, have not been well studied in the case of Somalia.

${ }^{38}$ See Guadagni, 'Colonial Origins', 5-8, 12, on the Italian land laws in Somalia and the frequent opposition of the local population. This resistance was independent of the Dervish movement and based on people's direct material interests.

${ }^{39} \mathrm{Cf}$. Cassanelli, The Shaping of Somali Society, 231.

${ }^{40}$ Guadagni, 'Colonial Origins', 25.
} 
fruition mainly after the Dervish revolt had fizzled out, and in southern areas where the Dervishes were much less active.

\section{Incipient modernity, Dervish revolt and violent transformation}

The colonial venture inevitably was one of incipient modernity in the widest sense. Italy and Britain brought a (rudimentary) state administration, new modes of governance and political action and the use of state force, as well as material changes, new technologies, motorized transport but also modern firearms, economic exploitation and colonization of land and other natural resources.

Somalis often reacted negatively in a variety of ways but were also accommodating and tried to profit from new opportunities, especially in the coastal areas and the agricultural south. One important response, however, came to be couched predominantly in a religious idiom of resistance. In 1899 an anti-foreigner insurgence was formally declared by Sayyid Mohammed 'Abdulle Hassan (1864-1920), (abbreviated as MAH), a well-educated Islamic teacher (sheikh) and militant proto-nationalist from the Ogaden clan. ${ }^{41}$ Sayyid Mohammed was a member of the Salihiyya Sufi order, which originated in Saudi Arabia and was influenced by the puritanist Wahhabi movement. At a big northern Somali clan assembly in Burao that year, he raised the flag of resistance against the 'Christian invaders' in Somali lands. At this point he had about 4,000 to 5,000 followers. His insurgency came to be known as the Dervish movement ${ }^{42}$ and had its strongest base among the D'ulbahante clan of the Darod clan family (see Figure 13.1). In the years to follow, his aim was to create an autonomous space, beyond the reach of the colonial powers, and to develop an alternative politico-religious order with the contours of a strict Islamic theocracy. To this effect, the message was spread with intimidation and brute force. In the border area of Italian and British Somalia, the movement built settlements and fortresses for its fighters and followers. A predatory

${ }^{41}$ His mother was from the D'ulbahante (also part of the Darod clan family). Mohammed 'Abdulle Hassan was often called Mullah or Sayyid. The epithet 'Mad Mullah' (see Jardine, The Mad Mullah) did not originate with the British or the Italians as is often thought but is a translation of the Somali expression wadaad wal ('lunatic religious leader/priest') used in the late 1890 s by Somalis opposed to him. See SheikAbdi, Divine Madness, 55.

${ }^{42}$ The word darwish is Persian, originally meaning Islamic mendicant. It is generally used for members of Sufi orders. In Somalia, members of the Salihiyya Sufi order in particular were called 'dervish', and Mohammed 'Abdulle Hassan liked having his movement called thus. 
economic system based on pastoralism, raiding livestock, looting caravans and confiscating trade profits from coastal populations emerged.

Remarkably, the initial act of this revolt in August 1899 was not a massive attack on the British but on two religious villages of the Ahmadiyya, a Sufi order that had not displayed total support for the Sayyid's call for a jihad. ${ }^{43}$ This is a telling event which foreshadowed the nature of the insurgency. Indeed, MAH's movement was directed as much against other Somali as against the British or Italians.

Initially, MAH appeared to call for transcending segmentary clan divisions but soon he started playing upon them. ${ }^{44}$ In the years 1900-1905, the insurgency wreaked havoc in the north-central Somali areas, and was combated by the Italians and especially the British. After this initial phase of revolt, MAH reached a political compromise with the British and the Italians in 1905, known as the Illig Treaty, under which he was allowed an autonomous area in the Nugal Valley, and freedom of movement and religious practice. He then had an armed retinue of some 5,000 to 6,000 fighters, with their dependants.

For about four years things were quiet but in 1908 a new phase of violence began, again not targeting colonial troops but the coastal sultanate of Hobyo, the Majerteen clan in the northeast, the Hawiya area, and even the Rahanweyn in the southeast. ${ }^{45}$ Only in 1912 did MAH's troops attack the British in Berbera. After 1909 the insurgency again grew in strength. In 1910 the British had even decided to concentrate their forces in the coastal areas in order not to lose resources and men in fruitless forays into the interior, which was of no real interest to them. Due to their mobile warfare and the depth of their retreat lines on the Ogaden Plains, the Dervishes were hard to pin down and defeat.

The repeated campaigns of the British and Italians could neither root out the movement nor prevent its devastation of other Somali clan groups and their resources. Throughout the twenty-year insurgency, the majority of victims were other Somalis, not colonial troops and their supporters. Indeed, MAH's revolt, through its use of often callous and indiscriminate armed force against Somalis perceived to be 'against him' and his Ogaden clan, transformed existing patterns of clan coexistence and cooperation, undermined the heer, led to internal disarray, and generated new antagonisms that proved to be a burden in the future. Interestingly, the Dervish insurgence was denounced in a letter written in 1909 by Sheikh Mohammed bin Salih Rashid, the founder of the Salihiyya order of which MAH was a member. Although it might have been at the instigation of the Italians that some Somalis (among them 'Abdullah

\footnotetext{
${ }^{43}$ See Lewis, A Modern History, 69.

${ }^{44}$ Prunier, 'Segmentarité et Violence', 388-89.

${ }^{45}$ The Warsangeli clan, however, declared support for MAH's cause in 1908.
} 
Shahari, a former close adviser to MAH) went to visit the Sheikh in Saudi Arabia to get such a condemnation, the letter nonetheless had a significant impact on many of MAH's followers. It was not a 'somewhat mild denunciation', as Lewis terms it, ${ }^{46}$ but as is evident from the text, ${ }^{47}$ a quite outspoken and threatening condemnation that even questioned MAH's Islamic identity.

The second decade of the revolt continued with in-fighting and raiding of clan groups, religious leaders and regional chiefs that opposed him or tried to work out a compromise with the colonial regimes. It did not bring the stated aims of MAH any closer. The year 1911-12 came to be known as the Haaraama 'Une, the 'Year of Eating Filth', ${ }^{48}$ reflecting the famine, chaos and communal hatred generated by the Dervish movement. In view of this, the British changed their policy in late 1912 and founded the Somali Camel Constabulary as an expeditionary force to end the Dervish movement. It would still take seven years to do so, partly because from 1914 to 1918 the British were hindered by their commitments elsewhere during the First World War.

Towards 1920 the insurgence movement was weakened, and the social basis of MAH's authority and rule among clan groups in the north declined. He still had followers, and held out in his impressive fortified settlement at Taleh (see photo). The British wanted to put an end to his activities and after MAH declined negotiations, they undertook one last offensive in July that year, assisted by Somali troops of the Habr Tolja'elo and Habr Yunis clans and, ironically, of the D'ulbahante, who had once been MAH's strongest supporters. Several British planes from Aden were used to drop bombs on the Taleh fortress. While the military impact of this action (with 20-kg bombs) was limited, the psychological aspect was important, and $\mathrm{MAH}$ and his hard-core followers fled to Ogaden territory in Ethiopia. There he was approached concerning new negotiations and a truce, but again he refused, humiliating the peace delegation. In December 1920 he died in Ethiopia either of malaria or of an infectious disease, leaving a Somali people more divided than ever.

As noted above, the trans-clan Sufi brotherhoods (turuuq) in Somalia did not create sufficient crosscutting loyalties to prevent or neutralize clan-based rivalries, often generated on the basis of material interests (pasture, livestock, territory, trade profits and women). Throughout his insurgence, MAH remained at odds with the leaders of the Ahmadiyya and Qadiriyya, as well as with numerous clan groups across the country. Indeed his main base was always

\footnotetext{
${ }^{46}$ Lewis, A Modern History, 75.

${ }^{47}$ Given in Jardine, The Mad Mullah, 184-85.

${ }^{48}$ Lewis, A Modern History, 77; S. Samatar, 'An Open Letter to Somalist Scholars', Horn of Africa, 13 (1990), 88-89.
} 
within the Ogaden clan. Many opponents, whether religious men, clan elders or coastal sultans, were assassinated on his orders. One notorious example is that of the prestigious Qadiriyya sheikh Uways bin Muhammad al-Barawi, killed by a Dervish hit-team in April 1909. ${ }^{49}$ Sheikh Uways had been putting up resistance against the foreigners in his own way but he refused the violent, divisive path of the Sayyid, whom he denounced in a series of poems. In 1909 MAH had his own Qadi killed for dissent, which according to Jardine ${ }^{50}$ caused the defection of about four hundred Dervish fighters.

MAH's mission also generated vehement polemics with other important Somali religious leaders, for example, Sheikh Abdallah Yusuf al-Qutbi. ${ }^{51}$ This was expressed in poetic combat, often in strings of poems in response to each other. A reading of the poetry for which the Sayyid became famous ${ }^{52}$ shows it to be full of references to the fighting against foreign 'infidels', but also to the bashing of those Somali individuals and clan or lineage groups that were opposed to him. Farah Abduf and Kapteijns ${ }^{53}$ note that Somalis view his poems often as brilliant, but frequently also as vulgar and divisive. Presumably they mean his frequent references to slaughtering and smashing his enemies, and showing pride in this. Sexual insults of his opponents also abound. Somali poetry has a genre of curse poems, the gabaar-awayti, ${ }^{54}$ a veritable "poetics of violence' marked by aggressive, stabbing images and metaphors of uprooting and annihilation, and MAH's poems certainly fit into this category. But in his case, these poetic images were also part of a politics of violence. As many of his opponents found out, such passages were exhortations to be taken literally. MAH's remarkable poetic gifts added much fuel to the force of his message. Poetry was part of his struggle and was widely recited in the years of the insurgency. His last recorded poem Dardaaran (written in the year of his

\footnotetext{
49 B.G. Martin, 'Muslim Politics and Resistance to Colonial Rule: Shaykh Uways b. Muhammad al-Barawi and the Qadiriya Brotherhood in East Africa', Journal of African History, 10 (1969), 472. See also Lewis, A Modern History, 70, for mention of earlier assassinations of prominent Somali leaders.

${ }^{50}$ Jardine, The Mad Mullah, 186.

${ }^{51}$ Sheik-Abdi, Divine Madness, 9.

${ }^{52}$ See Samatar, Oral Poetry for an excellent and now classic study.

${ }^{53}$ Mursal Farah Afdub \& L. Kapteijns, "'The Defeat of the Infidels": A Poem by Sayyid Muhammad 'Abd Allah Hasan of Somalia', Sudanic Africa, 10 (1999), 27-47. See also Samatar, Oral Poetry, 202.

${ }^{54}$ Cf. S. Samatar, 'Sarbeeb: The Art of Oblique Communication in Somali Culture', in J.K. Adjaye \& A.R. Andrews (eds), Language, Rhythm and Sound (Pittsburgh, 1997), 49.
} 

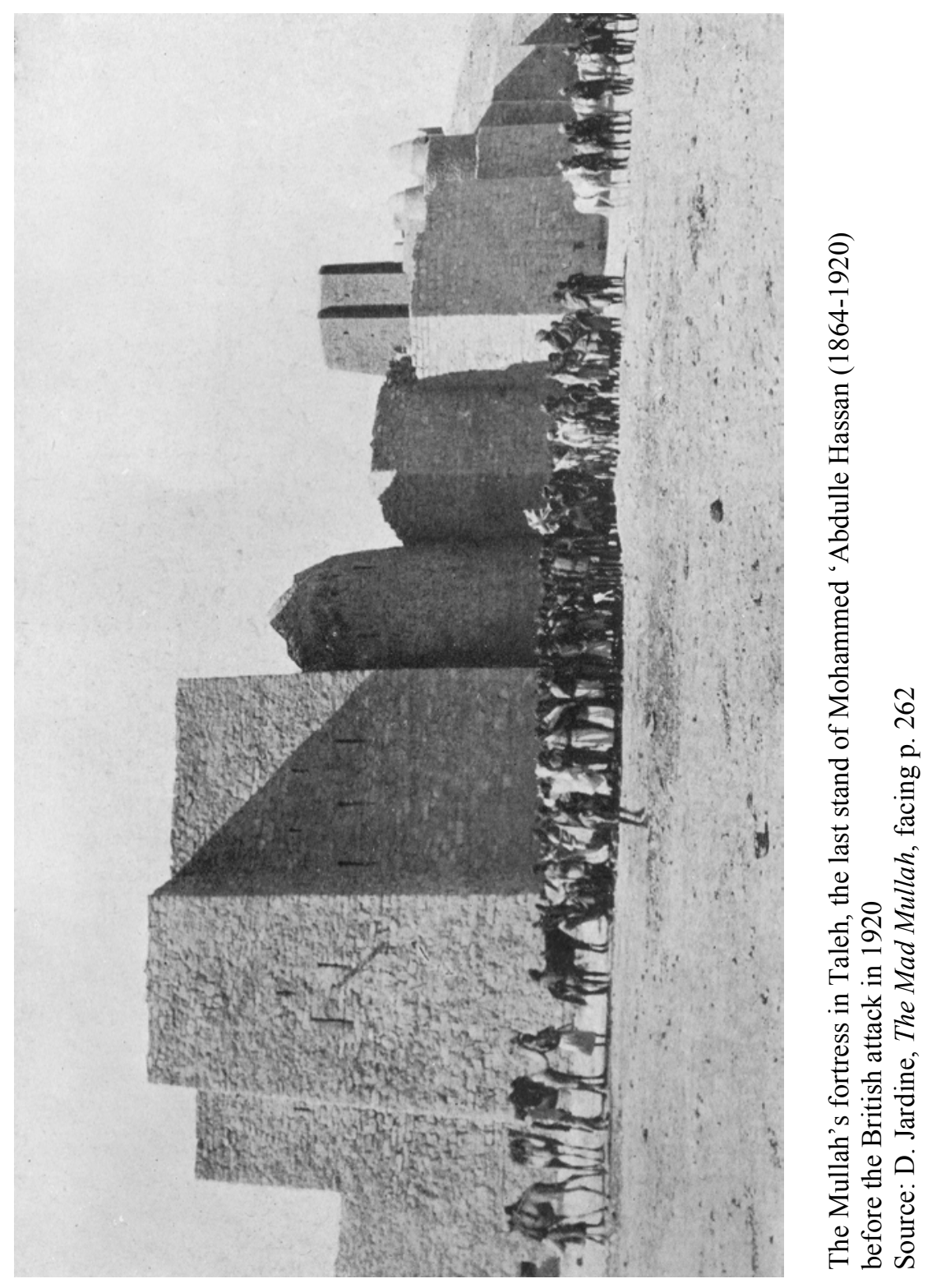
death) reveals what imaginative force and religious zeal he could display, ${ }^{55}$ although it is also a testimony to the utter failure of his project. Indeed, this failure has made it clear that his poetry was the message; the political reality was always quite different. Although he started out as a sheikh and a wadaad, MAH is not remembered as such. Nor was he ever regarded as a saint by later generations of Somali. In the course of his violent campaigns, he effectively lost any religious authority he may have had, and his personal reputation declined markedly in later years. ${ }^{56}$ A wadaad is by definition a religious mediator between clans: MAH became the opposite. The end results of his Islamist insurgency avant la lettre $e^{57}$ were large-scale material and human destruction, ${ }^{58}$ deep divisions, new clan hatreds, and no end to the colonial presence.

\section{The transformation of armed resistance into politics: 1920-1960}

In the years from 1920 until the start of the Second World War, the impact of colonialism on Somali society increased notably. Both Italy and Britain became more committed to the colonial venture, modestly investing in road building, agriculture, well drilling and health facilities. ${ }^{59}$ But only Italy, under Mussolini, promoted a real colonization, intended to make the country a settlement colony. The effects of colonial policy on Somali land tenure, pasture and water rights, and thereby on transhumance patterns of clan groups, were problematic, especially in the south where Italy wanted to develop its agricultural projects. Land was taken from its traditional users, new boundaries were drawn, clan families and clans were divided and cut off from each other, and their modes of subsistence threatened. ${ }^{60}$ Indigenous patterns of leadership were devalued and

\footnotetext{
${ }^{55}$ See the text in Sheik-Abdi, Divine Madness, 176-81. It was republished in a different translation by Mursal Farah Afdub, L. Kapteijns \& Hasan Farah Warfa, "Parting Words of Wisdom" (Dardaaran): A Poem by Sayyid Muhammad 'Abd Allah Hasan of Somalia', Sudanic Africa, 11 (2000), 25-34.

${ }^{56} \mathrm{Cf}$. the accusations of contemporary poets cited by Samatar, Oral Poetry, 164-65.

${ }^{57}$ The mode of thinking of MAH, as evident from his poems and letters (for example to the British authorities, see Lewis, A Modern History, 78-79) indeed shows remarkable similarity with present-day Islamists' discourse.

${ }^{58}$ Jardine, The Mad Mullah, 315, (over)estimated the number of people killed directly or indirectly as a result of the Dervish war to be about 200,000.

${ }^{59}$ Lewis, A Modern History, 104-5.

${ }^{60}$ Laitin \& Samatar, Somalia: Nation in Search, 61-62.
} 
undermined. The insights of Italian scholars like Colucci $^{61}$ into customary tenure and decision-making in Somali culture were not much heeded in colonial policy. The colonial regimes did not make any major investment in formal, modern education in Somalia and no new class of urbanized educated Somalis emerged to formulate a nationalist movement. This only came during and after the Second World War.

Resistance was fomenting but before the Second World War did not take on an organized, collective form. While a vibrant Somali local politics developed - as far as the colonial regime allowed it - the political scene showed a complex balancing act between clan-based politics and nationalist political organization. The violence and internal chaos seen in the Dervish days did not return. There were small-scale rebellions but not wide-scale organized protests on a national basis. For instance, the 1937 Camel Corps mutiny appears not to have been inspired by nationalist motives but primarily by direct material causes. ${ }^{62}$

The Second World War meant a radicalization of Somali politics and a growing unease with colonial governance. The Italian East African Empire collapsed in 1941 following the Allied military victory, and the debate about the future of its constituent parts began. Ethiopia regained its independence and part of the Somali-inhabited Haud and the Ogaden were ceded to it.

In 1942, former British and Italian Somalia experienced a period of British Military Administration (BMA) until 1950. In the report of the 1948 UN Four Power Commission, reporting on Somalia to help prepare its political future, the opinions of a wide section of Somalis were presented. ${ }^{63}$ From this report one can deduce not only that the economic interests and agricultural schemes of the Italians had created serious tensions concerning matters of land, labour, ${ }^{64}$ territory and 'clan borders', but also that British-Italian political competition and Somali party politics had created great rifts. The effect was further opposition between clan families. For instance, people from the Somali Youth League (SYL), formed in 1943 and in favour of speedy independence, were not liked in the south. They were seen as a mainly Majerteen group and were opposed by the Hizbia Digil-Mirifle Somali party active in the riverine areas of

${ }^{61}$ M. Colucci, Principi di Diritto Consuetudinario della Somalia Italiana Meridionale (Florence, 1924).

${ }^{62}$ See Jama Mohamed, 'The 1937 Somaliland Camel Corps Mutiny: A Contrapuntal Reading', International Journal of African Historical Studies, 33 (2001), 615-34. The same was true of a revolt of the same corps in 1944.

${ }^{63}$ See L.V. Cassanelli, 'Somali Perceptions of Colonial Rule: Testimonies to the Four Powers Commission', in R.W. Harms et al. (eds), Paths toward the Past: African Historical Essays in Honor of Jan Vansina (Atlanta GA, 1994), 143-55.

${ }^{64}$ The Italian forced labour policy was especially hated by Somalis. 
the south. ${ }^{65}$ This again illustrates the values attached by clan groups to their own traditions and to self-determination in the game of clan politics and reciprocity. Colonial policy had aggravated rather than lessened such tendencies.

In 1950 Italy - though defeated in the Second World War and with a dubious colonial record - received a UN trusteeship to administer its former colony of Somalia for ten years. The British retained northern Somalia, also to prepare it for independence. Collective insurgency movements like the Dervishes did not appear in either country. While the public memory of the revolt of the 'Mullah' (MAH) was vivid, it was not a political example. But in the new party politics that emerged, factionalism and regional divisions among clans, clan families and caste groups were not overcome. Also, the Italian political model for Somalia was based on transposing a centralized state to a decentralized, rebellious country, an approach that had adverse effects on local politics and clan-group relations. ${ }^{66}$

In this state context, clan politics came to have a lasting appeal, despite the objective challenge of colonialism to the Somali subjects to unite, and despite the growth of the idea of Somali unity across the various colonial frontiers. The colonial state arena, with its disregard for local leadership, autonomous structures and customary law, created a 'spoils system', whereby competition for the distribution of state resources on the basis of identifiable constituencies was the game. Accordingly, after the Second World War and the BMA period, new 'tribal' political parties emerged alongside the more pan-Somali SYL ${ }^{67}$ and the Hizbia Digil-Mirifle party: for example, the Marehan Union, the Progressive Majerteyn League, the Hamar Youth Club (in Mogadishu) and the Hawiye Youth League. They garnered to a specific clan-based constituency even at a time when an agenda of national unity might have been expected to be the best way to promote a viable independent Somalia. As Tripodi states: '...the new state organization became just an instrument in the hands of predominant clans, who administered power according to their own interests' ${ }^{68}$ In a way, the Somalis fell into a political trap set inadvertently by the Mandate authorities.

\footnotetext{
${ }^{65}$ See Cassanelli, 'Somali Perceptions', 145-46, 148-49. See also his citation of the complaint of the Elai clan community about all Somali political parties, ibid. 153-54.

${ }^{66}$ Cf. P. Tripodi, 'Back to the Horn: Italian Administration and Somalia's Troubled Independence', International Journal of African Historical Studies, 32 (1999), 79.

${ }^{67}$ With mainly Darod and Hawiye membership.

${ }^{68}$ Tripodi, 'Back to the Horn'.
} 
Independence and an attempt at state formation: The irredentist illusion

In 1960 the two Somalias, ill prepared and divided by under-funded and topdown colonial rule, became independent. After five days of separate independent existence, they joined together as one state. A multi-party political system evolved, and for a while things looked promising in the new era of nationalist fervour. A careful politics of clan balancing at the national level started but soon factional manoeuvring and elite competition, aimed at the selective use and control of central state power, resurfaced leading to a creeping fragmentation of the polity. The conditions for this lay partly in the faulty political system not recognizing the continued importance of clan identification at a social and cultural level but also in the colonial land policies, that more than ever had tied clan rivalries to material interests around resources, generating conflicts no longer covered by the heer, the legal rule of clan elders and religious mediators (wadaad).

In 1969 General Mohammed Siyad Barre, chief of staff of the Somali army, took power in a coup, deposing a fragmented, faction-ridden government and an impotent parliament. He declared a state-socialist programme of development aimed at education, economic growth, literacy campaigns, an improvement in the rights of women, and neutralizing customary law and clan politics, even clan identities. Instead of constructively engaging them in a consociational or federal formula, he denied them and tried to forcefully repress them. As is known from the literature, this campaign of denial took on hilarious forms, with people asking each other about their 'ex-clan', it being forbidden to ask what their clan was. ${ }^{69}$

When he came to power Siyad Barre did not instigate clan rule. His system of governance was initially led by the ideology of 'scientific socialism', and he employed anyone who showed ability and personal loyalty, also those from marginal groups. For instance, his long-time defence minister was a member of one of the minority castes but his policy of alleged 'declanization' amounted to a denial of people's primary identifications and of the structures of regional power and prestige. His Marxist-modernist policies were directed against heer, clan law, and local civil-society institutions.

Over the years, Siyad Barre's orientation to his own clan (Marehan) and that of his mother (Ogaden) increased. A turning point was the debacle in 1977-78 in the Somalia Irredenta war against Ethiopia, aimed at taking the Ogaden. The

\footnotetext{
${ }^{69}$ See also the joke cited by Ch. Geshekter \& S.A. Warsama, 'An Introduction to Humour and Jokes in Somali Culture', in R.J. Hayward \& I.M. Lewis (eds), Voice and Power (London, 1996), 147.
} 
attempt to wrest this vast area up to the city of Jijiga from Ethiopia was a costly illusion that brought the regime to the brink of disaster. Instead of unifying the Somalis in a common cause, it led to internal recrimination, clan division and a decline in the development commitments of the regime. Internal opposition movements with an agenda of liberation emerged in various parts of the country.

After 1988, the first year of the devastating war against the Somali National Movement in the Isaaq-dominated north, Siyad Barre reverted to relying fully on the so-called 'MOD' alliance ${ }^{70}$ and began excluding people from other clans from power. In a predictable development, this led to an aggravation of clan rivalry ${ }^{71}$ manifesting itself in pervasive distrust and enmity among people and perceived clan groupings, as well as in violent conflict. Subsequently, a speedy decline of the national state and the emergence of clan-based factional contestation for power went hand in hand. The various revolts in the country in the north, in the Majerteen area, in the Hawiye area and in the southern coastal cities - seemed to usher in an era of freedom and equality, but it eventually turned into the opposite. Armed revolt and insurgency became a way of life adopted by the clan-based militias and factions that saw easy ways to gain and profit. The new links of the Somali economy to export markets as well as external political forces (including international organizations and aid agencies) played an important role in enhancing such tendencies.

It may not be fair to compare Mohammed 'Abdulle Hassan with Mohammed Siyad Barre but what can be said is that both their nationalist programmes failed because of their ruthless application of ideologies and violent practices that ignored and indeed actively suppressed the social structures and cultural values of Somali life. Foremost among them were segmentary clan identification, customary law, the prestigious role of clan elders and clan councils, and the traditions of egalitarianism and local autonomy. Their policies evoked clan-based movements fighting for freedom as well as a culture of violence rooted in feuding, the settling of scores and looting.

${ }^{70}$ See footnote 7.

${ }^{71}$ Cf. M. Jama, 'Trajectoire du Pouvoir', 423. 
Table 13.1 Approximate population distribution of the six clan families

\begin{tabular}{lr}
\hline Digil & $4 \%$ \\
Rahanweyn & $16 \%$ \\
Dir & $7 \%$ \\
Isaaq & $22 \%$ \\
Hawiye & $23 \%$ \\
Darod & $21 \%$ \\
Ethnic and national minorities & $4-6 \%$ \\
\hline
\end{tabular}

The last Somali government census was in 1987 so these figures are estimates only. The total population of Somalia is thought to be about 7-8 million. In Ethiopia there are about 3.2 million Somalis, and in Kenya the figure is estimated to be about 340,000.

\section{State disintegration - clan resurrection: The post-1991 period}

After 1991, the basis of collective political action was sought in the resurrection of clan identities, though shifting in scope according to the level of clan $(t o l)$ segmentation. Initially the element of freedom fighting was obvious. The southern Rahanweyn and Digil groups, choking after years of central state oppression, aimed for autonomy. The Isaaq-dominated north successfully fought free from southern, mainly Hawiye and Darod, domination but tensions remained with the D'ulbahante and Warsangeli clans (that had in the past largely supported the Dervish movement). In the south and northeast, factions based in a majority clan family were formed and became the units of insurgence and revolt, for example the opposing Abgal and Habr Gidir subclans within Hawiye, heading two wings of the USC movement. But here the aim was no longer a national state or an Islamic-inspired restoration of order and justice but survival, predation and the building of fiefdoms as large as possible. Almost all major clans saw the emergence of their own parties, militias or combatant groups. While these are manipulated by elite sections within the clans, they nevertheless were formed on the basis of kinship thinking and segmentation. In the past decade, several dozen such groups have emerged, even down to the smallest size of a lineage. For instance, the tiny group of Reer Barre in the north at one point also claimed to be a political party. The major ones still involved in political entrepreneurship and violence in Somalia today are listed in Table 13.2.

The main clan-militia leaders/entrepreneurs active in southern Somalia, especially in and around Mogadishu, are Ali Mahdi Mohammed (an Abgal businessman), Hussein Mohammed Farah (a Habr Gidir), Osman Hassan Ali 


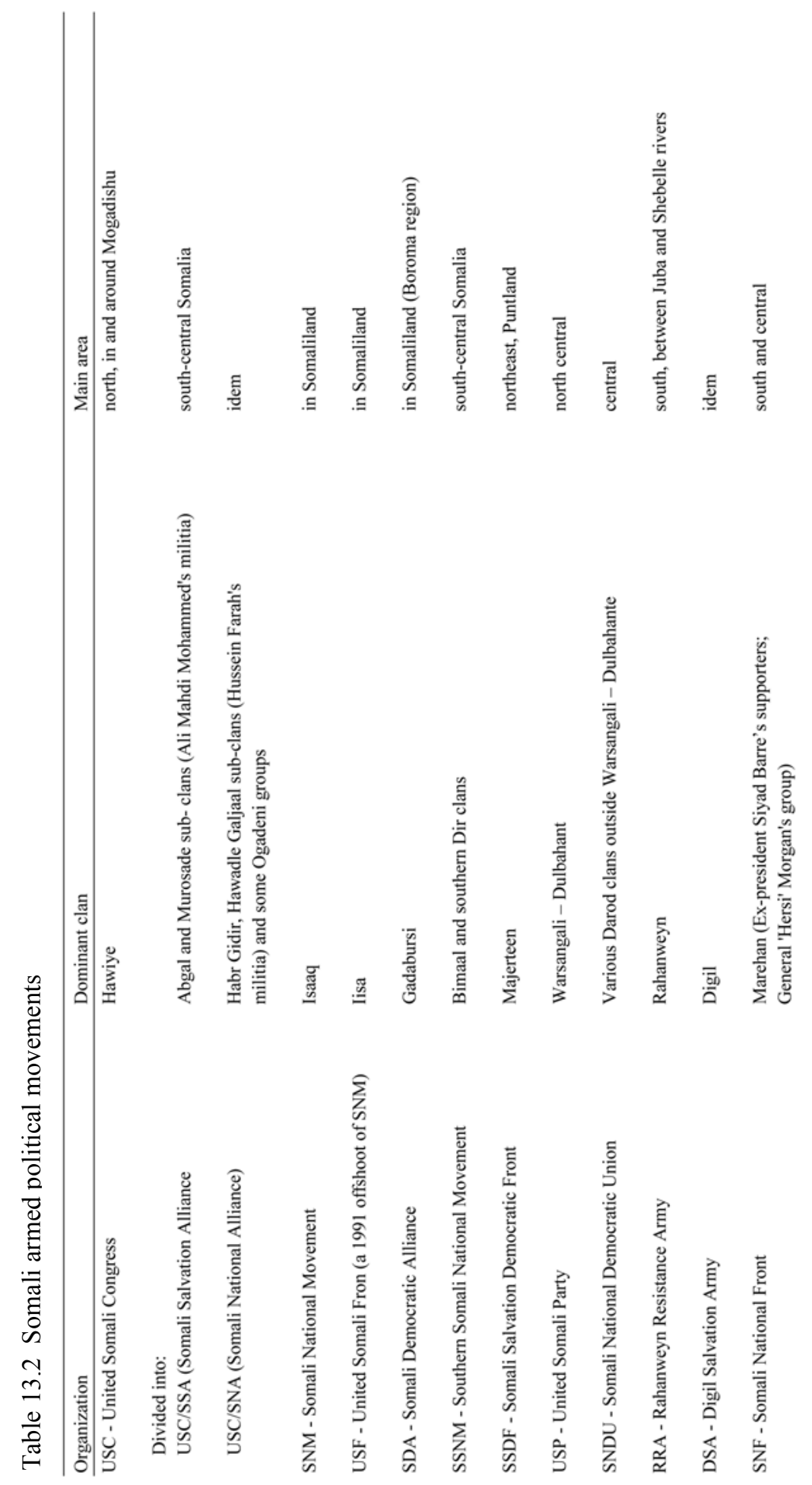




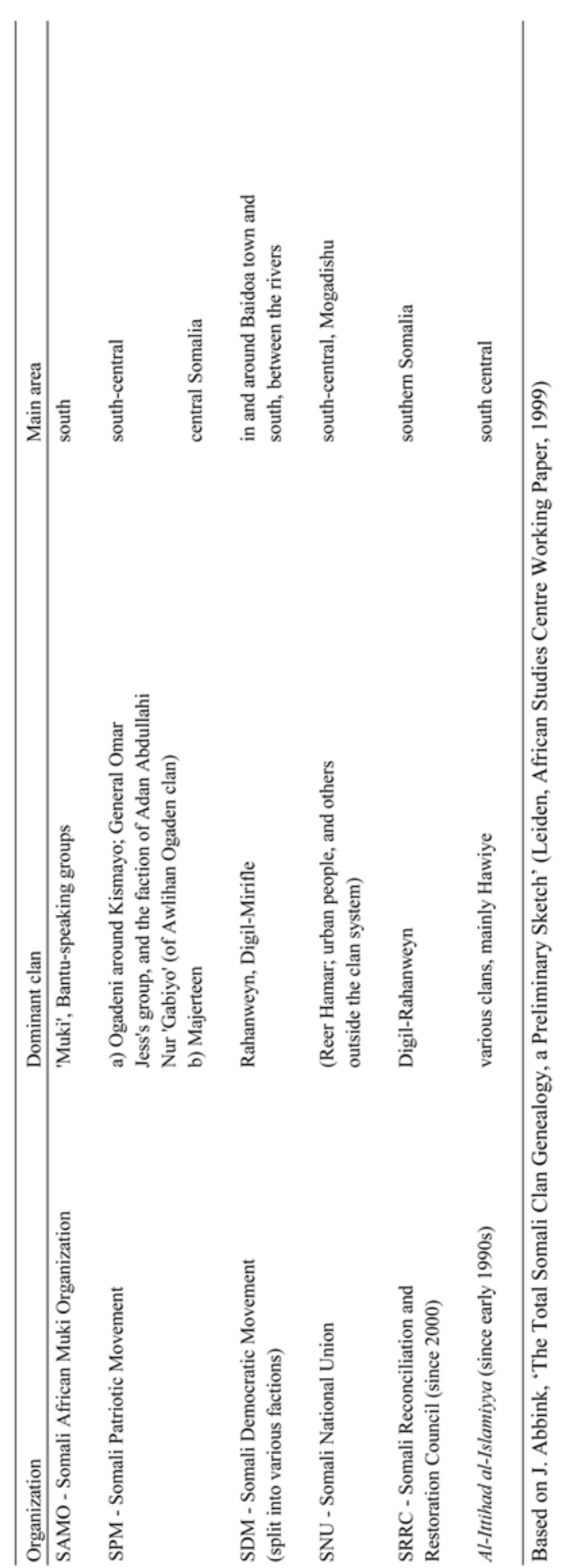


Ato' (Habr Gidir), Muse Suudi Yahalow (Abgal), Muhammad Qanyare Afrah, Mohamed Hussein Addow, Bashir Raghe, and Husayn Haji Bod. They are predominantly from the Hawiye clan family and often head factions of the various organizations mentioned in Table 13.2. All have used moryaan, the heavily armed, roaming groups of young fighters living by intimidation and predatory activity, to further their own interests.

Fierce resource competition emerged between these various organizations and militias, be it for land, livestock, fragments of the state machinery, possession of former nationally-owned facilities like airports, contacts with NGOs and aid agencies, trade and export routes, or arms imports. There was also a marked but often ill-reported dimension of sexual politics involved, as the larger clan-faction groups claimed forceful access to women from weaker groups, especially in the southern agricultural areas and the big cities on the coast. This politics of humiliation aggravated clan divisions and communal anger.

In addition, the traditional inequalities between Somali pastoral groups and urban elites, especially from the big clans like Hawiye, Majerteen and Marehan on the one hand and the Waable (caste minorities) and Bantu groups on the other, were reproduced, if not reinforced. ${ }^{72}$ Together with the agricultural Digil-Rahanweyn, these vulnerable groups were a major target in the civil war and the warlord fighting, with most of their resources being taken or claimed. In this respect, nothing had changed since the pre-colonial era except for the severity of resource exploitation and destruction. Several authors such as Prunier and Schlee ${ }^{73}$ have tried to see some 'order in the chaos', i.e. the regularities underlying the violence of armed groups, shifts in their alliances, economic activities etc. There are indeed notable regularities and patterns but the only predictable factor is the orientation of Somalis towards clan identity and their structuring of political action in similar terms.

The Somali central state of 1960-1991 has gone forever. The various independent regional administrations in Puntland, ${ }^{74}$ in Somaliland, and since 2002 in the South West State in the Rahanweyn area ${ }^{75}$ can be seen as having emerged from resistance against any central government dominated by clans other than the majority ones in their own region. As no region is homogeneous,

\footnotetext{
${ }^{72}$ Cf. Mohammed-Abdi, 'Les Bouleversements Induits'.

${ }^{73}$ Schlee, 'Regularités'; Prunier, 'Segmentarité et Violence'.

${ }^{74}$ See M. Doornbos, 'When is a State a State?: Exploring Puntland', in P. Konings, W. van Binsbergen \& G. Hesseling (eds), Trajectoires de Libération en Afrique Contemporaine. Hommage à Robert Buijtenhuijs (Paris, 2001), 125-39.

75 See the declaration on www.somalilandnet.com/warya/2002/somalianews/10532. shtml
} 
there are constant tensions within these new units for political and economic control, often fuelled by claims of kin loyalty, segmentation and the idiom of rivalling clan sub-units.

As the work of Compagnon and Marchal ${ }^{76}$ has shown, in most cases the use of violence was instrumentalized by clan-faction groups without a clear programme, except an economy of violent loot and intimidation. The traditional Somali waranle ideal - that of warriors legitimately defending the interests of their clan and territorial group - had transformed into the entrepreneurial violence of moryaan, the armed youths active both independently and in the service of clan elites or so-called warlords, the entrepreneurs of violence. Most major Somali traders at some point began supporting or organizing armed clan-faction groups to advance their interests and monopolize resources like import-export lines. ${ }^{77}$ Towards the end of the 1990s, this culture of living by looting was not only limited to the militias and moryaan but had also spread to the general population, especially in the urban areas.

Revolt and resistance thus dissipated into a generalized culture of violence based on shifting alliances and without any wider socio-political aims. Any distinction between moryaan and politically inspired fighters became blurred. The situation in many areas of the south is still marked by this kind of everyday violence by looting rebels without a cause except for intimidation and extortion. In this situation, the underlying continuities of clan and lineage distinctions and of locally based interests in Somali society are notable: clanbased groups form the units of survival and reproduction. ${ }^{78}$ They keep providing people, also in the cities, with a basic identity used for collective identification and instrumental gain.

\footnotetext{
${ }^{76}$ D. Compagnon, 'Somali Armed Units: The Interplay of Political Entrepreneurship and Clan-Based Factions', in C. Clapham (ed.), African Guerrillas (Oxford \& Bloomington, 1998), 73-90; R. Marchal, 'Formes de la Violence et de son Contrôle dans un Espace Urbain en Guerre: Les Mooryaan de Mogadishu', Cahiers d'Etudes Africaines, 33 (1993), 295-320.

${ }^{77}$ Compagnon, 'Somali Armed Units', 85.

${ }^{78}$ Several authors have stressed the role of the ideology of expansive reproduction in Somali culture. Cf. I.M. Lewis, Understanding Somalia (London, 1993), 13. The Somali population growth figure is high at $4.43 \%$, with a fertility rate of 7.01 children per woman. See www.wifak.uni-wuerzburg.de/fact $98 /$ so.htm
} 


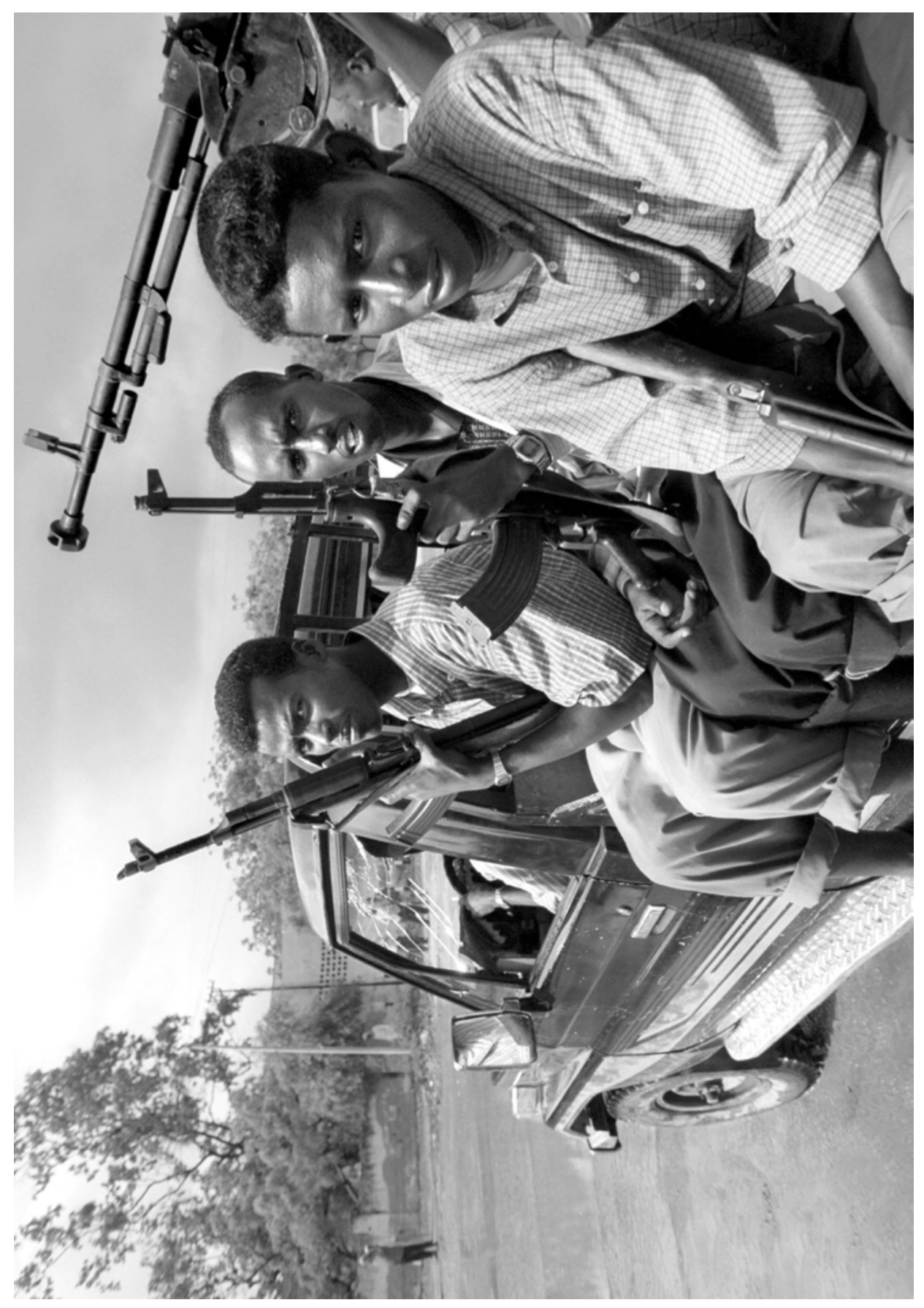

Moryaan in Mogadishu

Source: Hollandse Hoogte, Amsterdam 


\section{Resistance and revolt as a way of life?}

After the fall of the Siyad Barre government in 1991, the famous statue in Mogadishu of Mohammed 'Abdulle Hassan, the declared proto-nationalist hero of Somali nationhood, was '...defaced and later toppled, to be sold for scrap'. ${ }^{79}$ This was no doubt a poignant symbolic event, underlining in the eyes of many the total demise of Somalia by violent internal rivalry and factional fighting. It was simply the outcome of the same processes of territorial and clan-based division that had plagued Somalia in the time of Sayyid Mohammed 'Abdulle Hassan's insurgence. Kin groups based on tol remain the ideational and material survival mechanisms in times of state collapse and economic decline. Such groups, be they clans, sub-clans or mag-paying (lineage) groups, provide an element of social and psychological identity even - or perhaps especially to uprooted people estranged from their socio-cultural orders. But these groups are not based on ancient hatreds. Clans and clan-thinking appear not to be atavistic elements of the past reasserting themselves. They are, and always were, 'identity vessels' in a stateless environment that give agency to people. In this sense, the fall of the MAH statue in the capital symbolizes another turn in the cycle of internal disarray and rebellion that has characterized Somali society for the past 150 years - a cycle whereby only the names of protagonists, the alliances, and the number and extent of violent conflagrations differ while elements of continuity are notable.

Briefly recalling the various periods of revolt in the past century, we see similarities. In both episodes described in this chapter powerful political movements arose, the first instigated by a charismatic but destructive and divisive religious leader (wadaad) turned war leader (Mohammed 'Abdulle Hassan), and the second by a warrior (waranle) gone awry (General M. Siyad Barre), whose rule led to the growth of liberation movements, civil war and the rise of the moryaan generation in a sort of stateless limbo. After 1991, these various movements quickly transformed into, or engendered, clan-based factions whose leaders appealed to clan identity and/or interests that placed them against each other, mocking both traditional and Islamic ideas of peace or mediation. In any of these periods, it is therefore difficult to label all these movements of revolt as 'freedom fights'.

Sayyid Mohammed 'Abdulle Hassan may have had an agenda of Islamic revivalism against a foreign colonial presence but he created a regime of pervasive repression against his countrymen, leading to chaotic violence and unprecedented clan reckonings that were self-defeating vis-à-vis the colonial powers. Siyad Barre, in the Marxist-socialist spirit of the times (1960s-1970s),

\footnotetext{
${ }^{79}$ Sheik-Abdi, Divine Madness, 212. (A photograph of the statue appears on p. 210.)
} 
came to power on a ticket of anti-clanism, equality and social development, but his rule ended in utter tyranny with the state being seen as a mafiose association. ${ }^{80}$ The period of clan-based factions after 1991 yielded a precarious liberation of certain hard-hit regions (Somaliland, Puntland and the DigilRahanweyn South) by their own forces while the rest of the country saw a descent into mayhem or violent predatory rule.

There is both continuity and change in the nature and political relevance of clan segmentation and in the use of violence in Somalia. The big difference with the traditional, pre-state situation now is that most of the violence since 1991 has been fully instrumentalized, released from its social context of legitimate self-defence and of competition for basic interests of clan/lineage groups in the pastoral or urban trade economy, regulated by law, heer or mediating elders. As the persistent presence of clan militias and warlords as well as the many groups of moryaan (a new term and phenomenon in Somali history) makes clear, predatory violence and the culture of looting could not easily be 'retrieved' within the socio-cultural frameworks of Somali society, all the more since there was no real ideological rationale to be discerned. While many violent militia groups active today were once part of political movements - or still claim to be - their wider political aims have become lost in nebulous clan-based conflict, opportunism and violently defended business interests. Violent action became an entrepreneurial activity - a rational means of accumulating resources, though at the expense of other Somalis (and foreign aid agencies). The destabilizing effects of this soon became clear but such activities could not easily be stopped. Continuities with pre-modern conditions are evident in that clan-based politics proved to be quite adaptable to the modern setting of a stateless Somalia, perhaps even more so since the two meta-narratives of Islamic revolt (Mohammed 'Abdulleh Hassan's movement) and of state socialism (in the Siyad Barre era) failed so dramatically.

After January 1991, a process of conciliation and rehabilitation was slow in coming, except in Somaliland. Here independence was declared under the SNM and a national project of rebuilding a state administration was initiated. Puntland, under the Somali Salvation Democratic Front (the SSDF, founded in 1978 by Majerteen), and Southwest State (in the Digil-Rahanwein area) followed in early 2002, but were weaker institutionally. During the late 1990s, social rebuilding and grassroots initiatives for civic and economic recovery were largely initiated by people tired of the daily violence, especially clan elders, customary law experts, women's groups, Islamic (Sufi) orders and some

\footnotetext{
${ }^{80}$ Prunier, 'Segmentarité et Violence', 396.
} 
other local Islamic groups and courts. ${ }^{81}$ But southern Somalia, including Mogadishu, has lagged behind. Paradoxically, this is also the area where the claim to restore national order and unity through a 'transitional national government' (TNG) for all Somalia was put forward following the 2000 Arta Conference, a meeting of reconciliation of Somalis called by the President of Djibouti with UN assistance and held in the town of Arta in Djibouti. The above claim seems weak in view of the ongoing conflict in that area, divided among six clan-militia leaders, and the limited representativeness of the conference. Interestingly enough, the TNG is backed by the local Islamic movement in Mogadishu ${ }^{82}$ that has adopted methods of force similar to those of the warlords, with armed militias driving around in 'technicals' (pick-up trucks mounted with machine guns) to intimidate opponents. The TNG, led in 2002 by Abdiqassem Salat Hassan (a Hawiye Habr-Gidir), is also regularly accused, mostly by non-Hawiye opponents, of trying to win support in other regions, such as Puntland, by subversion.

In many parts of Somalia today, revolt or resistance against any form of political or other authority, especially if it is perceived as clan-based, seems to have been institutionalized as a way of life: a whole generation knows nothing else.

\section{Conclusion: Cultural structure and political conjuncture}

The past decade of statelessness and regional conflict after President Siyad Barre's downfall shows similarities with the colonial period during and after the Dervish insurgency. At that time, internecine fighting, generated by external influences and the challenges of modernity, also produced chaos, thousands of casualties, economic disruption and deep clan divisions instrumentalized by war leaders. While the present political conjuncture in Somali history shows new forms of violence and conflict, continuities in cultural and social structure are remarkable, going back to the frameworks not only of clan organization and kin-group identification but also to traditional disputes and material interests related to land and other resources. But a century later the cycle has gone further, with Somalia's constituent clan-based

\footnotetext{
${ }^{81}$ See S. Arnold, 'Islam and Somali Clan Wars', 25 May 1996, on www.netnomad.com/ islam-clanwar.htm

${ }^{82}$ There were credible reports that Arab countries bankrolled the TNG and its associated Islamic groups. See Reuters news message of 26 June 2001, 'Chief Says Saudi Arabia is Destabilising Somalia'. Also A. Le Sage, 'Somalia: Sovereign Disguise for a Mogadishu Mafia', Review of African Political Economy, 29 (2002), 134, 37.
} 
units, especially in the urban areas and the South, showing little inclination to come together, even if these various movements have achieved some sort of political order in their own areas. The perception is that a Hawiye has no understanding of Majerteen problems, that the Darod should keep away from the Dir, and an Isaaq has nothing to tell the Rahanweyn. A pervasive and distrustful localism has settled in Somalia. In a typical phenomenon of globalization, Somalis in the diaspora are enhancing this discourse of localism and clan-thinking, as is evident from the highly polemic and sectarian nature of Somali Internet website contributions. Indeed, these exchanges on the numerous sites on Somalia would merit a separate study of divisive and often aimless 'diaspora politics'. ${ }^{83}$

Somalia in recent years has shown that in permanently unstable political conditions new models of socio-political organization and conflict management need to be sought, based on the centrifugal, loosely 'federative' character of Somali society. Under some conditions a centralized legal-bureaucratic state is one option, but not necessarily the best. This, in a way, 'post-modern' situation of contested authority and decentred state power is full of challenges for both the notion of a viable social order in Somali society in particular and for political theory in general. ${ }^{84}$ There is no direct prospect of resurrecting a central state order among the southern Somalis, and authority structures that emerged elsewhere - while promising in Somaliland and fledgling in Puntland or South West State - remain fragile and conflict-prone. The Transitional National Government of Somalia in Mogadishu (since 2000) remains a shaky and localized structure with only a façade of national authority. It is beset by rebellious and/or criminal groups, is incapable of maintaining public order or regulating illegal economic activities, and is contested even within its own ranks. ${ }^{85}$

Power and the control of resources in Somalia - including land, livestock, trade profits, women, ${ }^{86}$ and qat - are very fluid but remain based on the wielding of armed force. This is reinforced by the near-universal spread and possession of automatic weapons across the country, leading to a 'democratized' and instrumental use of violence. ${ }^{87}$ These resources are a continuous bone of contention between local groups and clan formations vying

\footnotetext{
${ }^{83}$ For some samples, see: www.somaliawatch.org; www.mudug.org; allpuntland.s5.com; somalitalk.members.easyspace.com and www.xamarcadde.com

${ }^{84}$ Cf. M. van Notten, 'From Nation-State to Stateless Nation: The Somali Experience', (forthcoming).

${ }^{85}$ See Le Sage, 'Somalia: Sovereign Disguise'.

${ }^{86} \mathrm{Cf}$. Lewis 2001.

${ }^{87}$ See a recent report on the continuing flow of illegal arms to the Horn by the UN IRIN news service of 15 July 2002 on www.irinnews.org
} 
for survival and predominance in a world ill-contained by traditional frameworks of national law and custom.

There is an emerging consensus among Somalia observers that imposing a unitary state based only on abstract individual rights and top-down government is less fruitful than a policy of recognition of the existence of these collective identities based on clan thinking and buttressed by traditional systems and customary laws related to land use and territory, especially in the interior of the country. As caste and ethnic minorities as well as people of the coastal cities have different identities and economic concerns, a forced unitary regime will only perpetuate division and centrifugal conflict. In addition, the economic situation in southern Somalia is now one resembling the 'ultimate free market' with no regulatory institutions, great entrepreneurial freedom, and deals based on trust (clan members) or on extortion and intimidation (non-clan members). It is, however, a system where the bills are not paid: environmental pollution and exhaustion continue unabated. The visibly devastating effects of this might eventually press the various clan and territorial groups to work towards reaching an agreement.

Ultimately, a durable socio-political order in Somalia will have to take into account traditional institutions like the recognized clan elders, religious mediators, and the heer. ${ }^{88}$ There is significant transformation in Somali society, but also notable continuity in 'tradition'. A historical and cultural approach to the politics of Somalia shows that such institutions would contribute by addressing the concerns of most Somalis with underlying issues like tol segmentation, the rhetoric and practice of (clan) group equality, and their desire of mutual respect and having rights and duties met. More intense inter-clan communication and negotiation in an institutional manner would be equally necessary. Institutionalizing regular meetings of local stakeholders in the various regions also seems necessary. In recent years, new possibilities have been opened up by NGOs or women's groups mediating and organizing peace activities as well as small-scale economic ventures. ${ }^{89}$

Somalia has thus to be re-imagined anew, not only as a political idea or state but also as a cultural and social order in line with the values of clanship and customary law. That a reinvention of traditional Somali notions of values, religious identification, clan belonging and civilizational identity should hereby

\footnotetext{
${ }^{88}$ S. Samatar, 'Somalia: The Politics of Poetry' emphasized the role of poetry (as in Mohammed 'Abdulleh Hassan's time) but this genre has virtually disappeared from Somali public life in the last 20 years.

${ }^{89}$ For examples, see Asha H. Elmi et al. 'Women's Roles in Peacemaking in Somali Society', in D.L. Hodgson, Rethinking Pastoralism in Africa. Gender, Culture and the Myth of the Patriarchal Pastoralist (Oxford \& Kampala \& Nairobi, 2000), 121-41.
} 
stand central - and not imported Western, Arab or Islamist ideas - seems reasonable but is by no means sure in view of constant external pressure by the UN and powers like the US, the EU, Saudi Arabia and some Arab Gulf states.

Southern Somalia is still in a 'cycle of rebellion' that is becoming increasingly vicious. The entrepreneurs of violence and predation dominate the scene, and any overarching authority structure or normative framework is absent. What was achieved in the rest of the country should, however, not be underestimated. There has been a remarkable movement towards restoring a social order based on local courts, heer, clan elder mediation and in some cases a resurgence of religious (Islamic) mediators and women's NGOs. But even these positive developments have been largely based on clan-group identities.

In view of the Somali game of clan prestige and the façade of status and nominal equality, as previously emphasized by Hussein Adam, ${ }^{90}$ an 'integrative structure of constructive conflict' should be sought if the county intends to move forward. ${ }^{91}$ Even then, some conflicts in Somalia may not be solved except by ignoring them. Disagreements should be given room to be expressed, though without the prospect of immediate resolution. The main thing would be to build structures that could contain the escalation of violence. It is also an illusion to think that a non-violent consensus structure can be built in a country with persistent natural resource scarcity and decentred, kin-based polities with deep-rooted traditions of autonomy and collective honour. This is evident from the simmering conflicts within Somaliland and Puntland and along their border, cutting across certain clan territories. ${ }^{92}$ It is interesting that the Puntland administration, dominated by the Majerteen, is trying to win over parts of the D'ulbahante and Warsangeli sub-clans in Somaliland, appealing to clan unity under a higher level of segmentation: all three form the Harti clan that is opposed to the Isaaq dominant in Somaliland.

For the construction of a more comprehensive political order, recognition of cultural continuities in Somali society would remain necessary, despite their transformed, violent articulation in the post-state era. In this respect, a down-up 'building block' approach to conflict resolution and the creation of a wider

\footnotetext{
${ }^{90}$ See Adam, 'Militarism and Warlordism'.

${ }^{91}$ As all observers of contemporary Somalia feel bound to offer their advice, I follow suit. For a recent example, see also M. Doornbos, 'Somalia: Alternative Scenarios for Political Reconstruction', African Affairs, 101 (2002), 93-107.

${ }^{92}$ See http://news.bbc.co.uk/hi/english/world/africa/newsid_576000/576721.stm (on the 1999 tensions) and the IRIN news item of 15 July 2002 ('Somalia: Troop Build-Up Creates Tension in Sool') on www.irinnews.org
} 
social order - as advocated by I.M. Lewis, Ahmed Yusuf Farah ${ }^{93}$ and others in the early 1990s but rejected by the UN - still offers the most reasonable way ahead. It implies avoiding a top-down, externally funded model of politics, and rediscovering traditional units of decision-making and legal discussion, some regulation of economic life, and creating working administrative structures at the local level of clans and clan-family regions. This is already happening. In Somaliland, Puntland, South West State and several coastal cities, some precarious progress was made in the last few years, despite the internal segmentary tensions. These units - in themselves also based on a federative association of sub-clans and urban elites and agreement to respect their interests, including at some point the heers - might at a future date decide to form a state confederation. Unfortunately it seems that the 'Arta process', leading to the TNG, has subverted this long-term development because it posited the need for a state at a point when most Somalis were not in agreement about its desirability and shape. The unitary state of the thirty-year independence era had left an image of internal division and disaster that worked against any resurrection of such a structure.

Finally, there is also a wider regional context of the Somali conundrum as it concerns neighbouring countries in the Horn. The prime example is Ethiopia, again deeply involved in Somali affairs, ${ }^{94}$ as it was in the time of Mohammed 'Abdulle Hassan when it encroached in the Ogaden and staked claims with Italy and Britain. ${ }^{95}$ Ethiopia was sucked into the post-1991 Somali problems precisely because of the country's internal divisions. For example, Hawiye faction leaders invited or allowed Eritrean troops and insurgents of the separatist Oromo Liberation Front (OLF) to operate against Ethiopia from their territory during the Ethio-Eritrean war of 1998-2000. Also, al-Ittihad groups in the Luuq area made attacks into Ethiopia in the late 1990s. Ethiopia came to oppose the transitional government in Mogadishu and to support the

\footnotetext{
${ }^{93}$ See Ahmed Yusuf Farah \& I.M. Lewis, Somalia: The Roots of Reconciliation. PeaceMaking Endeavours of Contemporary Lineage Elders: A Survey of Grassroots Peace Conferences in 'Somaliland' (London, 1993).

${ }^{94}$ In February 2002, the Ethiopian ambassador to the UN, Dr Abdul-Mejid Hussein who is of Somali origin himself, spoke about the instability in Somalia and was quoted by Reuters as saying: 'If the Somalis don't solve their problems, then we will do it for them...We won't wait for ever.' He was strongly criticized for this by Djibouti and by the Transitional National Government of Somalia in Mogadishu (see http://www.irinnews.org/report.asp?ReportID=23245). There is, however, no doubt that he meant what he said and tensions still remain high.

${ }^{95}$ See Lewis, A Modern History, 57-58, 69, 71, 72. Ethiopian interest in Somaliinhabited territories must be seen in the light of the Italian policy of systematic infiltration into Ethiopia. Cf. Lewis, ibid. 89-90.
} 
Somaliland government, as well as the forces of the Rahanweyn Resistance Army (RRA) and the Somali Reconciliation and Restoration Council (SRRC) based in the Digil-Rahanweyn area.

Since 11 September 2001 the Somali case has assumed added relevance in the aftermath of the global terrorist challenge from the Al Qa'eda network, which allegedly has had training camps and a network of activists in the country. According to American and Ethiopian intelligence sources, small Somali Islamist groups (for example Al-Ittihad al-Islamiyya) were connected to this network and in 1993 participated in the torture and killing of American servicemen during the failed 'Operation Restore Hope' ${ }^{96}$ Hence, what happens in Somalia concerns more people than only the Somalis and their immediate neighbours, although that is probably the least of their worries. The wider conflict potential of a fragmented, segmentary society is much greater than its constituent parts can imagine. This is part of the tragedy of what are often called 'collapsed' state orders (cf. Sierra Leone, Congo, Afghanistan, parts of Pakistan). Such societies are nevertheless part of globalizing networks with economic, religious and political interests. Somalis, at least those clan factions interested in an Islamist or anti-Western agenda, may come to join new international forms of resistance against Western and other domination. ${ }^{97}$ Thus, another cycle of conflict and violence would be initiated, creating new formations of clan power and identity but boding ill for the emerging social order and economic rehabilitation within Somali society itself. The above account may illustrate that gaining an understanding of the politics of contemporary Somalia requires a rethinking of definitions of rebellion and resistance and their socio-cultural basis, as does any imagining of a 'functional' Somali state in the classic sense. The twentieth-century Somali state certainly

\footnotetext{
${ }^{96}$ When the Al-Ittihad group became active in southern Ethiopia in the late 1990s this provoked a major retaliatory campaign by the Ethiopian army in the Luuq area, leading to the collapse of the group's military wing and the elimination of several of its core leaders by Ethiopian or Ethiopian-supported troops. Since then, the Al-Ittihad has followed a largely domestic Somali agenda, although it maintains active links with an international Al Ittihad network existing in the Gulf States, Sudan, Pakistan and other countries. It is highly unlikely that $\mathrm{Al} \mathrm{Qa'eda}$ remnants will regroup in the unpredictable environment of Somalia. (After Pakistan and Muslim aeas in the Caucasus, they would perhaps, in Africa, be most likely to choose northern Nigeria.)

${ }^{97}$ For a conservative US view, see J. Philips, 'Somalia and Al-Qaeda: Implications for the War on Terrorism', The Heritage Foundation Backgrounder, 1526 (2002), 1-12. www.foreignpolicy-infocus.org/commentary/2002/0201somterror_body.html provides a more liberal viewpoint - see K. Menkhaus, 'Somalia at the Crossroads of American Policy'.
} 
was made through cycles of rebellion, but 'who resisted who and what' at crucial moments was unclear. The definition of the state was always in question. While resistance seems to have been an inherent part and thus constitutive of the state in many parts of Africa, in Somalia it was as much against the state - any state - itself. 


\section{List of authors}

Abbink, Jon

African Studies Centre, Leiden, the Netherlands

e-mail: abbink@fsw.leidenuniv.nl

Aregawi Berhe

African Studies Centre, Leiden, the Netherlands e-mail: ezanareg@hotmail.com

De Bruijn, Mirjam

African Studies Centre, Leiden, the Netherlands e-mail: bruijnm@fsw.leidenuniv.nl

Deutsch, Jan-Georg

University of Oxford, United Kingdom

e-mail: h0208daj@rz.hu-berlin.de

Ellis, Stephen

African Studies Centre, Leiden, the Netherlands e-mail: ellis@fsw.leidenuniv.nl

Gewald, Jan-Bart

African Studies Centre, Leiden, the Netherlands e-mail: gewald@fsw.leidenuniv.nl

Idrissa, Kimba

University of Niamey, Niger

e-mail:kimba@intnet.ne

Melber, Henning

Nordiska Afrikainstitutet, Uppsala, Sweden

e-mail: henning.melber@nat.uu.se

\section{Ross, Robert}

Department of African Studies, University of Leiden, the

Netherlands

e-mail: r.j.ross@let.leidenuniv.nl 
Seibert, Gerhard

Fundação para a Ciência e a Tecnologia (FCT), Lisbon, at the Centro de Estudos Africanos e Asiáticos (CEAA), Instituto de Investigação Científica Tropical (IICT), Lisbon, Portugal

e-mail: mailseibert@yahoo.com

Van Dijk, Han

African Studies Centre, Leiden, the Netherlands

e-mail:dijkh@fsw.leidenuniv.nl

Van Kessel, Ineke

African Studies Centre, Leiden, the Netherlands e-mail:kessel@fsw.leidenuniv.nl

Van Walraven, Klaas

African Studies Centre, Leiden, the Netherlands

e-mail: walraven@fsw.leidenuniv.nl 